$$
8 i-50
$$

\title{
Gas-Cooled Reactor Programs Annual Progress Report for Period Ending December 31, 1973
}
P. R. Kasten
J. H. Coobs
A. L. Lotts
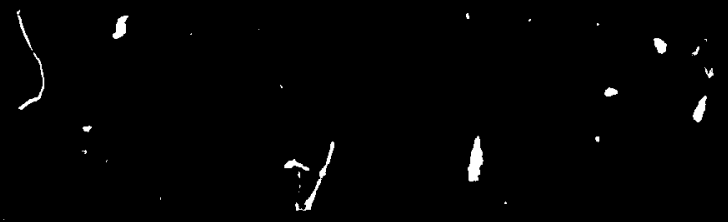

\section{OAK RIDGE'NATIONAL LABORATORY}

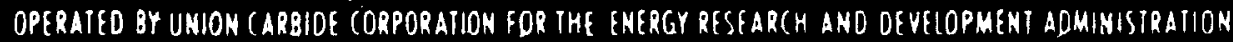




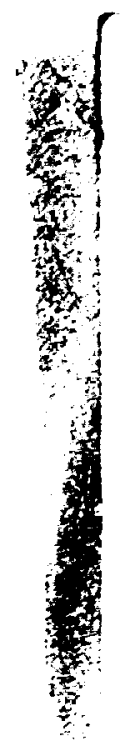

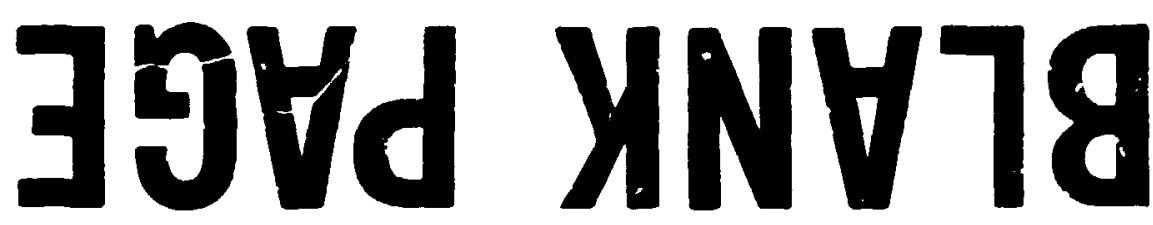

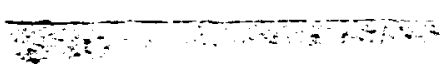




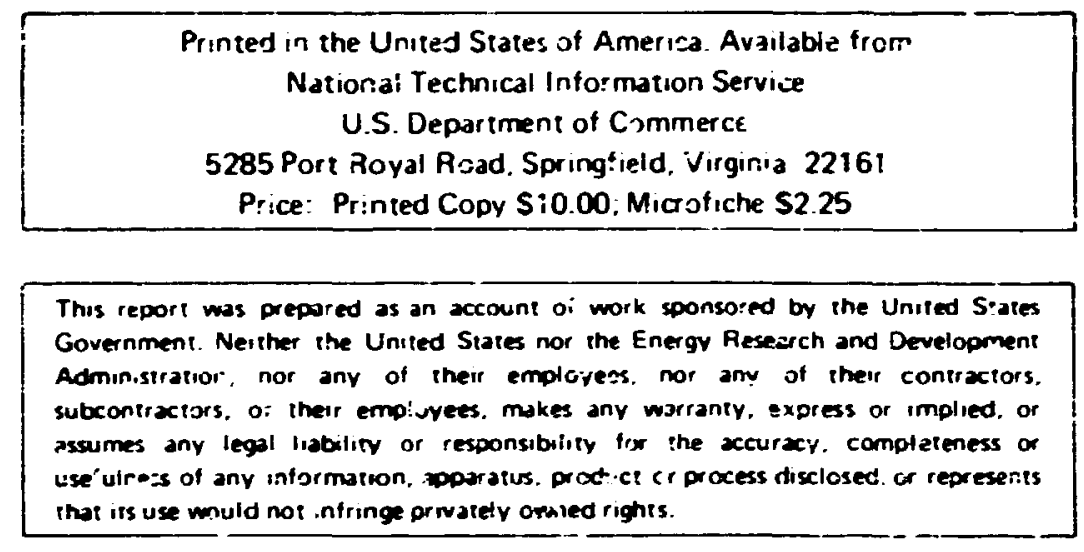




\section{GASCOOLED REACTOR PPOGRAMS ANNUAL PROGRESS REPORT TOR PERIOD EINDING DECEMBER 31, 137?}

P. R. Ka:ten, P;ogram Difector J. H. Coobs, Associate Director A. L. Lotts, Associate Director

\section{APRIL 1976}

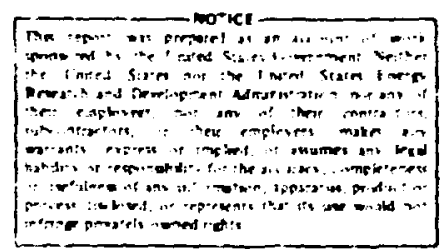

OAK RIDGE NATIONAL LABORATORY

Oak Ridge. Tennessee 37830 operited by UNION CAABIDE CORPORATION for the 


\section{PART I. THORIUM UTILIZATION PROGRAM}

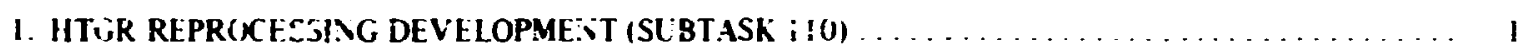

1.1 General Developmen: 1100 [General Atomii Connany IGACILead] $\ldots \ldots \ldots \ldots \ldots \ldots$ I

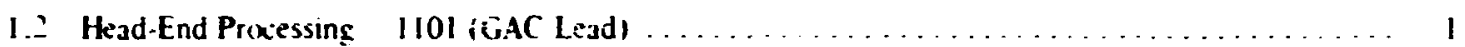

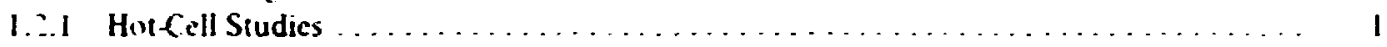

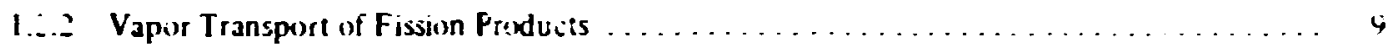

1.2.j Experimental Studies of a Whole-Block Burner $\ldots \ldots \ldots \ldots \ldots \ldots \ldots \ldots \ldots \ldots$ II

i.3 Solvent Extraction 1102 (GAC Lead) . . . . . . . . . . .

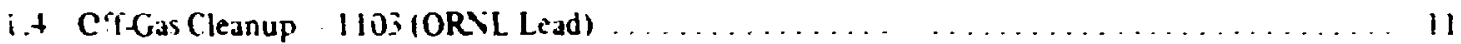

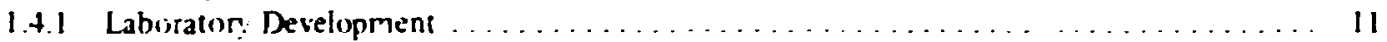

1.4.2 Enquncering Deveioprient . . . . . . . . . . . . . . . . . . . . . . 14

1.5 Proibit Preparation - 1104 (Allizd Chemical Corporation Lead) . . . . . . . . . . . 15

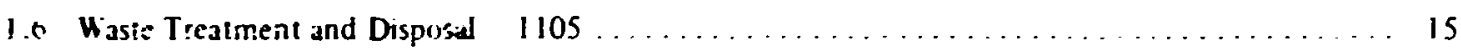

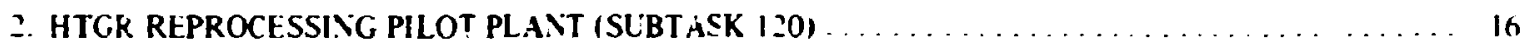

3. HTGR FLEL REFABRIC ATION DEVELOPME.IT ISLBTASK 2I0! $\ldots \ldots \ldots \ldots \ldots \ldots \ldots$

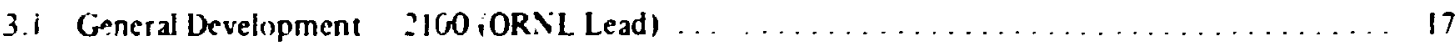

3.2 Cranium Feed Freparation 2101 (ORNL Lead) $\ldots \ldots \ldots \ldots \ldots \ldots \ldots \ldots \ldots \ldots$

$: 3$ Resin Loading 2102 (OR.

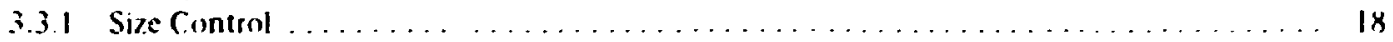

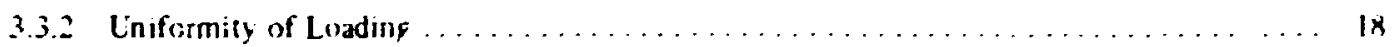

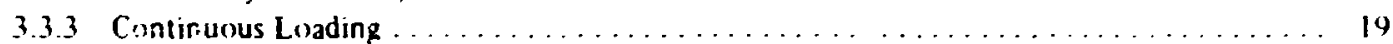

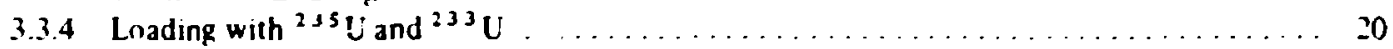

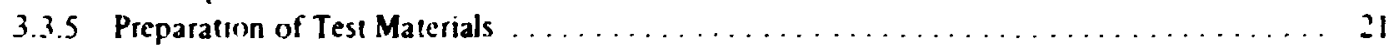

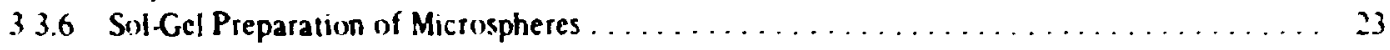

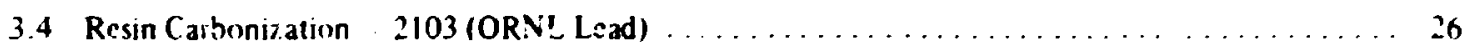

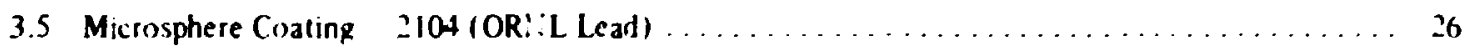

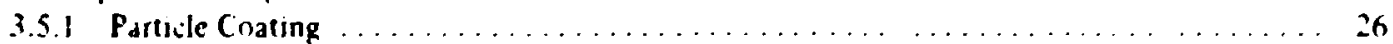

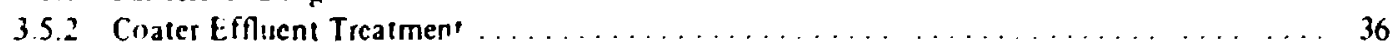

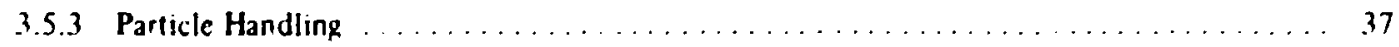

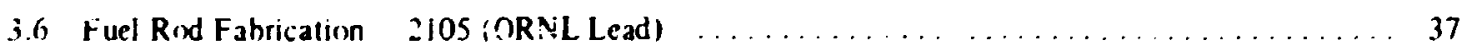

3.6.1 Particle Dispersing. Blinding. and Loadirg $\ldots \ldots \ldots \ldots \ldots \ldots \ldots \ldots \ldots \ldots \ldots$

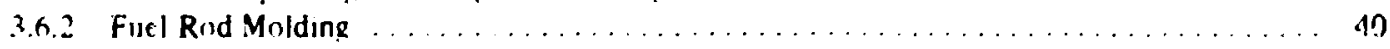

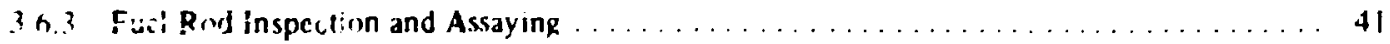




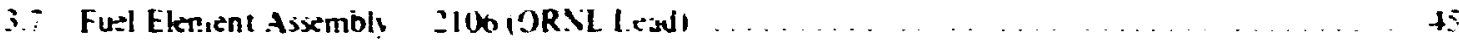

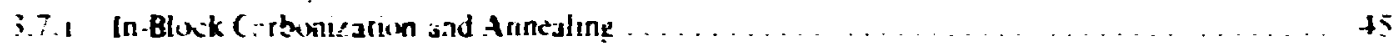

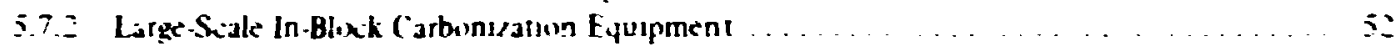

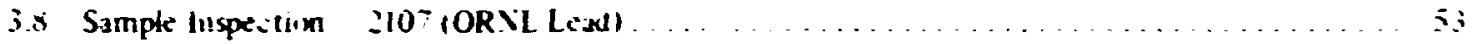

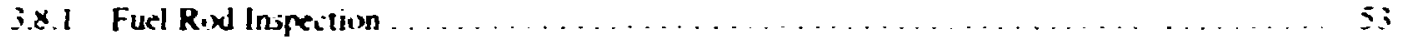

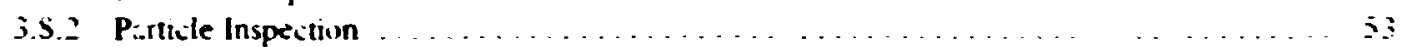

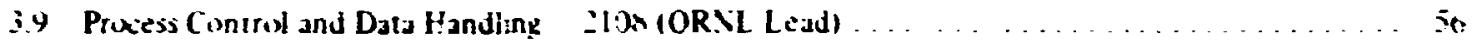

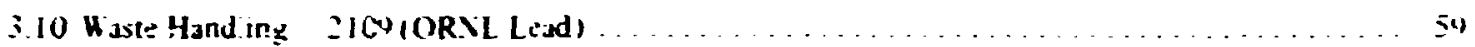

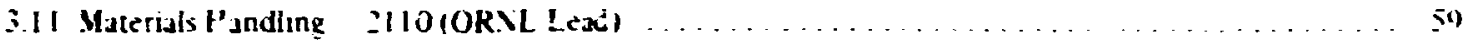

4. HTSR FLEL KEC

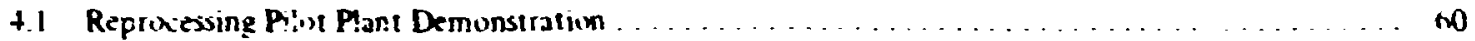

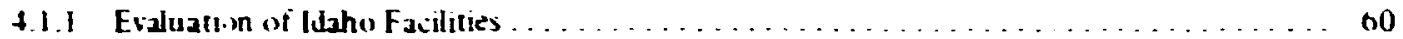

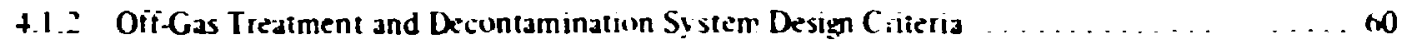

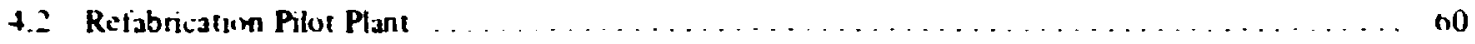

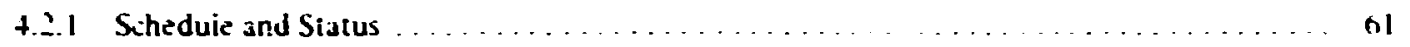

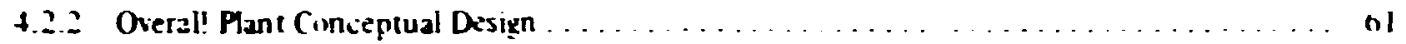

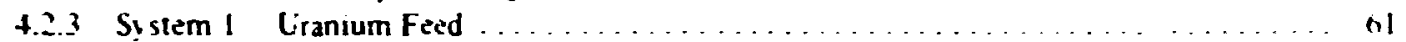

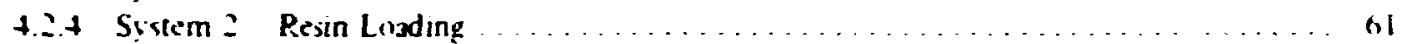

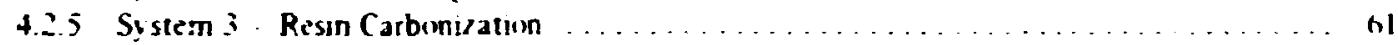

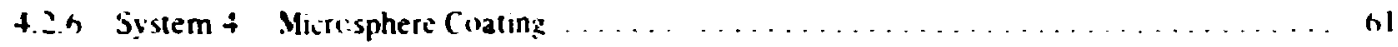

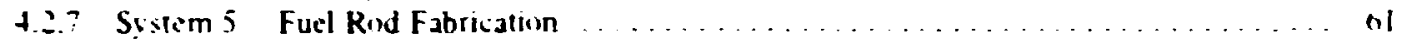

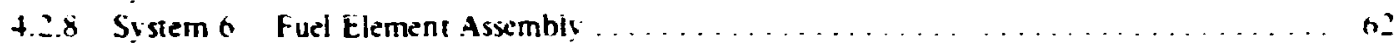

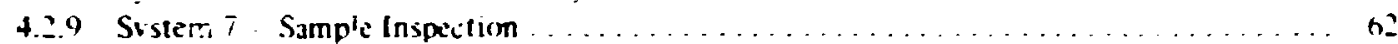

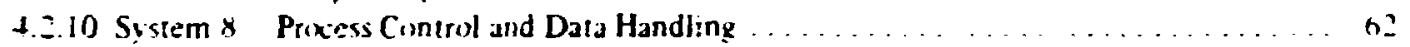

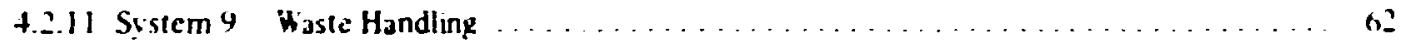

4.2.12 System 10 Materials Handling . . . . . . . . . . . . .

5. STLDIES AND EVALLATION OF HTGR FLEL RFC YCLE SYSTHMS $\ldots \ldots \ldots \ldots \ldots$

S.i Evaluation if HTGR Recycle Prnisses $\ldots \ldots \ldots \ldots \ldots \ldots \ldots \ldots \ldots \ldots \ldots \ldots \ldots \ldots$

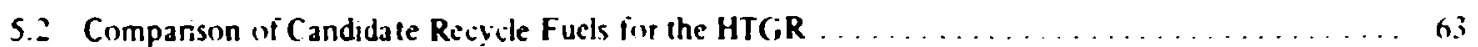

S.2.1 General . . . . . . . . . . . . . . .

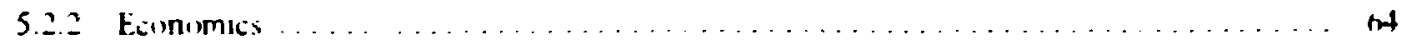

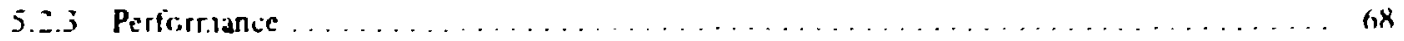

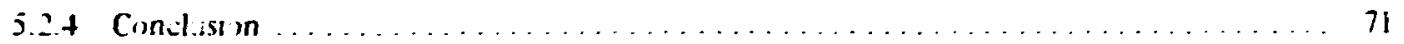

5.3 Economico of Timing of HTGR Fucl Recycle $\ldots \ldots \ldots \ldots \ldots \ldots \ldots \ldots \ldots \ldots \ldots \ldots$ il

PART II. HTGR DEVELOPMENT PROGRAM

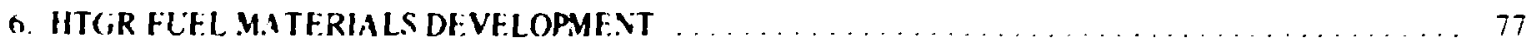

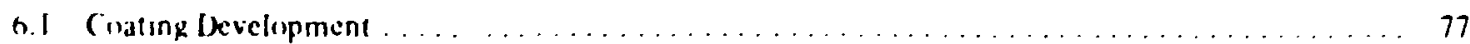

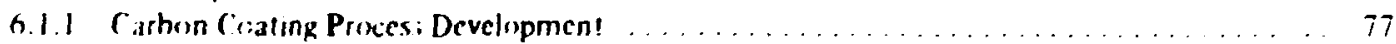

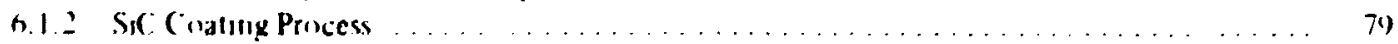

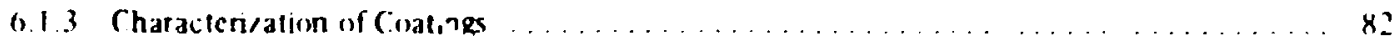

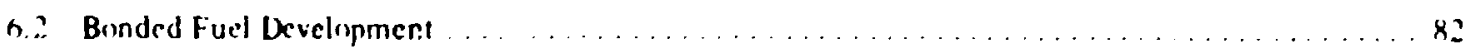

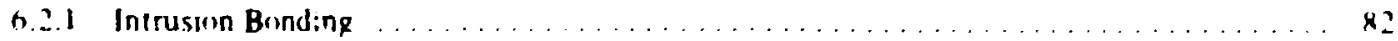




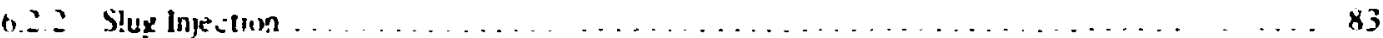

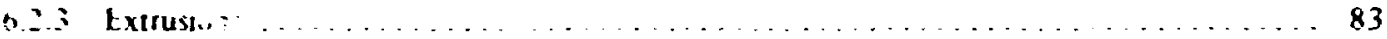

h...t Irijdiation. Results on Simir!.led txtrisions $\ldots \ldots \ldots \ldots \ldots \ldots \ldots \ldots \ldots \ldots$

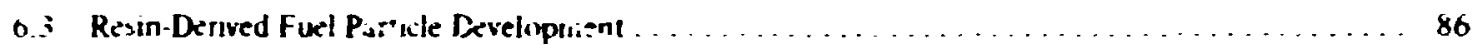

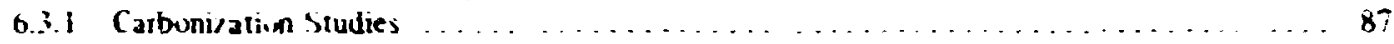

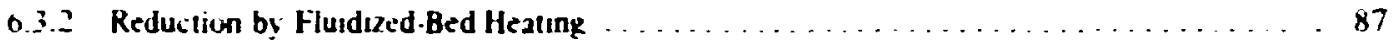

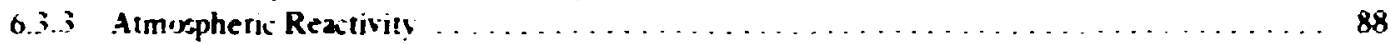

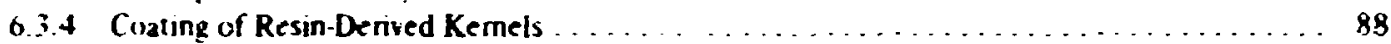

7. HTGR FLEL IRRADATIONS AND FOSTIRRADIATION EXAMINATIONS ... . . . . . . 89

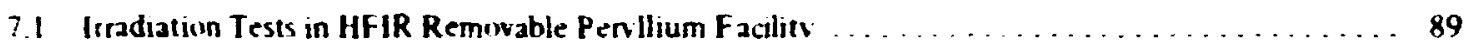

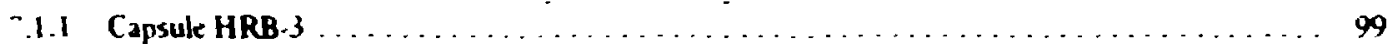

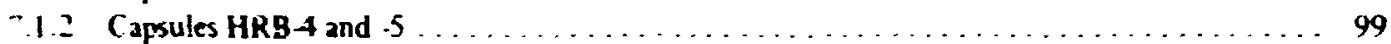

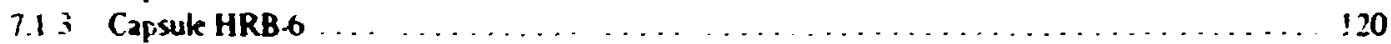

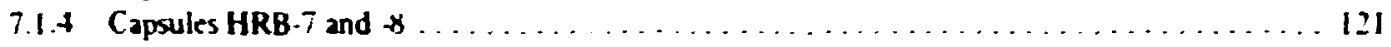

7.2 Irradiation Tests in the HFIR Target Facility $\ldots \ldots \ldots \ldots \ldots \ldots \ldots \ldots \ldots \ldots \ldots$

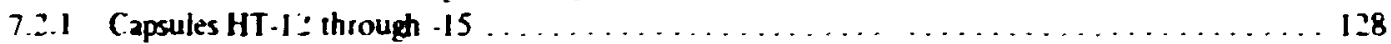

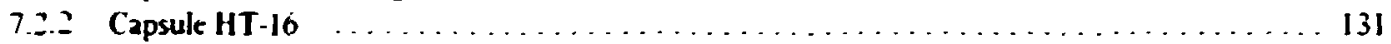

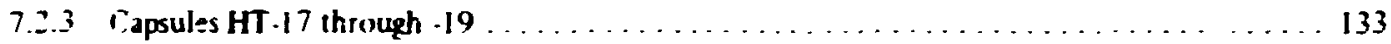

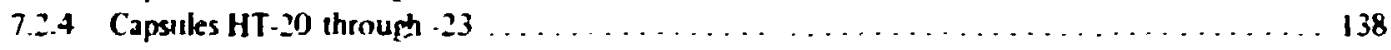

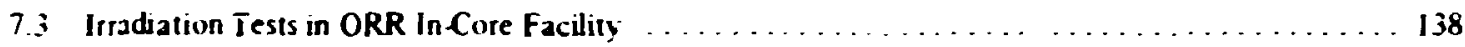

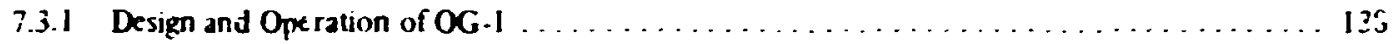

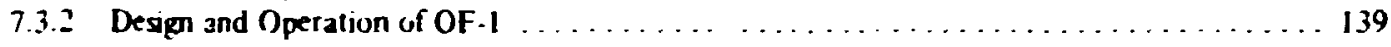

7.3 .3 Preparation of Specimens for OF-I Irradiation Test $\ldots \ldots \ldots \ldots \ldots \ldots \ldots \ldots \ldots \ldots$

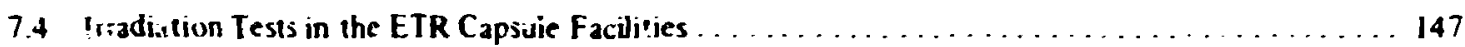

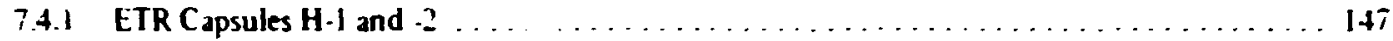

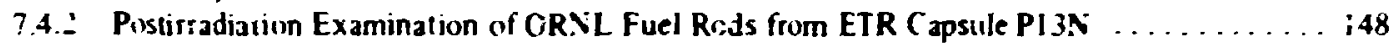

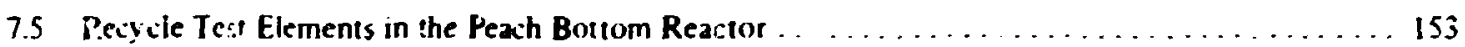

7.6 : Vuclear Analysis in Support of Irradiation Experionents $\ldots \ldots \ldots \ldots \ldots \ldots \ldots \ldots \ldots \ldots \ldots$

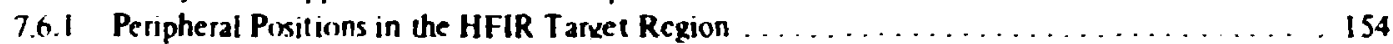

7.6.2 The RB.5 and Rb-7 Facilities in the HFIR Removable Berillium $\ldots \ldots \ldots \ldots \ldots \ldots \ldots$ I5:

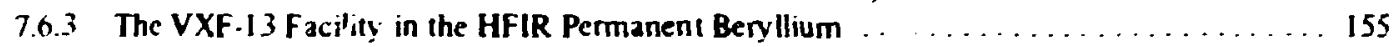

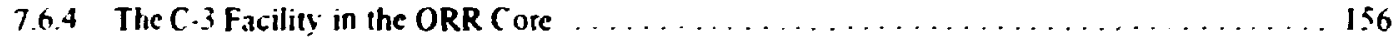

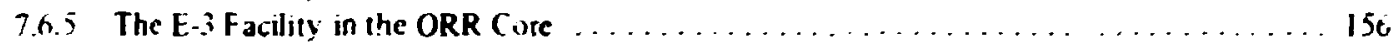

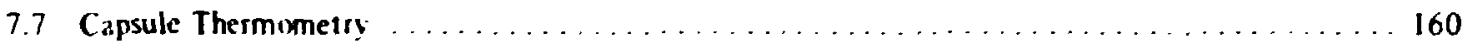

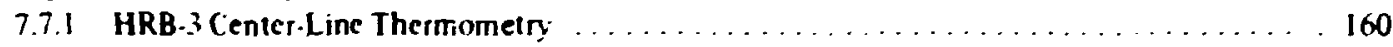

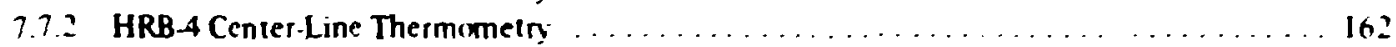

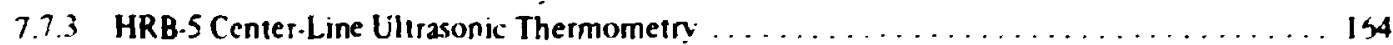

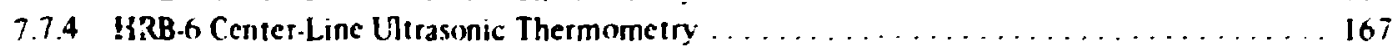

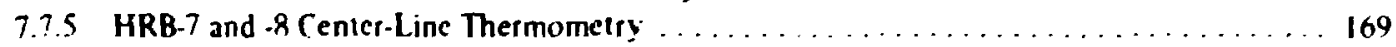

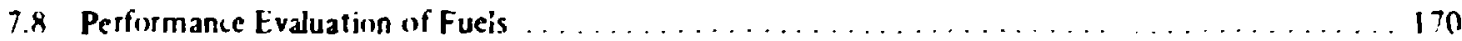

8. PRESTRESSFD CONCRETF PRFSSURF VESSEL I PVRC I DEVELOPMENT $\ldots \ldots \ldots \ldots \ldots$

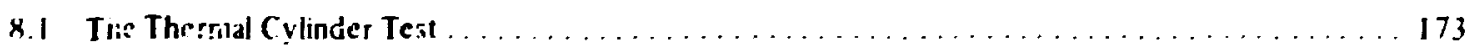

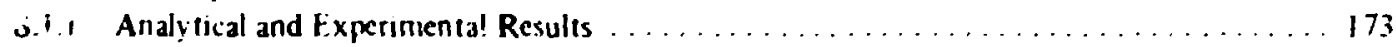

$\times 1.2$ Disassemhly of the Thermal Cylinder Model $\ldots \ldots \ldots \ldots \ldots \ldots \ldots \ldots \ldots \ldots \ldots \ldots$

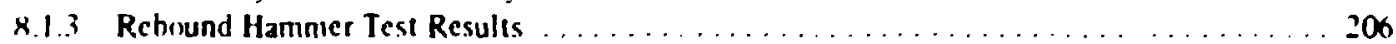

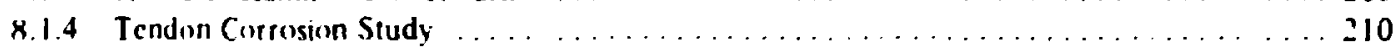

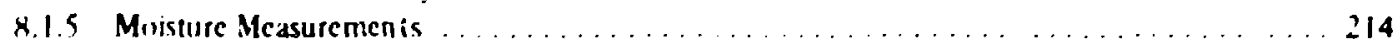




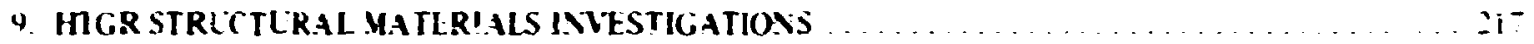

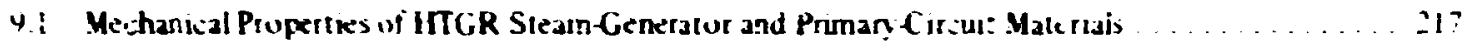

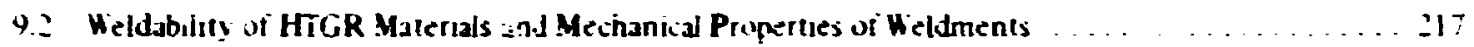

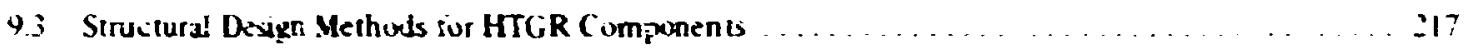

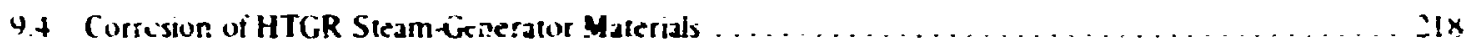

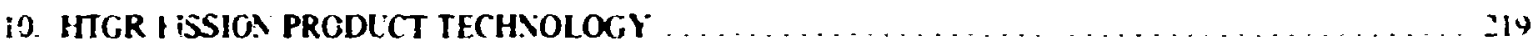

10.1 Mathe'natizal Analysis of Fission Product Release from Pyrocarbonf uated Fcel Particles . . . . . 219

IU.2 Pusturradiacion Measurements of Cesic an Rekase . . . . . . . . . . . . . . . . . . . 20

10.3 Status of Estimation of Cesium Releasi from Biso-Cuated Fuels During Iradiation . . . . . . . . . 2:

II. HTGR FLELCHEMISTRY

I 1.1 Mass Ironsport in Fuel Particles in a Temperature Gradient . . . . . . . . . . . . . . . . .24

11.2 Gas Pressure Measurements in Coated Particles . . . . . . . . . . . . . . . . . . . . 25

11.: Chemical Compatibility of Fuel and Fission Products with Cositias $\ldots \ldots \ldots \ldots \ldots$

PART III. HTGR SAFETY PROGRAM

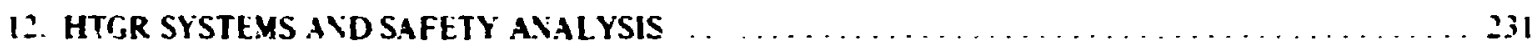

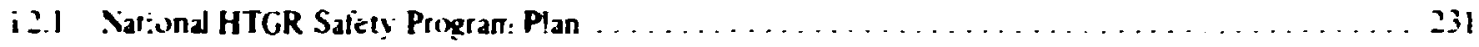

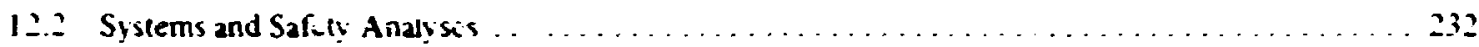

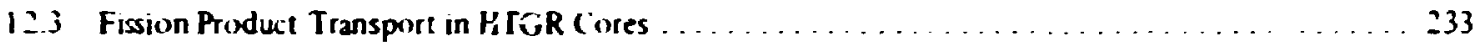

12.4 Calculation of Fission Product Inventories in the Peach Boltom Reactor . . . . . . . . . . . . . 233

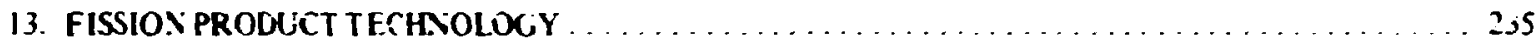

1 i.l Iodine Adsorption and Desorption Studies . . . $\ldots \ldots \ldots \ldots \ldots \ldots \ldots$

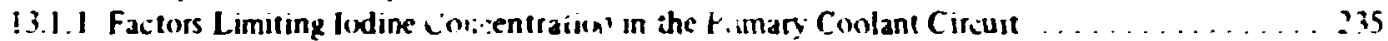

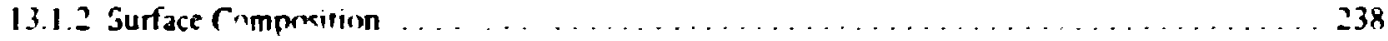

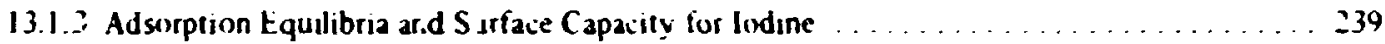

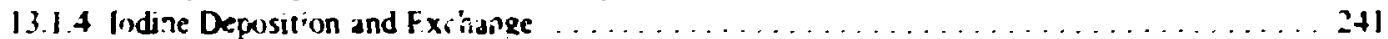

13.1.5 Remowal of Kodine from the Primany Coolant as Meial lodides . . . . . . . . . . . . 242

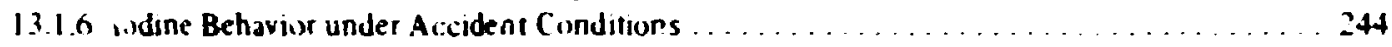

13.2 Fission Product Bchaviur in ihe Priman (ircuil of the Peach Bollum HTGR ........... 246

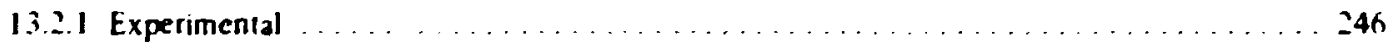

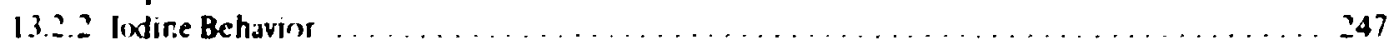

13.2.3 The Behavior

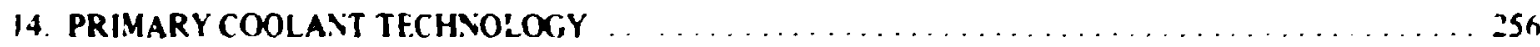

14.1 Evaluation of Coolunt-Core Interactions and Conlant Compisition During For St Vran Startur . . . . . . . . . . . . . . . . 257

14.2 Computer Analysis of ine Effects of Steam Ingress into the Coxiant Circuit $\ldots \ldots \ldots \ldots . \ldots .57$

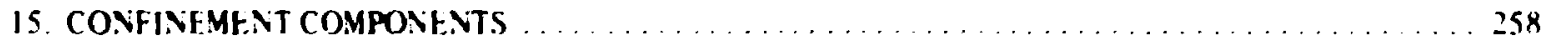




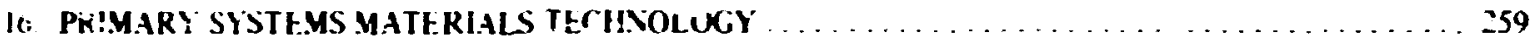

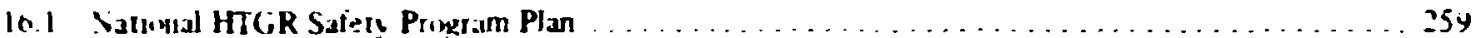

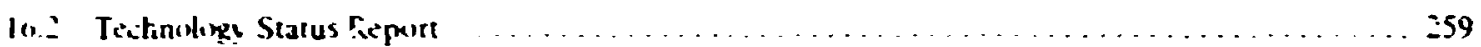

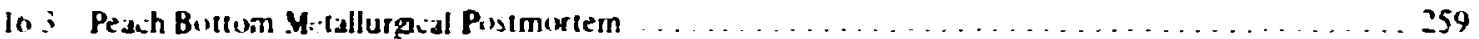

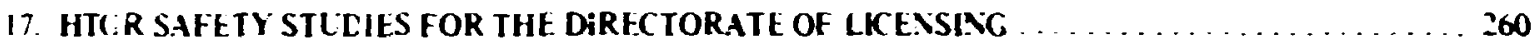

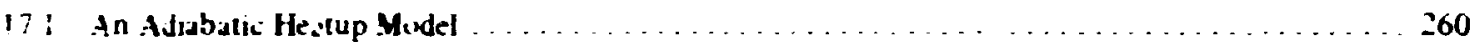

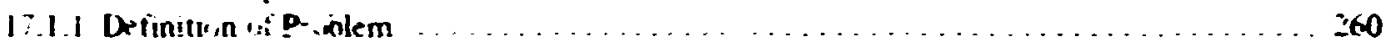

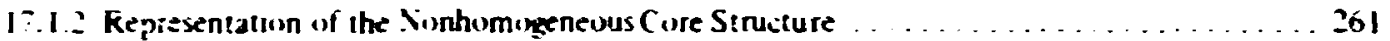

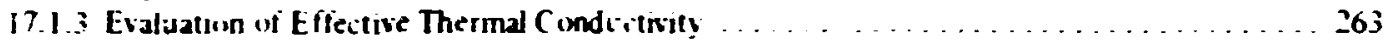

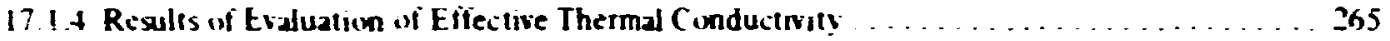

17.1 . Development of Tw.)-Diminsionai Adiabatic Heatup Model . . . . . . . . . . . 267

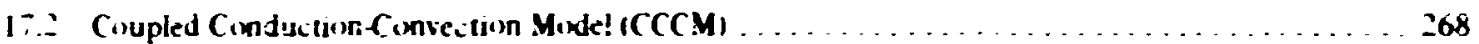

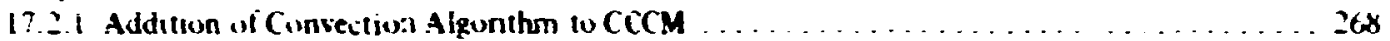

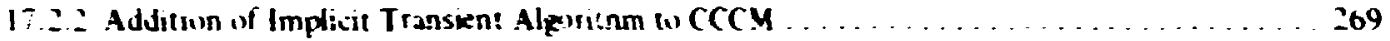

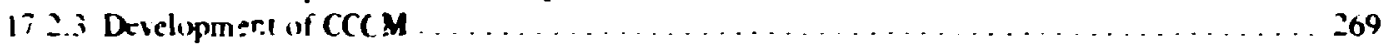

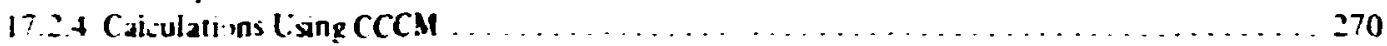

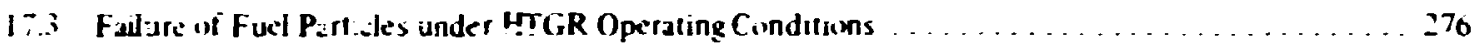

1 1. 1 Falure of Particles 's Mas: Transport in a Tempeiature Gradient . . . . . . . . . . 276

17.3 .2 Coalid-Particle Periormancic Mudeling . . . . . . . . . . . . . . . . . . . . . 279

17.4 Sensitivity of HTGR Fuel Performance to Material Properties and Particle Design . . . . . . . . . 285

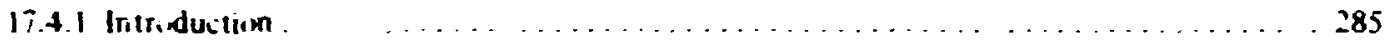

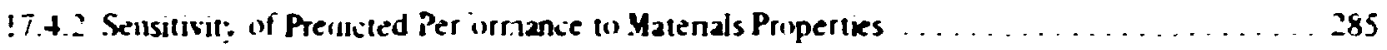

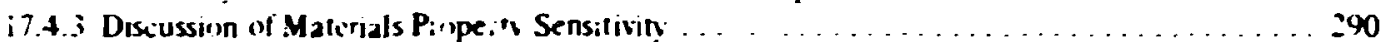

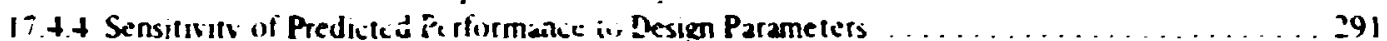

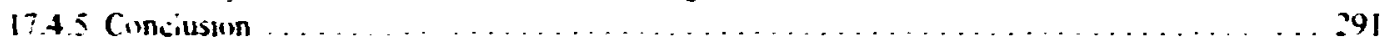

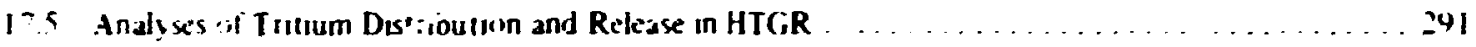

PART IV. GAS COOLED FAST REACTOR IROGRAM

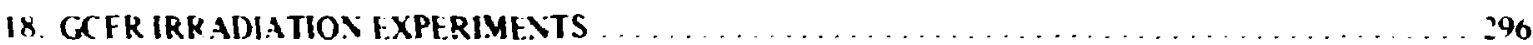

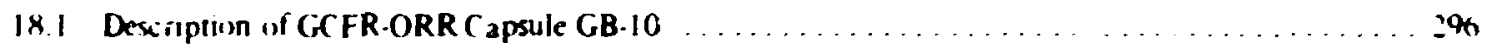

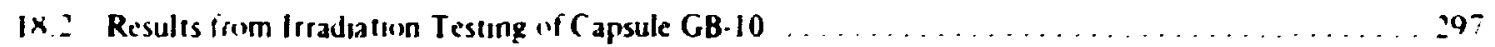

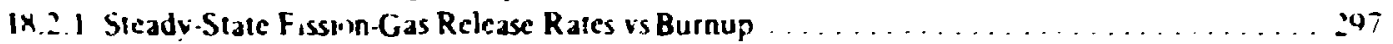

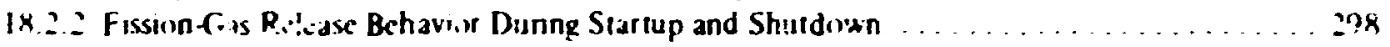

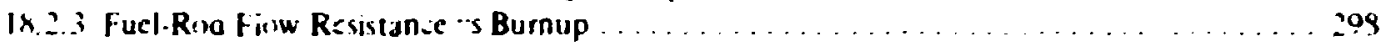

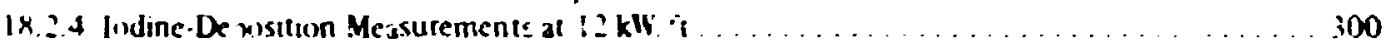

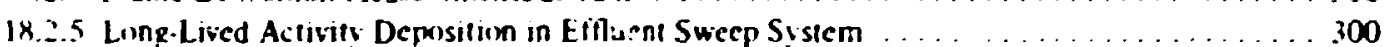

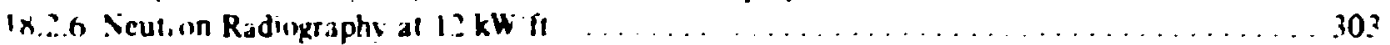

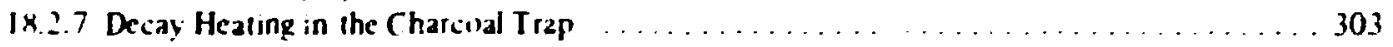

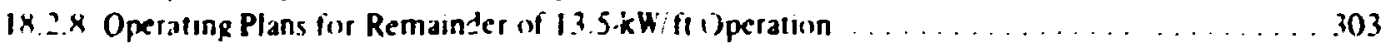

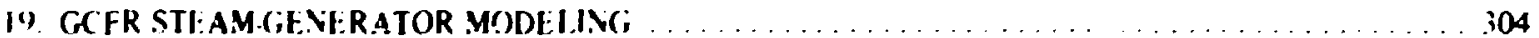

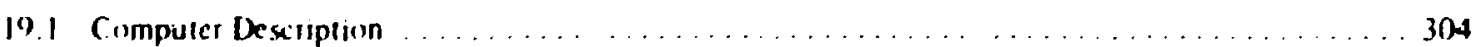

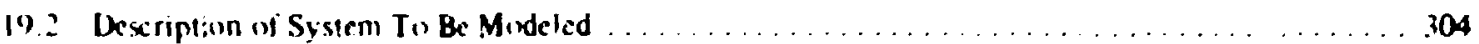


เาi

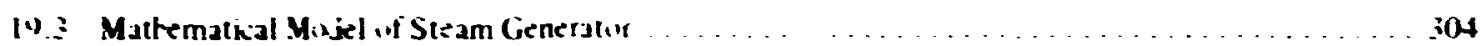

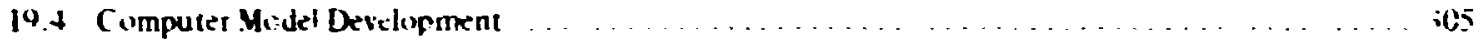

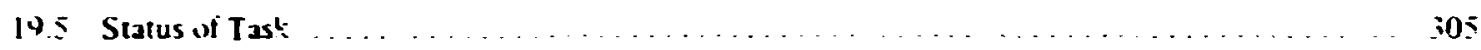

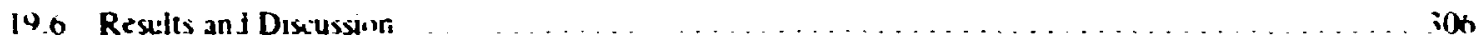

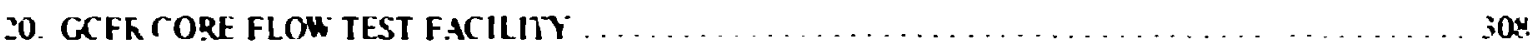

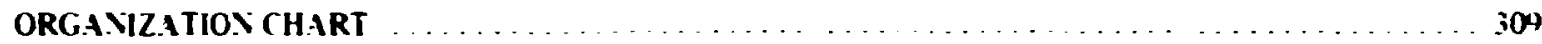




\section{Foreword}

The Ciss-Cooled Reacior programs being carried vat at O-k Ridge Nationai Luboratory cintribulc to li:e development and evaluation of high-limperature gascoried reactors (HTGRs) and of gas-iensicu fast reactors (GCFRs). These progerams. spunsered by the C.S. At smi Energ Commission (LSAEC). Include the Thonum Lilization Progran IHTGR Fuel-Resicl Development Program). the HTGR Base Prigram, the HTGR Safery Program. and the GCFR Program. The major effort is in HTGR technolins: with empliasis on fuel and fuel-recycle development. and iricludes fuel fabrication and irradiation iestirg. headend processing. fission product behavior. and tuel performance studies. Work is also carried out on the perfurmance of prestressed concrete reactor vessels (PCRVs) under possible reactor conditions. $\mathbf{H}_{\text {iork }}$ in G(FR iechnology emphasize; development of a cire now test loop to be used in fluid flow and hear transter studies of GCFR core assemblies: other work involves fission product behavio: in a vented fuel element. shielding studies. and s. :em response studies of a steam generator. Close coordination is maintained with General Atomic Company (GAC) relative to their efforts in the design and development of gas-cooled reactors and in HTGR fuel-recycle development.

Major incentives for developing HTGRs are the prospects for economically allractive power production. improved fuel utilization. the potential for obtain. ing low envirunmental impa 1 at a disersily of plant sites. the potential for ligh-icinperature diret: cycle and process heat applications, and the pertinence of the compoinent technoling io GCFRs. The gond neutron ecomomy and fuel performance permit high hurnup and associated low fuel-cycle costs. The high-lemperature capahilily of the graphiti core structure facilitates reactor plani operation a: high: thermodynamic effi. ciency, and tious requirentents lin leat dissipation to the environment are relativily low. Excellent fission preduct retention bs the isated fuel particles leads to coolan! circuits with iow radiuactivit: levels. Further. the high exposures attainable with HTGR fuels permut tise development of economic fuel reigiling. At the same rime. the development of fue'-recycle technolog? is important to the commerial acieptance of HTCR; as eionomic power producers.

The luei-recyle effort is part of the national HTGR fuel-recycle development progiam being imred out by the USAEC at ORNL. GAC. and the Idaho Chemical Pronessing Plant (ICPP). The objective of the fuel-recycle progran is to develiap the pertinent technology so

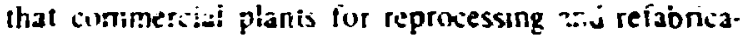
ting HTGR fuels car be built and op:rated econcmically. The operations to be considered take place between the discharge of spent-fuel elements f $\cdots:-2$ : the reactor and the relum of refabricated fuel eiements to the reactor: these include fuel shipping. ;orage. fuel recovery and purificalion. refabrication and waste management. The work involves fuel-reprocessing development. fuel-refabrication developrent. iradiation testing of refabricated fuels. and fuel-recycle systcm analyses involving th: economics associated with vatiois processes and equipment. The program at ORViL includes development of headend pricessing meth.uds for irradiated fuels and associated off-gas cleanup

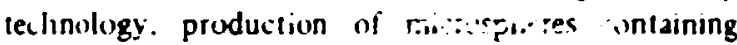
recycle-type fuel. microsphere coating tcihnology. re. cycle-fuzleleitsent labrication technoling. issuciated equipment and process development. recycle-fuel irradi. ations. and fuel-recyile evaliation analyses.

The HTGR fuel tevelopment work at ORNL is largely concerned with evaluating understar.ing and inpiov ing fuel performance and with siudying the behavior of certain fission products. including heir effects on fuel performance. Coateci-particle fuel sludies involve irradi. ation testing. with emphasis on demonstration of satisfactory fucl and matcrials pifformance at the 
required tue! burnup) and tast-neutron fiuences. including the testing and development of recicle fuels. In these tests. the High-Flux Isotope Reactor (HFIR) has proved highly usetul as an irradiation facility: an inziore taifity at the Oak Ridge Reiearch Rezitor. alsu being usid provides relative!y large volunies for testing fuel hidies.

in work un PCRV's. a t'lert lai cylinder experimeni has been cumpicted to study the time-iepenaerit stresssirain behivior of a simulated seoment of a PCRV vessel. Th: prestressing. pressure. and thermal-gradient condition. were tliose expected under HTGR design conditions: prior io disassembiy a otilt-in heater was activaied (1) simulate a hot-spot condition. The results have been an:aiyzed.

Relativa is HTGR safety studies, a fission product technolingy program has been under way for a number of years that involves the behavior of fissioni products and : if fuel ander various circums:ances, including abnormal conditio is. Included in these efforts is a tis.ion product surveillonco program being arried out in the Peach Bottom HTGR. which provides informa. tir: w. fission product behavior in an HTGR entironment. These studies vere comrnned for part of the yesr, with the experinerilal studies subsequently being transferred to the HTGR Base Program. At present. HTGR safety studies concert: analysis of acident sequenies and of postulaied consequences aild assessment of fission product and coolant technology. oi core and component technology. and of materials. instru. mirtation, and containment behavior as they relate to HTGR safely.

The helium-couled GCFR offers a high bie?ding ratio. a doubling lime or about 10 years. a sore conversionn ratio of approximately 1.0 , and a small reactivity change frem loss of coolant. The high core conversion ratio makes possible extended operating periods without refteleling and results in iow reactivity swings ditring fuel expositre. Since the fuel performance requirements for this reacior are basically cimilar to those for the liquid-me:al-soled last bieeder ieastor (L.MP BR). the GCFR program draw heavily on the fuel development of the LMFBF program. The ORNL fuel work for the GCFR involves irradiation lesting of luel pins. IrradiaHio. test ras!!: for a second vented fuel elemerit wer: obtained curting this report period, with encouraging results. Otter work heing carried out in the FCFR prigram includes plarıing and devciopment work a
Core Flow Test L(x)n (CFTL) io be titil:aed for heal trasile: and huid tlow testing of simulated G:FR iuel assemblies: GCFR shieiding studies with emphasis on ne:troil s:reaming evalua'sns: and mathematical mudeling if the GCFR .teent generator :o simulate respinse unfer transien conditions.

Work 0.1 gis-iocker reactors in also being perforned in Europe. w th signilican: afforts being carried out in the HTGR concept hy thi L:agon Project and by Germaliy. Assuiater information pertaining to HTCR research and ac:- :pmeat work is whtuined through the USAEC Dragur. ISTCR Agreerient and the USAEC; KFA Exihonge Arrangement Thase exchange programs include information on fiol develcoment. oerfurmance and :esting. fission product behriol, fuel teproressing. matends performanice. ard sateiy.

The urganization of tris repert is 'ased on ar: orderly presentation ei technical information which large! fulluw's pringiam lines but not completely. The principal exception is Chapter 7. which cuvers werk supported by the HTC,P Base Program and the Thorium Utilization Program; the results from irr: 'iatior: testing and postiradiation examinations of various fuels are beiter understoud when presented in in integrated maniver. In general. hewever. the report present's information associated with specifi: progranis as follows: Thorium Utilization Prograin, Chapte - I tirolach 5. 7 : HTGR Base Progran, Clapters 6 through 11: HTGR Safety Program. Chapters 12 through 17; and GCFk Program. Chapers 18 through 20. The chapters that ar: associated with the Thoitum Utilization Program are organized accerding (1) il. sublasks identifled in thr Naliona! HTGR Fuei-Cycle Development Program Plan and in i89. No. 10516. the nrogram and broget proposal. Thus. the work on sublask 110 . Reprocessing Deveiopment. appears in Chanter $I$ and work on subtasi 120. Reprocessing Prototype Frility, will appear $\mathrm{i}$ Chapter 2, although in the reporting period only advissiry and review function; were involved and no work is reported. Similarly, work on subtask 210. Refabrication Poccess Development, appears in Chapter 3 . and Chapter 4 presents the progess of design work for subtask :?0. Refabrication Prointype Plant. Chapter 5 presents the risults of work un subtask $3: 0$. Erangering and Economic Studies, while the resulis frum Recyole Fuel leradiations and Examinations. suhıask 230. are combined ir, Chapter 7 with similar work supported by the HTGR Base Progiam. 


\section{Summáry}

\section{PART I. THORIUM UTILIZATION PROGRAM}

\section{HTGR Reprocessing Development (Subtask 1:0)}

The Reprocessing Pilot Plant isk 100 is divided into two major subtasks: Reprocessing Development IChap. 1. sublask 110) and Reprocessing Pilor Plant (Chap. 2. subtask 120). Th - development subtask is the primary rrsponsibility of General Awmic Company (GAC). but ORNL has a major role in tuo of the work un. is (headend processes and off-gas cleanup). and activily on these units is reporic 1 here. The pilot plant sub ask is the primary responsibility of Allied Chenical Corporation. and our activit: this calendar year was limited to review and conment functions.

1. 1 General development. No activity siheduled.

1.2 Head-end reprocessing development. Hoicieil studies of irradiated HTGR-ty; : fuels were cintinued i.l small-siale test: aimed at identifying reloase patterns and distribuition of tritium, " ${ }^{5} \mathbf{K r}$, and various fission products of Jiffering volatilities. Both carhide- ard oxide-base fuels were examined, with burnups of ahout 16 and 35\% FIFA respecilvely. Tritium and krypton releases from the two fuel types difiered significantly in that these nuclides iend or he retained in the oxide fuels. The more volatile fission nroducts. such as ruthenium and cesium, were found dowristream from the turner in relotively large quantities but were effectively removed by condensaliti! and filration. An activation product. ${ }^{75} \mathrm{Se}$, was completely volatilized out of the burner but was condensed in cooler parts of the system.

Calculatons and ady nee planning were done for more suphisticated studies of vapor $(r \cdot n$ port of fission products. Tracer level experiments in contact facilities may be necessary in orde: to obtain defiritive data on certain alpha and beta emitters.

Both experimental and theoretical work was done on the whole-block burner concept. Experimental messurements on ano-sixth-scale unit showed tiat the concapt was feasible in terms of atlainable rates and temperature. A theoretical study of hurner temperature control oy recycle if burner gases suggested that an "adiabatic bu. ner" concept was very desirable. This approach limits reactor combustion temperature by mea is of the C. $\mathrm{CO}_{2}$ reaction and should be of value for other burners also (e.g.. nuidized-bed burners or shaft iurnaces).

1.3 Solvent extraction. vio activity sitieduled.

1.4 Off-gas cleanup processes. Lahoratory studies dealt with three systems: $\mathrm{Kr}-\mathrm{CO}_{2}, \mathrm{XeCO}_{2}$, and $\mathrm{CO}_{2}-\mathrm{I}_{2} \cdot \mathrm{H}_{2} \mathrm{O}$. Work on the distribution of krypion? hetween gaseous and liquid $\mathrm{CO}_{2}$ was completed. Measurements on th:e distribution $~^{*}$ xenon in $\mathrm{CO}_{2}$ were started, and the daia are reported. As expected, xer.un is more soluible in liquid $\mathrm{CO}_{2}$ than is krypion. hy faclors of about $t$ a, $50^{\circ} \mathrm{C}$ and ahout z al 1$)^{\prime} \mathrm{C}$. Work was started on the $\mathrm{CO}_{2} \cdot \mathrm{I}_{2} \cdot \mathrm{H}_{2} \mathrm{O}$ systemi. and preliminary data indi:ate that $H_{2} O$ and $I_{2}$ react with each other in liquid $\mathrm{CO}_{2}$ and that $\mathrm{H}_{2} \mathrm{O}$ and $\mathrm{CO}_{2}$ form a molecular escraciatun complex in the guseous phase

An expcrinental crigineering facility was designed and built (o) rbeain indamental engincering data on the KALC prosess firypton ahsorption in íguid carhon diexide). The fasltiy. which consists of packed ahsorption and struper iolumns plus associated comprassors. is in the final shakedown slage. A computer model was 
developed for the $\mathrm{CO}_{2}-\mathrm{Kr}_{1}-\mathrm{O}_{2}-\mathrm{N}_{2} \mathrm{CO}$ system to help analyze cxperimental results

1.5 Product preparation. No k-tivity siheduled.

1.6 Waste treatment and disposil. Nin activily siheduled.

\section{HTGR Reprocessing Pilot Plast (Subtask 120)}

Dinnx this reporting period. wtivity at ORNL on this subtask consisted of reviewing desten documen's for the pilot piasit and initiating the preparation of the preliminaiy system design cesiription of the of t-gas cleanup sy stem.

\section{HTGR Fael Fabrication Development}

In this step in the HTGR fuel cycle the nitiale solution containing reprocessed ${ }^{33} \mathrm{U}$ is converted. in. horcell-type facilities. into fuel eiements for use in an MTIR. The objective of the national HTGR refabrication development program is to develop technology so that commeridal HTGR refabriation plants can be built and operated e.onomicaily. This gual will be Iargely met by the design. construction, and operation of the Furl Refabrication Pilot Platı (FRPP) io be installed in the exi-ting Thorium-Uranium Recy:le Facility (TLRF) at ORN:.. The processi's and equipmeni applicable to remote refabrication in the FRPP will be developed under subtask 210. whiie the design, corstruction. and actual operation of the FRPP will be done in subtask 220. Work in subtask 220 is covered in Chapter 4.

Work in HTGR fuel refabrication piocess development has been goirg on for a number of years at ORNi. The work this year is reported in sections parallel 'o the systems of the FRPP. The change to utilize a kernel derived from a weak-acid resin (W.AR) instead of a sol-gel-derived kernel was made at the end of this report period: therefore. the sol-gel work is reported under resin loading. The majority of the work accomplished during this report period was in the areas of coating. rod fabrication, anci clen ient assembiy.

3.1 Ceneral development. Work in this area invoives the condination and review of all functions of this subtask and subtask 220. preparation of recycle fuel specifications, and development of material acimmstability procedures. Activity has primarily heen in trchnicai input and roview of the design descriptions fo tile FRPP.

3.2 Uranium feed preparation. No development activities scheduied.

3.3 Resin low ding. The change to a kernel derived from WAR was made atter this report periad was completed. However. the resin development work is reporled in this section to conform with the new format. even though that work was supporied in part by the base program in 1973. Solgel work is also reported in this section.

Resin kernets of the desired size were obtained by wet screening the commerial product reieived from the inanufacturer. A yield of about $35 . c$ was obtainc: in the desired size range. The volume change that resin undergues through various cunversion steps wat determined. Initial measurements show that within ? ivading batch, individual resia kernels are uniformaly loaded and that :ariations :rem batch to batch are small

The use of a modified Higgins colimn for the continuous loading of WAR was successfully demonst rated.

Loaoing of WAR with both $=35 \mathrm{U}$ and $: 33 \mathrm{U}$ was earried out successfuliy using a batch proces. Over 500 $g$ of ${ }^{25} \mathrm{U}$ was losded onto WAR :o provide irradiation specimens. In addition, $5 \mathrm{~kg}$ of ratural uranium was loaded on WAR to provide material for development work on carbonization and coating.

The puiled nozzle system for preparing sol-gel spheres of uniform size and diameters has continued to operate vary satisfactorily. In this system, the breakup $\mathrm{oi}^{-}$the sol slreams is m.de more uniform by irnposing a vibration on the sol a: the natural frequency of drop formation. Ruutine use of the system has corsistently given kernels with average diameters within 1\% of the predicted value anil standard deviations of about ir of the mean diameter.

Kiernels containing ${ }^{233} \mathrm{U}$ and ${ }^{2.15} \mathrm{U}$ with $\mathrm{Th} / \mathrm{U}$ ratios of 4.2. 2. 1 , and 0 werc prepaled for irradiation experiments using the pulsed nozzle sysiem. Absut 300 $\mathrm{kg}$ of $\mathrm{ThO}_{2}$ was preparzd for developmelli.ul .esting.

The Sulex sol preparation of (ThUX), spheres is the preferred flowstect for Th/U ratios of 3 is 4.25 . This process was demonstrated at a rate of $10 \mathrm{~kg} /$ day with excellent results.

3.4 Resin corbonization. In this step in particle preparation, uranium-loadod $W A R$ that has been dried to $110^{2} \mathrm{C}$ is carbonived to $\mathrm{UO}_{2}-\mathrm{C}$ intermediate product. Work has juit hegun in this area.

3.5 Microsphere coating. The engineering-scale coat ing furnace was upgraded by replacement of the furnace support structure. base. and electrodes. Porolis plates of differen: genmetries were evaluated. and a new type o: porous plate gas distributor was developed. The buffe; coating process was shown 10 be reproducihle. A comprehensive experiment relating process variahles (1) numerous low-lemperature isotropic coating propertics 
was completed. and the result was a muth impreyed understanding of this costing proxess A sirubber using liquid perchloricethylene was develuped to treat the eflluent genesaled by the carbon costing proxess.

3.6 Fuel rod fabrication. The principal activities in fuel rod labrication are dispensing. blending. and lixading particles into molds: injectio. wi the matrix into a bed of particles to forri a fucl rod: anu inspecting and assaying fuel rues.

A sysiem using compression valves to volumetrically dispense particles was developed. With this system. íssile and fertile particles can be dispensed within $0.5^{\circ}$ ? of the average reight specified for a fuel rod.

The appioach to blending we have invstigated involves splitting the charge required for une fuet rnd into len approximately equal incremen's and sequentially loading each increment into a ficl rod mold. A nechanized blending device using tis rechnique was designed, constructed, anit placed in'o coeration ot the lahoratory fuel rod machirc. Or:r initial evauatlen of this Slender has shown that the uranum and thoriu 7 content per in:h of fue! rod is vell within the $\pm 5 \%$ target speciflicaions.

The siug injection proxes: for $m$ idiag fuel has been demonstrated (i) be suitab!c in all aspecis for the remote fabrication of HTCR and reiycle fuel roxis. Over $\mathbf{2 0 . 0 0 0}$ iuel rods have been made on the lahoratory fuel rud machine by this process.

The apahility to perform rapid and accurate nondestructive assay of special nuclear materials is an essential par: of the FRPP ior meeting safeguards and material accountability requirements. Design and development work has been initiat ad on several devices and techniques ( $)$ assay the fissilc and fertile content of the type of material io be processe' in the FRPP. Thase include (1) 252 Cf neutron interrogalion devices for active assay of fuel kernels and rods. (2) a calorimeter device for very accurate assay of individual fucl rods. and (3) a passive gamma scanning device for sensing rod-io-rod fissile loading variations.

3.7 Fuel element assembly. The principal activities in fuel elemert assembly are fuel element kading: carbonization and annealing: end plug. dowel. and poison :nd loading: and fuel e!ement inspection. Eiforts during this report period have been confined to carbonization and annealing.

A problem of in-niock carbonization and annealing has been the increased endency for particles to he broken during carbonization-annealing and irradiation tes:ing compared with the old process of rarborizing the fuel rods if $\mathrm{Al}_{2} \mathrm{O}_{3}$ powiler. The problem is apparently a resul of the difference in pitch carboniza. tion conditions that result in a higher pitch oke yield.

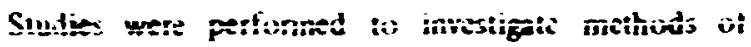
lowering the pilch-oke yield in in-block carbunization. and it was found that additives to the matrix material would reduce the pitch-coke yieid to the desired ievel. The influence of particle strength on the tendenc; of particles to break during carbonization and irradiation lesting was recognized. and a means of delr.mining particle strength was initiated.

The design? of a furnace ior the carbonizition and annealing of full-size HTGR fuel blocks has begu: . This furnace. which is a vertical shaft type capable of $1800^{\circ} \mathrm{C}$, will be the protstype of the furnace we expect to use in the FRPP.

3.8 Sample inspection. This task inciudes development of tectriques and equipment necessary for the design and operation of the samfte inspection system in the FRPP. Principal devesupment during this periud has been in red and particte inspection.

In rod inspection. a tinique was developed fo: quantitatioe characterization of the pore structure of fired fuel rods $b$ : infiltration of a low meiting metallic alloy ints the fucl rod and examination with a qu:.:"itative televisien microsiope.

A higitemperalure $\left(1500^{\circ} \mathrm{C}\right)$ ih'orine leach technique svas developed tor determinirg hroken particle fracions in fired fucl ronis. This technique apfears capable of determining quantitatively as few as one broken particle in a fired fucl rod.

In particle inspection. an improved singularizer was added to the particle size analyzer. The particle size analyzer continues to look very piomising foy the measuring of particle dismeters at various stages of manufacture. In coating density determination. the differences between the gradient column and mercury iisplazement values were resolved quantititively. This led to a new, more precise method for determination of low-temperature isotrop.c (LTI) coating density. Techniques were developed for characterizing particle shape from the radiograph and for characterizing surfaceconnected porosity of the $\mathrm{LT}$ roating by nickel impregnation.

3.9 Process control and data handling. The principal activities in this area are involved with application of state-of the-art control techrinlogy is the FRPP. Work ii: this area is not scheduls:d to begin before July 1974 .

3.10 Waste handling. Work in this area is primarily in developing waste packaging and waste assay methods. During this year, activity has been directed toward formulating a work p'an for the waste assay method.

3.11 Materials handling. No deve'opment activities scheduled. 


\section{;. HTGR Fuel Recycle Pilot Plant Studies}

Coniepiual desizn of the HTGR 5...t Refabrication Pilot Plant was started in July 14?3. The plant is being designed to pr xess $\$ 5 \mathrm{~kg}$ of uranitrin and thorium par day. Thus is equivalent w hout 2.5 fül elements per Jos. which would fif operated contin siuslyly) supply a reacior such as the Fort Si. Vrain witt : "ycte tukel. The unit operations of the pilot plant iill vary from ito 5i: of the -nticipated commercial s ee. The pilot flant. ti be installed in the Thuriuntiranium Recyicle Facility at OR.VL. is being designed fior remote operaii) and nainienanic beciuse of the kighly radioxitive substances to be handled. Phase 1 of the conceptual design. cunsisting of derailed criteria. flowshets. and intlines of system design desiriptions. was completed: the conceptual design is sitheduled for completion by July 147:

\section{Studies and Evalurtion of HTGR Fuel Reycie Systems}

Highlights diring thus reporting period included a detisiled ussessment of the economic and irradiation perlormance considerations assonisied with a change in the reference recycle tissile partick from $\left(4\right.$ Th. $\mathrm{L} \mathrm{O}_{2} \mathrm{t}: \mathrm{s}$ the weak-akid-resin-derived $\mathrm{U} \cdot \mathrm{O}_{\mathbf{y}} \cdot \mathrm{C}_{\mathrm{y}}$ and a study on optinize the :iming of the introduction of fuel reproceessing and refabrication on a comunercial basis.

The available economic and ; erformance data on the mixed-roxide and weak-acid-resin (WAR) fissile fuels were aciumulated and studied in detail. It was concluded that the WAR system offered the potential for superior irradiation perforniance. and the sketchy eionomic data suggested that use of this particle would be no more expensive than the mixed-oxide particle. which was ther the reference. Therefore. ORNL and General Atomic recommended to the AEC that the reference particice he charged.

The riming of the introdicition of commercial ca. pacily for HITGR fuel reprocessing and refahrication was shown to be somewhat or al. in that large deviations from optumal timing can lead io greatly increased luel cycle ansis. The study showed that for the presently assumed HTCR consinuction schedule. calling fior the first large reactor to go on line in 1979. commercial reprocessing of spent fuel should hegin in 1984 or 198.5. Optimal timing was also shown to be someshat insensitive to changes in some of the im. purtant cost paraneters. such as uranium ore susis dis toll enrichment charges. Another interesting item pointed out by the study is that a delay in the introduction of commercial iapaity from epcimal is much more costly than carly introduction of th:s spacily.

\section{PS.RT II HTGR DEVELOPMENT PROGRAM}

\section{HTGR Fud Materials Dretopment}

The principal whjectises of the luet developinkent program include the preparation and characierication of coated particles and fuel rods fin use in irradiation tests designed to demonstratc the pertiomance of fiscls at HTGR designl conditions of $t$ investigate pricess latitude and property ariations in order to establish specifications. In addi:ion. the development of allemale iabrication pricesses that iffer substantial improvemenis in tuel performance is eraphidsized as applizable. During this reporting periend. signifion: lorelopments were made on coating technoligy. resin-base kernel processing. and extruded fuel rod fabrication.

In cuating process devclupment. maintaining athermal conditions during coating runs by use of mixed hydroarbin gases enabied subsiantial progsess in minimizing property gradients thereby enhancing irradiation performance of pyrocarbon coatings. A cimmercial product. MAPP gas, which consists mostly of unsiturated hydrocarbons. was shown to have distinct id vantages for temperature control during coaing rurs Otter conating developments consisted of a study of the reduction of undesirable carbon deposits by adition of oxidizing diluents to the coating gas. and the definition of minimum hydrogen-to-silane ratios inecessry io maintain aceptable coating pruperties wtile n!aximoing the SiC depesition rate.

Process developments on resin-derived kernels insluded the definition of accoptable conditions for rapid carbonization (de-volatulization) of the loaded and dried resins and the description of procedures for partial or complete conversion ot the carhonized resins to carbide while controlling particle density and the amount of excess carhon. The atmospheric reactivity of all compositions of resin-derived kernels indic.tted that exposure to moist gases nust be prevented.

Studies of allernale fuel rod fa orication processes included preparation of extruded specimens fo: use in studies of the thanges in thermal conductivity curin: irradiation and the irradiation testing of simulated cxtruded fuel rods. Thr extrucled fuet rinds exhibited anisotropic hehavior under irradiation. as expected: diametral shrinkage al moderate fluences was followed hy swelling. but the original dimensions were nill 
excected even di exposures exceding the $i$ min fluencis.

\section{?. HTGR Fuef Irradiations and Pontirradiation Evaluations}

T.I Irradiation Tests in the HFIR Remonable Beryllium Facility. Durng this reportme period. the irradiation o! HRB capsules +f and - 5 was conpieted. and postirradiation examination (PIF) of the fuel was performed. Twa llems of major interest were revealed in the HRB 4 and -5 experiments. First. there appears lo be J prob!em of mechanical interaition between poricic indings and the matrix material in fuel rods which have been artonized in bloxk. The bond between the uster L.TI coating and the matrix is sutficiently strong that the outer LTI is hr ken away from the Sic laver as hulh ihe coatung and the matrix densify under irradiation. This hehavior was not noled in fuel rods which hod been arhoinized in blexk. Anotiner significant observaion was the chemkal atlack of th. SiC layer in the Triso fissile particles the fuel was Triso WAR I:C, fissile and ThO, Bise tertile) hy rare-earth fissim preducts. This was the :irsi obseria. lion of this hehavior in OR.NL irradiation tests. hut such beliavior has been ohserved in subsequent tests a.ld in tests conducted by wher investigators.

Irradiation and Pif of capsule HRB-h were alse completed. The was the first test in the HFIR of fully enriched fuel. The fissile particles were ( + Th. U)O2 with buth Biso and Triso coatings and contained both $23{ }^{3}$ and 23 . This experiment was also the first compartson of the irradiations af these two isotupes i. uranium. Buth fucls performed well. and no difference coluld be deternined hetween them. There was no evidence of fission penduct atlack if the SiC layer on Triso-couted parti.les. Amoxba (kernel migration! was observed in the mixed-rxid: fissile particles. and the migration data ware added to master plots to supplement data from other experiments.

Capsules HRB-7 and -rive planned and ionsinucled during this reporting persint. The eupsules will he inserted into the reactor early in $i 974$. These apsules were planned before the change in the refirence recycle fissile particle was made from (ATh.IX) Io the weak-acid-resin-derived particle. The capiule contains a varicty of livels. including sol-gel UO, work-acid-resin $U C_{2}$. mixed-nxide kernel, with different lhorium to uranium ralion. and 233 [ and 2.15 (i-hearing fuels. will buth Biso and Triso designs. The performance comparisons between the (4Th.UM: and weak-acid-resin parficles described in Chapter 5 of this report were based on fucls irsdated sepa-aldy. In no case vas there: a cimparison of the two uels irradiated in the sonie eapsule under the same conditions. Such a imparisur will te poussible with $1 ; R^{-7}$ and $\$$. and the djid for this test should shed more light on the kecision made recenily to change reteren.e fissle partikles tior the recyite fuel elements.

In addition to the irradiation experiments completed in the HFIR remowble beryllium ixilities. :wo addi. tional iciomplishments wer: completed which should greatly enhance our experimental apabilities in the tuture. Two new facilities have been added to the HFIR Io supplement the existing fiacilities in the removable iseryllium reflectur. One of these ficilities is a muderate nux pusition in the permanent beryllium reflector and the second is an out-of-iore thennoxouple calibration furnace which permits the calibration of HRB capsule thermoriouples betore. during. and at the end of the iajudition. The pirmanent beryllium facility is of particular importance because it permits the imariation of iully enriched pure fissile particles in a neutr.m flux l.w enough to reduce the power per particle values to accepiahle levels.

7.2 Irradiation Tests in the HFIP. Targei Facility. Irradiation and PIE of the HT series HT-12 through -15 vere cimpleted during the reporting period. These experments wete designed in lest various coating dexigns applicd (1) thinria kernels which weic irradiated as lense particles. The results of the experiment were somewhat confusing. in that sorite camples which were expected (1) fail did nol fail and sime samples which were expected io survive failed. In addition. some pa.i:-le hatches which falled at one exprsure survived a longer exposure. These icsults are still being analyzed. Iradiation and PIF on capsules HT-17 through -19 were alsi cormpleted. These experiments were designed I1) investigate the influence of the very importan" parameler. anisorropy. on particle performance. Thi experiments were conducted on loose coated thoria kernels, with different coating lechniques :ued to vañ the preferred orientation of the L.TI coating hetween 1.0 and 1.7 . The generat trend noted in examining the results of this experiment is that amples with BAF values greater than 1.1 survived at low temperatures but failed at high temperalures. The low and high temperaiures are presently defined as specimen holder temperature's of 900 and $1250 \% \mathrm{C}$. hul the actual tempet..ures of the colated particles are several hundred degrees higler.

7.3 Irradiations in the ORR Core Facilities. The ORR core facilities were completed during the reporiing period, and irradiation testing was initiated in each. The 
C-3 position was used io irradiate the $G A C Q_{i-1}$ experiment. which was designed (o) test graphite samples. This experiment was sompleted during the reporting period and the irraliatod material relt:rneu to GAC for examination.

The E-3 pusition was utilized for a jount ORNL GAC ciated-particte fuel experiment. The G.AC gortion of the experiment has been desigmated $P I=Q$ and the OR. IL partion OF-I. The entire apsule is alsu desig. nated Of-1. The upper two-thirds of the capsule is ociupied by PI:Q and the lower ane-third by OF-I The OF-1 ispsule was still under irradiatiox. at the end of the repurting beriod.

7.4 Irradition Tests in the ETR Capsule Facilities. All GCR Program irradiations in the ETR were com pleted prich to the heginning of the reporting period. Postirradiation examination and anjlysis of the $H$ capsule experiments were completed during the period. and a topical report was issued.

Pustinadiation examination of two ORNL specimens irradiated in GAC capsule PI $\mathrm{N}$ was also performed during the reporting period. These specimens : ortained fuel similat to that irradiated in the HRB-3 experiment described in last yea:'s annual report. There wax substantial thermal nugration (amoeba) of the SAR fissile particles in thrse specimens. No such migration was noted in the HRB-3 experiment. On the other hand, no inigation of the thoriacontaining fertije fuel was noled in PI 3N. whereas it was noted in HRB-3.

7.5 Recycle Test Elements in the Peach Bottom Reactor. If the seven recycle test elements (RTEs) initially inserted into the Peach Botlorm Rextor. one element (RTE-7) was examined prior to this reporting perind. Examination of the secind element dischaged (RTE-4) was begun during the reporting period. The third element discharged (RTE-2) is awaiting examination. and the remaining four elements will be discharged from the reactor in the fall of 1974. The PIE of RTE-4 had proceeded only to the point of dimensional inspection and visual examination of the fuel rods by the end of the reporting period.

7.6 Nuclear Analysis in Support of Imadiation Experiments. Neution fluxes and unit reacior: rates have been measured for several of the experimsen:d facilities used to irradizie GCR fuels. The following facilities have been studied during the reporting period: peripheral target positions in the HFIR target region (used for HT capsules), the RB-5 and KB-7 facilities in the HFIR removable heryllium region (used for HRB capsules). the VXF-13 facility in the HFIR permanent heryllium region (used for preirradiation of HRB capsules starting with HRB-7). and the C-3 and F.-3 facilities in the ORR core (usced for fuct and traphile :xperaments).

7.7 Capole Thermometry. Fyperinkents have been conducted in firur HTCR iuel HFIR :rradialion apsules (HRB-3. 4. -5. and 6) to ketelop impiosed tempersiure sensurs for the 1000 to $1500^{3} \mathrm{C}$ ter, perature range. Tungsten-h:nium thermix-uples wete used ti meisure fuel certer-line temperatures in HRB-3 and 4 : thenium pulsetho ulirasonic inermometers (IST) were uscd in HRB-5 and 6. Methods for measuring and correcting for decaliostion of the 1,00 types of thermometers were developed: thermocinuples were :orrected by the use of l(x) resixtanke measurements. and UST's were corrected by measurements made during eactor thut. down isthermai conditions and by pertirradiation slibration updating. usirg an in-poxl whole-apsule clibiation fumace. Multijunction. multikxp tungsien. rhenism fuel ienter-line thermocouples were designed and buri: for the striceeding experiments HRB-7 and $-x$.

7.8 Perfermasce Evaluation of Fuets. The $\mathrm{H}$ ispsules described in Section 7.4 provided some unique prohlems of performance evaluation. The capsules wrie irradiated for four cycles in the ETR and removed from the reactor at the end of each cycte. The iapsules were accidentally inserted into the reactor upside down at the beginning of the fourth cycle. causing very high cemperatures in the half of the capsule rasigned in operate in the low-nux end of the core. Thi- plus the lack of instrumeritation in the experiment and tice very interesting fuel performance characteristics noticed during PIE of the experiment. precipitated a very extensive analysis of this experiment.

\section{Prestressed Concrete Pressure Vessel (PCRV) Devekpment}

The thermal cylinder experiment is a relatively long-ierm rest of a one-sixth-scale single-cavity PCRV barrel section model under a combination of loadinga simulating HTGR nperaling conditions. The results are used Io evaluate the capability of existing analysis methods to determine the stress and strair behavior of complex structural models.

Since termination of the vesse! operating period simulation in December 1972. which culminated with an off-design hot-spot tesl. the model has heen dosassembled. sectioned. and subjected to post-mortem studies. Although the concrete apparently retained its basic integrity as evidenced by complete absence of structural cracking. the inner row of axial prestressing tendons suffered severe corrosicn cracking that led in most cases to failure of one or more wires. The cause of the tendon corrosion and subsequent failure remains io 
be identified. During the hot-spul experinent. a snall semikircular aica of ioncretic unruediately adjacent is the heating element experinixed a substantial reducism in strength as determined using a siteromeler

We have also compared the experimental dato frem the model stress and stean gages with alculated resulis whtained us:ig the SAFE.CRACK tinite element analysis computer pringram. Data ihtained frum funitioning strain gages were ti gavd agseerrent with each other as well as with calculated results. The analysis generally tended "o underestimate heating strairs and to overestimale methanial loading strains. The titanium. embedment stress cells behaved inconsistently at times. however. they generally munitored lower stresses than the corresponding values calculated for meihanikal loxdings. The recults if cimplemeniang gas evaluatuns made using coxnpanion concrete cylinders are alsi dsiussed.

The nuclear nosisture probe used to monilor the thern.al sylinder moxket was calibiated at Waterways Exper ment Statiun (US. Army Corps of Engineers). Exrispi for a signifiant loss of monsture from the core regi on of the moniel. little if any mizasion of nivisture was menitored during the thermal oylinder experiment.

\section{HTGR Structural Materiats Imestigations}

A program was iniliated in lale $19 ? 3$ 10 investigalf. the properties and hehavior of HTGR structural alle ys. As presently conceived. the prongram is divided into four related areas civering high-lemperaltire mechanical properties. weldiug. slnuctural design methods of HTGR steam-generator and priman-circuit materials. and sleam currosion. Experimentai work is in progress in the mechanical properties and corrosion areas.

\section{HTGR fission Product Technology}

10.I Muthematical anolysix of fission product release from pyrocarbon-coated perticles. Diffusion equations applicable to cesium release from pyrocarhoncoated fuel particles were reviewed. Equations for slab genmetry weic compared with ti. ise for spherical geometry in order to simplify the solution of diffusion problems involving a depleting potential. Equations were also developed in cover the case of c cons ant potential changing io a depleting potential.

10.2 Postirradiation mesurements of cesium release. Annealing experiments on separated components of coated particles revealed that sone fraction of cesium is permanently trapped in the kernels during annealing experiments. An unpredictable surge in release rate was دșa thsierved during sume anneals. An apparalus for Ie.r. wing inceremenls of the ratings in order to wbiain concentralion profiles has been scristructed.

10.3 Status of eximation of cesiem retese from Bisocoated foets during irradiution. The fraclional release of cesium from reference Biso-icaled fertic particles luring irradiation was alculated using best estimates of the diffusion coefficient for cesium in the coatings and the expected fue! temperature distribution. This exilmate is sufficiently uncertain that more complete limits for HTGR conlant activit must be determined and in-reacter release measureinents mads before deciding unequivocally that Biso coating will perform satisfactorily.

\section{HTGR Fuel Chemiatry}

11.1 Mas transport in fuet paricles in a temperature gradient. The work durirg this report period dealt mainly with theoretical and experimental analyses o: mass transport effects. such as kernet migration. in ITTCR oxide fuels. These Inslyses were advanied sienificantly hy the arailability of experimental measurements of kemel migration from the fuels irradiation program desiribed in Secionn :.4. In-rexitor experimenis with carbide- or nitride-containing $1 \mathrm{O}_{2}$ particles were initiated in evaluate the poscible ritigation of kernel migration by these means.

I1 2 Gas pressure measurements in coated particks. A pringram for the measurement of gas pressure and oxygen poiential in ir.adiated fucl particles was developed. and the expenmental apparatus was consiructed and lested.

11.3 Chemical compatibility of fuel and fasion products with cooting. Lli-rature surveys were petformed Io deliseate polenlis chcmical means for improving the retention of cesiuri:. harium. and strontium by oxide kemels.

\section{PART III. HTGR SAFETY PROXRAM}

\section{HTGR Systems and Sufety Analysis}

The major activity during the year was preparation of a Vational HTGR Safely Program Plan in cooperation with the General Alomic Company (GAC). The plan. completeu in December. was suivequently divided into two parts and converted into a Planning Guide for IITCiR Salety and Safety-Related Re:earch and Devel opment. the latier heing identified primanily with the HTCR base program. 
Development work was sonunued on a metlend fior Jiagranmatk presentation and iogal analy sis , f ariJent xeyuences. and i new approwh was alippled iaxed on a small number as consihidated intristing exents

1 iompu:atoonal mudet for dexirihing fission pouduct Jitiusion and transport in HTGR cires was in iutred frinn GAC. alapted ior use un ORNL imputers. tested. munfifict and extended in sume detaik, and appliced lo a feu benti-mark pruhlems. It will v.bsixquent'y he used ror andysis of pastirradiation measur. ments of fision product distributions in the Peach Bultum Reatur tuet and prirsary circuit and for studies of fission product rekease critera fior bra HTGR sures. Hsw in connetion with the ubservalions on Pexh

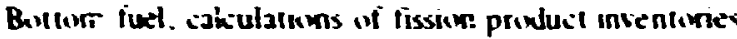
were performed and the resuils compared with expertmeni.

\section{Fission Proviuct Technology}

Priposed ragulalo!: restrictions of 15 mren sear on thyroxd duse rexulting from release of indine. if ex tended to HTGRs. will limit the prinuan ixolant content of udine to perhaps in $\mathrm{Ci}$ of $131 \mathrm{l}$. Therefore. wome iodine remowal from the helium by surfaces is required. Since thermuntynamic elculutions indicalic utat satiaes may he oxidized. aourptuon iswiherms were whisined from measurements of indine sdsorption in $\mathrm{Fe}_{3} \mathrm{O}_{4}$ : these messurements indieate that surtace apaily limils could be approxhed as uperation of the reacior continues. Relalionships desirihing indine ex. thange between gas and surface indkaled that if suich processes incurred at usetul rates. surface sapaity requirements winuld be usefully redu:ed. The possinility of removal by depusition of volalice metal indides was assessed. and it was liound that indide stabilities increased in the order of $\mathrm{Ni}_{\mathbf{r}}$. Fe. $\mathrm{Cr}$. and $\mathrm{Mn}$. The desorpinn of lusine adwirhed in iron punder was measured at temip:s:atures up to to0 ' C. Interpectation in terms of parlilion conefficients suggested that release duing poslulated depressuriation kidents might be usefull; limited

lixdine and cesium disinbuinons were delermined in the Pearin Bufiom ITTGR conlant ircuit. Helium leaving the orre contains very little arganic and dusthorne iodine: these forms appear downstream of the steam generator. Cesium from core 11 appears to be entering the primary ionler circuil al a rale of aboul I Críyess after tomo effecilive full-puwer days of operalion

\section{Primary Coolant Technology}

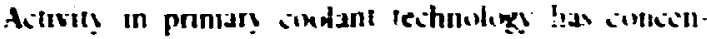

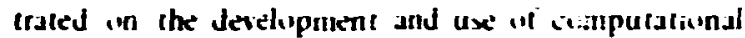

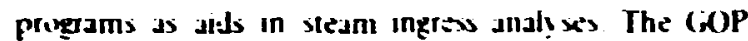
ciake. diseloped at Bultetke Paitic Nirlouest LahordIorics. has been adapted fur use in \& CDX (YBI:R :4 systen: this ciole is to be emplunded in an effirt tos eslablish the semifieanic of radiolytio rejetions an ciolant compessilien using Fon St Vian startup data. The OxIDE-: inde. Jeveloped al (ienkeral Ilemik: Cimpany. has been annertied fior use on an IBM in0 91: this cinde will be emplinged is an ald in the identification of ermponents that are particularly sulnerable to ucdative altak.

\section{Confinement Components}

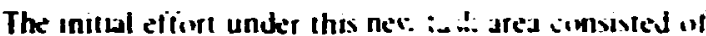
a preliminar revieu of recent literalure an prestresued

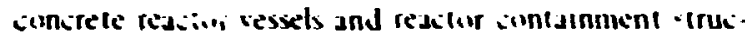
tures to pronde harkgrinend material isyuired for the HTGR Safery Progranı nlur.uing gunde

\section{Primary-Systems Materials Technology}

Study was intialed lo identify those areas related I" ITT: $R$ primary-ssitem structural maierials thai mas have a significant intluence an salets. As part of this effurt. a repurt on the slatus of HTCR metallic structural materials is heing prepared. Plans have heen develuped firr the rei...wal and metallurgieal examina. turn aif selected components of the Peach Bullom profory pe HTGR

\section{HTGR Safety Studies for the Directorate of Licensin}

This work was initiated in Nivemher 11972 at the request of The Gasfinded Reaniors Branch (GCRB) of the Direclurate of Licensing (DOL) in support of their response of licensing applications for HTC $; R$ plants. An overall goal of the wiork was in develop and provide io the GCRB certein analylical methods. ssusily in the form of somputer programs. for use in theit evaluatuons. The effort was redirected in Septemher $107.3 \mathrm{hy}$ the request (1) evaluate specific sections of the first general lopical licensing report submilted hy the Cienera: Atomic Company (C;AC). 


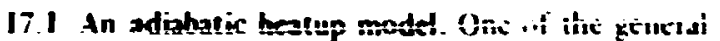
problems under study required the detemnanation of semperatures throughoul the core of the reator following a complete loss of forced convective comblant t1)u accompanied by a simul!anecus r acitor trip. The exthent deceloped for this aliulation was hased on a seneral multidimensional heat conduction computer prugram alled HEATING that existed at OK. $L$. The developments necessary for the application of this program to the problem involved a study to deterinine the brast compusite representation of the core and the selection of the appropriate initial remperature distributions and buundary conditions. The study progressed through a series of one- and two-dimensional models. and the primary computations were performed using power distributions and dimensions given for the core of the Furt St. Vrain Rexilur. since this was the only desigi for which detailed inturmation was available.

17.2 Coupled conduction-convection model (CCCM). To determine the temperatures developed in the core of the HTGR during periods of furced convective how. a convertive calculation was coupled to the conductive calculations existing in the HFATING program. Io incorporate this iealuit. it uas necessing to assume a specific geometric moxdel. this eliminated the ability to specily the general geometric uptions of the HFATIXG program and maxe the alculation specific for this representation of the HTGR core Calculations were performed for operition under fullpower conditions for certain anges or input parameters. Computations were also perforned for the conditions of reduced coulant how uricer emergency conditions. and the results were compared with the computed results presented by GAC in the licensing topical report. Agreement was good when the coxlant flow was relatively large the nominal caparily of the core auxilian cooling systems): however. the singlechannel model was unable to predict the redistrihution of now due to huoyancy forces deveioped at very low flow rates.

1-.3 Failure of fuel particles under HTGR operatin: conditions. In the evaluation of the upper operating limuts ior the HTCR fuel as specified in the licensing topleal report. reviews were made of hoth he effect it mass transport within the fuel kern! " the "Amon ha" effectl and nethods of estimating the sio"sses developed in the particle coratings as a funcition of irradiation exposure and temperalure. Both of these effecis were characteriked hy specitic models. anc a review of physical property data anu proposed meihods of analyses was made. In particular. thice existing cimputer prugrans STRETCH. TRISO. and STRESS:- were execuled. and the resultant predicled behavior was sumpared. andyzed. and recimiled.

17.4 Sensitivity of HTGR fuel performance to material properties and particle desig. As a contunuation of the evaluation of the operating limits fi: :he HTCR fuel. a sludy was made of the sensitivity of $H T C R$ fuel performance as a function of material properties and particle design. The cumputer program STRESS-2 was used for this evaluation. since it had been shown to produce results that were comparable to the results of the wher cudes when appripriate input parameters were selected. The aniysis indicated that for the Trisi particle. with the exception of the PyC irradiation creep and deformation characteristics. the influence of materials properties on predicted performance was small. It was found tlat design considerations sach as the relationship of the kernel volume to buffer volume were most important.

175 Andysis of tritium distribution and rekase in HTGR. A computer progeram was written to represent the source terms of iritium in an HTGR system. With the specification of diffusion and reprocessing rate constants. the relative movement of :he tritium through the sysic.: and its inventory as a function of operating history can be calculated.

\section{PART IV. GAS-COOLED FAST REACTOR PROGRAM}

\section{GCFR Irradiation Experiments}

In the joint OR.SL-GAC-ANL irradiation testing program for the evaluation of (L: $: \mathrm{PuO}_{2}$-fueled metal. clad fuel rods for the gasionled fast rezctor (GCFR). current emphasis is on the testing of fuel rods of the vented-and-pressure-equalized concept. the present reference fuel-rind design fo; the GCFR. This concept eliminates the large pressure differential across the ciadding by venting the fuel-rod interion to a pressure. equaliation system and at the same time henefits from inlornation heing developed in LMFBR fucl-rod testing progran.s.

18.1 Description of GCFR-ORR capsule GB-10. The current irradiation test. capsule GB.10. and the pre. ceding one. capsule GB.\%. were designed (1) permit an initial evaluation of the owerall performance of the vented-and-pressure-equalized fuel rod. Various aspects of the GCFR pressure equalization system are also neing studied in these tests. The test conditions are typical of those expected for a GCFR fuel rind except for the ahsence of significant fast-neutron exposuic. 
Pisiurradiatiess examinalion of like GB-4 tuet rind, whih was irratuied it a peak fourer level of $14 x$ ill if $w$ a fuel hurrup if approxinustely 54.000 IWd metni an oi heay metal. contunued ai AXL and GAC into calendar sez: !o:3 The GB-4 exper:ment prowided sutsontal infornution on the fiscien minduct release behavior to be expected from the GCFR vented iurl rind. and the results have been used in many aspects of the GCFR pressure equalizallin st stem desizh.

The GB-il) luel rind. similar to GB-9 bul desiened u:th greater capability for measuring fission prenduct retejse and transport. is treing uperated in three suciessise peak power steps: 12. 13.5. and $14.8 \mathrm{~kW}$ ft. Sweep line innections to the GB-10 rind perinit tission priduct release measurements inder as mian: as !en ditferent sweer flow modes. including pasiags of the sweep through the entire rod. which simulates a leak in the cladding of a GCFR fuel pin.

18.2 Results from irradiation testing of capsule GB-10. Steady-state fission-gas releace rates have hern measu.ed as $a$ function of time at the 1:- and 13.5-kW if power leyels under all the planned sweep linv modes. The fissiun-gas release hehavior uhierved during the operation of GB-10 to date has beren cinsistent with llat ohscrved during uperation uf apsule GB-4 in th 1 there is a strong continumbs release during operation that is quite sensitive to power level and temperature changes. No significant activity bursts have been observed during shutdowns and startups.

Radiation surveys of the GB-10 effluent sweep lines in the reactor poul and value boxes at reator shutdown periods have indicated $\$ 00$ Io $700 \mathrm{mR}$ hr of long-lived activity on the lines and up (1) $12 \mathrm{R} / \mathrm{hr}$ at a junction box where welded couplings exist in the sweep ines. $A$ segment of the effuent sweep line that was remowed from the system while installing additional valving read $300 \mathrm{mR}$ hr. The principal activilies found were due $\mathrm{t}$ ${ }^{131} 1{ }^{1.14} \mathrm{Cs} .{ }^{13} \mathrm{Cs} .{ }^{140} \mathrm{Ba}$. and ${ }^{140} \mathrm{La}$

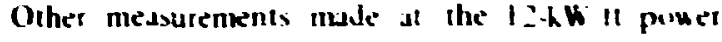

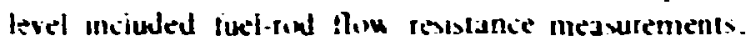
hdine-depasiliın neasurements al a fuel hurnup level if I8.I(10) MHd metrik lon. and (toservatuons of deras

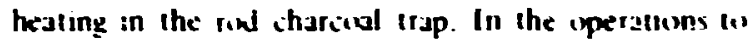
date. we hwe seen no signticant lission prinduit decay heating of the trep. Veutron rediography at II kW ft

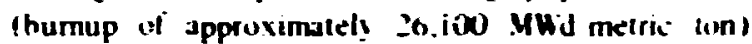
showed that the Y-in.-long mixed-oxick fuel column had seltled abinut $\%:$ in.

\section{GCFR Steam-Gencrator Modeling}

General Alumk Company personnel have develiped and used a digutal smputer coxle lin simulating various gase.:Heú lasl hreeder reactur (GCFR) system Iransients. The ni:del of the once-.tringh steam generator used in this sode was. of necessity. niv very detailed or fine structured. This fact. plus the finit that little computer simulation of ince-through stean generalors has heen done. led in some duubts as fo the adequary of their steam-kenerator mudal.

In response fo the above-mentioned situation. a very detailed midel of the once-thrugh stesm generator has heen developed un the ORNL hybrid computer. A test transient was run an buth computers with similar results.

\section{GCFR Core Flow Test Facility}

The Core Fluw Test Facility for the Gasforded Fast Reactor (GCFR) development program will provide a systen in which helium at appropriate flow. lemperalure. arid pressure condilions can be circulated iwer electr artridge heaters that simulate a GFFR luel assembly. The proposed test program will study the response of fuef assemblies Io design steady-state and transient conditions. During 1973 the facility requitements were defined, and work on a conceptual design was initiated. 


\title{
Part 1. Thorium Utilization Program
}

\section{HTGR Reprocessing Development (Subtask 110)}

\author{
K. J. Nots
}

\begin{abstract}
Reprocessing is that part cí the High-Temperature Gisfingled Reactor (IITCR) firel recycle in which spent fuel clements. after couling abuut six montins. are treated Io recover the $233 \mathrm{~L}$ in a furm suitable for subseyuent refabriestion min recycle fuel. The ubjec: ive of this subtusk is (1) develop the technolong necessury firr the design and uperation of the HTGR Fuel Reprencessing Pilut Plant (FRPP). which is in be built at the Idaho (hemial Priceissing Pant (ICPP).
\end{abstract}

The major steps in reprocessing are !cad-end reproc: essing funil 11011 . which includes ilus'ing. burning particle separation. and dissolution: so lvent extraction (unit 1102) to scparate the thoriu-a. uranium. and lission prodicts from each other: of -gas cleanup funit

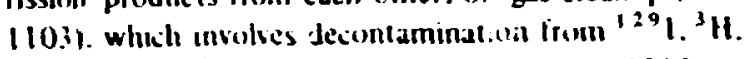

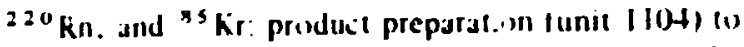
cunvert the ${ }^{23}{ }^{1}$ (1) a suitable form fo shipment to the Refabrication Plut Plant al ORNL: and waste treatIIknt and disposal funit 1105 ) is convert the various waster II a firm suitahir $\therefore$.., eventual disposal. Our wheduled develupment 1:tivity this past year was in the areas of head-end reprox: ssing and off-gas cleanup.

\section{I.I GENERAL DEVELOPMENT - 1100 [GENERAL ATOMIC COMPANY (GAC) LEAD]}

No activity scheduled

\subsection{HEAD-END PROCESSIN, - 110: (GAC LEAD)}

\author{
V.C. A. Viughen
}

\subsubsection{Hut-Cell Studies \\ C. L. Filczerald}

These investigations. which involve hot-iell burn-leach or burn-grind-burn-leach studies if irradiated HTGRtype iuel specimens. are designed to characterize the behavior of the varius nuciides of interest throughout the various stages of processing. Experiments were completed this repor! period with specimens ubtained from a recycle test element ${ }^{\prime}$ (RTE) and recjece luel test capsules $\mathrm{H} \cdot \mathrm{I}$ and $\mathrm{H} \cdot \mathrm{I}^{2}$ '

Recycle test element 7 (RTE-7) was removed irum the Peach Bitlom Reactor after 252 effective ful!. power days. The average element burnup was estimated by GaC 10 he 2.38' FIMA. A peak last-neutron flience of $\sim 10^{21}$ neutrons $\mathrm{im}^{2}$ was aciumulated. ${ }^{3}$ The

1. R. P. Moriswetre and K. P. Sieward. Recycle Test Element Desien. Fantication ond Assmbi. GA-10109 iscptember 19711.

2. GiCR.TL: Programs Annu. Progr. Rep. Sept. in. 1971. ORNL-4760. pp. 6566.

3. GiCR Progamis Annu. POop. Rrp. Dre. BI. 1972. ORILL. 4911.p. 116. 
fuel iombinatlon uxed in sur experment cintatined large Trisociuated The: iertik particles and smaller Trisomivated l(C: fissile pattikles Its pe 1). whish is a combindturn quite sinuiar to that issed in the Firt St Virm Reditur.

Reiyle tuel test aspsules H-1 and H-2 were urabialcd in ine Engnecring Test kedilor (ETR) to the tuil Jesign tast then:e of $i \times 10^{21}$ neutrons im during

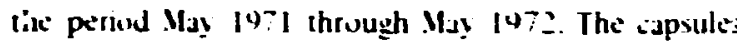
were dicidentally ioverled during the last quarter of the irradatior. periud. which eaused stgninizant physcial damige to a number of the spicinkens. Of the less damiged speimens troull thex: reicle iuel apsules. those selected for ou: experiments were $112-2.112-3$. and 12.4. The tucl combinations sontankd in these sperimens dre. respectively. 10 : fissile particles.

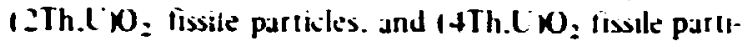
cles. All sontain $\mathrm{ThO}_{2}$ tertile particles. and all puticles are Biso coated. The tertile particles approxinute thuse planned for large ennmerial realors. Experments with H:-: and HI-4 were completed during this report period.

\section{RTE-7 experiment}

Procedure. The primary purpus: of th: experirkent was to ubtain fissiont-gas relcase data using improved

4. Ibid. pp. 37 . equipment ishown in Fig. 1.1 tor gas Irdppilly and tiitration of particulates. Al carlier axpernment with this sume fuel was repurted last leal ${ }^{*}$ The tuel rod was

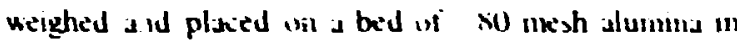
the buttum of the burner asxembly and burned usms d: oxygen tlow rate of iON $\therefore$ mm. The cirnbustion guses were anlyzed by passing them through $(1)$ a $20-\mu m$ purc sintered titetal filter and a $0.2-\mu m$ pore silver menibralle filter. buth maintained at $500 \%$. and then through snuther $0.2-\mu \mathrm{m}$ silver menibralic tilter. I Celman ubsolute filter. and molecular sieve iraps llior tritum removal). all mantained at ambient iell temperature The gases were then passed through $\mathrm{CO}_{2}$. $\left(\mathrm{O}\right.$. and ${ }^{\text {st }} \mathrm{K}$ : delecturs. a CuO uxidizer. and additional mole: ular sieve traps to ensure cumplete tritium removal, th...14. hh a wet test meter. and then intw a bug. The burner ash was separated into a $+45 \mathrm{~m}: 3 \mathrm{sh}: 354 \mu \mathrm{m}$ ) fertule irjition, a $+\$ 0$ mesh $1>177 \mu \mathrm{m})$ lissi : iraition, and a 90 mesh $(<177 \mu \mathrm{m})$ tines iraction consisting of the slumins and broken poiticles. The fines irjettun was leached twics with Thorex reagent: the lertile and tissile trations were edich ground. burned. and kadehed twice with Th:rex reagent. The +45 mesh fertele :ration was held at $850^{\circ} \mathrm{C}$ lit I hr after burning and the $+80 \mathrm{mesh}$ tissile iraction was held at $850^{\circ} \mathrm{C}$ fir $10 \mathrm{hr}$ after completion of burning to determine if additional lisson products were evolved. During secondary burning of the lertile and fissile fractions. Iwo $20-\mu m$ sintered metal filters vere used: all other ieatures were identical with the intial burming operation.

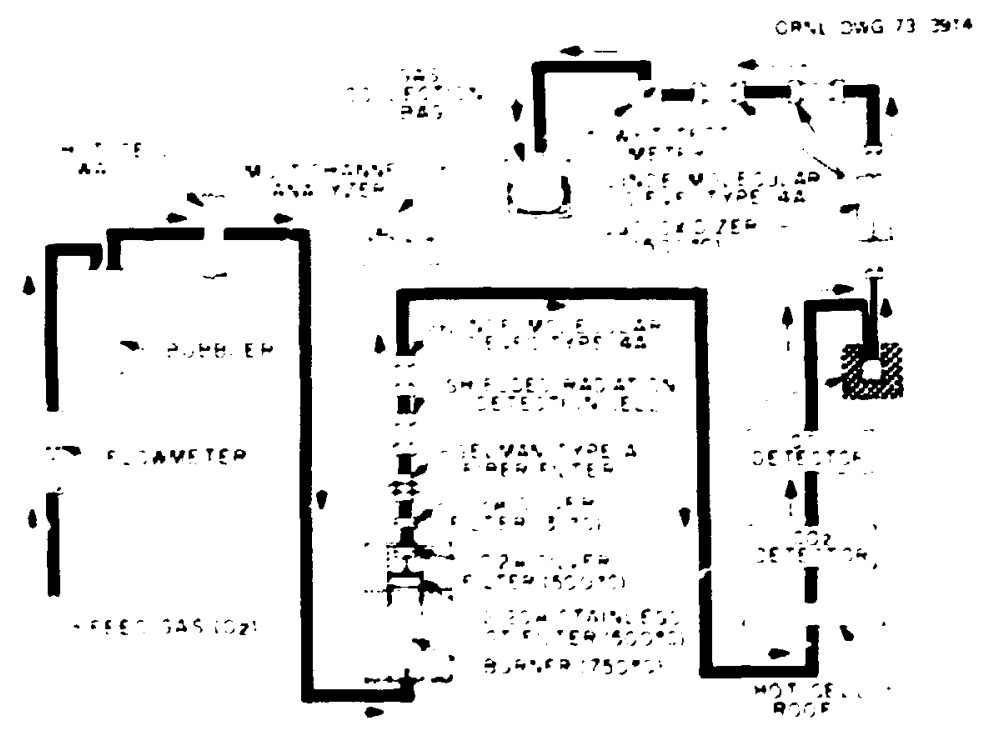

Fig. I.I. RTE-7 fuet stick burning. 


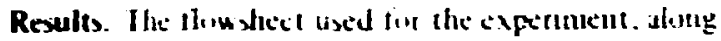
with thit netghts of the matcrials inwolved in eath

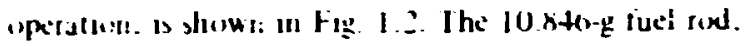
the $x$ innd if the $6 \%$ reds removed tim hole 7 . was

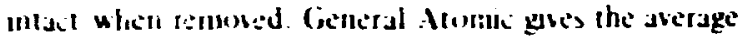

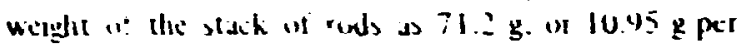

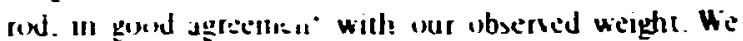

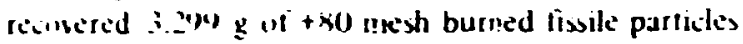

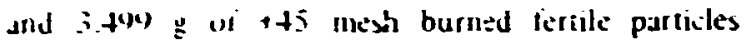
(burned dunil is the SiC cuating). These weights cricspond with 5.215 and +250 g of fissile and tertile

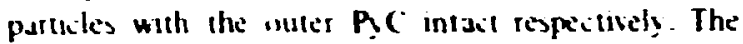
Inial of thex weights 19.46 ol agrees with the stick

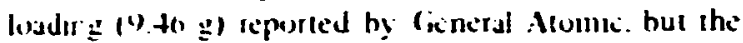

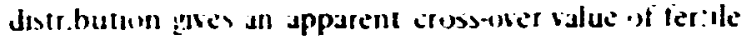
forisole parthles of S.12:

Table 1.1 gises the distribution and amounts of

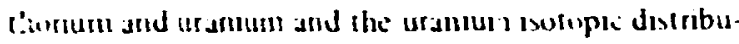

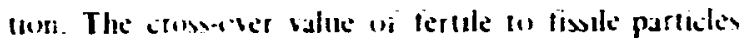

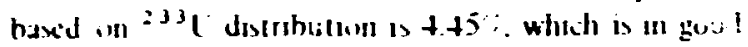
strement with the value whismed from the weignt distributurn above. Additunally. the stossater value of fissle en ferille based or 235 destribution is $005 \%$.

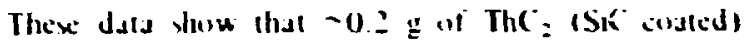
pused the +45 mesh sireon and was retained with the

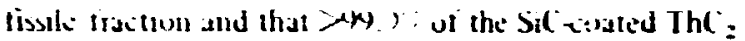
particies se: $<<5$ and $>x($ ) mesh. Subs yuent thorium analy sts of the tissle dissolver solutions indicaled only about 3 : cross-urer. but the mitemal consisterit! , th the uranum balues makes them dipear more realistic ti.jn the thornum values. This is apparent from th: 1.450 .5 of therium recovered from an inpit of 2.214 s witr ar. estimated $1^{\prime}$; burnup. This ins:cates a thorium materlal

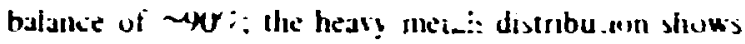
that the discreparley is in the fertule if itton. Pussuble explanations are handing losses or lixsiong product inlerference with the insis thal procicdure. The urinum

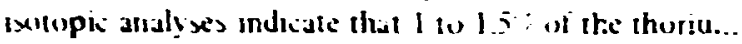

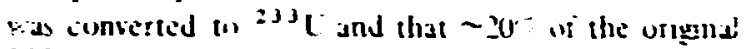
$23 l^{\prime}$ tissiuned.

Fission-gas release. The amounis nt released tritium

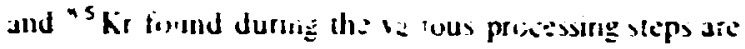
shown in Table 1.2. The lotal quantities. appressed is

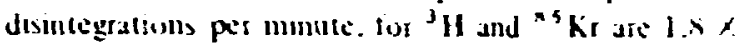
$10^{9}$ and $1.5 \times 10^{1 !}$ respecilively. These results difier irom those of an: prebious RTE-7 experiment in twis slgumint respects, mote Was a llected this time and the ${ }^{3}$ II destribetan was ditierent. This incresse is Jue

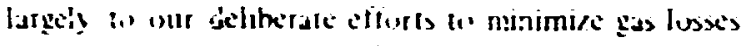
and to sbold hydrolysis af the thorium an.j urjun

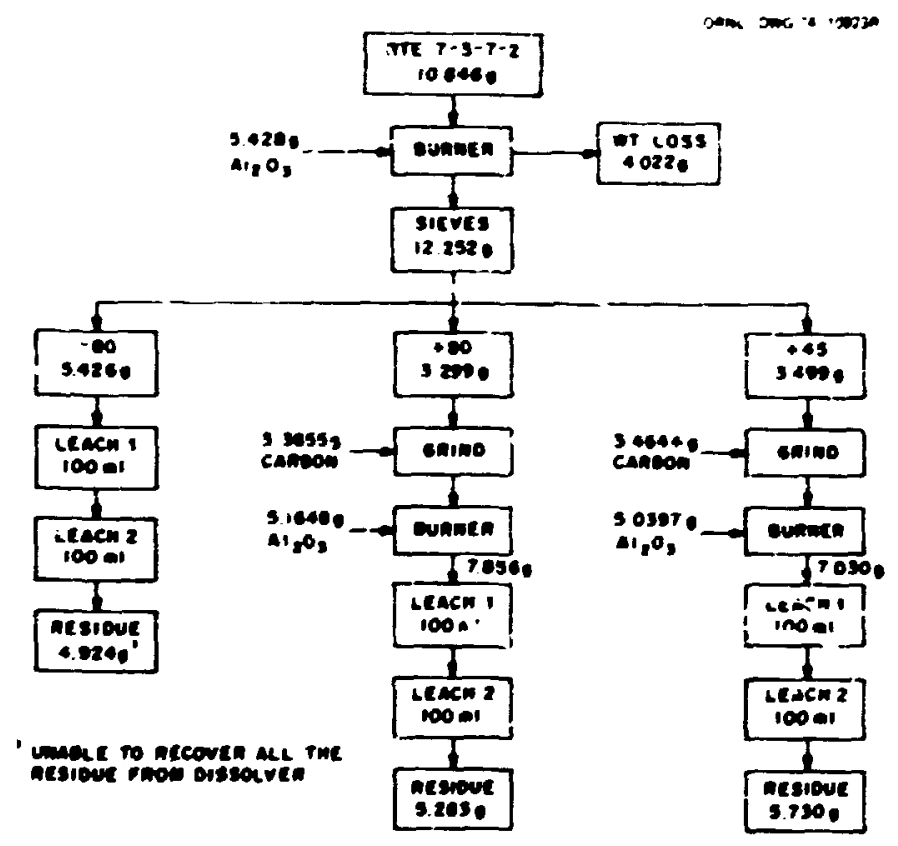

Fi. i.2. Flowsheet for RTE.7 experimen:. 
Tabke 1.I. Cranium and thorium distritus ton fur RTE.-7 experiner.t

\begin{tabular}{|c|c|c|c|c|c|}
\hline \multirow[b]{2}{*}{ Iswtipe } & \multirow{2}{*}{$\begin{array}{l}\text { Preirradiation } \\
\text { as - narged } \\
\text { ngrad }\end{array}$} & \multicolumn{3}{|c|}{ Ponterradiation } & \multirow[b]{2}{*}{ rot-l } \\
\hline & & $\begin{array}{c}+45 \text { fractoll } \\
\text { (E) }\end{array}$ & $\begin{array}{c}\text { +SO tration } \\
\text { (2) }\end{array}$ & $\begin{array}{c}\text { so frats:it } \\
\text { (t? }\end{array}$ & \\
\hline$=33 \mathrm{C}$ & & 0.02245 & 0.00107 & $0.0(1)(4) 5$ & $0.11+07$ \\
\hline$\because 39$ & $0.1^{2}+407$ & 0.00104 & 0.01456 & $0 .(n)(0) 1$ & 6.00561 \\
\hline$\because 4$ & $0.566=0$ & 0.00023 & is. 4 ith! & $0.004: 31$ & 0.45310 \\
\hline$=\cdots \cdot \mathrm{C}$ & 0.00107 & 9.04001 & $003+65$ & O.DNo1 & $0.0346 ?$ \\
\hline$\because 00$ & $0.035+5$ & $0.007: 1 b$ & $0.02135 b$ & $0.000 \times 810$ & $0.035+50$ \\
\hline Iutsl & $0.60811^{1}$ & 0.03154 & $0.5,6: 4$ & 0.00718 & $0.55+46$ \\
\hline Thoriuril & 2214 & 1.87240 & 0.0708 & 0.0131 & 1.4563 \\
\hline
\end{tabular}

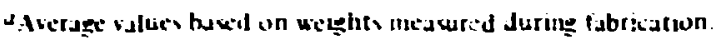

bislues beced un prerradetion ins:upti inalyses: all other postirradiation values were medxured.

\begin{tabular}{|c|c|c|}
\hline & 3 & $\cdots r$ \\
\hline rotsl :dis min! & $1.746 \times 10^{\circ}$ & $1.53 \times 10^{\prime \prime}$ \\
\hline \multicolumn{3}{|l|}{ Percent of totsl in: } \\
\hline Iritul burn & 26.11 & 0.129 \\
\hline bioskdh & Olin & 0.010 \\
\hline fertile frsic(1) n $(+45)$ & $0.0 n$ & \\
\hline Girmd & 0.06 & 1.281 \\
\hline Burn & 13.23 & 3.20 \\
\hline Soush & (i. 21 & \\
\hline leach & 0.02 & 0.020 \\
\hline Toisl & 1352 & 3.461 \\
\hline \multicolumn{3}{|l|}{ lissic iracteon i+80: } \\
\hline Cirnd & 0.01 & $1: 3.016$ \\
\hline Burn & 56.77 & 77.377 \\
\hline So,sh $12 \mathrm{hr})$ & 2.24 & \\
\hline Sordk $(8 \mathrm{hr})$ & 1.64 & \\
\hline Liah & 0.04 & 0.125 \\
\hline Total & $60 .+2$ & 96.518 \\
\hline
\end{tabular}

uldesgndtion 7.3 .7 .2 indigates RTI-7. fuel body 3 . hole 7 , fucl red :

arbides durials. the grinding operations. The latter was accomplishe's by grinding in a clused grinder with a peuge al argon t"; $\mathrm{H}_{2}$. The purge gas was then passed litrongla a hot (uo) oxidation unt fto convert the $H_{2}$ and any 3l! t" waler), and the water was removed with molecular sieve traps before the gas was rollected for "s kr antasis.

The ${ }^{3} / 1$ distributuon is different his time in two tespeils: more was relealsed during the handling of the fissile fruction:. Ind. of this fon:in, mist was released during the actua: hurning (and not during a post-burn fulding period as beforel. The new distribution is far filure relizble thon the prior results hesaluse of the special effurs lade to colle: ati libe gese: this time. Based on th: latest data. Iwo prints of interest tre

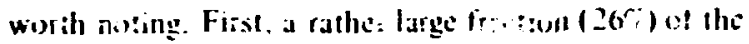

${ }^{3} \mathrm{H}$ was released during a post-burn holding period. second. based on ${ }^{85} \mathrm{Ki}$ release. the fracitint of braken particies was small. so son!c other fiator must aciount fior the ${ }^{3}$ II releas d during intial burning. Thus. onc anst assume that the ${ }^{3} \mathrm{H}$ associated with the matrix carbon is inot cue lo termary fisson but rather is a result ai light element impurities in the matrix andior is adsorbed from the cuolant gas. The ${ }^{3} H$ ho!dup during snd after the lissile fidetuon burn l:ay result from chemisorptio n en uranium :xide and might require long burning limes in order los lewer the ${ }^{3} 11$ conlent to aceptable livels for subsequent "queutus processing.

Fission product distribution. The distriblition of fission products in the off eas syste?n is summariaed in Table 1.3. The iration of each nuclide th: theind its way inlo the off gas syst $2 m$ ranged from $0.644^{\prime \prime}$ for ${ }^{144}$ (er lo 100\%; for ${ }^{75} \mathrm{Se}$. As expected, the fraction of ruthenium was quite high (25.6(2\%). with cesium alsu) lairl: bugh $\left(\sim 6,{ }^{\prime \prime}\right):{ }^{75}$ Se, found only i.: the matrix carborl. mast be an attivation product from ${ }^{74} \mathrm{Se}$. whith is present as an impurity. We estimate that i ppm natural selenitam could aeioment for the observed ofi-gas activity.s

5. (C. W. Kec, personal conmunicallon. 
Table 1.3. Fission prodict distribution (dis/min) in fltce train used ill processing socond fuel rod from RTt.?

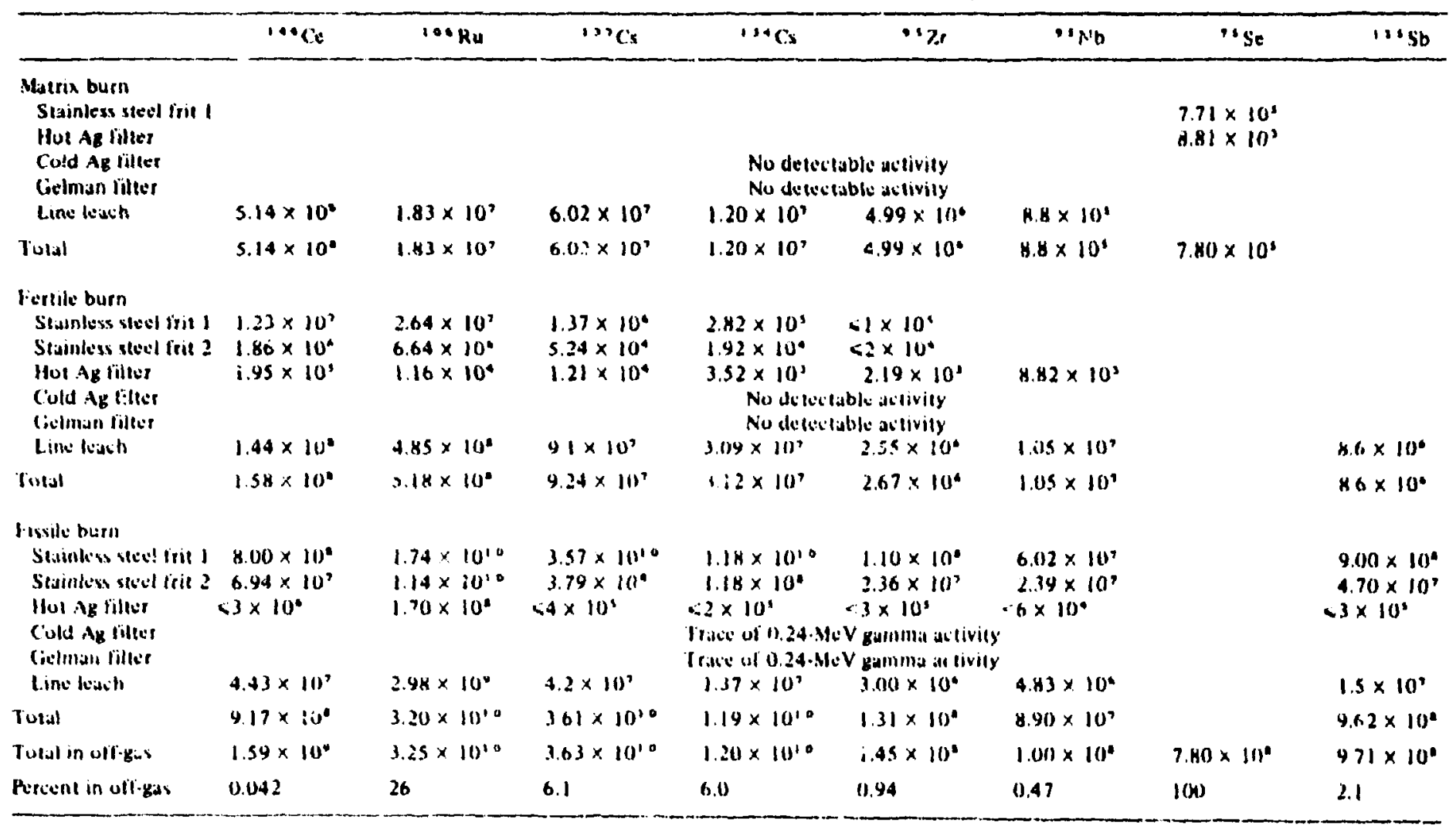


Gencrally. activity lound in the ofi-gas stream is conientrat :d in two plikes: on the tirst stainless steel irit. Fhere it is trapped with coarser partisles los condensation products: and in the line that joins the hot $1500^{\circ} \mathrm{C}$, silver filter is the culd $\left(-30^{2} \mathrm{C}\right)$ silver filter. Where : iondenses. To signiti-ant amounts of ativity reached the second silver tiltet.

\section{H-iapsule experiments}

Procedure. The seneril tlowisheat fir these experi ments was bern-leah li.e.. an grinding step keded). and the spevilis operaitons were $(1)$ weigh. 1 ! burri. (3) sick to xeparate by size, $(+1$ dissolse. and $(5)$ cullext any residues. Enyphasis during iuning was concentrated on $(i)$ recosery and iasideriation of voatile didd snitrained materials in the orit-gases and 121 reduemonaxidation iy ding intended to rorec tritium and

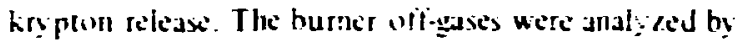
passing them ahrough a $20-\mu \mathrm{m}$ sintered stoinless sted iiller. a tive-st ige esiade impactor. and a (3. $2-\mu \mathrm{m}$ siter membran: filter. all mantanied a: $500^{2} \mathrm{C}$, and then ihrough a water-ieted condernser. anwher 0.2-jm silser meinhrance lter. a fielmali absolute lihter. and molciular steve traps fior tritium icmoval), all maithtaned al ambicnt celi temperature. A pre-burn period at $\mathrm{K}$ ( $\mathrm{C}$ in an inerl atmosphere was used in all aflempl (1) desorb ant lission gascs in the thatsix arbon. Two

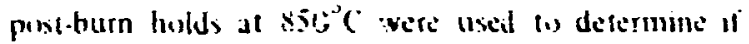
fissint gases that were not relessed promply daring hurning woild the slowily released. Ail gas sicum: antalis J wher $\mathrm{H}_{2}$, or $\mathrm{H}_{2} \mathrm{O}$ (1.a a hubbler) (1) provide isstepic diutun at intium. Thus the octall burning operation consisted uf six stoges:

1. hild at $\times 50$ ( fin i he in $\mathrm{Ar}+: \mathrm{H}_{2}(100 \mathrm{a}$ min) proter la hurniley.

2. hurn with u.ll temperalue ai 750 ( $\mathrm{C}$ in "wet" air at

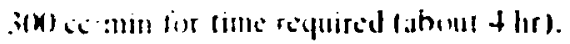

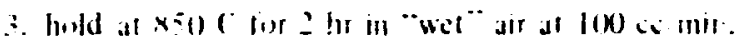

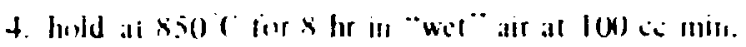

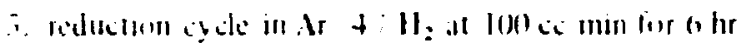
at $x$ ind

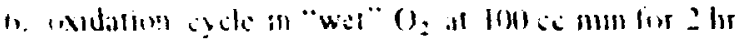
.1 $\times 5018$

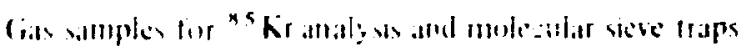

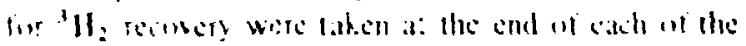

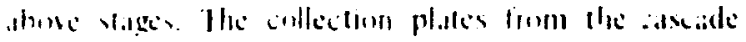

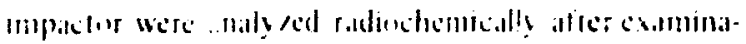

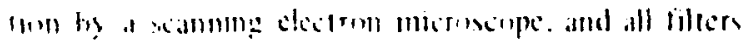

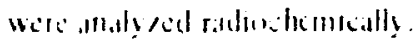

Selective utsoulution of the uramiumbearing fissiie irativins was tested by using builing iullientrated $\mathrm{HNO}_{3}$ prior to dissulution in Thorex reagellt. A similai treatment sequetice vas used for the thoria fertile iractions.

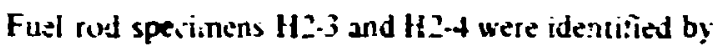
their chemical behavio: during provessing. since the identiliadtion makings ofi t.ie simple iuntainers were :llegibic.

Results. The thowstect used tor the experinents is shoun in $\mathrm{Fiz.} 1.3$. As nentioriced previousl: inveision of the test apsules during the iast irradiation c. cle alised siguticant damage (1) some of the specimens. These particular specimerts cunsisted of several sinall picies and a high perientage of isuse powder. Thus. complete tuel ruals were nut proiessed. and sample weights were about $x(y$ : : 1 a complete rud. Heavy intials recor" shiu that separation of ferrile and lissile tractions with nitric stid was suciessiul in the first experiment $1>0.5 \%$ but not in th: seiond. Material balances lior the first experiment were poor. which indieates that we did not get a representative purtion of the li.:l rud (i.e... We obtained a higher perientage af matrix arbon than normal). Weights were reasurabic for the second experimesit. Isulopic analyses show that abuut $4.3 \%$ of the original ${ }^{235} \mathrm{U}$ fissioned and that aboul $l .8 \%$ of the thorium was collberled (1) 233 ! $\mathrm{i}$.

Fission-gas retease. The distribition of the fission iasses ${ }^{5} \mathrm{Kr}$ and ${ }^{3} \mathrm{H}_{2}$ dearing the various stages of prencising lin lle irst two cxperim!:nts is s'lown in Table I.4. Thess (wo expeilinents were on specimens

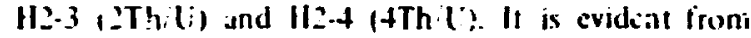
thes" dita that there are ditferences in the krypton and ${ }^{3} H_{2}$ relealse patterms. The significant diflerence in the *5 Kr release is during dissolution of the fissile fiac ion. The majorty of the ${ }^{*} \mathrm{Kr}$ remaining was released with H.VO, dissohtuton in the first experinent 12Th/\%). whercis Ihorex disonlution was recpuired to affect this iclease in the secund experiment (4Thil). Differences stand out also in the ${ }^{3} \mathrm{H}_{2}$ relesse. i.t the pre-hum hold Ar $\left.\mathrm{f}^{\prime} ; \mathrm{H}_{2}\right)$ and in the rediction cycle $\left(\mathrm{Ar}+: \mathrm{H}_{2}\right)$. Thes diffecllos show that fision-gas relejse pallerns all valy wilh the Ih 1 ration in the tissile particles.

Fission preduct distribution. The distribution of selested fission prodicts in the burner off-gases for these experiments is shown in Tabies 1.5 and $i$.6. The bulk if the volatile or entraned material was concen. trated on the roughing filler and in the tiot $\left(500^{\circ} \mathrm{C}\right)$ aligas lines 1 he general distribution is sirialar $(0$ prev..nus ditla. He are still in the process of analyeing the data from the cascad: impactor. nut prelimbary 


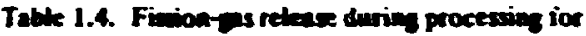
experiments H2-3 and H2-4 (percent of totel collected)

\begin{tabular}{|c|c|c|c|c|}
\hline & \multicolumn{2}{|c|}{$85_{K_{r}}$} & \multicolumn{2}{|c|}{${ }^{2} \mathrm{H}_{2}$} \\
\hline & H2-3 & H2-4 & $\mathrm{Hz}-3$ & $\mathrm{~Hz}-4$ \\
\hline $\begin{array}{l}\text { Pre-bum soak } \\
\left.\text { (Ar \& IF } H_{z}\right)\end{array}$ & 0.33 & $0.8 ?$ & 7.04 & 30.30 \\
\hline Eurn (air) & 49.22 & 59.77 & $6+49$ & +6.20 \\
\hline $2-h r \operatorname{soa} \alpha(2 \mathrm{er})$ & 557 & 1.51 & 2594 & 3.02 \\
\hline $8+h x$ suak $(2 u x)$ & $<0.79$ & 0.86 & 1.68 & 7.36 \\
\hline 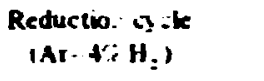 & cois & 0.33 & 0.40 & 8.66 \\
\hline Oudation cyite (0:) & $<0.09$ & c.07 & 0.09 & 0.52 \\
\hline \multicolumn{5}{|l|}{ Fines } \\
\hline $\begin{array}{l}\text { L-I(HNO, ) } \\
\text { 1-2(Thorex) } \\
\text { L-3(Thore) }\end{array}$ & $\stackrel{a}{0.79}$ & $\begin{array}{l}0.03 \\
1.30 \\
0.06\end{array}$ & $\begin{array}{c}2 \\
0.002\end{array}$ & $\begin{array}{l}0.17 \\
3.01 \\
0.25\end{array}$ \\
\hline \multicolumn{5}{|l|}{;etulde } \\
\hline $\begin{array}{l}\text { L-I\}HNO, I } \\
\text { L-2, Thorex) } \\
\text { L-3,Thores) }\end{array}$ & $\begin{array}{r}0.21 \\
18.32 \\
0.22\end{array}$ & $\begin{array}{r}0.14 \\
16.37 \\
0.07\end{array}$ & $\begin{array}{l}0.12 \\
0.08 \\
0.03\end{array}$ & $\begin{array}{l}0.27 \\
0.05 \\
00 !\end{array}$ \\
\hline \multicolumn{5}{|l|}{ Fissile } \\
\hline L-I(HXO, \} & 11.16 & 0.10 & 2.115 & 0.04 \\
\hline$L-2(4 \times 0)$, & 0.17 & 0.09 & U.0s & 0.04 \\
\hline L-31ThoreN) & 9.61 & 18.40 & (1.i4 & $0.6 ?$ \\
\hline I-4(Thorev) & 0.35 & 0.08 & 0.01 & 0.0 : \\
\hline Total & 100 & 10] & 100 & 100 \\
\hline
\end{tabular}

"Not dGike.

Table 1.S. Distribution of fiscion products for sperimen $112-3$

\begin{tabular}{|c|c|c|c|c|c|c|}
\hline & "se & $\cdot 2 \mathrm{Zr}$ & ${ }^{\prime n A} R u^{d}$ & 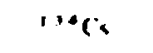 & 38 & 1480 \\
\hline Tolal detivity. dis/min & $7.0 \times 10^{3}$ & $74 \times 10^{10}$ & $2.3 \times 10^{21}$ & $5.3 \times 10^{20}$ & י'וo & $i .111^{1}:$ \\
\hline \multicolumn{7}{|l|}{ Distribution, $\%$} \\
\hline Burner ash & & 99.59 & 80.88 & 38.27 & $2 \times \times h$ & yo.88 \\
\hline Stainiess stecl frit (hot) & & 0.37 & 15.40 & 52.53 & tisx & 0.10 \\
\hline \multicolumn{7}{|l|}{ Off-gos system } \\
\hline Hot off-zas line & & 0.04 & 3.61 & 9.08 & ith & 1102 \\
\hline Inupactor ( $500^{\circ} \mathrm{C}$ ) & & $<0.001$ & 0.004 & $0 . n$ & $n .07$ & nImI \\
\hline Hol AE filter ( $500 \mathrm{C}$ ? & 226 & $<0.001$ & $-\cdot n(\mathbf{k}) !$ & $.11 \mathrm{mi}$ & (SOR)I & $-(1 . .1 \times 11$ \\
\hline Condenuer $\left(-20^{\circ} \mathrm{C}\right)$ & 28.4 & $=0.001$ & $\cdot 0.001$ & $\cdot(n(x))$ & $.0 .18) 1$ & $\because \boldsymbol{1} \cdot \boldsymbol{I}$ \\
\hline Cold $A_{\mathbf{B}}$ filter (RT) & 21.1 & $<.001$ & $\cdot .0 .(\mathrm{NO})$ & $\cdot(n) 1$ & $0 \mathrm{~mol}$ & .6164 \\
\hline Crelman filter (RT) & 27.9 & $<0.001$ & $n \mathrm{ml}$ & $.0(n) 1$ & $n(x))$ & 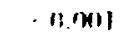 \\
\hline Cold off-Ras lint $(R T)$ & & 0.003 & n.n: & 11.14 & nol: & $.0 . m 1$ \\
\hline
\end{tabular}

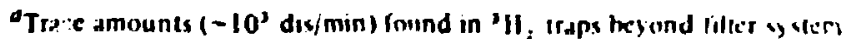

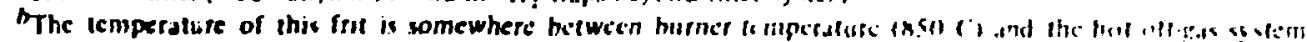

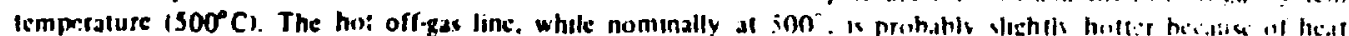
carricit ous of the burnet by the hol guses. 
Tatk 16. Distribution of tivion products for speciomen H24

\begin{tabular}{|c|c|c|c|c|c|}
\hline & "'Z: & $10 \cdot \mathrm{Ru}$ & $\because \mathrm{Cs}_{\mathrm{s}}$ & $\because C_{x}$ & $19 \mathrm{Ce}$ \\
\hline Total aitivity. dis $\min$ & $2.75 \times 10^{10}$ & $3.87 \times 10^{11}$ & $5.55 \times 10^{20}$ & $2.90 \times 10^{21}$ & $1.87 \times 10^{12}$ \\
\hline \multicolumn{6}{|l|}{ Distribution, $\vec{c}$} \\
\hline Burner ash & 99.27 & 3398 & $\{2.52$ & 48.62 & 99.47 \\
\hline Stainless steel frit & 0.71 & $: 5.89$ & 55.86 & 50.00 & 0.16 \\
\hline Hot off-ess line & 0.07 & 0.17 & 1.32 & 1.19 & 0.02 \\
\hline Impacior & 0.002 & 0.03 & 0.28 & 0.24 & 0.001 \\
\hline Hot Ag falter & $<0.001$ & $<0.001$ & $<0.001$ & $<0.001$ & $<0.001$ \\
\hline Condenser & $<0.00 !$ & $<0.001$ & $<0.001$ & $<0.001$ & $<0.001$ \\
\hline Cold ts filier & $<0.00 \mathrm{i}$ & $<0.001$ & $<0.001$ & $<0.001$ & $<0.001$ \\
\hline Gelman filter & $<0.001$ & $<0.001$ & $<0.001$ & $<0.001$ & $<0.001$ \\
\hline Cold off tas line & 0.07 & 0.03 & 0.04 & 0.04 & 0.07 \\
\hline
\end{tabular}

ORML OWG 74-10922

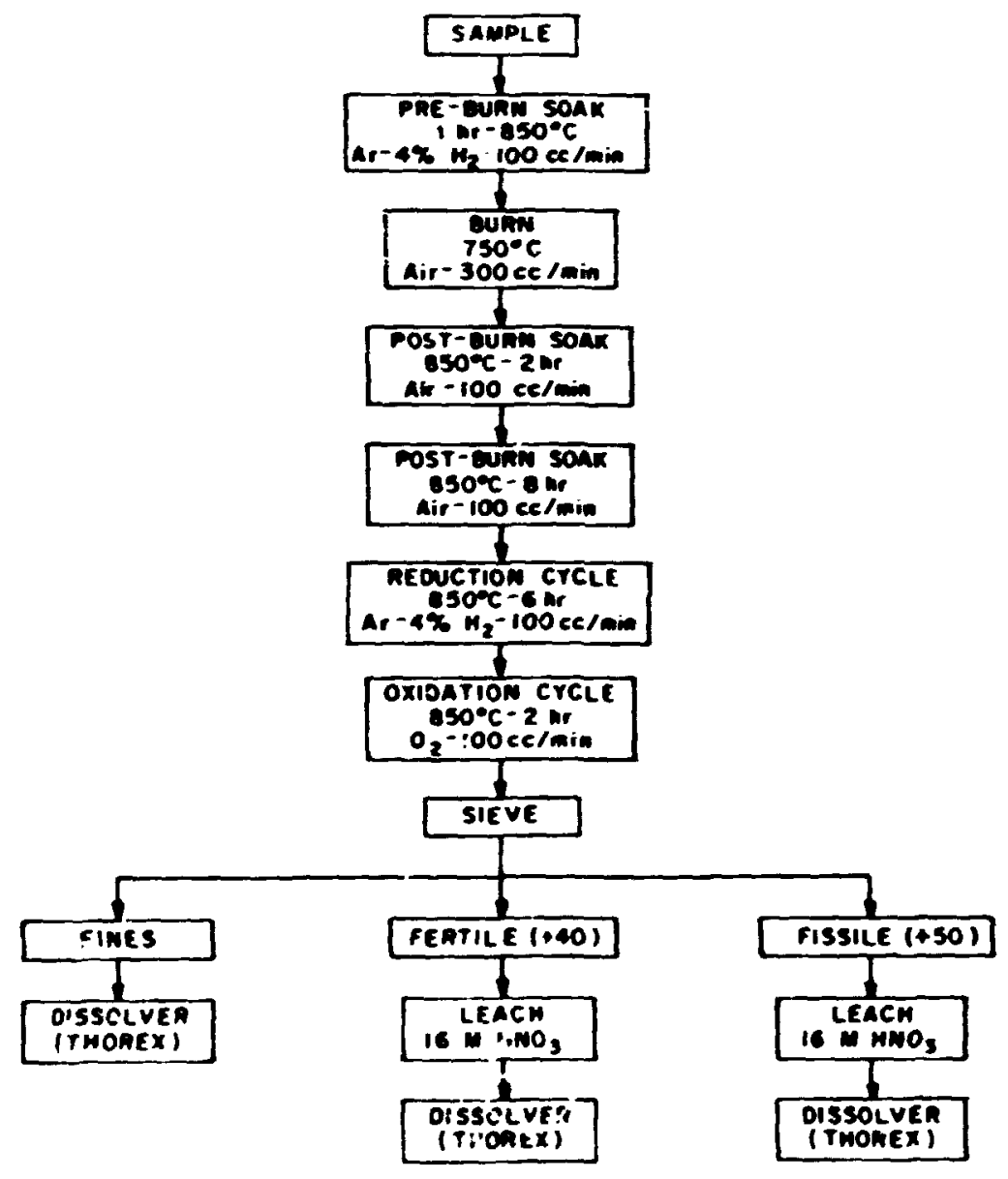

Fin. J.3. Flowsheet used for H-capsule experiment. 
andysis indicates that the compusition is uniform for each of the particle size frations.

\subsubsection{Vap:- Trasport of Fraion Products \\ J. H. Shaffer}

In the heacend repruiessing of spent YTGR fuet elements. graphite malrix and particke coating man.:ials will be burred in uxyeen and the residual ash processed for the recovery of fossive and fertike materiais. Provisions inave been made for the decontamination of the burner afluent to emove entrained solids and to separate known gaviuus fission products. Huwerer. allowable fission product release rates. as estabished by federal effluent regulation. correspund to very low vapor pressures in tie process effluent siseam and represent very small fractions of inventury values. Consequently. the availabte data and potential laboratury methods were assessed to an experimental program for examining vapor transport charaiteristics of various fission product elements under simulated conditions in the graphite bumer.

Niecessary fission product decontamination factors for an H:GR fuel reprocessing plant have been estimated un the basis of told volatilization of all fiscion products entering the plant." Although the graphite burning process will be designed to retain most of the fission products in the residual ash. the values cited for the quantities and specific ativities of the various nuilides. process dilution faclors, and alluwable aiborne concentration limits provide a realistic basis for assigning significant vapor transport parameters. Permissible loss rates for the various fission products were calculated using a plant and stack dilution rate of $10^{13} \mathrm{ft}^{3}$; day. Vapur transpurt rates that would result from a process effuent stream of $5.2 \times 10^{5} \mathrm{ft}^{3}$ per metric ton of heavy metal per day were calculated as hypothetical vapor pressures assuming lotal gas behavior and monatomic nulide species. Limiting vapor pressures for exh element were calculated from these values and consideration of the relative abundance of each isotope. These values. shown in Table 1.7. indicate that analytical detection levels corresponding to vapor pressures as low as $10^{-10}$ torr may be required to oblain significant results from an experimental investigation.

The graphite burning process will be accomplished under controlled conditions in order to regulate bumer

6. J. W. Snider and R. F. Leure. Proc. I2th AFC Au Cleanime Conferencr. Onk Rudg. Tenn. Aug 28 3l. 1972. CONF. 720823, wol. II. pp. S01 29. January 1973. temperatures within limits of 750 to $1300^{\circ} \mathrm{C}$. This control will probably be achieved by regulation of graphite and oxyen feed rates into the burner. How. ever, the manner by which this control is athieved may affect fiscion product transport in the system. Concivably. exiess oxygen in the feed stream could promote oxjdation of certain fiscion products to more volatile valence states. Similarty. a deficienay in oxygen would impoce more reducing conditions, which may promote the formation of more volatile suboxide or metalli: secies.

The thermodynamic feasibility of the events cited above annot be established with certainty tor many of the fission product elements. However. data from which the rapor pressutes of both metals and axides may be estimated have been published for a iumber of elements of interest to this program. Values calculated for lemperatures of 1000 and $1500^{\circ} \mathrm{K}$ are also shown in Tabte 1.7. Estimates for vajor pressures of the elements were reported by Margrive.' and those for the oxide species wete cakulated from the compilation by Bedford and Jackson" for oxygen parial pressures of 0.1 atm. A preliminary review of these values indwates that certain elements (including cesium, ruthenium. antimony. tellurium. setenium. :in. and silver) may have sufficient volatility under mildly oxidjzing conditions at $1000^{\circ} \mathrm{K}$ to exceed allowable effluent sandards. At slightly higher temperatures. uranium volatility may be significant.

The dala illustraled abuve are applizable where pure condensed phases are present. Under burner conditions. the various fission preducts may have much lower thermodynami aitivitixs owing to their inclusion in condensed phases with urania and thoria in the ash. Lnder conditicns where $\mathrm{UO}_{3}$ volatility becomes signifcant, the vapor entranment of certain of these fission products may also become significant. Consequently. the siope of an applied experimental program should in-lude an appraisal of the effects of condensed phase composition on the relative volatility of solute elements in $\mathrm{U}_{3} \mathrm{O}_{\mathbf{2}}$.

The experimental program will use equipment designed to investigate the volatilities of selected fission product nuclides at terr.peratures to $1300^{\circ} \mathrm{C}$. The experimental procedure. which will employ a trenspiration rechnique, will provide for the measurement of

1. J. L. Margave. The Cheracterization of Hod Temperature Vapors. Wilcy, New York. 1967. pp. 47880.

8. R. (;. Bedfozd and D. D. Jackson. Vinatilities of the Fission Froducl and Ironnm Oxides. UCRL-1 .J14 (Jan. 20. 19651. 


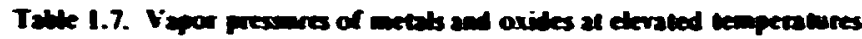

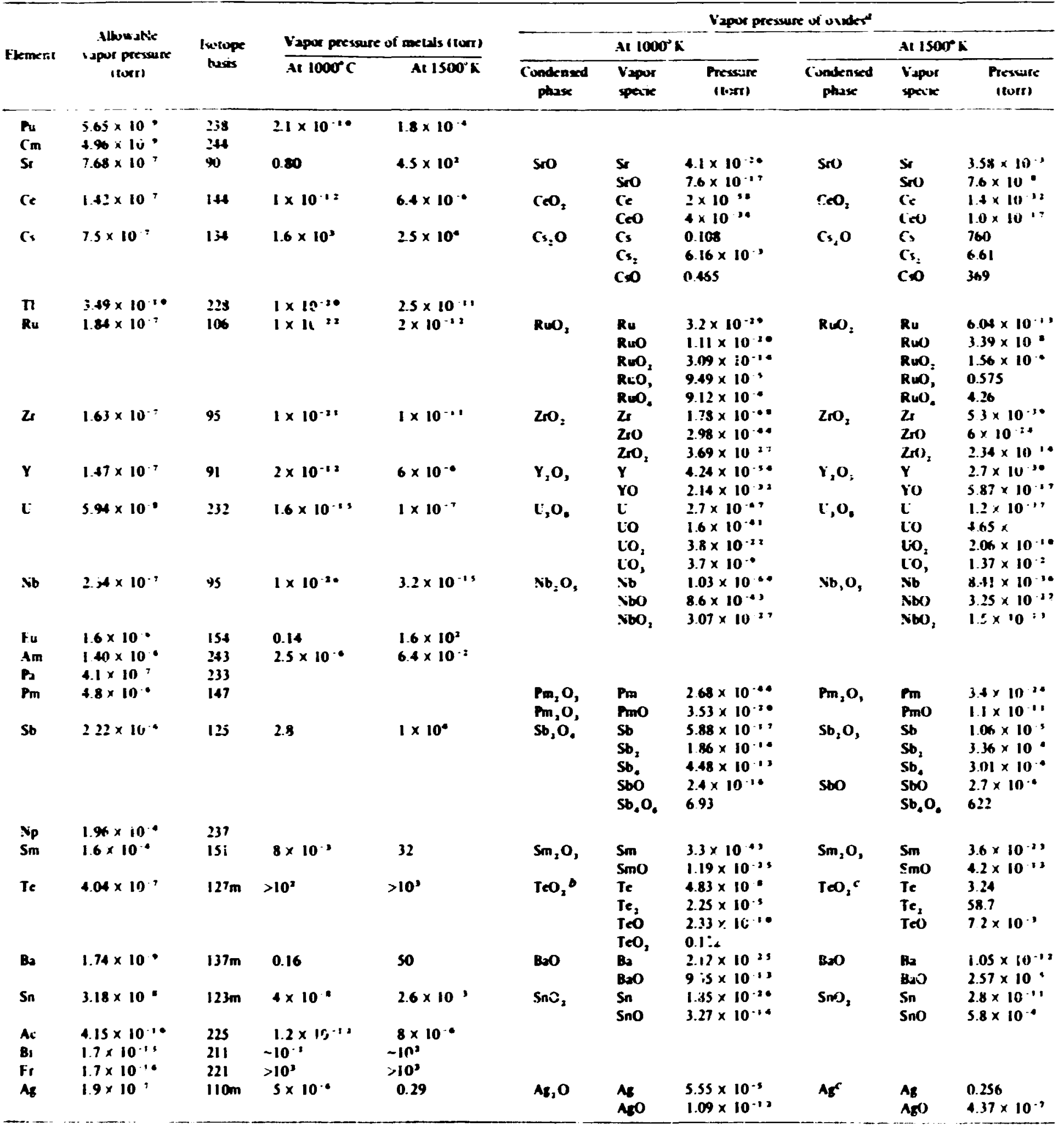


speics that are transported by potentially rea:tive gas maxtures of $\left(\mathrm{O}_{2}\right.$. ( $\mathrm{O}_{\text {. }}$ ind $\mathrm{O}_{2}$ ihrough a modified clfusinn-type cell anc depasited on a iulketor plats. Rulwiracers will he imiorpuraled in the preparation of slatting inaleriab li. permit analy ses by radiochemical nkethends.

\subsubsection{Experinental Studies of a Whole-Dlack Burner P. A. Hass H. Barner1-Wiemer}

F xperumental stucis were made using une-sivith-sale stixk pecpared by three axid cuts initass civners of the hex.gunal HTCR fuel blinks" The primipal nechanism if heal removal was by radutist irom the graplite to ithe arr-ionled metal burner w aits. Sime the wie sixth hiork is mol syntmetnial. calcu!diuns for ei:ne: correlation of experimental data or theuretia: apprisches are difificult. The range of allow sble gas How sates wa limited by the aparity at the viteas system. Burning could not be inantained at low $O_{2}$ innceti!rations due In excensive heal lisse's by buth radiatun li: the wals and by the heat ispailiy of the diluent gas

Experimental results with the wie-sxith blink busner

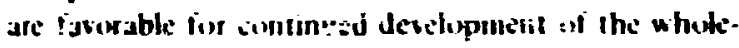
blink humer cinficpt." Oxygen ian be rejiled with an HTCK tuel blexi a prefical rates for sulk temperatures in the range of $\mathbf{x}(\mathrm{x})$ w $1900^{\circ}($. The ext $O$; conticentrations wil to lon over at least past at this range if the ges is thanneled thruugh the cimblant hotes

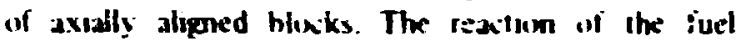
biochs for specilied burner condituns is reproducibie without fluituations. passivainen of the graphite suriace. or ofher unpredictahle varialions. Tugether. these reiults indicate tha: we can get a pratical. reprinducible graphile burning ratc and a low exil $\mathrm{O}_{\text {: concentratiun }}$ for som: $\mathrm{O}_{2}$ \& $\mathrm{O}_{2}$ mixlutes al sume temperatures beluw $1600^{\circ} \mathrm{C}$. The results do not allow us to predict the reyuired temperature or the exit (CO content.

An adiabatic llow rexitor concept is now reciom. mended with recycle of anded gas to provide temperature contril and heat remoral. ${ }^{10}$ A simplified model was selected. and computer programs were writcil (4) calculate cas compositions and tempiratures through the burner Complete utilization of $\mathrm{O}$ : or low exit con-

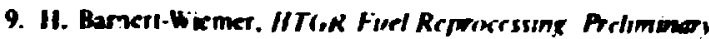
fixpernmenul Sturters of a Whole Bkck Burnr. ORNL-TU 4518 in preparation).

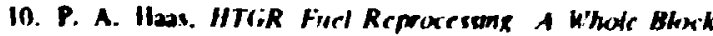
Burner wils Rerbir of Cinded bes for Trmprealure Commot. ORNL-TM-4519 (in preparation) centrations of $\mathrm{O}_{2}$ depend on zraphi e temperatures hiqh erenuth Io prodice $\mathrm{CO}$. whish : sets with $\mathrm{O}_{2}$ ir. the bulk s. I: sices mil appear fontlical to operiate with

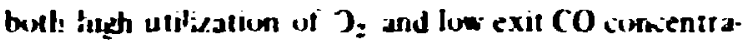
inn. Insteys. the burner conditiuns should be chosen to clearly four either maderate asmentrations of $\mathrm{O}_{2}$ ur

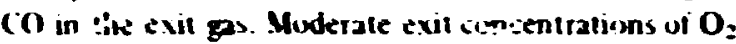
would alkw liner gaphite temperatures and wesuld probably give the desired burning ates fici three axially aligned blesks. Moderate exit iuncentrations of $\mathrm{CO}$ would asure higher burner opaities bu: would result in higher temperaturss and mure complex burnei contrul heharior. An experimental adiabatic burmer is recommended (1) verify the caliulated results. The general cunclusings wulci also apply to adiabatic lluidized-bed if fixed-hed bimers

\subsection{SOLVEYT EXTRACTION - IIO2 (GAC IEAD)}

Sininily siheduied.

\section{I.\& OFF-GAS CLEANUP - 1103 (ORNL LEAD)}

$$
\text { R. W. Class }
$$

\section{I.4.I Laboratory Developaneat}

$$
\begin{gathered}
\text { R. D. Ackley K.J. Wulh A. B. Mexervey } \\
\text { J.T. Bell S.F Ruxion }
\end{gathered}
$$

\section{The system $\mathrm{Kr} \cdot \mathrm{CO}_{2}$}

The KiLC iknpton absorption in Iqqund $\mathrm{CO}: 1$ prixess is being developed for removing ${ }^{\text {s }} \mathrm{K}$ irom inc burner off-gas generated in the head-end reproxiessing oi ITTCR fuel. To povide the bovis lior process desygn coliulatinns. the distributien of kry ptor. between gaseins: and liquad $\mathrm{CO}$ : was investiga!ed in the laburaton wer the 52.8 to +29.1 (c ange. as desirited pi: ously." "The results were expressed in terins of a separation izitor. $F_{K r} / X_{K r}$. which is the rati. of the motk iraztion of knyptom in the geseives phase to that in the likquid phase and which decteases with inireasmg Iemperatuie lifom: 29.4 to 1.4 for the above temperature range).

More recently. the effect of adding aboul $?$ Fiecri-1 $2\left(\mathrm{CCl}_{2} \mathrm{~F}_{2}\right)$ to the $\mathrm{K}_{1} \mathrm{CO}_{2}$ sy stem was investigated at $36^{\circ} \mathrm{C}$, aild tike wbserved separation iactor was nul afiected by the Freon. The laboratory work on the $\mathrm{Kr}+\mathrm{CO}_{2}$ system is complete, and a final report is in preparatiin.

11. Gick Aograms thnu. Arop. Rep. Dro. 31. 1972 ORNL-4YI1. PF. ; 8 
The system Xe- $\mathrm{CO}_{2}$

The betuvivi and dispousition of xenun in the K.ALC provess are cunsiderably less cruilal than lor ${ }^{8} \boldsymbol{K}$, becouse the ralivative fission product xeron isolopes have relatively short halfities and the cuoling times for HTGR tuets are about 150 days Huwever. obtaning Me-CO: distribution data analuguus to thuse ubtained for the $\mathrm{Kr}-\mathrm{CO}_{2}$ s! stem was deemed advisuble. portikuiarly in siew of the appreciable suncentration of siable xenun in the bumer ofi- 3 s. Acordingly - the separation finturs for xemm in $\mathrm{CO}_{2}$ have been determined over the $\$ 510+30 \mathrm{C}$ range

The equipment and experimental lechnques were enerally the same as these used in the KrtCC wurk."1.12 and the traier was 's' experimental thange inak during the course of the Xe-CO: measurements was the replacement of the sngte-tannel analyzer with \& multichannel anaiyzer. thus giving an improved measurement of the ${ }^{13} \mathrm{Xe}_{\mathrm{S}}$ 81-keV phor.speak. A xenun concientration si about $10^{-3}$ mule 5 was used.

The $\mathrm{X}_{2}-\mathrm{CO}_{2}$ resulis are presented in Table $I . X$ and in Fis. I. The shape of the xenun separation faitor is temperature plot is sumilat to that peviously utherved for krypton. As expected (because of the prednited higher solubility of $\mathrm{X}$ ). the xenon separalius ixiturs are lower thas thuse for knpton by a iaror thai vatks with tempeiatur: For exampte. the ratio of separatiun iators is approximately 0.25 at $50^{\prime} \mathrm{C}$. and this rath in-reases with temperature ind appricathes unily near the intival iemperature as the the individual separation iartors. Sume of these results and thuse iu: the Kr-CO; sysiem were repurted at an AlS meeling in Vivember I:7.;.'

There has been wrike suncern that the kryplion and

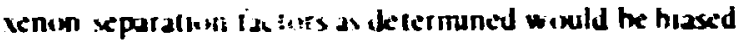
higf If there should be a condensed filn in the sirnder innet wall above the trquid level and or if there shouid he a mist in the vapor. The eylinder temperatures were unifiom in oblaning the results disiussed above: that is. the separaitun iaturs were delermined lor the silurated or nearly saturales ispar al equihbrium with the liquid. A group of $\mathrm{Xe}$ - (O): measurements wers per.

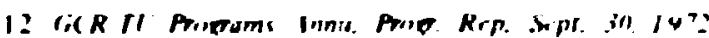

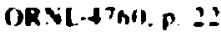

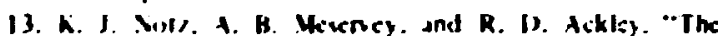

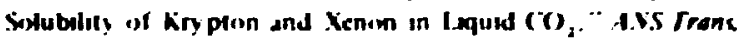
17. 318 11973)

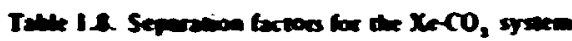

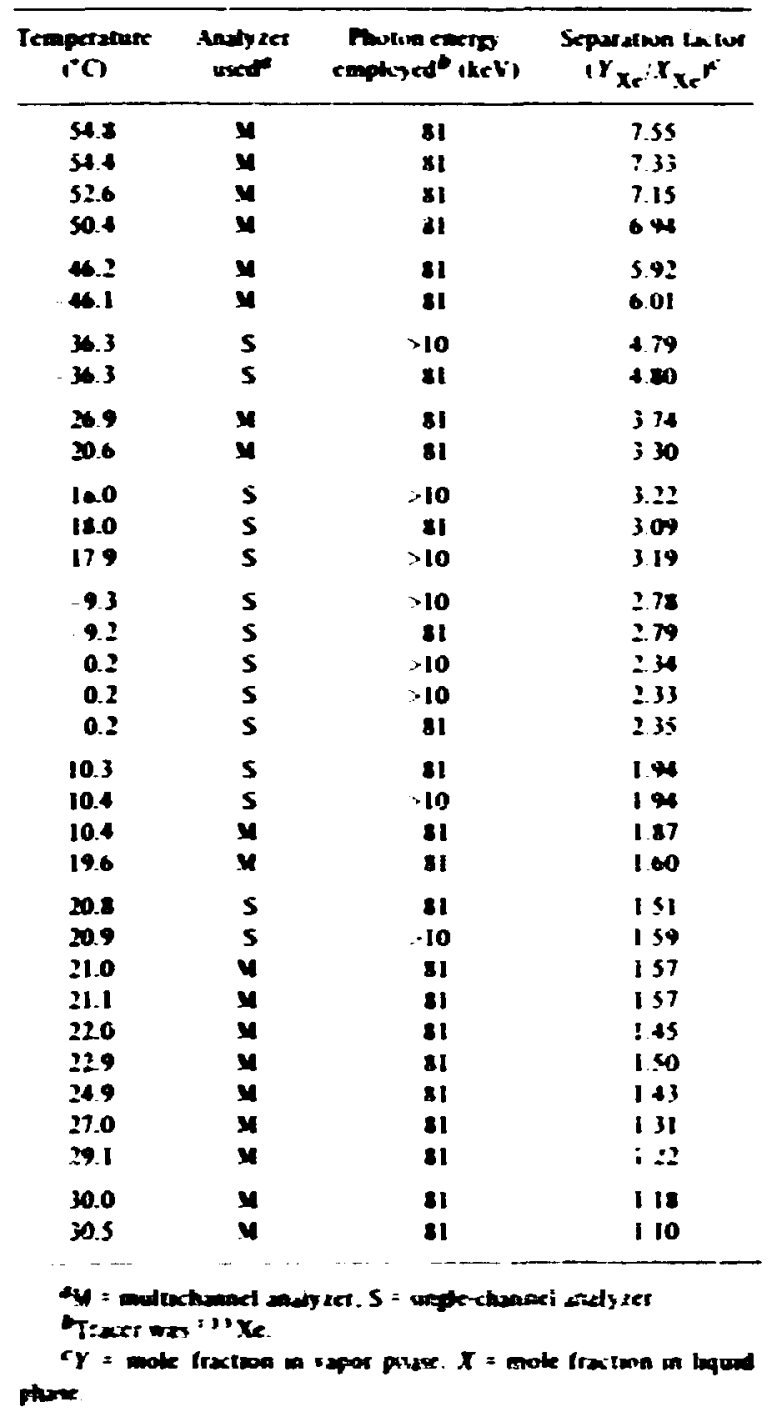

furmed recently in which the separalinn faciors were determined with the vapor phase at a is mperalure somre $10^{\circ}($ higher than that of the Inoud phase. This technique should minimize any These particuia. neasutements were restricted (1) the prejected remperalure range of aclual KAlC iperaliun.

4h fo 20 'C. Final calculalion of the corresponding separation facior is inurumplete. but preluninary values indicale that there are no delectable film and of mist effects in the carlier separatinr. facturs. 
Onink DEG 74-1050s

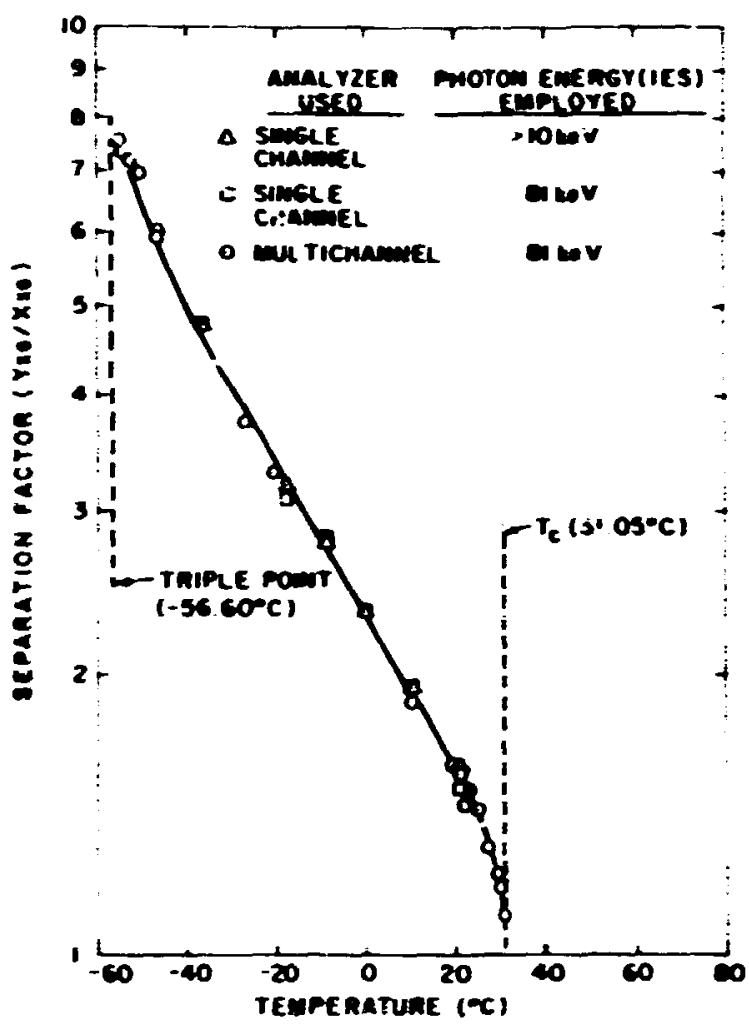

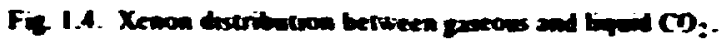

\section{Nin. system $\mathrm{CO}_{2} \mathrm{H}_{2}+\mathrm{H}_{2} \mathrm{O}$ (Ref. 14)}

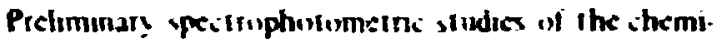
siry if HTCR lissenn products in liquad an.l gecinu. CO: hale shown that 1: is rall tery siahle in ('): thil H: 0 N assmialed with ( $0_{2}$. and that $11: 0$ t irfict derreases the sutulity of !: in the threezumparent ysiem

The H:(2, O): hinal: sysicm was sludied t., estahl.ti lechniques for -naly ing waler in the lhece anpmen: system. Hiwever. carly results indicaled mitecular asuriation of II:O and $C_{2}$. and a mu:e rigurous investigalion was inifisied hecause of the prossuble

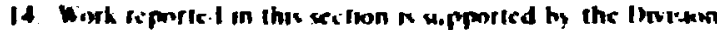
of Fhy swa Rewedich and is inc:.sded in this repmrt hecause of ifs deccl ulilifs In the Thorium I 1lhra:.on Fropsum.
}

entrapment of $T_{2} O$ in the $\mathrm{KALC}$ pruiess. The concenIration of water in liqual of gascous $\mathrm{CO}_{2}$ can be wbictred by the intensily of the $1.88+2$ assurpution band. whinh is tharaireristic of the $\mathrm{H}-\mathrm{O} H$ sinkilure. The mular absorptivity of this band for $\mathrm{H}_{2} \mathrm{O}$ in Irquid (O) was determined io be $\$ .0$ for the 5 io $25^{\circ} \mathrm{C}$ range by difierential techniques and by cumbining the literacure data for the sulubility of $\mathrm{H}_{2} \mathrm{O}$ in $\mathrm{CO}_{2}$ with wur abserved absurbance data. The vapur-phase association of $\mathrm{H}_{2} \mathrm{O}$ with $\mathrm{CO}_{2}$ wax studied by ubserving the $\mathrm{I} .88+4$ $t$ and for the sapur phase over liqued $\mathrm{H}_{2} \mathrm{O}$ al $\mathrm{CO}_{2}$ p.essures of 100 to 900 ps. The amuent of $\mathrm{H}_{2} \mathrm{O}$ rapur ovs' pure $H_{z} O$ at thexe temperatures sannol be datcited is thexe techniques. but the amount of $\mathrm{H}_{2} \mathrm{O}$ in the uspor inireased with the $\mathrm{CO}_{2}$ pressure. The data have been interpreled by assuming ihat the following equilibnum is established in the vapor phase:

$$
\operatorname{MCO}+\mathrm{H}_{2} \mathrm{O} \stackrel{\mathrm{K}_{n}}{=} \mathrm{KO} \mathrm{O}_{2} \mathrm{H}_{2} \mathrm{O}
$$

The innientratken of H:O $\mathrm{m}$ the vapor phase was assiemed to be cinstant. and the absorbanie al I. Xk $p$ wis assumed io represent the $\mathrm{ICO}_{2} \mathrm{H}_{2} \mathrm{H}_{2} \mathrm{O}$ species unly. heiduse $\mathrm{H}_{2} \mathrm{O}$ ciruld not be deteited withut the $\mathrm{CO}_{2}$ iverpressure. If these assumptinns are sald. a luganthmk- plot of product comientratun is $\mathrm{CO}_{2}$ ioncentraIin should be incar with a stope si $n$ and an intercept if In $\boldsymbol{\Lambda}_{n}^{*}$-where $\boldsymbol{K}_{n}^{\prime}$ is the produl of the cuncentrativn quirient $K_{n}$ and the $H_{2} O$ comentration. The logarithmk plots at 15.25 . and $10^{\circ} \mathrm{C}$ are shum in Fig. 1.5 . Thus analy sos indiates that there is motecular associaIien of $\mathrm{HI}_{2} \mathrm{O}$ with $\mathrm{CO}_{2}$ and that the ascuctation does not distupt the II $\mathrm{O}$ II struilure of the water. Furthermixe the $10_{2} 11,0$ mote ratio in the vapirphase

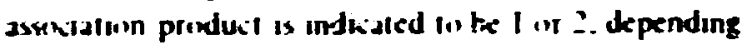
on the lemperaluti and the (0): pressure

The sositic absurption spectrum of $1:$ in lapuid $\mathrm{CO}_{2}$ was ibserved l., he sumlar to that if $I_{\text {: in }} \mathrm{Crl}_{\mathrm{s}}$ and n-ficuanc: that is. 10 : appeared io be a nompitar solicent lin I: The I: band was at $51+1 A$ in liquad CO. \& shit of approvimately \& 0 A as cirmpared with that in $\mathrm{CCl}_{4}$. The intensily of the l: hand decreased ath time. andicaling that ihe 1: was reating. and the deition if wister to the $\%$ : increased the rate of $1:$ reacion, as shiwn ia the lasi column in Table 1.9. The chicic urjiun of $11: 0$ in irqued $\mathrm{CO}$ : was monilored by the l. $\mathrm{A} \mu \mathrm{g}$ hand with a metar ahsorfitivity of 4.0: this $\mathrm{H}_{1} \mathrm{O}$ hand alsu deiteased in the three-ommponent sysIen. Indicatin;: that the $H_{2}()$ was reaiting with the $l_{2}$. 


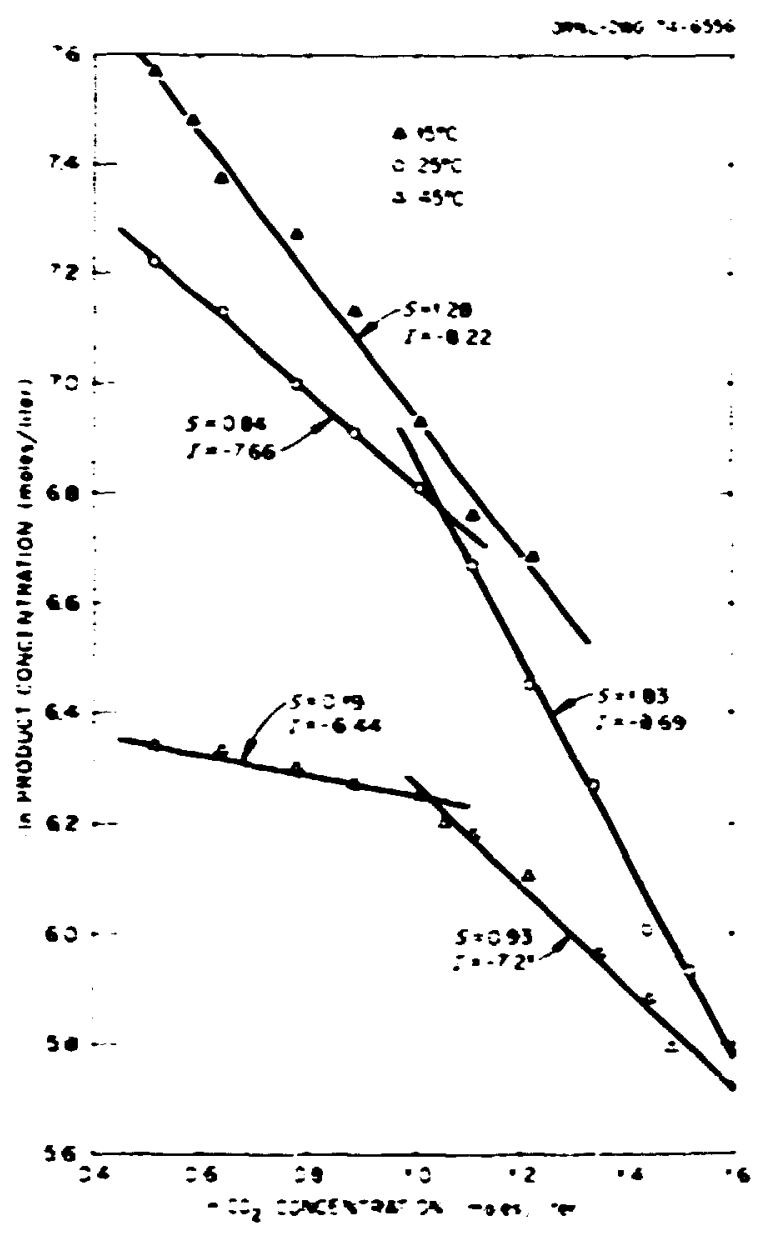

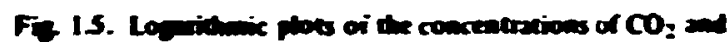

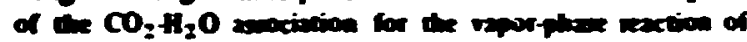
$\mathrm{CO}_{2}=15.25 .215^{\circ} \mathrm{C}$.

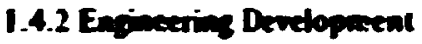

$\begin{array}{ll}\text { R. W. Glass } & \text { H. W. R. Beaujean's } \\ \text { H. D. Cochran } & \text { D.M. Levins" }\end{array}$

A process for treating the burner off-gases from HTGR fuel reprocessing plants for the remuval of ${ }^{\text {s }} \mathrm{Kr}_{\mathbf{r}}$ is being developed al ORNL. The engineering development utilizes the ORGDP Selective Absorption Pilot Plant and an experimental engineering faility at ORNL the Off-Gas Decimtamination Facility). The desggn of

15. Gu 's scentist from KFA Juluch

16. Civest exentist from the Australian Alome trnergy Commkwon.

\begin{tabular}{|c|c|c|}
\hline 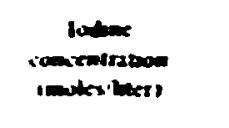 & 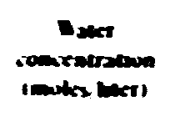 & 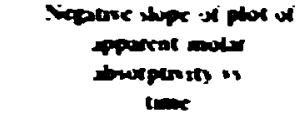 \\
\hline$\underbrace{10}_{2024}$ & 15 & $\begin{array}{l}10 \\
300 \\
110\end{array}$ \\
\hline $3 . \mathrm{mt}$ & 19.3 & $\begin{array}{l}+4 b \\
2.23\end{array}$ \\
\hline 1974 & 22.1 & $\begin{array}{l}500 \\
230\end{array}$ \\
\hline 2707 & 31.4 & 5.3 \\
\hline 4.45 & 43.1 & 5.8 \\
\hline 6.003 & 49 & 10 \\
\hline 454 & 74.8 & 214 \\
\hline 5.301 & Tal & 165 \\
\hline 2961 & & 12.3 \\
\hline
\end{tabular}

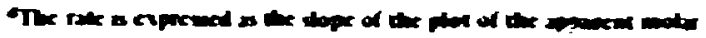

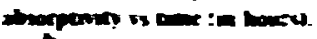

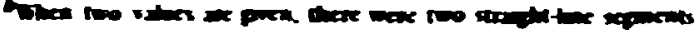

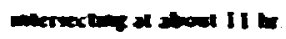

the ORIL iadhy was thusen to give a sysicm cumplementany to the ORGDP pike plant. The KALC provess alkows separation of knpton trom both inght gases 10. $\mathrm{X}_{\text {: }} \mathrm{CO}$ ) and $\mathrm{CO}$ : - with ahree mank separikins in a single privess. The off gos decontaminatinn facifily allows study of a setected separalion with a seind column in allorer resyck of process streams. The KALC studies in the ORCDP pilot plant will allow siudy of the entuc KALC process. An iverall KALC process control system and a propusal to ieed unly cundensed laquid to the absonber are concepts itas will be rested.

The KALC process requires three major separations and 2 fourth. relatively easy. concentration of light pases above the third ex stripper separation. In the absurber. nearly all the knypion must be absorbed into liquid $\mathrm{CO}_{2}$ withoul absorbing excessive amounts of light gases $\left(\mathrm{CO}_{2} \mathrm{O}_{2}, \mathrm{~N}_{2}\right)$. The light gases, saturated with $\mathrm{CO}_{2}$ at the absorbet condi:wns tut decontaminated of kryplon. are dicturged. in numerical terms. be liquidi vapor ralio $(H / h)$ mist be geater than $K_{K}$ and less than $K_{\mathrm{O}_{1}}$ or $K_{\mathrm{CO}}$. Where $K$ refers to the equilibrium vaporiliquid distribution for the desigated companent. In the fractionator. nearly all the light gases mist be 5 -mowed from the linquid $\mathrm{CO}_{2}$ without removing an excessive fraition ol the krypeon. and the $I . / V$ value must he approximately equal to $\boldsymbol{K}_{K}$ and kess than $\boldsymbol{K}_{\mathrm{O}_{2}}$ or $\boldsymbol{K}_{\mathrm{CO}}$. The light gases removed from the liquid $\left(\mathrm{J}_{2}\right.$ are refurned to the absorher feed. In the siripper. the light gase: are removed completely from the liquid 
$\left(O_{2}\right.$, and the $L$. $P$ value must be less than $K_{K}$, In order (1) wbtan a hrgh vulurxe reduction (i.e.. a high $\mathrm{Kr}_{r}$ comientration). it is necessary that the irationator efficiently remuve the $\mathrm{O}_{2}+\mathrm{N}_{2}+\mathrm{CO}$ from the liquid $\mathrm{CO}_{2}$ : also the siripper eas remuval tale mus, be cunisolked in a mannet that pruduces the desired cuncentration of krypton in the pos striam leaving the stripper.

\section{Hroress andyses}

Evaluation of the KALC provess will pruveed in tl,ree slazes: III predicion of the provess performance based un seteition of a model and theoretinal cahulations: 2) measurement of provess performance during experimenIl operation of the two devetupanent ixilities: and 1 i) analyses of the experimental results to provide general correbations. umprowed preditions of provess perforis: ance. and infurasation for provess design or siake up.

The devel ament and initial results frum an equilib rum-siage mudet of the KALC proces were reported previously. 17 a dated dexiaption of the moded and a summany of aldated results have sunce been re.

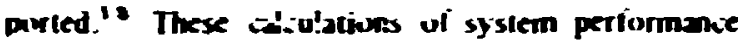
were useful in assessing the potenizal impait of upsets in offeas the rate and curteosation on the petform. ance of KALC provess uperations planaed at KPP. Con-lusinns are that the muderate upsets antiuipated fe.m operations suh as turner startup and shestown can be accummodated by the KALC process if a modest as holdup wilume and recycle apobility are in-luded in the provess."

A mudel for computer ahulatums has been deteroped to analy re experimertal results from the ORYL Oif-ios Decontamanation Fainity as well as from the ORCiDP Sicleitive Absurpiun Pilut Plant. The mode depuls a cintinumus cuuntericurtent paiked column with necsoary recigontum of varying lojuid and vapur fow rates. The cikubilims yold a value of the

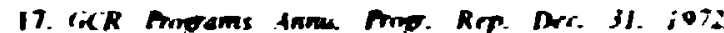
IRSL-49II.

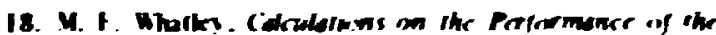

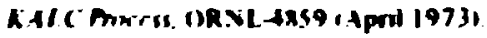

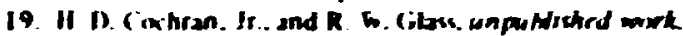

volumetric average mass transfer cuefficient for each compunent that best fits the measured inkt and outlet concentrations. Such values of the mass transfer cueffizent may b: correlated (using the Frussling correlation) and thus form the best basis for suakup and provess desigh.

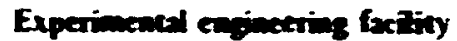

A maior step in the development of the KALC prucess has been ine decion and instaliation of an Off-Cas Decontamination Faility at ORAL. The faility consis's of twe pated columes fone for absorption and une for stripping). compressors for gas recycte. and pumps to provide liquid flow. Standard refrigeration units aro used to ahbeve the nominal $-30^{\circ} \mathrm{C}$ te.nperature required for processing conditions. The $1 / 2$ in.dimu absonption column will be used in conjumition wh the j-in.dion stripping colurn to allow study of these uperations on a complete recyck basis for pas sirean rates of ? to $10 \mathrm{x}-\mathrm{m}$ and liquid rates of 0.5 to $1.5 \mathrm{ppm}$. The farility is in the stakedown staps. anc uperations should bejin shorth;

Ore exsentid measurement during expenimental studies iv the ORNL OrfGas Decontanination Faility is the inpion concentrations using is $\mathrm{KI}$ tracer. The - K $K_{1}$ concenirations in six feed and product streans from the wo columas will be continuously monitored $u$ ing in-line beta sintillation frow cells. Gos and laquid suples ian be withdram from points throust sui the plant. and colbeted samples will be counted to determine " $\mathrm{Kr}$ concentration and analyzed for the num radioative componints. Both absorber and stripper culumns have eight sampline points. four liquid and four gas. spoced equidistanty abon the columns to enable concentration profiles in be measured. Temperatures. pressures. and flow raies an alsu be measured throughout th system.

\section{I.5 FRODUCT FEPARATMON - IICA (ALUED CFEMCAL CORTORATION LEAD)}

Wo xitivity scheduled.

1.6 WASTE TREATMENT AND DWTOSAL - IIOS

Wo activity scheduled. 


\title{
2. HTGR Reprocessing Pilot Plant (Subtask 120)
}

\author{
J. H. Snide:
}

The sbjecture of this sublast of the fuet reaycte development program is to apph the tecturotons developed undet subtask 110 (Repruvessing Devetufment) to a pilotplant-siak demonstratum of the provesses and equipmetit for reprocessing ITGR twel. Equpanent must be desigened. budt. and uperated II Amuast tate the following uperatiuns

I. Iransier and preparainon of iuel etements fir repricessung:

- inushing of the luet ekments:

3. burning the graphite in a fludued bed butner:

4. separation of the fertike and fissak mirispheres: crushing the glicion arbode curing on the fissak minrospheres:

5. buming the crushed microspheres.

$n$. dissitution of the uranum and thoriun. In the bumed. crushed mk-tospheres.

- separation of the undissolved sutids iskion arhide hulls. et: I from the leatak:

c. separation of the thorium and uranium ifen the fission products by sutwent exirativen:

9 . separation and purifiation of urznum hy whent extraikn:

10. preparatken and pakariat the uranum producl fin shipment and surage as reyrited:

II. demunstration ef privesser and cyuponent liog indine. intium. krypion. and partikubite reminal from the pruiess wifeas steams:

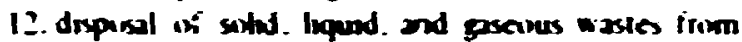
the proxesses.

Durne the curtent year. the aitwit! at ORNL in this sublask sonssied inly of reviewing desugen devuments fiet the promotype plant as requested hy Alived (Themanal Coporatim and unituane he preparainm is the pretuminan system design deinption for the iffeas cleonup sysem. witk unit 1203 . 


\title{
3. HTGR Fuel Refabrication Development (Subtask 210)
}

\author{
J D. Sease
}

In ths sep in the HTGR fued cycte. aitrate sulation contanume reprovessed $23{ }^{3} \mathrm{C}$ is connented into fued dement: for use on an HTGR. The objective of the HTGE fuet refabniation process devetoponeat is to devetop the rectimkng necexsary for the dexigh ana upetaliun of the HTGR Fued Refabriation Fins: Plant IFRPP. The palor plant. wheh will be desponed i:y remoitc inerztion and mantcrance. wll requite the devekspovent if pectui proceses and equipment fin thas firstuf-atind mateas fuet refabrivatun olant. The concitwes of the refabmiatum derehopment program will be met by

I. exthishmert ori a process thinsheet.

2. dectiponent if prowisype equifonent cumpinients in subsystems.

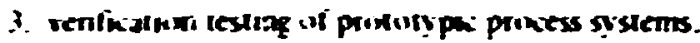

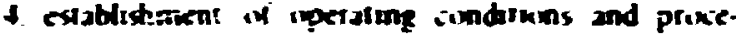
ders.

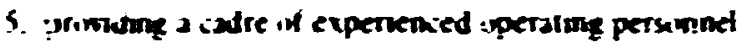
ior the prowitype plant operation.

wink in HTGR fud refabriatum dechpment": has heen gung ire tix i number of years at ORVL However. dunte thes ttpun periad. rencwed uateres and mireased fundrag have aicelerated the inspul of this atrvit: cumpared wih frevinus years. The change (1) utulue a kemel dermed from weat-aid resun (TiAR) ustead if 2 olyet-denred kernet was mode at the end if this report perned. This repaxi reikits thas change in

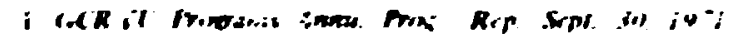
casi tis:?

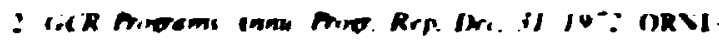
411 the reference partikte but alss covers developanent arort assuciated with the sol-gat-derived keracts.

The wotk in refibrivation devei noweat is subdivided mito 11 wroth unsts pardel io the ituction of the pior plapts. These work tnits are

1. unil 2100 exeneral developonent:

2. unil 2101 uraniam feed preparatur:

3. unit 2102 resu lisading:

4. unit 2103 resn carbuatiatun:

5. unit 2l04 mintosphere coalmg-

6. un: $210^{\circ}$ ioel rod iatriatum

?. urat ziOs fuel element zserediy.

飞. unn 210? compie inspection:

9 unit 2los process ciont it 2rod dats handing:

10 zmil 2109 wasle has tling:

H. en : 110 materials hmdme.

\subsection{GENERAL DEVELOMENT - 210 IOANL LEAD;}

J. D Sease

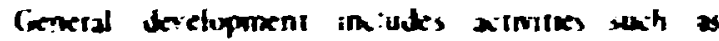

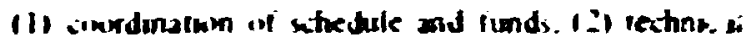

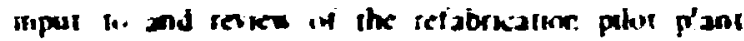
dexing desirplkm IPDD, and the system dexgn dr. sinpliwas (SDDs). (3) preparation of recyice (w.: product and provess specificalions: $($ \&) developmeris if the material cisiuntablaty. nuikar matenals site-

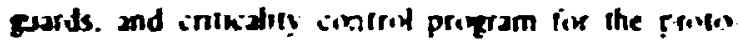
type plant. (5) preparation of eperating privedunt: speiffialiem of iperating imdillons. evalualuns cos

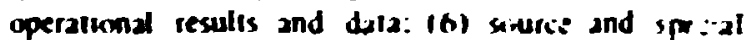




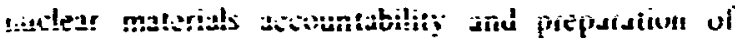
reports as required for materiais acountability and r.aterials protection: and (7) preparauon of design descriptions and operating frocedures for mindified process equipnient.

\subsection{URANIUM FEED PREPAKATION - 2101 |ORNL LEAD|}

Vo development jotivity is sihedul .

\subsection{RESIN LOAMNG - 2102 (ORNL LEAD)}

$$
\text { P. A. Haas K. : Sorz J.H. Shaftict }
$$

The objective of the resin loading subtask is to develop the - oviess and protulype equipment for loading ion exchange resin with ${ }^{23} \mathrm{U}$ and for drying the luaded resins. A principal advantage of the resinbased preparation of kernels is that many of the sritical product properties can be established and controlled for the feed resin before any radioactivity is present. Another advantage of the resin prociess is that the amount of material that must be frocessed through resin loading. resin carbonization. and microsphere cuating systems is reduced by a tactor of 5 when compared with a (4Th.UX) kernel. The resin loading development involves three principal areas: (1) resin feed greparation to supply resin with properties adequate to meet prodect specifications. (2) urdis: : lee $j$ preparation !o convert uranyl nitrate solution from a reprocessing plan! into the form required for the resin loading. and (3) resin loading and drying to provide loaded resin suitable for feed to the carbonization furnace.

The decision to change the reference particle from a 14.25Th-U $\mathrm{O}_{2}$ sol-gei particle to the WAR particle was made after this report period was completed. Development work on the WAR for this year was supported by the base program bit is reported here for uniformity. Also reported in thi, section is development work ihat was done for the sol-gel-derived ki; nie!.

Sul-gel processes. which have bein under development at URNL for a number of vears, have been used i.) prepare a variety of thoriuri and uranium oxide and carbids' sphezes. The OR'sL scl-gel processes for preparing high-densily oxide sphere', require (I) preparing al aqueous oxice sol: 12$\}$ vispersing the sol as drops into an :iganic fluid, usually 2ethyl-1 hexanol (2EH). and tren removing water from these drops to give solid gei $f$ articles: and (3) drying anc firing at controlled coritit rn: 10 remove :vlatiles. sintering to a high den. $v$ a:do rodicing or converting chemically as teciessary. Major deveiopnent thi: engineering-siale demonstration of the Sutex priviss E: : the preparation of (Th-UX, sill and the preparation oi micruspherss using the sul.

\subsubsection{Size Contrel}

lon exchange resins protuced by ecrmmercial manufaitures cover a rather wide size range. numinally $\mathbf{2 0}$ to 50 mesh. To obtain the correct size for fuel kemel isse. t.te resin is wet screened. We are doirg this with an 18-in. KASON unit. Size distribution data for 50 liters of Amoerlite ICR-72 $\left(\mathrm{H}^{+}\right.$form) are given in Table 3.1 . These results fit a normal prob.c. lity distribution fairly well, with a mean size of $680 \mu \mathrm{m}$ and a standard deviation of $100 \mathrm{\mu m}$. Various fractions of this size separated resill were used to prepare irradiation test materials and other test samples of uranium-loaded resin. A yield of $25 \%$ was obtained in the size desired for fissile fuel kernels ( 32 to 38 mesh).

Table 3.1. Size data foz So liters of Amberlite IRC-72 ( $\mathrm{H}^{+}$form)

\begin{tabular}{|c|c|c|c|}
\hline \multirow{2}{*}{$\begin{array}{c}\text { Sirten size } \\
(u \mathrm{~m})\end{array}$} & \multirow{2}{*}{$\begin{array}{l}\text { Screen sizx } \\
\text { (mesh) }\end{array}$} & \multicolumn{2}{|c|}{ Volume percent } \\
\hline & & Each fraction & Cumulative \\
\hline 965 & 22 & 9.4 & 9.4 \\
\hline $87 n$ & 24 & 8.4 & 17.8 \\
\hline 785 & 26 & 5.5 & 23.3 \\
\hline 715 & 28 & 15.5 & 38.8 \\
\hline 630 & 32 & 6.6 & 45.4 \\
\hline sos & 38 & 25.1 & 70.5 \\
\hline 440 & 44 & 8.7 & 79.2 \\
\hline 370 & 50 & 4.8 & 84.0 \\
\hline$\$ 10$ & 60 & 90 & 93.0 \\
\hline 310 & & 7.0 & 100.0 \\
\hline
\end{tabular}

a."Tensile Boating C1าth" screens.

During the vari-us conversion sleps involved in processing resin from the as-received $\mathrm{Na}^{+}$form to the final producl. the resin undergoes a series of iolume reductions. These are summarized in Table 3.2 .

\subsubsection{Unifomity of Laading}

Uniformity of riernel composition is important with reg rd to core physics. accountability, and quality assuri :ce. In :irris of uranium ioding, uniformity is of concern on at least four leve!s:

I. within a single resin bead, the uniformity of uranium lnading along the radius: 


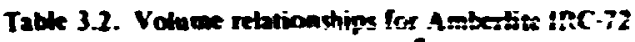
resin beod kernets"

\begin{tabular}{|c|c|c|}
\hline $\begin{array}{l}\text { Initial ( wet I velume } \\
\mathrm{N}_{\mathbf{x}} \text { f form } \\
\mathrm{H}^{*} \text { form }\end{array}$ & $\begin{array}{l}201 \mathrm{ml} \\
100 \mathrm{ml}\end{array}$ & $\begin{array}{l}79.5 \mu^{\circ} \\
627{ }^{\circ}\end{array}$ \\
\hline \multicolumn{3}{|l|}{ Louded (Jry) roiume } \\
\hline $\begin{array}{l}\text { At } 110^{\circ} \mathrm{C} \\
\text { At } 130^{\circ} \mathrm{C}\end{array}$ & $\begin{array}{l}76 \mathrm{ml} \\
79 \mathrm{ml}\end{array}$ & $\begin{array}{l}561 \mu \\
556 \mu\end{array}$ \\
\hline Fired (fines!) volume at 1 s, $20^{\circ} \mathrm{C}$ & $26 \mathrm{ml}$ & $400 \mu$ \\
\hline Finai (?ured) weighe at $1000^{\circ} \mathrm{C}$ & $53 \leqslant$ & \\
\hline \multicolumn{3}{|l|}{ Partick density } \\
\hline $\begin{array}{l}\text { At } 1000^{\circ} C(70=1=(i) \\
\text { A: } 1250^{\circ} C(75 w 1 \neq U) \\
\text { At } 1750^{\circ} C(90 \text { wt } \neq U)\end{array}$ & $\begin{array}{l}3.4 \mathrm{~g} / \mathrm{ml} \\
3.7 \mathrm{~g} / \mathrm{ml} \\
5.3 \mathrm{~g} / \mathrm{ml}\end{array}$ & $\begin{array}{l}400 \mu \\
380 \mu \\
315 \mu\end{array}$ \\
\hline
\end{tabular}

Loading: 1007 of cepacity with $\mathrm{CO}_{2} 213.4 \mathrm{meq} / \mathrm{ml}$ wet resin in $\mathrm{H}^{*}$ torm).

Eouivalem! diameler.

2. within a single loading batch. the uniformity of uranium loading from bead to bead:

3. within a single source of resin. the uniformity of uraniur loading from one lnading batch to another (or. for continuous column loading, from one time period to another):

4. for a single type of resin, the uniformity in capacity from one batch to another

We already have information on levels 1 to 3 and can make some reasonable predictions about level 4.

Within a single bead, the uranium density along the radius appears to be constant. Knowledge of resin manu.ture and structure would predict his. the relative constancy of percent uranium loaded onto different diameter beads of the same resin provides indirect evidence tilat this is so, and radiographs of loaded beads confirm it within the limits of capability of this technique. It was shown earlier that "outer shell" loading of uranium, leaving an unloaded center, could be don: with WAR in the $\mathrm{Na}^{*}$ or $\mathrm{NH}_{4}{ }^{*}$ form for exchange times of liss than I hr.' Conversely. outer shells could riot be obtained with st rong-acid resin, with WAR in the $\mathrm{H}^{+}$form, $\mathrm{cr}$ with WAR in $\mathrm{Na}^{+}$or $\mathrm{NH}_{4}{ }^{+}$ forms for exchar:ge times greater lian $1 \mathrm{hr}$.

The following density data $(\mathrm{g} / \mathrm{ml})$ were obtained by W. R. Laing for 24 individual WAR bearts that were fuily luaded with uranium:

$$
\begin{aligned}
& 2.093 \quad 2.108 \quad 2.114 \\
& \begin{array}{lll}
2.097 & 2.128 & 2.117
\end{array} \\
& 2.101 \quad 2.109 \quad 2.118 \\
& 2.104 \quad 2 \text { ing } 2.119 \\
& 2.105 \quad 2.110 \quad 2.120 \\
& 3.105 \quad 2.110 \quad 2.120 \\
& 2.105 \text { 2.i1 } 2.127 \\
& \begin{array}{lll}
2.1117 & 2.113 & 2.128
\end{array}
\end{aligned}
$$

The densities were deter:ained in a gradient culumn using resin beads that had been sampled at randum from bout I liter of 32/38 mesh resin that had been loadeu as a single batch using $\mathrm{UO}_{3}$. The loaded resin was washed thoroughly to remove any uranyl nitrate and stured wct. Densities were measured on wet beads that had been blotted to surface dryness. Wet beads were used because we were certain that all the internal porcsity was fully filled with pure water; had the beads been dried first, there would have beell uncertainties introduced from variations in the degree of dryness, the amount of trapped ait after immersion in the denciiy pradient column, and the actual density of the column nuid that did penetrate the voids. Since the jensity of dried beads is about $1.7 \mathrm{~g} / \mathrm{ml}$ aic ine volume shrinkage due to drying is about $20 \%$, one an calculate that the :vet beads centain about 75 vol $S$ water, witich includes the void volume in the dry beads plus the swelling of the resin itself from imbibition of water. From the very narrow range of tilese data $( \pm 1 \%)$, une can conclude that both the uranium content and the roid volume are constant from bead to bead withia a single batch of WAR.

The fourth possible source of variations in loading, due to differences in the exchange capacity of resins from batch to batch, still needs to be investigated.

\subsubsection{Continuous Looding}

A technique for conti..ucus loating using a mocified Higgins column has been demonst-ated previously for strong-acid resins, which are able to extract all the uranium from a uranyl nitrate solution. ${ }^{3}$

With WAR. effective loading of uranium is achieved from an acid-deficient uranyl nitrate solution that is obtained by reacting uranyl nitrate with excess $\mathrm{UO}_{3}$ as

3. (;CR Propams Annu. Arogr. Rep. Dec. 31. 1972. ORNL 4911. p. 31. 
t.llows:

$$
\mathrm{UO}_{2}\left(\mathrm{NO}_{3}\right)_{2} \stackrel{\mathrm{UO}_{3}}{\rightarrow} \mathrm{LO}_{2}\left(\mathrm{NO}_{3}\right)_{2}-\mathrm{x}(\mathrm{OH})_{\mathrm{x}}
$$

where $x$ is ab.sat 0.6 . In batch loading. the uranyl nitrate. $\mathrm{CO}_{3}$, and resin are mixed together. In the continusus-iolu.nn methud, the aid-deticient uranyl nitrate contaitis exiess resin and loads only to the degree that $y$ ields nearly stuichiometric uranyl nitrate:

$$
\begin{aligned}
1.5 \mathrm{UO} \mathrm{O}_{2}\left(\mathrm{NO}_{3} \mathrm{~h}_{1 .+}(\mathrm{OH})_{0.6}\right. & \stackrel{\text { excess resin-H }}{\longrightarrow} 0.45 \mathrm{R}_{2} \mathrm{UO} \\
& +1.05 \mathrm{UO}_{2}\left(\mathrm{NO}_{3}\right)_{2}+0.9 \mathrm{H}_{2} \mathrm{O}
\end{aligned}
$$

The uranyl nitrate effluent is then recyicled by reciontacting it with excess $\mathrm{UO}_{3}$. Using th: previously described equipment, ${ }^{2}$ uranium was loaded onto WAR (Amberlite IR(-72) at the rate of $100 \mathrm{~g}$ per hour (in a I-in.-riam column). The uranium distribution profile over the working length of the column was obtained by sampling the resin every 6 in. and analy zing for uranium content (Fig. 3.1). Although this profile is not nearly as sharp as that obtained for strung-acid resin, it is sufficiently well defined to indicate that full loading can be attained in a reasonable length.

\subsubsection{Loading with ${ }^{235} \mathrm{U}$ and ${ }^{233} \mathrm{U}$}

The adaptability of the resin loading method for preparation of $f_{1}$ iGR fuels will be influenced by process technolugy and by possible radiolytic eflicts on proiess materials. Process equipment for buth primary and recycle fuel preduration must be designed and arranged sicording to restraints imposed by nuclear criticality consideratiors. Additionally. equipment ksed for recyile feed materials must also be suitable for remotely controlled operations. Radiolytic eifects ori process materials may result in degradation of the resin particles and alteration of the redox porential of the uranyl nitrate feed solution. Evaluaitons of these parsible effects cismprise a part of the chemical development program on the resin loading process.

During preceding investigations of the resin loading process. 1 number of small batches containing approximately $200 \mathrm{~g}$ each of highly enriched $(93$ to $97.6 \%$. $235 \mathrm{U}$ were piepared for irradiation experiments. The batch loading procedure for thes naterials was that routinely used for loadings with r.ormal uranium from aid-deficient uranyl nitrate solution (Fig. 3.2). Without exieption, these preparations were free of detectable degradation of either the resin particles or the feed solution. Although these conclusions are based on

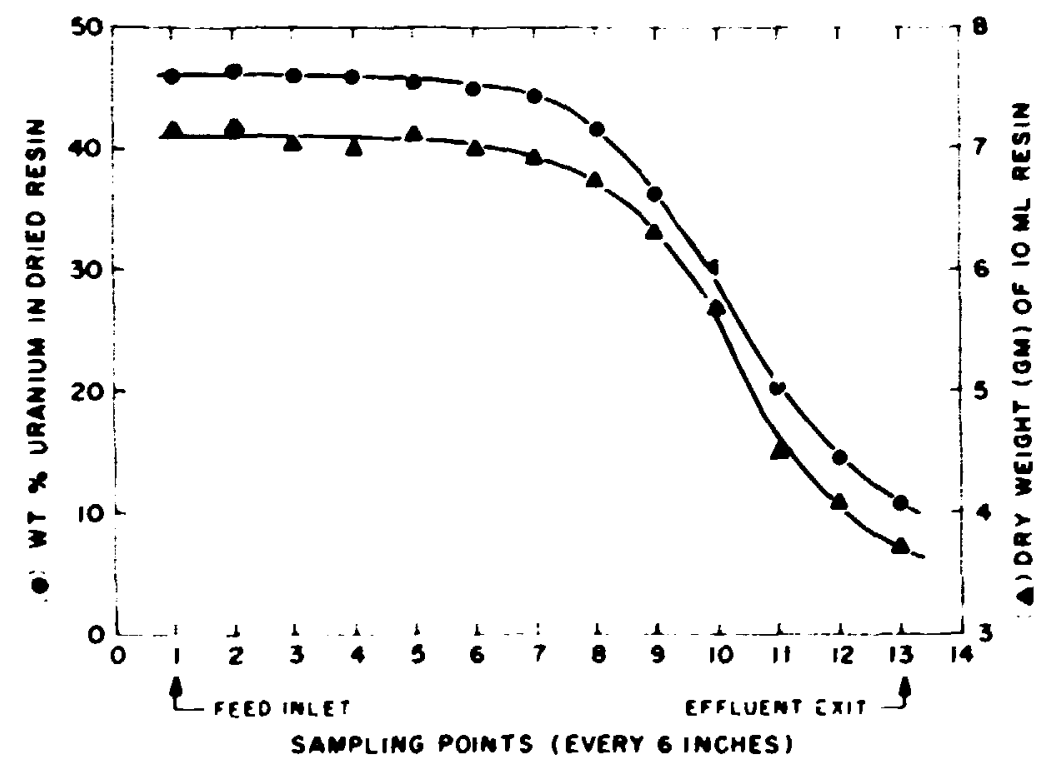

Fi2. 3.1. Uranium pmofile for weak-acid resin loaded in continuo.'s column. 


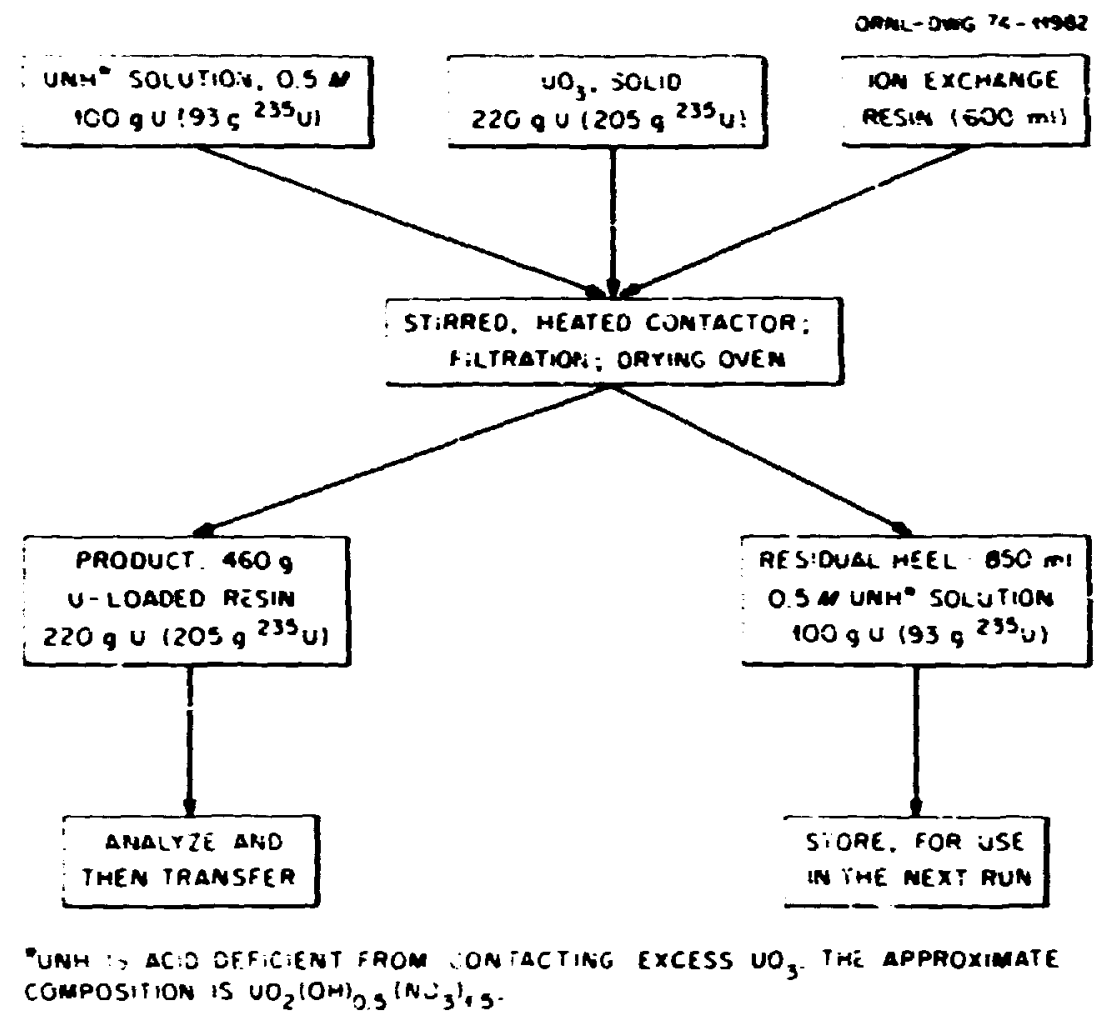

Fin. 3.2. Batch loading of wak-acid rasin with 23 s.

limited experience. there is no available evidence that the preparation of initial or makeup HTGR microspheres fueled with $235 \mathrm{U}$ shouid be impaired by undesirable radiolytic effects.

However, the suitability oi the method for use with recycle fuel requires that the resin loading operation be satisfactorily performed with recovered ${ }^{23} \mathrm{U}$. with no sigrificant effect on the chemical process or resin particle from the radioartivity of associated ${ }^{232} \mathrm{U}$ daughters. At an early point in th, developrient of the resin loading process, a trial run had been conducted with freshly separated ${ }^{233} \mathrm{U}$ (which contained about 7 $\mathrm{Ppm}^{232}$ (j). Althu, gh the resin was successfully loaded with uranyl ion in he experiment, with no observable degradation. precipiation of the uranium (presumably as a hydrous U(VI) oxide) was ncied." Since the precipitated phase h.id not been observed in previous and subsequent experiments with normal uranium or

4. Ihw. pp. 2830. with solutions erriched in ${ }^{235} \mathrm{U}$. the phenomenon has been tentatively ascribed to radiolytic effects.

We recently demonstrated that precipitation of the uranium during the !ading operation can be eliminated by continuous sparging of the uranyl nitrate solution with oxygen prior to and during the ion exchange process. Whether or not this simple modification is sufficient to avoid the precipitation nuisance under the practical situation in which substantially higher radiation intensities are involved awaits further experimenial study.

\subsubsection{Preparation of Test Materiabs}

A significant part of the chemical investigative effort assiciated with resin-based microsphere development has been the preparation of loaded resins for carbonization studies and for irradiation test specimens. During 1973. approximately $10 \mathrm{~kg}$ of uranium as uranyl ion was loaded on selected ion exchange resins as 
idlums:

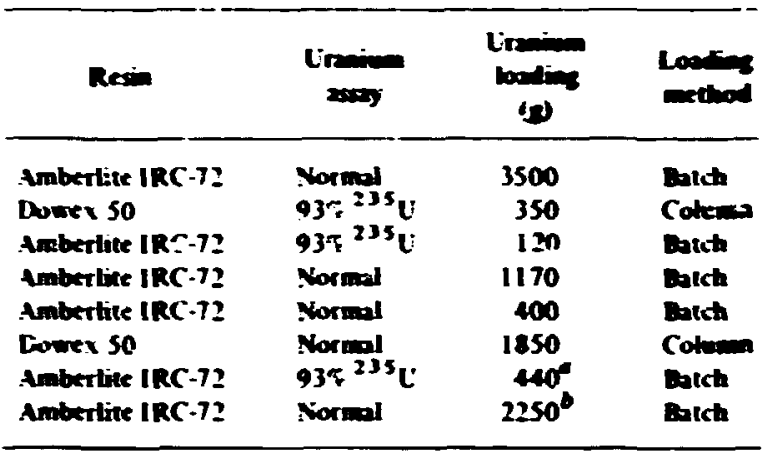

Two bodings at $220 \mathrm{~g}$ exh.

OFine loading at 450 g each.

In each case, uranyl ion from uranyl nitrate solution was exchanged with the resin in its hydrogen form. Loadings on strong-2cid resin. Dowex 50. were made from stoichiometric UNH solution at concentrations of a'xut $0.05 M$. Loadings on weatricid resin. Amberlite iRC-72. were made from 0.3 to $0.5 M$ uranyl nitrate solutions. However. iess favorable exchange equilibria for weak-acid resin than for strong-acid resin tave required the introduction of acid deficiency in the uranyl nitrate solution to achieve full loading- These laboratory-scale preparations, as well as larget engineering-scale operations. have used the method of adding $\mathrm{UO}_{3}$ to the uranyl nitrate solution to achieve acid deficiency. 5

Recycle of this solution in successive batch loading operations requires only the addition of sufficient $\mathrm{UO}_{3}$ to satisfy the exchange capacity of the resin batch. In lasget plant operations, acid deficiency can probably be introduced more satisfactorily by partial denitrasion of the UNH feed solution by either steam strippirg or solvent extraction with an organic amine.

The repeated preparation of these test materiak has provided a basis for improving experimental techniques and for examining some themical equilibria asociated with the looding process. Parameters of the resin looding process that may become important to fuel development technolosy include the controlled partial looding of resin particles and the simultanerous loading of various cations and uranyl ion. Partial loodings of uranyl ion may be a cirecl method for oblaining variations in density of the carbonized or oxidized

5. P. A. Hax, HTrR Fued Developmenr. Use of $\mathrm{LO}_{3} 10$ Land Corion firchenge Resin for Microrpthere Mrepurefion. ORNL. TH 3817 (September 1972)

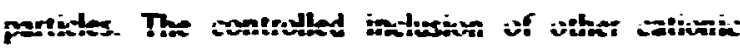
species in the looded resin may have utility for inproving physical properties of the fuet kernel. for fision product retention. and for nutlear performance aplications requiring incorporation of a bumable puison with the fissite material.

Two experiments were conducted as a preliminary examination of exchange equitibria in nitrate solution between samarium as $\mathrm{Sm}^{30}$ and uranium as $\mathrm{UO}_{2}{ }^{2 \circ}$ after the biter had been loaded anto WAR (Amberlite IRC.72). In one experiment the resin wo londed nearly to its exchange capacity with uraium ( -49 wt $q$ on dried resin): the second corresponded to an approximate 89\% uranium loading Sumarium exchange ívn: nitrate solution was examined on $10 \mathrm{ml}$ aliquots of wet resin in a range corresponding 'o 180 to $730 \mathrm{ppm}$ by weight somarium with iespect to uranium. The data were slculated as distribution coefficiet ts

$$
\left.\mid D=\frac{\text { (moles solute: gram iesis) }}{\text { (moles solutefliter solution) }}\right]
$$

and correlats d with the reaction

$$
2 \mathrm{Sm}\left(\mathrm{NO}_{3}\right)_{3}+3 L \mathrm{CO}_{2} \mathrm{R}_{2} \Rightarrow 2 \mathrm{SmR}_{3}+3 \mathrm{LO}\left(\mathrm{NO}_{3}\right)_{2}-
$$

Fots of these distributions axcording to the equation

$$
\ln D_{U}=\psi_{3} \ln D_{5 m}-1 / 3 \ln K_{2}
$$

by linear regression yielded a value of 0.67 for the slope of each of the two data sets. For a lasting thai zontained 45.9 wt $\%$ uranium in the dried rean, the -quilibrium quotient $K_{Q}$ had a value of 0.86 (glits $)$ : for a loading that contained 42.7 wr $\%$ uranium in the dried resin. :he equilibrium quotient was 0.68 (g/liter). These results illustrate that simultaneous kading of trace elements with uranyl ion will be strongly dependent on the relative loading of uranium on the resin. Preliminary examinations of equilibria asociated with the uranyl ion exchange reaction also show strong dependence on the composition of the uranyl nitrate exchange media. For resin loaded to 70\% of its capacity with uranium and in equilibrium with $0.3 M$ UNH solution. the ratio of nitrate ion to uranyl ion is approximately $2.25\left(\mathrm{NO}_{3} / \mathrm{U}\right)$. This value decreases to about $\mathbf{2 . 0 0}$ fc: fully loaded resin. These tentative results indicite tina $\rightarrow$ more complete understanding of the chemical equilibria asociased with the resin exchange reactions may permit more seisctive process control than can now be realized. 


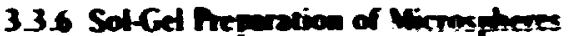

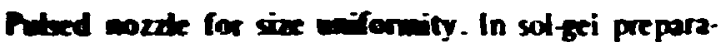
tion of spheres. the formation of sol drops is a critizal operation. since uversized and undersiaed spheres constitule the principol offspecification material. The putsed nozzle tectinique that was reported last year has continued to operate very satisfactorily.

In this system. the treakup of sol streams from orifkes or capilaries is made more uniform and regular by imposing a vitraion at the natural frequetry of drop formation. Routine use of the system has consistently given kemels with averng diameters within 14 of predicted values and standard deviations of about 19 of the average diameter. Detailed results have been reported." About $300 \mathrm{~kg}$ of ThO $\mathrm{O}_{2}$ spheres and smaller amuents of $\mathrm{ThO}_{2}+\mathrm{HO}_{2}$ spheres wete prepared (see Seits. 2.1.2. 2.1.3. a:2d 2.1.4). Thoria spheres of two larger average diameters wete prepared to demonstrate results for a wider range of diameters. Diameters cakculated from nozde conditions along with experimental measurements were as follows:

\begin{tabular}{|c|c|c|c|}
\hline Siodede ty & $\begin{array}{c}\text { Hedicted } \\
\text { (i) }\end{array}$ & $\begin{array}{l}\text { sined } \\
\text { in) }\end{array}$ & $\begin{array}{l}\text { Sounder } \\
\text { deviation } \\
\text { (H) }\end{array}$ \\
\hline One capilary & 595 & 594 & 3.7 \\
\hline Ore capilary & 694 & 680 & 6.1 \\
\hline Ouc capilary & 690 & 695 & 5.4 \\
\hline Eijht orifoes & 392 & 394 & 14 \\
\hline
\end{tabular}

45\% confidence interval, normel distribution assumed.

An increased sol viscosity appears to be favorable to transmission of the vibration to the point of drop formation. but a low sol flow rate as used for a small dove box sphere-forming column is unfavorable.

(TH-U) $\mathrm{O}_{2}$ and $\mathrm{UO}_{2}$ sphere preparation with ${ }^{23} \mathrm{U}$ and ${ }^{25} \mathrm{U}$. $\mathrm{ThO}_{2}{ }^{235} \mathrm{UO}_{2}$ spheres with $\mathrm{Th} / \mathrm{U}$ ratios of 4.2. 2. 1. and $\mathrm{O}$ and $\mathrm{ThO}_{2}{ }^{23}{ }^{3} \mathrm{UO}_{2}$ spheres with $\mathrm{Th} / \mathrm{U}$ ratios of 4.2. 1 , and 0 were prepared for irradiation experiments. Four batches of ${ }^{235} \mathrm{UO}_{2}$ sol 13008 of ${ }^{235} \mathrm{U}$ per batch) and (wo batches of ${ }^{23} \mathrm{UO}_{2}$ sol $(100 \mathrm{~g}$ of ${ }^{233} \mathrm{U}$ per batch) were prepared by precipitation peptization and mixed with $\mathrm{ThO}_{2}$ sol to provide these compositions. The improved procedure for formation of uniform sol drops was used for these preparations.

6. P. A. Hax and W. J. Lackey. Imporoed Size Uniformily of Sov.tiel Spheres hy Imposing a Vibration on the Sod in Disprion Nozzles, ORNL-TM-4094 (May 1973).

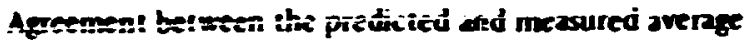
diameters was good. and the uniformity of size was much betier than that of previous small batch preparations but not as good as for routine preparation of $\mathrm{ThO}_{2}$ spheres.

$\mathrm{THO}_{2}$ icrosplace preperacion. Routine preparation of $\mathrm{ThO}_{2}$ spheres was comtinued for about six months to prepare 300 kg of $39 \mathrm{C}$ - and $500 \mu$-diam spheres. Three repons provide complete descriptions of our preferred procedures for prefaring $\mathrm{MHO}_{2}$ spheres. - The 2ethylthexanol (2EH). which is used in microsphere forming. wa; charged into the engineering-scale $\mathrm{ThO}_{2}$ forming sys em in April 1972 and remaned in use. with additions on ty to mzintain an inventory of about $\mathbf{2 0 0}$ liters, for an acumuiated operation of about $600 \mathrm{~kg}$ of $\mathrm{ThO}_{2}$ spheres withcul any apparent effects on the sphere formation. Surfactants were added to it: $2 E H$ at the rate of 0.68 of Span 80 and 38 of Ethemeen $S 15$ per liter of sol feed for the 390 or $500-\mu \mathrm{ThO}_{2}$ spheic:

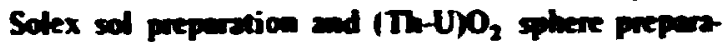
ism. The preferted sid preparation flowsheet for $T_{i} / \mathrm{U}$ atom ratios of 3 is 4.25 is a continuous solventextraction process. The uranium is UVI) and the sol is $\mathrm{MhO}_{2} \cdot \mathrm{LO}_{3}$. This proxess was demonsirated with sphere preparation at the rate of $10 \mathrm{~kg}(\mathrm{Th}+\mathrm{U})$ per day." The same sol preparation equipment with minor modifications was satisfactory for rates of 1.0 and $1.5 \mathrm{~kg}$ $(T h+U)$ per hour, but operation was poor at $2.0 \mathrm{~kg}$ $(T h+U)$ per hour. ${ }^{\circ}$ This equipmest is critically saie by geometry and has other tharacteristics that are desirable for remole operation with ${ }^{23} \mathrm{U}$. The equipment design has been described.' This Solex equipment was put into operation to prepare $\mathrm{ThO}_{2}-\mathrm{UO}_{3}$ sol containiag natural uranium and $a \mathrm{Th} / \mathrm{U}$ ratio of 4 . The initial objective nas to accumulate a srock of sol and;or gel spheres for studies of zphere drying and otler refabrication opeiations. Mechanical uperation was excellent. with no difficulties after 20 months without

7. P. A. Has, Focess Requirements for Prepung $T h C_{2}$ Spheres by the ORVL Sol-fed Hocess. ORNL-TM-3978 (Decembet 1972).

8. P. A. Hass. Sol.Gel Arepuraion of Spheres: Deran and Oprevion of Fundied Bed Columas, ORNL-4358 iSeptenber 1969)

9. C. C. Hws. B. C. Finney, and W. D. Bond. Engineenng: Scele Dewonswarion of the Sot-Gel Process Prepurion of 100 $\mathrm{k}_{\mathrm{R}}$ of $\mathrm{MHO}_{2}-\mathrm{CO}_{2}$ Microspheres of the Rate of $\mathrm{JO} \mathrm{kg} / \mathrm{d} y$. ORNL-4544 (May 1971).

10. P. R. Kasten et al. (iCR-TL Progams Anw. Prog. Rep. Sept. 10. 1971. ORN L-4760. Pp. 30 - 31

11. J. W. Snider. The Desigen of Engineering-Scale Solex Equipment, ORNL_4256 (April 1969). 
use. This startup with a new charge of solvent and a different teed along with sume uperational errors revealed the importance of some chemical thowsheet iniena: these will be disciussed individually. Two appriantes is using Sulex sols for ITh-i:10: spheres with Th $\mathrm{C}$ ratios of 10 were tested.

The electrival conducivity of the sols provides an evicllent theik on the sol quality with respect io privess upsets of the presence if some impurities. Values of $\mathbf{4 0 0}$ to $\mathbf{8 0 0}$ micromhoxiom $218^{\circ} \mathrm{C}$ for the dulute $(<0.5 \mathrm{M})$ sul produit are iavorable. while hiqher values are unfavorable. Any sudium in the sol results in In equal molar in:rease in the nitrate concentration and inireases the sul conductivity. Sume of wit leed had sodium conientrations of 300 to $\$ 00 \mathrm{ppm}(\mathrm{Th}+\mathrm{C}$. and this had a delectable effeit on the sol condustivitr. The new solvent appears to need a better pretreatment than the preliminary aid-caustic-water washes. Tnete has always been excessive solids. or "inud." It the rgani-2queurs interfares when starting with new sitvent. but the effects or the product sol were ubsiured by uiher startin problems. Apparently these dirty interfaces result in sntranment. We started without a water sirub after he caustic regeneration chlumn. and the entrainment of sodium in the solvent from the regeneration was carrying sudium to the sol and giving high sol product conduilivilies. Careful analyses showed a detectable. but toterable, entrainment of sodium for tean interfaces and an excessive entiainment for dirty interfaces. This problem is completely eliminated by using a water sinub iontaitor alier the caustic contactor, and all future operations whli use this water sirub. Soi product conductivities are als: a sensitive indication of inadequate extration of nitrate in the first nitrate extraction. This may cesult from a low solvent flow rate. a low caustic fiow rate (with incomplete regeneration of the amine). or inadequate mixing in the regeneration contactor.

Operation of the Sollex system with an inadequate flow of iree amine resulis in formation of a precipitate in the digester. This precipilate requires shuldown and cleanout of the system because it cannot be fiushed th.rough by simply using normal system flows. This effect was observed once when we accidentally operaled with an inadequate caustic Alow rate to the amine repeneration contactor. In this case. a large increase in sol produci co.ıductivity occurred before precipilation. An agiator speed of $350 \mathrm{rpm}$ in the regeneration conlaitor may $q$ a borderline mixer efficiency and incirmplete regeneration of the amine, and thus is another cause of precipitation in the digestor.
Part of the evapuration of sel was carned out with continuous uperation of the evaporator. The takiolf of product was manuaily controlled. since the sul density control was previousify fourd to be unsatisfailuny. Continuous uperation appears to be aiceptable other. mse.

Previuus observations for preparation of $\mathrm{ThO}: \cdot \mathrm{CO}_{3}$ gel spheres' 2 were confirmed. The 2EH compusilim required for fluidized-bed formation of spheres from MoO $-1 O_{3}$ suls varies with the Th $C^{-}$ratio. the $\mathrm{NO}_{3}{ }^{-}(\mathrm{Th}+\mathrm{U})$ ratio. and the digstiun-aging time of the sot. Cenerally. buth Span 80 and Ethumeen S IS must be added io the 2EH. Excessive sticking and clusterine vicur if Span 80 is nut present, while Span 80 alone results in nunspherial parti.les. The following corditions have generally resulted in goxd gel spletes.

1. The sol preparation flowsheet is with countercurrent flow of aquearus and organic and an excess of the organi (1) give the minimum $\mathrm{NO}_{3}{ }^{-} / \mathrm{Th}+\mathrm{C}$ ) blis) and dilule sin corduntivities of $\$ 00$ lo $\$ 00$ mintomhusicm.

2. The sed is digest ed at $\sim 100^{\circ} \mathrm{C}$. usually by carrying out the evaporation ior cencentration al almospheri press ure.

3. The conkentrated sid is allowed it age at kast several days. and preferably for mure than a week. betore sphere preparation.

4. Approximately equal concentrations of Span 80 and Ethomeen $S / 15$ are used in the $2 E H$.

5. The tolal concentration of surfaciants and degradation products must be limited lo avoid craiking of the $g$ l spheres: $>0.5$ vol $q$ is very likely (1) cause cracking and $<0.3 \mathrm{rol} \%$ is the preferred concentration.

Ion exchange as part of the 2EH recycle is not useful for the $\mathrm{ThO}_{2}-\mathrm{UO}_{3}$ sols. The sols do not cimtain any formate. and the countercurrent sol preparation flow. sheet leaves the minimum of nitrate free for pussible extraition into the 2EH. The ion exchange degrades the Span 80 into a less cffective form. and replacement of the Span 80 results in excessire accumulations of degradation products. Thus the best recycle procedure is simple distillation to remove water and a slow partial replaxement of the 2Ell inventory to limit degradation products. Batch surfactant additions at the rate of 48 of Span 80 and 1 of Ethomeen S/IS per liter of $\mathrm{ThO}_{2} \cdot \mathrm{UO}_{3}$ sol feed the surfactants are added to the 2EH) maintained satisfactory column operation for the low:onductivity sols. Cracking of the gel spheres

12. P. A. Hask intemal memorandum. June 1973 
during drying increased frelkeably when the cumulative suriaiant additions imiluding the initial amounts reached a 5 vet?. This confirms the need for a 2EH replacment rate if abuul 2 leers per liter of ThO $--\mathrm{LO}_{3}$ wi or o liters per kaigram of $\mathrm{TH}_{2} \mathrm{O}_{2}-\mathrm{LOO}_{3}$

The principal requirement fir contrui of trying conditions is to prevent iraking. If the get spheres in the IEH surry discharged from the sphere-forming column are tree of racks. sraking during drying and firing appears io be primipally 3 result of excessive rates of volatilization in the spheres. This ovicurs frum the following three sussices of heat.

1. Excessive rates of healup from exisinally supplied heat the critical ange is 100 to $180^{\circ} \mathrm{C}$. where must of the volatilization ociurs. For an individual sphere. relatively high rates. perhaps as high as $10 \mathrm{C}$ min. would be aiceptable. For heat tansfer through bulk spheres. the individual sphere rate of heatup ian be muct. higher than the average rate. si) the allowable average rate decreases as the quantity of sphere increases.

2. Excessive rates of heatup trom burning of the remaining organins or carbun in air during liring. Firing of ThO, $-\mathrm{CO}_{3}$ or ThO: in air is an efi ictive and simpic way of assuring low carbxn iontent and high densities. but drying $10=20^{\circ} \mathrm{C}$ in steam is nocessar: $\mathrm{t}$.) prevent excessive rales of temperature rise and iraking in $\mathrm{ThO}_{2}-\mathrm{CO}_{3}$ or ThO: spheres of $\mathbf{3 5 0}$ or $400 \mu$ fired diameler. Drying w lower temperatures or without steam may leave enuegh iganixs and carbun that spheres of this size irak during the buming

3. Excessive rates of heatup during exothermic rexitions in the gel with $\mathrm{X}:$ - or U(VI) as uxudicing components and organics as reducing components. The concentration of organics must be sinpped to a low value to prevent cracking when this reaction acurs. This effect is not a significant problem for our standard Howsheets for $\mathrm{ThO}_{2}$ if $\mathrm{UO}_{2}$ : these spheres can alway. be dned to $220^{\circ} \mathrm{C}$ in steam withoust exothermi: reactiuns.

The third effect is troublesime for $\mathrm{ThO}_{2} \cdot \mathrm{UO}_{3} \mathrm{get}$ sptieres and controis the design of an engineeringsiale sp.lere dryet. Fot most batches of $\mathrm{ThO}_{2}-1 \mathrm{CO}_{3}$ spheres. the exothermic reacioin starts in spheres at 170 to $200^{\circ} \mathrm{C}$. progresses through the whole dryer over a period of minutes. anc iauses iemperature rises of 100 I1) $300^{\circ} \mathrm{C}$ in !ess than $1 \mathrm{~min}$ for an individual sphere. Spheres dried 10 over $170^{\circ} \mathrm{C}$ in steam generally undergo the reaction without craking: spheres not dried to $170^{\circ} \mathrm{C}$ are likely 10 crack. When the $\mathrm{ThO}_{2}-\mathrm{LO}$, sils have higher NO, $/\left(T_{h}+U\right)$ mole ratios than the stondard 0.! 2. itat Exviticamic reactions start at lower temperatures and drying without cractung becomes yery difficult.

The recent experimental results with the $\mathrm{ThO}_{2} \mathrm{LO}$, get spheres cinnirm these generalizations on drying. For $\mathrm{NO}_{3}-(\mathrm{Th}+\mathrm{li}$ ) mole plins of 0.1 . or less and $\$ 0.4 \mathrm{rol}$ $\because$ surfaizals in the 2FH. gel spheres vere dned usang 2 24ht dying cycle and fired to give good $\mathrm{ThO}, \mathrm{LO}$ spheres. Temperature exiurseons ociurred for every batch of $\mathrm{ThO}_{2}-\mathrm{LO}$, with $\mathrm{Th}^{\circ}=4$. but excescive craking micurred only for $\mathrm{NO}_{3}{ }^{-1} \mathrm{Th}+\mathrm{C}$ ( ) atios $>0.1$ ? ix for high surfiactani concentrations in the 2E:I. Sudies are in progess to develop a shorter. of simplified. drying tycle tor the $\mathrm{ThO}_{2}-\mathrm{LO}_{3}$ gel. Use of 3 high liow rate of reycted areon plus steam did not appear (o) be adequate to delay or control the temperature excursions. Preliminary tesss of hearing to $180^{\circ} \mathrm{C}$ in 2EH are favorable: apparently the exuthermic reartion ociurs. hut the temperature is controled by heat removal by boling 2EH.

Our solfel prikesses had been demonstrated for S.Hex ThO $-1 \mathrm{O}_{3}$ sils with Th. $\mathrm{L}$ ration of hetween 3 and 4.25 . The General Alumic Company selection for their reterence luels liommercial plants) may be $\mathrm{UC}$ :

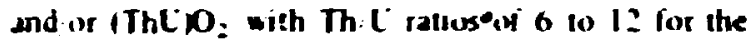
fissife particles. Therefore. we tesied two approaches for use of Suter sit to prepane ITh-l: 0 ; spheres with Th. L : alus of 10.

For one approaith. we mixed $\mathrm{ThO}_{2}-\mathrm{CO}_{3}$ Sotex sul with $T h \cdot C=4$ with $:$ nar siandard $\mathrm{ThO}_{2}$ sul to gre sw with Th $C^{\prime}=16$. This mixed sin was better for sphere preparation than the Sxtex syl alone and gave excelient fired sheres. One porssible variation of this approanh wivuld be w disperse the ThO: powder in a dilute Solex sol with a lower (perhaps If Th $\mathrm{C}$ ratio. This would minimize the size of Sulex equipment and waste and cinuld eliminate the need for Solex evaporations and for minimum $\mathrm{NO}_{1}{ }^{-1}$ 'Th + Li ratios

In the second approah. we operated the Sulex equiprient with nitrate ieed solutions of $T$ th: $C=10$. The dilute sul appearance and conductivity were very Rnd. The evapurated sut was very llund and could probably be cincentrated to a higher $(T h+1)$ molarity than could the suls of $T_{h}: l=4$. analyses shrwed a

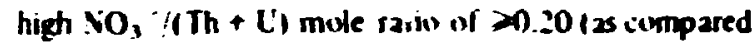
with about 0.12 fir $T h, \mathcal{C}=4$. Spheie preparation was nox suciessful. with difficulties in agreement with the high $\mathrm{NO}_{3}^{-}$innientration. Large lemperature excursions dunng drying resulted in more than 795 cracking of the gel particles of all batches tested. Both a small distortion and some clustering were iroublesome 
chring furmation of the ef spheres. From past expenexes. we wuald expeit to allevite these two spherefurming problems on evarating to 1 higher concentiation. but the hidh mitrite cuntent would still re. Iti in excessive craking during drying-

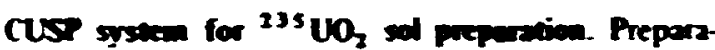
tion of UO= suts in CUSP equipment with a cepacity of 1 and 4 ke of 10 : per batch has been demunstrated and repured." 3 A system was dexigned for preparation of $1+\mathrm{kg}$ bacthes of ${ }^{33} \mathrm{LO}_{2}$ sol. Currenty. the processing equipment has been isbriated and installed in a new entosure. and the assembly is ready for installa tivn in Building 3019. The work remining to be done by ORVL forces curreatiy progresses on a second priority 25 crafismen are arilable. since mo definite program coramitment existed. Should a commitment appear and the necescary manpower be allocated. the system could be placed in operation within about 60 dxy. The plotonia-sol-making and dense microphere fabrization equipinent has been on sandby for several years: one of the enclosures (innolved in plutonia sol preparation) is in poor condition and should be replaced before operations could resume.

\subsection{RESN CARLONIZATION - 2103 (OANL LEAD)}

\section{R. Johnson W. J. Lekey}

The objective of the resin carbonization work unit is to develop a process and the prototype equipment for reducin uranium-loaded weak-acid resin kernets to an intermediate $\mathrm{CO}_{2} \mathrm{C}$ product. In the finst step of the mecrosphere costing operation (wotk unit 2104). the $\mathrm{UO}_{2}-\mathrm{C} \mathrm{ma}$ uspheres will be partially converted to $\mathrm{UC}_{2}$ The resultant fuet kemels will contain approxima'sty 75 arok $T \mathrm{UC}_{2} .25$ mole $7 \mathrm{VO}_{2}$. with an excess of carbon. The size and density of the converted fuet kernet are strongly dependent on the provess variables during resin carbonization.

The carbonization process consists in fluidizing the laded and dried resin kemets with an inert gs and then heating the particles to reduce the resin to carbon. A gaseous hydrocarbon reaction product must be swept out of the carbonization fumace and scrubbed to prevent the formation of deleterious tar and soot on the cool surfaces of the furmace. The carbonized rasin

13. B. C. Finney and P. A. Haxs. Sod Ired mocess fingunerenne

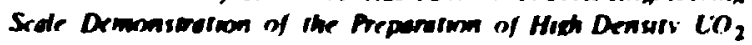
Microsnteres. ORNL 4 shn2 iNovember 1972) partintes are pyropherix and must be handied anu transferred remolety in an incet atmusphere.

Resin iarbunuation development onl began in alendar sear lyit.

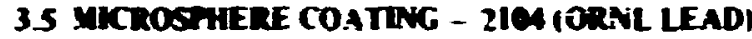

$$
\begin{aligned}
& \text { w. J. Lextey F.C.Dons } \\
& \text { w. H. Pethin M. K. Prestun } \\
& \text { R.S. Lowne }
\end{aligned}
$$

The chentive of the mictusphere cuating work unit is to experimentally develop tie proceses and equifment needed to remotely coat HTCR fud partintes. In this regard. we will obtzin provess and equpment performance data needed for the design and mucification of the coating system for the FRPP. Mirrusphete cuating is divided into three areas:

1. partinte cuating. which consists of kemel connersion and applicativn of porous and dense sarben costings as well $x$ silicun carbide coatings to frsibe fuet partictes:

I coater effluent treatment. in which the eflluents from the carbon and silicon carbide coating opera. tions are rendered into a form suilable for disposal:

3 partick handling. which includes particte transfer. storag. classifinativn. weighing. batchire blending. and sampling.

The recently revised cuating process flowsheet for the pilit plant is shown in Fis. 3.3. Two idential cooting iurnaxes ate planned. each of which wll operale independently: that is, the fumaces operate in parallet. 2a "exh fumace is capable of depositing all the coating layers desired. This paralke nperating scheme. when compared with series operation. reduces the amvunt of bookkeping required firs characterization and inventory purposes.

\subsubsection{Protide Coning}

Fluidized-bed-type partick coaling equipment and proceseses are being developed for remo'e coating of recycled HTGR fwe. The reference recycte fosile particle is of the weak-acid-resin type described in Sect. 33.

The uranium-loaded resin particles are carbonized prior to coating. and the desired frarion of the $\mathrm{UO}_{2}$ is reduced to $\mathrm{UC}_{2}$. The fuel kemels are then coated with a Triso coating. Fcr particles of this type. about $3 \mathrm{~kg}$ of uranium will be costed daily in the Thorium-Uranium 


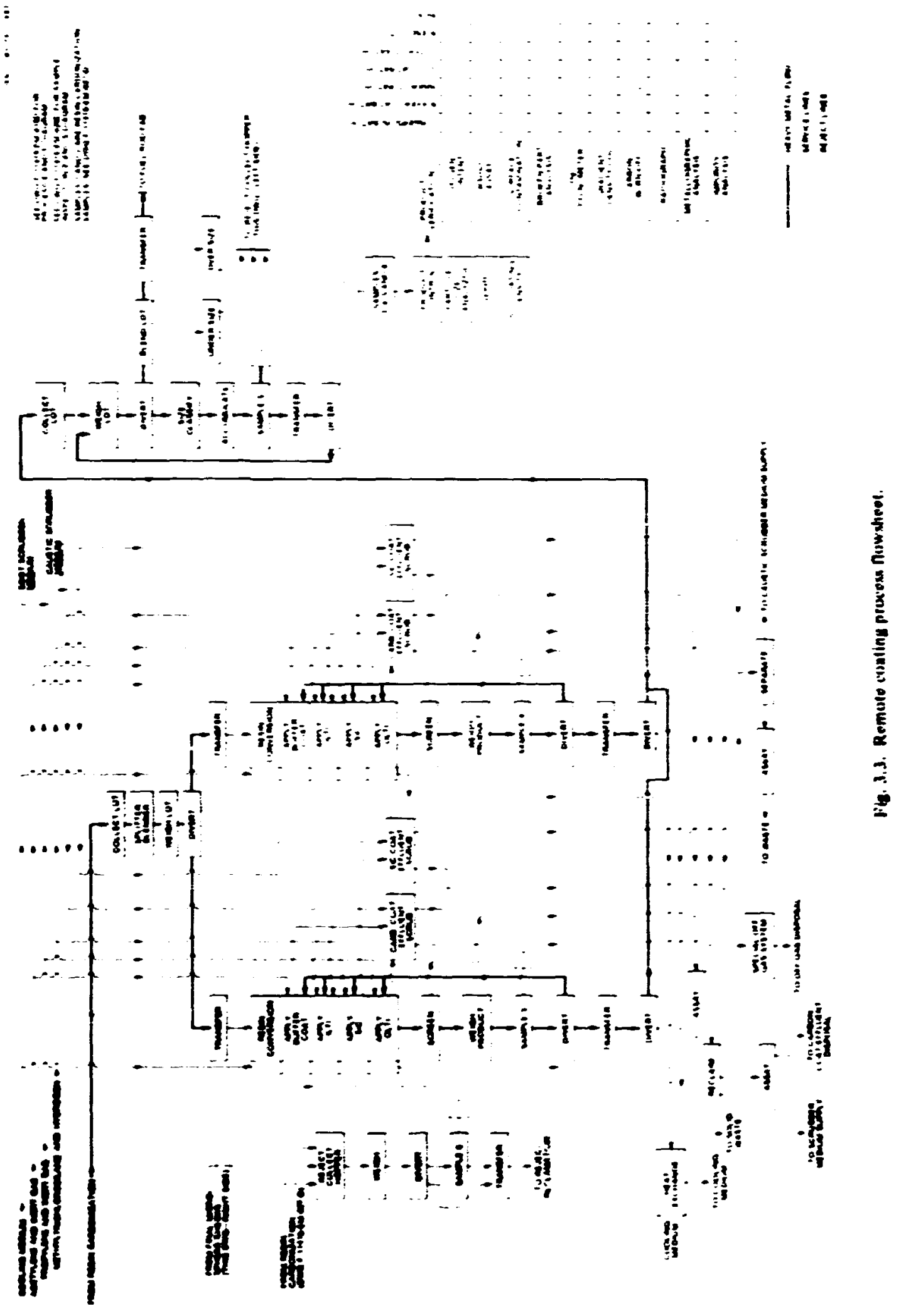


Recick Fadily ITLRFI pdut plant. A verelupmental engancering-sale cuater. dxinbed pectimosly. 14.15 has been upeialminid for soneral vears. Naye efforts this year cunsosed in umprowng several pirtions of this equipment and velaeng $a$ better understanding of the processes used to depusit buth the setykenc-krived porcus buffer coating and the propskeniderived denst carbun coatiag.

Equipareat medtication. The major mudifination to the j-in dian enpanering-siale coatung fumace was neplarement of the furnace support structure. base. and electroxes. An isumetrin drawing of the muinfied coater is shown in Fig. 3.4 . The intilevered support and new electrodes allow better aciess to she hwer poition of the coater and thus allow increased thexibility in the design of both the gas disiributor and the partike unfooding system. The new dexipn eliminates dicashunal owertieatung of the eleitroder and is n.ors arienable lo remute upetation and maintenance.

The engenering-siale coater wa mudified so that a porous plate (frit) npe gas listributor could be used ir addition to the consenticnal conial distributor. Porues

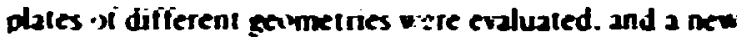
ape disinbutor, shown in Fig. \$.5. was develinped." The nes firt is thought to be superior to previnus init desugns tor the fidlowing reasuris.

I. The clating gates) is brought nez: the buttum of the int by a sinde water-ionted nouk and thus the nukzle and fint holder are as sumple as that usod with a ilat int

$\therefore$ Conirary to a flat int of uri:fiom thikkness. nearly 1:. of the Eosting ges thows thiough this sis thinned regions of the newly desugned itt. and thus the gas vetorit: is comparatively hy. Because of the hy grs veloity. heatung of the gas within the fat is minumized. and thus decomposition of the gis and plugejig of the int with carbon are atsol minumared or etimnaled. Pugeng is als) mininized heiause ihe thinneci region of the int is at the boltom and is incted more efficiently by the water-iusted gas injectiv.

3. Since there arz no nocules protruding through the frit. liss of particles down through suct, holes cannoil aciur. and the int in be used as the boltom of an unloading vessal.

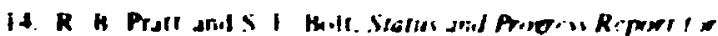

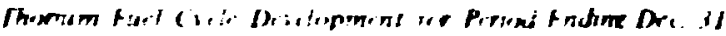

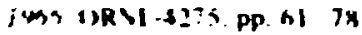

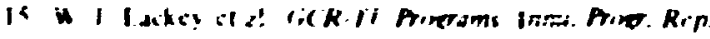

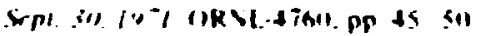

in Patent appiked ior
}

Roxulis to date with ints if the new desuen have heen must enivuragang. There ha been in meassable inirease in ressiase to the of gas ihriugh ti.e ints dunne the course of clating. whih inthates that plugeing is mox kicurnng. A pulished seitkm of a int that ass used is depasit buth bufter and limetemperature Isulteph (LTI) cuatungs was exmined mirusiopaially. and no arben depasuls were seen in the thinned regon in the frit. Depassits wete easuly seen mituscupailly in the ci:d :ype of flat ints. One of the sew fints wo used for linu butiter and finu LTI coatung rurs without experiening plusgane. Sume difficulties hre been enivuntered with eath of the fnts we have wiokid with. Sexing of the int in the hotder sufficheni!y to prevent kalage of gas has been trimblesume. I new hotder is being teogned to eliminate keakage Nso. witi enth of the int g-nnetres. sume partkles allere I.. the fint. To cumbat his problem. we are curren:k fabriating fints with siceper slupes. Properties of cartun cuatings deprsited usun. Inits are reported in the fullowing section.

The aetylene supity system for the engin mng-sual: croter and fir a seciond 5-in. tiam cooter ass modufied (1) All,w use if hipher aretylens flow rates. Ten actyken: cy!inders were connected lo a summin

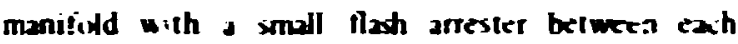
cylindes and the manitidd. A larpe flash arrester was lusated between the manifidd and the cuatei. ant a vented relkef value was anstalked tis prevent iverpresus. uatuon of the manifidd. The system is desipund (1) iperate at 15 pse in order to prevent the pumtaneirus dicampasitinn that ian ixcur at higher pressures.

Commercial surrices were lonated for two types of heal shiclds that siuuld be supenor. especially for remite uperation. II) th- molybdenum heat shields currently used in the protistype ciating furnace. One type consass of ragdized arbon felt. Whe the othet cinsisis of muttilayers of corrugated ifatoil sandwiched between carbun telt. A hollew cyhnder of each lype. sultably sued fir the 5 -in. diam prots: pe coater. was recieved from the vendors. Buth are isfikzently rigua lin be free standing and appear sufficier it y ruged fort remelte handling-

An assessment was made of the ecomoilitic and sichnical advaniages and disadvaniages assucia: of with use of 3 !n diam cuaters in a remote HTCR icfabncation plant rather than 5 in.dian cuaters.' 7 Th. I wger

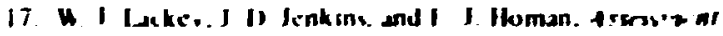

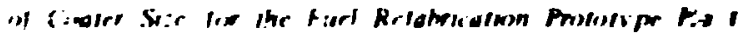

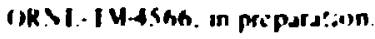




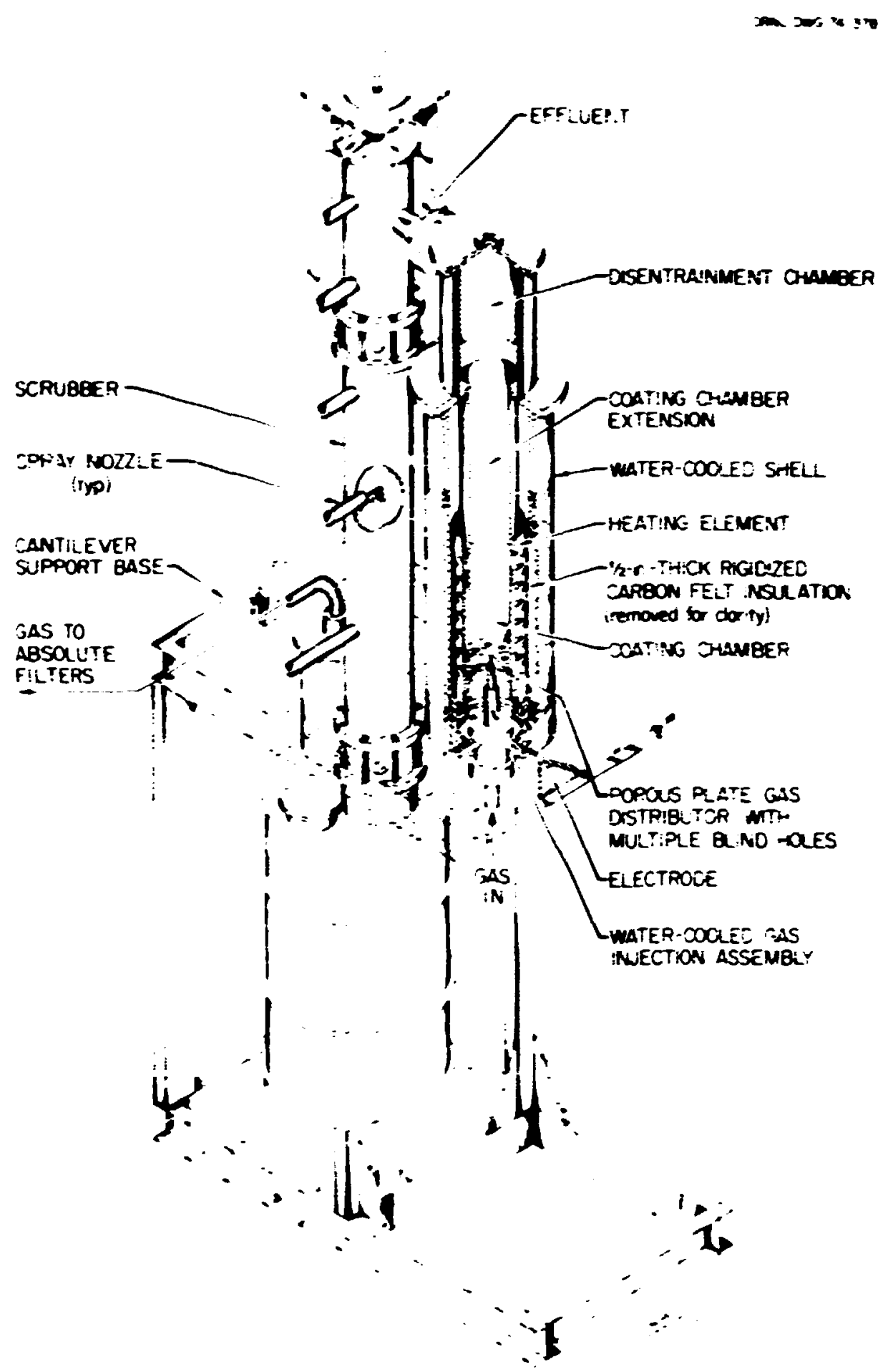

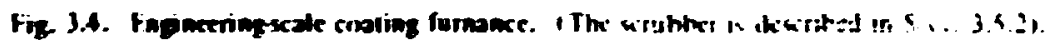




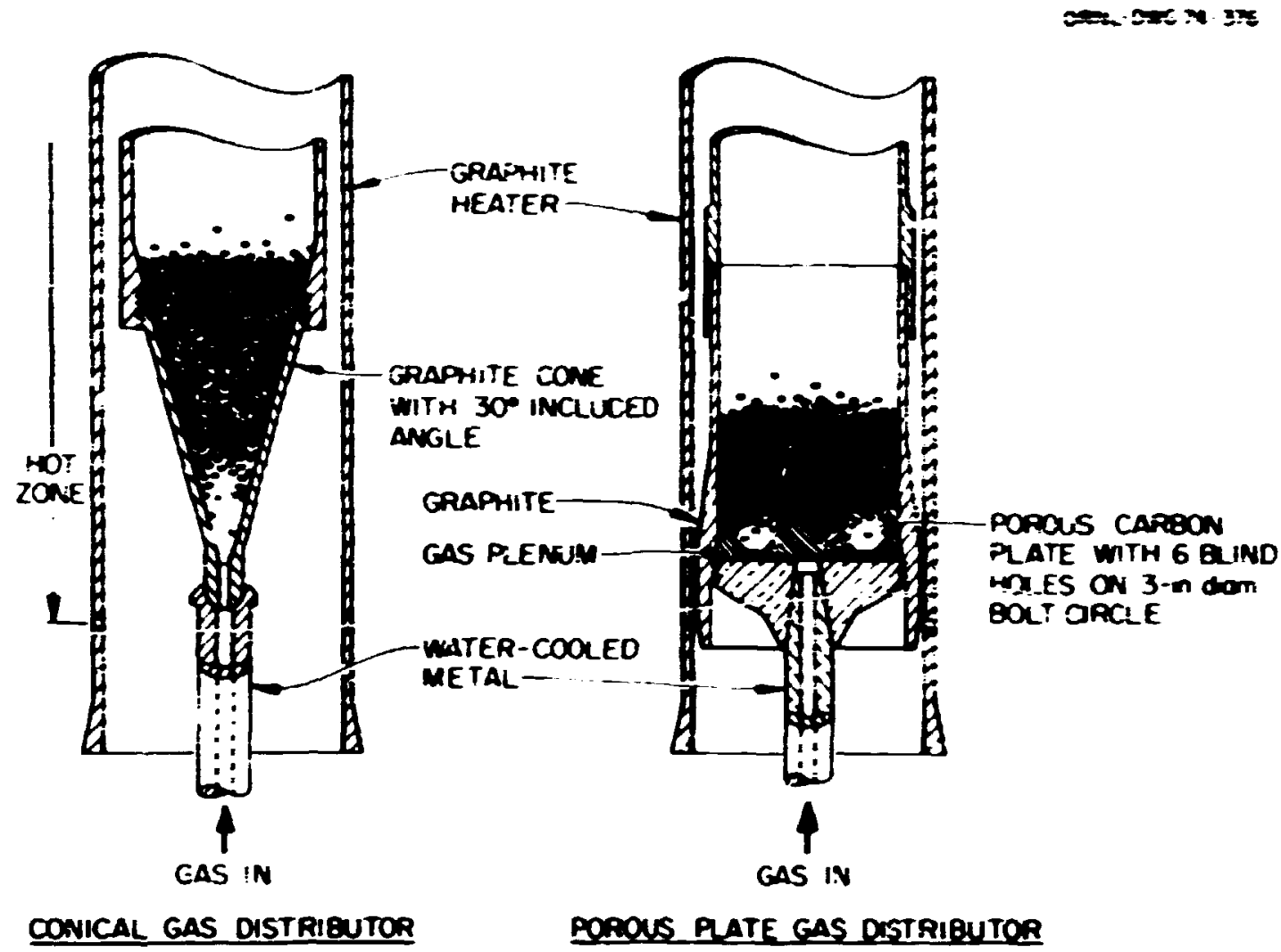

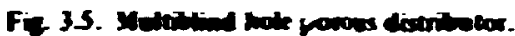

coater is ilearly favised from the ecurromix standpoint. Fince criticality considerations dictate that 9-in.diam coaters must never be flooded with hydrogenusus materials. the fumaie coolant and soot scrubbing nedia annot be water or any othar hydrogenues material. Suitable aternative materials that are not givd moderators appear to be availabte. Development of a 9-in.diam coater to the state currently existing for the 5 -in.-diam engineenne-scale coater was estimated to require abuut 51 million and $21 / 2$ to 3 years.

Hroces development. The first coating deposited for either Biso- or Triso-coaled partikles is a porous carbon huffier layer. One function of the buffer layer is to provide void space for acommodation of fissin gacs and fuel swelling. Therefore. the buffer cuating density and thickness must be controlled to ensure that ample void space is available. A method was developed whereby the quality of one buffer coating run could be compared with another having different values for density and coating rhickness standard keviation. The method is based in the assamption that a bufier thictness of less than $65 \mathrm{~mm}$ promdes madequate vind volume for a particle that has a bufier densary of 1 . I gicm and a kemet dasneler of $350 \mathrm{~km}$. Thas is though: tii be a reasinable value fon the intical nud volume. since for a partikte batch having a buffer density of 1.1 g $\mathrm{cm}$.' an average buffe: thi-kness of $100 \mathrm{~mm}$. 25. a hatch thitness suaciad devition withm $15 \mathrm{~mm}$. it ian be hown that 17 of the particles will have kess than the satical vow solume.

The modet was developed with Buscomated parricles in mind. oust the conctusions reached comierning the relative quality of diferent buffer contung are equally valid for Trisu-ioated particles. Particte batches are rated by calculating, and comparing the percentase of partickes per batch that have less than the sritikal wod volume. The curies in Fig. 36 show the values of densily and costing thickness siandard deviation that yield 0.1. N.j. I.0. and 2.07 of the parikles with kess than the intical mid volume. For example. the pount 


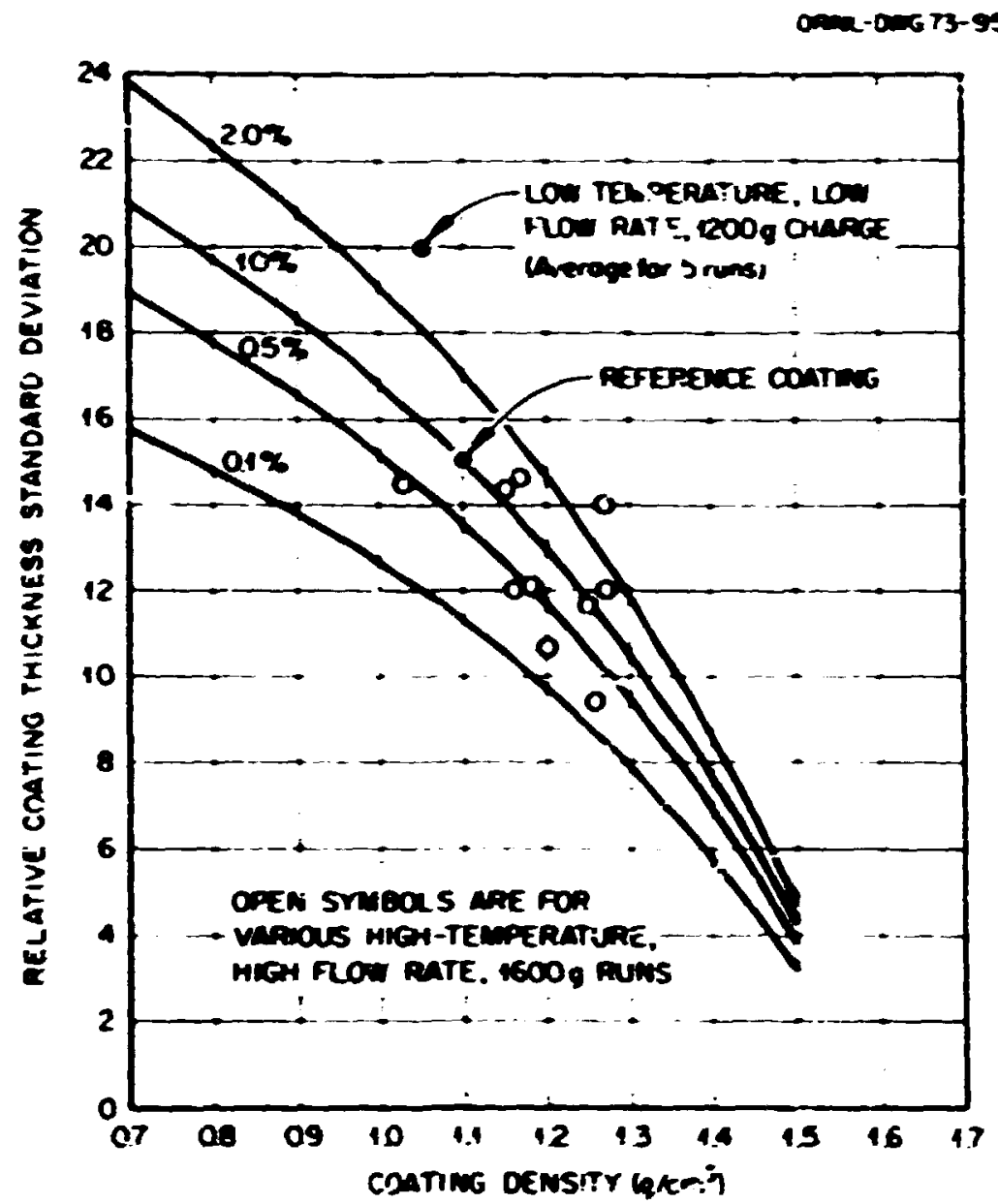

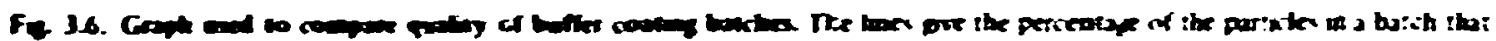

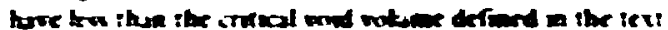

Wheted "effereme soosine" represenss a parikik balih that has a buffer deasoly of $1.1 \mathrm{~g}^{\prime} \mathrm{cm}^{3}$ and a civating theikness standard demaing of is am. Vive that the pinnt ialls in the 1\% line. meaning that 1\% of the porticles have s vind vilume less than the assumed intäi ralu. Alsu shown on the figure are dala parnis for sereral cupting runs made wh the $5+n$ diam

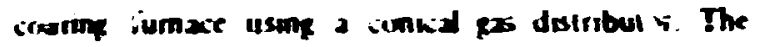
uppermust ponnt iflled cuctel represents ive ciptung nus mode usong nonideal clationg condutuns. and the nunber of porticks having less than the critial roud ndume exiceds 25 . On the other hand. each of the open ciriles represents a coatung no node using various umprined cindiriuns, namety. higher temperatures and hyper aretylene tlow rates. Sote that the highiemperaiure ant highon-rate rurs yictd impioved ildings even though the tharge ras larget. These data puins for the umprowed conditums saiter about the I: Ine and are thus generally equal in quality to the refien.mie coatung. This gaph illustrates a phencmenon that was genetaly observed for the buffer cuating prours that is, as the provess vaniables were aliered in 3 mangier that resulted in a lowet value for the coating thickness standard seviation. Thete was a concurrent inrresse a cobting densaly. This interaction makes it necerory to use a method sush a that desinbed bere when the quality of (wi) or more buffer batihes is being compared 
Figure 3.7 gives results fi: arditional bulfer coating

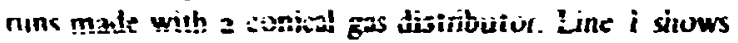
that as the diluent llow rate is increased, the coating thickness unifurmit; improves but the coating densit; simul.aneurs!lv increases. The net is:su't is that the provile: qualit; ;s virtually independent of the dilw.all How rate. I Alherugh s:: siown in the grapt, product quality is improwed oy increasing the acutylene flow rate. I Lines : and 3 of Fig. $3.7 \mathrm{sh}$.w that product quality is imprcved slightly as the c:arge is reduced from $3.2 \mathrm{~kg} \mathrm{to} 800 \mathrm{~g}$.

Figure 3.8 gives the results for burfer coatings depusited using porous-plate-type gas distibutons of variess geumetives. The results are rathe: independent of geometry and sluster about the $i$ and $2 \%$ lines The froperties are amazingly similar to those obtained with the conical tistributor. especially when one considers that the gas and particle tlew patterns and velucity are so dissum:la: tor the (wo gy pes of distributors.

The excellent reproducibility of $a$ e buffer coating process was demonstrated by makin, 1 : nominally idertical runs. The coating conditions were as follows: kem. $1=250$ to $420 \mu \mathrm{m}$-diam $\mathrm{ThO}_{2}$. temperature $=$ $1475^{\circ} \mathrm{C}$, acetylene flow rate $=5 \mathrm{sifm}$, helium fow rate $=$ $2 \mathrm{scfm}$. time $=12 \mathrm{~min}$, and coating char ber $=$ new single inlet $30^{\circ}$ included angle cone per run. The more importan coating properties are summarized in Table 3.3. The overall impression to be gained from studying the data is that each. coating run yielded a bigh-quality product that varied only slightly from une run to another, even though a large charge $(3200 \mathrm{~g})$ was used. The coating density varied from a minimum a 1.125 to a maximum of $1.147 \mathrm{~g} / \mathrm{cm}^{3}$, which is trivial. consiuer. ing that the specification will likely be $1.1 \pm 0.2 \mathrm{~g} / \mathrm{cm}^{3}$.

ORNI-OWG 73-9140

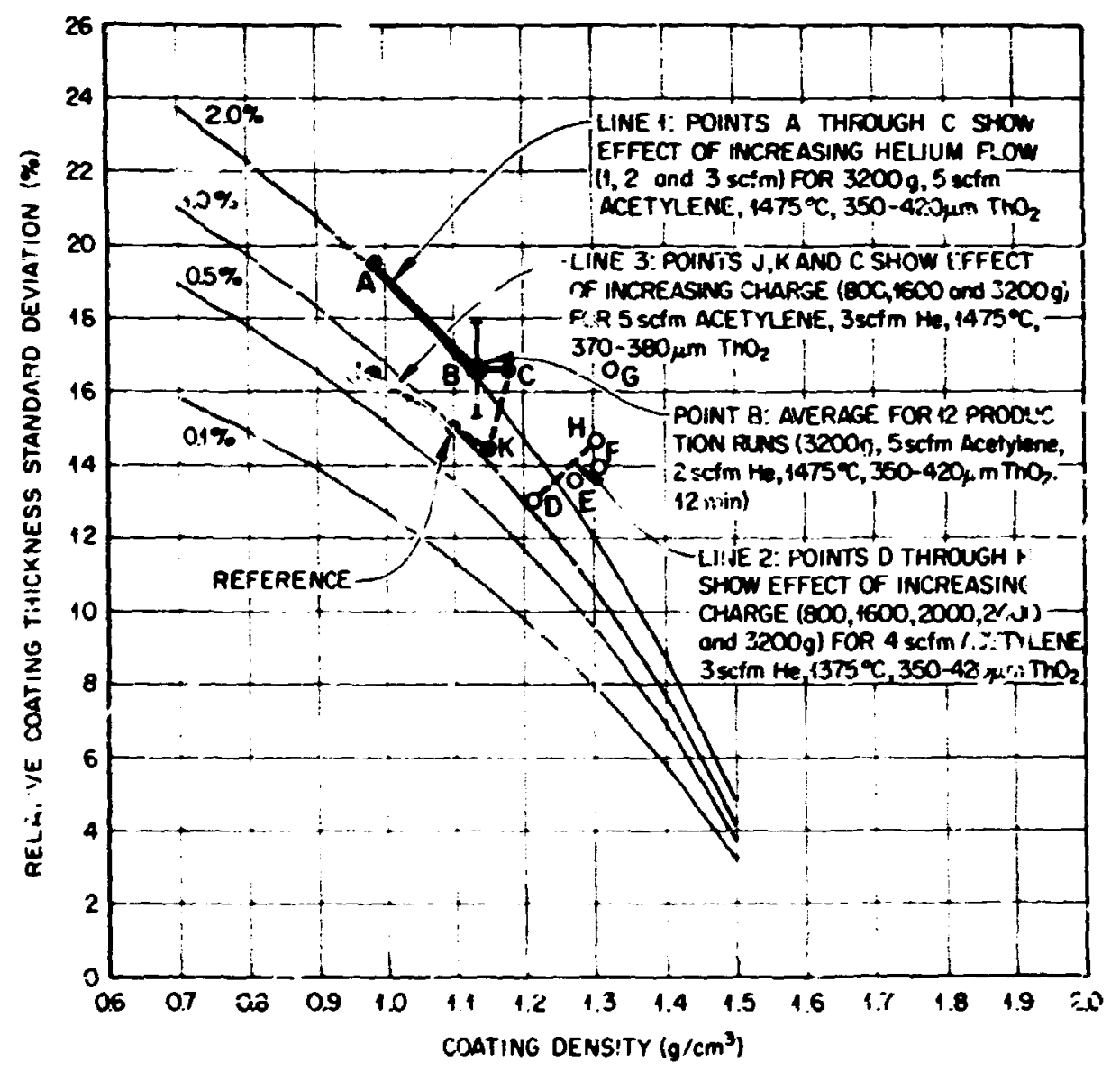

Fin. 3.7. Effect of diluent flow rate and charge on the quality of buffer coating. 


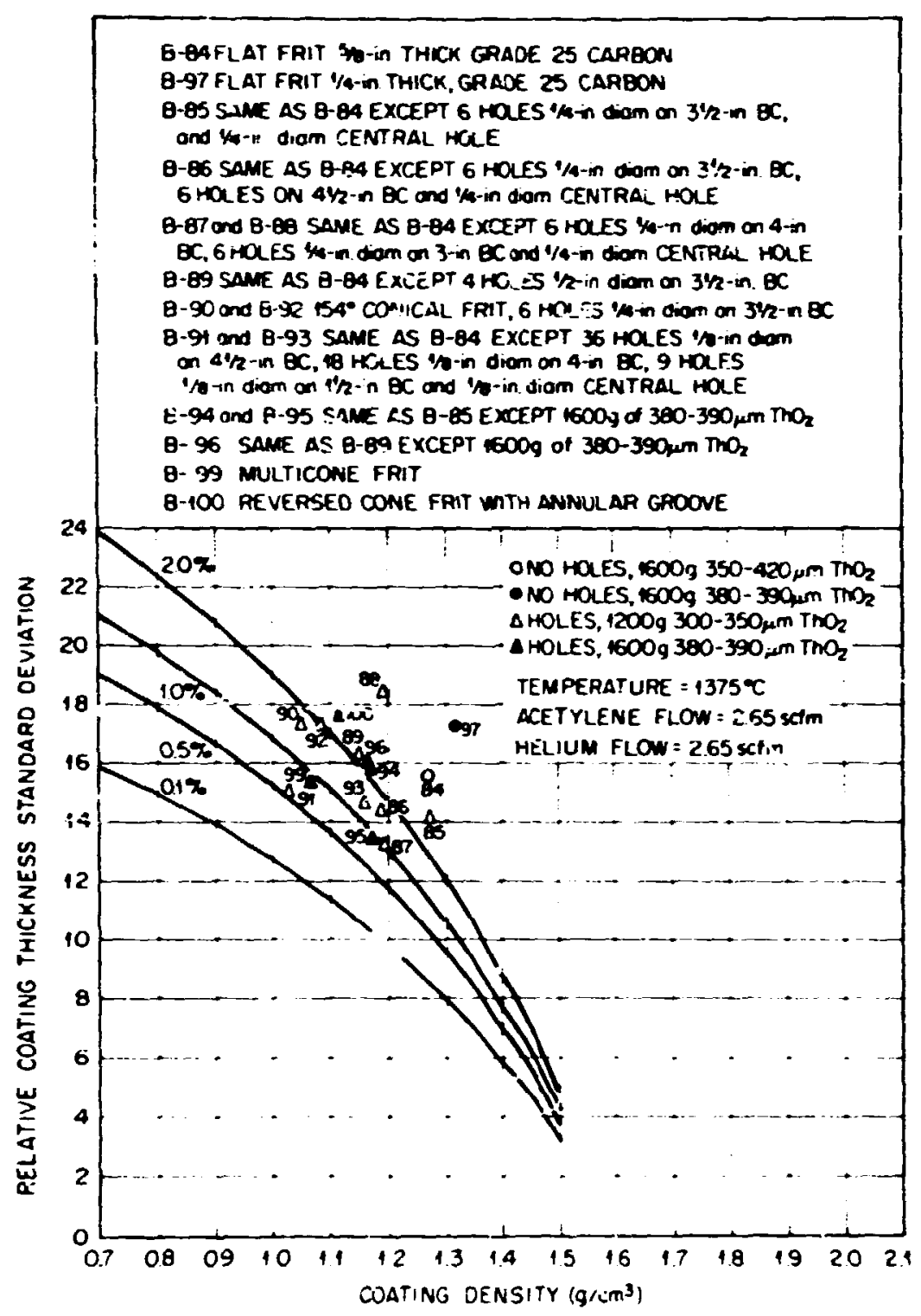

Fiz. 3.8. Quality of buffer coatings deposited using various geometrie; of posous plates.

The minimum and maximum average ccailag thicknesses of $98.5 \pm 3.3$ and $107.5 \pm 3.3 \mu \mathrm{m}$ are also strikingly similar. Other points of interest include the following.

1. Coating densities calculated by iwo different meihods were in excellent agreement. The method that utilized burnoff and mercury density measurements was slightly more nrecise than the method that utilized bumof? and radivgrapin measurements.
2. The efficiency $0_{i}$ utilization of the input carbon was $53.0 \pm 0.4 \%$.

3. On the average. $99.95 \pm 0.06 \%$ of the input kemel weight was recovi.ad.

Now shift attention to tile isotropic carbon coating dicrived from propylene. the so-calied LTI coating. A large number of carefully controiled LTI coating runs were conducted using the 5-in.diam coating furnace to determine the influence of propylene flow rate, 
Table 3.3. Beffer production runs

\begin{tabular}{|c|c|c|c|}
\hline $\begin{array}{l}\text { Run } \\
\text { Xiv. }\end{array}$ & $\begin{array}{l}\text { Cuating } \\
\text { vensity } \\
\operatorname{ly} \tan ^{3} \mid\end{array}$ & $\begin{array}{l}\text { Coating } \\
\text { thiskness } \\
\text { ikmi }\end{array}$ & $\begin{array}{c}\text { Coating thickness } \\
\text { stondard desiation } \\
(\tau)\end{array}$ \\
\hline A-273 & 1.147 & $98.5^{2}$ & $13.1^{a}$ \\
\hline A-275 & 1.130 & 107.3 & 17.7 \\
\hline A-277 & 1.126 & $1075^{2}$ & 16.7 \\
\hline$A-278$ & 1.133 & 102.3 & 17.8 \\
\hline A-279 & 1.132 & 102.9 & 19.2 \\
\hline$A \cdot 280$ & $1.125^{\circ}$ & 103.6 & 17.8 \\
\hline A-281 & 1.130 & 100.6 & 14.0 \\
\hline A-282 & $t .14 t$ & 103.7 & 14.5 \\
\hline A-283 & 1.130 & 103.1 & $20.0^{b}$ \\
\hline A.284 & 1.138 & 105.1 & 17.0 \\
\hline A-285 & 1.135 & 100.5 & 16.6 \\
\hline A-286 & 1.138 & 99.8 & 14.9 \\
\hline Av & $1.134 \pm 0.004$ & $1027 \pm 1.8$ & $16.6: 1.3$ \\
\hline Ref. & $0.9 \cdot 1.3$ & & 15 \\
\hline
\end{tabular}

Minimum

Maximum.

temperature, ilarge, and presence vs absence of $a$ helium diluent on the coating properties and process. Properties that were characterized in detail were $(t)$ coating density: (2) coating thickness and siandard deviation: (3) microstructure: (4) surface characie:istics, such as roughness and depth tis wilich the coatings were permeable:(5) percent upen porosity.(6) fraction of broken coatings: (7) partic le shape: and (8) particle strength. Process responses of interest vere efficien.y, coating rate. extent to which carbon :-ifiltration increased the buffer coating dei.sity, and loss of particles. Most of the LTI coating runs were made using the conical gas distributor. Results pertaining to a porous plate distributor are identified as such. The more important results are summarized below'

The fraction of defeclive LTI coaings, a', measured on the as-coated particles using the chiorine leach technique, was sirnngly related to LTI coating thickness. This correlation is shown in Fib. 3.9 for particle batches prepared using wide ranges in cualing tempera. ture, propylene flow rate, and charge. It should be c'ear that the thin coatings resulted from the use of unusually low temperatures. hi.h flow rates. and/or high charges; and higher quality particles having thin coatings could presumably be made by using more conventional coating conditions. Nevertheless. these data clearly point out the importance of coating thickness. With these same particle batches, the particle erush strength was found to increase with coati.n thikness. Also note in Fig. 3.9 that the fration of defective particles was reduced by in-place annealing. This in-place annealing was conducted in the coating fumace immediately after depositing the LTI cating. and the particles were allowed to co.t only aftc. annealing. Since in-place annealing rediced the fraction of defective particles by factors of $\mathbf{2 0}$ and $\mathbf{3 0}$ for the two ases shown in Fig. 3.9. it is assumed that the cuatings are stressed in the as-deposited condition, and additional stresses imposed during cooling result in exceeding the fracture stress in the case at unannealed particles. Additional evidence that the as-deposited cuatings are stressed is that the crush strength is increasad by annealing. There is sonir evidence that the properties of the buffer coating influence the failure fraction, thus indicating mechanical interaction between the buffer and LTI coatings. This evidence is preliminary, but note in Fig. 3.9 that the defective fraction is higher for both the cone and frit when the buffer was a composite batch (batches used to make the composice ranged in buffer density up to $1.4 \mathrm{~g} / \mathrm{cin}^{3}$ ) as compared with the case where the buffer had a density of $1.1 \mathrm{~g} / \mathrm{cm}^{3}$.

More nearly spherical particles were produced by increasing the propylene now rate and by decreasing the temperature ard charge. Additional analysis showed tha: the influence of propylene flow rate and charge was attributable to a variation in deposition rate and that all that was needed to predict particle shape was depcsition rate and temperature, as shown in Fig. 3.10. Addition of a helium diluent to the propylene resulted in a slight improvement in particle shape, but other detrimental effects (lower efficiency and greater blowover of particles out of the furnace) offset any sligh. benefit derived from use of a diluent.

We determined the effect of process variables on the depth to which LTI coatings were permeable as measured by the dickel zarbonyl technique described in Sect. 3.8. Note in Fig. 3.11 that when the charge or temuerature was altered so $<10$ give a higher deposition ra!e. the depth to which the coatings were permeable increased. However, when the propylene flow rate was altered to give a higher deposition rate, the permeatle depth surprisingly decreased. When a helium diluent was added to the propylene. the permeable deptin was decreased 10 values varying from 40 to $70^{\circ} \%$ of that for coatings applied similarly. except without the diluent. Annealing of the particles reduced the permeable depth only a smail amount.

Loss of material during coating as a result of particles being blown out of the furnace or as a result of parti ' 


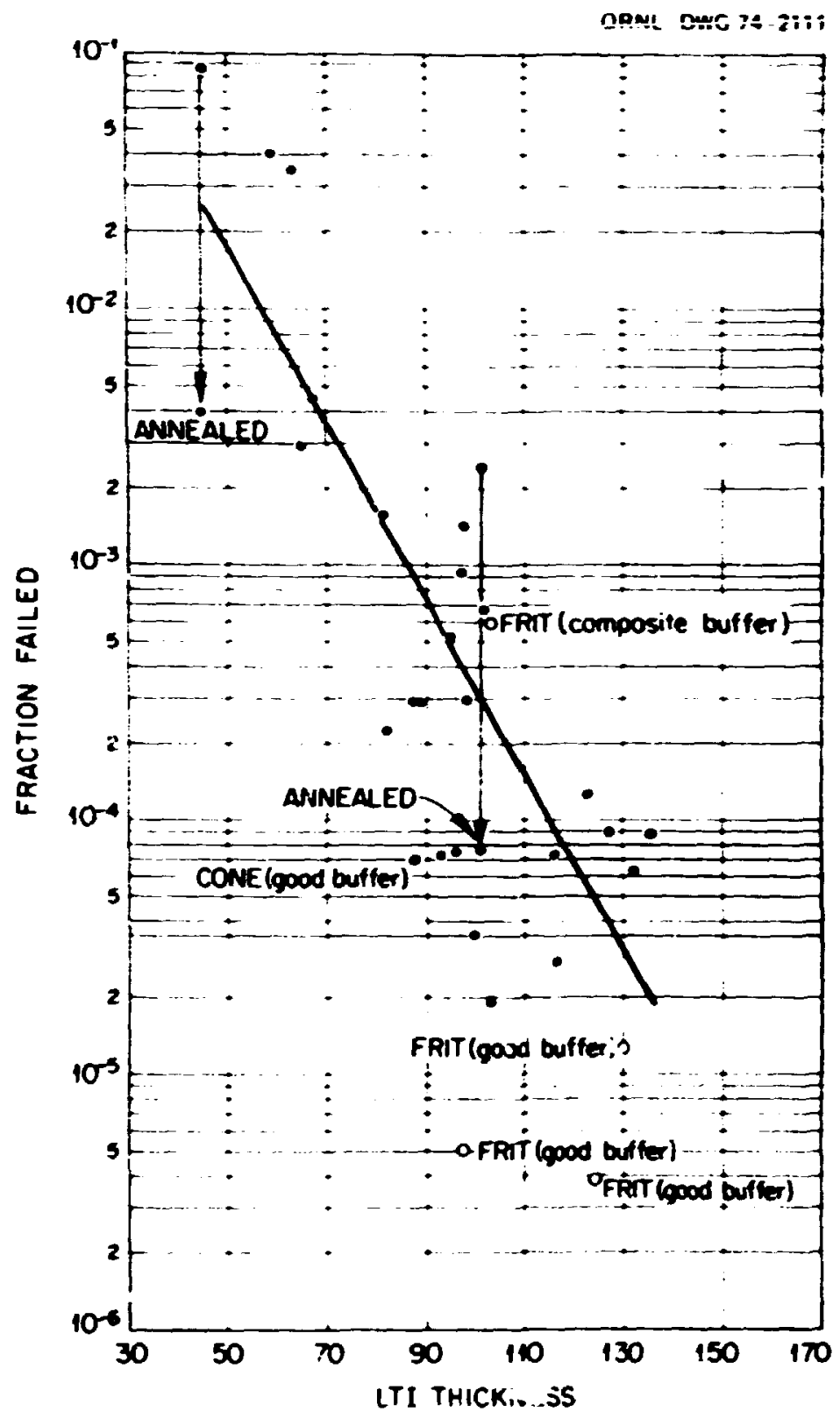

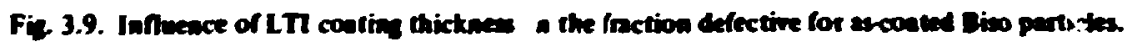

adhering to the sooty graphite coater components was higher than desired. The average loss of heavy $m x$ :al was $0.7 \%$ when no diluent was used and about $2 \%$ with a diluent. Loss of material was enhanced by large charges and high gas flow rates.

For a wide range of operating conditions, the coating bulk density. that is, the corrected gradient density as described in Sect. 3.8. ranged from 1.75 to $1.95 \mathrm{~g} / \mathrm{cm}^{3}$. Coating density increased with increasing temperature (temperature of outer surface of coating chamber). reached a maximum, and decreased with further increase in temperature. At the higher temperatures, the dependence of density on temperature was strongest for lower propylene now rates. At $1450^{\circ} \mathrm{C}$. the coating 


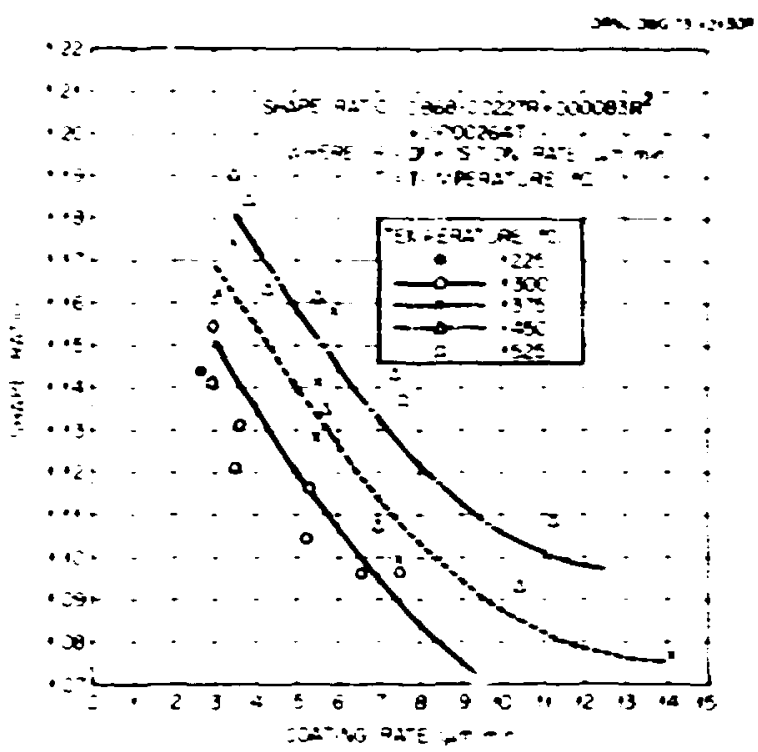

Fin 3.10. Cometation of particle shape to conting rate and tesperature.

density increased on increasing the propylene llow rate from 2.5 to 4.7 sitm, while at $1300^{\circ} \mathrm{C}$. the density decreased with increasing flow. For duplicate coating runs. the average spread in coating density was 0.01 $\mathrm{g} / \mathrm{cm}^{3}$. indicating that sufficiently good reproducibility can be obtained.

A $2-1$ 'm-thick sealer layer previously applied to the buffer-coated particles did not prevent carbon from infiltrating the tuffer coating during deposition of $\mathbf{L T}$ coatings. The extent io which the density of the buffer layer was increased was greatest for runs at low temperacure and ingh propylene flow rates. The increase in buffer density varied from near zeri) to a maximum of $0.15 \mathrm{~g} / \mathrm{cm}^{3}$. with $0.08 \mathrm{~g} / \mathrm{cm}^{3}$ being average. There was no close correlation with either coaling rate or L.TI coating density.

The surface texlure of Bisomioated particles, as observed with the scanning elcitron mictoscope at magnifications up to $10.000 \mathrm{X}$, was relatively unchanged, even when the coating temferature. propylene flow rate. and charge were varied over wide ranges. Neither did the addition of helium noticeably affect the surface morphology. The surface area of Biso-coated particles as measured by t'le BET technique was about 50 times the geometric arca and was reduced by about $20 \mathrm{t}$ on annealing $30 \mathrm{~min} \mathrm{a} \cdot 1800^{\circ} \mathrm{C}$.

Initial information allewing comparison of the product prodused with a cone to that produced using a

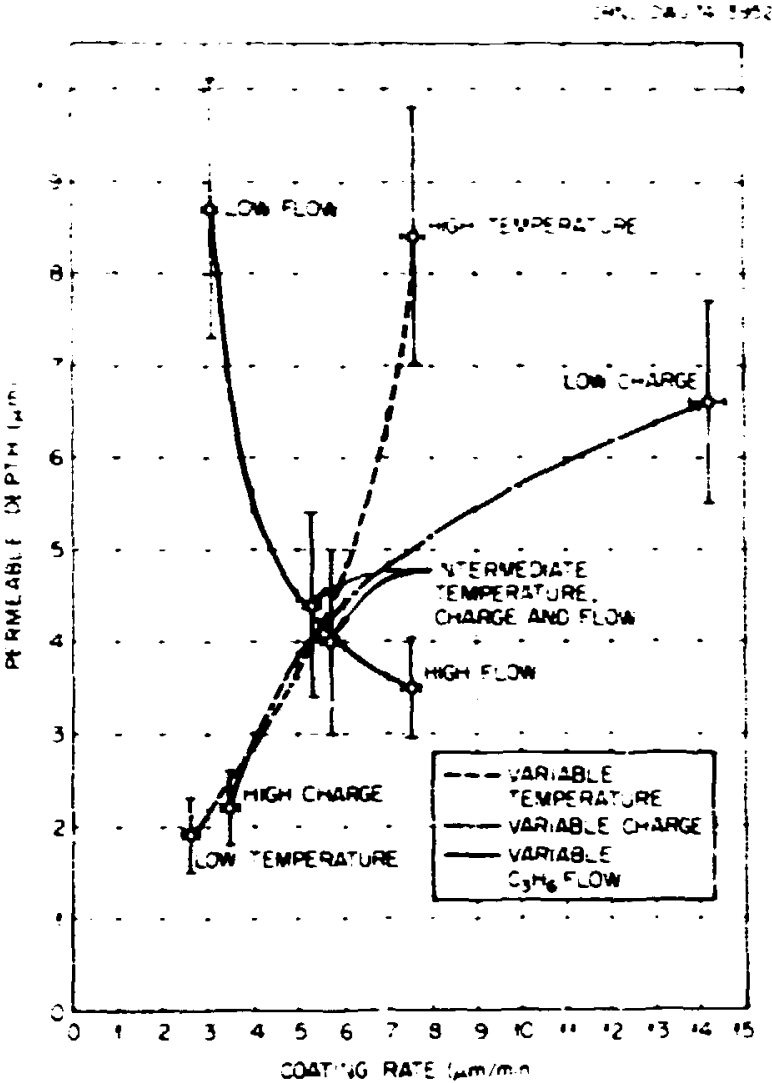

Fir 3.I1. Infuence of process conditions on the depth to which the LTI coating is permeable.

porous-plate-type gas distributor was obtained. Pusitive aspects of the porous plate, when used to deposit LTI coatings, are that Bisu-coated particles are more spherical and the efficiency with which the propylene is utilized is higher when compared with a cone. With a frit. the loss of particles 35 a result of blow-over may be lower, but loss of paricicles as a result of adherence to coaler components is greater. For constant process conditions, the depth to which the ITI coating is permeable is slightiy larger for parti-les made using a irit. Numerous additional comparisons, including the applicability of a frit for teposition of $\mathrm{SiC}$ coatings. must be made before final selection of the type of gas distributor to be used in the pilot plant.

\subsubsection{Coater Effluent 'freatment}

The $\mathrm{NaOH}$ scrubber that will be used to remove the $\mathrm{HCl}$ from the effluent generated during deposition of 
SiC coatings was described previously. "to have now disigited. isoricated. and tested a sumewhal similar scrubber for removing suvt and condensable iyórocarbons from the eftluent present during deposition of carbon coatings and during carbonization of resin particles. The new serutioer is shown in Figs. 3.4 and 3.12. Basically, the serubber consists of a tower that forces the effluen: to be contacted by sprays of liquid perchloroethylene. Perchloroethylene $\left(\mathrm{C}_{2} \mathrm{Cl}_{4}\right)$. a nonhydrogenous. ronflammable organic solvent. wets the soot and dissolves the condensable organic vipurs. The resulting slurry is capable of holding appreciab'e quantities of soot, that is. $>100 \mathrm{~g} /$ liter. The gas entering the scrubber is at about $600^{\circ} \mathrm{C}$. and thus the perchl-roethylene is pumped through a heat exchanger to maintain the temperature in the lower portion of the tower and in the reservoir at about $25^{\circ} \mathrm{C}$ in order to minimize loss of solvent by evaporation. The sirubber has been used successfully for deposition of buffer and LTl coatings and for resin carbonization.

\subsubsection{Particle Handling}

A particle sampler consisting of a ten-stage conical riffler was designed and fabricated, and evaluation was

18. v. J. Lackey et al. GiCR Programs Annu. Prokg. Rep. Dec. 31. 1972. OR.SL +911 . pp. $33+2$. bezun. With ten stages the sample! ideally remivits 1/1924 of a particle baich. Initial tests show that the sample is unacieptably biased toward large particles. Since the orifice size abrve the cone as well as the rela ive pusition of the stages are suspeit. modifications are $n$ progress

A continuous gyratory screen-type particle size classifier was set up for use with both coated and bare particles. Fite sereen diameter is 18 in.. and the material throughput is high. Use of this equipment will determine its suitability ior remote use as well as expedite size classification of particles needed for various development efforts.

\subsection{FUFL ROD FABRICATION - 2105 (ORNL LEAD)}

$$
\begin{array}{ll}
\text { R. A. Bradley } & \text { J. E. Rushton } \\
\text { J. D. Jenkins } & \text { M. G. Willey }
\end{array}
$$

The purpose of this work is to deve!op processes and equipinent suitable for fabricating about $\$ 000$ fuel rods per day in the FRPP. The fuel rods, whi:h are $1 / 2$ or $\%$ in. in dianeter and 2 t 3 in. long. contain mixtures of fissile and fertile coated particles and graphite shim particles bunded by a matrix of pitch binder and graphite filler.

The principal activities in fuel rod fabrication are dispensing. blending. and loading particles into molds:

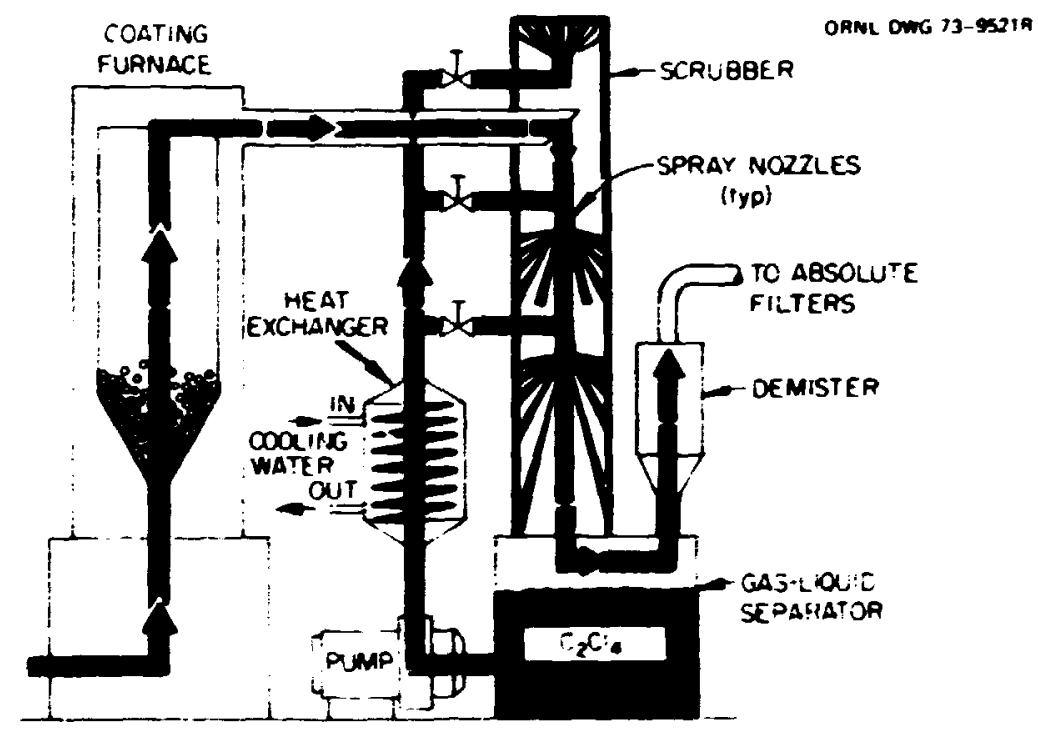

Fis. 3.12. Perchloroethylene scrubber for removing soot and condensable hydrocarbon liquids and solids from the effuent rnerated during the carbon coating proxesues. 
injecting the matrix intu a bed of partikes to form a rod: and inspecting and assus ing luel rods.

\subsubsection{Particte Dispensing. Biending. and Looding}

The particte dispensing. blending. and loading system must be apable of rapidy dispensing precisely cuntrolled quantities of fissile. tertik. and shim particles and blending a:ad luadin ${ }_{b}$ them into the mold in such $a$ manner thes they are distriwuted uniformly thrughout the tuel r.d. Our goal for dispensing fissile and fertile particles is to control the an'sunt of uranium and thorium in individual rods $(t) \pm 1$ a $d n$ srespective!; Our target specification for blending is that the variation in heavy-metal content per inch of fuel rod be $<5 \%$.

We have diveluped a system asing compression valves io voluan trically dispense the particles. This systent is illustrated in Fig. 3.13. The compression valve cunsists of a section of elastumer tubing enilused in a container such that pneumatic pressure can be applied to the outside of the elastumer tubing. When presture is applied, the tubing collapses. thus closing tt: valve. Venting the air pressure upens the valve and slows the particles to flow from a hupper through tile compres- siun vive intu a collector tube with an adjustable measuted volume. Alter the culle-tor tube is filled. the compression valve is clused. and the partickes are emptied from th: colkitor tube through 2 valve at its base.

The vulumetric dispensing system installed on the laboratory automatic fuel rud machine has three sets of hoppers. compression valves, and adjustable collector tubes - one each for fissile. fertik. and shim particles. The three types of particles can be dispensed simultaneurisly or sequentially.

We have exaluated the use of this system for volumetrically dispensing pariicles using both bare $\mathrm{ThC}_{2}$ particks and Bisu-ioated particles. (iosely sized. neariy spherical baie $\mathrm{ThO}_{2}$ particles were used in preliminary experiments to eliminate the effect of particic shape. particle size distribution, ait.l particleto-particle density variations on the precision of the dispensing system. The precision with which particles cuurd be dispensed was determined by vol-umetricaly' dispensing 100 samples from a hopper in sush a manner that ten groups of ten samples exih were obtained uniformly alung the length of the hopper. At the beginning of each test, the hopper contained about $2 \mathrm{~kg}$

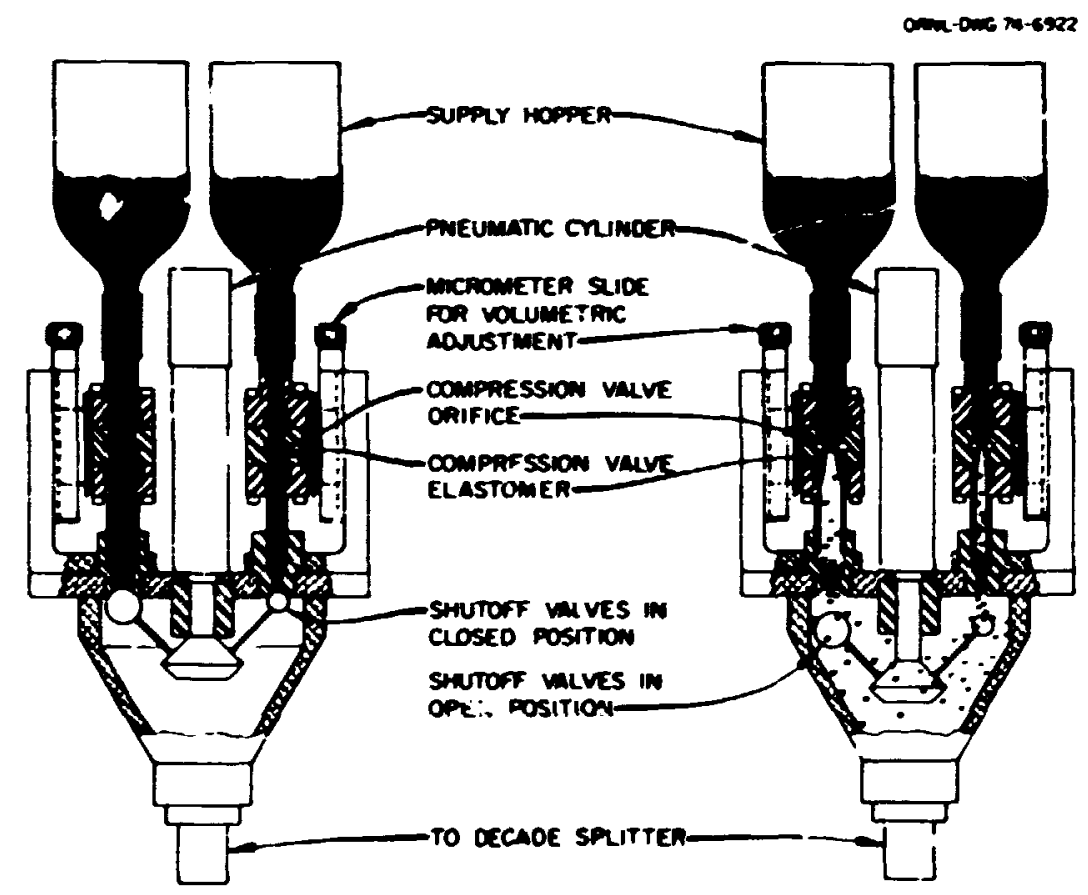

Fi- 3.13. Automatic volumetric particle dispensing system. 
of bare ThO particks or about 1 kx of Eisuciuated partkelas. The relative standard deviation if the 100 samples fie.. the slandard deviation expressed as a percellt of the mean) was used (u indicate the precision with which particles could be dispensed. The results ubtained with Bisurioated particles followed the same yualitative trends as thuse obtained with bare $\mathrm{ThO}_{2}$ particles.

We found that the ratio of the inside diameter of the compression valve and volumetric collector tube to the mean particle diameter was an important variable. As illustrated in Fig. 3.14. the relative standara deviation decreased slightly as the diameter ratio was decreased from 20 to about 9 . As the diameter ratio was decreased from about 9 to 6 , the relative standard deviation increased sharply. This increase in the relaive standard deviation is atributed to bridging of the particles. causing variations in the packing efficiency.

We also found that the precision with which particles are dispensed is affecied by the elastomer pressure, that is. the pneumatic pressure applied to the outside of the elastomer compression valve. As shown in Fig. 3.15. the relative standard deviation decreases is the elastumet pressure increases. For the $1 / 3$-in.-ID valve used to dispense fertile particles $(750-850 \mu \mathrm{m})$. the optimum

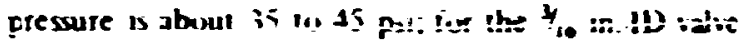
used fur fisite partikes. the upeimum pressure is oout 50 to 09 psi.

The preciston with which barious weights oi tissile and lertile particles an be volumetricalls dispensed with the sysiem ins:alled on the laburatury autumatic fuel rud mahine is shown in Tabic 3.t. The range of weights of tissile and iertile particles per luel rad is expected to he about 1 to 1.5 and 6 to $14 \mathrm{~g}$ respecisvely. Tle weight wili dzpend on the coated parlicle desigal, tuel rud size. and tuel loading per element. Wi:h the volumetri dispensing system present!y in use. the se amounts of fissile and fe-tile particles in be dispensed with a relative standari deviation of $\$ 0.5$ and $0.3 ' \div$ respectively.

The appruach to blensing that we have investigated involves splitting the iharge requirad fur one fue! rod into ten approximately equal increments and sequer: tially loading each inctement into the fuel rod mold. Although the fissile. fertile. and shim particles within any une increment may not be pe' itly blended. the relative amounts of fissile. fertile. and shim particles in any increment will be about the same as in any other increntent. This splitting technique was selected beizuse it is the must possitive way of assuring tha: the fissile

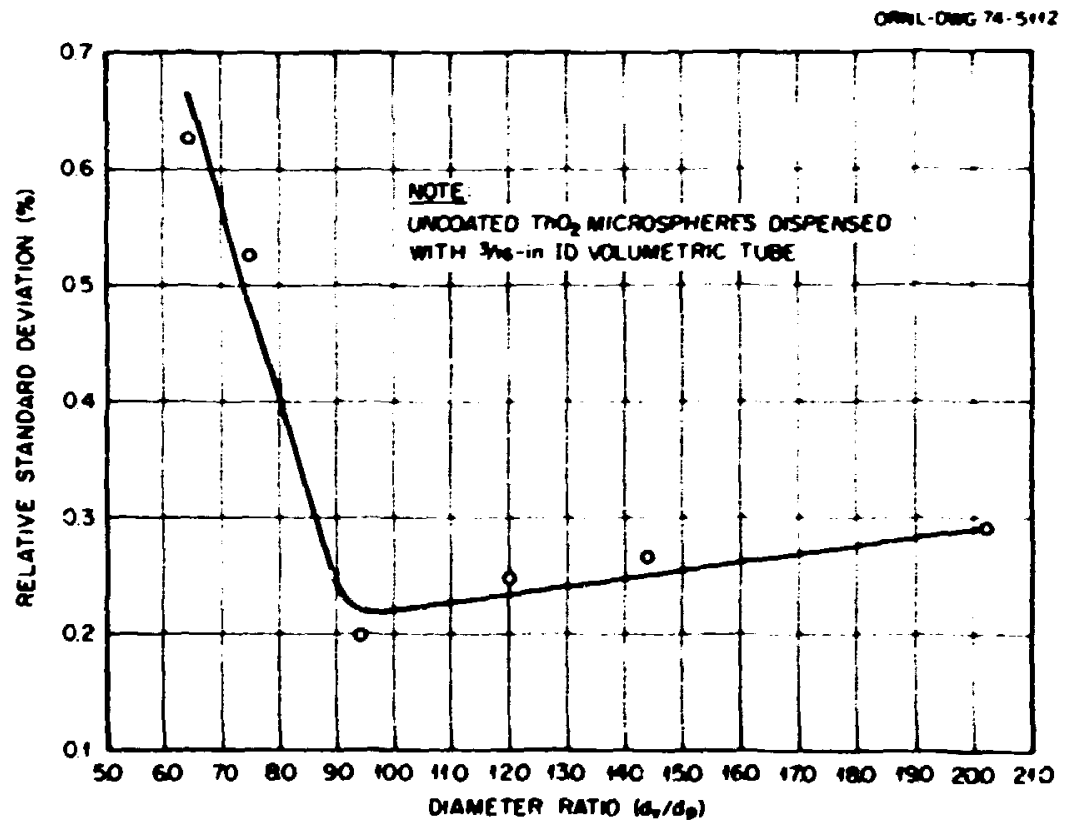

Fi. 3.14. Effect of diameter ratuo on relative stand and deviation. 


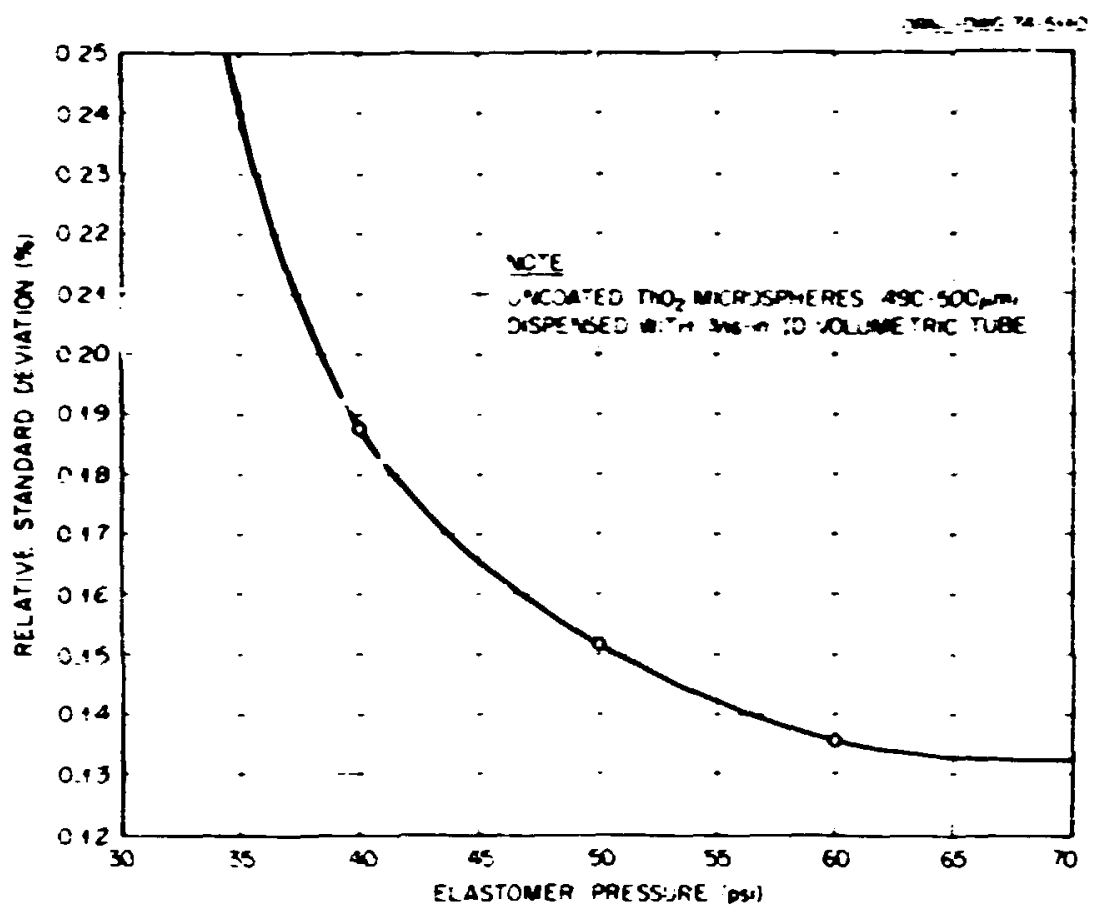

Fic. 3.IS. Effect of ebstomer pressure on relative scandard deviation.

\begin{tabular}{|c|c|c|}
\hline Purticic type & $\begin{array}{c}\text { Weat sampt weight } \\
\text { igt }\end{array}$ & $\begin{array}{l}\text { Reluine slarderd } \\
\text { dev ution } \\
\text { frof mean) }\end{array}$ \\
\hline $\begin{array}{l}\text { Fissute } \\
1500-550 \mathrm{Lm})\end{array}$ & $\begin{array}{l}0.669^{2} \\
0.854 \\
1.031^{\circ}\end{array}$ & $\begin{array}{l}0.69 \\
0.60 \\
0.49\end{array}$ \\
\hline $\begin{array}{l}\text { tertule } \\
\quad 75 n \text { s50 } 8 \mathrm{~m})\end{array}$ & $\begin{array}{l}5.311^{\circ} \\
6.877 \\
85112^{\circ}\end{array}$ & $\begin{array}{l}032 \\
0.23 \\
020\end{array}$ \\
\hline
\end{tabular}

Manimum volume ohtainable with present valie.

DMavimum volume oblainabte with present valve: maximum rotsime ian be uncreased by replocina unsert in valve

and lertile particles are distributed along the eniste length of the fuel rod. Preliminary evaluation of this blending lechntyuc was reported previnus!y."

He installed a sbsem an the laboratury fuel ind machune for auformatically spletting a charge of particies and merementally fouding them in:o the fiee rod mold. This system is illustrated in Fig. 3. In. Fialustion of the system aparated in an antomatic mode continues to
Shus that the uratitum and thoriun content per irich of

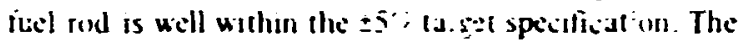
sistem is still under exaluation (1) letermine the degree of homugeneaty ashievable on a ine? siale lie.. less than 1 in.).

\subsubsection{Fuel Rod Molding}

The slag injectoun prociess for molding fuel rods and an automiatu machine for fabricating fiel rods by this process werc desintbed previuusly. ${ }^{\prime 9}$ To form a fuel rod. : pretiomed shug oi matris is inserted into the mold contaning particles. the mold is healed to melt the inatrix. alid theri ihe matrix is injected mto the bed if particles by applyng pressure to the lipp punch. viter cooling to anbient. the fucl rod is ejacted irom the molld.

The baboratory automatic fucl rod machone is a rotary index uble to which it eylindrical molds are altached. Fach mold is indexed through a series of operating stations that load and heat the mold, inject the matrix. corll the mold. and eject the molded fucl rod.

19. R. A. Hiddicy il al. Ci(K Programs anmu. Progr. Rep. Der. 31. 1072. 0kNI.toll. pp it Sh 


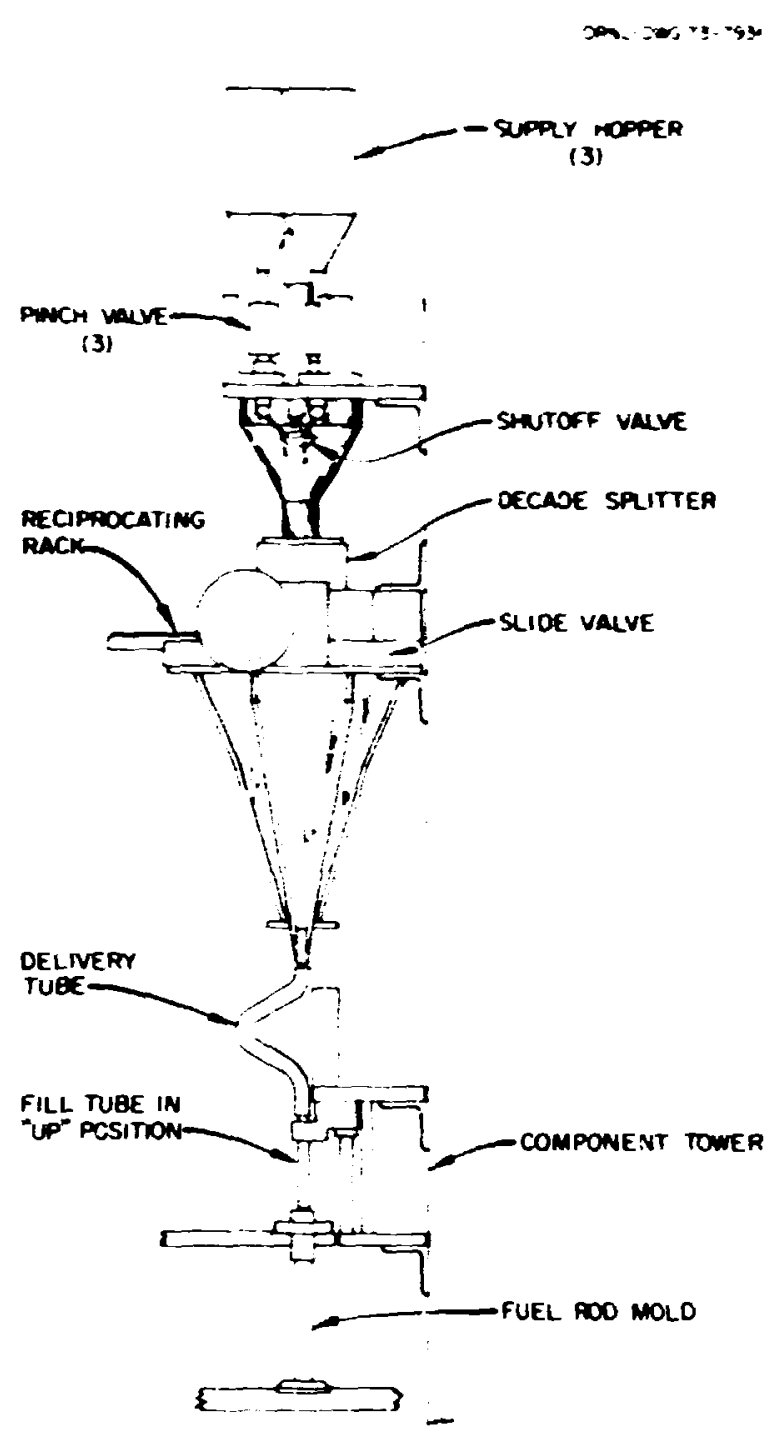

Fig. 3.16. Automatic particle dispensing and blending syst $=m$.

Denteng this report period. we installed the autumatic particle disper.sing and blending system dexiribed in the previous seition on this machenc.

Our evaluation of the slug injection process indicates that it is scitalyle in all aspects for the remote tahrication of HTGR recycle fief iads Our experience it lahriciting more than 20.000 fuel reds on the laboratury automaic fuel rod machine provides ionfidence that the fuel rod fabncation system being Jesigned for the FRPP will perform satisfiaturily.

\subsubsection{Fuel Kod laspection and Awos ing}

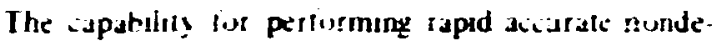

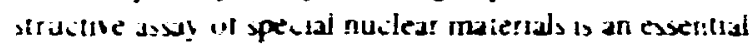
part of the TLRF demunstration prugram Specia! nuslest matenais assa) is recessirs to ensure that AtC jifexuards and divountabilit! requiremerits dre being met during plant upersian. lo provide yuality controil and quility assurance laturmation on tixe fiallity vitput. and to: mantan resituria material baiance antrul on material in process. buth iur procescontruj purposes dod to ensure inticality sitet!

Nondestructive assat of lissile and tertile materiai. an be athiered by erithe? of two basic techniques (passive and aituse). In the passive techniqua. the inherent radiuditwity of the materia! of interest of some companion isulope is used as an indialut of the presence of the materiali in the setwe technique. the sumple is interrugated by some pene:rating radiation and the resulting induced deturity used to meastia the midterial content. $\boldsymbol{H}_{\mathrm{c}}$ intend to utilize buth types ot tichniques for the assas of fissile and fertule materiats $\mathrm{m}$ the TLRF iacilits.

Design and developrnent work has been initiated on xhra! devies and tichnques to assy the fissile and tertik cuntent of the types ai materia! la be processed through TLRF. These includi: (1) thu is a r acutron interngation devices for the active assay $\therefore$ fuel ruds and fuei kernels. (2) a caiorimeter deviec for the very dicurali assay af individual tuel rods. 13 - passive Fummd sounning device for sensing rod-to-rod hissile loading vartatums. 1 t a : limated gamma sianniag device in deteit inlyomugeneous fissile luading distrlbuion; th individual fuel rods. and 151 a iechnique for usirg cintentlonal radiograpiss in corjunction with 1 Quantimet image andyer to determine the homuge. lity of heavy-metal irading in ficel ruds. The status of eich of hese is disiussed in mure detal below.

$2 s=$ Cf acfire neutron intestogation devices. The verifi. catton of total fissile material content in the refabricati.: fuel rods will be made with an in-line nundesefuctive assay system. The disay equapment consists of $a^{252}$ Cf neutron source surrourated by heavy water for neutron moderation. The fuel rods are assayed by irradiatirg them with thermal neutrons from the caliConium irradiater and detecting the fissiur: neutrons emicted from the fissile material in the rods

A cross-sectional diagran of the ${ }^{252} \mathrm{Cf}$ irradiator is shinis? in Fig. 3.17. Fuel reds from the fabrication line are fed liti: a fewising rod carriage lerated between the : "ivy-water moderator aid the polyetnylene reflector. As the rod carrage rotates. the fast-nciatron detectors 


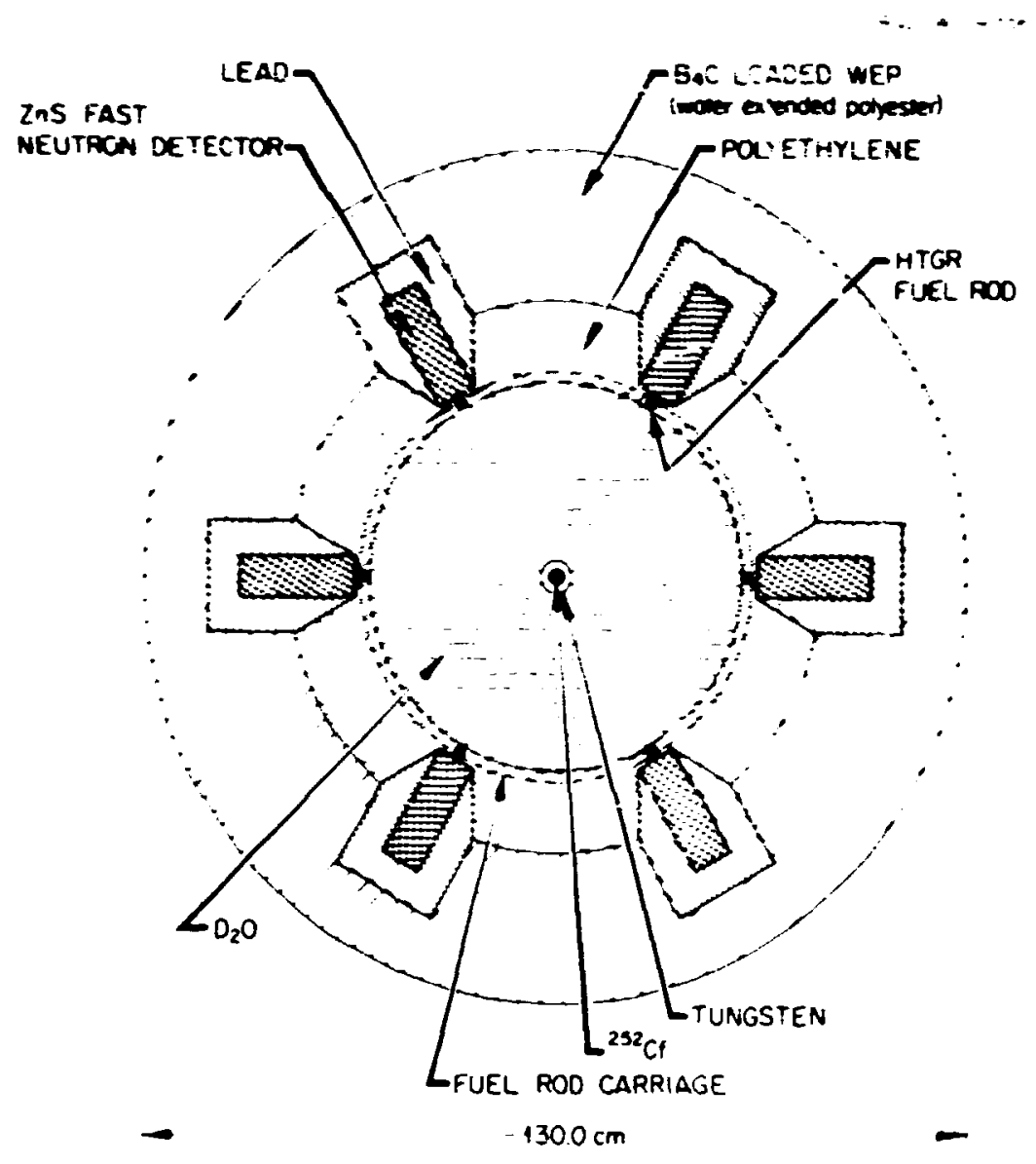

Fig- 3.17. HTGR fuel rod asay system.

count the fission reutrons that are induced by the thermal irradiation. The fissile content of a rod or zJoup of rods is determined by comparisosl with fuel rod standa:ds.

The nuc'ear design of engineering-scale equipment for this assay tevice is under way. The nuclear calculations to study the effect of different moderator materials and peometries on the ${ }^{233} \mathrm{U},{ }^{235} \mathrm{U}$, and ${ }^{232} \mathrm{Th}$ fission rates inave been completed. The calculated count rates per gram of ${ }^{233} \mathrm{U}$ and ${ }^{232}$ Th for the device are shown in Fig. 3.18 as a function of radius. The neutron source for these calculations is $1 \mathrm{mg}$ of ${ }^{252} \mathrm{Cf}$, which has a neutron emission rate of $2.3 \times 10^{\circ}$ neutrons/sec. Also shown in the figure is the ratio of ${ }^{232} \mathrm{Th} 10^{233} \mathrm{U}$ count rates for a fuel rod with a $T h / U$ ratic of 10 . The results shown in Fig. 3.18 demonstrate that it the fuel rod carriage position, the sensitivity to ${ }^{232} \mathrm{Th}$ is negligible .ompared with ${ }^{233} \mathrm{U}$, so that the neutron colnt rate is due oniy to the fissile material in the rod and to fast unmoderated neutrons from the source.

Further nuclear calculations are in progress to deter. mine an irradiator configuration that optimizes the signal-to-noise ratio of the neutron detectors. the ${ }^{252} \mathrm{Cf}$ source strength, and the selection of neutron detectors. A series of experiments is planned to study the suitability of three lypes of fast-neutron detectors for the in-line assay system.

Calorimeter assay device. One prublem with all nondestructive assay devices is that they require calibra. ion using samples of known fissile and fertile content. The fissile or fertile content uf the calibration samples must be known to a greater degree of accuracy than that demanded during routine assay of the proisso material. Currently. such accuracy can only h: dcilleved 


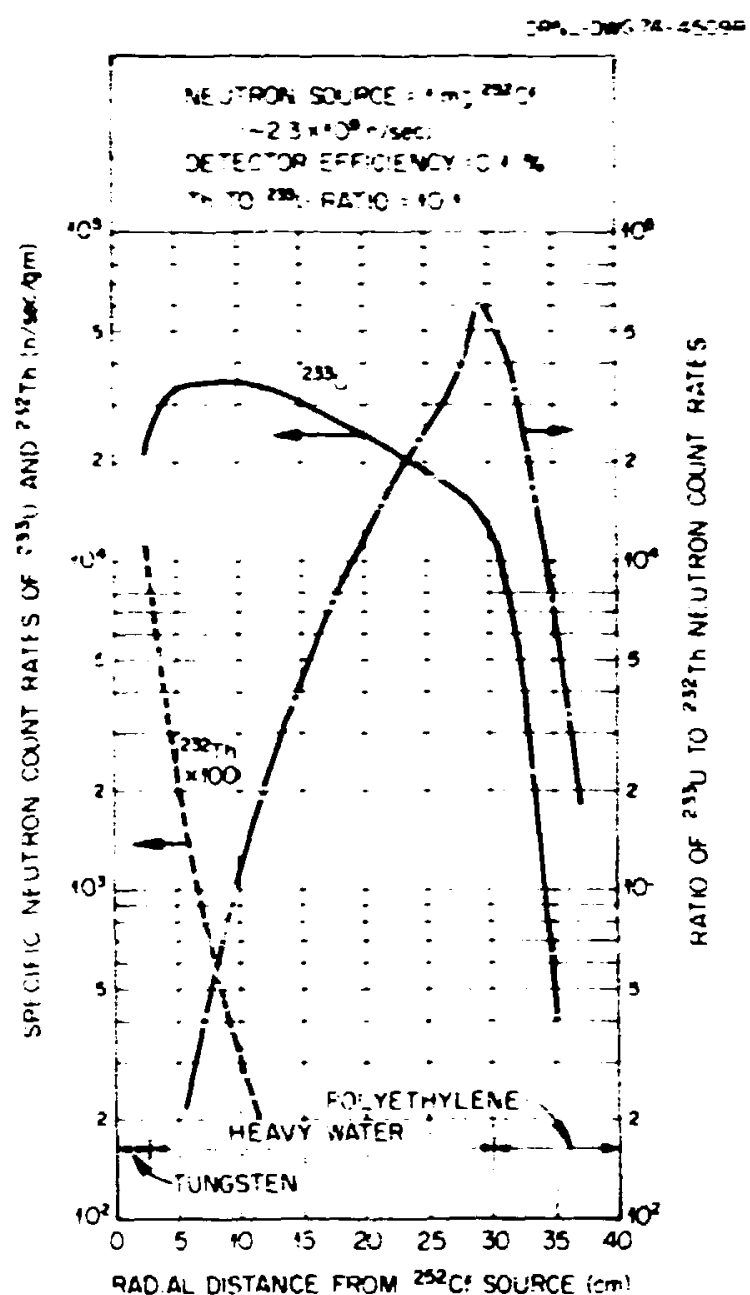

Fig 3.18. Specific neutron count rates and coint rate ratios of ${ }^{233} \mathrm{C}$ and ${ }^{232} \mathrm{Th}$ irradiated in the ${ }^{252} \mathrm{Cr}$ atay tevice.

by wet chemistry, which infortunately cesults in the destruction of the sample.

Calorimetry (i.e.. measu-ing the heat output of a radioactive sampie either from it: own spontaneous dicay of from fissions induced in the sairiple by nestrons from an external suurce) provides an alternative nondestructive method of potentially geat accuracy for determining fissile content. However. such a tcchnique suffers from a very !w throug'iput capacity because of the long tiries necessury $\left.{ }^{\prime}\right)$ : ttain thermal equilibrium.

We have completed calculations whic. ndw.3in inat calorimetric techniques are liasible for ussaying fi:l rods containing ${ }^{233} \mathrm{U}$ and ${ }^{23}$ \% Th. A device has been iesign:d itig. 3.19, that will assy winh mistenal hy measunes, the temperalure rise of the sample and ample hilder, relative to an isothermal inntainer. due to lissiuns insuied in the sampla by neutruns from $a$

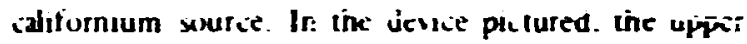
heater is mantanid at the same temperature as the sample hulder to climinate cunduitive heat loss along the hanger. All heal luss must therefiar : be by radiation to the cuntziner walls. allowing tn rel. siye!; small heat generation rate 12 : $\times 10^{-5} \mathbf{w}$ assiming a $100-\mu g$ alifornum source and $0.25 \mathrm{~g}$ of ${ }^{233} \mathrm{C}$ in the sample to result $u$ il an induced $\therefore \Gamma$ of approimimiely $\Sigma^{\circ} C$. well within the limits of acis rate detection.

The mechanical design of th- calorimater device is exsentially complete. and instriction of a test unit is imminent.

Passive gamma scanning tevice. Or: problem in assaying ${ }^{23} \mathrm{~L}^{32}{ }^{22}$ Th reprocessed fuel is the inherest high garıma baikgruund present in the samples due to the unavoidable cuntiomination by ${ }^{232} \mathrm{C}$ and its gammaative daughters. This gamma activity is a function of buth toe incentration of ${ }^{232} \mathrm{~L}$ in the ${ }^{233} \mathrm{l}$ and the length of time elapsed since the uranium was purified to rer sove the decay daughters. Hecause of the time di endence of the $232 \mathrm{~L}$ daughter activity. ih's signal canot te used for an absolute indicator of uranium content. Howerer, on a giin fuel bat $h$ with a common processing history, the $2 \geq 2 \mathrm{U}$ daughter activity dxes provide a strong signal that will allow rapid comparison a! the uranium loading of individual rocis relative to other rods in the same batch.

The mechanical and nuclear design of such a device has been initiater.

Collimated gamma homogeneity inspection device. One pussible technique tor deternining the distribution of fissile and fertile material within a fuel rod nondesiructively is (1) sian the rod for axial variations in zamma activily. iitis can be done by moving the rod past a collimator slit and measuring the fluctuations in the transmitted gamma sctivity.

A positioning device exists to traverse and rotate a fup! ivi past a collir.jatur slit in a contrulled mariner. We are currently :n idjifyirg the electronic controls of this device to mase it compatible with existing cuunting equipment. We interd to test the technique by sianning neutron-activated rods to determine fissile material distribution and unactivated rods to determine fertile material distribution.

Quantitativi radiograph examination by Quantimet. Radiogi aph of fuel rods clearly show the heavy-metal fuei kerncls within the rod. The calculations we have col pleted indicate that quantitative information on 


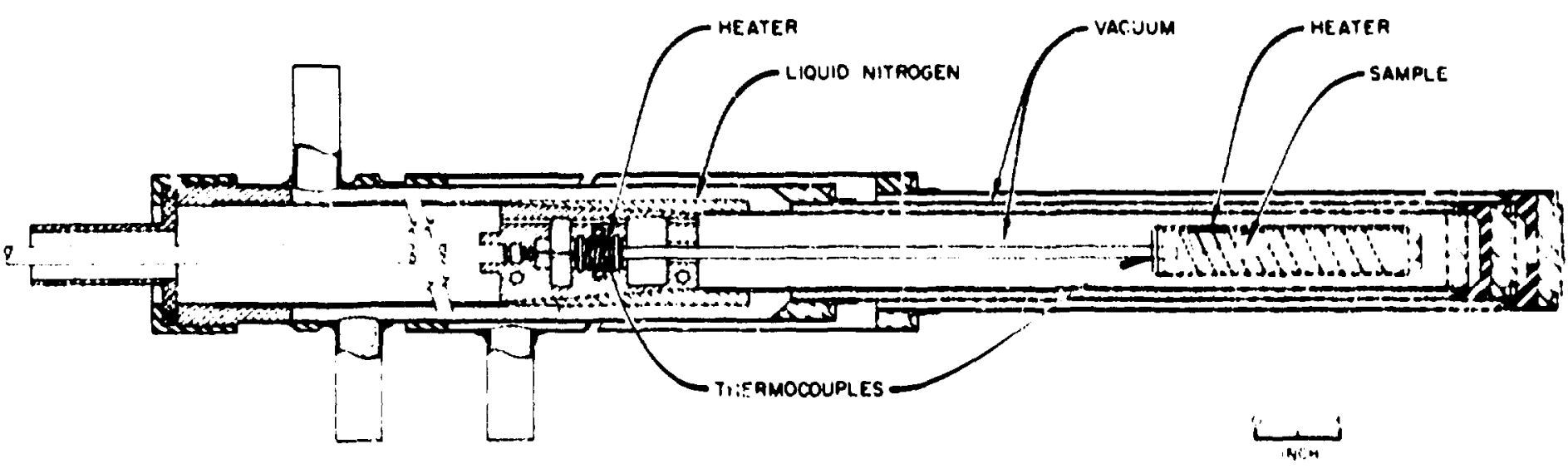

Fig. 3,19. Axsyy calorimetor 


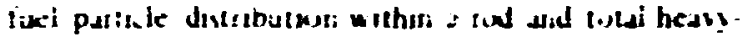

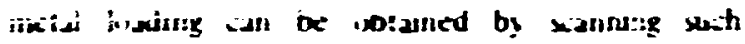

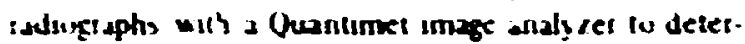
mume tive rato isi propested sernel area tu tutal rud arca on the radugugh The lutal prupeited kerict area in the ictaled duredly to heary-metal loadeng. and. by xinning the lind in inirements. Intumatiun ian be uhtaned in foudrig homwzererty.

Pretimusars cipenments using the Quantimet iailit! a! Y.I: cinfiran inu calculations and irsikale that the echmyute is poumising.

\subsection{FUE ELEFAT ASTEMRY - 2106 (OXNI LEAD)}

$$
\text { 1. J. (. put:s }
$$

Ih: tuel ctoment inbricatun develupment work is

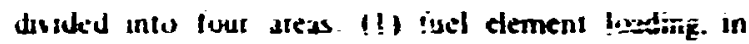
which green (untiges; iuci ruds are luaded into the luet cierinent bles: 12, iabunisation and ansalung. in which the loaded tael element blukik is heated to about

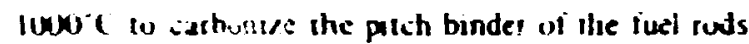
and then annealed at $i \times C 0^{\circ} \mathrm{C}$ to remuve residua! bulatiles and stabilke lusel tod dimensiuns: 13 i end plag. jured. and poison rixd luading. In which poisun red: are hraded intu the elemeint anj graphite pluga and duwels ure places in the livel hules and iowel foles and

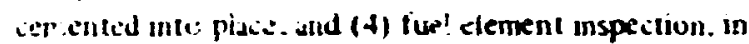
whoh the assembled ele:nent is inspeited and prepared fir shipment to the teactiol for stored). Eifort during the tear has been confined to the carbonization and annealine area oi this work.

\subsection{In-Block Carbonization and Annealing}

After the green luet roxi is mulded by the slug injectlon process, it is heated to $1000^{\circ} \mathrm{C}$ to carbonize the pitch binder. However. since the pitch is thermoplastic. the rod must be supported during carbonization io prevent dimensional distortion. In the past. fur! rods have been supported during carbonization by packing th:m in aluminum oxide or graphice powder. Althurghis this frovides adequate support for dimensional stability. $\mathrm{It}_{\mathrm{x}}$ : remote fabrication of tuel rods would be greatly faciliated if this stop could be eliminated. It has been propuseci that the green fuel rods be loaded directly inso the graphite fuel element blo:ts and curbonized and anneaied in situ.

Accelerated iriadiation :ests have revealed a potential publem assuciated with tits in-block carbonization te.hnique. The HRB-4 and -5 irı adiationtests (see Sect. 7.I.2) showed that a rod carbonizad in packed $\mathrm{Al}_{2} \mathrm{O}_{3}$

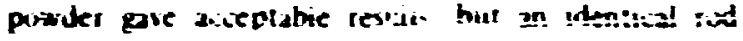
carbunued in a graphite tube liv simulate inblock cabcrizatural gave unacieftable results and contaizad thions fuel particles with broken outer caatings ifig. 3.20) o: p;:-iytu carbin iLI!) after irradiation. fxamination if cumparabie as-fabriaied rods showed Wat the cuds carbunized in $\mathrm{N}_{2} \mathrm{O}_{3}$ had a low pich coke yreld $(2, x)$ and a ven porcus matrix microstruiture. bul the rods cathurised in-tube had high pitch soke yixlds $\left(3 Y_{\text {r }}\right)$ and a much denset ratax microstructure. Examunation of the as-iabrialed fue! ruds showed no ennpletely broken cuatings from either mode of carbunual on. but several iuel particles in the rud cr.runicer in the graptite tube showed the initiation of lears :-: it $\cdots$ ilet cuating (fig. 3.21). It appears that as the riatr:x shrinks duning carbumizalion. there is a mechankal inceraction of the matrix and the surface of ihe fuel partivile vuter cuating. Since in-tube carbonization resulis in higher pilch cuke yields. mure shrinkage. and a denser structure than in-powde: cartonization. there is enough matrix-particie insterastion to initiate tears in its coatings during in-tube carbonization but not during in-puwder arbonization. Additional shrinkage dung the irraliatim lests car. cause the tears to propagate until aclual breakage vecurs.

A study of the intbluk irbonization provess was initiated io mure clearly undersiand the matrix-particle interaction. with the utimate goal of pericrming in-block carbonizatior, wihuut damazing fuel particies and thes produce fuel rods which. from par: irradiatinn tests. wouid be expected to gave aiveptable irradia!ion test results. Since the pasi irradiation tests indicated that acicprablc iest results were associated with low pitcli coke y ields labout $25 \%$ and a uniform and porous matrix mikrostructure. the initial phase of the study was to determine the in-block processing conditions that would produce these :haracteristics.

Ir. order to lower the pitch coke yield of the standard matrix 171 wt .7 Ashland A.240 pitch and $29 \mathrm{wt} ; \%$ Asbury 0353 natural lake graphite tiller). the two primary piocess conditions studied were heating rate and atmosphere used during arbonization $10800^{\circ} \mathrm{C}$. Since the lihermogravimetric (TGA) analysis of the 4.240 pitch showed thial $97.5 \%$ of the weight loss oicurs between 250 and $650^{\circ} \mathrm{C}$, a group of carbonizathon runs was made using an argon atmosphere at various heating rates $\left(1\right.$ to $\left.i 0^{\circ} \mathrm{C} / \mathrm{min}\right)$ between 250 and $650^{\circ} \mathrm{C}$ but with a constant. tather fast $\left(5^{\circ} \mathrm{C} / \mathrm{min}\right)$. rate fri:n riom temperature to $250^{\circ} \mathrm{C}$ and from 650 to $800^{\circ} \mathrm{C}$. This included a run at the highess heating rate possible (approximate!y $100^{\circ}(\mathrm{min})$ ublained by placing the fucl rods into a furnace that was already at a 


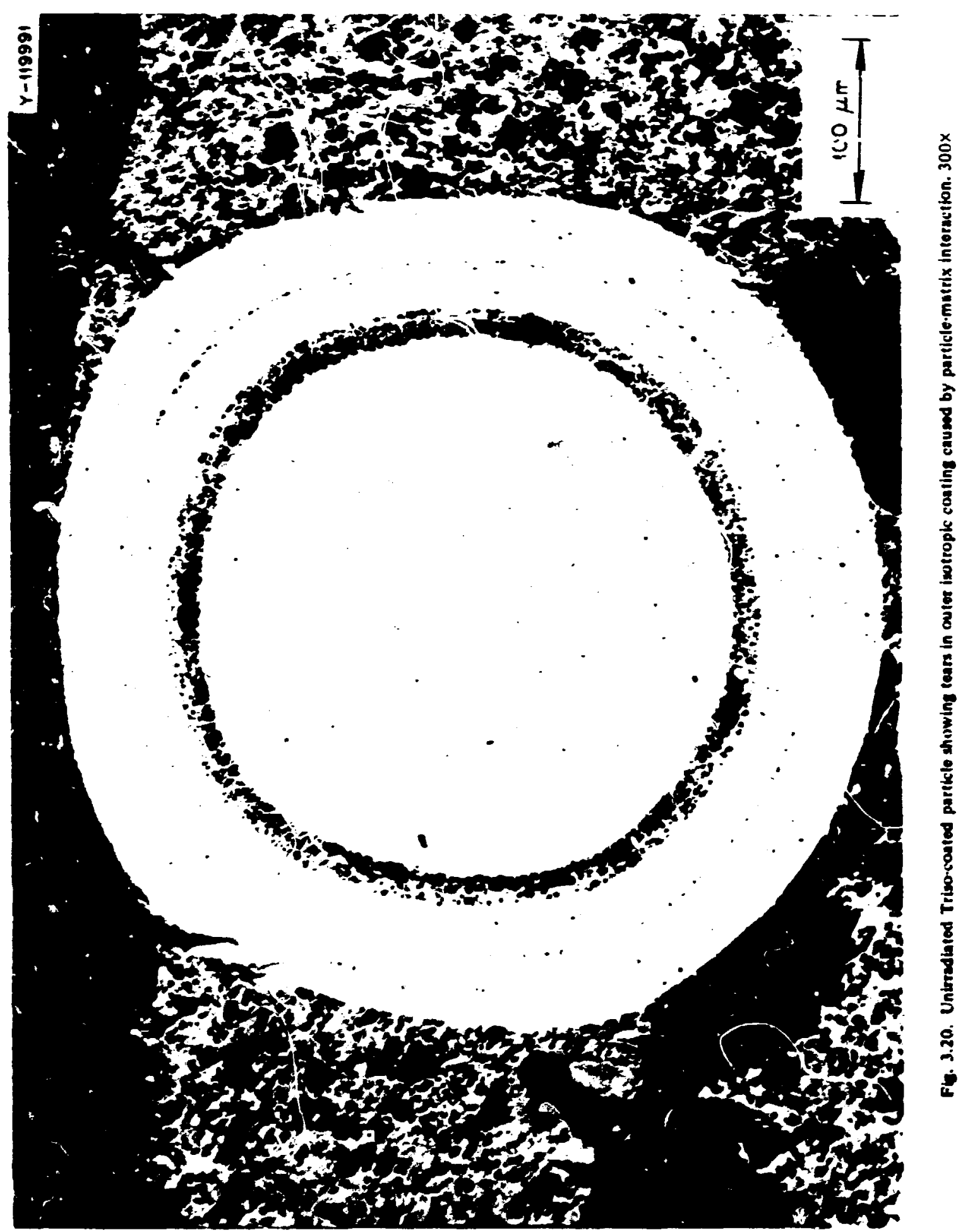




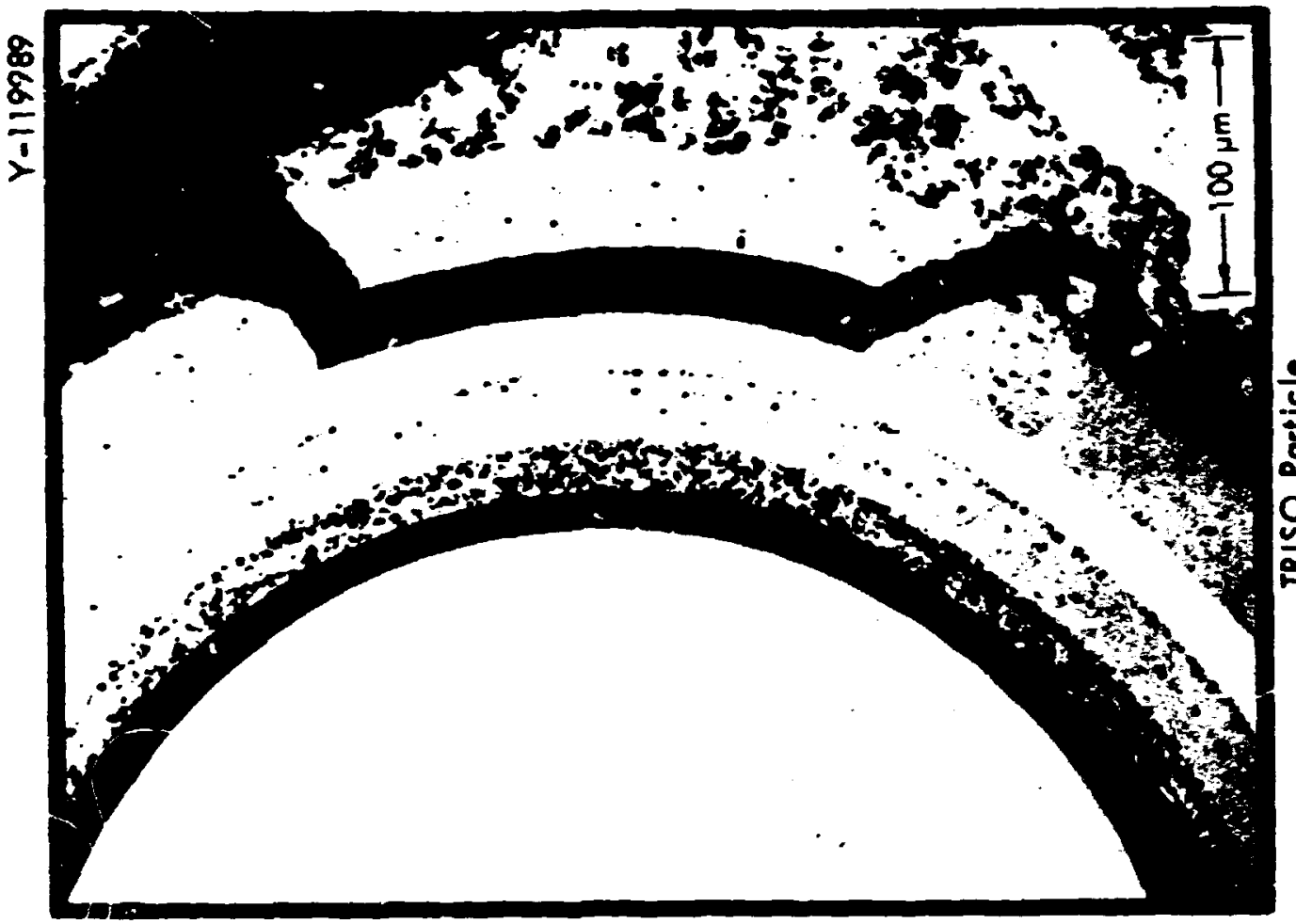

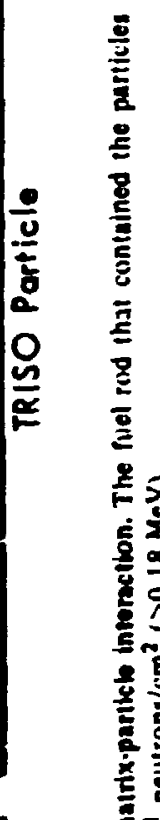

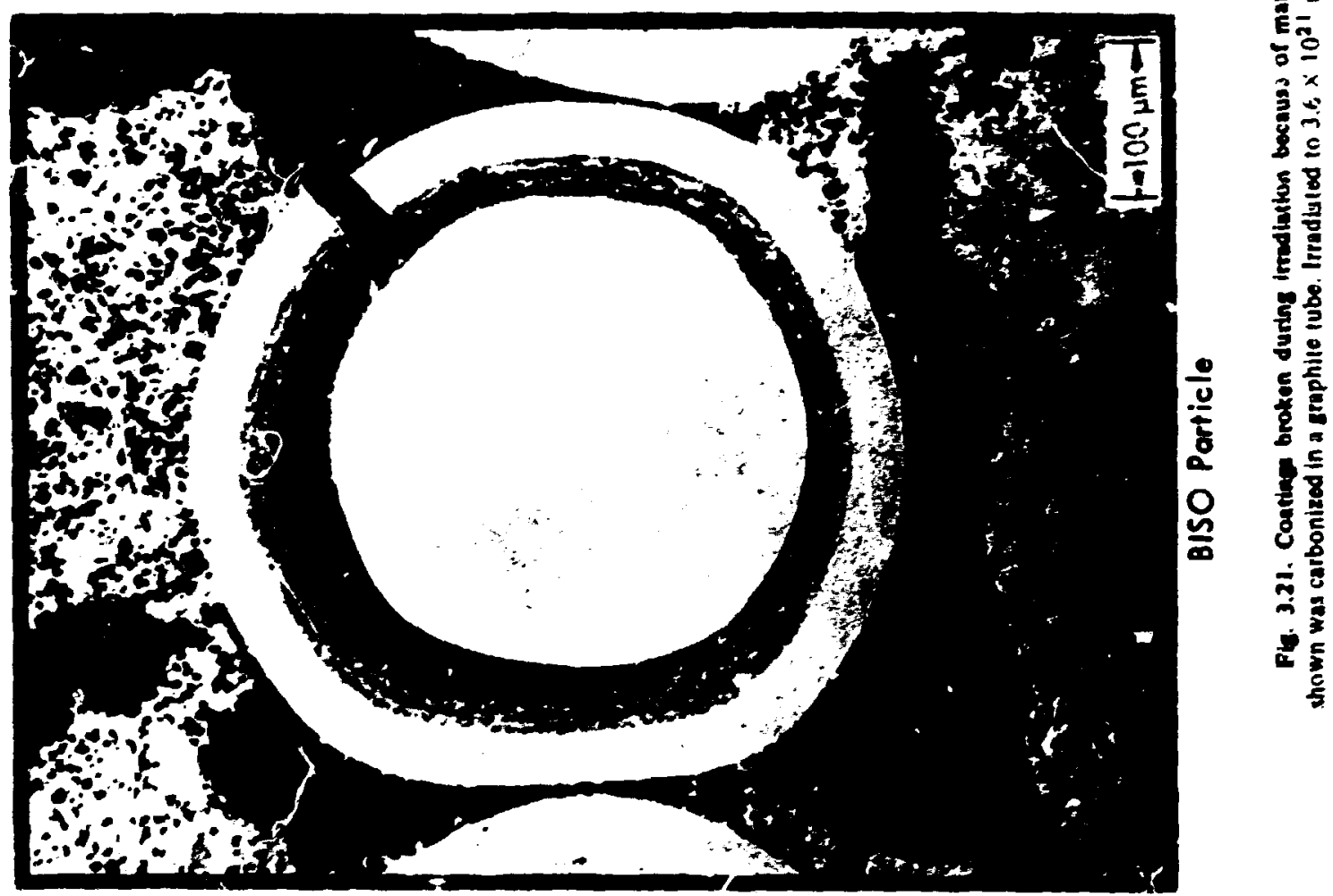


temperature of $650^{\circ} \mathrm{C}$. In exch run. Iods were iar bonized boith in paiked $\mathrm{Al}_{2} \mathrm{O}_{3}$ powder and in graphite tubes (to simulate in-block carbunization). itter carbunization. the fuel inds were annealed at $1800^{\circ} \mathrm{C}$ and the pitch cuke yield wa; determined. A second group of runs was made in vacuum at similar heating rates, with the pitch cuke yield results shown in Fig. 3.22. The significant resules for these runs are lissed below.

1. Fuel rods packed in $\mathbf{A l}_{2} \mathbf{O}_{3}$ powder in an angon atmusphere have an overall low pitch coke $y$ ield. and it only increases from 15 to $22 \%$ when the heating rate is increased from 1 to $10^{\circ} \mathrm{C} /$ min.

2. Fuel rods in graphite tubes in an argun atmosphere have the highest overall pitch coke yield. but it decreases firm 45 to $35 \%$ when the heatlig rate is increased from 1 to $10^{\circ} \mathrm{C} / \mathrm{min}$.

3. The major effect of heating rale. buth in arion and in vacuum, is ob! sned at $10^{\circ} \mathrm{C} / \mathrm{min}$. with only a small additional effect ob:ained by heatire at $\sim 100^{\circ} \mathrm{C}$ imin.

4. Carosining in a graphite tube in vaisum further reduced the pitch coke yietd (at $10^{\circ}($ in.in) to about $25 \%$. which was one of the goals of the investigalion.

Although arbonization in vaiuum producter the desired lwir pitch icke yield, it is not as easily adapted to a coninuuus. remotely contrulled provess in a hot-itll as an inert atmusphere process. Therefore. another inethod of lowering the pitch coke yields but still maintaining an inert atmosphere process was the

OPNL-DNG 74-1501A

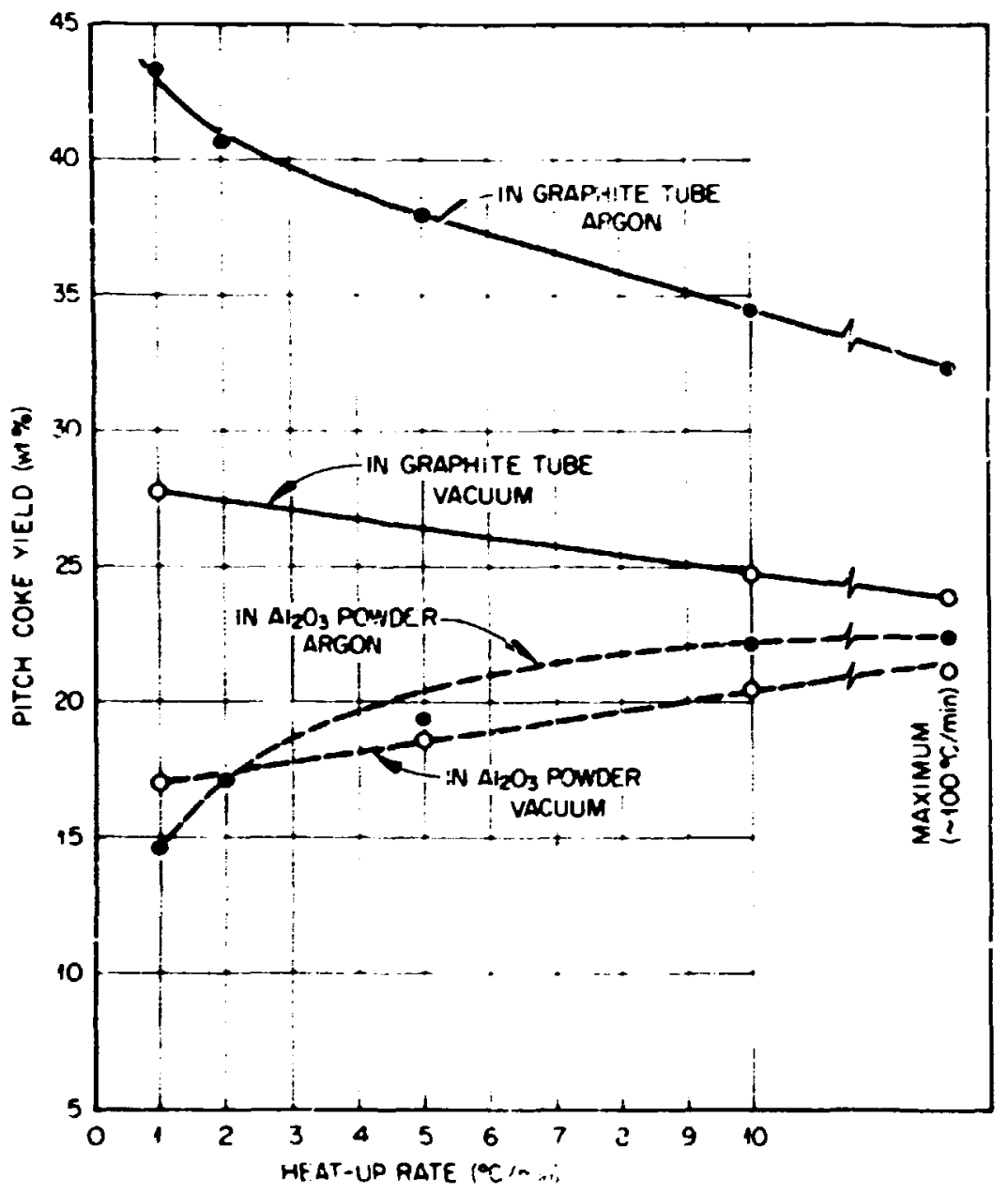

Fir 3.22. Carbonization. of HTGR fud rods using Ashland A.240 putch. 


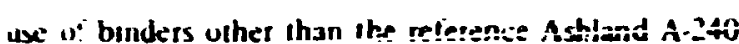
n:- n. Alermative binders studied incliaded (1) Ashland A-1 70 pilich. 12) mixlures of A-?40 and A-170. and (3) A-2 +0 ivith additives that have very little cuke yield. These alditives included an internal lubricarit. a lightweight wil. and an Ashland commercial product. APO vil. All tabricaled fuel rods were subunized :both in $\mathrm{Al}_{2} \mathrm{O}_{3}$ puwder and in (ube) un 3 common ran in an argun atmusphere at a heating rate of $6.7^{\circ} \mathrm{C} / \mathrm{min}$. A summan of the reculting pitch ioke yieids is shown in Fig. 3.23. The significant results shown by the data are iisted below.

1. In-tube carbonization using the reference A-240 pitch gave a coks yield of ahout $34 \%$.

2. In-tube carbunization using mixlures of A-240 and A-170 reduced the coke yield to about $27 \%$.

3. In-sube curbonization using A-170 alone reduced the cuke yield to the gual of $25 \%$

4. In-lube arbonization using A-240 with various amuunls of any une of the additives cove yields in the range of 27 10 $31 \%$

5. Carbunization in $\mathrm{Al}_{2} \mathrm{O}_{3}$ powder produced the sime gineral results except at an overall lower coke yield level.
From ine ciala. It is apparent that the pitch coke yield frum in-tube carbunization in an argon atmosphere can be reduied to the $25 \%$ level by using A-170 pitch. Again. this is close to the desired goal. but only irradiation tests could demonsirate if it is low enough. If lower yields are desired. they could be obtained by using either A-170 with additius: ar A-240 with more than une additive.

In addition to low pitch coke yields, 27other goal of the in-block carbonization study was to produce the uniform. poruus matrix muctostructure previ:susly obtained from carbonization in packed $\mathrm{N}_{2} \mathrm{O}_{3}$ powder. The difference in the matrix microstructure from these two carbonization cechniques is shown in Fig- 3.24. In the heating rate studies. the pitch coke yieids were reduced fiom $\sim 45$ to $\sim 35 \%$, but this did not significantly alte: the matrix microstnucture. However. the tests performed linder vacuum reduced the coke yields W the $25 \%$ level previously obtained in packed $\mathrm{Al}_{2} \mathrm{O}_{3}$ powder in argon. Under these conditions, the matrix microstructure also approached that previously obtained in $\mathrm{A}_{2} \mathrm{O}_{3}$ powdet, that is, a uniforr: and porous structure. This similanty in structure is hown in Fis. 3.25. Although processing under vacuum is not planned. it is

ENOER CONACSITION (mt

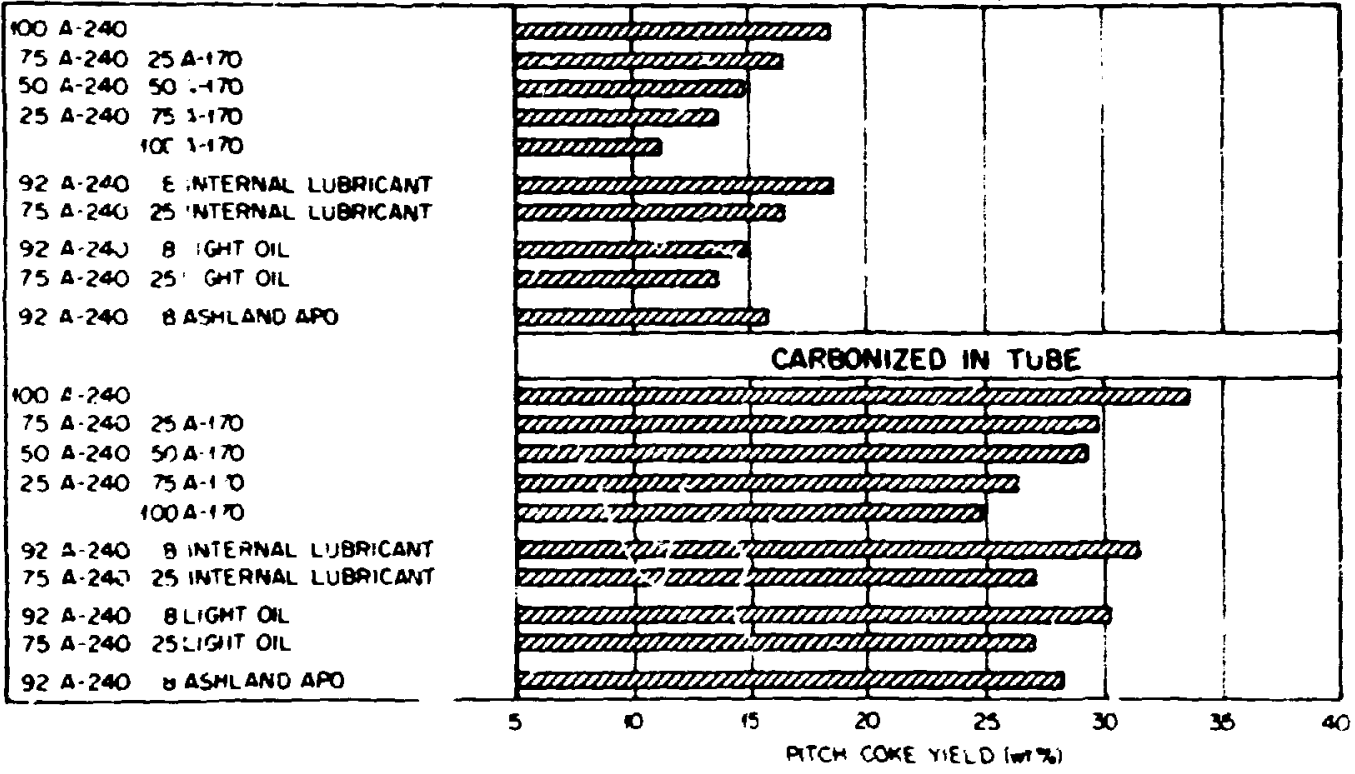

Fis. 3.23. Fitch coke yield of fuel rods made with various binder materials. 

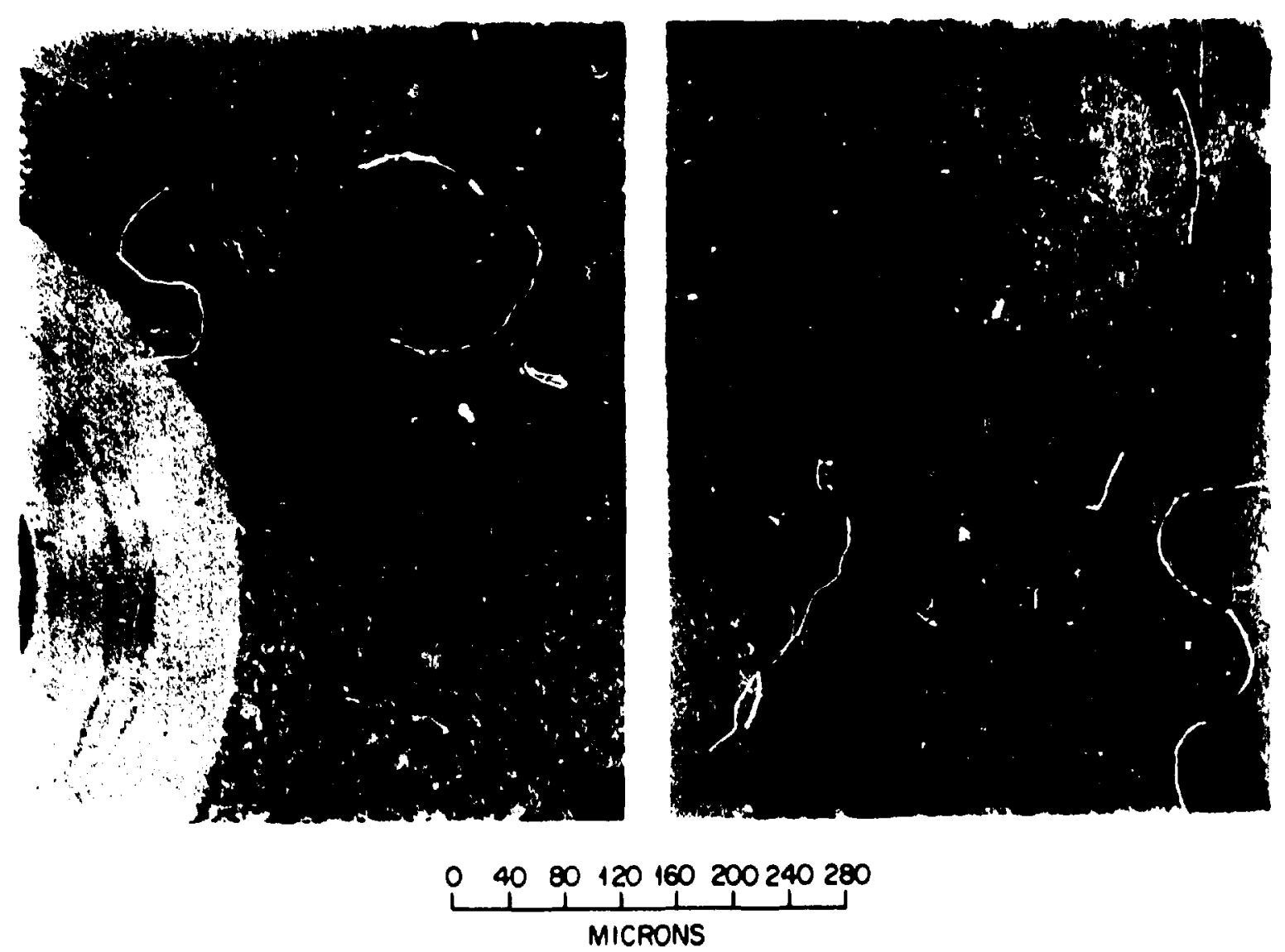

\section{IN PACKEO Al $\mathrm{O}_{3}$}

10
22

\begin{abstract}
CARBONIZATION TECHNIOUE
\end{abstract}
HEATING RATE $\left(^{\circ} \mathrm{C} / \mathrm{minl}\right.$ PITCH COKE YIELD (wI \%)

Fig. 3.24. Matrix microstruclure of HTGR fuet rods carbonized in an argon almosphere. 


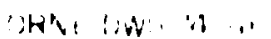

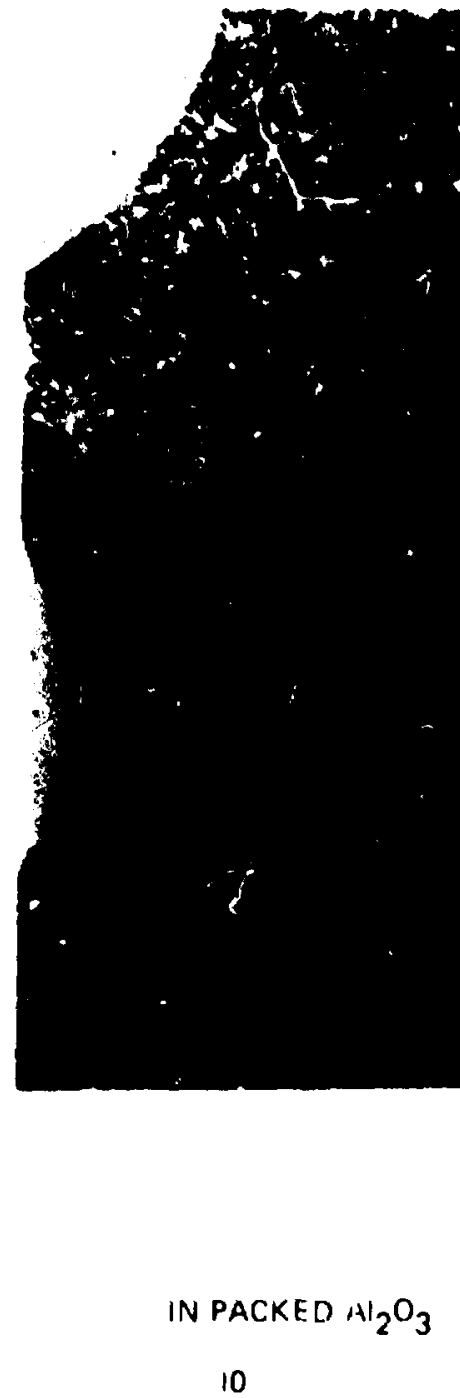

20

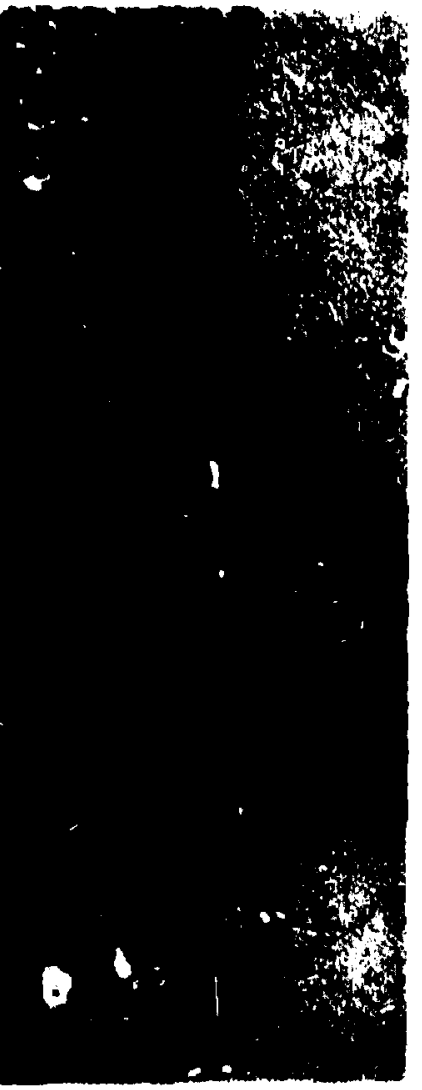

\begin{tabular}{l}
0 \\
$L$ \\
\hline
\end{tabular}

MICRONS

CARBONIZATION TECHNIQUE

HEATING RATE ( $\left.{ }^{\circ} \mathrm{C} / \mathrm{min}\right)$

PITCH CIJKE YIFID IWI

IN GIRAPHITI IUIBE

10

Fu 3.25. Matrix microsiructure of HTCR ruel rods carbonized in vacium 
encouraging po demunstrate that the indrix m:ars-

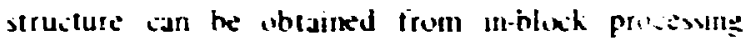
similar (a) that from $\mathrm{Al}_{2} \mathrm{O}_{3}$ proressing.

As mentioned presurusly. The ultimste pod of this study was to pertorm in-bluck artwomed:lan! nithout damaging fuel pirticles due to matrix-particle inieration. The initial phase wi t $^{2}$ stud: approached the problem by reducing the jmount it interation by making the matrix weaker (low pitch coke yieids and puruus mistustruiture). Anuther approach to ihe problem would be to make the particles stronger. This part of the stuity was to determine what fuel pritic: strength was rcquired (1) prevent damage due (1) this interaction. Progress wis made toward this goal. Fuel ruds were iabrieated using ruel partikles of varying rupture strengths I mean rupture strength determined by bro aking individual particles in a small Instron tester: whuse daringed particle content had been determined by the shlorine leach technique (see Seit. is). The rods were carbunized in $\mathrm{AI}_{2} \mathrm{O}_{3}$ powder and in graphite tubes. and the damaged particte content of the fired rods was dx ternined by th!orine leach. The results /as shown in T: jle . Sisindicate the following.

I. The unannealed particles with lower rupture strengths $(3.97$ and 4.88 (b) showed some damaged particles when carbonized in $\mathbf{A l}_{2} \mathrm{O}_{3}$ powider and considerably more when carbonized in a graphite tube. In both sases. the wejker of the two unanneal od batches showed more damaged particles.

2. The annealed particies had higher rupture strengths $17.13 \mathrm{lb})$. and the chlorine 'each ialed to detect any particle damage due to in-blick arbonization even at high pilch coke yields. The ripture strenglh tecinicus for evalusting coating qualty appears promising. and work will contlitue in this area

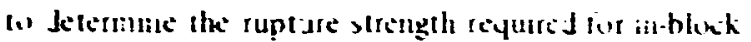

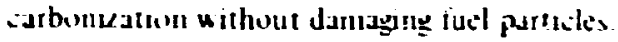

future work will the direiled loward an increased conderstanding of the matrix-particic mierjelion and its relation to coke yield. matrix stristure. and tuel partkic damage. As mentioned previously. undeceptatic irradiation tasis were experienced with rods that only had the initiation of lears in the as-fibricated rod. Deteition of these particitis torn cuatings of a statisti. cally significant 'evel is $n$, pussijle at this time. Thus, irradiation testir $g$ will have to re dune to complete :ite esaluation of the in-black arh mization preress.

\subsubsection{Large-Sale In-Block Carbonization Equipment}

Wiork to date has been confineri to in-tube carbonization that can only simulate in-bluck conditions. Modifieations die being made to adapi laboratory equipment to us" at least small portions of typicai large tuel element blocks. The use of full-size blocks will not be pussible until the large arbonization furnace fnow being designedl is fabricated and iristalled in TURF. In order to be cionumical for a future commercial-size plant. a continuous-operation-type furnace appears most attractive. The vertical position design appears farored over the lourizontal pusition design due :o raterials of consiruction. linitation of moving pats at the high uperating temperature $11800^{\circ}(\mathrm{l})$. and the low maintenance and reniotely operable requirements of the hot cell. Thus a contiruous. vertical-iype furnace is being designed within the ve:tical space limitatioils (2) it) of the hot cell.

The furnace will br. resistance heated and will use four individually controilej anes $t 0$, shtain a temperature gradient up is isci ${ }^{\circ} \mathrm{C}$ followed by a cooling zone to

Table 3.5. Damaged fuet particle content of fired fuel ands

\begin{tabular}{|c|c|c|c|c|c|c|}
\hline \multirow{3}{*}{$\begin{array}{l}\text { B.t. h } \\
\text { Vin }\end{array}$} & \multirow{2}{*}{\multicolumn{2}{|c|}{ orturg lucl particless }} & \multicolumn{4}{|c|}{ Ired fucl roxls } \\
\hline & & & \multicolumn{2}{|c|}{$\begin{array}{l}\text { Carhonised in } \\
1,(1), \text { prwiler }\end{array}$} & \multicolumn{2}{|c|}{$\begin{array}{l}\text { Carhomized in a } \\
\text { siaphile luhe }\end{array}$} \\
\hline & $($ inditisn & $\begin{array}{c}\text { strength } \\
|\ln |\end{array}$ & $\begin{array}{c}\text { Pitch ioke } \\
\text { vield } \\
\text { iw! : }\end{array}$ & $\begin{array}{l}\text { Vumber at } \\
\text { daniarca } \\
\text { Pariules }\end{array}$ & $\begin{array}{c}\text { Pifch coke } \\
\text { ykle: } \\
\text { |nt }\end{array}$ & $\begin{array}{l}\text { Vilmber oi } \\
\text { daniaged } \\
\text { particle. }\end{array}$ \\
\hline $1.42 i$ & I n.inriteled & $\therefore \therefore 7$ & $18 ?$ & in & 27 & 39 \\
\hline $1.4: 2$ & I n.dincedied & $5 x$ & $17:$ & 7 & 321 & $2 h$ \\
\hline$J-4+1)$ & Inncalied & $7.1:$ & $2::$ & 2 & 351 & ! \\
\hline
\end{tabular}


redice the temperature befiure unluading To lea! the furnace. the tuel element bluci will be pliked ustu a luading inister. placed un tup af the furnace. and $\therefore$ :ided to the iulumn of bluiks til the furmaie as required. The column of bloiks muses dow mward in a nearly continuous minter. and. when a couled blonk reaches the unluding chanber at the buttum. it is urlouded to niake room for another blukk lo be losded at the top of the furmace. The most serious desgn problems are to obtain the required high temperalure followed by rapid coviluwn and the desten of the rather large valves required tor the pussage of the fuel e!"ment blocks within space limitations. Operatiun:a! prciolems will inciude the fact that the heatine rat: for the iarge blorks may vary both airuss the diameter and alung the leright. Such a variation would atien the coke yield. The variation in porusiry knuwn to cxist beiween the center and the penphery of the lat blenk will also affect it:a cuke yield. Present in-iute arhumsam witt onl $;$ an $x-1 n$. lisel colur $n$ int the cube has showr. that a rod that is orly une rod removed from the eind of tube has a coke yield avoul 4 ; higher than the end rox (typica!: 7 vs 335 ). The magnitude of the problem with a fuli-s ale block is expeciec to be exen greater. since the luel column will be 30 in. ling.

A cunsiderable portion of luture work will be directed loward scaling up the arboniation equipment and process to handle the large fuel element hlo-ks. Equipment limitations will limit the first slep of this :o just portions ot hioxis. As mentioned previously. present small-siale work has indieated many vanables will be atfected by the seisup lo the large fuel element blocks.

\subsection{SAMPLE INSPECTION - 2107 IORNL LEAD)}

\section{W. It. Peilin}

This work dilit consists of the developmes: work required for design of the sample inspertion systers of the FRPP. Devices and tecliniyues must be developed io assure that representative samples are selected. Statislical work is required in determine simpling levels that will provide adequate assurance lior the datagenera!ed Candidate inspiction and analylleic' to hnlyues must ho lested to ensure dhat they measure the destred attrihuti with sufficient precision and acilualy. Techmplies will be nodilied as required io he more sutatile for the shielded gove hov oneralions required in the FRPP.

\subsection{Fuel Rad Inspection}

Microstructure. Since metallngraphle exammattun is a rather qualitative evaluatw, subiest in persmal has. woik was intiated un a technique to ubtain a juantitstive measurement of the matrix misustructure. The

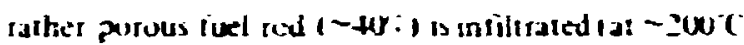

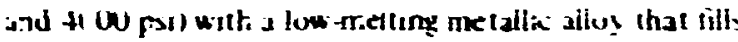
twoth the maxro- and mirupurusity ai the giarille matrix. The relutere perientages of exh pure ly:e are Jetermined by examination with quantilative teles! son mkrusiupe. Carciu! polishing of the sampk is reyuired to allow the dark surtizes of the graphite or luel particles to be distengushed from the lighi surfizes of the metal-filled pores.

Brukes particte fraction. A major problem in ihe tuei -haraileruation is the determination of the damazed Ibriker or eracked, rucl partick irailun. Presiously. the damiged pollitie tiation was determined by the

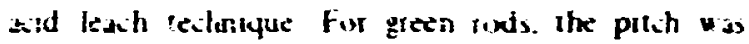
dissolved in pyndine. Whic tired rids were deinnsulidated $\because$ ekitrexheriliai neans prot lis lexhing However. Itic princiure was dow. the jeconsolidailun step had the putcritial for danayng particles. and penetratwr: it a bers tine ink hy the aid rolution was yuestlumable

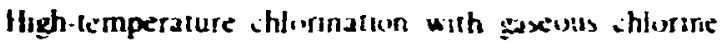
thas been demensiralied l, corncert exphexej heass meetal in danaged tuel partsice (a) the volatrie chiorsdes that is be quantitaticly geconered anc: soxitrophoro-

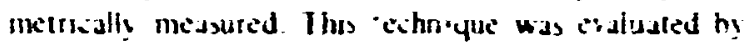
compartion of the amount if hest meisi lesihed with the number of detest. os particles deteited hy nista.

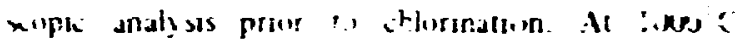

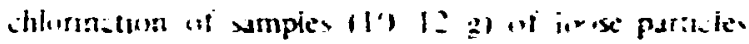

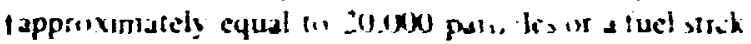
insolingl required $t$ is 6 hi :', silict quantitatse

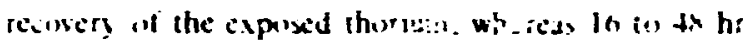

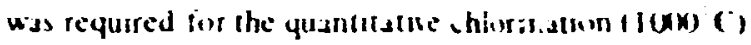

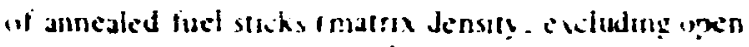

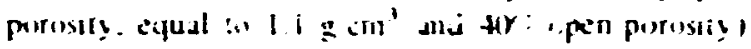
that were duped with i 1 lo nroken paricies it

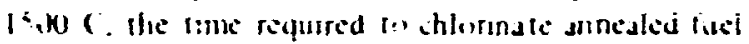

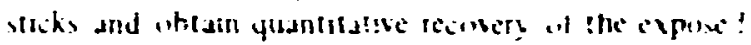

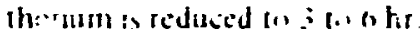

ine shl rindtion lechngute was bund an werk with

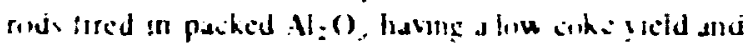

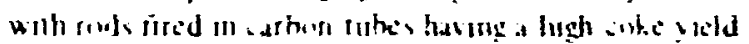

\subsubsection{Partick Inspection}

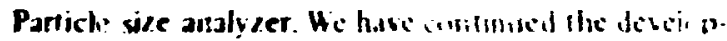

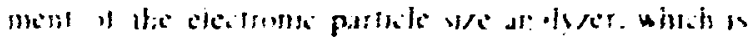

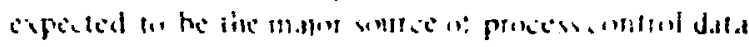

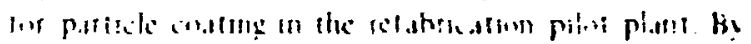

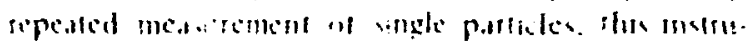

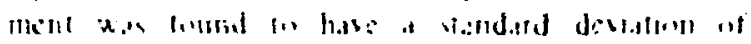




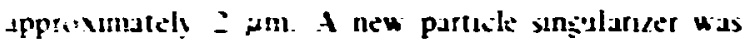
jachoped o :nsure that unly a single partikle could be I: the light bearr: it any unc tumk. thus ensurmy an sizirate count. This singularicer (fig. : $:$. 0 ) is a rutating adiated drum that Mikis up partales indisdually un fivies in the jrum. As ed:h hole rejohes the proper misition with respest to the analyzer delivery tube. an ar let posilien insede the drun dislodyes the paricle

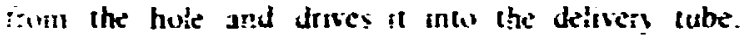
Ithough this unt operates at a slower particle teed : ste than the jet punp smgulariet previously uxed. it works with a mich wider temge of partikle size and dilusis it.c use of vicuum to move the particles through

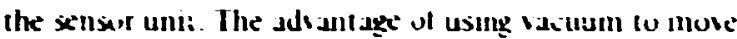
the partries is that stolil ve! hoies iall be pliced in the xensis blexk to prevent the buildup of dust on the pholucell ur the optiis.

lew hardware was destented and fabricated for the particle sise anslyerer to sllow the incorparation of : rot.jing plast: disk with various sized dots to sene di a secondary standard. When not in use. the disk is positioned with a cutaway purtion in the light beam. Figure 1.27 shows this equipment with the supporting metal block omitted for ilarity.

Cooting density. In inother area of work. Iwo different techniques for measuring the density of LTI

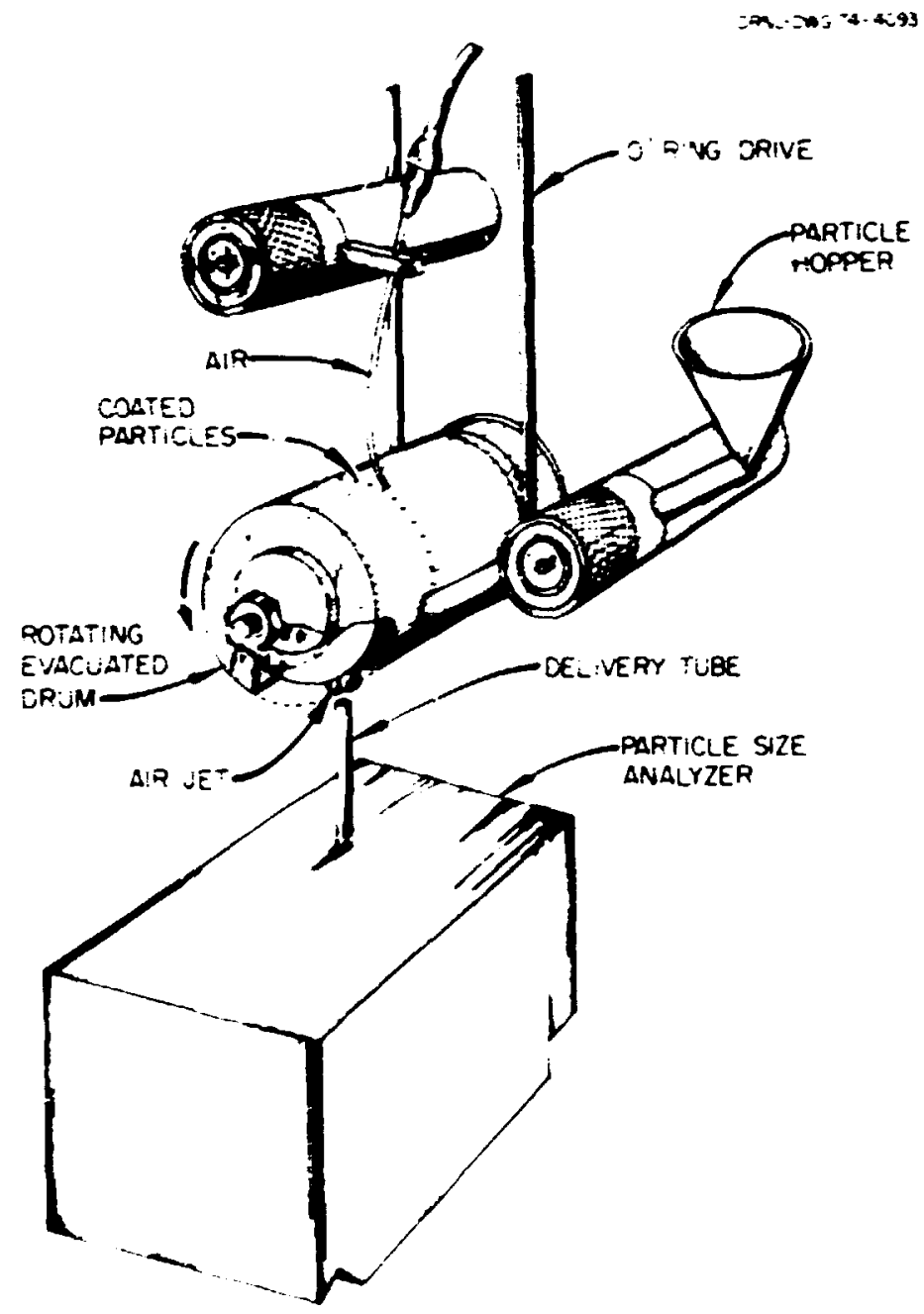

Fig. 3.26. Particle singularizer. 


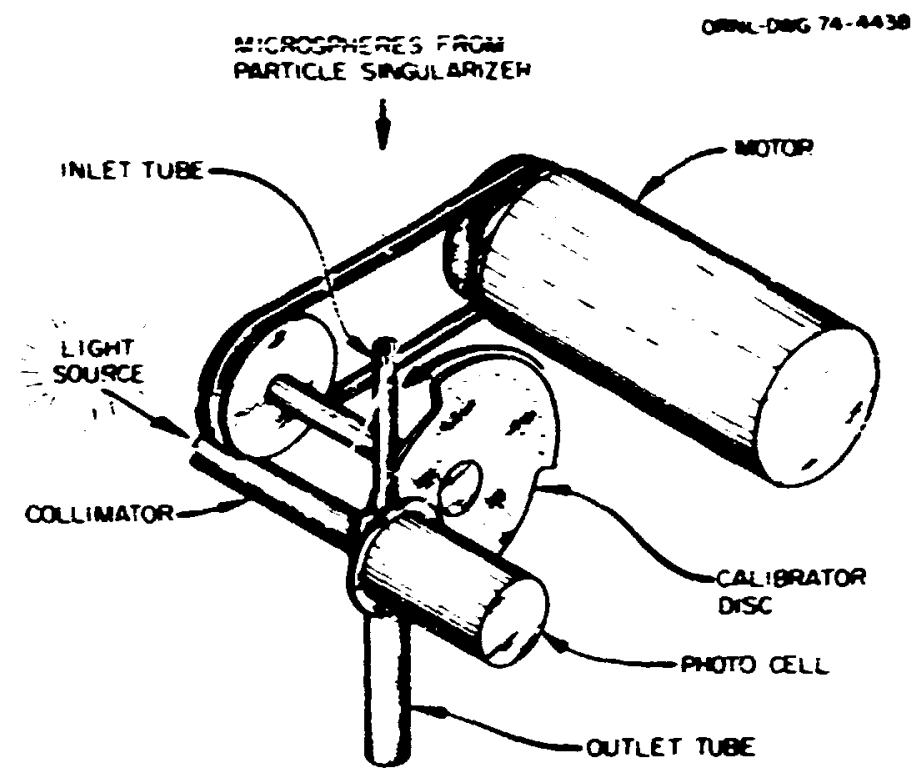

Fi. 3.27. Paricle size inalyier.

coatings were evalusted and compared. The two techniques are (1) gradient density. where a fragment of an LTI coating is placed in a column of liquid having a known density gradient from top 10 bottom. and (2) alculation using the befor. and atter-ioating particle density as determined by low-pressure (250 psi) vercury pycnomety and the percent carbon before and after coating as determined by combustion in air or oxygen. The gr tient density technique gives a higher value than the mercury pycnometer bunoff technique. We speculated that the reason was the gradient density liquid filled the open pores of the coatıng. tisus yielding a value higher than the actual bulk density. A quantitative understanding of the bias has been obtanned

The LTI coating was deternined for en batches of partic!es ${ }^{20}$ with $\mathrm{LTl}$ coatings deposited directly over $\mathrm{ThO}_{2}$ kernels to climinate any confusion caused by infiltration of the buffer coating during drposition of the LTI coating. A imparison of columns 2 and 3 in Tahle 3.0 shows that the gradient density is invariably higlier than the density de:crmined by the low-pressure mercury dycuneter bumoff technique. The open porosity values in column 4 were caliulated using the wabon witent and partiole densities as determined by

211. Provided hy R. L. Healty mercury pyinometry. using pressures of 250 and $1 \$ .000 \mathrm{psi}$. and ate thus a measure of the open porosily penetrated by i5.000 psi of mercury. Assuming that the liquid in 11 e gradient density column penetrates these same pores. one can use the open porosity and the gradient density values to calculase the riulk density. The calculated bulk densily values giver. in column : agree very closely with the densities omtained by the mercury pyinometer burnoff technique. This excellen. agreement gives confidence that the mercury pyinom. eter burnoff technique is aciurately measuring the bulk coaling density and that the gradient density values can be corrcited if the perient porosity is also measured. Since carbun infiltration of the bulfer during defusition of tic LTI coating leads to e:roneously high lensity values from the mescury pycnometer burnoff tech. nique. the density obtained by correcting the gradient density for open porosity will be the praferresi technique for niost Biso-ioated particles.

Although previous : csults have shown a correlaticn between densi:y and perient open porosity. there are exceptions which nake it necessary to measure the open porosity of each sample. For example. samples J-353 and $\mathbf{J}-358$ of Table 3 o have appreciab!: different bulk densities $(1.895$ vs $1.81 \%)$. b'tt the gradient Ginsitics are near'y identical since the coatings have widely different value; of percent open porosity. 


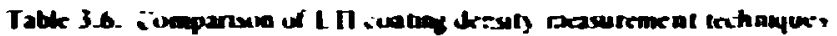

\begin{tabular}{|c|c|c|c|c|}
\hline serpic h. & 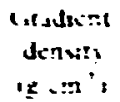 & 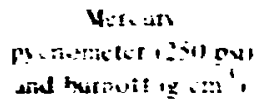 & $\begin{array}{l}\text { that: } \\
\text { fernit? } \\
\text { ind }\end{array}$ & 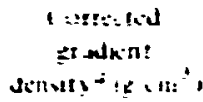 \\
\hline 1. 240 & $i 1:$ & $194:$ & $\therefore-\nabla:$ & !nt1 \\
\hline 1.:- & $1.1^{-}$ & 154 & $\therefore+1^{\circ}$ & $1 \cdots:$ \\
\hline $3 .: 5 i$ & $15 i 2$ & $1+4$ & $::-4$ & 143 \\
\hline $1 .:: Z$ & :1013 & $1+x$ & (1) & $i 445$ \\
\hline Jーミ: & 1.400 & 1.345 & $20+1$ & i $\times 4:$ \\
\hline 1- :54 & $i: 2 i$ & $\operatorname{lnth}$ & $+4 i 5$ & $1 \mathrm{nt}:$ \\
\hline 1.55 & $=144$ & $\therefore .411$ & 13 i44 & :11:- \\
\hline J- : :an & 145 & $15: 3$ & $15: 4$ & $|x \div 1|$ \\
\hline 130 & 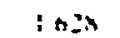 & 1583 & Ioy! & $15 x$ \\
\hline J- :5s & 144 & $1 \times 12$ & na: & 119 \\
\hline
\end{tabular}

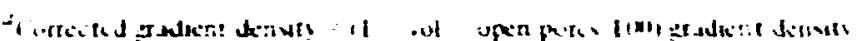

Particie surface purusity. Durthy the prokess in

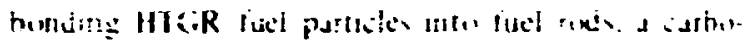

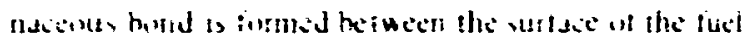

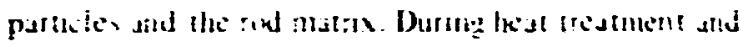

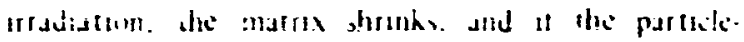

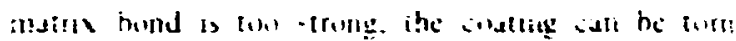

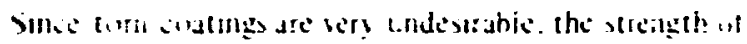

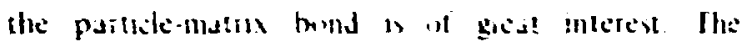
streng!h of this bothd is suggested fi: be relsted wis the roughrless and ar porosity of the anter late at the pyrinarbon coullagt

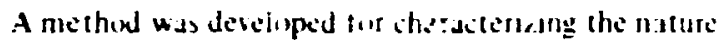
of the surtace of cisied partiates. Oi particulat meres: was th: depth to whih the curbont cuatugs were permedole. since this coluld be unportent in determunge the strength ot the particle-matrix bond. In this methed. the cepen pores of the parti.les are empregnaled with nekel by remusung all guses from the epen pore

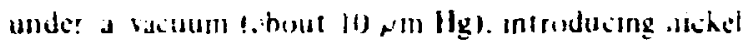
arthony l vapur at a pressure at 1 etm. and decomp why the arbonyl at the surface if the particles hested (o)

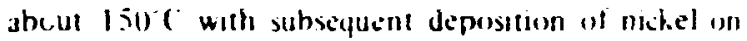
the wath of the open pures. I pon exammatlon of at inetallographeally polished eross sectom. if is possible 11) determisic the depth (1) which the pores were interonnciled with the surfate. since alf open pores contan meta' depostis. Figure 3 . $2 x$ is an illustration of partictes trested hy ihs techntque.

Particle shape. A tedinkue was deseloped to: quanto. tatively meastiring the thape of enated partactes. The index af merit. Cermed "shape ratur." is ohtanted by doviding the contung thickliess on une side of a partucle hy the the diness on the side that is diametrically opposile. The lapge thicknesi is always placed in the

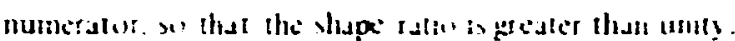

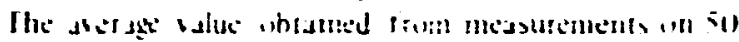

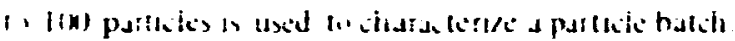

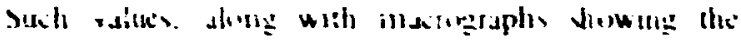

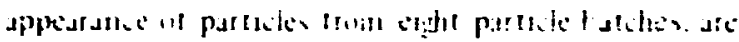

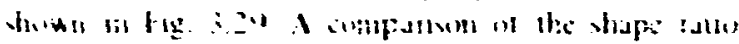

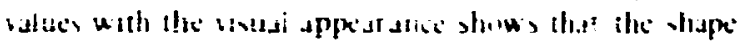

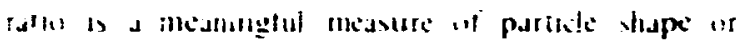

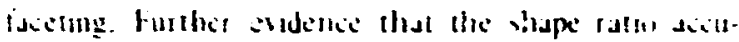

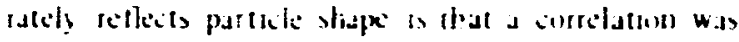

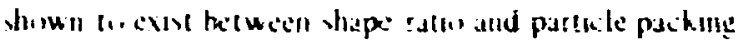
t:dertan.

\subsection{PROCESS CONTROL AND DATA HANDLINC - 2108 (ORNL LEAD)}

\section{R A. Bravile; B. C. Dugson}

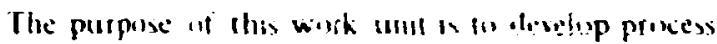
control and datu handlung lechnology necessary for the

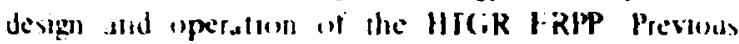

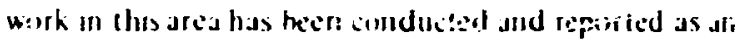
mte eral part of the work on individual w.urk units fe.g.

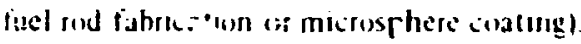

The usc if a computer system for the operation of the pitot plant appears in be mandatory. particu. larly fi.e material aciountability as il relates to safe. guards and crilicality sontrol. fin quality control

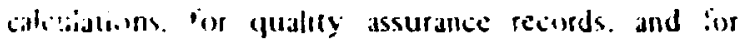
supersisury control of alarn condiluns. Development work is required 4 apply industry-developed inctru. mentalon and computer tilerfacing technology to the FRPP.

The mstrumentatum and data handling industry wili he surveyed to determine the statz of the ant in corterol 

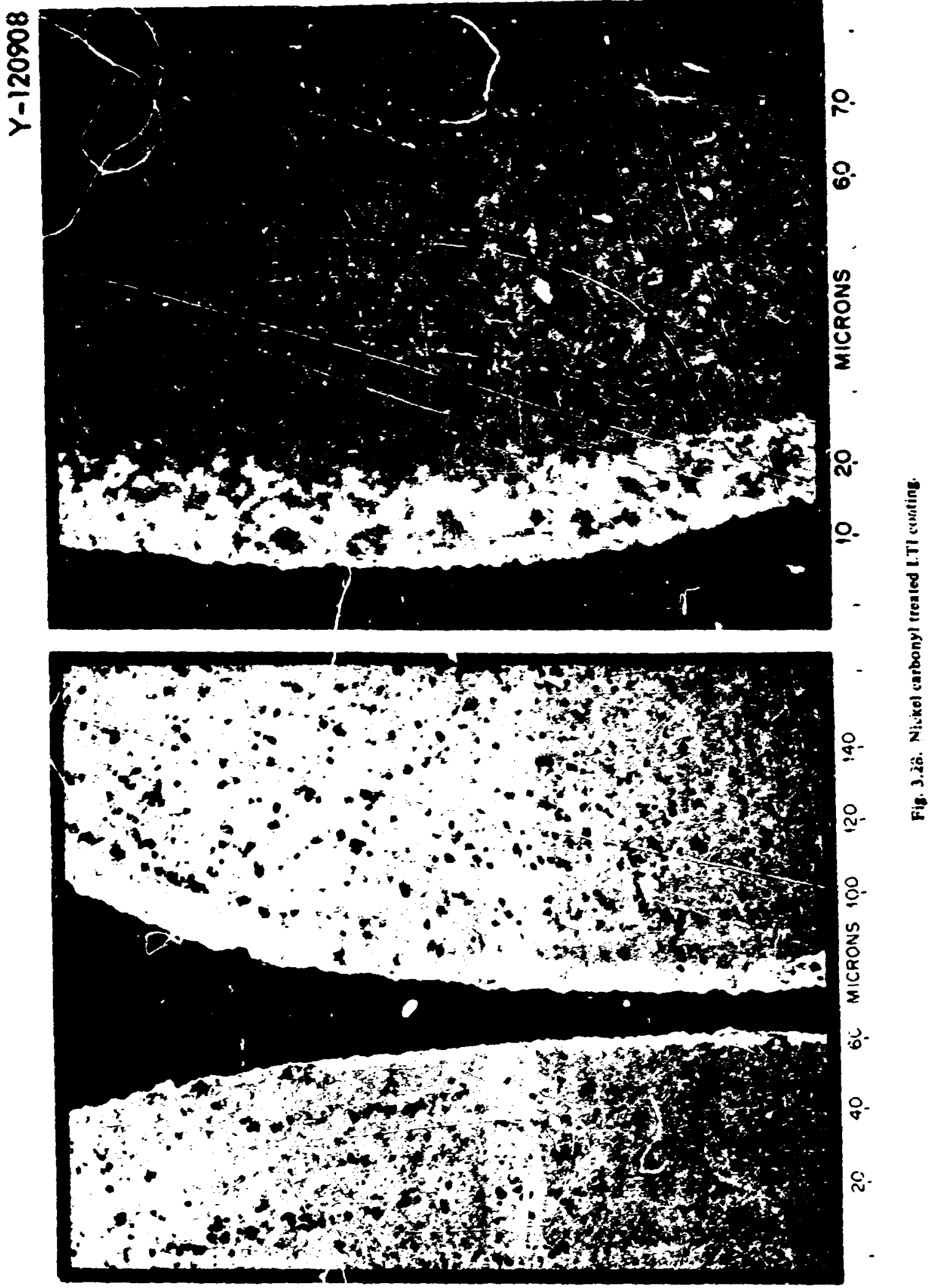

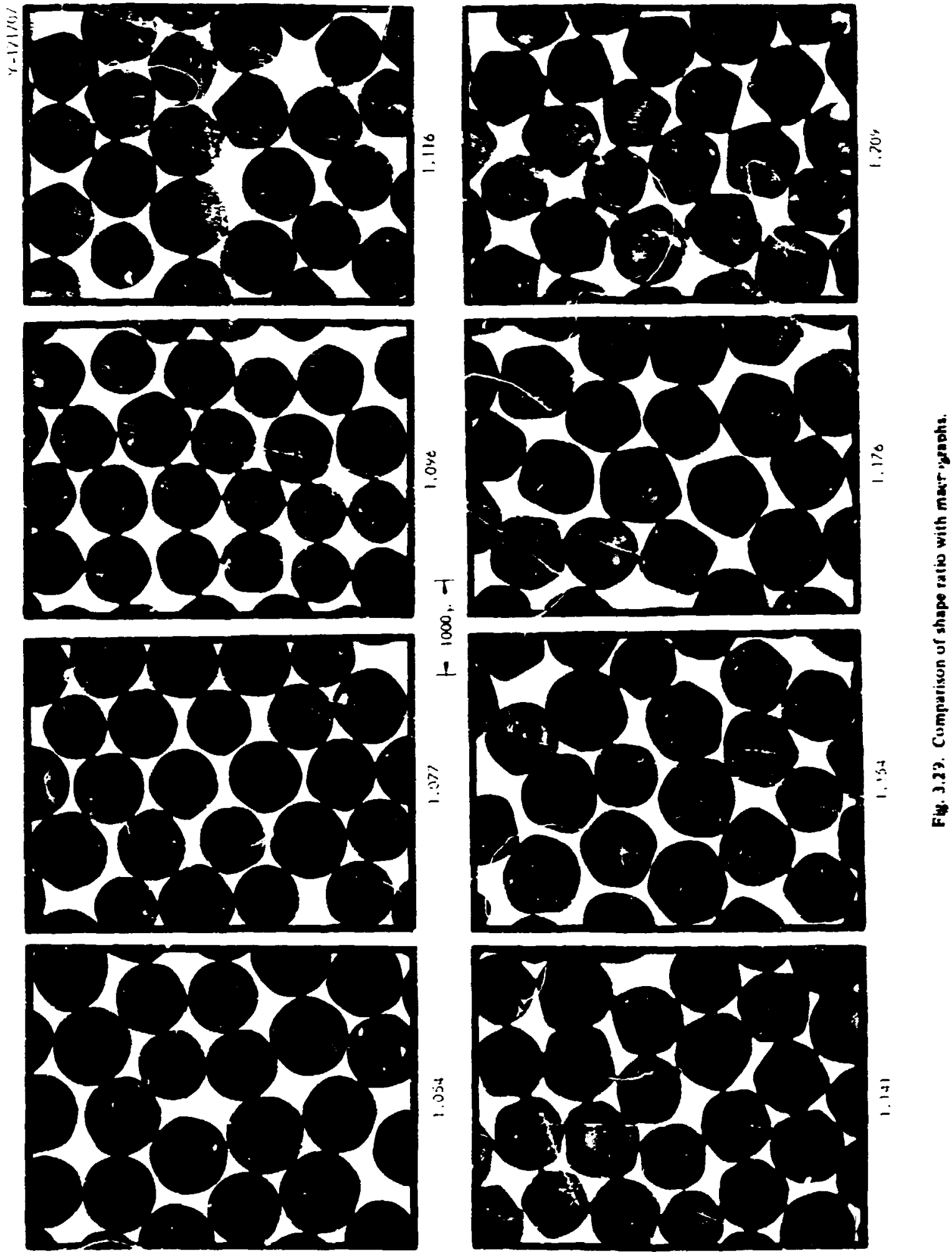


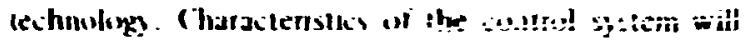
be develuped in terms of ictundaniy and stnchromua-

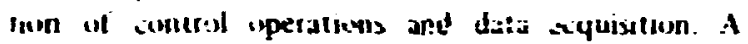

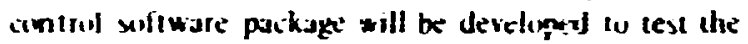
iundankailal comepls. Thus paikage will je applined to a xheried system to determise adequaty al the cuncepts

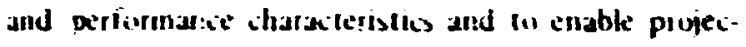
tide. of requatenents in terms of specilications for the final a segn of ite precess ...introl system desen.

\subsection{WASTE HANDLING 2109, ORNL LEAD)}

\section{J. D. Jenk!ns}

The sbj-iture of the wigk unit is to develup trec waste izendling teithulog nocessiry fut the design and uperation : tix I RiP. The work in this area has been primarily in th: developnerit it wasic paikagng and waste assiy t.xethods. This werk included xetr:tion of standard waste contaners to fuolngate waste handlis.g and assy ticuurements. develupment of remotic ion-

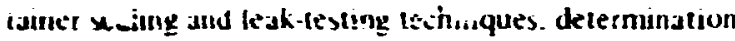
of waste rongacilin requirements and methods. and baggng techniques for transterring of waste vat of the hot all. Equipment for these "pperations is being desipned.

Waste assig is inecossiry to meet the nu-lear material

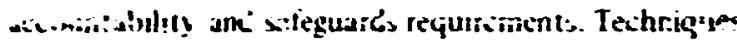
Jr: iveing develuped lier assaying the various types ui waste.

Current plans are :o assiy solid. hegh-fissle-zontent wasic (1.c.. reject provlucil with a salorimeter device lovated in on: of the processing vells. For low-level wolid waste. i xiparate system based un gamma xianning of the ${ }^{23} \mathrm{C}$ decay daughters is bing consadered Euring this teat aclivity in waste assay has been direited toward tormulutir.e a work plan.

\section{II MATERIALS HANDLING - 2110 (ORNL LEAD)}

Ni development axtivities are scheduled. 


\title{
4. HTGR Fuel Recycle Pilot Plant Studies
}

\author{
J. W. Ancerson' F.C. Davis
}

Th. HTC? Fuel ! s... : : :ilot Pont demoniration will he :is c'a'minaious of the HTGR ?uet recycie developmen! fr.gram. Tr: wria has tien divided between two plasts: lise Reproce ing Pijut Plant and the Refabricatiun Pilot Plant. is : ':monsration :rill establish the iechrical feasibility if straing HTGR fuel elements in a remotely operiod : :riity using highly radiuactive feed ma* $a^{*}$ ials recovered $[: ;$ in spent reactor fuel. The pilc plant demonstration wili vet. the practica. ility and reliability of the equipment and provess designs. provice a demuristration of operating and maintenance michods and procedures. provide process data and design information micessary for scaletp to com.ner ial plant sizes. provide data and irformation on nuclear salezurrds and criticality control. and indicate those areas in which arditional development wort miy he needed. Durng the past yc ar. the conceptual design of the Refai, ication Pilot p!rnt equipment was begun: it is schedu'id fur.. iple. tion du:ing FY.7\%.

\section{4.! REPROCESSING PILOT PLAR: DEMONSTRAIIOIY \\ J. W. Snid'r}

\subsubsection{Evaluation of Idaho Facilitics}

The HTGR Prototype Fual Processing Facility, as conceptually designed. will ocrupy portions of four exising facilities plus a nuw facility." The facihlizs and their functions are described below.

1. The crushing, burning, classification, dissolution. and SiC hull handling will be done r. cells 1. 2. 3. and 4

I. Preseni Iddress: Project Managemenil Corporation. CRBR. Oak Ridre. Tenn.

2. Einvirorince:'ol Impact Study on IITGR Fuels Repmo. es. in Facillties. Notional Reactor Testing Station, idaho. WASH. IS 4 (January 10?4). of Building 640. A macharikai crane. fi b: constructed al.p cell 2 under tike Röser Progra.s. will be used for fuel element handling.

2. The acid-ihorex (solvent extraction) prucess will be lorated in cells A. C. and D of Building $60 I$.

3. Analytical functions will be performed in Building 627.

4. Prodex: load sul will be performed in a new facility (Building 556) kcaler south of Br..ding 640. Pertions of the heat-renovis! and venti!stlo: systems of

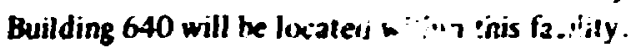

5. The off-gas proce $=$-rill b: ' ater! in the middle cell of Buiding 604 .

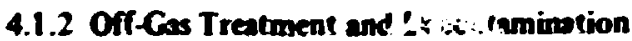 System Desion Criveria}

The off-gis flowsheet is based in . : : ie following process steps: ( 1 ) iodine removal 'ssing iead and silve: zeolites, (2) radon renioval using molecular sieves. (3) tritium removal using molecular sieves, and (A) krypton iemoval using the KALC pre 2.

The is are to be two off gas systeiris for the process o.f-g: iseams: one for all headend process steps up to ar. including the dissolvet and hull washing and tanthe: for ail remaining pruces: sieps.

\section{4.. RFFABKICAIION IIILOT PLANT F. C. Davi:}

Process flowsheets and equipment and system diagrams for th,e ten princessing swstems to be lo:ated ir. ite ;'ilot plant were prepared. These flowshiets and diagrams $r$ :nlect th: latest advancemen's unde subtask 210. Detalled critical-path schedules were pri:parcis to enumeral: a!l the activities necessaiy in nriduce the conceplual disign for each processing sysiem. Ten system design desiriplion n:!" "ik, in I one plar.! design 
dexitiption outline were prepared. saction I wi each of these dicuments. the Funclional and Design Requirements. was in preparation io serve as a basis fo: the conceptual design of the equipment within the svsiem.

Comeptudi design $s^{t}$ the equiprent has teen progressing at a rate to sumplete the effert hy July 1. 197:- lems re wining additional development efforts are being identified and relate-1 lo sublasi 210

\subsubsection{Selwotule and Sentox}

The cornceptual design sudies for the Fuel Refab. rization Pilot Plant were co:ntinued at a low kevel during the first half of t'is rapurting period. Efforts conlinued in preparine proces riow diagrams and equipment and systerns diaguans $f \cdot y$ each of the ten $r$ 't systens in the piant: (1) uranium feed. 12) resin loading. (:- resin carbonization. (4) microsphese cootine. (5) fuel rod fabrication. (6) fucl elemene assembly. (7) sample inspation. (ix) process cuntrod and data handlirg. (9) waste handling. and (10) materials handling. Exh of these systems was atranged into subsystems and conpunents of istated equipment items.

The engineering eiforts were substantially increased during the last hall of thr reporting period. Phase 1 of the conceptual design. consistinz of detailed criteria preparation. cumpletion of the process flow diagrams. completion of the equipment and systems dizgrams. and preparation of outlines of the systein design iescriptions. was initisted to be completed in 1974. $r$ erreptual desigr of equipment was begun to be impicisd hy suly 1974 .

\subsubsection{Overall Piant Conceptual Design}

Preiiminarv plans and procedure documents have been prepared and circulated for review and -omment. T'xese doumicnts cover design procedures. document control. document review and approval prociedures. ducument revision procedures. external revicw procedures. sishlask $\geq 20$ organization and responsibilities. elc. i hese documents are presently being used tu serve as a hasis for timely and efficient operation of the conceptual design activities.

The - -essary modifications and additions to TURF. Building 7930, to efficiently house and operate the pilot plant are being studied. This includes areas for a sar le inspection labura:o'y, an instrument room to hor:se the various iostrumt nt racks and parkels. and an area for the comp'utici $f_{-21}$ lities necessary to operate the pilot plant.

\section{-2.3 System 1 - Urening Feed}

Chemial flowsheets have been prepored for the uranium feed system. These nowsheets schematically indicate the process ilows and now rates identify equipment items. and show equipment relationships and the interfices with other systems.

\subsubsection{System 2 - Recin Loading}

The resin loading system has recently replaced the sol preparation system as the process to demonstrate the production of fuei kemets in the pilot plant. Chemin' flowsteets and equipment data steets had ween prepared for the sof preparation process. The corkeptual decign work on the resin badini system. is being :intizied by pteparing flowsineets and eouipment and sysiems diagram:

\subsubsection{Syxtem 3 - Recin Cotoniantion}

The resin carbonization system has recenty replacd the mikrosphere preparation system as the process to prepare mikrospheres for the ensuing processes in the prototvxe plar:! Chemical flowsheeis and equipment data sheets had been prepared for the nicicosphere preparation process. The conceptual design work on the resin carbonization system is being initiated by preparing nowsheeis and equipmeni and systems dagrams.

\subsubsection{System 4 - Microsphere Cosing}

The precoating and postcoating equipment items have been conceptually designed. These items include fuel particle hoppers, diverter valve. size slassifier. shape classiñer, weighers, sampler. and the lot blender. The conceptual design of a typical coating fumace and its peripheral equipment is in progress. This includes the fumace. tle fuci particie unlooding mechanism. the scalping classifier, and a scrubber to treat the effluent gas generated during the coating operations. Equipment arrangement layouts are prepared io study the relationshin of equipment. the viewing iimitations through the hot-cell indows. the limitations of the remotely operated manipulators, ard the interfacing whih other systems.

\subsubsection{System 5 - Fuet Rod Fabriation}

All the subsystems that comprise the fuel rod fabrication macrine have been conceptualiy designed. The designs of the fuel rod transier subsystem, the fuel rod integrity inspection subsystem, and the fuel rod assay subsystem are in progress. Equipment arrange ment layouts are being prepared to study the various 
subsystem relationships. the viewing limitations through the hotwell windows. the limitations of the remotely operated manipulators. and the interfacing with other systems.

\subsection{Systen 6 - Fod Element Arrably}

The equipment items nacessiry to perfiern the many sieps in fuel element axeribly have been identified and are in various stages of conceptual deager. The fuel etement losding ma:hine, the iniericell tansfer unit, and the load verificailon and end plug insertion unit have been corceptially designed. Conceptudidesigns of the other units are in progress.

\subsubsection{System 7 - Sample Inpection}

The uni's necessary to periorm the inspection of the fucl paricles. the fuel rods. and the fuel etement assembly sample have been identified. This list bas in an altered since the reference iuel has changed from

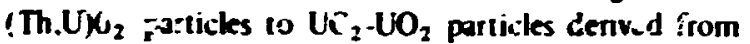
uran:- m-lwaded resins.

\subsubsection{Sysedm 8 - \\ Process Control and Datu Handing}

The :equirements for power control, sensor, and data handling and storage are being identified to det:rmine the needs of the process control and data handling system. Each of the other systems in the pilot plant a: being analyzed is determine their powe; consumption and instrumentation iro irements. Appropriate sensors and control systems iri being designed iniv the provessing equipment subsystems to provide proper interfacing with this subtask.

\subsection{Syates 9 - Wast Handing}

Each of the process systems in the pilot glant hrve been analyzed to drtermine the amount and type of wate materials that will be produced. The capability of the existing TIRF fxility to handle wastes is being sudied to determine the additional equipment that will be necessary to service the filot pant provess. A fuel reject rate is being estimated for each system in the pilot plant and the type of fuel rejeits that would be expected. These estimates will be used to direat the conceptual designs of packaging and asoying equipment that will be necessary.

\subsubsection{Systen 12 - Materids Handing}

Each of the process systems in tive pilot plant huve been analyzed to determine the type arid amount of materials to custoin opeiations. These materials include feed and support inaterials to the process, scrap and off-specification materials generated by the process. and the pinducts coming from the process. The needs determired by this study ar being compared with the anabilities of the existing TURF faility to detern.ine the additional requirements that must be provided. Plans and procedures are being formulated to perform a thoruugh check-cut of the existing in-ell ciane and manipulator system. This system must be made op:raional to handle process equipment being instalied in the cells for development testing- 


\title{
5. Studies and Evaluation of HTGR Fuel Recycle Systems
}

\author{
F. J. Horman \\ A. L. Lots
}

The ebjectives of this task and the plan for atraining these ubjectives. stated in last, ear's annual report.' remain the same.

\section{S.I EVALUATION OF HTGR RECYCLE FROCESSES}

$$
\text { D. A. Dyslin }
$$

itome of the cumputer programs that are needed io perion:a proiis trade-off studies have been written. These are B.IL (material balance). CEP (copital co... and TCP (tutal capital cosi). The BAL program calialates the keavy-metal flow through it recycle plant as a funciion of rejec' rates in the various prociesses: CEP calculates the capital cust of exh indivitual piviess bluck as a functio., of heavy-metal thredsonol for that proxess; and TCP cakiviate: the tolal capital cust for a plant using the sutpu: from BA: and CEP.

In additur to capital custs. the hardware and operaling costs need to oe estimated. To aciomrish this. the BAL prugram will be expanded (1) luclude material baiance :-alculations for matcriais other than heav: metais such as gases and graphite bluiks. Mtis expanded AAL prigram will be used for establishing hardwate cost estimates. and its uutput wiil alw be used i? estumate unerating coss. Computer propamming for haidware and operaling cosis. which has begun. will be followed by compa:ion cost studies of commerital recycie plants.

1. J. W. Anderon and A. L. Lolls. liCk Roosems Annu, From. ReF. DNe. 31. 1972, ORNL4911, p. 63 .

\subsection{COMPARLSON OF CANDIDATE RECYCLE FUELS FOR THF HTGR}

\author{
F. J.Hrman
}

\section{2 .1 Generd}

The nuxed (Th.LiO, fuel with a 4.25:1 thoritm-to uranium ratio is iurrently the refe ence, aycle kemel for the HTGR. ${ }^{2}$ Revent evidence o: pour dimensional slability of this kemel at hiph temperatures and temper-aure gradients has causad some concem as to whethe- this particle will ferform adequately. This ancern has resulted in consideration of several other andidate fuels for use in recyus f:- l: ements. Among the alternatives are oxides. carbides, an $\mathrm{J}$ oxy carbides of uranium derived fron." weak-acid re sin (WAR): the :::'mgacid-resin-derived UOS system and aixed thoriumuranium oxides with higher thorium-to-uran:asm ratios itan the current reference kernel. These alisinatives must be compared with the present reference portick on the basis of buth irtadiation performance and economics. The present irradiatsin dila are not ade. quate to shuw a cleas aut advantage ul unc system ower another: only estimates oi recycle ecororrics are zurrently availabte. since no irGR recyite ficlity of any size has been bulis or upeiated. However. istadia. twon tess in protsess and uthess in the planning tapes shousd sirifixantly ilanfy the performance pisture. Detaileri coss estinazu:a are being made which should provic: valuatic pudance on the re'tre cints of

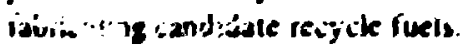

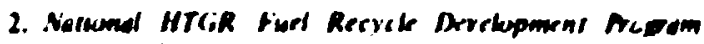

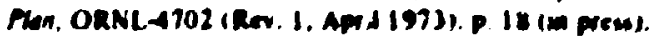


It is important that a reference kemel be seleited from the potential andidates as soon as pussible. Equipment is presenliy being designed for instaliation in the Thoriurn-Liranium Recycte Faility (TLRF). which is .0 be a pilut plant fur a large commercial labrization fuility for reycle iuels. Fanning and equipanent development for the TLRF is strongly deperi lent on the fuel system to be provessed there. Since equipment is siheduizd for installation in the TURF beginning in July 1970. the reference iveis should have alresdy been confirmed.

This repon describes presen! knowledge on the eimomios and perforsianie of the candidate recycte fiels. This will provide a :oundation upon whinh new infomation an be added to facilitate a timel: setection of a reference sysem for T'JRF.

\subsection{Ecomonies}

The overriding economi consideration related to the chove of particle for recycte fuxls is the amount of material that must be processed id. the shicldec ariion of the refabrization plant. To demunst. - : his puint. capital cost stimates will be presented for a combinaison reprocessing-refabrication facility that is apable $\cdot i^{\circ}$ suppuraing a 45.000-MW(e) HTGR economy. Gulf General Atomic (GCA) has estimated the tfroughputs and iapital ciss aswized with such 2 facility. ${ }^{3}$ so this disiusson will serve the dual purpose of comparing the economics associated with candidate recycle fuel kér.

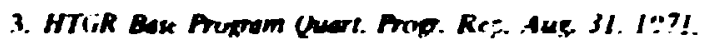
CurfiA-A-10784. pp. 15-48. nels and linking our economic estiniates to thuse made by Gulfi.

Gulf's escimates of the throughputs for the combination facility are given in Table 5.!. Since wie are not interested in the reprocescing part of this facility at the present. we will only estimate the cust of a fixility sized io reprocess 30 ; metric tons of ixeary metal per year. The estimate of $\mathbf{S 4 1}$ million is based on $\approx$. equat:or desiribed in Refs. 4 a.d 5.

Fuel element fabrication involves four major steps: (1) Kernel preparation. (2) costing. (3) iuel rod labrication. and (4) fuk l eiement assembly. These st-pos are basically th: azme as thuse used in fabicatio.l of fresh fuel. exispt that they must be acomplished in heavily sielded failities using remote techniques. Capital and uperating costs are therefore decidedly bigher lur reiycle fuet than for fresh fuel fabriated in a con:act iz-ility. It would therefore appeat loginal to minimize the amuunt of material that must be pricessed in the shielded pustion of the refabrication parit in urder to min.mize the amuuat of equipment and space.

Capital cast estimates" for the four siages of HTGR fuel ratabixition are given in Figs. $3.1 \mathrm{~L}, 5.1$. These figutes have been issed to eximate the cust ut retabricating !ITGR fuel for the 23 recyik elements at lin

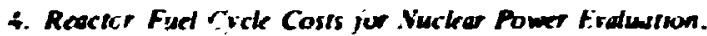
WASH-1099, p. 92 (December 197 I).

j. F. J. Homan. "Timing the Utilization of Recycle Fuels in ifig-Temperature Cas-Cooled Reactors," submitted to .Vucted Technolok:

6. J. W. Inderson and J. P. Jarvis. "Commerival Recycle Pher Srudies - Procex Evahurions." unpublished data.

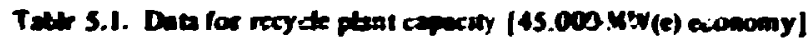

\begin{tabular}{|c|c|c|c|c|c|}
\hline \multirow[b]{2}{*}{ Proces } & \multicolumn{5}{|c|}{ Annual apacity (metric (ons) } \\
\hline & $\begin{array}{l}\text { Number } \\
\text { of fuel } \\
\text { elements }\end{array}$ & ${ }^{233} \mathrm{c}$ & ${ }^{233} \mathrm{C}$ & Th & Total \\
\hline Reprowiswink & 38.880 & $: 4$ & 5 & 288 & 307 \\
\hline 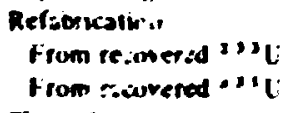 & $\begin{array}{r}12.645 \\
3 . t \div 9\end{array}$ & & & & \\
\hline 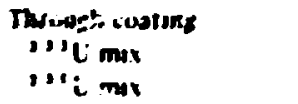 & & 14 & 3 & $\begin{array}{l}\text { S1) } \\
11\end{array}$ & $\begin{array}{l}14 \\
: 6\end{array}$ \\
\hline $\begin{array}{l}\text { Assembly } \\
\text { "it: mix } \\
\text { "Pli mix }\end{array}$ & $\begin{array}{r}12.645 \\
1.6940\end{array}$ & 14 & s & $\begin{array}{r}101 \\
29\end{array}$ & $\begin{array}{r}1: 5 \\
34\end{array}$ \\
\hline
\end{tabular}




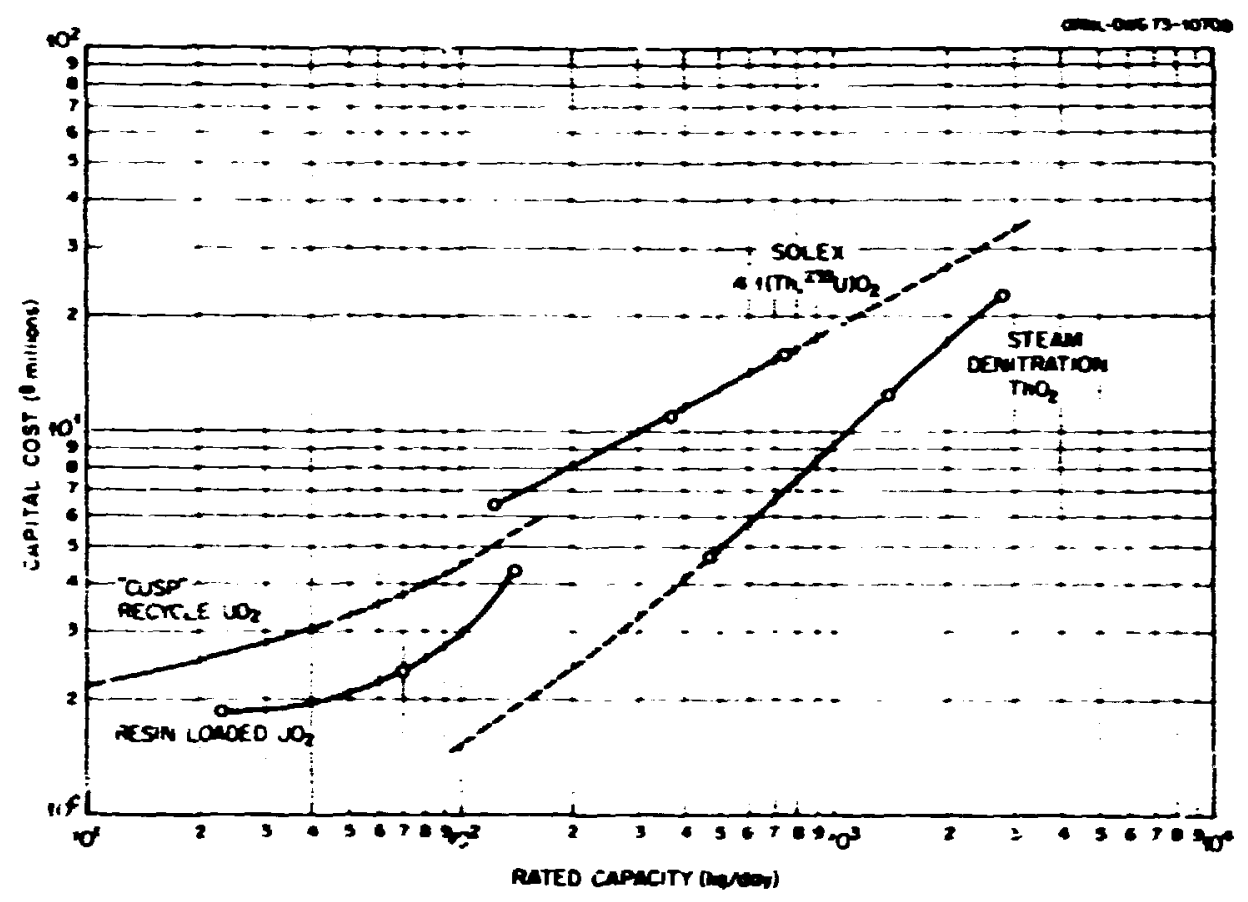

fic 3.1. Kerwd prepantion copital costs

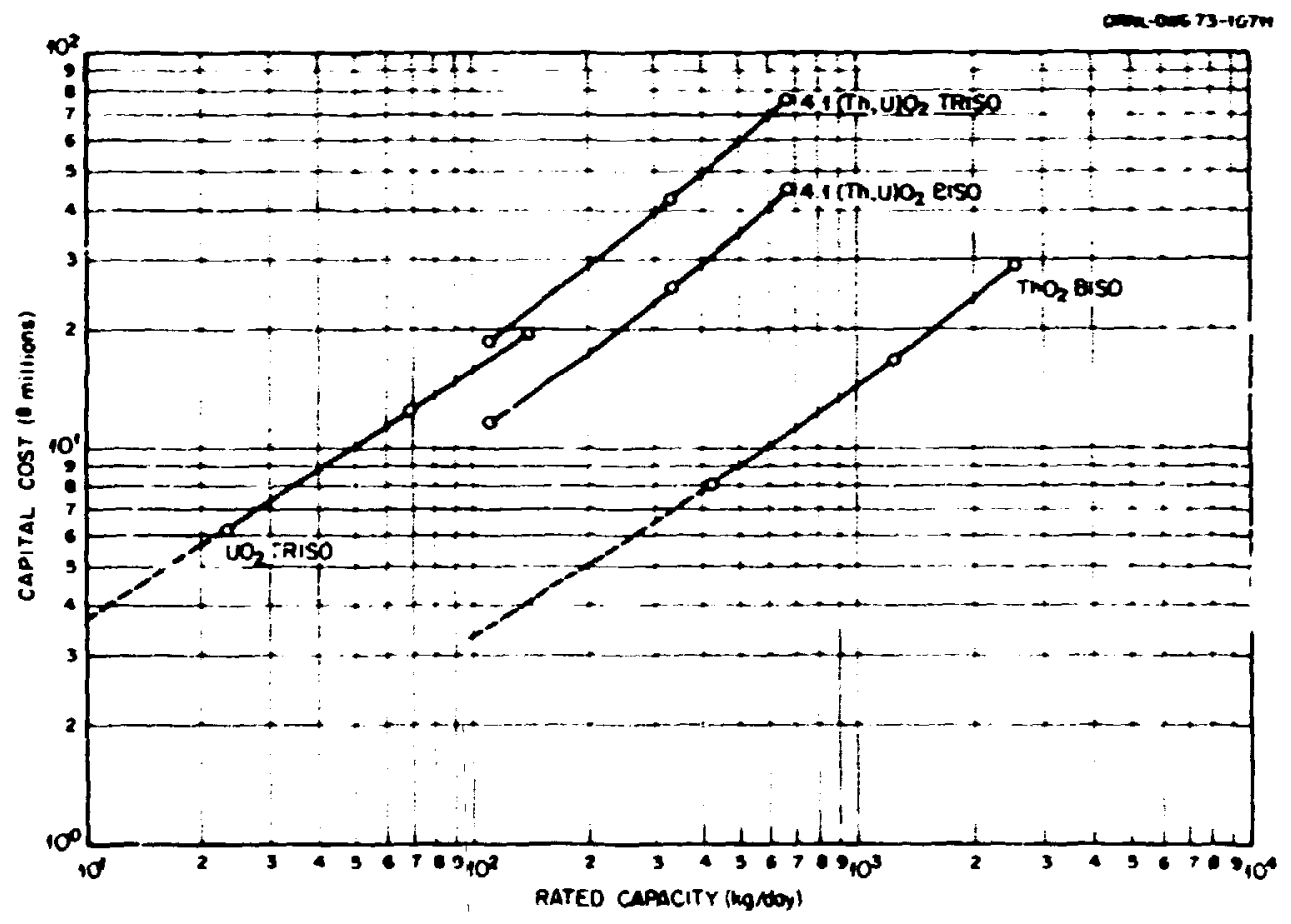

Fiz 5.2. Coating capital costs 


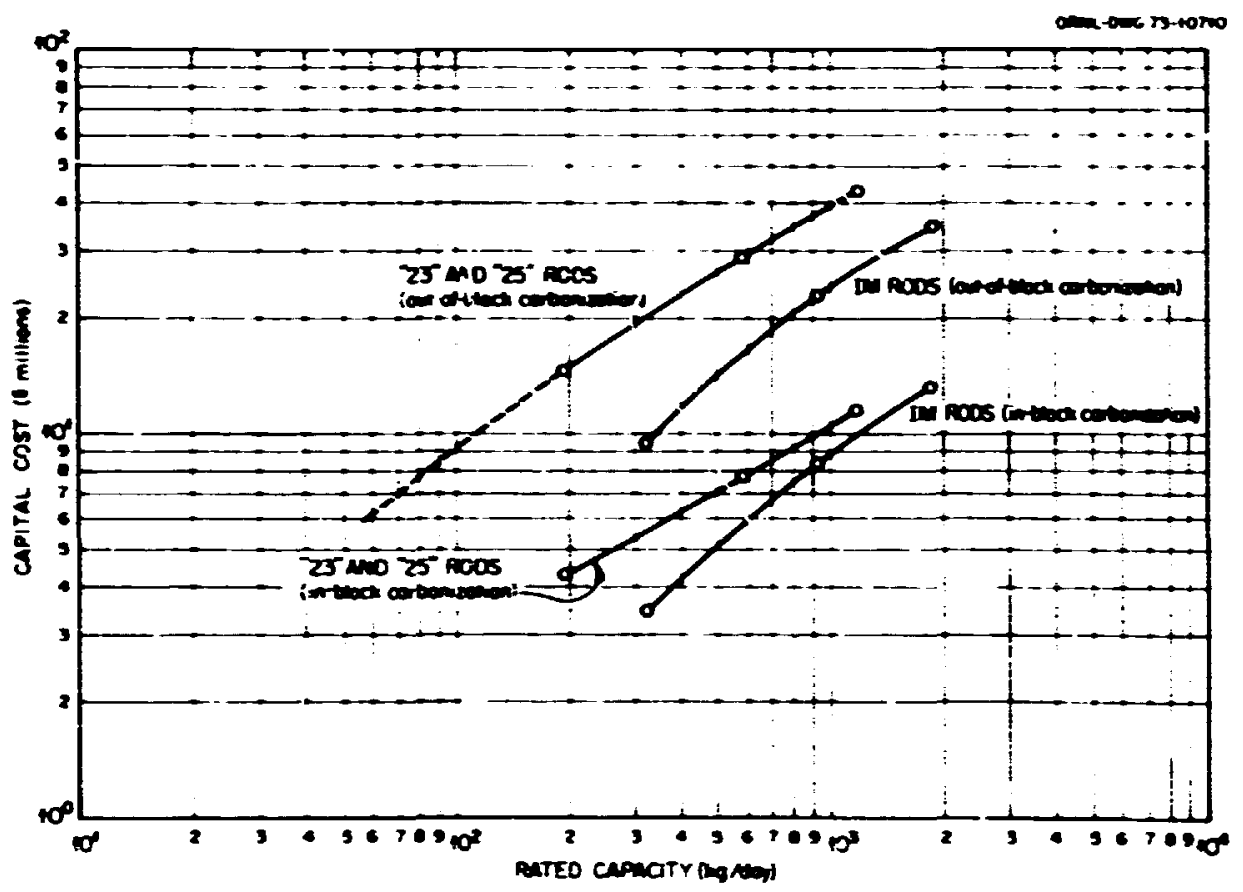

Fis 5.3. Foed rod fabrication

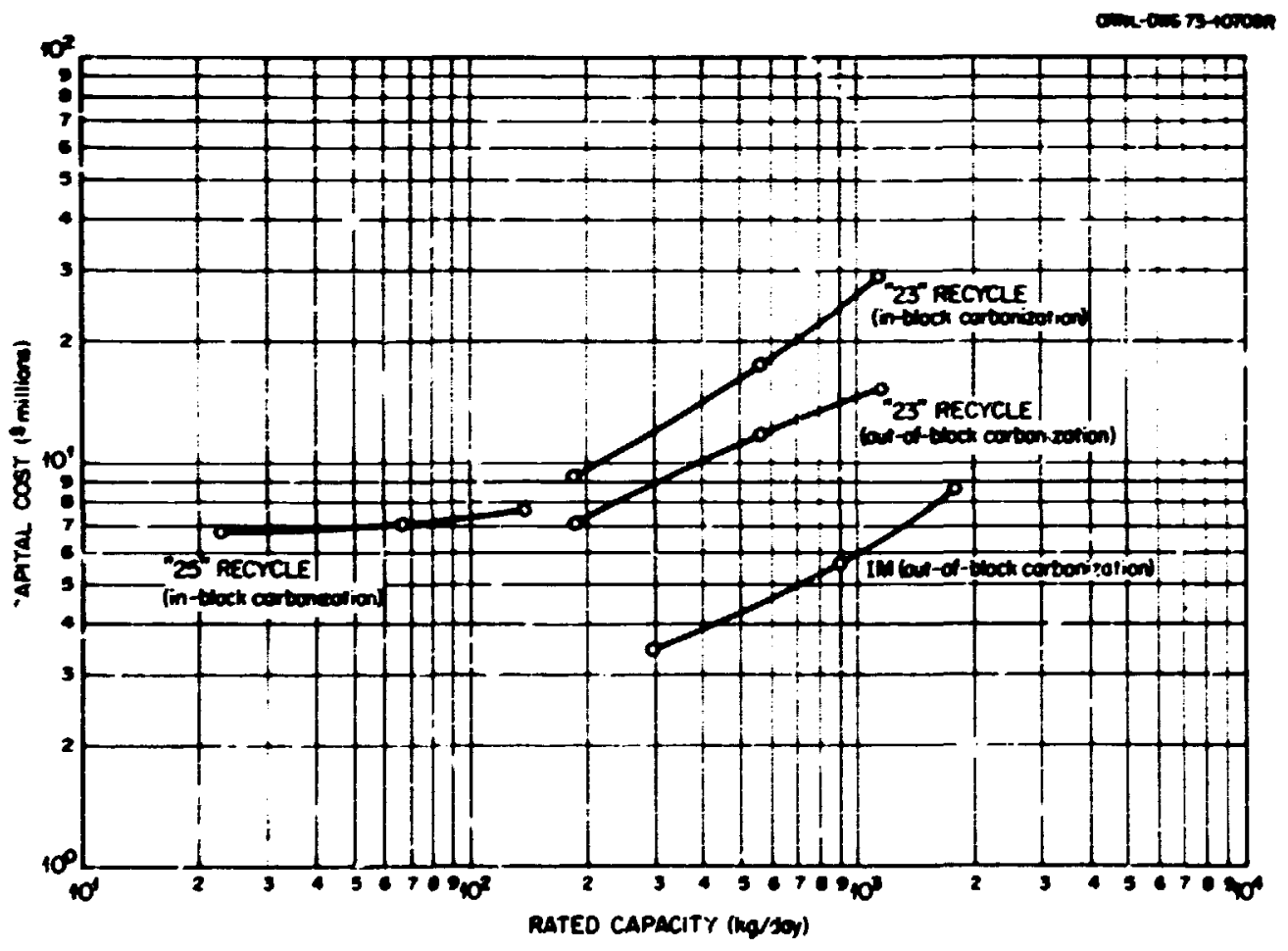

Fif 5.4. Fuet element aseembly. 
rate of 115 metric tons of heavy metal per year, as specified in Table 5.1. A load iator of 0.8 has been assumed for the refabrication plant. which means approximately 290 uperating dajs per year. At this rate. the plant must te ap ine of piciessing abuut $\mathbf{4 0 0}$ kg o. heavy metal per day.

The :hroughputs for the shielded and contait lines for refabrication of ${ }^{233}$ U-bearing recycle elements are given in Tabk 5.2 for 4:1. 8:1. and WAR 0:1 partides.

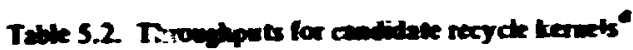

\begin{tabular}{|c|c|c|c|c|c|c|}
\hline & \multicolumn{3}{|c|}{ Metric tons/year } & \multicolumn{3}{|c|}{ Kilogamsiday } \\
\hline & $4: 1^{b}$ & $8: 1$ & $0: 1$ & $\$: 1$ & 8:1 & $0: 1$ \\
\hline \multicolumn{7}{|l|}{ Shidded live } \\
\hline Urmium & 14 & 14 & 14 & 48 & 48 & 48 \\
\hline Thorium & 56 & 101 & 0 & 193 & 348 & 0 \\
\hline Total & 70 & 115 & 14 & 241 & 396 & 48 \\
\hline \multicolumn{7}{|l|}{ Coatect line } \\
\hline Thurium & 45 & $\mathbf{0}$ & 101 & 155 & $\mathbf{0}$ & 348 \\
\hline Total & 115 & 115 & 115 & 396 & 396 & 396 \\
\hline
\end{tabular}

CApplies to refabrication of "'U-bearing recycte ek. ments for a 45,000-MT(e) HTGR economy.

"Thorium-uranium ratio in recyck fissile purtick; $0: 1$ is the WAR-derived $\mathrm{UO}_{2}$ keme!.
It is immediately obrious that the economics of the $0: 1$ partikle shuuld be farorable because so litite of the material need be processed in the shielded line. whereas the 8 : I particle requires that all the inean metal for the ${ }^{23} \mathrm{~L}$-bearing fuel elements be provessed in the shielded line.

Capical cost estimates derived from the throughyuts from Tabte 5.2 and the cost curves from Fig. 5.1 to 5.4 for the different steps are given in Table 5.3 for the keral compasiticns being considered. The resuks of this study show a 590 per kilogran adrantape for the WAR kernel over the 8:1 kernel and a 558 per kilogram advantage of the W:iR kemel over the 4:1 kemel. assuming all the kemels are Triso cuated. When the 8:1 or 4:1 kemels are assumed to be Biso coated. the $\cos x$ advanuge for the WAR kemets (still Triso) is reduced to 538 and $\$ 24$ per jlogram respectively- Whether commerially refabricat :d HTGR tuel will be of the Triso ar Biso design has not been established yet. The reference 4 : I design is biso cuated. but it is anticipoted that the TURF will be built with the capability of applying Tnso coating. There is some feeling among those working in the coated partiule fuel area that commercially reprocessed fuel ill require a Triso coating as well to maintain a "clean" coolant circuit. Even so. the capital cost estimates given in Figs. 5.1 to

Table 5.3. Hefabrixation capied costs for 23 recicle elements

\begin{tabular}{|c|c|c|c|c|c|}
\hline & \multicolumn{4}{|c|}{23 resche enciments } & \\
\hline & \multicolumn{5}{|c|}{$\operatorname{cost}\left(5 \times 10^{\circ}\right)$} \\
\hline & \multicolumn{2}{|c|}{ 4:i } & \multicolumn{2}{|c|}{ 8:1 } & \multirow{2}{*}{$\begin{array}{l}\text { UO }_{2} \\
\text { WaR } \\
\text { Triso }\end{array}$} \\
\hline & Triss & Biso & Tiso & Biso & \\
\hline \multicolumn{6}{|l|}{ Kernel preparation } \\
\hline Fissile & 8.9 & 8.9 & 11.5 & II.5 & 5.3 \\
\hline Fertile & 20 & 2.0 & 0.0 & 0.0 & 3.7 \\
\hline \multicolumn{6}{|l|}{ Coating } \\
\hline Fiscile & 33.0 & 20.0 & $\$ 9.0$ & 29.0 & 9.8 \\
\hline Feril: & 4.2 & 4.2 & & & 7.0 \\
\hline Fuel -ad fahriation" & 8.2 & 6.2 & 6.2 & 6.2 & 6.2 \\
\hline Assembly & 14.0 & $: 4.0$ & 14.0 & 14.0 & 14.0 \\
\hline Tot2! & $\overline{68.3}$ & $\overline{55.3}$ & $\overline{80.7}$ & 60.7 & 46.2 \\
\hline$s / k_{g} c^{c}$ & 177 & 143 & 209 & 157 & $11^{\circ}$ \\
\hline$\Delta \mathbf{s} / \mathbf{k g}_{\mathbf{B}}$ & 58 & $2 *$ & 90 & $\therefore$ & \\
\hline$\Delta z$ & 49 & 20 & 76 & $?$ & \\
\hline
\end{tabular}

Applies to equipment for 23 recyste element refabrication line for a $49.000-M W(e)$ HTGR econoiny.

Assumes irblock carbonization.

'Assiomes 30\%/yeas fixed charge rate and $400 \mathrm{~kg} / \mathrm{day}$ for 290 days/year. 
5.t refleit تisstantini cinnumk adventages lor the

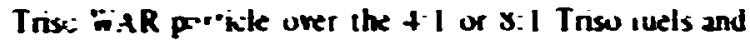
Itw 2 signi. ant advantage over the $f: 1$ or $8: 1$ biso ivels.

As shown biter in this chapter. the capital iust extimates presented tere are ul reasunable tertement with GC.A estimates ior 2 comboned ieprovessing-retib. rkation laility :=able 0 supporting 245.000 MW/e HTGR ecunomy. Even se. I should be pointed out inat there are sorke inadequaiks in the present analysis. For instance. should the $8: 1$ particle be used. there would be a one-partick s.stem. and the blending step (which is part of the fuel res tabriation procedure) cuidd be omitted. This would also save an inspection step. Presumably. blending of the thoria fertive particie with the WAR Triso fissile particles wuuld be more difficuit (and therefore more expers ") than bler-ing iertile and $+: 1$ tissire partikles. Subtie points such as this a:not cunsidered in the cakulatiuns preseated in Table 5.3.

\subsubsection{Performance}

buth the referenc: 4:1 ITh.LiO: particle and the WAR $\mathrm{CO}$ : and $\mathrm{IC}$ - particles have been tested under irradiation. All partio:es have sho:an rood periormance at i:w inperatures. : nd the 4:1 particles have shown the tendeniy to migras at elevated remperatures and temperature gradients. Huwever. becisuse of the uncertainty assiriated with the operating cemperatures and timperature grairents o: the experiments in which these oarticles were tested. nusitive ion:lusions athut their suitability for recycle appi"-ation have nut been made. To date. the WAR and 4:I Th. $\mathrm{CHO}_{2}$ pariicles have not oeen tested in the same experitiren: to gre siantitative comparisons of their performance under identical irradiation ;onditions. This experiment will be accomplished in the HRB-7 and HRB-8 capsules to the nserted into the HFIR in January 19it. The $8: 1$ ITh.Li $\mathrm{O}_{2}$ particle will be lested in these capsules as we:!.

In order (1) set the stage for the anticipaled results from HRB-7 and HRB-R. a review was conducted of all irradiation experiments in which the thrce eandidate re yole particles desiribed ainive were tested. This int rmation is systematically presented in Tables $5 . t$ and S.S. Some additional coniments on pertorinance of these cundidate particles ara given below

\section{Reference 4:1 Th. UN, recycie fuel}

As indicaled in Table 5.4. four of the ten $4: 1$ spitmens cuntained in HRB-l were examined metal. lugraphizally. Thei was nu coidence of the amuebs effect in any if tram. Ithuugh there was sume sliyht disiuturation in one sube of the partikis examined irum sompte of. In the highest temperature rod (SA) there was no evidenic ol amueba. althuugh amueba wis nuted in $\mathrm{CO}$ : kernels operating at sinular temperatures in nearby specimens.

There were approximately if fuel rods in RTE-7 cuntaingng relerence $f: 1$ itwo fucl budies. two hules per body. and six rods per hokel. Metailugraphy has been periormed on rods from 7-5-2: and their appearance was exielknt, as would be expected fiom this low expesure and uperating temperature. No additional mrtallugraphy is planned.

The tu fuel rods sintaining $4: 1$ fuel frum RTE + have not been metallog:-sphizlly examined. Several ruds will be examined in the future. but. because of the low operating remperature and exposure. the luel is expected to lonk goud.

Excensive information is available on $4: 1$ fuel from the $\mathbf{H}$ eapsules. 7 Terc were six samples containing 4:" ivel: four :uds and two louse beds. Kod H-I + ineraled at surface and center-line lemperatures of approximately 1050 and $1420^{\circ} \mathrm{C}$. respectively. for 97 effective full power days (EFPD) and at surfice and center-line temperatures of approximately $90 \mathrm{C}$ and $1200^{\circ} \mathrm{C}$. Isspectively. (ior an additional 39 EFPD. The maximum temperature gradie.t in this rod was approximately (wice that expecteci in a large HTCR, but the nuaxımu.? center-line temperature was approximately that in an HTGR. The rod fragmented intc two piaces when remuved from the capsule. bat the particles survived the irradiation in gour condition. Of the forly-two $4: 1$ particles in the plane of the polish. the only coating failures observed were for partic es that had labrication deficts (i.e.. were conted withulit a buffer layer). A sinall amount of keri. ?l migration was obseived. No litigration was observed in 5 parises from the plane of polish. and migratiun from : to $43 \mathrm{\mu m}$ was utsived in 23 of the particles.

Rud H.I.10 operated at very high surface and center-line temperatires for the last 30 EFF of the test. The ialculated surface ani certer-line :emperatures during this time were 1480 and $2150^{\circ} \mathrm{C}$ respe:tively. This center-line temperature was muct, greater than the $1400^{\circ} \mathrm{C}$ maximum temperature expected in an HTGR, and the !emperature gradient was about three iines the maximun gradient in an HTC $R$. Because of

7. R. A. Oistad el al. An Imatworion Test of Condulare

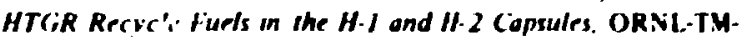
4397 (Suly 127\%). 


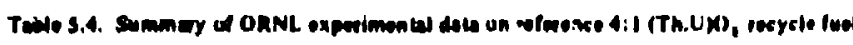

\begin{tabular}{|c|c|c|c|c|c|c|c|c|}
\hline \multirow[t]{2}{*}{ Evpeniment } & \multirow{2}{*}{$\begin{array}{l}\text { Sumplon } \\
\text { Adeniflication }\end{array}$} & \multirow{2}{*}{ 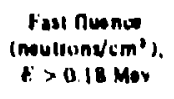 } & \multicolumn{2}{|c|}{$\begin{array}{l}\text { Muinup } \\
(+1)(M A) \\
\end{array}$} & \multirow[t]{2}{*}{ |xowan* cuml' } & \multirow[t]{2}{*}{ Innos: $x^{\circ}\left(6 / \cos ^{\prime}\right)$} & \multirow{2}{*}{ 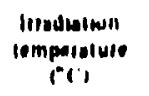 } & \multirow[t]{2}{*}{ Reenniks } \\
\hline & & & Finese & Forile & & & & \\
\hline \multirow{11}{*}{ HRQ $11^{\circ}$} & & $\times 10^{\prime}$ & & & & & & \\
\hline & is & 400 & 9 & 0 & $195 / 19180 / 31 / 13$ & & ) & \\
\hline & is & 4.0 & 9.1. & 0 & $195 / .17 / 30 / 13 / 31$ & & & \\
\hline & ic & 4.0 & 9.0 & o & $\mid y 3 / 31 / 20 / 1] / 31$ & & 170 & No moselluwephy \\
\hline & 3A & 6.6 & 12.7 & 39 & $109 / 111 / 20 / 131 / 31$ & & & \\
\hline & 36 & 6.6 & 12.7 & 59 & $198 / .11 / 20 / 31 / 9:$ & & 11si1. & Meralluwiophy \\
\hline & 4 & 7.3 & ij. & 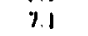 & $193 / 31 / 20 / 313 / 3,1$ & & $14011^{4}$ & Melalluweraphr \\
\hline & SA & $\mathbf{8 . 0}$ & 149 & n. 2 & $195 / 37 / 30 / 33 / 93$ & & $11 \cdots$ & Mocollowentiphy \\
\hline & sit & ..0 & 14.9 & n.2 & $195 / 37 / 20 / 3.1 / 13$ & & & No inotellewiephr \\
\hline & 6A & 7.4 & 14.0 & 1.4 & $195 / 17 / 30 / 13 / 3.1$ & & & Melallinglaphir \\
\hline & 68 & 7.4 & 1,0 & 1.4 & $195 / 31 / 10 / 313: 31$ & & 1140 & No moialluesaphy \\
\hline \multirow[t]{6}{*}{ HRQ 6} & IA & - & e & & $35(0 / 100 / 30 / 29 / 40$ & $01.19 / 149 / 12: 145$ & ( & $425(1 / h,(1) x),(110, \cdots+\cdots)$ \\
\hline & is & & & & $330 / 100 / 30 / 23 / 411$ & $7 / 16 / 1.95 / 3,1 / 48$ & & 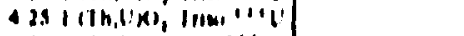 \\
\hline & 3i & & & & .1s(1)//00/20) & "1lis:1.95 & & 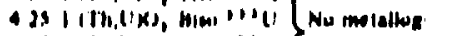 \\
\hline & 38 & & & & $i s 0 / 1(00 / 90)$ & $? 1119 / 1.99$ & & 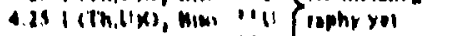 \\
\hline & $x$ & & & & $.190 / / 160: 40$ & $0 / 1.19 / 149$ & & 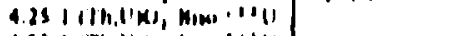 \\
\hline & 30 & & & & $350 / 100 / 90$ & ?1.19/1.49 & & 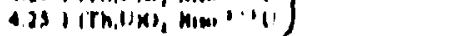 \\
\hline \multirow{4}{*}{ RTt. 2} & $.6 .1^{\pi}$ & nI & n2.4 & & 1ss:70/113s & (1) $1 / 11 / 142$ & 4ik) | 14811 & \\
\hline & 7.6 .2 & $n !$ & n2: & & $395 / 74 / 139$ & (1) $1 / 111142$ & 9at $|1| 111\}$ & Nas motollowlopht \\
\hline & 7.5 .1 & ni & n2.4 & & $.395 / 741135$ & (11) 1.1.111.91 & V(B) i(US)! & \\
\hline & 7.5.2 & .11 & n2.4 & & $33 s / 70 / 13 s$ & (10) $111,1 / 1,4]$ & 4nI 1191 & 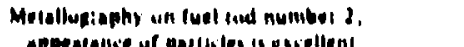 \\
\hline \multirow[t]{6}{*}{$\begin{array}{l}\text { RTt } \alpha^{\prime} \\
\text { VCopacuses }\end{array}$} & $\begin{array}{l}4.3 .110 \cdot 4 \\
1+14\end{array}$ & 6.1.5 & n.3.5 & & $\begin{array}{l}341 / 72 / 71 \\
.159 / 74 / 1 ; 5\end{array}$ & $\begin{array}{l}10111.111 .44 \\
10111.11 .42\end{array}$ & $\begin{array}{l}\text { nes } 12111 \\
14211^{\prime}\end{array}$ & 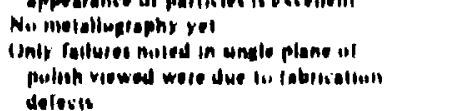 \\
\hline & H.1.10 & 3.4 & 16 & & $.159 / 74 / 13$ & $101 / 1.1 / 142$ & 21.311 & 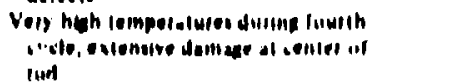 \\
\hline & H.16 & $\$ 6$ & 8.6 & & $393,94 / 139$ & $10.1 / 1.1 / 1.42$ & 16711 & 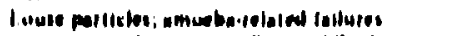 \\
\hline & H.24 & 1.3 & 7.3 & & $353 / 794113$ & 10111.111 .91 & 14.111 & 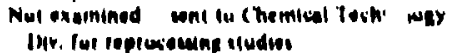 \\
\hline & $H \cdot 2 \cdot 10$ & $\$ .1$ & B. 1 & & $255 / 74 / 119$ & $111.1 / 1.1 / 1,92$ & Inan| & 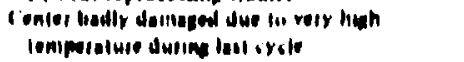 \\
\hline & $\mathrm{H} \cdot \mathrm{i} \cdot \mathrm{G}$ & 0.2 & 1.2 & & $195 / 79 / 1.13$ & $101 / 1.1 / 1.92$ & 16.00 & 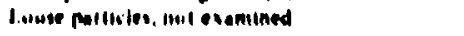 \\
\hline
\end{tabular}

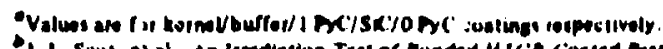

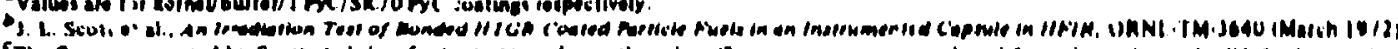

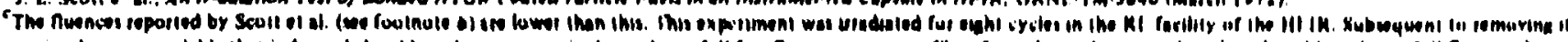

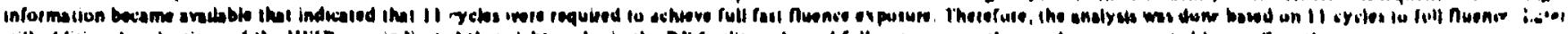

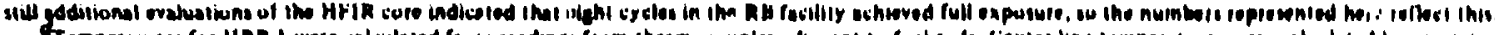

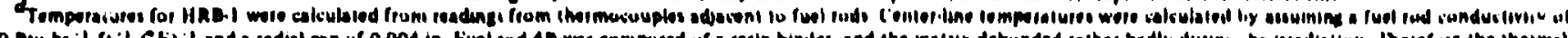

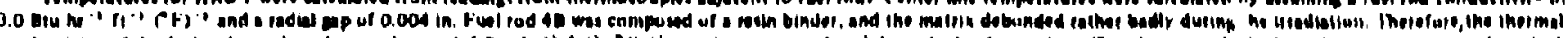

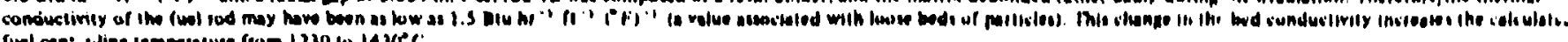

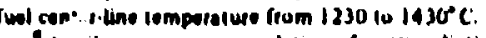

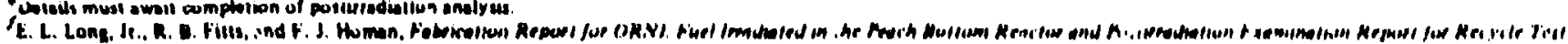

citements 7 and a cin publicetion).

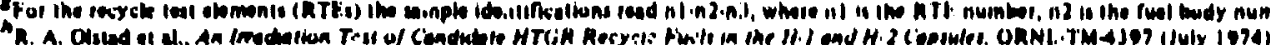

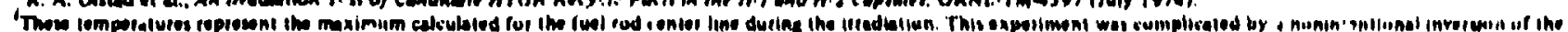

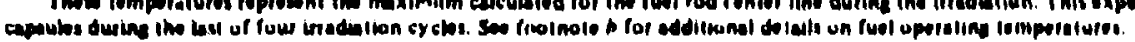




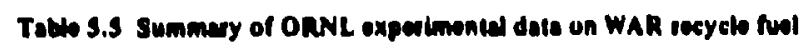

\begin{tabular}{|c|c|c|c|c|c|c|c|}
\hline Exporimont & $\begin{array}{l}\text { Somplo } \\
\text { idontiflcation }\end{array}$ & 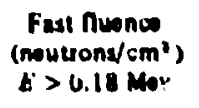 & $\begin{array}{l}\text { Burnup } \\
\text { (\% FimA) }\end{array}$ & Doesene (um) & Densily" $\left(\omega / m^{\prime}\right)$ & $\begin{array}{l}\text { Irindiulion } \\
\text { lemiperalure } \\
\text { p(i) }\end{array}$ & Romuks \\
\hline HT. & $1461\}_{30}^{1 R C}$ & $\begin{array}{l}\times 1011 \\
9\end{array}$ & c & $300 / 0 / 74$ & $? / 0 / 1.94$ & $1050^{4}$ & $\begin{array}{l}\text { Loun pailiclos, UC diunidized ( } 0.5 \times(0) \text {; } \\
\text { nu folluin }\end{array}$ \\
\hline $\mathrm{Cl}-28^{\circ}$ & $\begin{array}{l}1142 J 00 \\
F 1402 \\
H 1488\end{array}$ & $f$ & $f$ & $\begin{array}{l}350 / 0 / 74 \\
443 / 29 / 65 \\
460 / 19 / 67\end{array}$ & $\begin{array}{l}? / 0 / 1.93 \\
2.5 / 1.5 / 2.02 \\
1.9 / 1.3,2.02\end{array}$ & $\begin{array}{l}10001 \\
1000\end{array}$ & 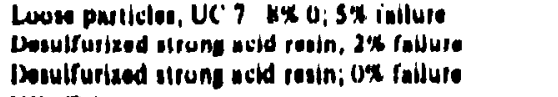 \\
\hline HRBA and -5 & $\begin{array}{l}1 A \\
18 \\
\text { IC } \\
3 \hat{3 A} \\
38 \\
3 C \\
3 D\end{array}$ & ، & ' & $366 / 45 / 30 / 30 / .30$ & $6.2 / 0.95 / 1.94 / 3.21 / 11.49$ & c & 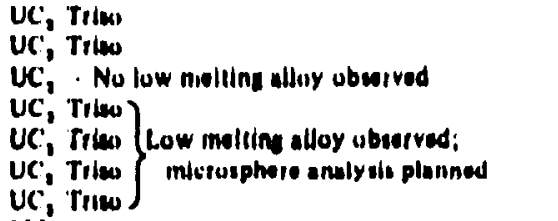 \\
\hline HRE-6 & $\begin{array}{l}\text { IC4 } \\
\text { ICs } \\
\text { IC6 }\end{array}$ & & & & & & 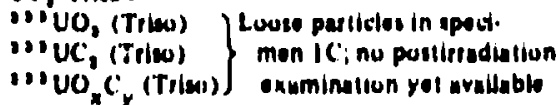 \\
\hline
\end{tabular}

Sen rootnote a of Table S.4.

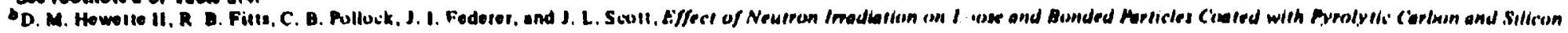
Corbide (in publication).

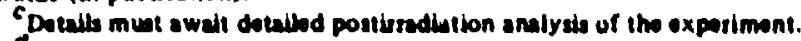

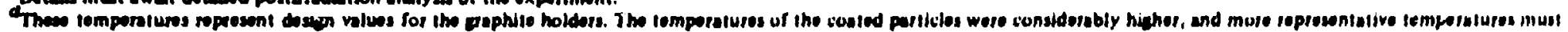
awei datailed andy the of ithe experiment.

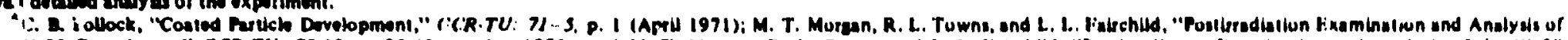

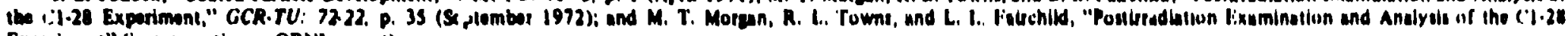
Ex firmen" (in peos rotion as ORNL ropori).

No poutiondition andyads parformed on ihts exporiment.

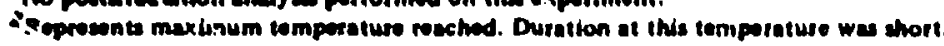


these severe thermal cunditions, the center of the rod was badly damaed aro a large amrunt of keinet migration ( 50 is 260 ur.) was ubserved. A core was formed in the center of the rod. and the zhizieni partictes were cunverted to a mixture of arbidi and eraphite shases.

Rat H-2-if also uperaled at very high temperatures during the last irradiation cycte. The aktulated sisf fure and centertine teinperatures were 1100 and $1800^{\circ} \mathrm{C}$. respertively; and the remperature aradient was abovi: three times the raximum gradient in an 1:TGR. As in rod H-1-10. the cencer of the rod was bodly i umaged ind a large amount of kernet migation 116 to $24 i \mathrm{~mm}$ । was observed.

Sample H-16. which consisied of loose partictes operated with calculated surface temperatures of 900 to $1020^{\circ} \mathrm{C}$ and centertine temperatures of $150 \mathrm{~K}$, to $1700^{\circ} \mathrm{C}$ during the test. Seveial particles in this sam le failed by the armoeba effect. and the preseme of some ccating fragments and bare kemels indicated pressure ressel failures as well. The kerr.ets in this sample sorwed moic fission-gas bubbles than the kerneis irradiated in bunded rods at comparable calculated teinperatures. indiating that the temperature akulated for the louse partikle bed may be too lox:- Rod H-2-4 was not examined metallographically. but was sent io thChemici Technology Division for reprocessing studies: loose bed H-2-b was not examined.

\section{WAR-derived fuel}

Very little quantitative information is available on the irradiction petformance of the WAR partirles. The tests in which these farjiles have been irradiated have not ytt been well analyzed. and cakialation of temperatures in WAR particles is complicated oy the shrinkage of the particle away from its coating. leaving a sizable gas gap. The kinetics of this shrinkage are not known.

Athough no amoeta migration has ever be-1, noted in WAR particles. sume disquieting behavior was noted in HRB-4. In four of the five samples examined metal. lographically. :he kernels appeared molten. possibly due to rareearth fission product attack on the silicon carbide laje?, resilting in introduction of silicon into the kemel. which forms a low-melting (about $985^{\circ} \mathrm{C}$ ) uranium-silic on alloy. This behavioi was noted only in HRB-4 (recall that HRB-4 and -5 are sister experiments. with HRB-S heing in the reactor to half the maximum HTGR nelition exposure and HRB-4 being in ihe reactor (o full fuence). Since HRB-4 operated to about 25\% FIMA in the fissile particles, whereas HRB-5 har on'y about half that burnup. there may be some thresbuld kevel of issiors produci concentration before thes behavin wairs. Molten kemels wete apparent in about 30\% of the particies vieied in the four specimens pulished. It should also be noted that tisis behavior ivas not exted in specumen IC. Since this spaimen tiza? higher thesind cundutivity matnx lan cxtrusion. whereas samples 3.1 through 30 were sluz injected) ant therefire lower temperatures. there must hare been fuei at the temperature of partiviles a: the surface of the sug-iniezied rods. where molten kerrieis were mued.

\subsection{Condsion}

From this review of ORNL irradiation data on the reference 4:I recyde partikte and the WAR artikle. it can be conctuded that alequate performanie is still to te demuns!rated for buth particles. Additionai =-:-iyses al: needed on the irradiations that have alreaty seen aci mplished, and the data from HRB-7 and 9 ineed to be studied in detail. These latter experiments $=150$ cuntain samples of the 8:1 kemel, which have never been tested at ORNL. In aitition. irradiation data from

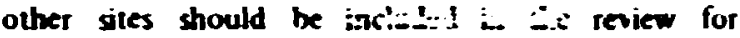
cumpleteness.

\subsection{ECONMalcs of TIMING of HTGR FUEL RECYCL.}

\section{F. J. Homan}

Preliminary wctk in this are: $w$ - uesu.ibed in the last annial report. "ince then, the work nas been expanded -..t published in the open liteiature. 910 The highlights an. resuits of the study are presented here.

This stud; was made to determire the roricink ally optimum time 'o regin teprocessung and refabricaic: of HTGR fuel as . iunction of the size of the HTGR economy. It is obvious that storing the spent fuel instead of recycling it immediately increases the amoun: of vigin is 5 i needed and also introduces the requirement for storage facilities for the spent-fuel blocks. On the other hand. to begin recycle operations immediately wculd be urieconomic vecause of the very smal size ot the re pivcessing and refabncation facilities

8. F. J. Homan. GCR Properams Annu. Prop. Rep. Dec. 31. 1972. OKNL $4911,7.71$.

3. F. J. Homan. "Timing inc Litization of Recycie Fuels in High-Temperature Cas-Cooled Reactors," Nud. Technol. 21(1), 5-15 (January 1974).

io. : : Homan. "Timing the Use of Recycle Fuel in the HiEk," Irans Amer. Niucl. Sac. 17, 314-15 (November (1,73). 
involved The study sught to timi a balance between these twil opprate effects to mminize the cust of ciectring produced by the hitC.R eivaury assumed. The mothot of cost calitation an description of tivel syite stexs" need nut be repeate. there. and tealy ubuiation : " the reaitor statup shedules for the HTGR ecisumis :-asidered was given in the last annual report." The cicnomic assumptions used in the Fral sisdy were the ome as those desiribed in the lest annuel. exiept that an inflatun rate of $5 \%$ yea wa adard. using 1278 as a base year

The results wi the study showed that $198+$ or $: 985$ was the uptimum time to begin luel reprocessing. This is shown in Fig. 5.5 . where the penaity fiei sarly or late

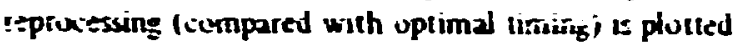
against initial reprovessing date . Vute the step incieax in penall; fur the brger HTGR econumies. Summaries of the presentworthed iuei sycke component costs and kevelized init costs for repro zsing. fabrication. and refabricaitur are given in Tables $5 . \lambda$ and 5.7 respec. tively.

On completion of a study like this. one cusid question whe iher the critical siy: of an HTGR e:onomy before reiy:le should io considered at ill. This question was resived by suciessively trunciting the 12t-rezitor conomy: the rescits for the variuus inuniated eciunomies are given in Tuific 5.8 . Niste that recycling reduces fiel iycle iusts in an economy ar smail as :wo large

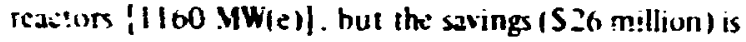
considerably less inail the levelized cust of the researich and developnent efint (.) develop reistle capabilities (about $\bar{x} \times 5$ milion ).
Amother unte:estung llem that cholved ficur. Ibe stud! wax the iniluence oi tncecased custs of separative work in ITTCR fuel iycte custs. Stike the cust of enriched uraniurs ropresents ihe miju pu:!iun si tivese susts. the projicted increases in ilse cust oi separative work sinils IStiti anticipated for privale inrkithent wil have considerable impait. The results of the study ar: summarked in Titk $5.9 \mathrm{ag}$ Fig. 5.0 . It is interesting

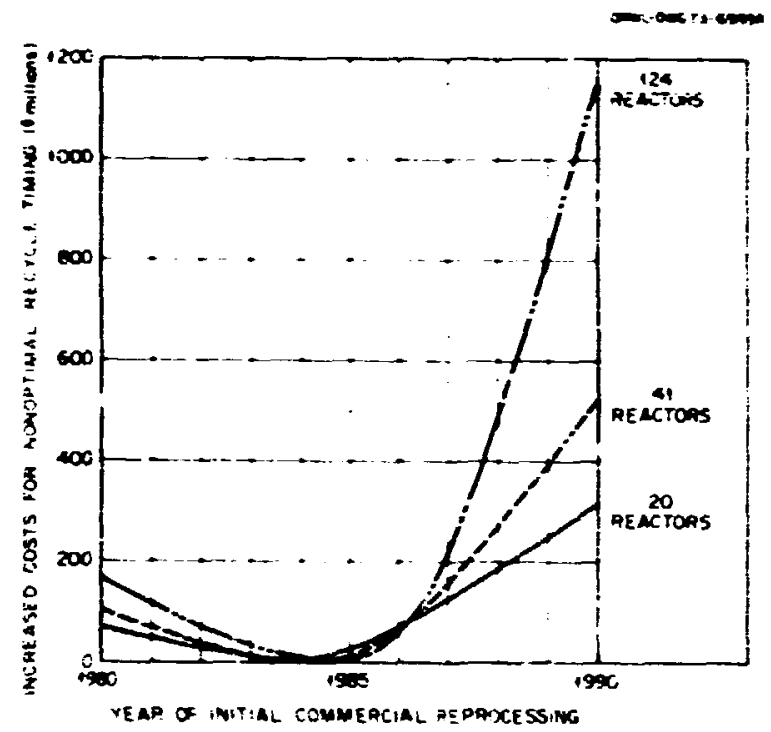

Fif 5.5. Cosi penalties for mooptimal recycte timing

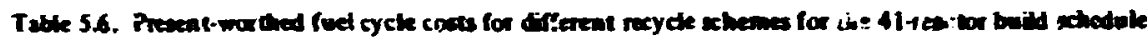

\begin{tabular}{|c|c|c|c|c|c|c|c|c|c|c|}
\hline \multirow{2}{*}{$\begin{array}{l}\text { Time for } \\
\text { initel } \\
\text { repro- } \\
\text { ressias }\end{array}$} & \multicolumn{10}{|c|}{$\cos ^{\circ}\left(5 \times 10^{\circ}\right)$} \\
\hline & $\begin{array}{l}\text { Repro } \\
\text { cesering }\end{array}$ & $\begin{array}{l}\text { Fasil- } \\
\text { aition }\end{array}$ & $\begin{array}{c}\text { Refibri- } \\
\text { eation }\end{array}$ & $\begin{array}{l}\text { Mock } \\
\text { storate }\end{array}$ & Thorium & Shippin & Uranium & Cre its & Total & $\begin{array}{l}\text { Levelized cost } \\
\text { (milla/kWhs) }\end{array}$ \\
\hline 1980 & 0.31154 & 0.33298 & 0.57993 & 0.22462 & $0.0 \div 463$ & 0.17929 & 3.5588 & 0.18568 & 5.0361 & 1.0536 \\
\hline 1981 & 0.29647 & 0.33293 & 0.56284 & 0.22553 & 0.03590 & 0.17929 & 3.5607 & 0.18528 & 5.0083 & .0473 \\
\hline 1982 & 0.23038 & 0.31281 & 0.54125 & 0.22629 & 003719 & 0. 17020 & 3.5614 & 0.18503 & 4.9735 & 1.0405 \\
\hline 1983 & 0.26902 & 0.33282 & 0.522 .28 & n.22844 & 0.03826 & 0.17 & 3.5669 & $0.1832 ;$ & 4.9536 & 1.0364 \\
\hline 1984 & 0.25413 & 0.33297 & 0.50319 & 0.23022 & 0.03936 & $0.1793 \mathrm{C}$ & 3.5780 & 0.190 .95 & 4.9362 & 1.0327 \\
\hline 1985 & 0.24017 & 0.33328 & $0.48+18$ & 0.24 n? & $0.0404 C$ & 0.17931 & 3.5962 & 0.17809 & 4.9394 & 1.0334 \\
\hline 1986 & 0.22879 & 0.33532 & 0.45011 & 0.29875 & 0.04107 & 0.17932 & 3.6335 & $0.1 \div 48$ & 5.0030 & 1.0467 \\
\hline $198 ?$ & 0.21868 & $\overline{0} .3594$ & 0.43052 & 0.36256 & 0.04304 & $0.1: 933$ & 3.6889 & 0.17109 & 5.0968 & $1.06 \times 3$ \\
\hline 1988 & 0.20815 & C. 34812 & $0411: 2$ & $0431: 0$ & 0.04296 & 0.17934 & 3.7590 & 0.16695 & 5.2132 & 1.0907 \\
\hline 1359 & 0.19048 & 0.35041 & 0.39172 & .49562 & 0.04384 & 0.17935 & 3.8414 & 0.16239 & 5.3304 & 1.1152 \\
\hline 1990 & 0.18372 & a. 35293 & $0.37 ! 49$ & 0.55825 & 0.04468 & $0.1793 ?$ & 3.9243 & 0.15951 & $5.455 !$ & 1.1413 \\
\hline
\end{tabular}

"Present worthed to Jan. 1, 1978. using a 10\% dixcrur I facirr.

BLevelized over 45 years ascuming look plant factor. 


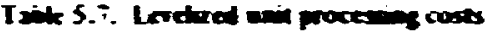

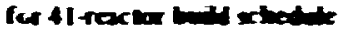

\begin{tabular}{|c|c|c|c|c|}
\hline \multirow{2}{*}{ 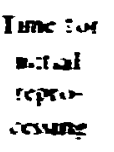 } & \multicolumn{3}{|c|}{$\left(\operatorname{msx}^{2} \times 5: 1\right.$} & \multirow{2}{*}{$\begin{array}{c}\text { iosi is biust } \\
\text { yearl } \\
\text { shete } \\
\text { sorare }\end{array}$} \\
\hline & $\begin{array}{l}\text { Repres } \\
\text { cexwens }\end{array}$ & $\begin{array}{l}\text { sabr- } \\
\text { sturn }\end{array}$ & $\begin{array}{l}\text { Refabr } \\
\text { aina }\end{array}$ & \\
\hline 1480 & 78.27 & 89.12 & $37.9 !$ & 5.9 .64 \\
\hline 1731 & 7450 & 89.07 & 30415 & $514: ?$ \\
\hline 1982 & 70.48 & 89.02 & 35219 & $: 17$ \\
\hline 1983 & $67 t 9$ & 88.43 & 30.3 & $29 i$ \\
\hline .984 & $64.0^{\circ}$ & $88.7 ?$ & 329.19 & $5 i+5 i$ \\
\hline 1985 & 60.74 & 88.50 & $319.1 \mathrm{i}$ & 493.17 \\
\hline 1986 & 58.86 & 88.21 & 309.70 & 473.46 \\
\hline 1987 & 57.38 & 89.72 & 289.65 & $\$ 56.61$ \\
\hline 1988 & 55.78 & 88.70 & 27.46 & 488.06 \\
\hline 1989 & 52.19 & 87.48 & .98 .41 & $\$ 35.78$ \\
\hline 1590 & 5152 & 86.29 & $: 79.96$ & $\$ 23.83$ \\
\hline
\end{tabular}

"Per kin "xum of bay metal.

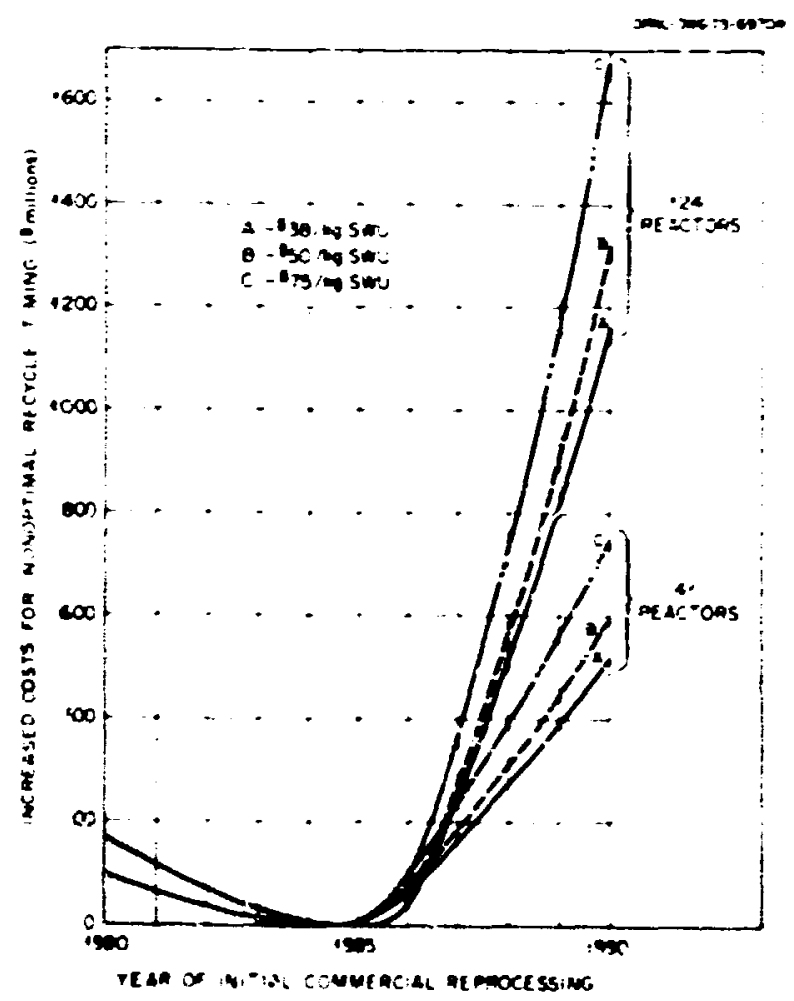

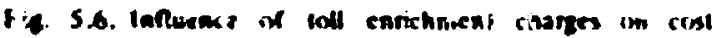
perasition. 
Table S.8. Summary of calculationu for all buifd achedule

\begin{tabular}{|c|c|c|c|c|c|c|c|c|c|c|c|c|}
\hline & \multicolumn{11}{|c|}{ Rebrefurs buill } & \multirow[b]{2}{*}{41} \\
\hline & 1 & 2 & 3 & 4 & 9 & 16 & $2 j$ & 39 & 124 & 254 & 20 & \\
\hline $\begin{array}{l}\text { Optimum year for } \\
\text { initial reprocessin }\end{array}$ & None & 1982 & 1982 & 1983 & 1961 & 1982 & 1483 & 1963 & 1985 & 19466 & 1984 & Iisa \\
\hline $\begin{array}{l}\text { Preseni-worthed fuel } \\
\text { cy cle custs, } \$ \times 10^{\prime}\end{array}$ & 0.39029 & 0.61723 & 0.79017 & 0.96882 & 1.6640 & 2.5452 & 3.7204 & 5.1255 & 12.919 & 22.5011 & 2.1630 & 4.9362 \\
\hline \multicolumn{13}{|l|}{$\begin{array}{l}\text { Individual custs for } \\
\text { optimum strategy, } 5 \times 10^{\circ}\end{array}$} \\
\hline Reproiessing & & 0.0961 & 0.112 & 0.121 & 0.182 & 0.211 & 0.236 & 0.267 & 0.357 & 0.441 & 0.145 & 0.254 \\
\hline Fabrication & 0.0805 & 0.0877 & 0.104 & 0.114 & 0.168 & 0.222 & 0.269 & $0.35 ?$ & 0.685 & 1.04 & 0.221 & 0.3 .33 \\
\hline Refabrication & & 0.150 & $0.16 ?$ & $0.17: i$ & 0.257 & 0.323 & $0.4(1) 0$ & 0.518 & 0.954 & 1.43 & 0.342 & 0.503 \\
\hline Block storage & 0.139 & 0.0558 & 0.0691 & 0.0942 & 0.100 & 0.140 & 0.199 & 0.231 & 0.467 & 0.718 & 0.152 & 0.230 \\
\hline Thorium & 0.00160 & 0.00261 & 0.00387 & 0.00519 & 0.0107 & 0.0186 & 0.0293 & 0.16417 & 0.114 & 0.196 & 0.021 & 0.1334 \\
\hline Uranium & 0.163 & 0.225 & 0.333 & 0.452 & 0.947 & 1.63 & 2.57 & 3.71 & 10.3 & 18.7 & 1.1.3 & 3.58 \\
\hline Shippiny & 0.00566 & 0.0111 & 0.0165 & 0.0219 & 0.0457 & 0.0818 & $0.12 k$ & 0.186 & 0.518 & 0.930 & $10.04 !$ & 0.179 \\
\hline Credits & & 0.0104 & 0.0156 & 0.0201 & 0.0488 & 0.0831 & 0.129 & 0.189 & 0.522 & $0.43 \mathrm{~A}$ & $0 .(14)$ & $(1 .|k|$ \\
\hline \multicolumn{13}{|l|}{$\begin{array}{l}\text { Levelized unit costs, \$ } \\
\text { Per kikugram of heavy metal }\end{array}$} \\
\hline Reprocessing & & 406 & 316 & 263 & 173 & 117 & 84 & 65 & 31 & 21 & 96 & 64 \\
\hline Fabrication & 467 & 374 & 299 & 25.3 & 169 & 130 & 107 & 92 & 63 & 35 & 115 & 84 \\
\hline Refabrication & & 1631 & 1218 & 1001 & 635 & 464 & 366 & 327 & 216 & 179 & 442 & .129 \\
\hline Per block/year. block storas & 653 & 1242 & 1071 & 911 & 801 & 639 & 526 & 478 & 357 & 3112 & 617 & $3(12$ \\
\hline \multicolumn{13}{|l|}{$\begin{array}{l}\text { Size of fust plant } \\
\text { Metric tons/year }\end{array}$} \\
\hline Reprocessins & & 19 & 28 & 39 & 76 & 136 & 225 & 331 & 1,040 & 2.132 & 168 & 344 \\
\hline Fabrication & 39 & so & 89 & 128 & 236 & 361 & 544 & 704 & 1,652 & $2,41,5$ & 267 & sjy \\
\hline Refabrication & & 9 & 13 & 17 & 37 & 65 & 105 & 158 & 492 & 997 & 81 & {$[1,3$} \\
\hline $\begin{array}{l}\text { No. of blocks, block storage } \\
\text { Costs with no seprocessing }\end{array}$ & 13.676 & $s|s|$ & 7256 & 13,108 & 10,717 & 18.789 & 35.255 & 42.389 & 126,557 & 245.4113 & $22,67:$ & 41,617 \\
\hline Present worthed, $5 \times 10^{\circ}$ & 0.39029 & 0.64356 & 0.88705 & 1.1227 & 2.1758 & 3.5081 & 5.2629 & 7.3809 & 19.046 & 33.187 & $3.85: 9$ & 7.1021 \\
\hline Levelized, mills/kWha & 2.5846 & 2.1828 & 2.0223 & $\$ .9275$ & 1.7169 & 1.6089 & 1.5376 & 1.4878 & 1.3794 & 1.3295 & 1.5812 & 1.4854 \\
\hline
\end{tabular}


(1) note that while the penalties assurizied with nonoptimal siming ir.crease drast:cally wi:it increased SWI cists. the opthmum aste fin initiai cummerial repracessing remains about the same.

Table 5.9. Variation in fod cycte rosts with separative work charges

\begin{tabular}{|c|c|c|c|c|c|c|c|c|c|}
\hline \multirow{3}{*}{$\begin{array}{l}\text { Time fur initial } \\
\text { repracssing }\end{array}$} & \multicolumn{9}{|c|}{ Levelzzed cost (millsi'k Whs) } \\
\hline & \multicolumn{3}{|c|}{20 Rexitors } & \multicolumn{3}{|c|}{41 Rasturs } & \multicolumn{3}{|c|}{124 Reactors } \\
\hline & $\begin{array}{l}\text { S38/kg } \\
\text { SWT: }\end{array}$ & $\begin{array}{l}550 / \mathrm{kg} \\
5 w i\end{array}$ & $\begin{array}{l}\text { S75/kF } \\
\text { SWLE }\end{array}$ & $\begin{array}{l}\text { s38ike } \\
\text { swi }\end{array}$ & $\begin{array}{l}\text { S50ikf } \\
\text { sul }\end{array}$ & $\begin{array}{l}575 \mathrm{~kg}= \\
5 W \mathrm{~L}^{\circ}\end{array}$ & $\begin{array}{l}\text { s38:ks } \\
\text { swt: }\end{array}$ & $\begin{array}{l}\text { s50ikg } \\
\text { sht: }\end{array}$ & $\begin{array}{l}\text { S75ike } \\
\text { sthe }\end{array}$ \\
\hline 1980 & $! .1622$ & 1.3226 & 1.6565 & 1.0536 & 1.2138 & 1.5479 & 0.94800 & 1.1081 & 1.4416 \\
\hline 1981 & 1.1537 & 1.3141 & 1.5482 & 1.0478 & 1.2081 & 1.5424 & 0.94406 & $1.104 ?$ & 1.4379 \\
\hline 1982 & $1.1+41$ & 1.3047 & 1.6393 & 1.0405 & 1.2008 & 1.5351 & 0.94081 & $1 .: 010$ & 1.4348 \\
\hline 1983 & 1.1372 & .2983 & 1.6339 & 1.0364 & 1.1969 & 1.5312 & 0.93817 & 1.0986 & 1.4327 \\
\hline 1985 & 1.1336 & 1.2954 & 1.6326 & 1.0327 & 1.1938 & 1.5291 & 0.93623 & 1.0969 & 1.4317 \\
\hline 1985 & $1.1+40$ & $\overline{1.3073}$ & $\overline{1.6475}$ & $\overline{1.0334}$ & 1.1953 & $1.5 \overline{312}$ & 0.93565 & 1.0969 & 1.4327 \\
\hline 1986 & 1.1617 & 1.3274 & 1.6725 & 1.0467 & 1.2102 & 5498 & 0.93906 & $1.10 \mathrm{i}$ & 1.4388 \\
\hline 1987 & 1.1862 & 1.3551 & 1.7070 & $1.066 ?$ & 1.2324 & 1.5772 & $\therefore 95 \div 76$ & 1.1166 & 1.4580 \\
\hline 1988 & 1.2092 & 1.3817 & $1.741 ?$ & I.09017 & 1.2599 & 1.6114 & 0.97212 & 1.1384 & 1.4850 \\
\hline 1989 & 1.2354 & $1.41 ? 3$ & 1.7796 & 1.1152 & 1.2881 & 1.6475 & 0.99475 & 1.1642 & 1.5171 \\
\hline 1990 & 1.2620 & 1.4420 & 1.8171 & $1.14 ! 2$ & 1.3179 & 1.6851 & 1.0192 & 1.1924 & $1553:$ \\
\hline
\end{tabular}

anderscores indicate minimums. 


\title{
Part II. HTGR Deveiopment 'Progran
}

\author{
6. HTGR Fuel Materials Development \\ J.Hi: inh, J. I. Xiull \\ W. P. Pulheri!
}

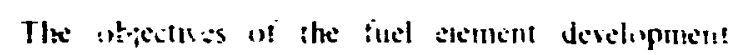

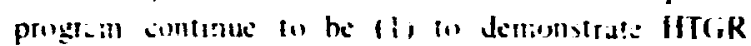
coated paricies and tiel reds lo hili hluenie arid hurnup of the redefor: 12; I, Jecelun diemative

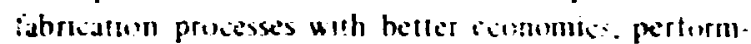
ance and recucle capability than reference malcidals. and 13 (o develor edvares fuels uith higher temper.lture apabilty than the feferance matcrals. Durng the past year the major emphases have heen placed on the first (vol).

In the area of cosied particles. the primipal effurt has been the enntmued development of the precess teithmology and chaiateriateon of kernels prodiced irem

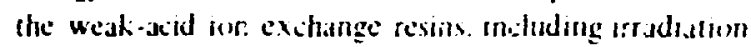
tesing. For fusl rod studies. almost the entite eftiort has been t" produce samples tor irradiallent te:-(ing. Difticulty in labricating the samples fin thermal conductivity measurements has delayed this iradiatum expert. ment considerably.

\section{I COATING, DEVELOPMENT}

\subsection{Carbon Coating Process Development}

\section{i. I. Beally}

Carton coatung process deselopment work was con. centrated in (wo problem areas ralated in deposition of derise fow-temperature isotropic (LTI) coltungs. The basic process used for depesituon of I.Tl coatings. which

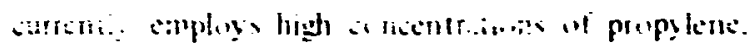

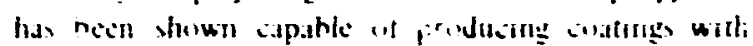

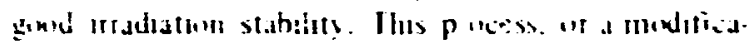

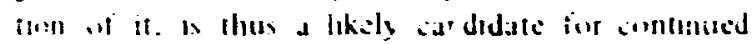

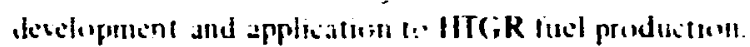

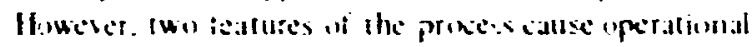

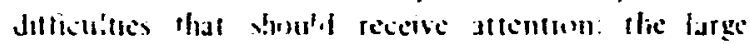

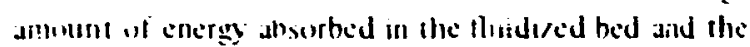

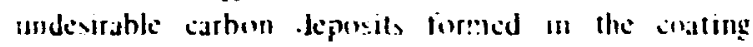
chamber.

Minimij:-s energy absorption during fluisized-bed

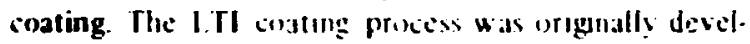
"ped unge propanc. which could be landled fairly wei!

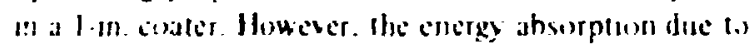
the heat idpactly and indishermic decompesstion of pinpanc reidered prixess sealeup impracicable. Sub. siltution of propylenc for propatie reduces this encrgy ahsurptum hy approxmately me-halt. and subsequ ent develipment has employed propyleste almost exclisively. However. the lieat absorbed in the bod. which is

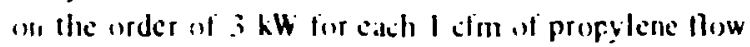

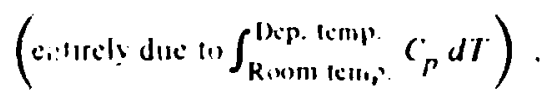

IIIay still impose a prattleable heat transfer !mitation (n) process scialcup.

From a process engunering vicwpoin. an athermal cotting process li.e.. onc which neither shsorhs nor generale, power) would be desirable. The combolling 

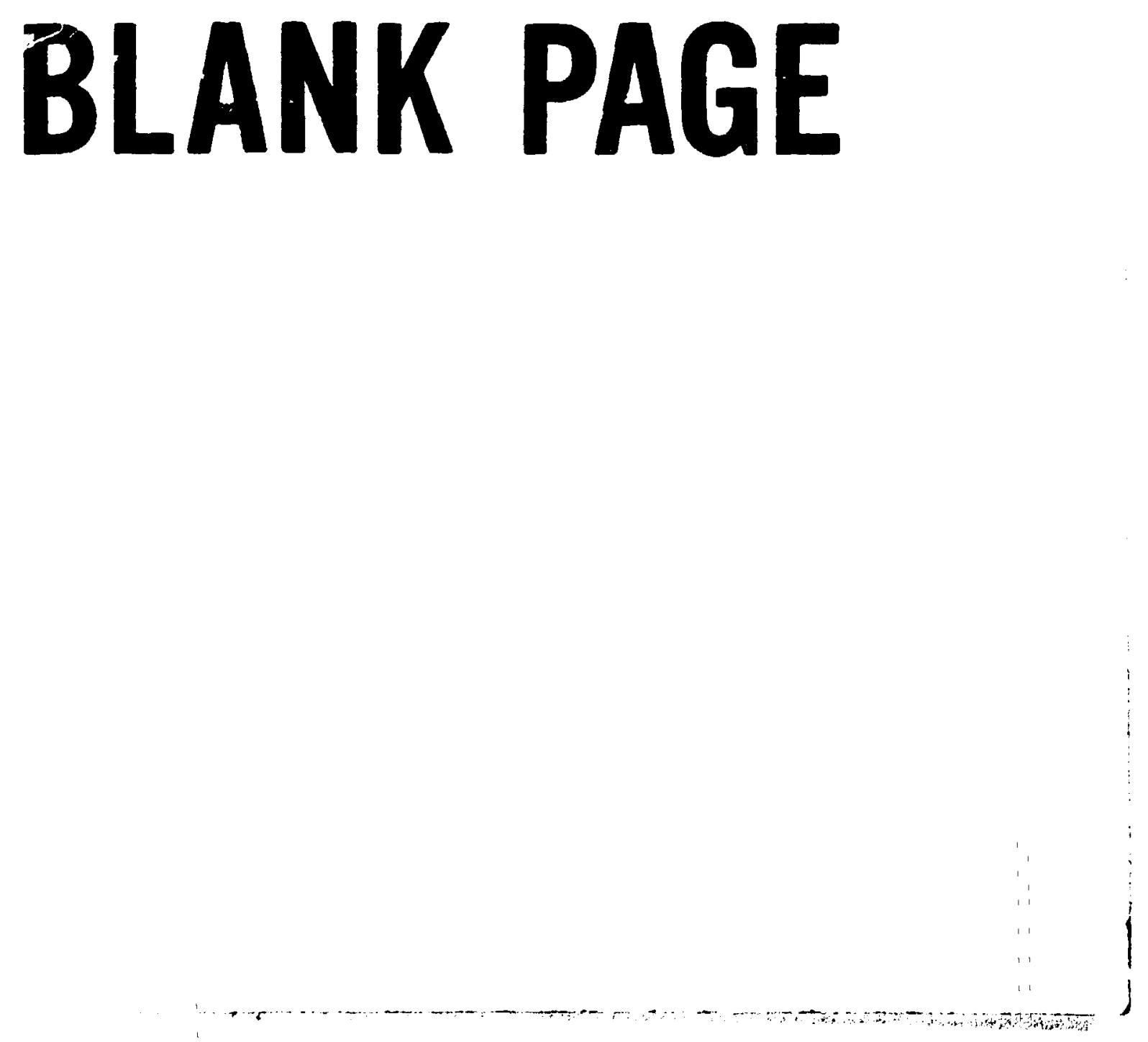
iunstersitun, of course. is thit the princss must yiekl a suitable product $O f$ the redily avilable inexpensive hydrucarbuns. only zielylenc produces an exiess of encres when heated irom near roum temperature to the coating temperatuse and decompused in the lividiced bed. Saturated hydruarbuns driompuse enduthernu sally an addition to the energi tequired fo heat them to ihe coating temperature. Piopslene decirripuses rearly sthermally but absorbs ionsikerable energy in beiris heated to ihe coatung terperatire as mentrunzd earti:ar This sugoests the prossbility of compensuting part wi the Fupstene heat absurpion by sreheatir.: It. Anwihet approsich to attaining an athe:mat ceatong process is lo btend actylene in appropridte amuunts with ineigs. absurbung hı draiarbons

Blends of aetylerie and ar. encrgy-absurbing hydrocarbun in easily be formulated tu provede an atherinal coating process. However. a cuncern is that acetykene decomposes muih mure rapidly than in! of the other inydruzarbons. and arbon frum the tho suturic gases is nci likely to be depirsited in the sanre reguon of the bed. Thus may or mal nut be detrimental to cuating trumugeneity. but products of such a process musi be examined istetully.

To setect the must appropriate hydrorarbon ít blending with acetylene and to shouse the best iuating conditions fos the mixture. It would be usctiul to ha:e data on depusition rates and civiling propertics produced by the individual specits. Since there was ral avalable information on use of xelylenc in high concentrations for depositun of h:gh-density coatings. a fiw experiments were conduclicu with acety!enc as the only carbion surice. Cualing variables axamined were deposition temperature and dilution with hydro. gen. helium. and hydrugen-helium mixtures. I: was found that high-density coatings in be depossted at reasonably high rates from acetylene. The effect of increasing deposition temperature was (1) increase rate and efficiency while reducing density in most cases. This correlates with results of LTl coating sludies with other hydrocarbons. Addition of hydrogen had an eflect similar 11 that of liswering the deposition temperalure. This is expested if addition of a reaction producl retards rate-conirolling steps in carbon fiormation. Also, as expected. the deposition rate and elfi. ciency and coating density for acety!erie diluted wilh heliri., were shified is a lower temper.ture relative (o) deposition from propylene of propane. iddifion of hy'trogen (o) acetylene seemed to adjust it', performance (1) Errespond clusel; io that of propylene dilated with inert gas. Thus. it appears that acetylene can be

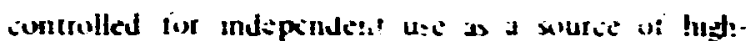
density iustings

The priman unte:est in sietylene for depusituon of dense suatings. hweicter. Is in biending it with another hyorviarton such as propslene to vitian a wukable t-ul heal batance. If hydrusen werc adied is the muxture i's ictaru decompusition of the aetylene. the propglenc deciompossitun probably ruld be sumilarly retarded In this iasc. huallugeneity if iualung reastiur:s through ithe bed moy not be improwid al all. Therefore. the wurh_bility of eiety kare-props,cne mintures mist still be imshterel yuestionible. and the mixing approsh must be evaluated by direst experi.nent with very iareiul product sharkiteriatin. This study xetves

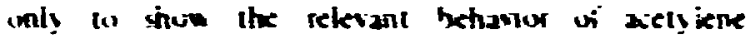
independently

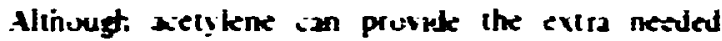
energ. It is nukh iess i.jovenient than gexes that in be handled as buik inguids under their uwn vani pressures. Other species thal priduce a nel encrg gan in a vuter in-lude alkne and methylactylene. both of which di: ver! expensive ard sumenhat unstate in purs lorrs. Huwever. these gases art be wotained in siablised furm in a reialively inexpensivi summerial produit known as MAPP as

MAPP is a trademark of Aircis. Im .. and stands for methyiactylene-propadiene (allene). MAPP gas was originally developed iy. Dow Chemical Company and is now sold by. Airco Welding Products as a substilute for detylene ir industrial cutting and weidir.p. MAPP gas is handled as a pressurized liquid in cylir ders or hulk in the same manner as propane. It is spe-ified as con. ianing. In the liquid phase. a maximum nt mole": combined methylacelyiene-propadicie and a minimum If mole " propane. butane, and iscbutane in comibina(ton). with the remainder being propylene and hutadiene. The alkanes act as stabilizers to preveni decompessition in the absence of oxygen. The net result is a coating gas that is calculated and verificd experi. mentally to produce anly about half the bed cooling effect of propylene. Experinients have shown MiPP deposits to be indistinguishable from propylenc de. posits when allowance was made in coating thamber wall temperatures to produce the same actual average hed temperatures. MAPP gas is now heing used rou. tinaly for deposition of LTl coatings in laboratory - vaters hecause at alluws helter temperature control than is possible with propylene. MAPP costings on inert and fertile particles are currenily being irradiated.

Reduction of carbon deposited on furnace parts. The sccond major problen mentioned for LTI coating deposition was that of reducing undesirable furnace 
Jepissits inat fiorni during application of earbon cuatirigs. The arbon depesits in various torms and amounts thr. standpoint of tube re.lse ur. in the worst cases. of simply completing a run. iwo dreas are paricicularly troubiesome: a :-r, nard deposit builds up near the bottom of the bed and sast aciumulates on the wall above the bed. Tu s ine evtent the hard buildup can be contrulled by gas inler sivzzle design and by its position relatise (I) the hot zone. However. the sout deposited abuse the bed aicumpanies all luw-temperature beluw abuut $1850^{\circ} \mathrm{C}$, cuating processes we have studied. In the cate of buffer cuatings. a very licht soot is deposited un all surfinas from the lup of the bed io the sout tilier In the case of dense isotrupic (LTI) coatings. a hezver sum condenses in all surfices from the top of the her cunk II the filier. These suol xioumulations screrely reatint the numbe: of .. aline runs that cail be

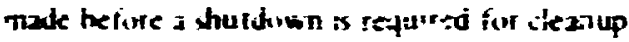

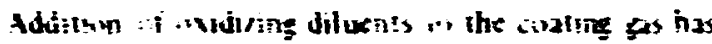

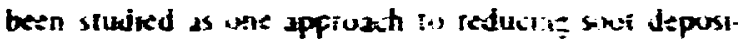

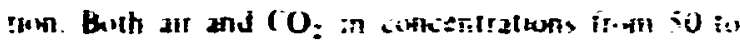

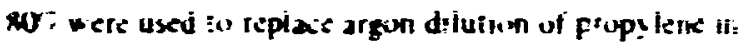
der.nstin? of LTI sulung with limited shicess. We nave fimanci no de:rimentai effots of the oxiduing speics on zalling propert!es. and there appear to be no satelv prublems with these mixicres as long as the propylene conccilatation in ait is kept well above $10^{\circ}$. approximately the explusive limit. The three diluents were compared for a depursitun temperature of $1325^{\circ} \mathrm{C}$ as follows. At sor, dilueni in propylene, there was no significant difference in argon. air. or $\mathrm{CO}_{2}$ ill depusition elficiency or in carbon deposited at an: point in the system. This $\mathrm{CO}_{2}$ resulted in slightly higher particle coating density, abutut $2.00 \mathrm{~g} / \mathrm{cm}^{3}$ compared with about $1.95 \mathrm{~g}^{\prime} \mathrm{cm}^{3}$ with ant ir argon. As the diluent concentration was increased from is to $80 \%$. argon had little effect on any of the measured parameters. Increasing air cincentration fron 50 to $80^{\circ}$ : caused a gradual efficiency decrease from 39 to 21\% a marked decrease in the amount of carbo: buildup in the cone but litile effect on soot denosits. and a decrease in coisting density from above 1.9510 about $1.82 \mathrm{~g} / \mathrm{cm}^{3}$ Increasing $\mathrm{rO}_{2}$ from 50 to 70 ? icsilted in some efficiency dectease. although not as great as with the same amount of air; little effect on con: deposit but a marked reduclion in upper tube sont accunulation: and no significant effect on density. The $\mathrm{CO}_{2}$ was not used above $70, \pi$ because the graphite coating lube was being severcly sxidized above the bed.
The lolluwing conclusions have bean d:awn from these experiments on ceposition of LTI carbon coati:igs from propylene.

Ii dilution less than $50 \% \mathrm{z}$; desired. there was little difference to the system or ihe product whether the diluent was argon. air. or $\mathrm{CO}_{2}$. The only signilicant advantage in being able to aciommodate an oxidizing diluent might be in replacing an argon supply by an air compressur.

If there is primary interest in reducing the hard carbon deposited at the bottorn of the fluidized ied. as might be the case with a porous plate system. dilution with air may be of great benefit. The optimum air conceistration in propylene for this purposc appears to lie in the range 60 to $75 \%$. The exact reduction in undesirable arbon formation ohtained by using air mither than argon would depend on system cesign. but may be more than $75 \%$

It primary interest IK- in reducing surv deposition in the cirsints thamber above the bed. $\mathrm{CO}$ : 1 ution

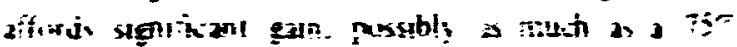

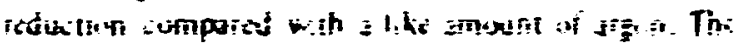

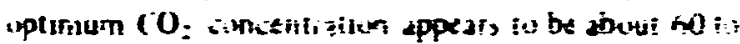
75:. tmpluying the upper part a: his range arovid requite an oxidation-resisiant tube wall such as SiC.

\subsubsection{SCC Cooting Process}

\section{J. I. Federer}

A silicon carbide (SiC) coating is applied to HTGR fissile and fertile particles to prevent or minimize migration of fission products to the outer surface of the particles durug service at reartor operating temperaiures. The SiC cuating is applied to a fluidized hed of particles as one of a series of coatings. being preceded and folluwed by pyrolytic carbon (PyC) coatings. The reactant gases used to produce $\mathrm{SiC}$ coatings are methyltrichlorosilane $\left(\mathrm{CH}_{3} \mathrm{SiCl}_{3}\right), \mathrm{H}_{2}$, and an inert gas such as argun or helium as needed for fluidization. IOther silanes could be used to prepare $\mathrm{SiC}$ coatings. but $\mathrm{CH}_{3} \mathrm{SiCl}_{3}$ has been adopted for this application.) Batches of HTGR particles are coated with SiC and PyC in similar coatings furraces using similar methods. One important way in which the $\mathbf{5} \mathrm{rC}$ coating process differs from the PyC coating process is the coating rate. Coating of $\mathrm{ZiC}$ are applied at a rate not exceeding about $0.3 \mu \mathrm{m}$, min, while $P y C$ is applied at rates of 10 $\mu \mathrm{m} / \mathrm{min}$ or mure. Silicon sarbide is applied at the lower rate for at last iw reasons: (I) a fear that inierior artings (prous $r:$ nonstoichiometric) will be obtained 


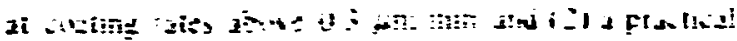

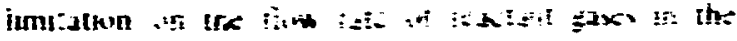

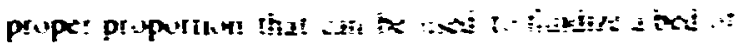

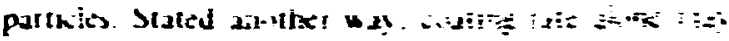

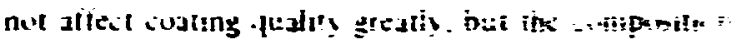
of reditanl pases uxed to sblsm high ilut

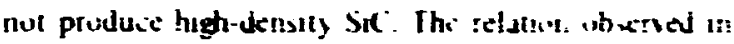
the prexint study between coxt ne chardeteristlos and the comperition of coating guxes is dexiribid as follows.

Experments werc conducted in which the cirting

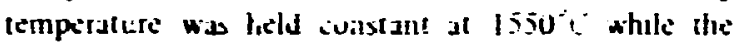
siane hux fllow rate of $\mathrm{CH}_{3} \mathrm{SiCl}$; per uait area of particles) and the volumetric hydrugen-(u-silanc ratlo were iaried. The conditions and some results of thesi experiments are shown in Table 6.1. The results shuw that $(1)$ the cuating rate increased almust in diretet propurion w the flux and 121 the density increased with increasing ?allo. I costing ratc of about $+\mu \mathrm{m}$ min wis , obisined for a tlux ef 1.1$) \mathrm{cm}^{-3} \mathrm{~min}^{-1} \mathrm{sm}^{-2}$. the hishest itxu. and the density of the conting exiecderi wh: at theoretial density, thereby ulfering prout that high iusting atte and density an be smultancously whtall ed. The heta rate and density were obtaiged with a hydrugen-silar:- ratio of $\|$ I $1 . ; \%$ silatie in the total mixturel. At the lower fluxes af 0.075 and $0.3 \mathrm{sm}^{-3}$

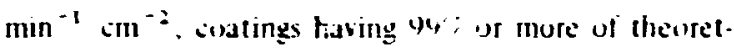
iel densily ware obtained at hydregen-silane ratios

Table 6. I. Conditions am' results of $\mathrm{SiC}$ coating experir is

\begin{tabular}{|c|c|c|c|c|}
\hline \multicolumn{3}{|c|}{ Conblitions } & \multicolumn{2}{|c|}{ (haracteristic. } \\
\hline $\mathrm{rim}^{-3}$ & $\int_{\left.\min ^{-1} \operatorname{cm}^{-2}\right)}$ & $\begin{array}{c}\mathrm{H}_{2}: \\
\mathrm{CH}_{3} \mathrm{SiCl}\end{array}$ & $\begin{array}{c}\text { Ruti } \\
(\mu \mathrm{n} / \mathrm{nm})\end{array}$ & $\begin{array}{c}\text { Denwity } \\
1 ; \text { if theoritusl) }\end{array}$ \\
\hline & 0.075 & 16 & $0.3 x$ & \\
\hline & 0.075 & 16 & 0.37 & $9: .7$ \\
\hline & 0.07 & $1 t$ & 0.13 & 98.8 \\
\hline & 0.075 & 16 & $0.3 \div$ & 49.2 \\
\hline & 0.075 & is & 0.33 & \\
\hline & 0.075 & 23 & 0.32 & 99.4 \\
\hline & 0.075 & 25 & $0 . .7$ & 94.8 \\
\hline & 0.07 & 39 & 0.41 & 99.8 \\
\hline & 0.3 & 5 & 1.39 & $\therefore 98$ \\
\hline & 0.3 & 11, & 1.54 & $\because 48$ \\
\hline & 0.3 & 14 & 1.58 & $-9 \hbar$ \\
\hline & 0.3 & 26 & 1.36 & 99.7 \\
\hline & 0.3 & 25 & 1.3 .3 & 99.7 \\
\hline & 0.5 & 6 & 2.39 & -98 \\
\hline & 0.5 & 12 & 2.38 & 98.7 \\
\hline & I.0 & 11 & 4.20 & 99.3 \\
\hline & 1.0 & 12 & S.fk & \\
\hline
\end{tabular}

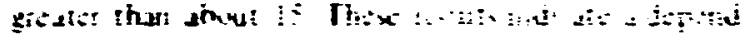

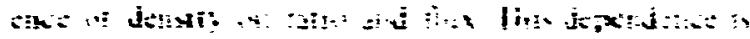

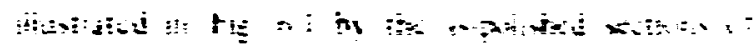
- U

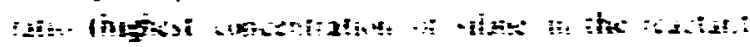

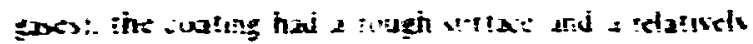
Lrgs anwist .

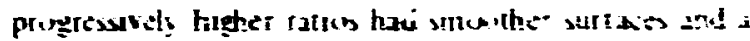
de-reasing amorint of grown-m par.sifs. Thex resuit.

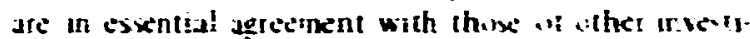
guturs. ${ }^{1.2}$

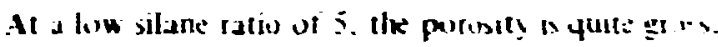
D shown in Fig. 0.I: huwevit. at higher rall.: numerous small pures lic on randomly spacd laser: parallel to the surfice of the cuatirg. Niternate denxe layers and relatively thin porous ljyers exist through the thickness of the coating. The most ohvisas reasunt for the vicurrence ef porosity is that one or more cuating sonditions change temparati.y. We suspected that liquid silane. which had conciensed in the water corled injecior of the coating tute. was ociasionally swept int " the fluidized bed. Wher :he risurred. the hydrogen-silan" ratio was temporarily luwied. which restelted in a tand of porosity in the coating. When the irijectur temperatere wa rased wapprovimately the boiling point if silane. the porosity did not ociur under the same our ittions tha: had pridused porosaty in other coatings. Th: observation amply demonstraled the necessity for a knover and constant flow rate if silane and hydrogen

The resuits that have been presented show that coating rate incresses atmust in direct pronorion (1) silane flux and that a certain minimum hydrogen-silane ratio is neceisary for preparatio: of dense rastings. These conditioris impose a restraint on coating rale. For a given surface area to be coated. a certain minimum silane flux is required to achicve the desired coating ratc: however. the hydrogen flow rate necessary to maintain a hydrogen-silane ratio that produces dence coutings may rejet narticles anl of the coating tube. This co:idition was closely approashed in the experiment in which SiC was deposited at approximately 4 $\mu \mathrm{m} / \mathrm{min}$; in fact, the ratio could not have been further increased without losing particies. Fortunately. dense coatings can be prepared at a sufficiently high rate that the $\mathrm{SiC}$ coating step does not have to be as slow relative

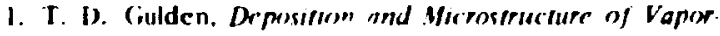
Drpositrd Siricon Carhidr i, A-8275 (Dec:. 1. i?47).

2. I. H. Vouce and D. N. Lamb. The Beperentan and

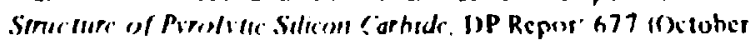
19641. 
PHOTO 3102-74

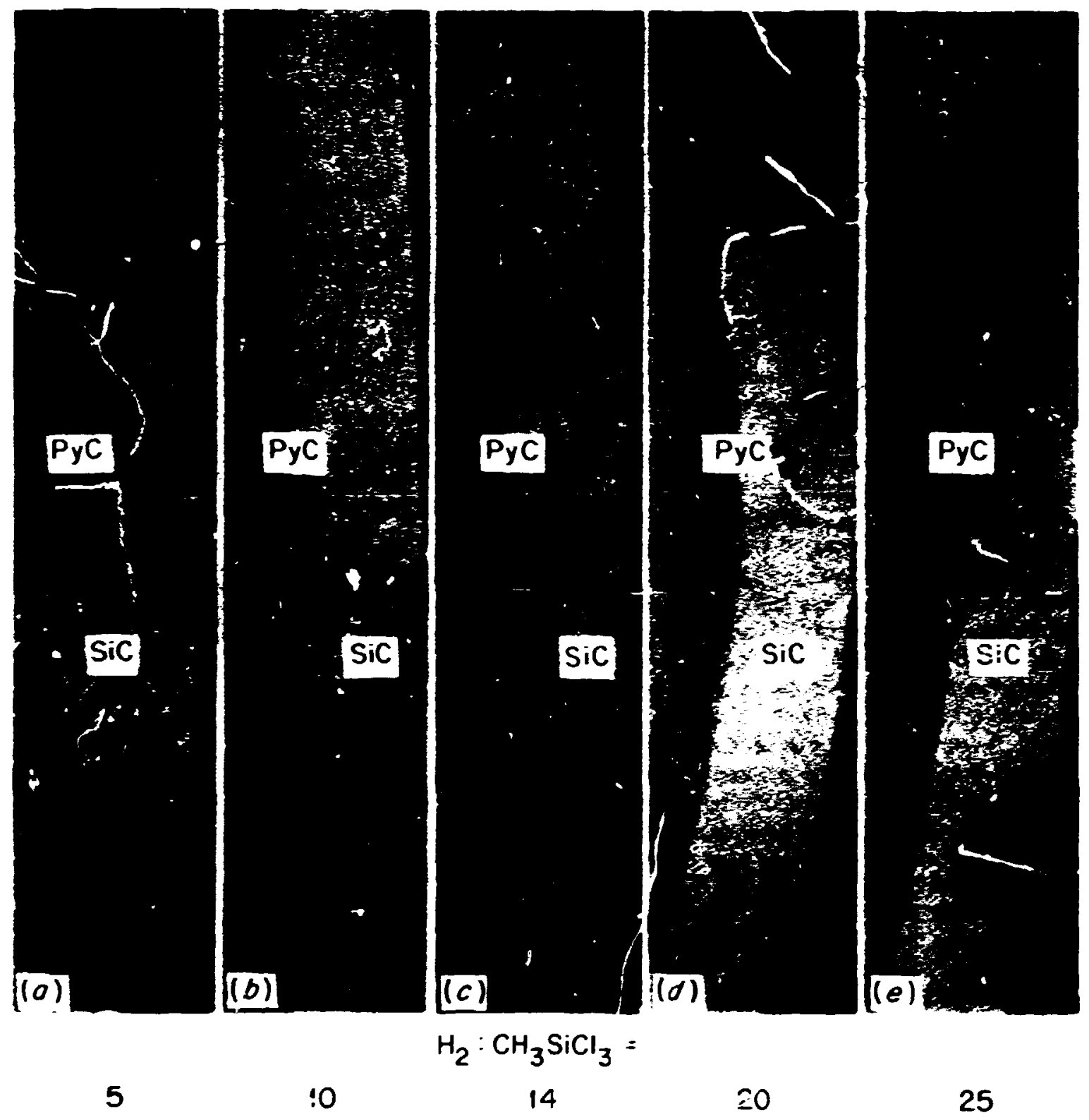

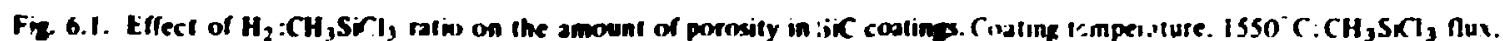
$0.3 . \mathrm{cm}^{3} \mathrm{~min}^{-1} \mathrm{~cm}^{-2}$ Ar prilished. 500 . 
to the R. iuating stcps is is currently praitled. This Ientative cidiclusiore is iontingent upon ocing ate to reproduce the above conditions in product-sile cuation iviricates

\subsubsection{Charaterimation of Coatings}

\section{R. L. Beatty E. S. Buritar}

The uptical IOPTAF) methud is izoured for munituring anixe ropy in pyrolytic arber: cuatings because 11 in be app!ied diseilly to nikiosphere coatings. while the cummunly used $x-i a$ method (BAF) reyuires !lat stip specimkns. Thus OPTAF is preferable beizuse prepa:ation of tlat specimens by cuatinz smail dishs or plates along with exh balih of micruspheres on $J$ routine basis is impraitica'. Also. the drorm: to willich the disk ioating is ecpresentative ot the microspin:custing is always a point of concern. However. the OPTAF measurements nust be slib-ated against i-ra! BAF determinations it results are to be correlated with aicumulated data and experienir.

Flat specimens stripped from disks cirated in a tluidized bed are the lugical thisice for the OPT AF.BAF calibration. Th:- lat strips ian be measured directly by buth : rhiliques and in be cumpared with correspundirg micrusphere coatings by the OPT AF measurements. Also. the appropriate rang: of anisutropies can be readily obtained from th- fluidized-bed cuatings.

A set of OPTAF-B.AF standards was prepared in cunjunction with the preparation of esated particles for irradiation experiments HT-I7 through HIT-IS 1 see Chap. 7). Sin:e the pu: ic of these lests was to compare ratings of varic. anisotropies, the coating runs involieci nrovided a convenient vehicle for tabrication of the required set of llat-plate specimens. The anisotropy specimens in this case were depusited unt: POCO graphite plates 0.310 in. $^{2} \times 0.030$ in. thick fluidized along with the particles. The cuatings were removed from the graphite substrate as 0.200 -in. ${ }^{2}$ plates and $x$ rayed. Each plate was placed in a collimated $x-r a$, beam with the plane of depissition at $13^{*}$ (the Bragg angle lor the first-order basal retlection I to tic beam. This produces a diffiractuon ring with a radial integrated interisity that is proportional at given angular positions (1) the number of irystailites with basal planes aligned paraliel to the corresponding angle in the specimen. Absorption correcitions must be inade (1) maintain the proportionality over the full 01 (1) 90 ? spail, hut absorptions at the 0 and $\mathcal{H}^{\prime}$ pussitions arc nearly identical. Thus. a BAF analytical technique developed by Tassisne $e^{3}$ an be applied t: the 0 and ()$^{\circ}$ relative intensitice "ithout sgnificant arrecti"m. This ntelhod was used for conveniente and :u jbotd uncttan sbsurption corrections. The x-ras films were xanned with an uptici nicturkersitumeter at ilk $U$ all

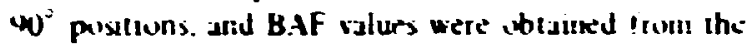
rullo of integraic $\rfloor$ intensities. Measutements int the HT-17 through HT-19 specimens showed BAF viut's angung from ! .00 io 1.73

\subsection{DONDED FUEL DEVELOMENT}

\section{R. L. Hamner J M Robbins}

The major efiort during the past year was devoted to suppoiting the irradiation testing program isee Chap 7. In solix instancej. significant process alteration was reyuired to produce the desired samples. These inclided development of seventhole fiel rods formed by intrusun bunding ior louse-particle sample hoiders. devising taihniques for producing slug-injected rods with a cential hole for thermometry and a molded-in identifistion mark. and attempting to extrude ruds to a fixed matrix density but variable fuel loading. These develupments are discussed briefly below.

\subsubsection{Introsion Bonding}

A fuel-containing bed holder to support loose coated particles was required for t.e HRB-6 experiment in HFIR to provide proper temperaturas during irradiation. The specifications called for a bonded fuel rod 2.25 in. long and 0.490 in. in diameter. with a 0.090 :n. central thermucouple hole with six 0.070 -in.-ID surrounding holes in a hexagunal array for containing the particles. The holder was to be a close-packed bed 16: vol $\vec{r})$ of coated particies with a matrix of 40 wt $\vec{k}$ Airco-Speer RC 4 graphite filler in Ashland 240 pitch. A special dic design was used that provided for seven wiouden rods around which the particles and matrix were contained. After carbusizing the specimens. the residue from the rods was removed. leaving the holes specified. Metal mandrels are preferred for forming holes in bonded rods because the use of wooden rods results in a more irregular hole; however. Icng specimens. even with one $h$ le. are difficult to remove from the mandrel beciuse the pitch shrinks slightly against it upon coroling after intrusion. The poor fuel distribution. wbserved in the holder was attributed to the fact that orly about three particle diameters separate the wonden rods used to generate the holes. thus leaving litlle space for blending the particles into the mold.

3. (i. Taswonc. (artwon 8. 3878811470$)$. 
Lerertheless. sound budies dequate li. the purpose were labricaied.

\subsubsection{Sing Iniection}

The matrix material tor the slug-injection process is nominally $28.5 \mathrm{w}$ ' $\mathrm{f}$ Asbury NF 6353 graphice in 1.: +0 pitch. It has been the praitice at ORNi to hut mix the filler $2 \cdot d$ pitch withuut benzfit of an inert imuspitere. However, the A-24", pitch is very susceptible to orygen pickup. which incteases the coke yields and. in iurn. leads to matrix-ioating inieration during arbunization, esocitally if ane in-biok. We attenipted to eliminate this variable by slurry blending the matrix in benzene at roum cemperature and ther: evapurating the ben/ene in vaisum at $90^{\circ} \mathrm{C}$. Howive: benzene is apparently difliculi th remuve iompietely from the pitih. since speimens iurmed from the raiuum-treated matrix were very interior. There was evidence of sticking io the punches. and the matm had large holes apparentiy caused by evolutson of the benzenc. All lurther develupment work has been dune with the nurmal hot-rmixed matrix.

The homugeneous blending of fuel and inert particles for fuel ruds having a iluse-packed particle bed is imetimes a problem. especially if there are three i mu:e types of particles having different densities and sizes. The methud used at ORNL by the fuel Cycte Engineering and Technology Group is to blend wih a decade splitter. which divides the charge into ten small increments before the s:e luaded into the mold. For irradiation experiments HRB-7 and HRB-8. fissile. driver. fertile. and inert particles were required. When the satio of the low-density inert particles to the remainder was about 0.5 . goud blending was obtaned by a "once-thiough" blend. However. when this ratio was increased to aboul 1.5 . the blend was grussly nonumiorm. Blending iwhe prixduced very satisfac ory res: Ilts.

In the prepatation of sluse packed bonded rods. It is desirable to keep the injection pressure as low as pussible ta present daniage he coated particles. The visiusity of the matrix. particle size. large differences in particles sures. and length all affect the pressurc required for injection. For irradiation experiments HRB-7 and HRB-X. coaled parlicles nominally $\$ 00$ and $500 \mu \mathrm{m}$ in dameier were specified for $0 . x \cdot \mathrm{in}$.long specimens. Injecilion was easily accomiplished at $\$ 00$ psi using only une size of parficle $(800 \mu \mathrm{m})$. We prepared specimens with bott. sises of particles having bolume raties. large lo small. of $50: 50$ and $75: 25$. Specimens having these hlends could not be lormed at 500 psi bit were nut difficult to torm at 300 psi ano a temperature of $175^{\circ} \mathrm{C}$. Acid kexh of particles from the green rods showed the fiaction of heavy metal leached to be 1 lo 5 $\times 10^{-2}$. well under the arcep!able limit of $1 \times 10^{-4}$

Specimens for irradiation experimeris HRB-7 and HRB-8 were also specified to have a central hole for thermucouple placement. The hule was formed by extending a metal mandrel through the punches. parinile bed. and matrix slug before heating and injecting the matrix. There was some diffrulty in removing the specimen from the mandret without disturtiur until a small resisianie heate: was designed to warm the mandre! is about $50^{\circ} \mathrm{C}$. There was consicerable difficulty in separating the top punch trom the mandre! because of the matrix that had exuded between the mandrel and the inside diameter of the purach. They could be separated only by heatiog the punch to about $160^{\circ} \mathrm{C}$ after :-moval of the specimen frum the mandrel or by soaking in a solvent for an exiended period of time. It was also cesirable to imprint an orientationidentilication mark on one en $J$ of the specimen so that dimensional measurements could be made at the same lucations belute and after irradiation. This was arcom. plished by maxhining a small ridge on the buttum punch which left an indentation on the buttom of the specimen as shewn in Fig. 6.2. Normally. the bond between the specimen and pumih would be bruken by iwsting the punch around the mandei. Howtic: to prevent damage to the specimen because of the ridge on the punch. il was necessary to desiga a device for pushing the mandrel away from the bottom punch. This proved readily possible and. as can be seen from the figure. the identifying rilark is clearly visible.

\subsubsection{Extrusions}

Our ex:rusion develupment during this period was directed toward preparing specimens (1) specified dimensions. matrix densities. and particle voluma load. ings for irradiztion testing. The nowsheet for cur pricess was presented previous!y. In the process whera laree quantities of material are extruded on a semiproduction siale. the binder. without diluent. is blended directly with the other components in an Kquart V.blender fitted with an intensifier bar rotating at a Now speed to ais in mixing without partinic breakage. It should also be nuted that a mix contaning soated particles is deliberately made wetter than desirable for unfueled grapinite extrusions so it can be extruded al

4. R. L. Hamner and $M$ Rohbuns. (FCR Programs Annu. Prop. Rrp. Dec. 3!. 1972. ORNL-49 I1. pp. 85 - 88. 


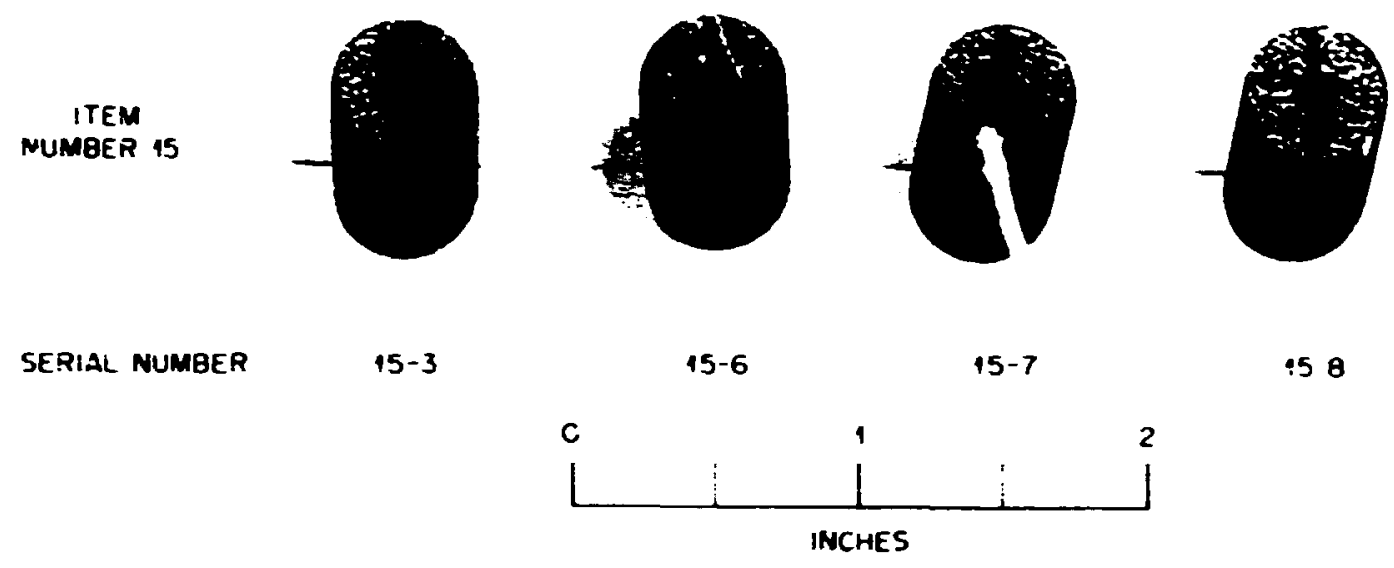

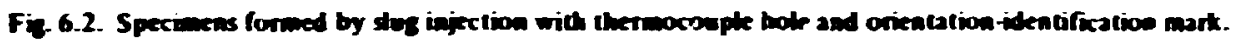

low pressures and thus reduce the chance of particle breakage. In the preparation of irradiation test $;$ r. imens. oniy smali gusntitics of cuated particles ate available. and preparation of large batches of ia:x requires a prohibitive amuunt of cuated particles. Sincic no suitable equipment is avalable for nixing smail batches with:uut partikle breakage. this opperation is performed arefully by hand using acetune as a diluent The cumponents are mixed as a slurry until the acetune is evaporated. This had led io 2 problem of reproduci bility of the cunsistency of the mixes irom oj::h to batch. with a consequent variability in matrix densities.

Graphitioed Robinsun cuke 1,200 mesh) was the filler seleice I for must of the extrusion development because it is conducive to labricating an isutropic body for guod irradiation resistance. Thermax, a spherical carbon black ti:at tends to lower the bincer requirement for extrusion. was substituted for the Robinson filler in amounts varying between 15 and 24 wi : Varcum (prepolymerized furfuryl alcohol) was used as binder for all extrusions.

One series of planned irradiation experiments (HT-20 through (IT-23) requires pseudo-fueled rods (see Chap. 7): hence the filler materials were heat treated to $2800^{\circ} \mathrm{C}$ to remove metallic impurities. thereby reducing the induced radioactivity after irradiation. Addition of this heat-treated Thermax caused the green matrix to have a consistency quile different from one in which is-recieived Thermax was used and required an additional 3 pph of binder. In addition, the extrusions were weak and if 20ur quslity. Since the as-recieived Thermax was relatively pure and produced goud extrusions. all specimens were prefiaged using this material.

Varcum was used as a binder becaliso of its low viscusity at room temnerature. Binder letels wod ranged from 2:3 to $27.5 \mathrm{pph}$ for the filler with an udditional $0.04 \mathrm{~g}$ of binder per cubic entimeter of coaied particies. For unfueled extrusions. the inini,num binder level appeared to be 23 to 24 pph: however. for very high particle volume loadings (4+; fo, HRB-6). this was increased to 27 pph to reduce $t^{t} \cdot c^{2}$ shance for particle lireakage.

For the s.ane matrix composition, higher extrusion reduction ratios generally resulied in a higher matrix densil, feg. for unfueled graphite an increas: in reducion ratio from 28 to 42 resulted in an increase in matr.x density from $1.6(1) 1.7)$.

Firf irradiation experiments ilT-20) through HT-2: we altempted further to miaintain cunstant matrix $d$ ansities for extrusions with wide variations in volume 'oadings by adjusting the reduction ratio and hoz:ing rate during carbonization as well as by utilizirs in-block and in-vacuun carbonization. Paricle volume loadings were varied between 0 and 40 vol ?r. An increase in volume loading above about 30 r resulted in a decica.ie in matrux density. especially al 40 vol $\%$. Unfueled extrusions. for example. generally resilled in nominal matrix densities of $1.7 \mathrm{~g} / \mathrm{cm}^{3}$. whereas matrix densities of extrusions with 40\% volume loading were lowe; to i.5 (1) $1 . h \mathrm{~g} / \mathrm{cm}^{3}$. The inconsistency in tive latter case is 
altributed to incionsistencies amung the difierent batithes of the same compusition beiause wi the actune uldition in blending components. This work is continuing.

Dimensional contrul was good for extrusions $1 \pm 0.002$ in. OD). provided the binder level was salisiziturily established.

Tine present aicptable levil tor exposed heavy metai due to particle breakage dunng fisbrication is $1 \times 10^{-4}$ iration of heary metal expusci per heavy metal iontined. Previousiy. we have been limited to unly une meth od of detecting bruken particles. exiept by metallugraghs, and that was in a-furmed green ruds whereby the matnx and particles wete separaied by dissulution of the matrix in pyridine folluwed by leahing the particles in $\mathrm{HNO}_{3}$ cont aining a trace of HF. There was no means of detecting broken particles atier lirial processing at $1800^{\circ} \mathrm{C}$. The Analytical Chemistry Division (D. A. Costanzo and J. L. Botts) has dune explorator; work to solve this problem with regard to extrusions from which exposed heary metal iannot be completely lexihed hy the use of $\mathrm{HNO}_{3}$ becasse of the high matrix densities. The general appruach is Io firsi find sume meats of separating the particles fro:a the fired rod, examine the patticles under a nicrusiope. and then leach with HNO, and HF. Extrusions having a matrix density of $1.7 \mathrm{~g} \mathrm{im}^{3}$ and a volume load $\mathrm{ng}$ oi 30: Bisuciuated ThO; particles were used. The first attemnt at deconsu'dation was by the use of :0; ammonium persulfate in concentrated $\mathrm{H}_{2} \mathrm{SO}_{4}$. The action of the aid was violent. and athough the rod was. deconswidated. the matrix broke down in relative large picies. most of which remained bonded to the particies or coaling fragments fiom the parictes. Alsut 20 ? of the particles had badly broken coaings. wherias sompanion samples submilled to metallugraphy shuwed no broken cuatings. This suggested that the violent action of the prucess combined with the strong bonding of the matrix caus:d the partucle breakage. Deconsolidatwon by electrolysis under cortain conditioins resulted in a fine division and clean separation of the :": ${ }^{\prime \prime}:$. This was aciemplished by deconsulidation in $1.1 / \mathrm{HNO}_{3}$ and a curient of $0.5 \mathrm{~A}$ for $+9 \mathrm{hr}$. using a platinum anodr and a graphice cathode immersed in the ele:trolyte.

A planned irradiation experiment (HT .20 througl HT-23) (1) measure the clecirical resistivity. therinal conductivity. and coefficient of theinual expansion hefort and aflet irradiation requires that the ext:usions be brazed after irsadiation (1) graphite iomponents necessary in raake the thermal conductivity measure. ments. The brating temperature must fall between the irradiation tempersture $\left(400^{\circ} \mathrm{C}\right)$ and the maxumurs temperature at which the therinal ienducionty will be measur-d 1700 is $750^{\circ} \mathrm{C}$. The luwel tempersture braze avalable. a Ax-T1-Cu allon. was satistaturs fur the juining uperstion (C. M. Slaughter and I. I Wuxhouse) but the brazing temperatute was two high $1950^{\circ} \mathrm{C}$ b. We were suciessiul in meetung the biske temperature specilication by linst supper plating the ends of the extrusions and the yraphite compunents and then bunding with is sliver-iupper alluy with a cuteith: and thu cempersture of $7 \times{ }^{\prime}, C^{\circ}$.

\subsubsection{Inradition Realts on Simulated Extrusions \\ C. R. Kennedy}

Sumples of extruded simulated iuel iods haie been irradiated in HFIR up to $2.5 \times 10^{22}$ neutrons $\mathrm{im}^{2}$ IE $>50 \mathrm{keV} / \mathrm{at}$ buth 715 and $450^{\circ} \mathrm{C}$. These samples were made a desinbed above but utaliaed a maxtre of 85 . Grest Lakes Carbon Curporation Xlocs and 15', Thermax as matrix filler. The binder was Variugn. a partially piepulymerized iurfuryl alcubol calalyzed with malei - shydride. The simulated fuel loading was 35; by wolsme The tinal heat treatment was limuted io $1800^{2} \mathrm{C}$. irsulimg in a nailux density of $\mathrm{i} .73 \mathrm{~g}=\mathrm{m}^{3}$. For ior.lparison. soinc results from an all-matrix graph. ite made by the $Y-1$ I Pisti and irradiated some years sgi" are also iricluded. This graphite conta!red no simu!: ted fuel but was iabricated firm the same raw materials. However. it was heat treated to $2800^{\circ} \mathrm{C}$ and had a tinal lensity of $1.9 \mathrm{~g} / \mathrm{cm}^{3}$.

The results o: the irradiation are shown in Figs. 6 .. I to 6.5. Figure $f .3$ compares the length and olume thanges of specimens irtadiated at 715 and $100^{\circ} \mathrm{C}$. Fig. 0.4 cumpares the fuel rod behavior (s) the all-mitrix ma: aria!. and Fig. 6.5 show's the effect of irradistion on the shear inodulus as measured sonnicaly. The cimensional :hangr data arc as expecied. with the nor: rapid volume expansion at $950^{\circ} \mathrm{C}$ rather than $715^{\circ} \mathrm{C}$. The densification is latget than for ine a'l-natrix fraphite. resulting from the inciumplece $1800^{\circ} \mathrm{C}$ heat t.camint and the lower ariginal de:isity. However. the volume expansion rates are no greaicr than thos: for the RY-1 2-29) iraterial. In fact, there is a slight suggestion that the simulated fuel articler may have noderact the expansion rate. The simulated fuel rod have at li ast the :ife expectancy of the all-matrix graphite. This is emphasized by the ahsence of a decrejse in the shear modulus shown in Fic. h.S. The niccha'ilial integrity of the irradiated fucl rinls is a: !aja! as jood as or belter 


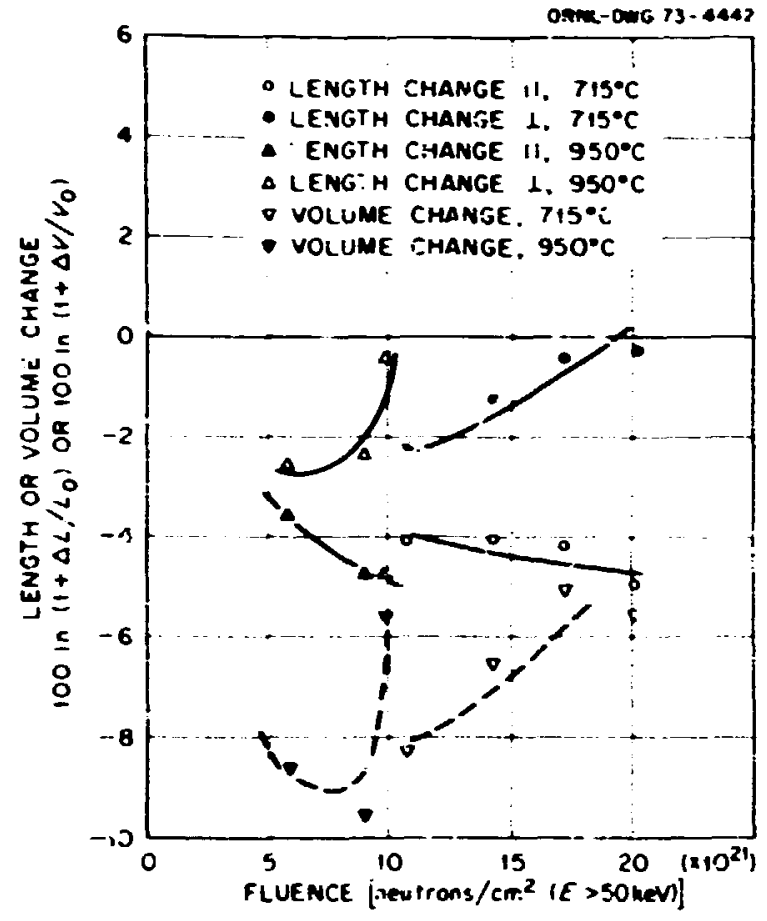

Fic 6.3. Results of irradiating simulated extruded fuet rods at 715 and $950^{\circ} \mathrm{C}$ in HFIR.

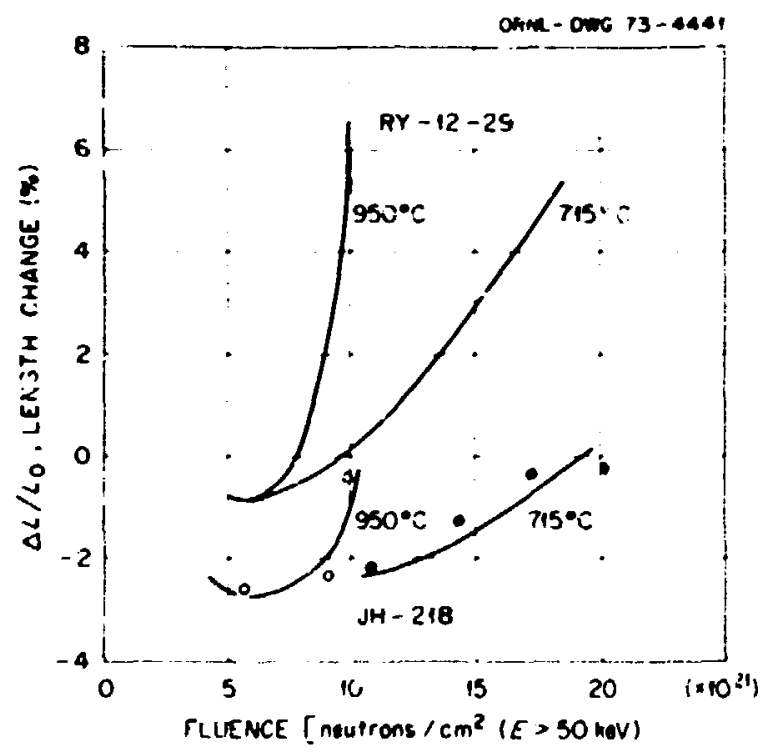

Fit. 6.t. Comparison of dimensional changes in the cross grain be navior of simulated (uel rod: (JH-218) and apphile (RY12-29).

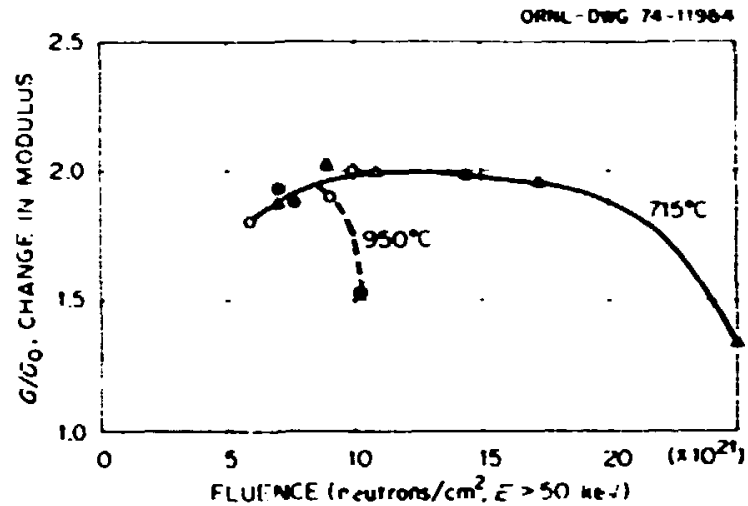

Fi. 65. Effect of in radiation on the sheri nodalus of simulated extruded for rods. Tosed symbols are all mairix rade RY1 2-29: oren simbris are simulated fuel rods.

than the unitr diated mat:rial. The drop in the shear modulus of ih all-matrix material indicates that the itfe expectancy of the fuel rods would not be much greater than $1 \times 10^{2}$ nowirons $\mathrm{cm}^{2}$ at $950^{\circ} \mathrm{C}$ or $2 \times 10^{22}$ neutrens $/ \mathrm{cm}^{2}$ at $715^{\circ} \mathrm{C}$. Fluences beyond these expusures would result in excessive diametral expansion and interaition with the muderator b'oxks. However. these fluerices are well beyond the design lifetime of the iuel rods.

\subsection{RESIN-EERIVED FUE:. PARTICLE DEVELOPMENT}

\section{B. Pollorik R. L. Heatty}

Fue! particles formed from cation exchange revins are attritive be"suse of simplicity of fabrication and relatively casier quality control in remote: fabrication operatioris. The uranium-loaded bead: are dried. carborised. partially conve:ted to carbide, and linally coated with multilayer coatings similar in : esign to coatings on other fissile paricies. The development wirk described previously win loading studies ${ }^{5}$ and on carbonization, cheracterization, and irradiation lesting ot particles derived from weal ... d resin (WAR) was continued during this reportiing perind. Goced resu!ts from irrudiation tegting of WAR fuels and rice recugnition of perfo!mance limitations on (Th-UXO, sol-gel kernels led to the adoption. carly in 1974. of the

5. K. J. Not/ and P. A. "laas, ıbıd., pp. $27 \quad 32$.

๘. C. B. Pollock and M. I. Silverman, ibid., pp. 90 95. 
Trisu-coeted WAR-derived particle as the reference fissic fuet for the HTGR Fuel Recycte Development Program. Although the decision occurred after this reporting period ended, the work on resin loading and asociated resin classification studies is reporied in Chapter : is part of work unit 2102 for the Fuel Refabricaicon Prucess Development. Othcr developmeni work in carbonization reduction or conversion, charaiterization. and cuating studies on WAR-derived particles is repurted here.

\subsubsection{Cabonization Studies}

Carbonization of uraniuriatoaded WAR microspheres has previously be:n shown to be a practicable method of proxlucing fuel particles. The luacing and carbonization were shown to be controliable and reproducible. and studies have been excended to determine limits on precesing cunditiors and effects of rarying these conditions' 1 product properties. All previous carbonization work had been carried out by programmed heating at 3 to $5^{\circ} \mathrm{C} / \mathrm{min}$ up to $600^{\circ} \mathrm{C}$. fisllowed by rapid heating to $1200^{\circ} \mathrm{C}$. This procedure resulted in a good product. but scieleratirg the fist slage would be very advantageous from the production-cost standpoint.

To uptimize the carbunization proxess. heating rate experiments were conducted to determine the maximum rate that could be employed without microsphere disintegration and to detc:mins the effects of heating rate on properties. The carbonization rate was gradually incrcased (1) about $80^{\circ} \mathrm{C} / \mathrm{min}$. approximately the .azimum heating rate of the furance being used. with the only apparent effect being increased wcight loss due to a lower resin coking yield. Microsphere integrity was re:ained even when the dried resin was puured into a fluidizing tube preheated to $600^{\circ} \mathrm{C}$. The heating rale achieved in this nianner. ahout $300^{\circ} \mathrm{C} / \mathrm{min}$, was limitec by the system heat capacities involved. Tolerance of this extreme heating rate in a material that is reduced about $40 \%$ in weight and about $70 \%$ in volume is apnarently due to an extensiva system of open porosity. True gel-type resins could not be carbonized at this rate, but Amberlite IRC.72 is produced by a method that retains a continuous network of in:erconnected porcsity. Finally, microspheres were disintegrated by pouring the:s into a furnace prehcated to $1200^{\circ} \mathrm{C}$ to establish that a :mining rate did exist. Trus from the s' ndpoint of retaining t!: integrity of uranium-loaded Amberlite IRC-72 microspheres of nominal $600 \mu_{1} n$ diameter (dried form), the miximum heating rite through the critical $\left(<600^{\circ} \mathrm{C}\right)$ carbonization range is greater than 300 but less than $1000^{\circ} \mathrm{C}$ min. However, in processing large balches the ca-bonization rate may be limited by the ability to acommodate the evolved volatiles. although product property considerations may be paramount ir any case.

Th.e heating rate through the early stages of carboni zation has a signifizant effect on the censity of the casbunized product. Increasing the carbonization rate reduces the resin coking yield. so that the product has a lower carbon content and a higher density. The carbon-to-uranium ratio in the carbonized matcrial varied from aboul 4 to 6 for heating rates of 300 and $2^{\circ} \mathrm{C} / \mathrm{min}$, respectively, while respective carbonized kernel densities were about 3.7 and $3.1 \mathrm{~g}^{\mathrm{cm}} \mathrm{cm}^{3}$. In either case the fuel form is nominally $\mathrm{UO}_{2}$ dispersed in a porous carbon ma:rix.

\subsubsection{Reduction by Fluidized-Bed Heating}

The procedures described above produce oxide fuel that may be used in that form or given further treatment to effect full or partial reduction to the dicarbide. This makes the WAR piocess unusually versatile: it is particularly attractive, since oxide. caibide. an' oxide carbide mixtures are all of interest. The oxide-carbiae mixtures are being studied because they offer the posibility of supplying oxygen to tie up lanihanide fission products while avoiding the excess oxygen produced during fissicuing in $\mathrm{UO}_{2}$ fuel. Carbo thermic reduction of the rarbonized $\mathrm{UO}_{2}$ microspheres was carried out by heating in a fluidized bed.

Treatment in a fiuidized bed ef'ects a contrulled reduction li.e., all particles get the same ireatment and the rejuction rate is cortrolled by the suecitic zas (Ar) flow rate foi any given temperatur as long as the open-port network is maintained]. The intimate mixture of $\mathrm{UO}_{2}$ and carbon. coupled with the short diffusion distances characteristic of fueled resin. results in a reduction rate being controlled by $\mathrm{CO}$ remuval rather than b; solid-state diffusion. As long as the material does not densify enough $t .2$ close oif the porusity network, a large batch (r.lorc than a few grams) may be assumed to maintain the equilibrium $P_{\mathrm{CO}}$ for a giver, temperature due to the reaction $\mathrm{UO}_{2}+$ $3 \mathrm{C} \rightarrow \mathrm{UC}+2 \mathrm{O}$. In this case the reduction rate is controlled by the specific gas now rate (argon now relative to batch size), and the reduction can be stopped at any point to produce desired oxide-carbide mixtures. Ful: reduction may be carried out at $1800^{\circ} \mathrm{C}$ in 10 to 20 min. depending on batsh size. while parial reduction is best done in the $1600101700^{\circ} \mathrm{C}$ range to allow hetter control. If. on the other hand. the matesial 
densifies sufficienty to block the sontincuus pore network before full reduction is ahieved. the reaction becumes diffusion limited and the gas flow rate control does not apply.

The abiity to control densification at high temperature is important whether the ubjective is tailoring partikle density or controlling reduction. From the standpoint of reduction conirol. two problems are en:uuntered if the maierial densifies or sinters. As desiribed above. the rate is ito longer regulated by gas flow, and the bed 1e:.uis :o ag innerate so that the batch is not triated unifoimly. Experiments have shown that sintering tenciency during reduction is strongly dependent on carbon content and hence on arbonization rate. A material in which reductica can be readily controlled ty gas flow is pioduced by very slow heating. about $2^{\circ} \mathrm{C} / \mathrm{min}$. through the early stages of carionization. Particles thus produced have a density near $3 \mathrm{~g}^{\prime} \mathrm{cm}^{3}$ and comprise a fuel phase dispersed in a nonsinterable carbon matrix. Although the above procedure resu!s in a good product, it is time consuming and may not be optimum.

In order to capitalize en the lolerance of Amberlite IRC-72 for raptd carbonization, experiments were condicied in which the loaded microspheres werc suicessively given a rapid carbunization, a buffer coating. and an $1800^{\circ} \mathrm{C}$ reduction. This technique aroided the bed agdomeration problem while allewing the $\mathrm{CO}$ to be removed rapidly through ine buifer. Further. application of the buffer immediately follow. ing carborization fixes thic volume inside the coating at the volume of the oxide particle. The buffer does not change dimensioris significantly while the fuel is being converted to carbidc. In some cases this procedure resulted in a void between the kerncl and buffer. while in others the huffer appiared to preveni sirinkage vi the kemel duing reduction. This kernel shrinkage tendency is. of course, related to carbonization rate as discussed earlier. In either case the free voiume associated with the kernel. exclusive of the bufier, is a direct function of kernel mass. This should be advantageous in pa::icic tesign where a range of kernel diamaters and suifer thicknesses must be accommodated. It has not yet bren determined whether a uniform, controlled partiai reduction can be effected in this nianner.

\subsubsection{Atmospheric Reactivity}

Carbonized fucled resin must bi handled in a protective atmosphere prior to coating. but ieativity with laberatory atmosphere varies with the stage of pro:essing. Experiments were conducted in which $1.0-g$ somples treated at 500,1200 . and $1800^{\circ} \mathrm{C}$. respicitively. were exposed to laboratory air and the weight gain was monitured as a function of time. After $96 \mathrm{hr}$. weight gains. ir the abuve order of treatment temratules. wre 7.0. 3.3. and 3. I r. indicating that highter temperature treatment resulted in increased stability. None of the specimens shuwed physical deterioration during expossure, and the 1200 and $1800^{\circ} \mathrm{C}$ specimens were retumed to approximately their origisal compositions on reheating The $500^{\circ} \mathrm{C}$ specimen. however partially disintegrated on reheating. These results apply. of course. only to small samples in which there is no significant temperature inctase on reacion. Larger batches renerate appreciabli heat and react more severely unlesi cooled.

\subsubsection{Coating of Resin-Derived Kernels}

Coaling procedures for resin-based kernels are essentially the same ar thuse for dense karrels except that gas flow rates are rediced to aciommoxdatc the lower densities. Cuating of resin particles an be done as a separatc operation. as with dense kernels. or can be combirits with the carbunization treatment discitssed above for the buffer. Experiments have shown that combining carbonization. buffer coating. reduction if desired, and dense carbon (LTI) coating in a single operation is a practicable procedure. The major drawbick to combining these steps lies in evaruation and meeting quality assurance requirements on the product. Methods are not yet available for determi:ing densities of the kernel or buffer after the cuatings have been apf!: :-. The inportant point is that severa! uptions are availa:!: for preparation of resin-based :ilel. and further development is required only for optimization.

Two batches of WAR-derived particies were coated ior irradiation testing in experiments HRB-7 and HRB-8. While coating designs have not been cpillii:cd to take full credit for the free volume incorperated i.l the resin kernels. the primary interest in thes: speci. inens is to compare their fuel migration hehaviois wi?n those of derise oxide and carbide fucls. 


\title{
7. HTĜR Fuel Irradiations and Postirradiation Examinations
}

\author{
J. A. Conlin W. P. Eatherly \\ J. H. Coots F.J. Homan
}

This 3.ugram supports boln the Thorium litilization (ThU) truiram and the Fueled Graphite Cevelopment Program. The $y$. rose of the fueled graphice irradiations is to tes! fuels mate in prod ictior scale equipment at exposures up to and exceeding HTGR design curditions of tempera use. power density burnup. and fasi-neutron exposure. The purpose of the ThU irradiations is twofold: 11 ) to provide irradiated fuel for develupment and demonstration of spent-fuel reprocessing and (2) to demonstrate the adequate performance of recycie fuel elements produced in pioduction-scale equipment. The irradiation facilities utilized for ilise tests include the Engineering Test Reactor (ETR). the Iigh-Flux Isotope Reactor (HFIR), the Oak Ridge Research Reactor (ORR), and the Pesch Bottom Reactor Aithough testing in the ETR is now complet: and the facility is no longer in use. the results of two ETR lests will bi: reported here. The ThU Irradiation.s are divided into capsule irradiations and large-siale irradiations. To date, the only large-scrie tests con. ducied have been in the Peach Bottom Reactor.

In addition in the irradiation facilities listed above which are currently in use. two new facilities are to bu used in the future. During this repurt period some planning ha: heen made for irradiations lu be conducted in the Firr St. Viain Reactor and the Dragon Reactor.

The status of all irradiations conducted to datr: under HTGR pringrams is in:laded in Tables 7.1 through 7.6.

1. B. I1. Montpomery el al.. "Irradiation Fuels in the HFIR Remnvable Beryllium Fadilities." (iCR Progams inmu Proxr. Rrp. Irec. 3I. 1972. ORNI. 49i1.p. 98.

\section{I IRRADIATION TESTS IN HFIR REMOVABLE BERYLUYM FACILITY}

\section{B. H. Montgomery J. M. Robbins}

R. L. Hamner

One type of HFIR irradiation experiment consists of insirumented and gas-swept sapsules that are opsated in tic iwo remuvable beryllium (HRB) facilities.' 'These capsules are of moderate size (I.3 in. diam) a.. I l.ave provisions for specimer: lemperature control by gas mixing and monitoring of fission gas release by analysis of gas samples. The rapsules aicommodate fuel specimens in a graphite support sleeve that is geometrically representativi: of a single fuel channel of a large HTGR fuel element. Fuel loading, temperai uire, powe: density. and bumup rate are limited cnly by the capai." ty of the fuel

Two new faclities have been added at the HFIR to complement th: existing removable beryllium (RB) facilities. One is a moderate flux irradiation facility in $a$ VXF position in the permanent beryllium (PB) reflec: tor. The second is an outwicore thermocouple calibra. tion furnace which peimits the calibration of HRB capsule thermocouples both before, during. and at the completion of the irradiation.

The ncw facility in the PB reflector permits the loading ot fully enriched fissile particles. iigher fissile particle dessities in the bonded beds (more representa. tive of HTGR fuel,). and the attainmeni of more representative burnup in the HRB capsules. The thermai neutron flux in the RB position is so high that only low fissile loading in the particles and low fissile 
Table 7.1. Dexcription and stalus of HRB irradiation experiments

\begin{tabular}{|c|c|c|c|c|c|c|c|c|}
\hline \multirow{2}{*}{ Lisperiment } & \multirow{2}{*}{ Spicimon description } & \multirow{2}{*}{$\begin{array}{l}\text { Maximum } \\
\text { fust nuencic, } \\
f:-10.18 \mathrm{MeV} \\
\text { (ncultuns } / \mathrm{cm}^{2} \text { ) }\end{array}$} & \multirow{2}{*}{$\begin{array}{l}\text { Maximuin } \\
\text { particlis } \\
\text { momperature } \\
10(0)\end{array}$} & \multicolumn{2}{|c|}{$\begin{array}{c}\text { Maximum burnup } \\
\text { (\%IIMA) }\end{array}$} & \multicolumn{2}{|c|}{$\begin{array}{c}\begin{array}{c}\text { Irrivdialion } \\
\text { schledule }\end{array} \\
\end{array}$} & \multirow{2}{*}{ Referente } \\
\hline & & & & $\begin{array}{l}\text { fissile } \\
\text { particlut }\end{array}$ & $\begin{array}{l}\text { fertile } \\
\text { particle }\end{array}$ & Stanl & lind & \\
\hline \multicolumn{9}{|c|}{$\times 10^{21}$} \\
\hline HRH.I & 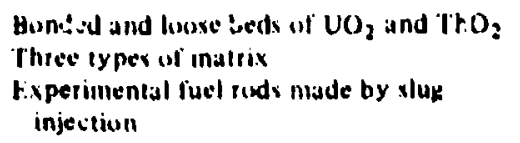 & 5.8 & $\sim 1 \$ 100$ & 22 & 7.7 & $N / 69$ & $2 / 70$ & ORNI. $[M \cdot .3640)$ \\
\hline HRB.? & 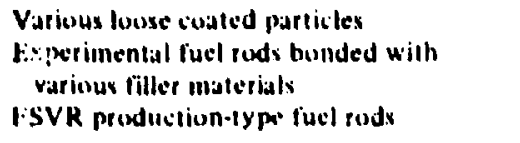 & 10 & 1200 & 311 & 15 & $12 / 70$ & $11 / 7 \mid$ & ORNI.T.4.39B8 \\
\hline HRB-3 & 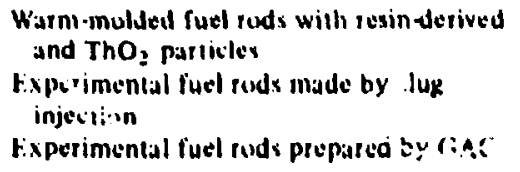 & 4 & $-16(1) 0$ & 28 & 15 & $1 / 72$ & $10 / 72$ & (JRNL.TM-T526 \\
\hline HREA & $\begin{array}{l}\text { Continuous-matrix fuel sods made by } \\
\text { extrusion } \\
\text { fxperinental tuel ruds made by slug } \\
\text { injection } \\
\text { lixperimental fuel rods prepared by (iAC }\end{array}$ & 10 & 12511 & 30 & 15 & $10 / 72$ & $6 / 73$ & \\
\hline HRB.S & Sume ax HRB 4 & s & 1250 & 16 & 4.8 & $10 / 72$ & $2 / 73$ & \\
\hline HRB 6 & $\begin{array}{l}\text { Experimental fuel rods made jy extrusion } \\
\text { tixperinental fuel rods prepared by (iAC } \\
\text { Experimental fuel rids made by slue } \\
\text { injection } \\
\text { Loose coated sol-zel and resinderived } \\
\text { particles }\end{array}$ & 8 & 1250 & 2.3 .4 & 9.7 & $2 / 73$ & $9 / 73$ & \\
\hline HRB.7 & 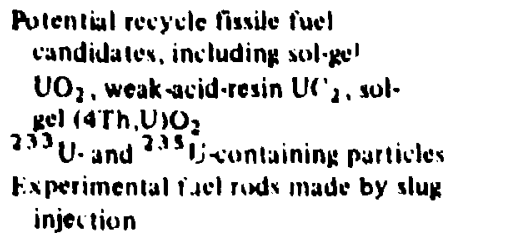 & & -1500 & & & $12 / 73$ & & \\
\hline HRB- & Sumbe as HRE 7 & & $\sim 12 \times 0$ & & & $2 / 7+4$ & & \\
\hline
\end{tabular}

"Siheduled. 


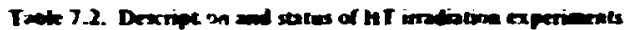

\begin{tabular}{|c|c|c|c|c|c|c|c|c|}
\hline \multirow{2}{*}{ F Netumeni } & \multirow{2}{*}{ Sor unen desxiptiun } & \multirow{2}{*}{ 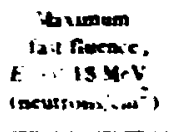 } & \multirow{2}{*}{$\begin{array}{l}\text { Mormum } \\
\text { partutie } \\
\text { comperature } \\
\text { ic) }\end{array}$} & \multicolumn{2}{|c|}{$\begin{array}{c}\text { Moxumim burnup } \\
\text { I: IIMAI } \\
\end{array}$} & \multicolumn{2}{|c|}{$\begin{array}{c}\text { Irradoemin } \\
\text { whedule } \\
\end{array}$} & \multirow{2}{*}{ Refereme: } \\
\hline & & & & $\begin{array}{l}\text { Finule } \\
\text { portinike }\end{array}$ & $\begin{array}{l}\text { Frtik } \\
\text { partike }\end{array}$ & Start & Ind & \\
\hline & $\cdots-$ & $\times 10^{21}$ & & & & & & \\
\hline IIT-I & $\begin{array}{l}\text { Lwine } \mathrm{mo} \text { : partaiks } \\
\text { nec sirups } \\
\text { andod beds of } \mathrm{ZO}_{2} \text { partutes }\end{array}$ & $b$ & $11+\infty$ & & 5 & $2: 63$ & $4: 6$ & 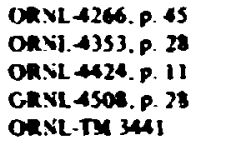 \\
\hline HT-2 & 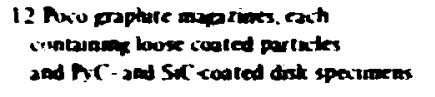 & 。 & $\begin{array}{l}\min \\
\operatorname{lin}\end{array}$ & 16 & 8.3 & 569 & $9: 69$ & OANL 4508. P. 16 \\
\hline HT-3 & 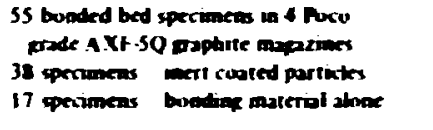 & 8 & $\begin{array}{r}73 n \\
105 n\end{array}$ & & & 968 & 1260 & $\begin{array}{l}\text { OnNL-4353.p. } 47 \\
\text { OxNL 4424.p. } 25\end{array}$ \\
\hline $\mathrm{HT}+$ & $\begin{array}{l}20 \text { bonked bed specimores. } \\
\text { topert lernets ondy }\end{array}$ & 7.5 & $\ln (x)$ & & & 8.69 & 1069 & $\begin{array}{l}\text { CONF-700401.p. } 456 \\
\text { OxNL-4504. p. } 3 \\
\text { OxNL 4589. p. } 20\end{array}$ \\
\hline HT.5 & $\begin{array}{l}\text { Lwose particks. Than, and furied resas } \\
\text { Dopaded comports }\end{array}$ & 15 & $\begin{array}{r}100 \\
900 \\
1920\end{array}$ & 9 & $\mathbf{s}$ & 1269 & $2: 70$ & ORNL 4589. p. 22 \\
\hline HT 6 & 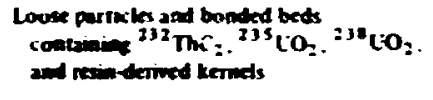 & & $\begin{array}{r}800 \\
1070\end{array}$ & 18.5 & 5.2 & $8 / 70$ & $10: 70$ & $\begin{array}{l}\text { ORNL } 1637 . \\
\text { DP. } 10.12 \\
\text { ORNL } 4760 . \text { P. } 134\end{array}$ \\
\hline HT-7 & $\begin{array}{l}\text { Various bose rooted partivits weth } \\
\text { magi ketpets }\end{array}$ & 9.6 & 1050 & & & 1270 & 371 & ORNL-TM455I \\
\hline HT: & 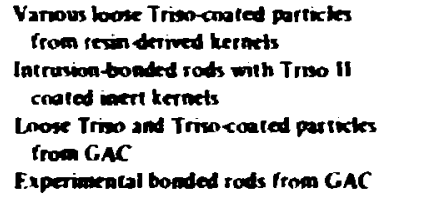 & 9.6 & $1.05 n$ & 19.4 & 9.7 & 5:7I & 271 & ORNL-TM455) \\
\hline HT-9 & 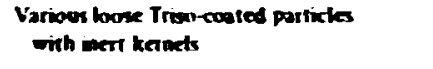 & 5 & 1050 & & & $3 / 71$ & $5 / 71$ & ORNL-T MASSI \\
\hline HT-10 & 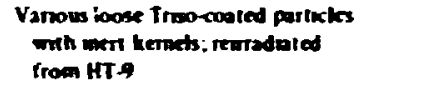 & 14 & $\cos n$ & & & $8 / 7 !$ & 12121 & 2RNL-TM-4SS1 \\
\hline HT-1I & Text canceled & & & & & & & \\
\hline $\left.\begin{array}{r}\boldsymbol{H T}-12 \\
-13 \\
-14 \\
-15\end{array}\right\}$ & 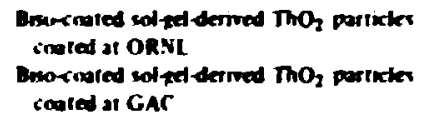 & $\begin{array}{r}4 \\
9 \\
13 \\
16\end{array}$ & $\begin{array}{r}1250 \\
-1550 \\
-1550 \\
-1550\end{array}$ & & $\begin{array}{l}2.9 \\
9.7 \\
12.3 \\
21\end{array}$ & $\begin{array}{r}9: 72 \\
10: 72 \\
1172 \\
1172\end{array}$ & $\begin{array}{l}10 / 72 \\
173 \\
473 \\
5 / 73\end{array}$ & \\
\hline HT.16 & 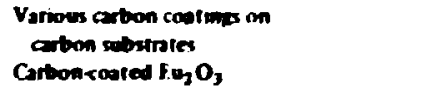 & 14 & 715 & & & $2 / 73$ & $7 / 73$ & \\
\hline $\left.\begin{array}{r}H T-17 \\
-18 \\
-19\end{array}\right\}$ & 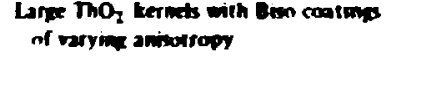 & $\begin{array}{r}147 \\
9.5 \\
14\end{array}$ & $\begin{array}{l}900.1250 \\
900.1240 \\
900.1250\end{array}$ & & $\begin{array}{r}2.9 \\
9.7 \\
17.2\end{array}$ & $\begin{array}{l}7 / 73 \\
7 / 73 \\
7 / 73\end{array}$ & $\begin{array}{r}9 / 73 \\
10: 73 \\
12: 73\end{array}$ & \\
\hline $\left.\begin{array}{r}\boldsymbol{H T} \cdot 20^{\circ} \\
-21 \\
-22 \\
-23\end{array}\right\}$ & 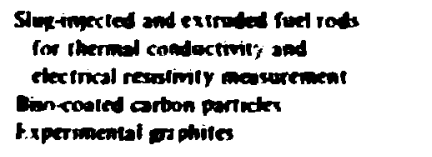 & & $\begin{array}{l}900 \\
900 \\
900 \\
900\end{array}$ & & & & & \\
\hline
\end{tabular}

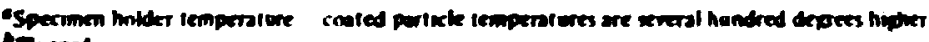

Cronmer. 


\begin{tabular}{|c|c|c|c|c|c|c|c|c|}
\hline \multirow{3}{*}{ Experiment } & \multirow{3}{*}{ Specimen description } & \multirow{3}{*}{ 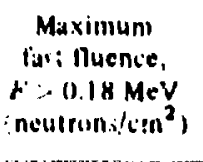 } & \multirow{3}{*}{$\begin{array}{c}\text { Maximum } \\
\text { particle } \\
\text { (emperalure } \\
\text { PC) }\end{array}$} & \multicolumn{2}{|c|}{$\begin{array}{l}\text { Maximum burnup } \\
\text { (1\% IIIMA) }\end{array}$} & \multirow{2}{*}{\multicolumn{2}{|c|}{$\begin{array}{l}\text { Irradiution } \\
\text { s'hedule }\end{array}$}} & \multirow{3}{*}{ Ruterencis } \\
\hline & & & & Fissilos & liortile & & & \\
\hline & & & & particlo & Particle & Slart & Find & \\
\hline \multicolumn{9}{|c|}{$\times 10^{21}$} \\
\hline A9.74 & $\begin{array}{l}\text { Th. UXC2 parlicles. } 3: 1 \text { ratio. } \\
\text { Triso cosating }\end{array}$ & $<0.1$ & 1300 & 2.0 & & \multicolumn{2}{|c|}{ I cycle ORK } & $\begin{array}{l}\text { ORNI. } 4133 \\
\text { p. } 33 \\
\text { ORNL } 41136 \\
\text { p. } 97\end{array}$ \\
\hline A9.8 & Bisoricated sultwi UO particles & $<0.1$ & $14(10)$ & 9.5 & & \multicolumn{2}{|c|}{2 ixcles ORR } & $\begin{array}{l}\text { ORNI.4133. } \\
\text { P. } 36\end{array}$ \\
\hline A9.9 & $\begin{array}{l}\mathrm{UC}_{2} \text { and } \mathrm{UC}_{2} \text { with Bisu and Triso } \\
\text { coatings }\end{array}$ & 0.1 & 1000 & 4.9 & & \multicolumn{2}{|c|}{ I IYcle ORK } & $\begin{array}{l}\text { ORNI. } 4133 \text {, } \\
\text { p. } 37 . \\
\text { ORNI. } 4200 \text {, } \\
\text { p. } 48\end{array}$ \\
\hline A9.10 & $\begin{array}{l}\text { UC with dense I worlayet } \\
\text { cosating }\end{array}$ & .01 & 10001500 & 8.9 & & \multicolumn{2}{|c|}{ I Iycle ORK } & $\begin{array}{l}\text { ORNI.4200, } \\
\text { p. } 48\end{array}$ \\
\hline A9.11 & Bisuriosted UC: & 0.1 & 10001500 & 12.4 & & \multicolumn{2}{|c|}{ I ircle ORR } & $\begin{array}{l}\text { ORNI. } 4200 . \\
\text { P. } 48\end{array}$ \\
\hline A9.12 & Hiscrioaled UO2 & $<0.1$ & $1550 \cdot 1650$ & 5.1 & & \multicolumn{2}{|c|}{ I iycli ORR } & $\begin{array}{l}\text { ORNI. } 4200 \text {, } \\
\text { p. } 51\end{array}$ \\
\hline A9.13 & Sol-kel UO, porous carbon couting only & 0.1 & 700.910 & 1.2 & & \multicolumn{2}{|c|}{ I Iycle ORR } & $\begin{array}{l}\text { ORNI. } 4200, \\
\text { P. } 54\end{array}$ \\
\hline AY.14 & (Th, U)O, particles, 3:1 ratio, Hiso coulted & 0.1 & 1250 & 1.4 & & \multicolumn{2}{|c|}{ I cycle ORR } & $\begin{array}{l}\text { ORNI. } 4266 \text {, } \\
\text { p. } 7\end{array}$ \\
\hline A9.15 & Bisorcosted UO pa ticles in bunded rud & $\therefore 0.1$ & 1250 & 35.5 & & $12 / 67$ & $7 / 6 k$ & $\begin{array}{l}\text { ORNI. TM.336I } \\
\text { ORNI. } 4266 \text {. } \\
\text { p.9 } \\
\text { ORNI.4353. } \\
\text { r. } 3\end{array}$ \\
\hline 89.29 & A'sorivaled UO & $\begin{array}{l}4 \text { duys } \\
\text { in reactor }\end{array}$ & 15001 & & & \multicolumn{2}{|c|}{ : cycle ORK } & $\begin{array}{l}\text { ORNI. } 4(1) 36 . \\
\text { P. } 99\end{array}$ \\
\hline 89.30 & UO 2 with PyC coating & $\begin{array}{l}159 \mathrm{lir} \\
\text { in reactor }\end{array}$ & 1400 & 1.8 & & \multirow{2}{*}{\multicolumn{2}{|c|}{ I sycle ORR }} & $\begin{array}{l}\text { ORNI. } 40.36 . \\
\text { P. } 102\end{array}$ \\
\hline B9.31 & $\begin{array}{l}\text { S...tei UO With dense I wollayel } \\
\text { "costing }\end{array}$ & .0 .1 & 14110 & 23.4 & & & & $\begin{array}{l}\text { OKNI. } 41136 . \\
\text { P. I1) } 3 . \\
\text { OKNI.41.13. } \\
1 . .17\end{array}$ \\
\hline
\end{tabular}


Tahle 7.3 (cuntinued)

\begin{tabular}{|c|c|c|c|c|c|c|c|}
\hline \multirow{2}{*}{ F ypriment } & \multirow{2}{*}{ Specimen dewrription } & \multirow{2}{*}{ 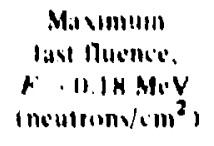 } & \multirow{2}{*}{ 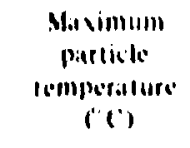 } & \multicolumn{2}{|c|}{ 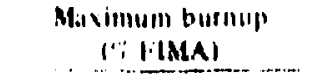 } & $\begin{array}{l}\text { Irridiatiun } \\
\text { vihedule }\end{array}$ & \multirow{2}{*}{ Retstencs } \\
\hline & & & & 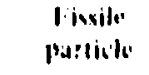 & 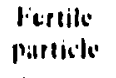 & Starl Ino & \\
\hline H9. $\$ 2$ & 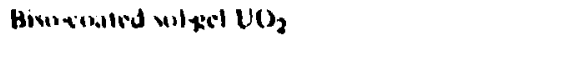 & $\sim 11.1$ & $14(130$ & 26.1 & & 4 syclex ORR & $\begin{array}{l}\text { ORNL } 413,3 \text {. } \\
\text { 1. } 42\end{array}$ \\
\hline B4.334 & Hivntibaled wallect $1 / \mathrm{O}_{2}$ & $\cdot 0.1$ & 1290 & 6 & & I'YSIE ORK & $\begin{array}{l}\text { (ORNI } 41.3 .3 \\
\text { n. } 37\end{array}$ \\
\hline H9.3.44 & 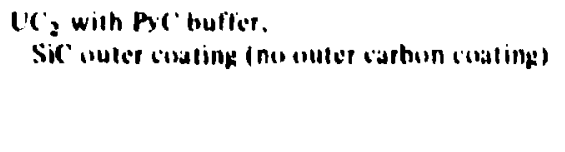 & .1 .1 & 1250 & 7.1 & & I IYCLOCRR & 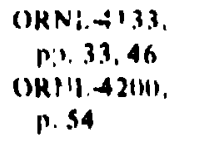 \\
\hline $189.95^{4}$ & Trisu I cosaling on wolpow $\mathrm{UO}_{3}$ & $\cdot .11 .1$ & 12511 & +.6 & & ICYCIOOKR & $\begin{array}{l}\text { ()RNI } 42110 \text {, } \\
\text { I. } 54\end{array}$ \\
\hline $89 \therefore 6$ & Uncisated t'('2 $2(16)$ particles) & $\cdot 0.1$ & $7(11) \cdot 1200$ & 5 & & I WCleORK & $\begin{array}{l}\text { ()RNI. } 42011 \\
\text { p. } 54\end{array}$ \\
\hline H9.37 & 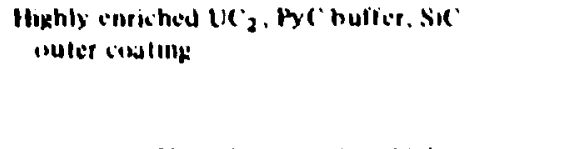 & .0 .1 & 1700 & 4.1 & & I YCHOCRK & $\begin{array}{l}\text { ORNI \&2(K), } \\
\text { N. } 54 \\
\text { ORNI. } 4266 \text {. } \\
\text { N. } 9\end{array}$ \\
\hline H9.38 & Hiwestbaled $U O_{2}$ three cosaling thicknew & $\because 0.1$ & 1400 & 7.8 & & ISYClO ORK & $\begin{array}{l}\text { (IKNI.4266, } \\
\text { n. II }\end{array}$ \\
\hline (69.194 & Hod wilh l.Il Hisw costing & 0.1 & $9(1)$ & 1.3 .2 & & I YYMU ONR & $\begin{array}{l}\text { ORNI.4200, } \\
\text { P.S6. } \\
\text { ORNI. } 435 . \\
\text { pN. } 4 \text { \% }\end{array}$ \\
\hline B9.41 & UC, with Trisu I cossting, in honded red & $\cdot 0.1$ & $1.1511 \quad 1761$ & 18 & & 3 cycles ()RK & 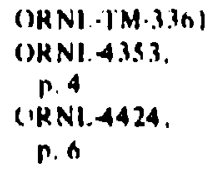 \\
\hline 19941 & 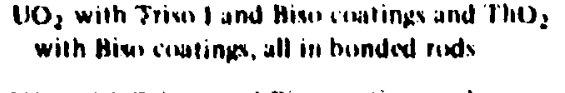 & .01 .1 & 6711 & 22 & $\cdot 10$ & & $\begin{array}{l}\text { (ORNI.4424, } \\
\text { TP. } 611\end{array}$ \\
\hline 18942 & 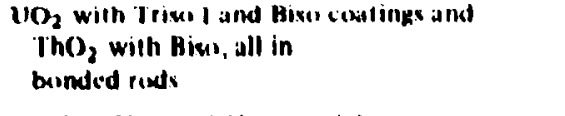 & $\cdot 0 . \mathrm{i}$ & 6.10 & 11 & $\cdot 10$ & 2 CYClex OIRK & $\begin{array}{l}\text { OHNI 4424, } \\
\text { MI. } 6.11\end{array}$ \\
\hline B943 & Cracked $\mathrm{UC}_{2}$ and $\mathrm{UO}_{3}$ parlicisis & .0 .1 & $\begin{array}{l}200) \quad 1400 \text { in } \\
\text { slers of } 2000\end{array}$ & 3.5 & & I Cycle OKK & $\begin{array}{l}\text { (1KNI } 45118, \\
\text { PI } 1216\end{array}$ \\
\hline
\end{tabular}


Table 7.3 (eoninued)

\begin{tabular}{|c|c|c|c|c|c|c|c|c|c|}
\hline \multirow{2}{*}{ Fymerimemt } & \multirow{2}{*}{ Specimen devcriptieun } & \multirow{2}{*}{ 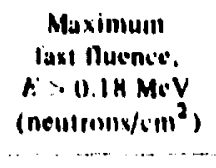 } & \multirow{2}{*}{\multicolumn{2}{|c|}{ 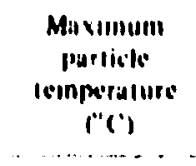 }} & \multicolumn{2}{|c|}{$\begin{array}{c}\text { Muximum burnup } \\
\text { (G) I:IMA) }\end{array}$} & \multicolumn{2}{|c|}{$\begin{array}{l}\text { Eradiation } \\
\text { schedulese }\end{array}$} & \multirow{2}{*}{ Referincer } \\
\hline & & & & & $\begin{array}{l}\text { livarile } \\
\text { Parlicke }\end{array}$ & $\begin{array}{l}\text { liorille } \\
\text { purticle }\end{array}$ & Stort & lind & \\
\hline 10.1 & $\begin{array}{l}\text { Two halchex of munuluyer } \\
\mathrm{HO}_{2} \text { and } \mathrm{tK}_{2}\end{array}$ & 0.114 & $11(k)$ & $14(N)$ & 44 & & $7 / 65$ & $7 / 66$ & 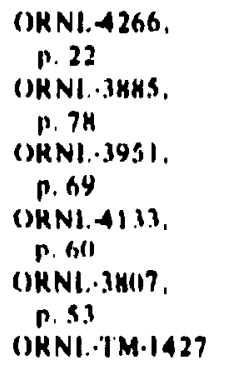 \\
\hline 19.2 & $\begin{array}{l}\text { Lexin parlickes. Sir } \\
\text { sodilings on } 2 \text { baliches }\end{array}$ & 0.02 & 12511 & $1.3(x)$ & $25.4 \quad 30.7$ & & $11 / 66$ & $7 / 67$ & 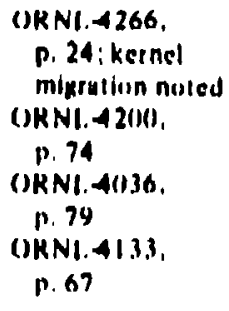 \\
\hline $1 \cdot 1 \cdot 1$ & 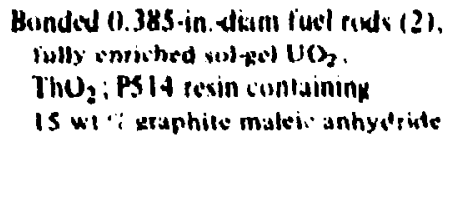 & 0.4 & $y(x)$ & $13(101$ & 43 & -1.11 & N/h7 & $4 / 6 x$ & 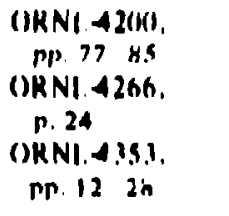 \\
\hline C).28 & 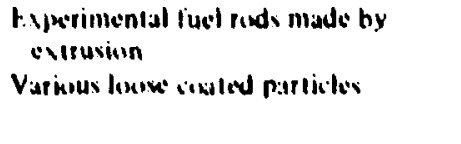 & 0.15 & I(MM) & & 11 & & $\mathbf{n} / 7 !$ & $12 / 71$ & $\begin{array}{l}\text { (IRNI.4411, } \\
\text { PI. } 149 \$ 2 \\
\text { ()RNI. } 4711 . \\
\text { PP. } 1.16 .37\end{array}$ \\
\hline Ol:-1 & 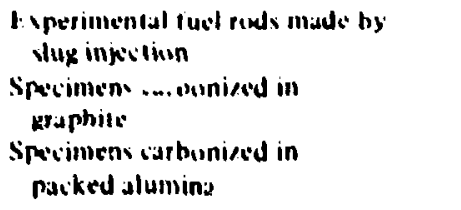 & & & & & & $8 / 7.1$ & $10 / 74^{h}$ & $\begin{array}{l}\text { ORNI 4MII, } \\
\text { IN. IIS } 16\end{array}$ \\
\hline
\end{tabular}


Table 7.4. Dexcription and stutus of FTR irrudiation oxperiments

\begin{tabular}{|c|c|c|c|c|c|c|c|c|}
\hline \multirow{2}{*}{ Fxpriment } & \multirow{2}{*}{ Specimen description } & \multirow{2}{*}{ 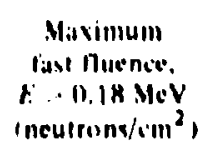 } & \multirow{2}{*}{$\begin{array}{c}\text { Masimum } \\
\text { particle } \\
\text { lemperalure } \\
\text { i"c) }\end{array}$} & \multicolumn{2}{|c|}{$\begin{array}{c}\text { Masimum hummp } \\
\text { (I.IA|A) }\end{array}$} & \multicolumn{2}{|c|}{$\begin{array}{l}\text { lerodfiatwen } \\
\text { s'lededule }\end{array}$} & \multirow{2}{*}{ Rotirtensic } \\
\hline & & & & $\begin{array}{l}\text { licule } \\
\text { particle }\end{array}$ & $\begin{array}{l}\text { Porliks } \\
\text { pitrlicl: }\end{array}$ & Sisti & I mil & \\
\hline$\ldots$ & $\begin{array}{cccccc}\cdots & \cdots & \cdots & - & \cdots & \cdots\end{array}$ & $\times 1101$ & $\cdots$ & & & . & . & \\
\hline $\begin{array}{l}\text { X.buskel-1 } \\
\text { ORN1.43-49 }\end{array}$ & $\begin{array}{l}12 \text { baltihes of Hixinesaled } \\
\mathrm{UO}_{2} \text { and } \mathrm{UC}_{2}\end{array}$ & $\begin{array}{l}\text { 0.59 (thurmal) } \\
\text { (0.067 (fiavt) }\end{array}$ & $\begin{array}{l}4(x), \\
14(1))\end{array}$ & $2 M$ & & hihs & $11 / n s$ & 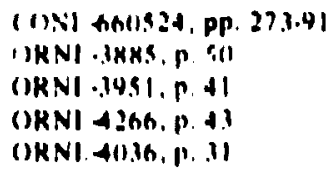 \\
\hline $\begin{array}{l}\text { X-baskel-2 } \\
\text { ORNLA3.97 }\end{array}$ & 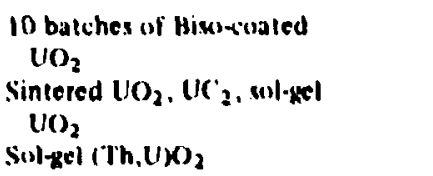 & 0.084 & $\begin{array}{l}4(4) \\
14(M)\end{array}$ & 29 & & $.1 / 6 h$ & $x / n 6$ & 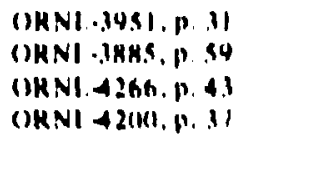 \\
\hline $\begin{array}{l}\text { X-basket.3 } \\
\text { ORNL. } 43.104\end{array}$ & 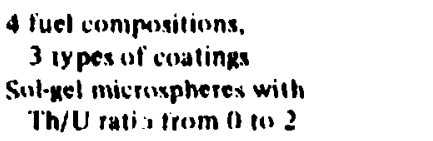 & & 1.4 liantl & $\begin{array}{l}400 . \\
1401\end{array}$ & 20 & $2 / 67$ & $4 / 64$ & 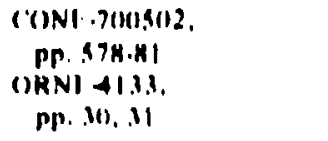 \\
\hline $\begin{array}{l}X \text {-hystati4 } \\
\text { ORNL.43.98 }\end{array}$ & $\begin{array}{l}\text { Various cosling dexigns on } \\
\text { nixedroxide wol-pel micro. } \\
\text { spheres with U/Th rallios } \\
\text { of } 3.2 \text { and } 4.6\end{array}$ & & 1.6 & $\begin{array}{l}4(M, \\
14(K)\end{array}$ & 211 & $9 / 66$ & $4 / 6 x$ & (IKNI A11.36, I. .II \\
\hline $\begin{array}{l}\text { X-basket.5 } \\
\text { ORNL. } 43.105\end{array}$ & 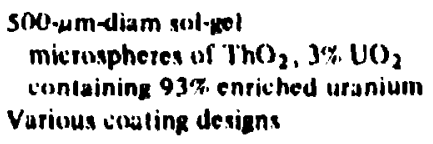 & $\begin{array}{l}1.3 \text { (the Imill) } \\
4.2(\text { fitul) }\end{array}$ & $\begin{array}{l}\text { inx), } \\
|\varangle ! !|\end{array}$ & & 5.12 & $h / 67$ & Y/71 & $\begin{array}{l}\text { (IKNI } 41) 1, \text { P. 124 } \\
\text { (IRNI }+1,1, \text { N, III }\end{array}$ \\
\hline H.1. & 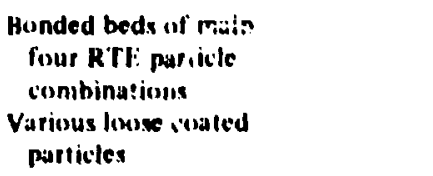 & 8 & $\cdot \ln (x)$ & $\$ 1$ & $\cdot 1$ & $6 / 71$ & $\$ 172$ & $\begin{array}{l}(I K N \mid+1) \| 1 . \\
\mid 11,116 . \\
\mid 1,\end{array}$ \\
\hline PI3N & $\begin{array}{l}\text { Warm unsided luel rowds } \\
\text { with texin-derived } \\
\text { fisuile and ThO } 2 \\
\text { fertile particles }\end{array}$ & $\$ .1$ & IS150 & 6h & 2.11 & $11 / 71$ & $2 / 7.3$ & $\begin{array}{l}\text { ORNI IMAIISh } \\
\text { OKNI AIRII. } \\
\text { P. } 11 \text {. }\end{array}$ \\
\hline
\end{tabular}


7.5. Dexiription and stafus of Poach Bottom irradiation ovgorimunte

\begin{tabular}{|c|c|c|c|c|c|c|c|c|}
\hline \multirow{2}{*}{ Experiment } & \multirow{2}{*}{ Specimen dexcription } & \multirow{2}{*}{ 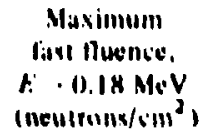 } & \multirow{2}{*}{ 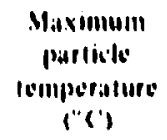 } & \multicolumn{2}{|c|}{$\begin{array}{c}\text { Mavimunn burnups } \\
\text { ("i IRAA) }\end{array}$} & \multicolumn{2}{|c|}{ 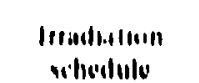 } & \multirow{2}{*}{ Holursinev } \\
\hline & & & & $\begin{array}{l}\text { Pawilo } \\
\text { particicie }\end{array}$ & $\begin{array}{l}\text { listlicio } \\
\text { parlicior }\end{array}$ & Simn & I'WI & \\
\hline \multicolumn{9}{|c|}{$\times 10^{21}$} \\
\hline $\begin{array}{l}\text { RTl-1 (1.TH-1) } \\
\text { RTV.-2 }\end{array}$ & $\begin{array}{l}\text { Candidule recycle } \\
\text { lueds ar bunded leeds }\end{array}$ & $\stackrel{a}{2.4}$ & $\begin{array}{l}12610 \\
12 b 1\end{array}$ & \multicolumn{2}{|c|}{ h. $3^{n}$} & $\begin{array}{l}4 / 31 \\
7 / 71\end{array}$ & $0 / 7.1$ & $\begin{array}{l}\text { GKNI.d-549, wn } 11.15 \\
\text { IIKNI:IM } 447 \%\end{array}$ \\
\hline RTE 4 & and losiwe particices & 1.5 & 1260 & \multirow{2}{*}{\multicolumn{2}{|c|}{$.1 .5^{n}$}} & $\because / 70$ & $4 / 72$ & OHNI.TMA4II. \\
\hline RTE:S & & $a$ & $|261|$ & & & $7 / 711$ & & n. 126: \\
\hline RTL:-6 & & $a$ & 1260 & \multirow{2}{*}{\multicolumn{2}{|c|}{$2.4^{n}$}} & $7 / 711$ & & ()HNI. 1761$), \mathrm{P}, 6.5$ \\
\hline RTL:-7 & & 1.0 & $1261 \mid$ & & & 71111 & $4 / 71$ & \\
\hline RTE.8 & & $a$ & 1260 & & & $7 / 711$ & & \\
\hline
\end{tabular}

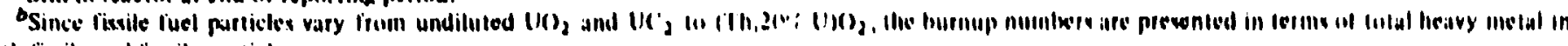
ousth fisvile and lertile partickes. 
Table 7.6. Dexiription and atafun of irrediatkin oxporiniente cionduciod in

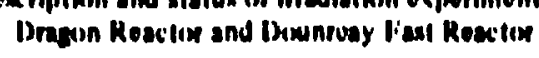

\begin{tabular}{|c|c|c|c|c|c|c|c|c|}
\hline \multirow{3}{*}{\multicolumn{2}{|c|}{ Ixperiment Specinen dencriptiunl }} & \multicolumn{6}{|c|}{ - } & \multirow{3}{*}{ Rorerenice } \\
\hline & & \multirow{3}{*}{ 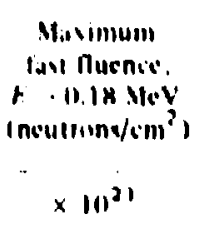 } & \multirow{2}{*}{ 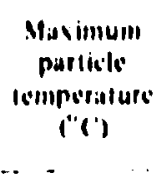 } & \multicolumn{2}{|c|}{$\begin{array}{c}\text { Masimum burnup } \\
\text { |'i |IIA|A| }\end{array}$} & \multicolumn{2}{|c|}{$\begin{array}{l}\text { Irfodtialliwn } \\
\text { cheduk: }\end{array}$} & \\
\hline & & & & \multirow{2}{*}{ 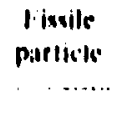 } & \multirow{2}{*}{$\begin{array}{l}\text { lertile } \\
\text { purticis }\end{array}$} & Sturt & Iind & \\
\hline$\ldots+\cdots+$ & $-\cdots$ & & & & & 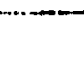 & -1 & $\cdots$ \\
\hline IJN-S & 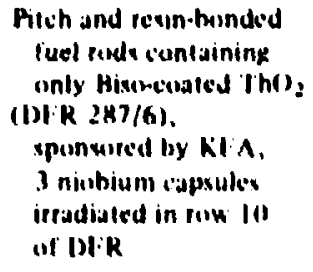 & x & 12511 & & - 1.11 & H/64 & $11 / 69$ & $\begin{array}{l}\text { ()RNI \&S(IK, } \\
\text { P. } \\
\text { ()XNI \&6.17. } \\
\text { P. } 2 !\end{array}$ \\
\hline $\begin{array}{l}\text { Iragun } \\
\text { coñperalive } \\
\text { experiment }\end{array}$ & 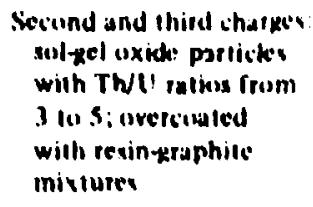 & 1 & $12(1)$ & $\begin{array}{l}22 \\
1+1\end{array}$ & $\begin{array}{l}\text { ined } \\
\text { alles) }\end{array}$ & $1 / 67$ & & $\begin{array}{l}\text { ORNL.I'M-16(1): } \\
\text { ORNI. } 10.16 \text {. } \\
\text { p. } 29\end{array}$ \\
\hline MI:I VII & 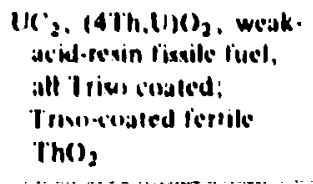 & $4^{\prime \prime}$ & 12.11 & his & $6^{4}$ & $1 / 7.5$ & $1 / 704$ & \\
\hline
\end{tabular}


partkic densities in the bunded beds at: pissible if exiessive heal generditis :a:;; sre to be aruided. This had made it impussible to test representiative fiel compositions or to shieve burnups greater than about 30? FIMA. The PB pasition has a thermal neutron flux is ye not aciurately known) af about half that of the RB pusition. By irradiating an HRB capsule in the PB irality first for about two HFIR cycles, it is possible (o) burn out about $50^{\circ}$, of the initial fissile loading. The iapsule san then be transfeited to the RB ianility. where the high fast-flux exposure and th- continuation of the fuel burnup is achieved. By this means we ian attain bumups above $5 \sigma^{-}$. FIMA with tissile particle loadings in the bed. about twice that pussible pre. viously. This arrangement also makes it passible to irradiate particles containing only ${ }^{33} \mathrm{C}$. Previously. this could only be dune if ane acepted excessi e paltinile power dersities a! ine start of the irradiation. The PB facility is similar in configuration to the RB fixilities and is completely cumpatible with them. It employs the same ressel head flanges and capsule-teadtu-HFIR-vessel sealing arrangement. A sapsule to be preirradiated in ihe PB faility is connected to the regular RB fa-ilities instrumentation. After preirradiativn. the apsule is transferred from the PB to the RB izeilities without the need for disionnecting or reconneiting any of the instrumentation or service lines. The first sapsule to be irradia: ad in the PB ficility was HRB-7 The installatisal. Operation. and transfer were quite iatisfactory.

The s.ond new facility at the HFIP is an in-purt thermocouple calibration furnace designed specifically for lise with the HRB capsules. The furnace I see Fig. 7.11 consists of a pipe into which the capsule can be

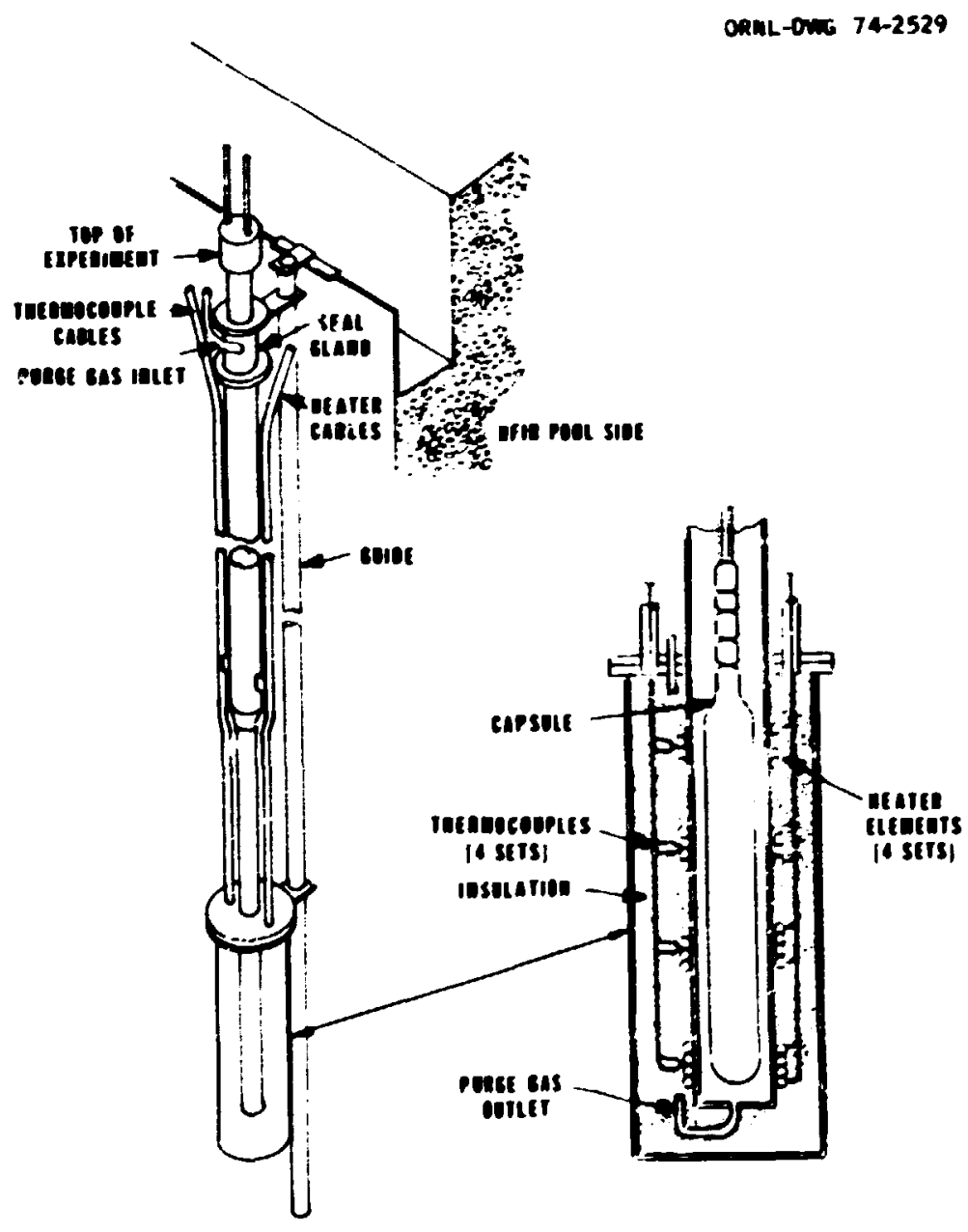

Fie 7.1. In-pond clibration fumance HREX. 
insett:d. A gland ai the top forms a gas-tigit seal with the upper end of the ap:ule leads. The lower end of the pipe has an insulated outer jacket with four sets of heater elements spaied axially along the heated section of the pipe.

To salibrate the capsuie thermocouples. the capsule is first removed from the reactor vessel if tive capsule has been under irradiation) and inserted under water in the furnace. After sealing the top of the fumace. thi water is bluval out of the furnace with helium. The heater are then turned on. and the capsuie thermocouples aie calibrated against those of the furnace. Temperatures to $800^{\circ} \mathrm{C}$ can be achieved. and the temperature gradients of the capsule under irradiation can be simulated by adjusting the axial distribution of power to the four heaters. The $800^{\circ} \mathrm{C}$ temperature limitation is due to the fact that the entir: apsule containinient. brized bulkhezds. etc.. are all heated to the same temperature. Higher temperatures could kepardize llie capsule containmeni ! ntegrity.

The HKB irradiations condu:ted duting the reporting period are summarized in Table 7.1. Briefly, a topical repor was partially completed for HRB-3, and irradiation of capsules HRB4, 5 . and $t$ was completed. Postirradiation examination (PIE) was cumpleted on HRB-4 and -5 and partially completed on HR3-6. The HRB-7 and 8 experiments were planned, the capsule design was completed, and fabrication of the fuel for these experiments was begun.

\subsubsection{Capsole HRB-3}

Irradiation of capsule HRB-3 was desiribed in some detail in the last annial report. ${ }^{2}$ Details of this experiment and of an experiment conducted in the ETR with similar fuel are included in a recently completed report ${ }^{3}$ Capsule HRB-3, the first capsule to contain a fuel center-line thermocouple. contained fuet specimens fabricated by both the warm-molding and the slug-injection methods. It was the first ORNL irradiation of HTCR fuel in which kernel migration (amoeba) ociurred in the $\mathrm{ThO}_{2}$ fertile particles. Three of the thirteen ORNL fuel specimens I(wo warm. molded rods and one slug-injected rod / were examined metallograpi:i:ally. Anoeba of the thoria was observed in two specimens: a very slight migration in one of the

2. Ibid, pp. 96107

3. F. J. Inman et al.. Imediation Performencr of HTCRR Fud Rods in HF7R Fxperiment HRB.3 and ETR Experiment PI3.V. ORNL-TM4526 (Oclober 1974). warm-molded sperimens and cunsiderably greater migration in the sluginjected sperimen. No amoebz was chserved in the other warm-molded spacimen. The combinations of a slightly higher heat rate for the slug-injicted specimen and the iuwer thermal conduc. tivity o tre slug-injected matrix aused these specimens to operate zonsiderabiy hotter tian the warm-moldeci specimens:

Superior pe:formance of warm-molded and extrudec fuel rods as compared to slugitijected rods opereting under similar irradiation conditions has been observed in several subsequent experimenrs. This is a'tributed to the higher thermal condutivity of the continuous matrix rods

\subsubsection{Capsiles HRE-4 and -5}

\section{Capsule HRB-4 (B. H. Montgumery)}

Design. The irradiation of the fourth instraminted test (HRBA) of boncied HTGR coated particle fuels in the HFIR RB faility was completed on Jun= 26. 1973 after $\mathbf{2 4 3 . 4}$ days at $100 \mathrm{MW}$ reator power. The design of this apsule was similar to that of the third apsule ${ }^{3}$ of the series. HRB-3. except that tire fuel rods were different.

The capsule. shown in Fig 7.2. was a double-walled water-cooled stainless steel vessel with outside and inside diameters of 1.292 and 0.967 in. respectively. The fuet specimens. which consisted of a series of 0.490 -in.diam bond'ad fuel rods having \& toval stack length of $I 5.32$ in.. were supported in a one-piece sleeve made of Pocs graphite grade iXF-jQ. The design test conditions $\left(1250^{\circ} \mathrm{C}\right.$ peak fuel temperature and $700^{\circ} \mathrm{C}$ in the graphite waii as $55 \mathrm{~kW} / \mathrm{ft}$ fission heat rate) were intended to match conditions typical of an HTGR.

Temperatures vere monitored by eight shealled 0.062-in.-diam Chrumel/Alumet thermocouples and one bare-wire $W$ - $3 \pi$ Re/W- $\leq 5 \pi$ Re central thermocisuple. The stainless-steel-sheathed th:rmocouples were incated in axial holes in the graphite sleeve adjacent is the fuet specimens (Fig. 7.3). Six of these thermocouples were coated with a 0.005 -in.-thick protective barier of chemically vapurdeposited :ungsien and two were uncoated. The central thermocouple lead wires were threaded through a (wi)-hole 0.06:-in. diam BeO insula. tor. The junction and lower 2 in. of the inslolator were shielded from the fuel surface by 3 three-iayer wrap of 0.0025-in.-thick thenium foil. The upper fuel specimens (IA. IB. and IC: see Fig. T.3) ina-1 a 0.090 -in. central hole for this thermoxouple. High-p.trity Fe. Ni. Ti. and Co nux -innitors in ReO in:ulator $t$ shes were la:ated ir: 


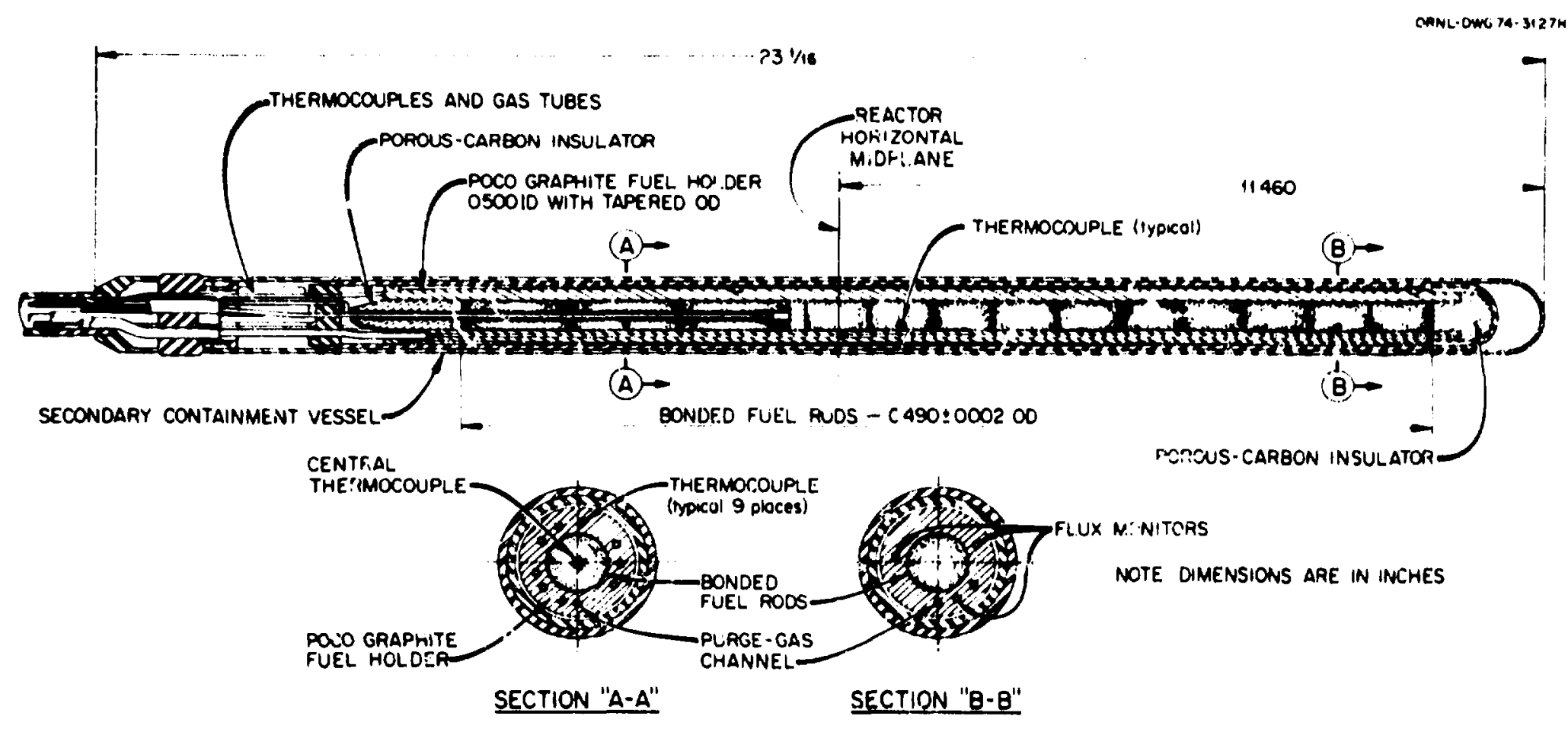

Fij. 7.2. HTGR instrumented capsule HRB-4 for arradiation in HFIR removable berylliuns facility. 


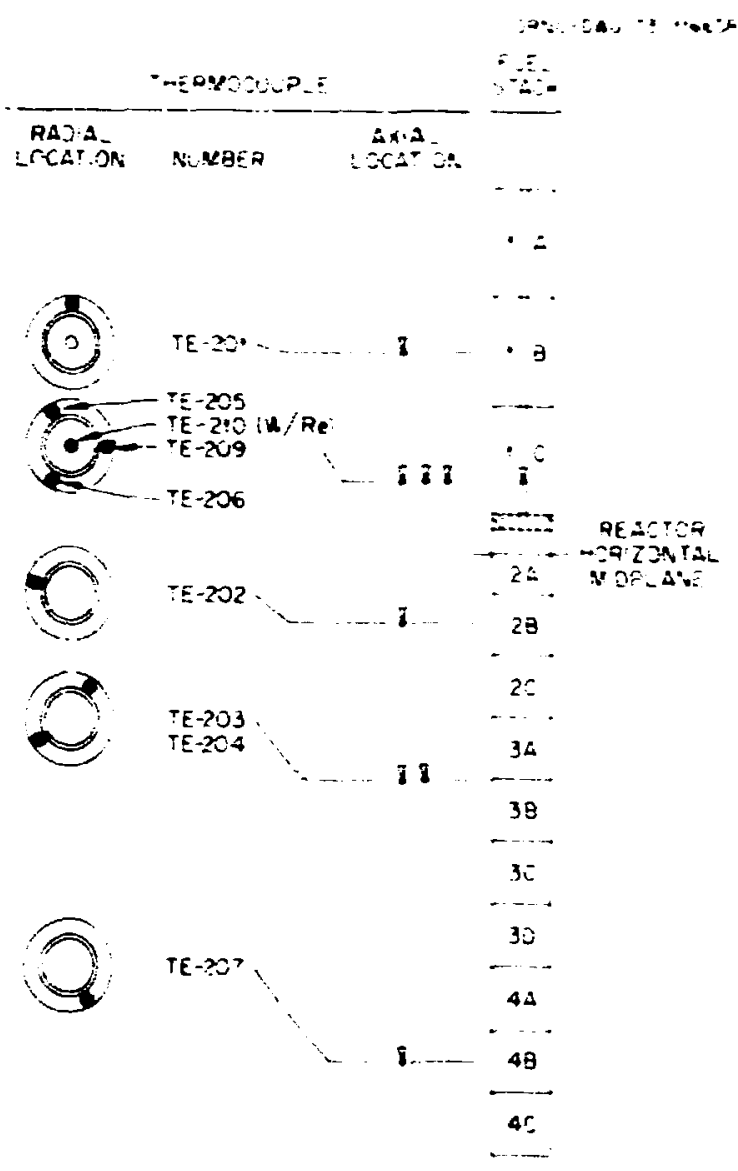

Fig. 7.3. Capale HRBA thermocouple locations.

the graphile sieeve in axial holes similar to those for the thermoxiouples. The graphite sleeve and the fuel spec:mens were continuously swep with a $3600 \mathrm{im}^{3} / \mathrm{hr}$ high-purtty helium-neon gas mi: cure at 1 in $2 \mathrm{~atm}$. Gas sompler of the sweep eifluent ware taken periodically for fission-gas release determinations.

The fuel loadings were increased in the upper end of the capsule to compensate for the loss of the volume created by the central thermocouple hole. Because of the high thermal flux in the HFIR RB facility. the ${ }^{235} \mathrm{U}$ is consumed rapidly (50, in ahout 16 days at the reactor midplane). To compensate for the luss of fissile material, the ${ }^{232}$ Th and ${ }^{238} \mathrm{U}$ content of the specimens was adjusted so that the fissile ${ }^{233} \mathrm{U}$ and ${ }^{239} \mathrm{Pu}$ bred in by neutron capture would provide continuing fission power with a minimum of power variation with time (sce Fig. 1.4).
The neutron flux and gamma heat. and hence the specimen heat generation, decreases in an approximate cosine function as one moves axially from the reator midplane. In uxder $t$, sbtain reasitiably uniform specimen temp:atures with this axially varying heat. generation pattin. we adjusted the thermal resistiv? of the radial gas gap between the grapiite sleeve and the sainless steel capsule wall inversely with the heat generation rate. This was acomplished by tapering the diameter of the graphite sleeve so as to increase the gas gap as one move: further from the midplane. The taper was made to provide a constant spicimen axial iemperalure pattern at the beginning of the irrad.ation. To compensate for overall power variations with time. the comprosition of the heliun-neon sweep-gits mixiure which aicupies the gas gap was varied to mintain the peak fuel temperature at th sesignt level. Hom:-s. it must be recugnized that neitner this nor any orher approach can provide uniform lemperatures for all specimens with time. The bumup rates and ${ }^{23} \mathrm{U}$ and ${ }^{259} \mathrm{Pu}$ generation rates vary with the flux and hence with axial position. The neutron flux also varies (increases) with time during a given reactor cycle but not in the saine proportion for all as ia. positions. (The percint increase is greater at the ends thait at the teacior midplane, This flux variation with time and prsition is common to most irradiation facilities and is not inique to the HFIR. We ieel 'ha' cur pariial solution to the problem is the best that can :-: done in this case.

Operation. Capsule HRB 4 was inserted in the RB facility (RB-7) on Oet. 8. 1972. and was urradiated Sor il HFIR suel cycles 1244.0 days al 100 MW reactor power). The irtadiation was completed and the capsule iemoved as sifheduied on June 26. 1973. Capsule operation was stable throughout the irradiation. and all test parannelers were within design limits. There was. as expecied. an initial drop in power as the ${ }^{235} \mathrm{U}$ was consumed. followed by a gradual pou er buildup which varied with tir:e. axiz! possition, and fuel loading. This is shown graphically in Fig. 7.4. which presents the calculaied fission power $k$-nerated by specimen $2 A$ near the reactor horizontal miciplane. The calculated fuel specimen loading. location. issiopic hurnup, and flu. ence (fast and the.mal) for each specimen are shown in Table 7.7. Note that the burnup was calculated in percent initial isotope fissioned. To obtain buinup in a particle. the following equation wi:l apply:

$$
\text { F FIMA/particle } \left.=\sum_{i=1, n}^{i} \text { (\% burnup of isotupe } i\right)
$$

(:nitial at. $\%$ of isotope $i)$ 
rade 7.7. Capale HRE 4 fuel pacimen location and lisading

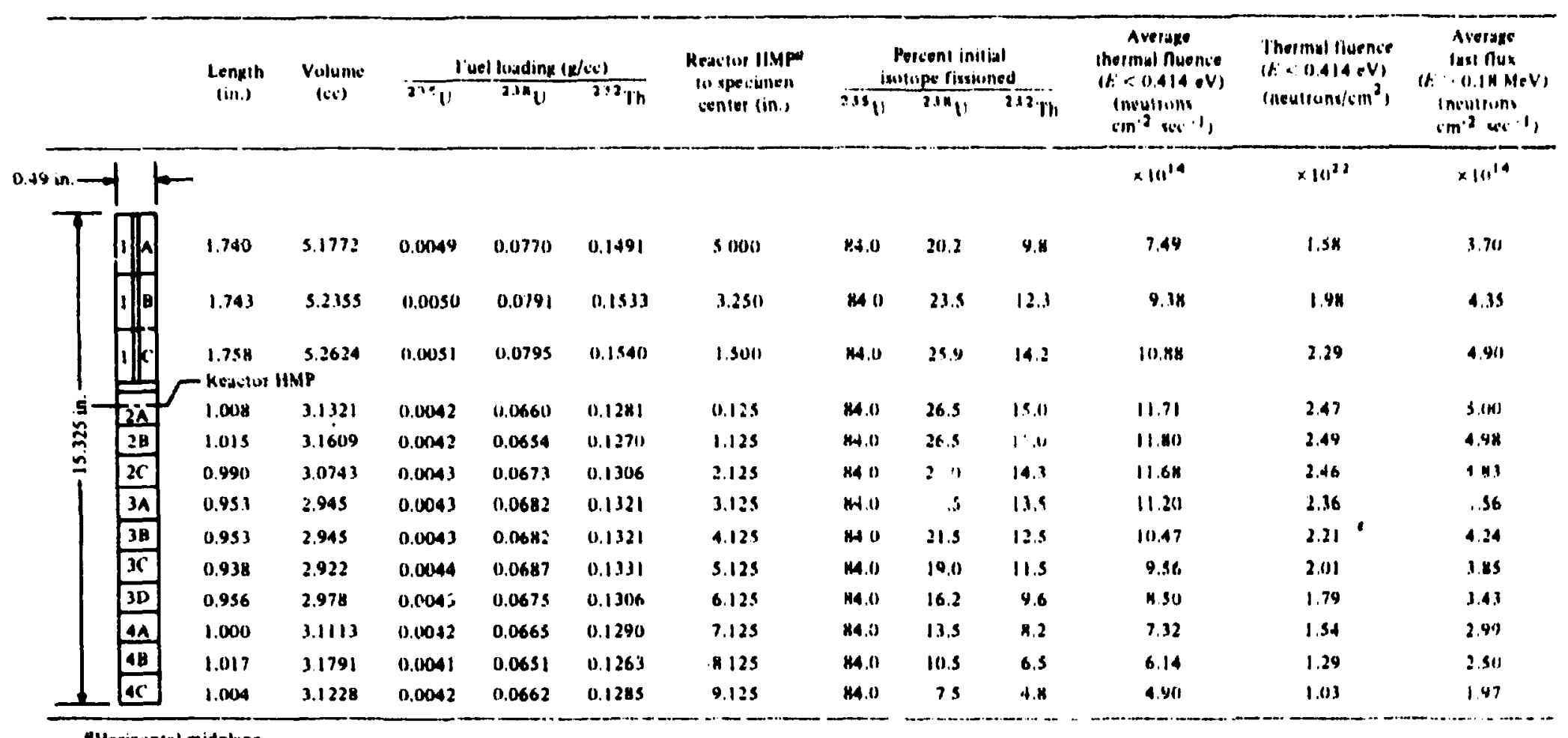




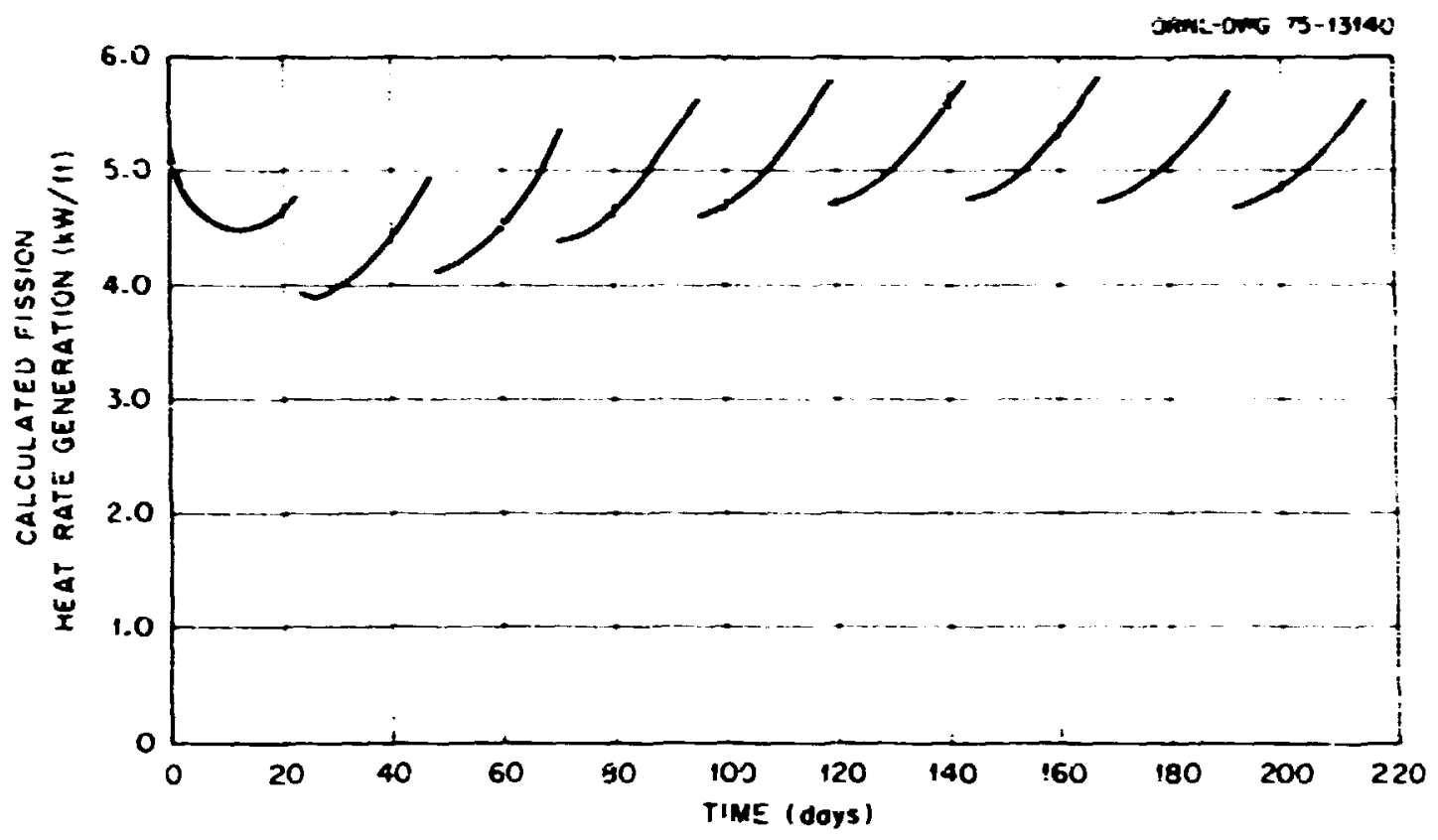

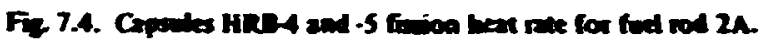

The burnup and fluemie are basad on a pak (iezilor horizontal midplane) fast flux $0^{-} 5 \times 10^{14}$ neutrons $\mathrm{cm}^{-2} \mathrm{sec}^{-1}(E>0.18 \mathrm{MeV})$ and an average pirturbed the:mal ilux of $1.18 \times 10^{15}$ neutrons $\mathrm{cm}^{-2} \sec ^{-1}(E<$ $0.4 i 4 \mathrm{eV}$ )

The helium-neon sweep-gas efnownt was sampled periodically io measure fission gas release. The rutios of rejease ratz 10 birth rale $(R / B)$ sf selected icotopes vs accumulated irradiation time are shown in Fic. 7.5 . The birth rales used in this calculation take into account the depletion of ${ }^{235} \mathrm{U}$ and fissions of bred-ir ${ }^{233} \mathrm{U}$ and $2{ }^{39}$ Pu. We first calcu' 'ed the daily change in isotopic composition of the fik, for each specimen and then the fission product yield from each fissionab!e isolope.

Typical plots of the time-temperdiure history for eight of the thermo:ouples during one HFIR cycle of operation (crcle 87 . the fifth cycle of irradiation for capsule HRB 4) are given in Fig. 7.6 : hrough 7.11 . Operating temperature was controlled by maintaining TE. 207 ar $940^{\circ} \mathrm{C}$. The shorl low-temperalure indication for all thermocouples at the beginnin; of eacin cycle was caused by capsule operation with a 100k helium sweep. which reduce, the thermal resistance of the gas between the graphite sleeve and the capsule wall and results in the lower temperatures. The capsule was operated with $100 \%$ helium periodically to provide a relative measure of the power generation as a function of temperature without the cumplication of an uncertain pas conductivity.

The operating history of the HFIR durng the tine sapsule HRB 4 was being irradiated is shown in Table 7.8 .

\begin{tabular}{|c|c|c|c|c|}
\hline \multirow{2}{*}{$\begin{array}{l}\text { HFiR } \\
\text { cycle }\end{array}$} & \multicolumn{2}{|c|}{ Cyok } & \multirow{2}{*}{$\begin{array}{l}\text { (mpetalken } \\
\text { imeredsyu) }\end{array}$} & \multirow{2}{*}{ 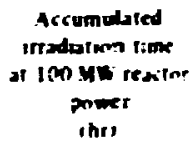 } \\
\hline & Presin & f.nd & & \\
\hline 13 & $10 \cdot 72$ & $10: 372$ & 15 & 3643 \\
\hline MA & $\ln 24: 72$ & 111172 & 18 & \\
\hline $\min$ & $1113: 72$ & $11: 1972$ & 5 & 4252 \\
\hline ms & 1 i 20172 & 121372 & $: 3$ & 14794 \\
\hline $\mathbf{m s}^{\prime}$ & $12: 13172$ & $1: 777$ & 24 & $3037 x$ \\
\hline M7A & 1493 & $1.111: 93$ & I & \\
\hline n7B & [ $12: 73$ & $2: 3: 73$ & 2: & $257: 8$ \\
\hline $8 *$ & 23.73 & $2: 26: 73$ & 23 & $3119 n$ \\
\hline 19 & $2: 27 ; 73$ & $3: 22: 73$ & 23 & 30645 \\
\hline 9 & $3: 23: 13$ & $415: ?$ & 23 & 42134 \\
\hline $9 i$ & 41873 & $5 / 11 / 73$ & :3 & 47642 \\
\hline $92^{\circ}$ & $5: 1173$ & $6: 3: 73$ & 23 & 53101 \\
\hline 93 & $6^{\prime} 3: 73$ & $626 / 73$ & 23 & 58548 \\
\hline
\end{tabular}




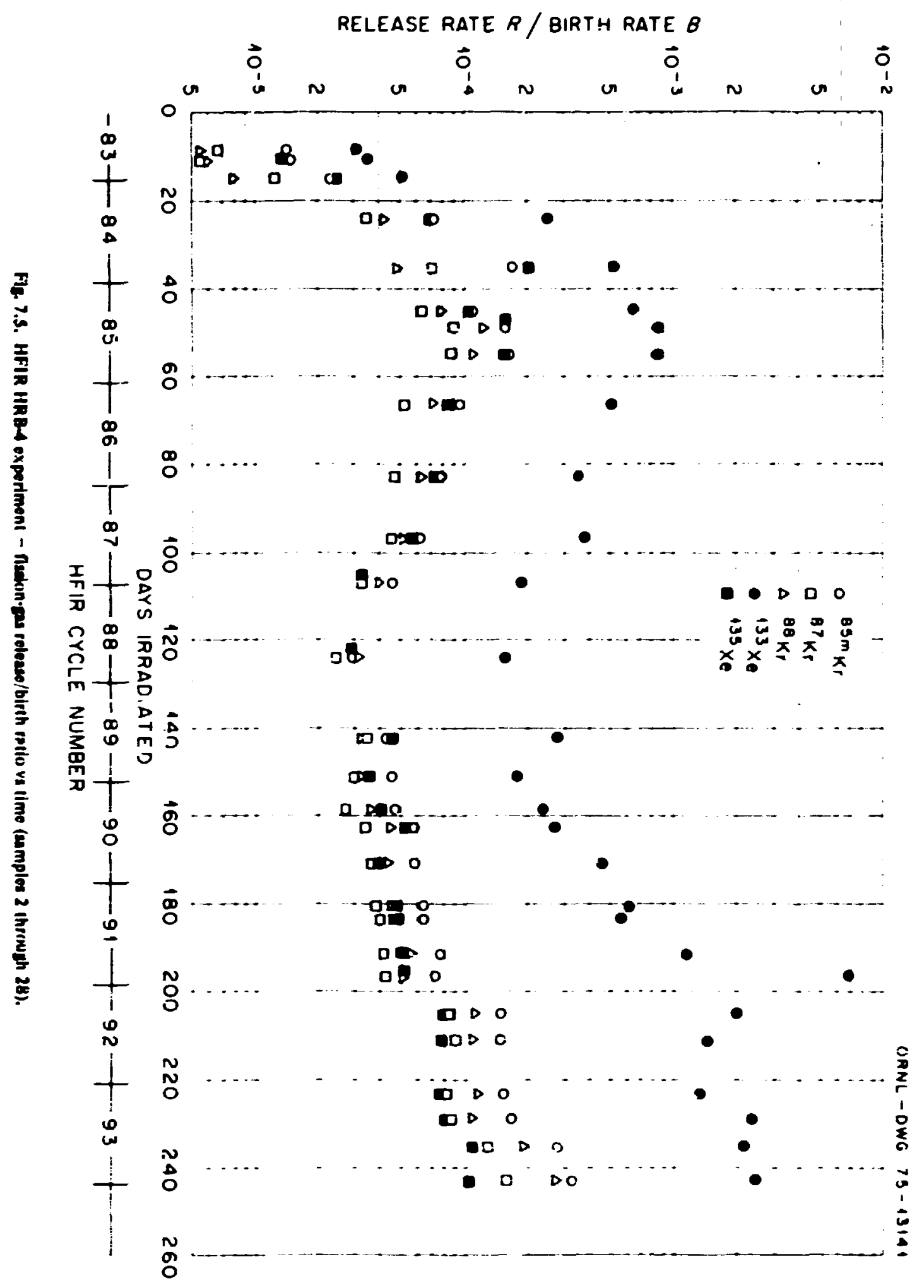




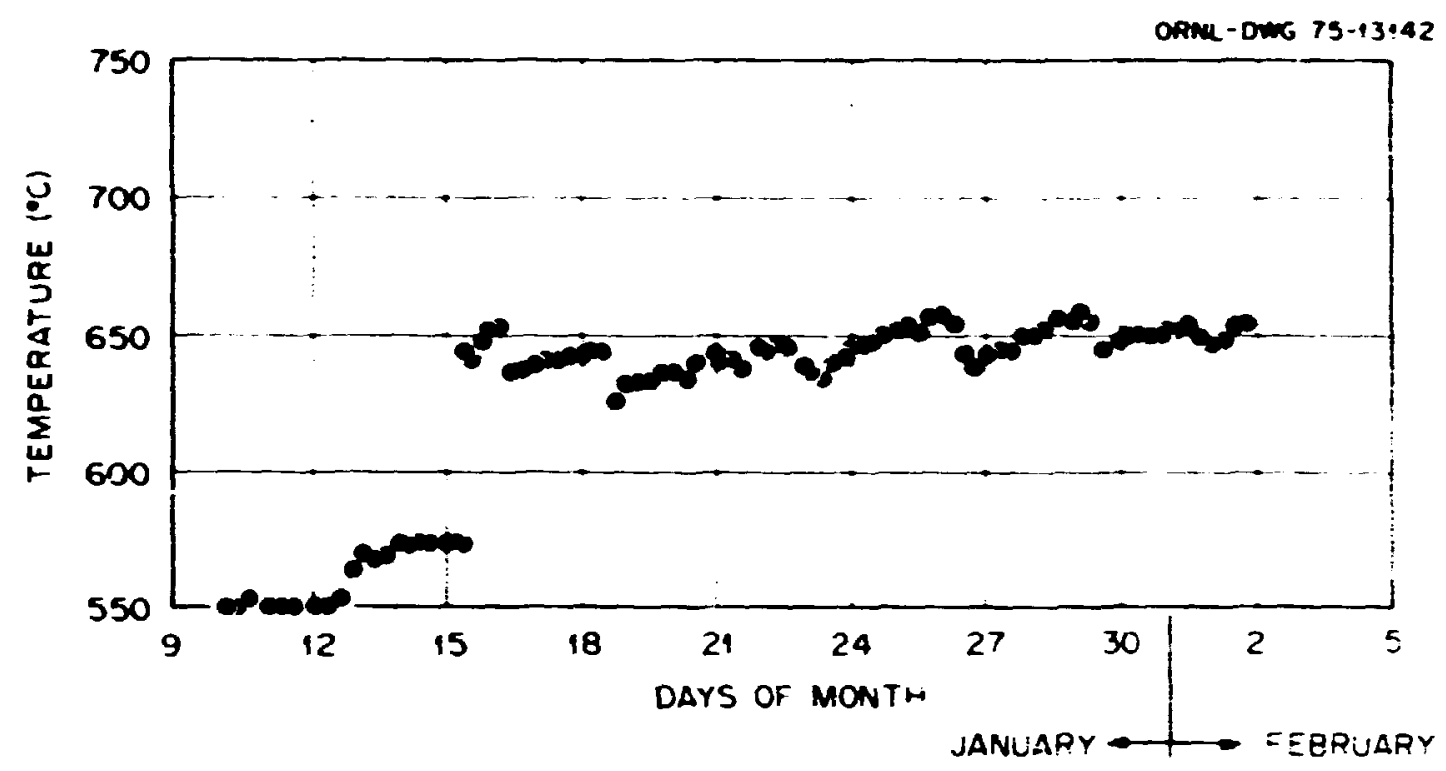
ion

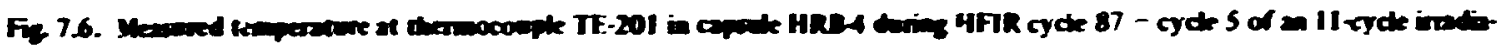

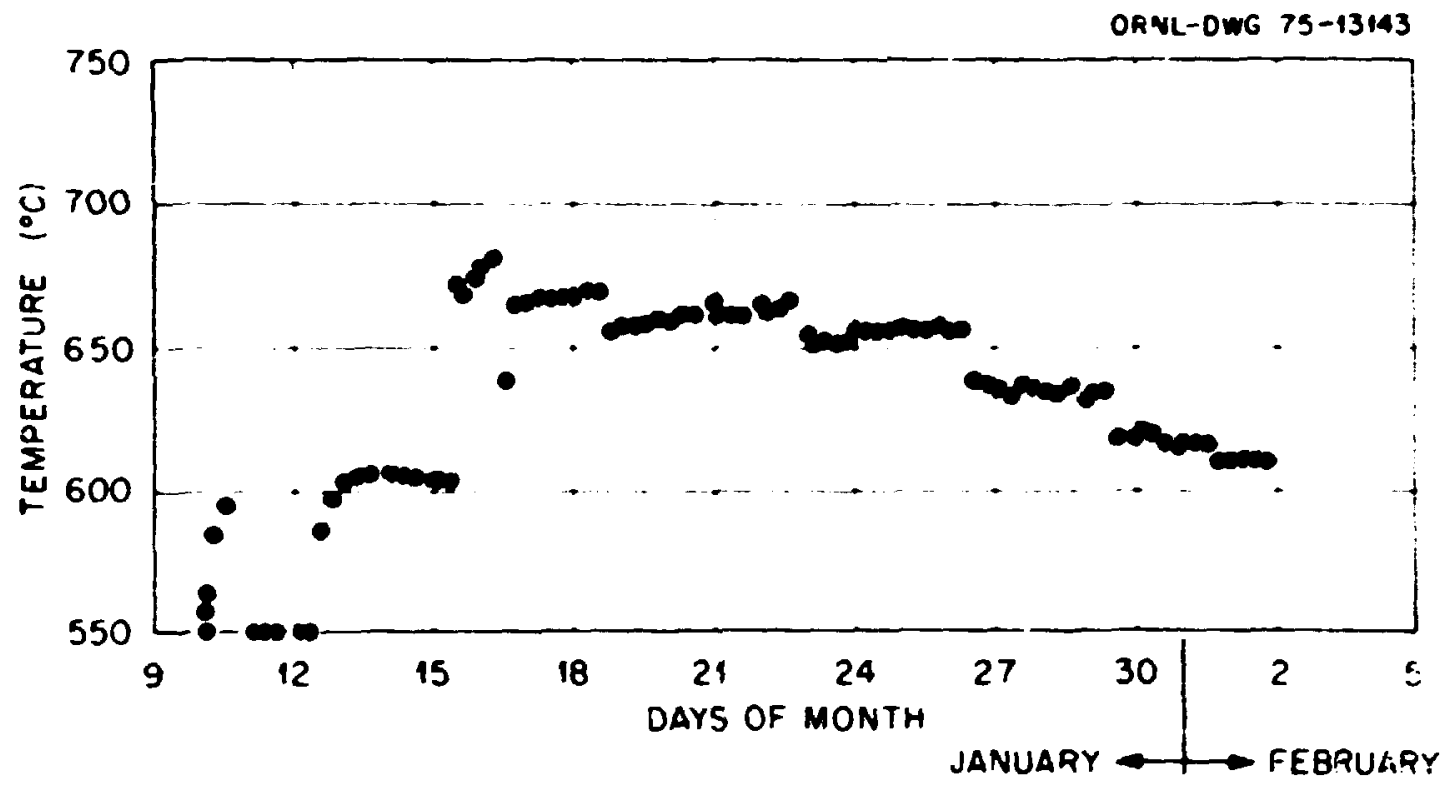

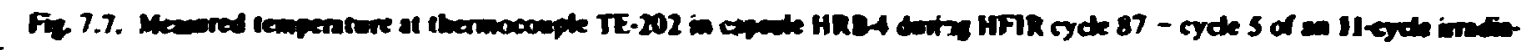
ion. 


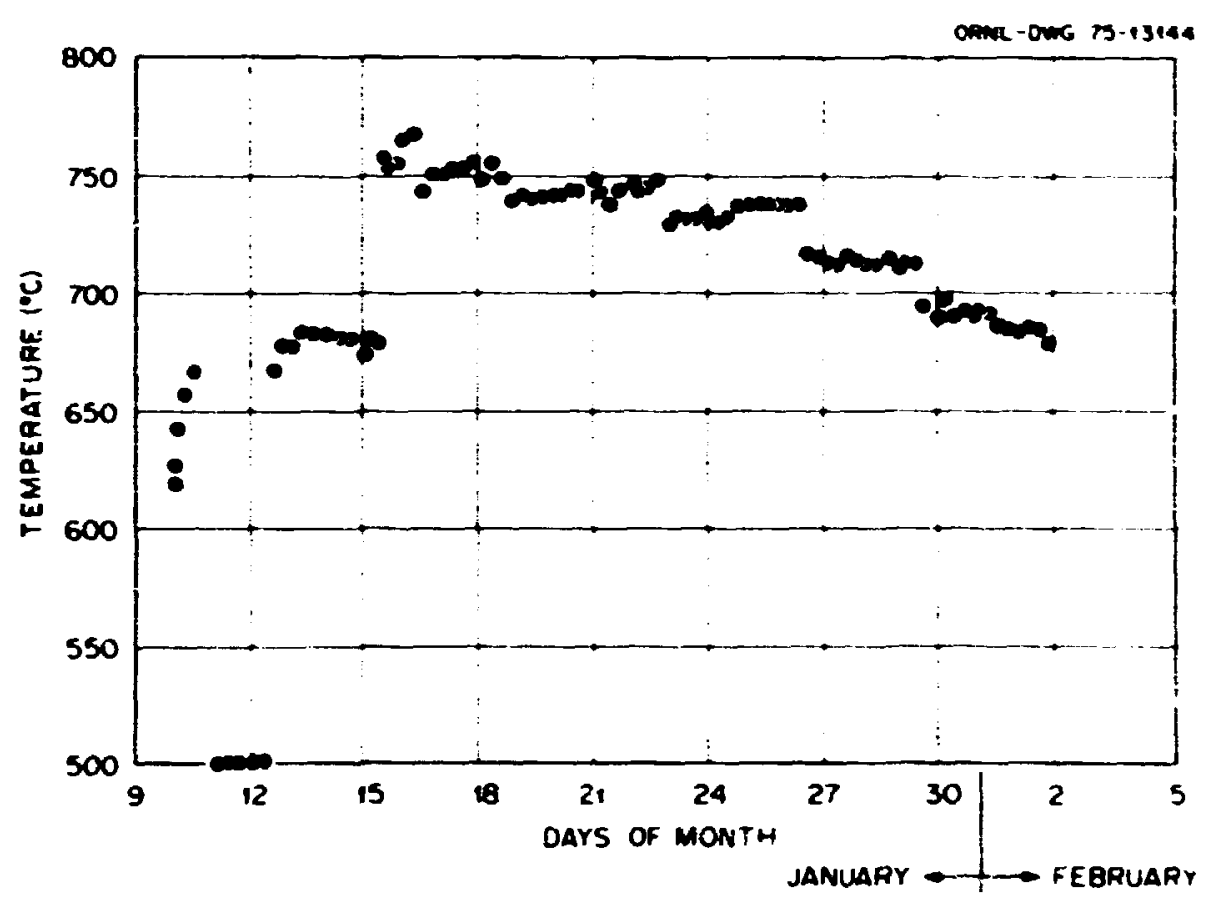

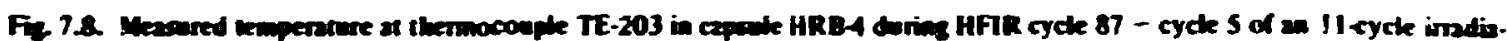
nom

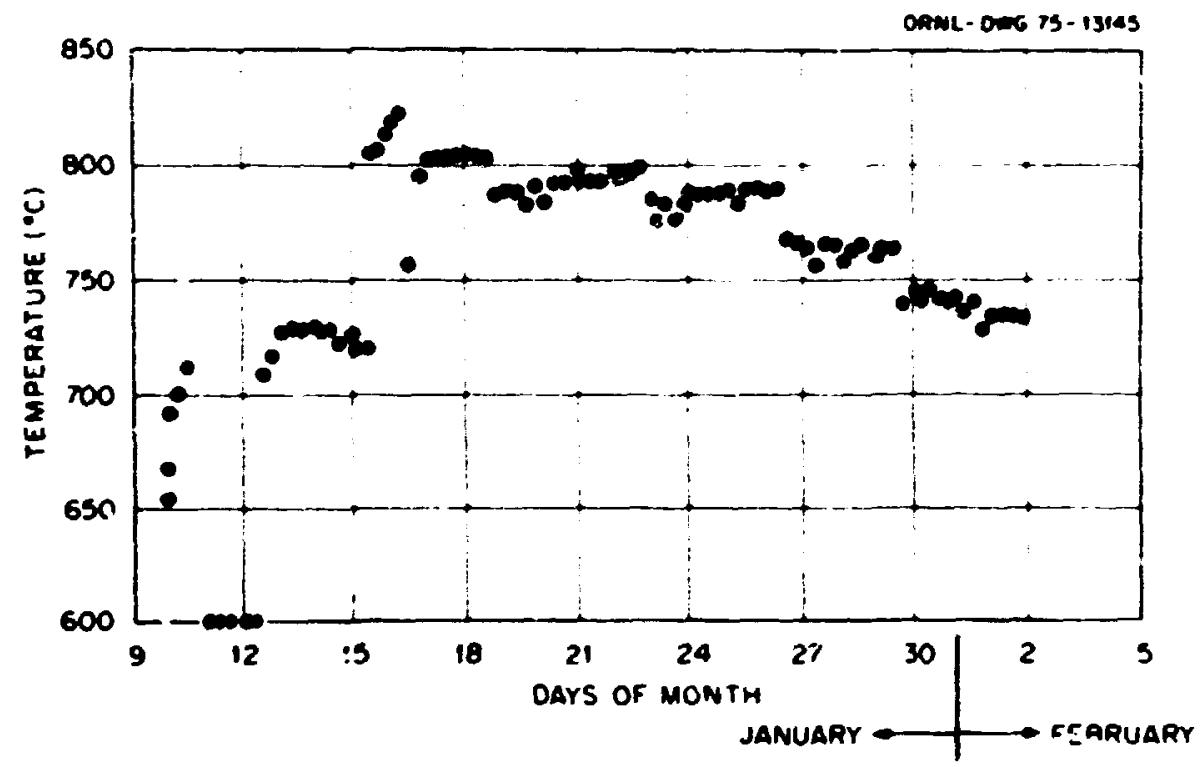

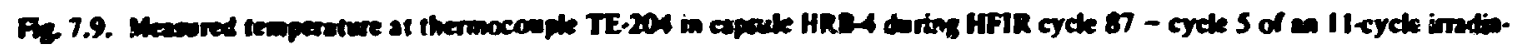
cion. 


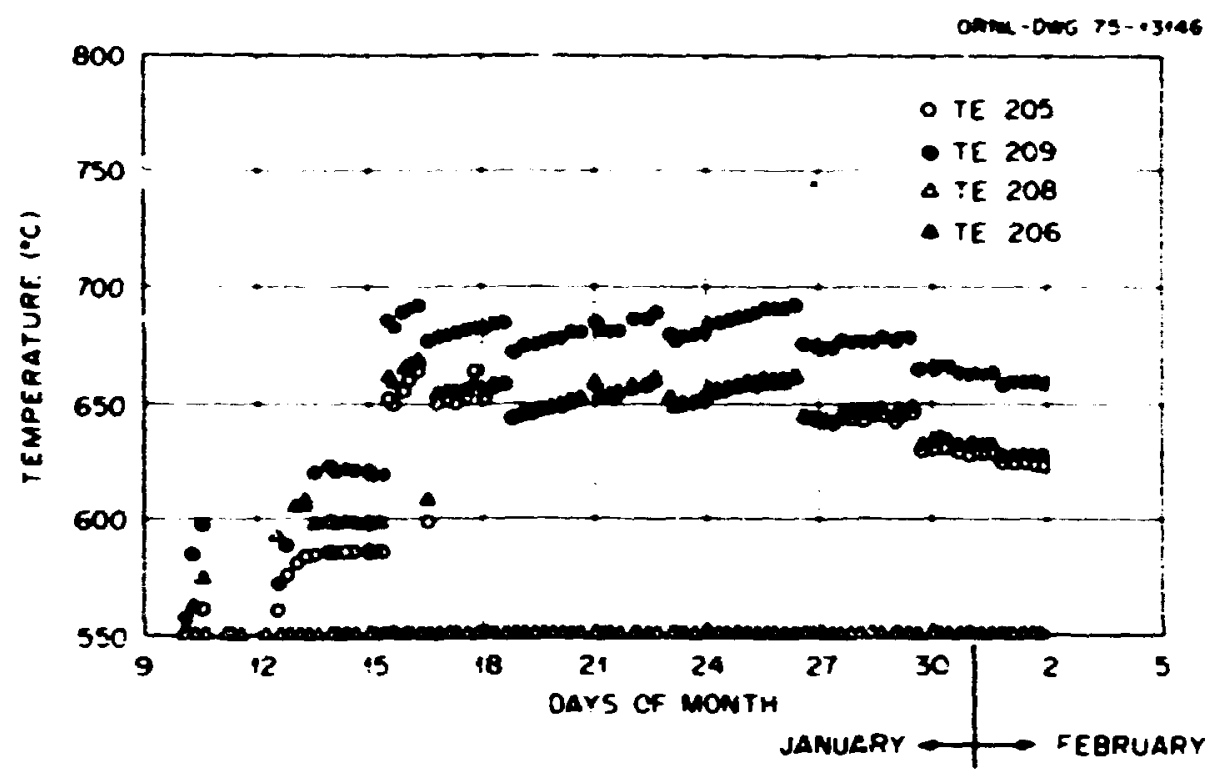

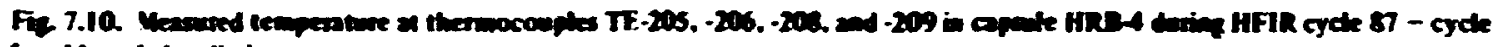
5 of a lleych indivion.

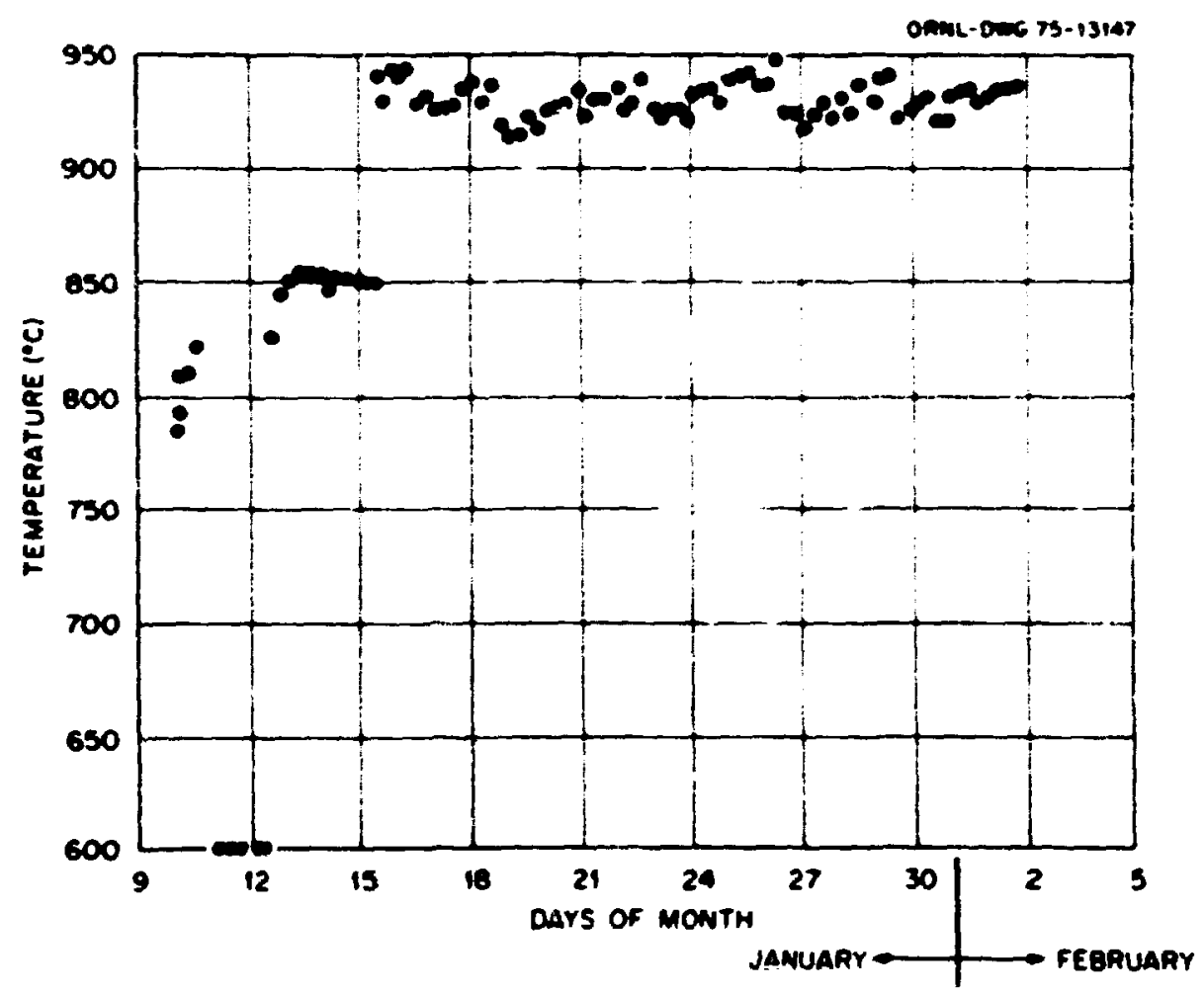

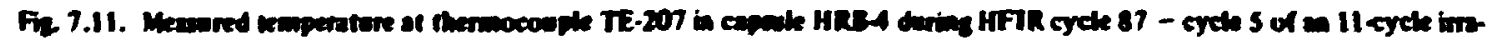
Caive. 


\section{Copoule HRes}

Desig. This capsule and the fuet specimens were i'entical to sapsule HRB- exiept that the WiRe thermorouple which monitors the central temperature of bonded bed specimen IC had been replaced by an ultrasonic thermometer (see Sect. 7.7). The thermocouple locations in the graphite sleeve. as shown in Fig. ?.12 differ only in the iength of TE-104 flocated adjacent to the interface of specimens $3 C$ and $3 D$.

Operation. Capsule HRB-5 was inserted in the RB-5 ixility at the beginning of HFIR fuel iycle 83 on $0 . t$.

8. 1972. The capsult was irradiated for five iycles
1107.4 days at 100 MW reactor puwert to a peak tisl lluence of $4.6 \times 10^{21}$ neuirons $/ \mathrm{cm}^{2}$ (f) $>0$. I $\mathrm{MeV}$ ) Due to the simiarity of this capsule to iapsule HRB 4 . the tission heat gene:ation for capsule HRB-1 Fig ? +1 applies. except that HRB-5 was irradiated fir only 5 HFIR cycles whereas HRB-4 was irradiated fur II syiles. The fuel specimen loading. lovition. isolopio burnup. and fluemie are given in Table ?4. The assumptions for these calculations are identical to those of HRB-4.

Samples were taken periodically of the sweep-gas effluent to obtain fissiongas R B ratios. These are

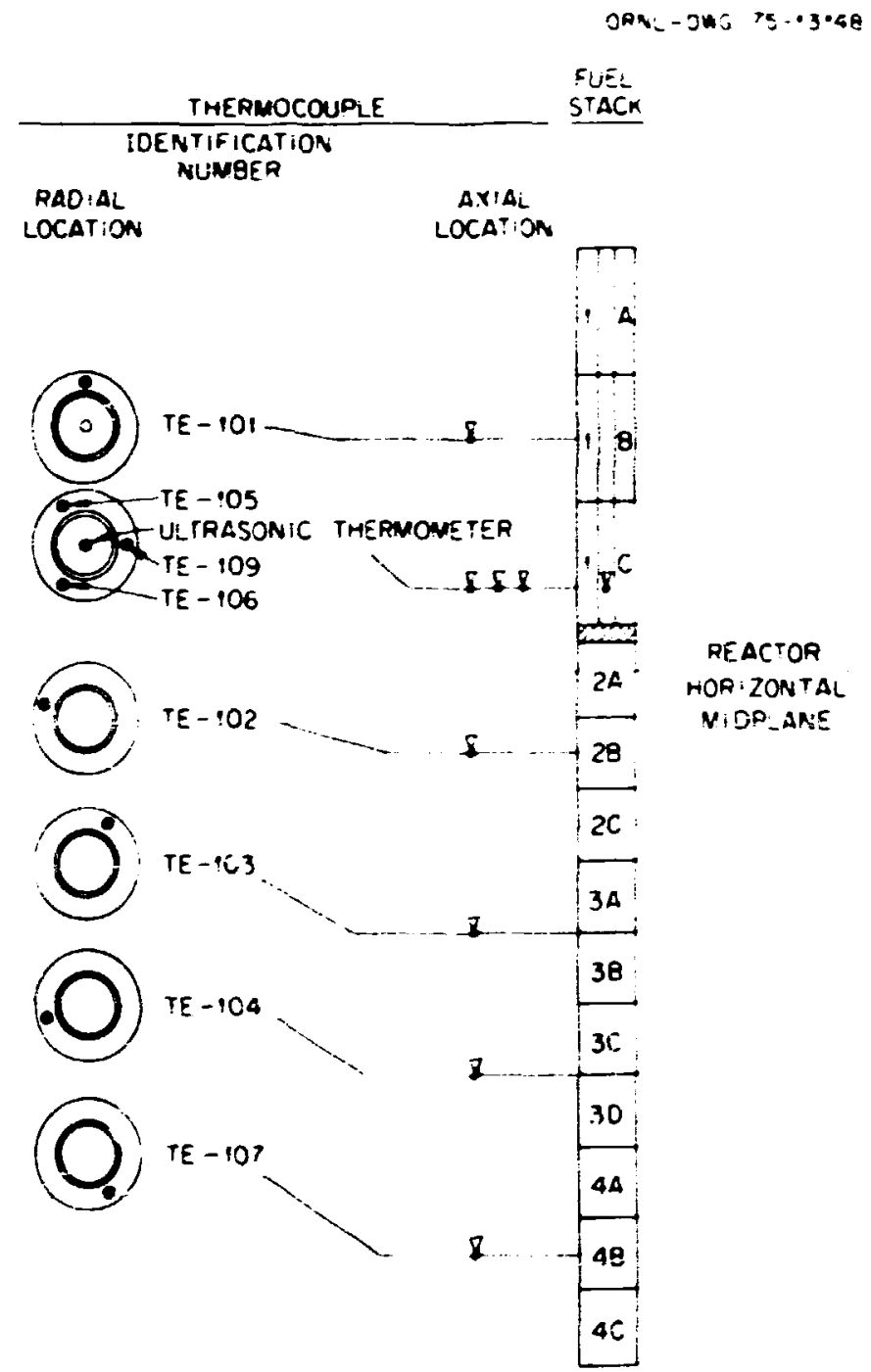

Fi. 7.12. Copale HRE-S thermoconple location. 


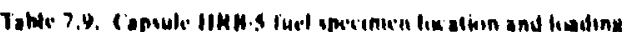

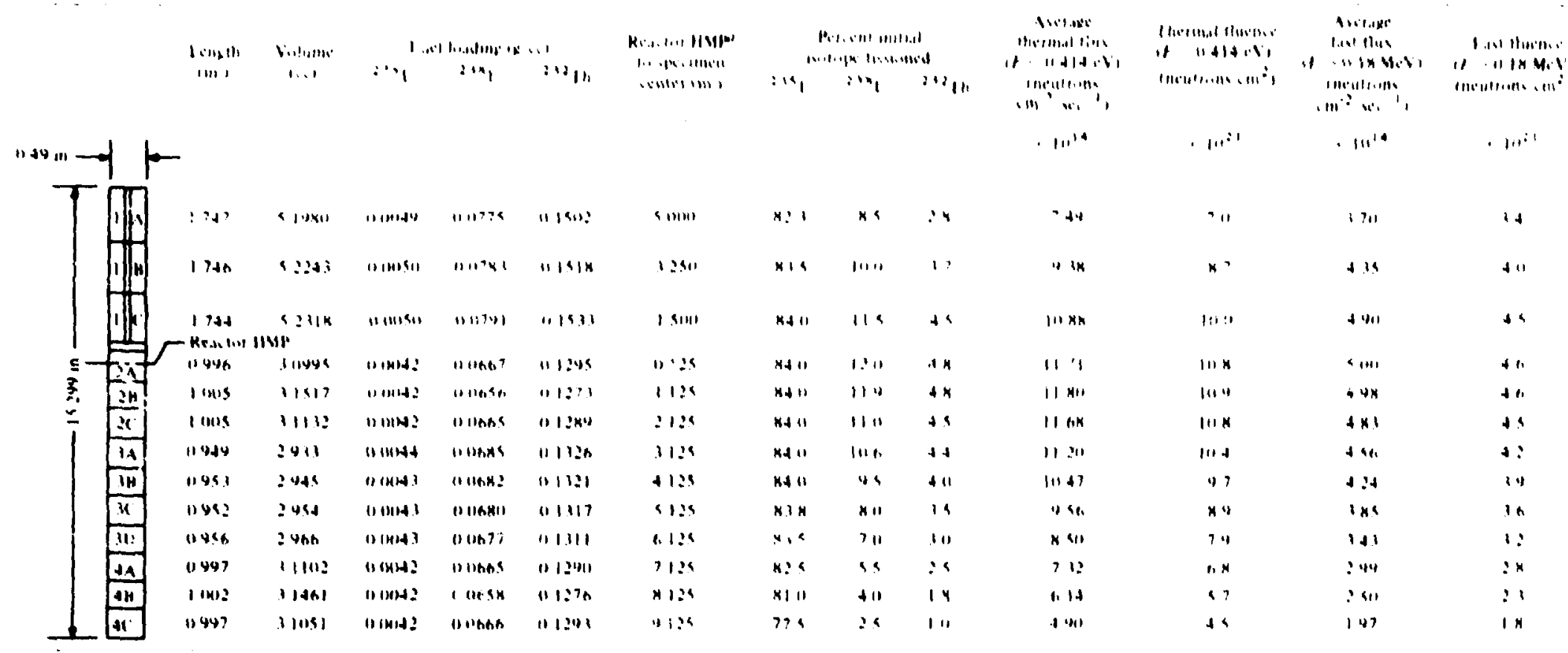




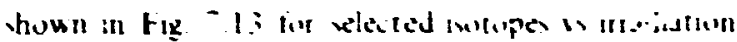
tmo*

Opersting tempetstute in the graphte lec:e

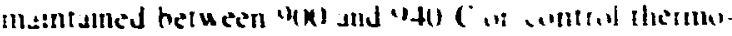

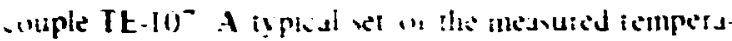

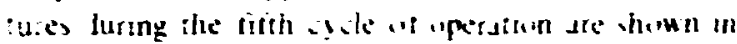
Fis:- It through - Is

The upersting history of the HFIR durng the ume

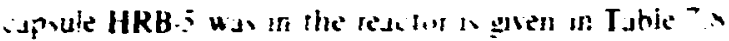

\section{Postirradiation samination of HRB 4 and -5}

it $L$ Liny. Jr.

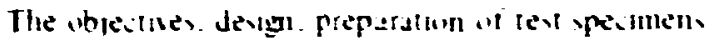

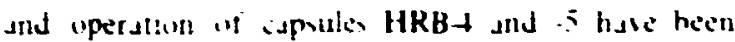
reported The dissumbly and samustiven of tho compunent, if these is m mirumented ispules were

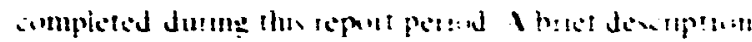

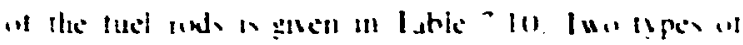

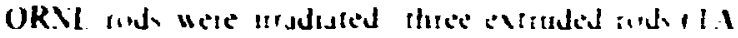

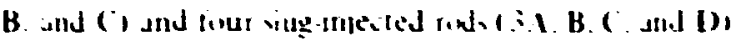

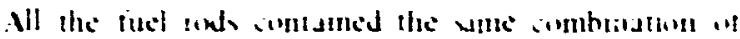

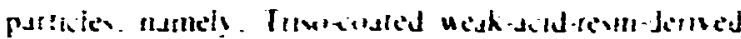

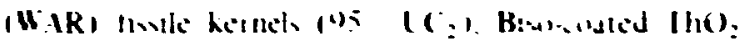

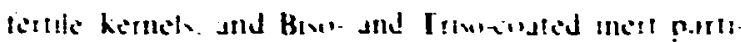

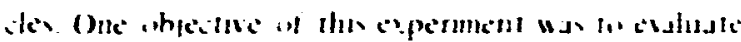

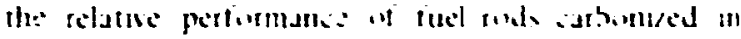

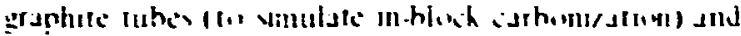

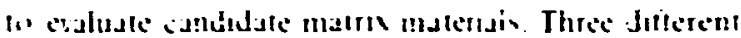

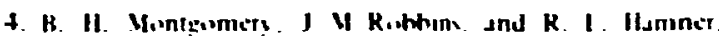

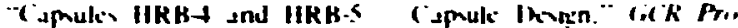

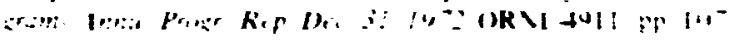
1:

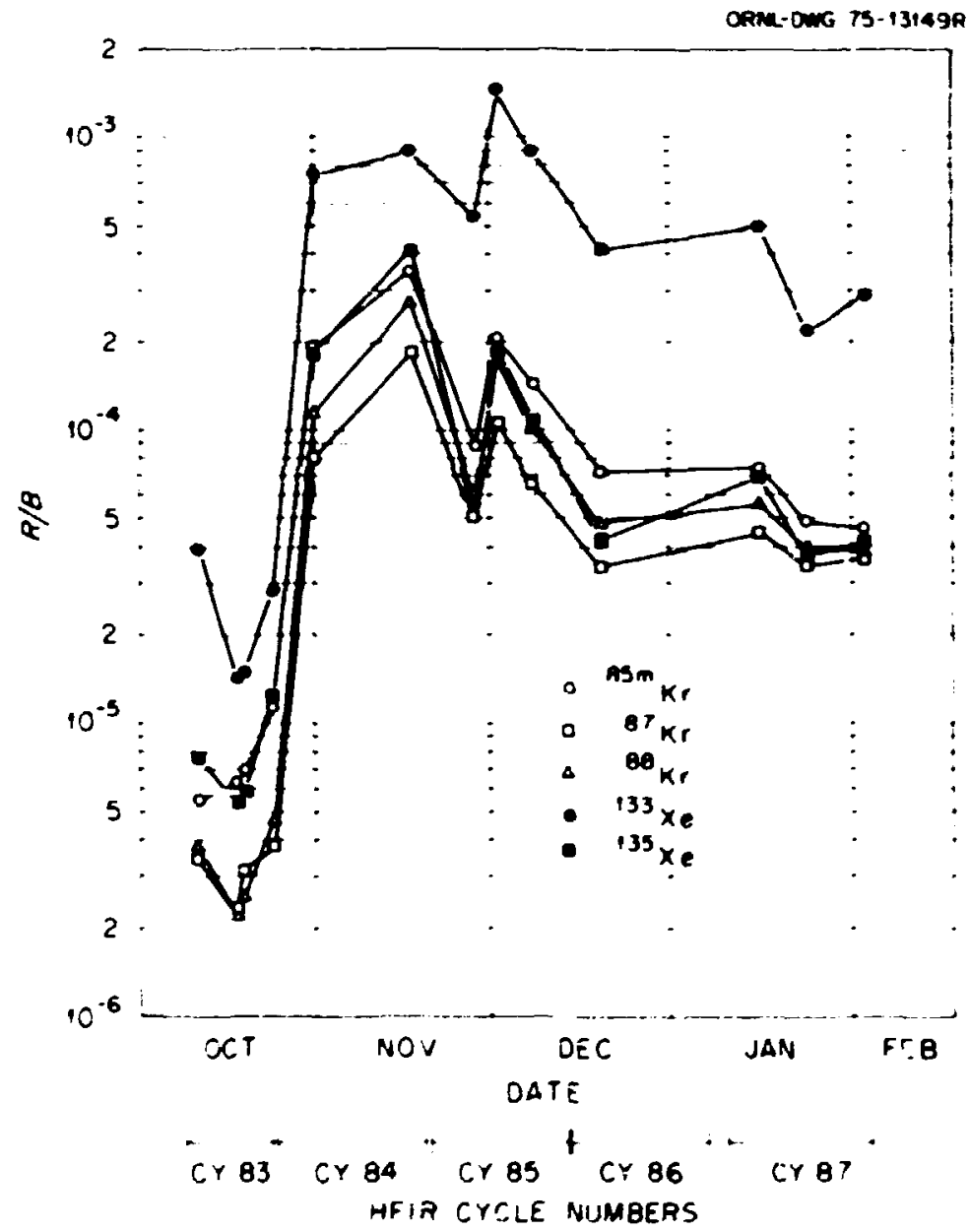

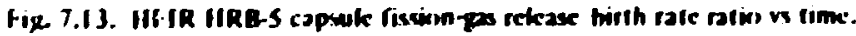




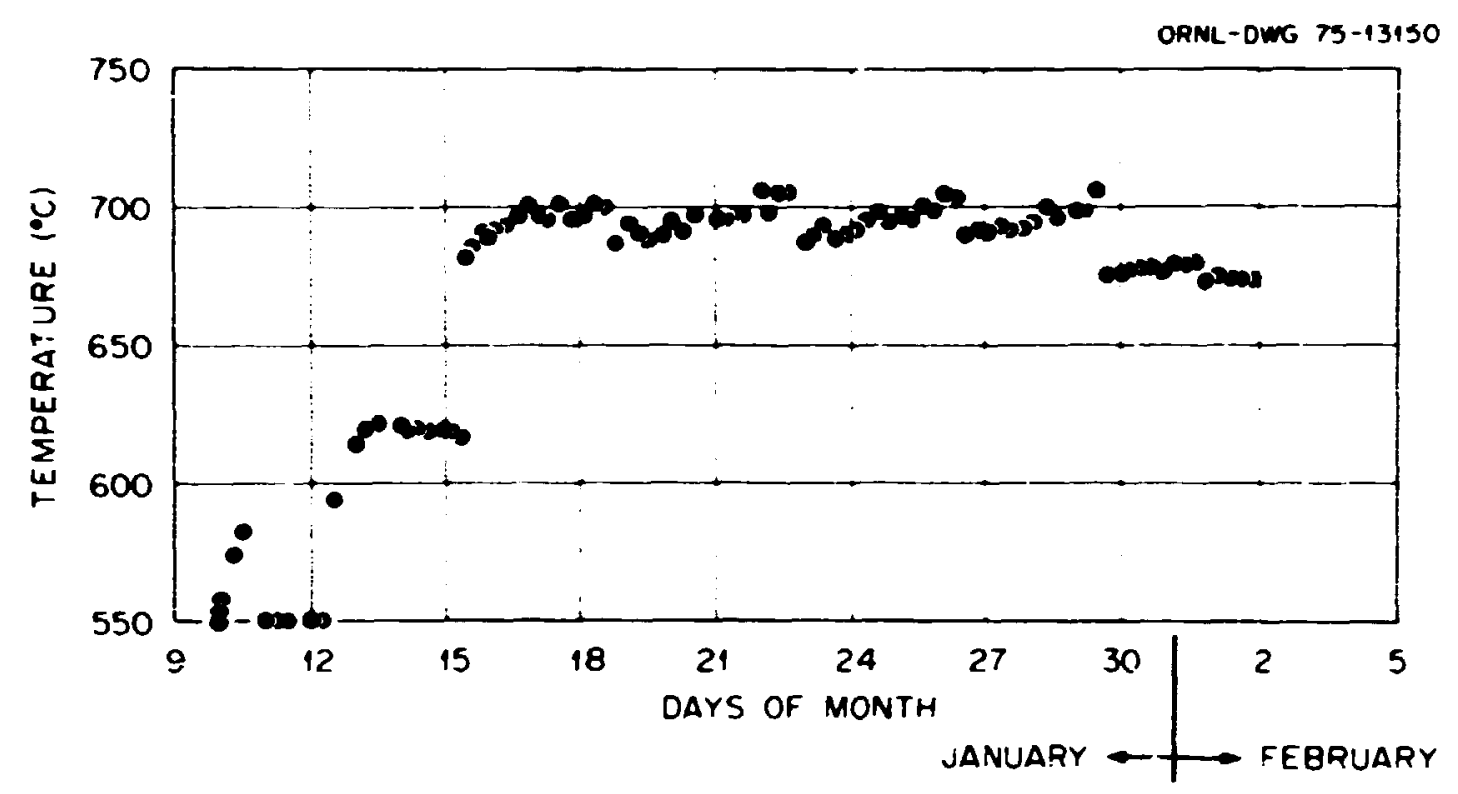

Fig. 7.14. Konsured Iemperature at ibermocouple TF-101 in capale HRB-5 doring HFIR cyck 87 - cyck 5 of a 5 -cycke insdiains.

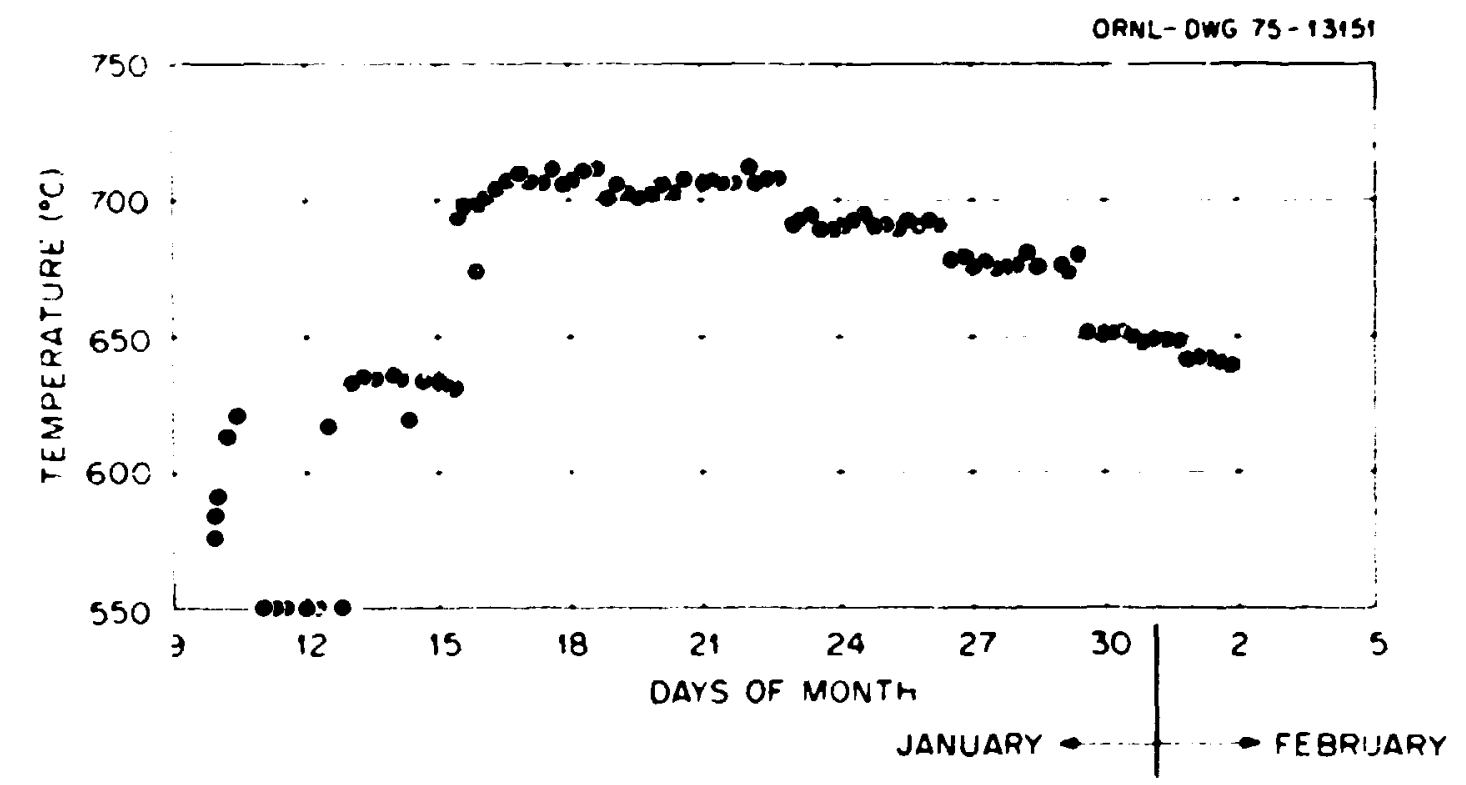

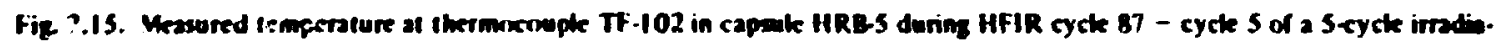
tiven. 


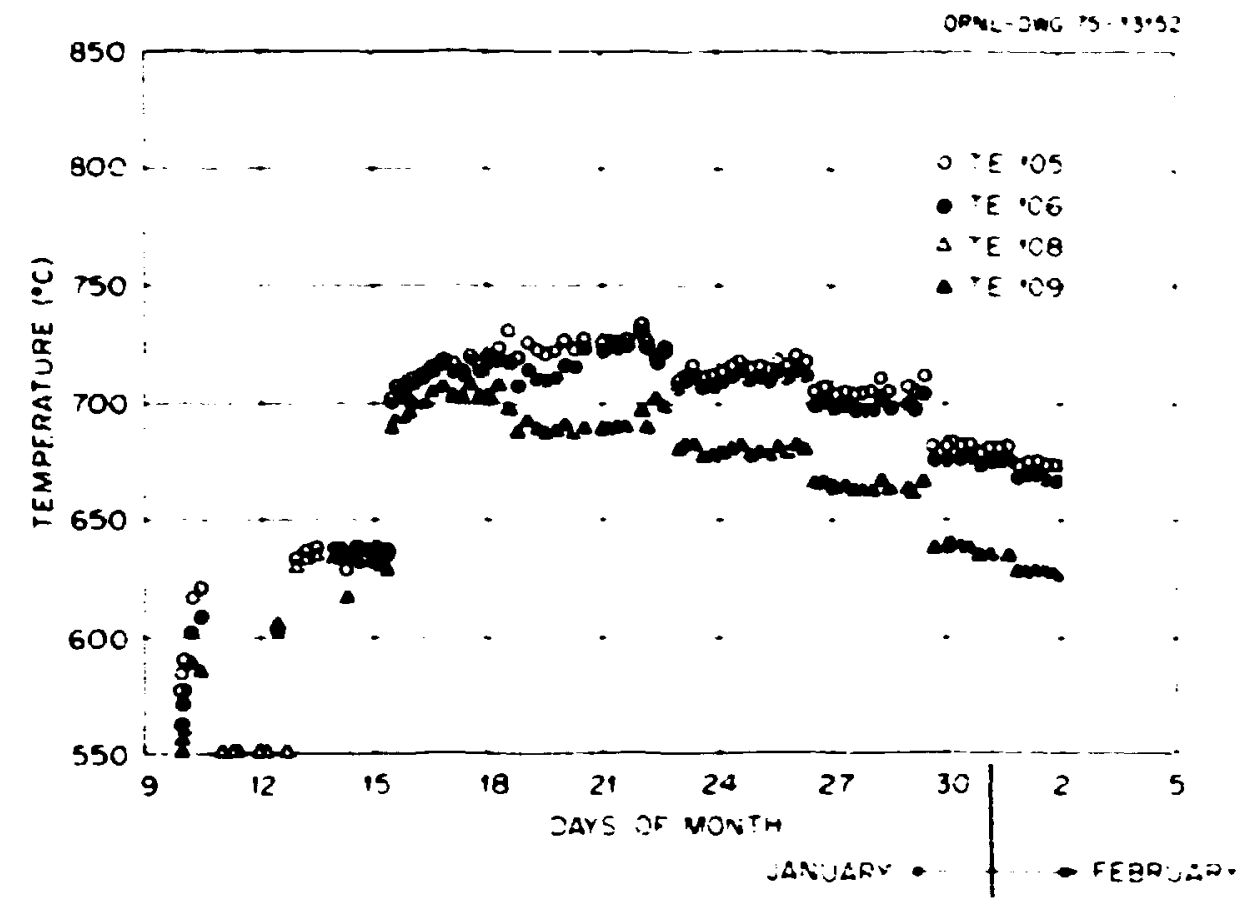

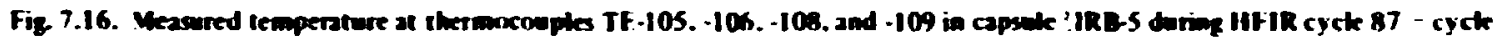
S of a s-rycte inradiation.

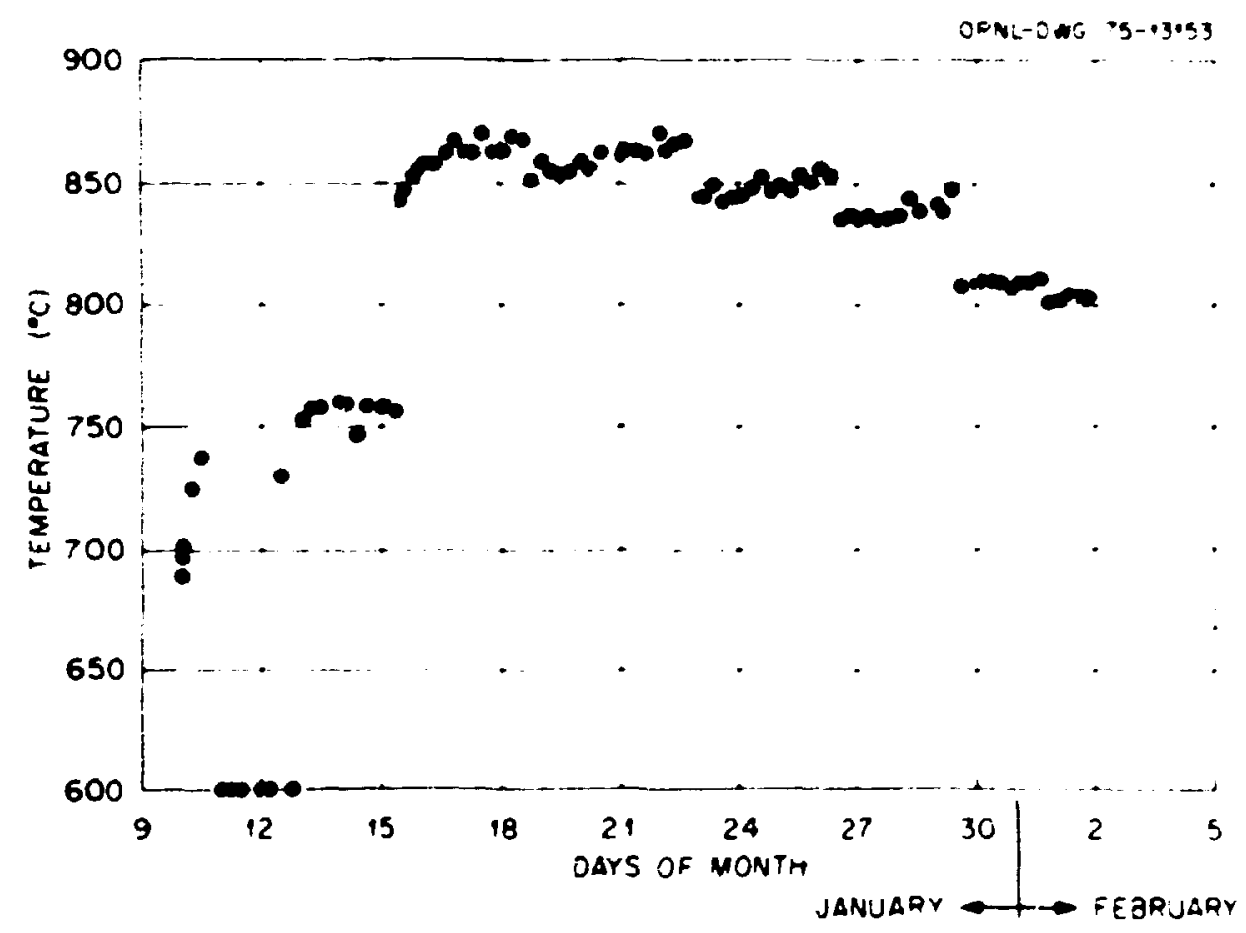

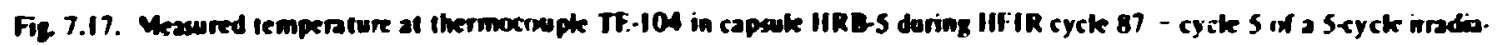
tirm. 


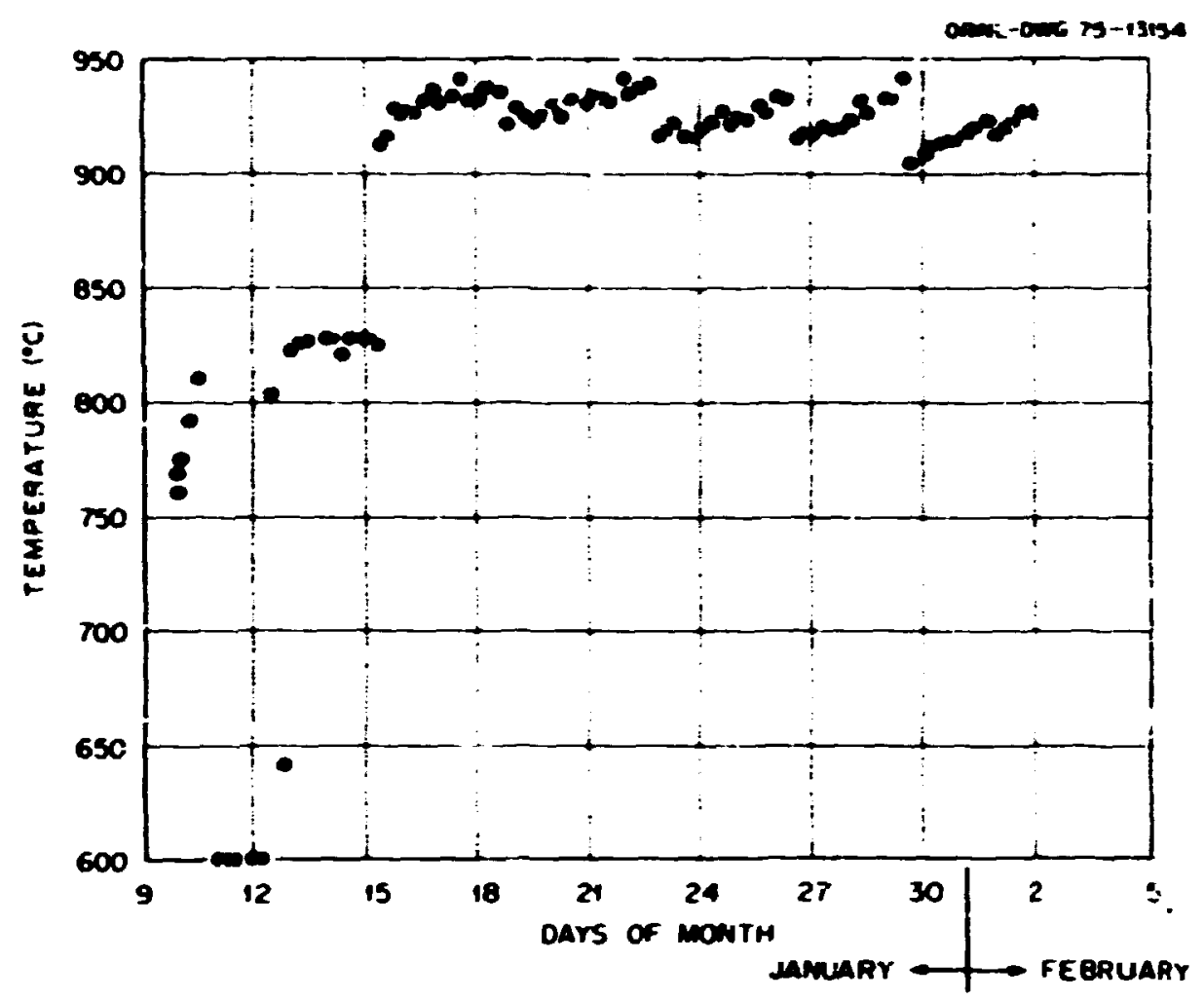

Fin 7.12 :" $\sin$

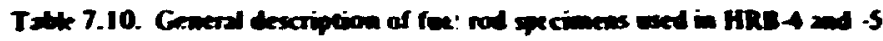

\begin{tabular}{|c|c|c|c|c|c|c|c|}
\hline \multirow{2}{*}{$\begin{array}{l}\text { Spricumen } \\
\text { No. }\end{array}$} & \multirow[t]{2}{*}{ Suppleed } & \multicolumn{2}{|c|}{ 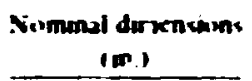 } & \multirow[t]{2}{*}{ Matm mitenul } & \multirow{2}{*}{$\begin{array}{l}\text { Partick } \\
\text { molume } \\
\text { hudrix } \\
\text { i, }\end{array}$} & \multirow{2}{*}{$\begin{array}{l}\text { Fobrkitmon } \\
\text { kcthnuque }\end{array}$} & \multirow{2}{*}{$\begin{array}{c}\text { Catbiniratkr. } \\
\text { monde }\end{array}$} \\
\hline & & Dumcter & Lenẹth & & & & \\
\hline $\begin{array}{l}\text { IA } \\
\text { IB }\end{array}$ & ORNL & $0+90$ & 175 & $\begin{array}{l}\text { Rubunson } \\
\text { prsphilined anke } \\
\text { snd Varium }\end{array}$ & 32.5 & Ixtrusmin & $\begin{array}{l}\text { In cinvered } \\
\text { oraphise ts }\end{array}$ \\
\hline $\begin{array}{l}2 A .+A \\
2 B .+B \\
2 C .+C\end{array}$ & Gar & $0+90$ & 1.0 & C.AC matervals' & $5 \leq 58$ & Admu & $\begin{array}{l}\text { In binck } \\
\mid \text { |H-32i) }\end{array}$ \\
\hline $\begin{array}{l}3 A \\
3 B \\
3 \\
3 D\end{array}$ & ORSI. & $0+90$ & I n & & mo 62 & $\begin{array}{l}\text { Slup } \\
\text { injecturn }\end{array}$ & $\begin{array}{l}\text { In packed } \\
\text { ulimmd } \\
\text { In hlokx } \\
\text { Ill.327) }\end{array}$ \\
\hline
\end{tabular}

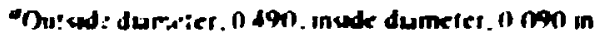

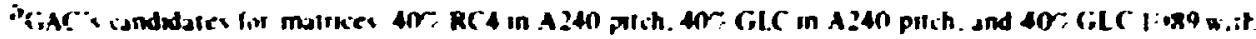
Thermu in A240 pulch

- loir Si Vran reference 
matric s and two difierent arbunuation monles i Tabic

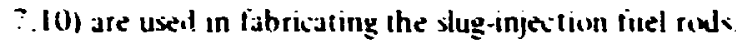

The arrangementit it in: fuel rinds in the apsules is shoun in: Fig. .2. The ther OR.il extruded row's were licated at the eop of the ispsule followed by three itc liue! rouls, the lin: OR.IL slug-injected tuch rods. and thrie additional GiAC rods. Silice the G.tC tuel ruds were returned to :heir hut isli factsty for eamination. there will be no turther mention of them in this disas:siun.

Capsules HRB - and -5 were in the HFIR fo: 5 and $I 1$ iyiles respectively. The litel rods operated at an average desigi leat rating of $5 .+\mathbf{k W}$ tit. The iuel reds in HRB 5 reached a peak fast tiux of abuut $5 \times 10^{21}$ neu. trensing $\mathrm{in}^{2}(\because>0.18$ MeV) und a burnup of about $16 \%$ FIMA in the tissile particles. Fuel rods in HRB-4 reached peak iast tluenies and hirnups about twite those of tle iuel rods in HRE.5. The general appearanic of the fus riols was good; only one rod from HRB-t (tuel lod $\mathbf{3}$ ) showed evidence of debonding. The sta.tuni correlation of tuel rod dimensional shange witl. fast thence $1>0.18 \mathrm{MeV}$ ) is shown in Fig 7.19. As

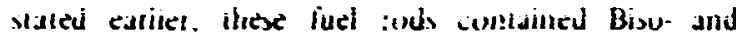
Trisozoated particles: the particle volume loading was to to 6? for the slug-injected rods and about $30 ;$ for the extruded rods. Th: matiix densities were about 1.7 $\mathrm{g} \mathrm{:m}^{3}$ lior the extruided rods diad ranged from about o.t fo $\left(x \leq \mathrm{m}^{3}\right.$ fior the slug-irjected rods. The onset of anis. Ir.opli shrinkage expected in the extruded rods wa: observed at aboul $6.5 \times 10^{\prime \prime}$ neutrons $\mathrm{cm}^{2}$. ihe surprising result was that the lose-packed (slug-in jected) rods showed the samf, anisotropic hehavior. A check of the dimensiors of tilc slug-injected green rods is arborized is annealed reds showed no trend l. wasd anisotropic shrinkage. On: way to explain this ctlect vould be to assume that the matries of the slug-injecicd rods as weli as :he extrucied ruds have a preferred orientation: and at tluences above $0.5: 10^{21}$ nellIrons $\mathrm{m}^{2}$. Biso catings will have densiti:-d suficiciently that the matrix becomes tie cont rodling ficiur rasulting in anisutropic shrinkage of the slug-injected luet rods. The continuous inatrix of an extruded rod is always :he controliting strunkage factur. since the volume of th: rod ociupied b; coated particles is only abot: $30 \%$.

Me'allographic seilions of the sluginjected fuel rods were examined to determine the effect of the arbonnization technique on the irradiation performance if the three matrices. No broken cosi:-las were found in iile rods containing the Fort St. Vrain (FSV) matrix (? 4 ) , r in the one with the experimental mattix carbonized in packed $A l: O$, $(j i$. However. a significa. sumber of the pyrolyticarabon coatings in the rods with the experinental matrices carbonized in graphite tu.Jes $13 \mathrm{C}$ and 3Di had failed as a result of partic:-matrix interaction. Examples of failed Biso and Triso cratiigs are

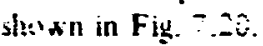

Examination of the as fabricaled rods contuining the OSV.lype and experimental matrices that we:e car'onized in packed $\mathrm{Al}_{2} \mathrm{O}_{3}$ revealed that in each cas.' the matrix was very purous and the individual graphite tiller particles were discernibls. Matrices of the rods arbonized in graplite tubes were much more dense. and ihe individual filler particles were not disiernible. The dencer matrices resulted from higher yield of coke from pit:h in the rods carbonized in graphite lubes. The as-fabrioated rods with the denser matrices sarboniced

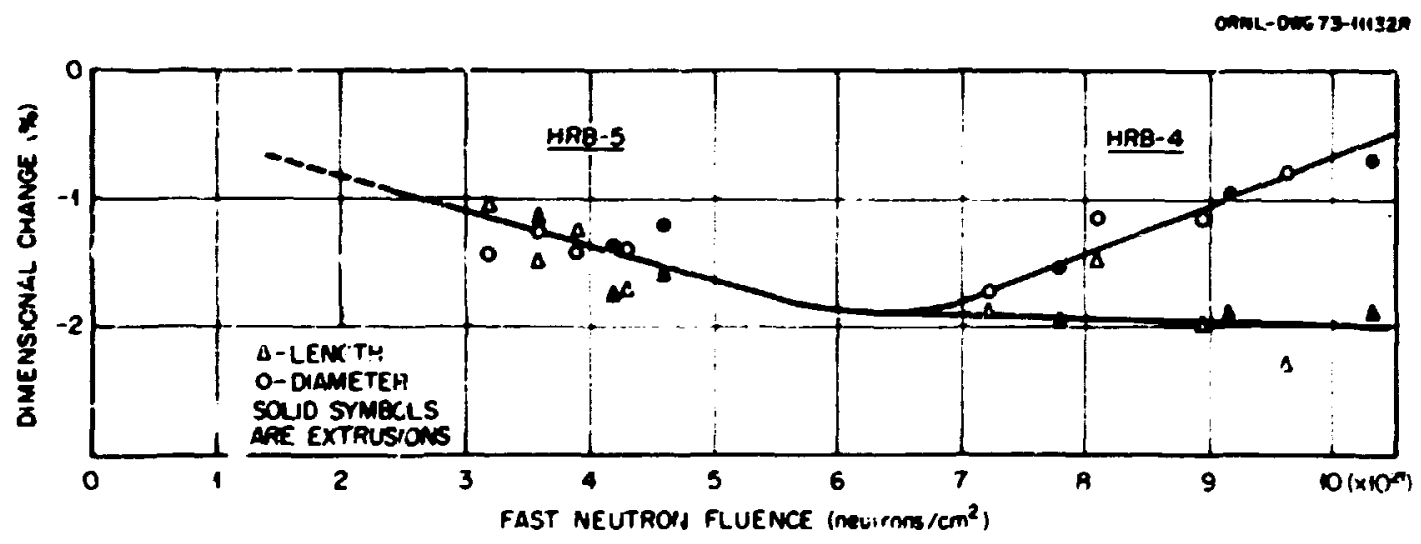

Fig 7.19. Dimensinal changes of fitel rods from HRB-4 and -S experiments. 

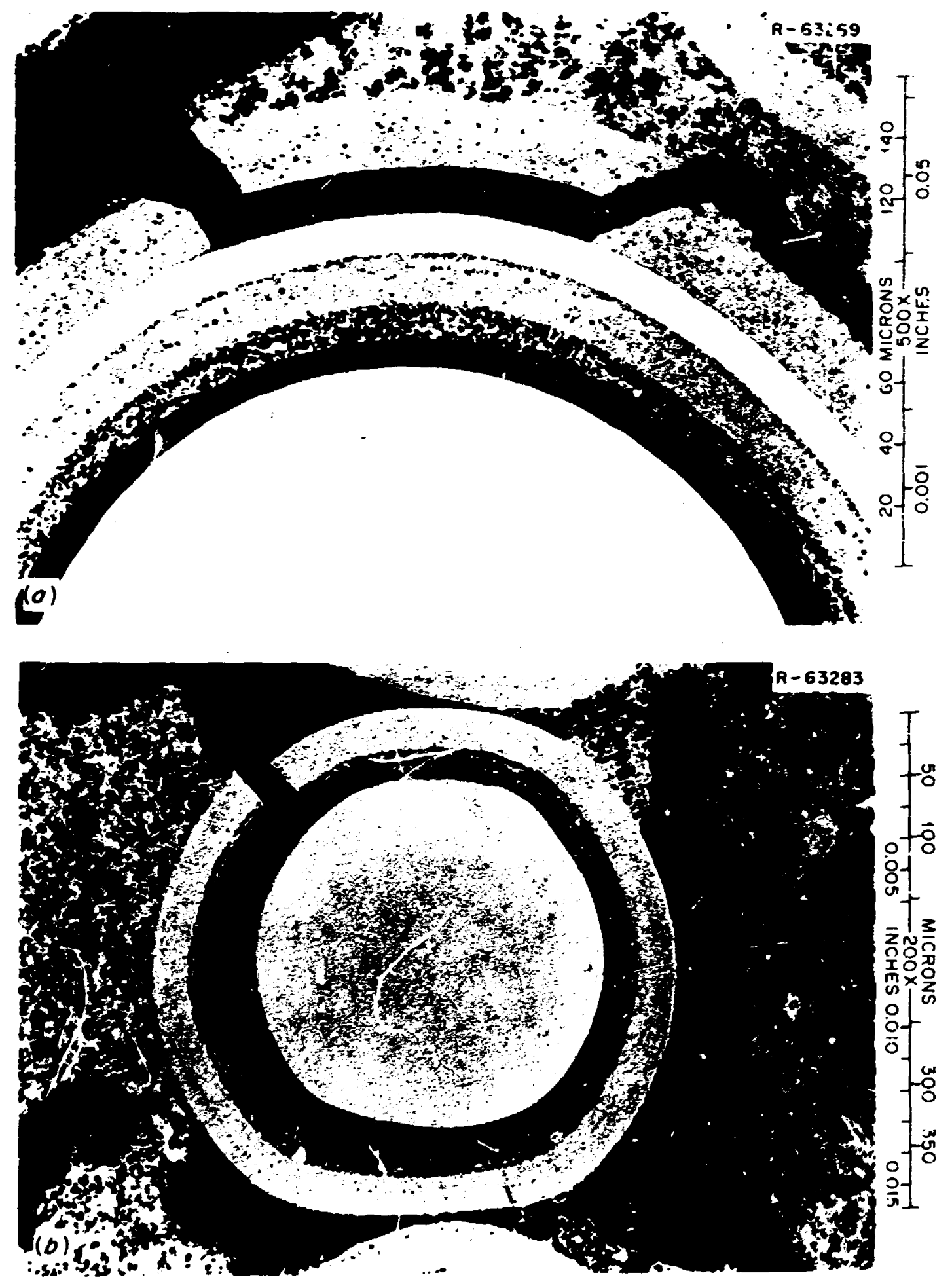

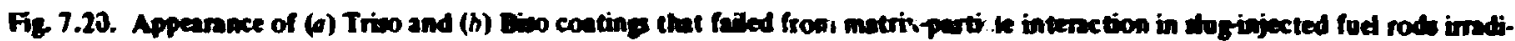
ated in HRE-5 
in graphite tubes cintained partisles with snisiti tears lsee Fiy. 7.21 in the outel coatings of the Triso-and ioisosiosted partisles. Thes tears initiated costing tilure as the matrix and cuating densified with tist-tiux dimaze.

Metallugrapitic examination of -sctions threugh th: extruded fuel rods revezled tinat \& signifiant number 1 - Stci of the SiC coatings on the Triso-ioated fissile kernels contained iracks. None of the SiC layers on the Trisizioated inert kernels exhibited sracks. I The thikness if the SiC iayer was aboul $15 \mu \mathrm{m}$ or the inerr particles and :2 $\mu \mathrm{m}$ on the tissile particles.) Close examination of the arihive sample revealed that fine iracks were present in the $\mathrm{SiC}$ layers on the fissile Darticles of the asextruded rods and were exagerated by irradiation. Sone of the low-temperature isotropic (LTI) outer layers on the fissile particles had faled. although a few $\left(\sim 2 r_{c}\right)$ of the inner LTI coating had ijiled in particles that contained cracked SiC layers. With the exception of one craked Biso inert particle. none of the Biso-ioated particles showed er - nce of potential failure. No chvious shanges were whserved in the matix as a result of the irradiation test. noi was th.re any evidence of particle-matia : entern-tion.

inus. it appears that inblixh iarounizition has fresented sime unexpetied problems. Also. there are inparent problems with tine extruded fuei roxis. since an unjiceptable traction of iraiked SiC layers were present in the Triso fissile particles in the as-fabriated condition. Irradiation testing either in-reased the number of iraiked Si layer: or merely enhanied them so that they were much more readily deteited.

Metaliosuphic examination of the fissile particles contained in the slug-injected rods that $x$-hieve $t$ fuil HTCR thuence revealed several potential problems for the $\mathrm{SiC}$ layers. The kernels of the fissile particle were compusad of WAR particles that had been :- inverted (I) 95. LC? The surfizes of the fuel rods were ab.ut $950^{\circ} \mathrm{C}$. an the center-line temperature was about $1250^{\circ} \mathrm{C}$ during the time of peak fission heat-genzration rate while in the HFIR test fxility. The foel rods reaihed a maximum burnup level of about $27 \%$ FIMA

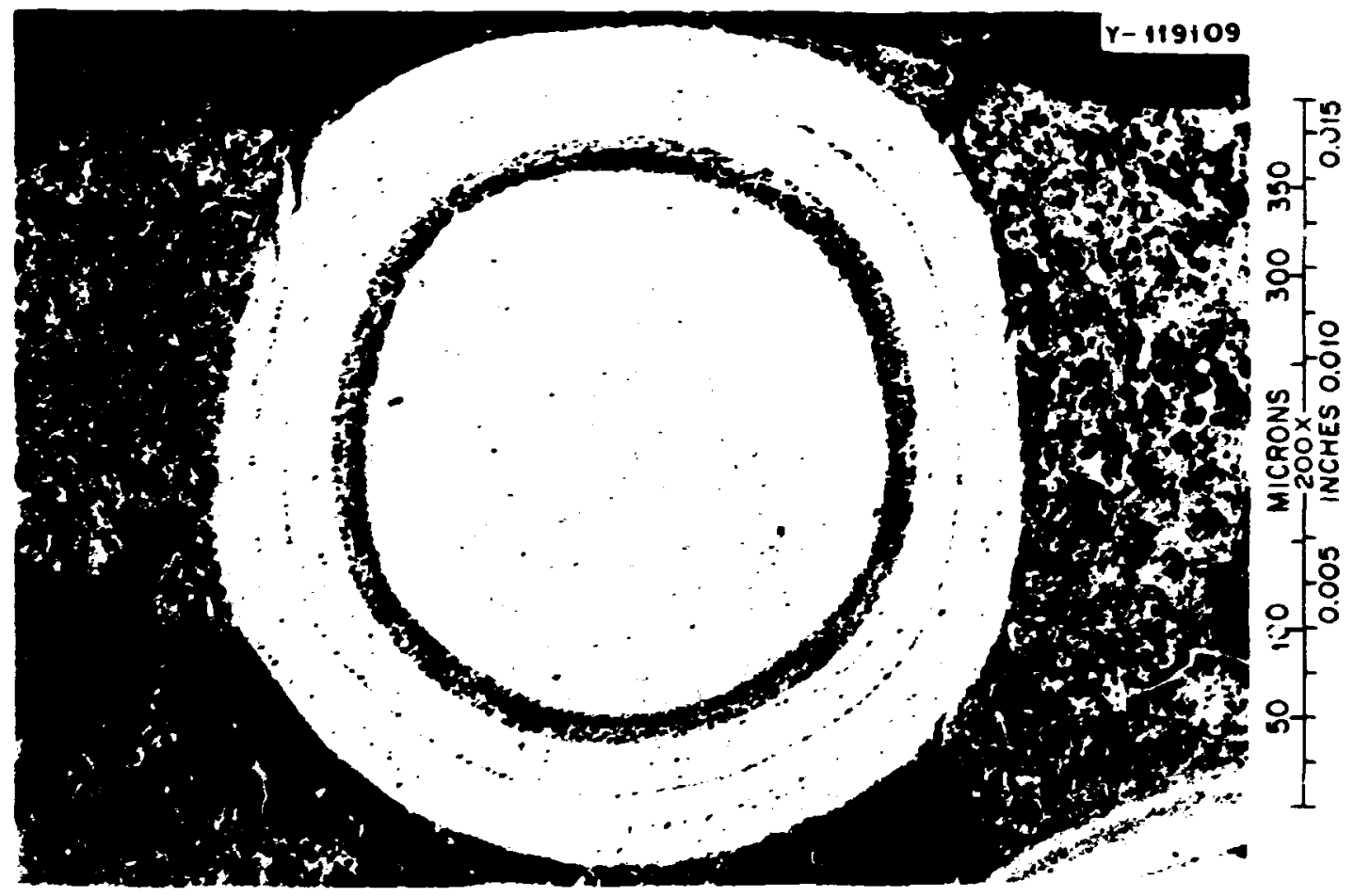

Fig 7.21. Unimadiated Trieocoated particle in control fuel rod for HRB4 and -5. (Note small tears in the peripheral region nf the outer coating.) 


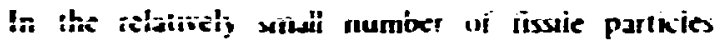
expined in the planes of pudish. at uut one-third shows evidence of attak in inner surfike regens of the SiC layers. This attack appears as ivalized reganns ond is met dependent on the temperatura grauient. The altaik varied in degree of severity frum only sligh: to connpiete penetration of the thickness of th: ST A reneral dagradation of the inner surtize of the SiC was alus apparent in many of the cuated particles. Anaiysus of a region of altak with the aid of an ekitron mikiprobe reveled the fision product palladium to be the -riprit. The results of this analysis are shown in Fig. ?.2" Sinice the attakiked regions appeared to have been molten. 2 -l:ak with a palladium-silioun phase diagram showed three euteitin's that have melting puints below the surfaic temperature of the fue! rads 115.5\% Pd. mp $800^{\circ} \mathrm{C}$ : approximately $45 \%$ Pd. mp $720^{\circ} \mathrm{C}: 585^{\circ}$. PJ. mp $850^{\circ}($ ). This result would be atypical of HTGR conditions. since the bulix of lie palladium present was

S. Max Hansen. Conritutio: of Binery thors. p. 1126. Mefica-Hill, 2d ed. 1958.

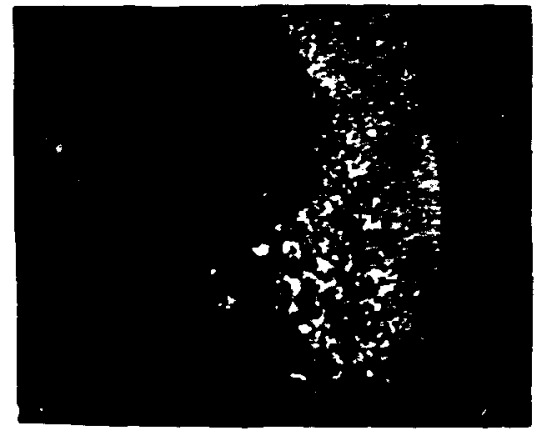

Optical Mierograph

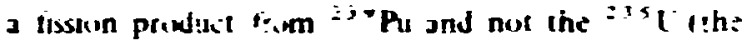

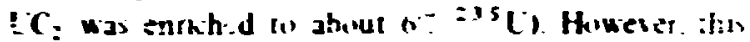

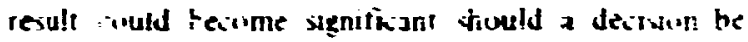
made ta in'upurale pluin.um in the HTCR tuel as as

In aditition to the sbust friblem. abuut one-fisurti of the LC: kernels appeared w, have been molten and were in intumate wrot with the inner LTI valing. and a metalin-like ifout had aliaied the SiC auting. vihougti nos SiC cuating had taled as a result. up in one-hali the thikness of the SiC appeared lo sase hoen

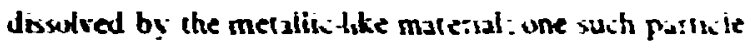
is shown in I iz. 7.2.;. The results irim an elestron In:-roprot a salys: of une of the muiten kerne? is shown in rig. 7. 4 . The rare earths La. Ce. Pr. and Mi were the fissiun proxi ats suxiated with the linalued dissulution of the SiC layer. Nine also, that uranium was not associated with this ieaction zune and that there ts no chvious comientration af silicosn in the kernel

The rareearth lission products were also found concentrated on the inner surface of the corler side of

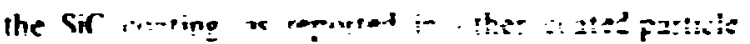

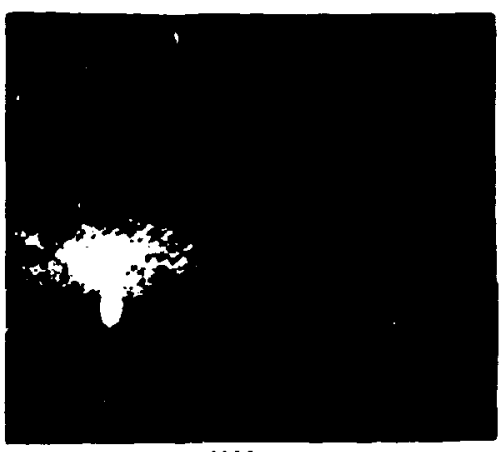

I) $M$

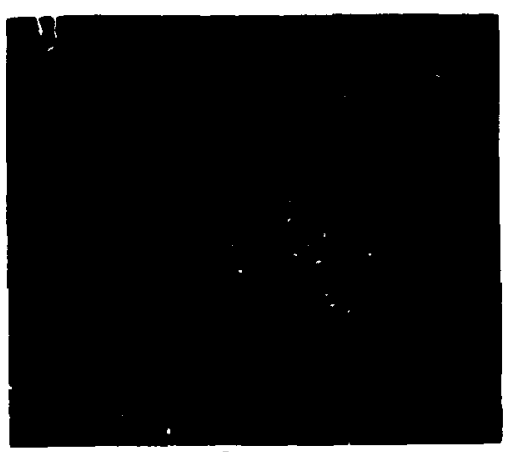

Pdto

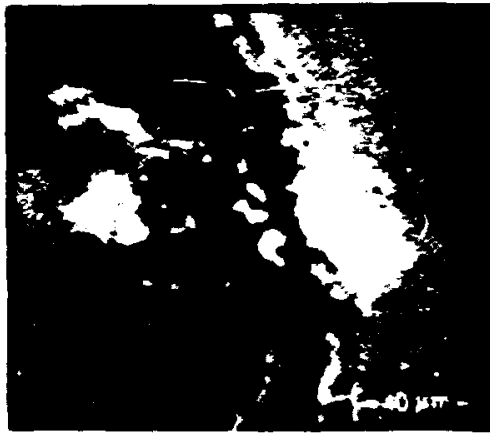

Jacksciviered Electrons

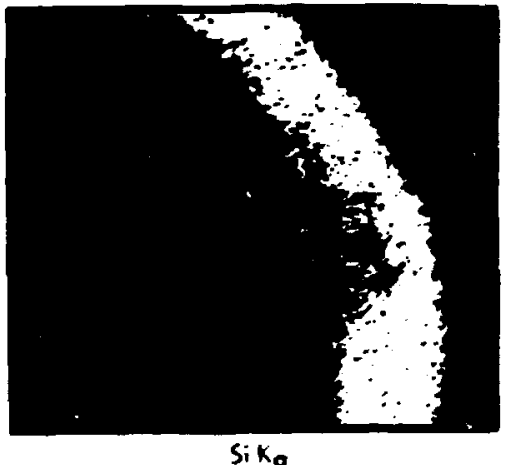

Fig 7.22. Palledium-gidicon cerbide reaction in a Trisocosted paricle from HRB-4, fuct rod 3A. 

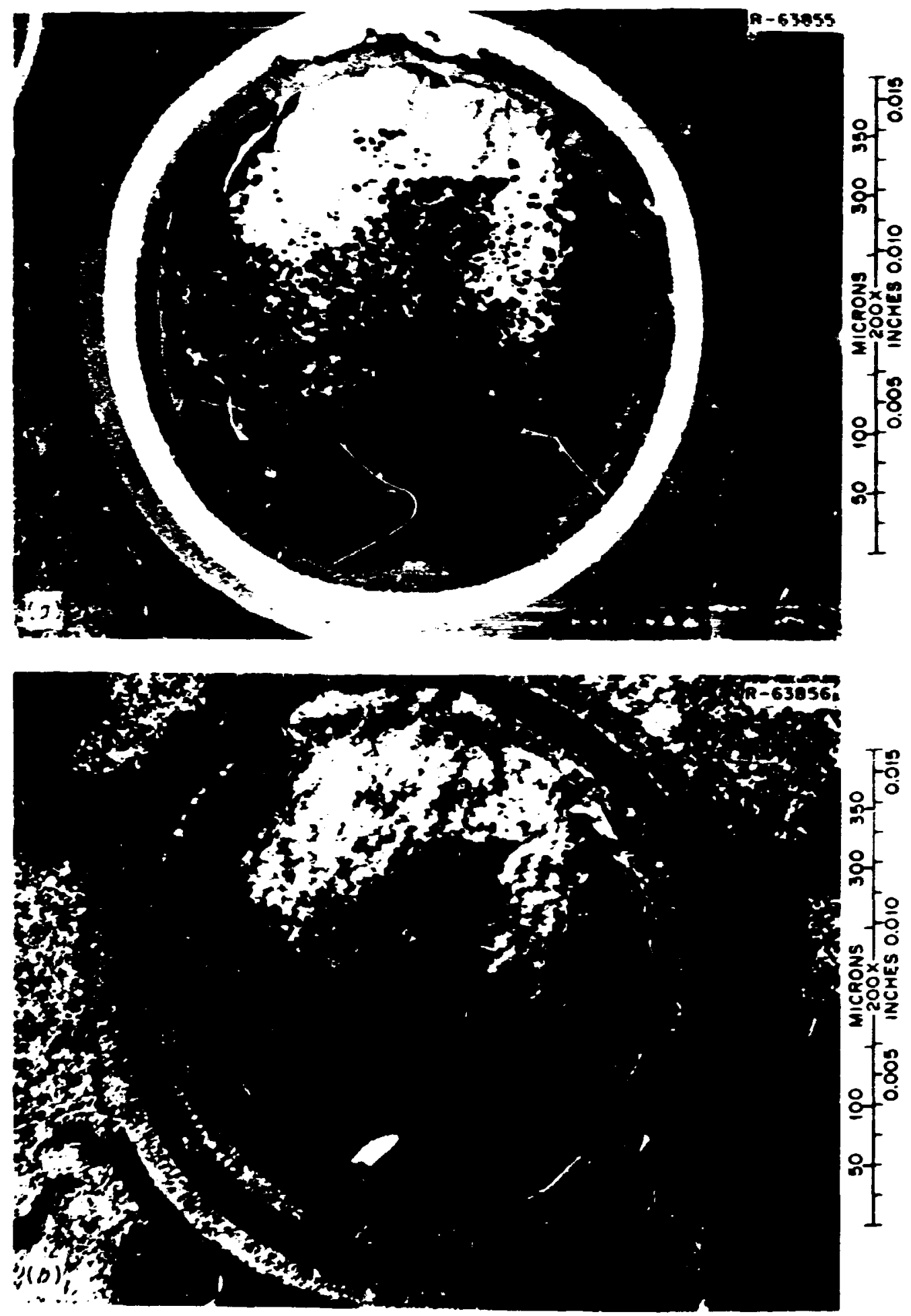

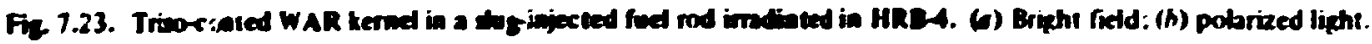




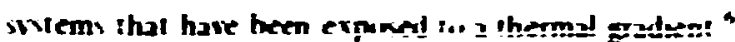
The piesenie of the rate earth led to penetratr.n il stwist halt the thkiknesw of the SR satung. Attaks by thith this are earth and paladium are vinewn in fig I:

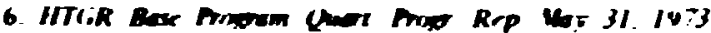
(j2161-11259. pp. 8793

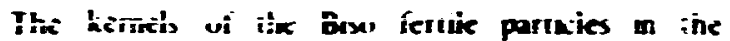
suetnpated fuet rod iA frum HRB 4 exhibited 2 shght "sminta" effect The ThO, kernels had migrated abusut Y0 $\mathrm{mm}$ it less. Altivugh there as mo measurable monemert of the Tho: kernets in the wher thrce fued rod. ine densified bufier reial zone was molkezbly darket in the hot sude of the ketnet. An eleitron mirupribe analyus taled to dera! any iteme-al

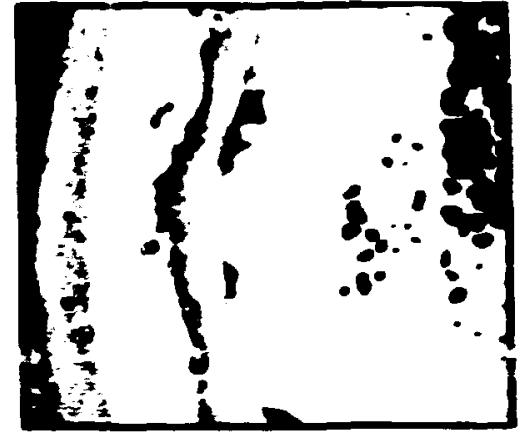

Ce*ic = Ptepograst

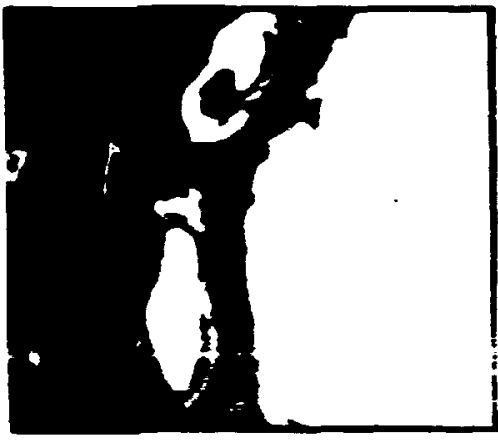

Bockscolveres 5 ect: $=-3$

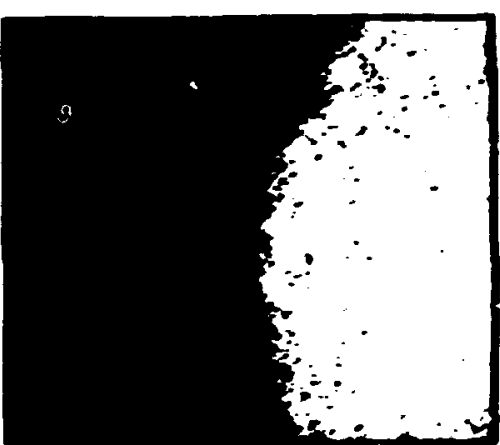

u Mo

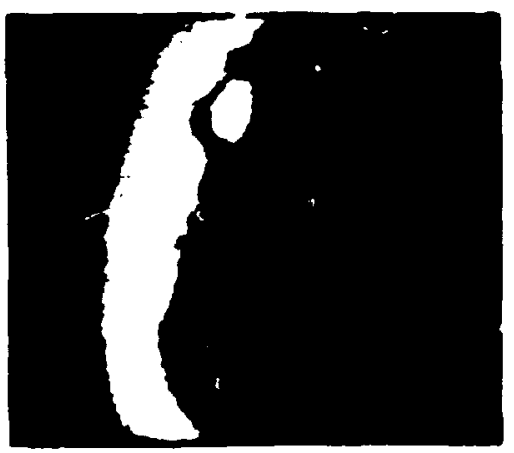

Si Ln

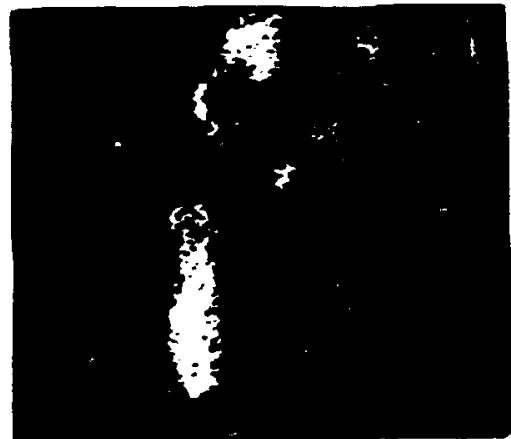

Lolo

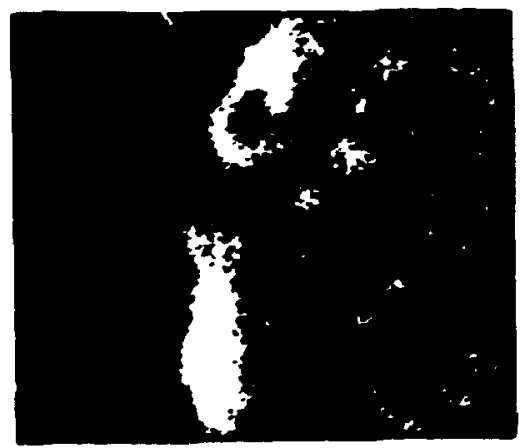

Ce ln

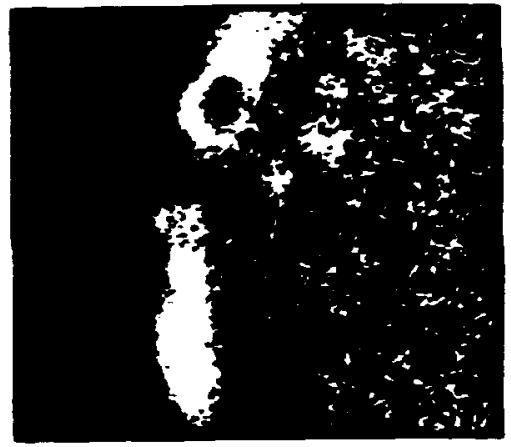

PrLo

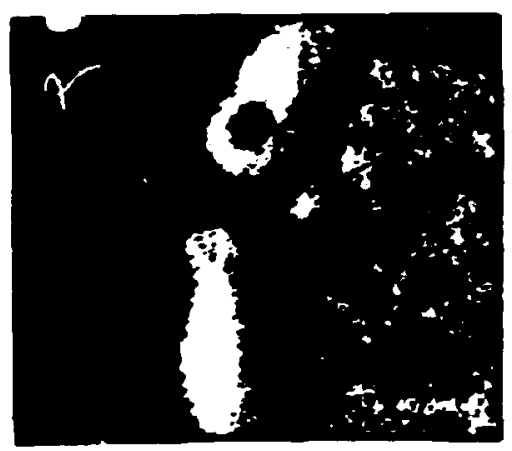

Noto

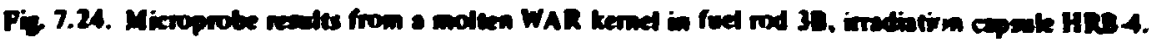




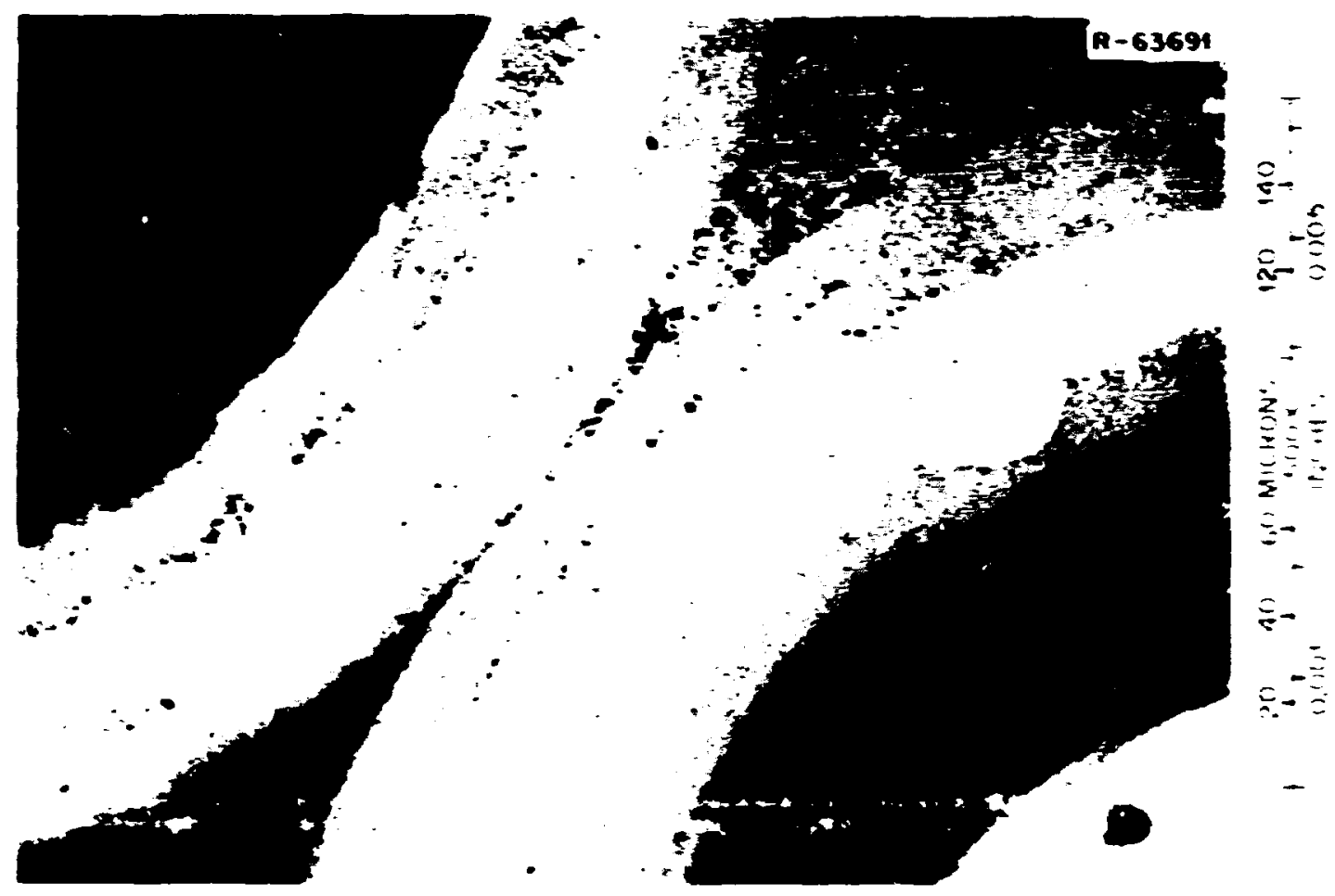

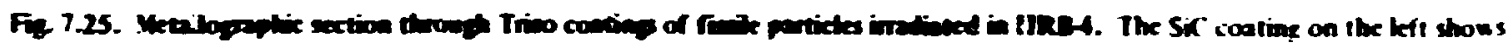
the resalts of attact by rarearth fision products; the SiC coatine on the ripht shows attact oy $N$.

jifie:eme between the hot and cold side of the butier layer.

The extruded rods operated at a higher heat rating and in a higher tlur than the Jug-inkited rids. However. the overali tempetature of the extruded rod was lower thun that of the slug-injected rods becuse of the higher matrix density. Metalkgtaphy showed that the WAR kernels had densified, as expecited: but in contrast l. :he fisilie particles in the vug-injected rods. there was ni evidence of fission producl attaik on the Sir layers Alıhough only a relatively few 123 , WAR kernels were exporsed in the plane of polish. there was no ilear evidence that any of the kernels were in the molten state during irradiation. Examinalson of the iertile particles showed no evidence of the "amoeba" effect or indication of potential failure.

\subsubsection{Capoule HRB-6}

\section{R. L. Hamner}

The sixth capsule in the series of HTGR.HFIR irradiation experiments in the RB facility (RB-5) was inserted in March 107?. The cipsule. designated HRB-6. was instrumented and swept with inerl gas inixtures in order to monitor the fuel pertormance. The experiment had five main objectives as lidlows

1. II compare the irradiation behavior of Bisucioated 4:I1Th. ${ }^{23} \mathrm{CNO}_{2}$ with Biso-iosted 4: IITh. ${ }^{235} \mathrm{UXO}$ as lexse parlicies and in bonded ruds:

2. I1) supply samples of particles containing ${ }^{23} \mathbf{L}^{3}$ and ${ }^{235} \mathrm{U}$ for sludy of fission product retention within the cuated particles and within a carbonaceous malrix:

3. In determine whether ihe differing fission product specira from ${ }^{233} \mathrm{U}$ and ${ }^{235} \mathrm{U}$ affect the carbon transport and kernel migation within coated parti. cles:

4. II further test fueled specimens prepared by exiruwon. sug injection. and intrusion bonding for dimensional stability when irradiated to full HTCR fuence:

5. 11) continue testing of ultrasonic thermometers as a means of measuring center-line temperalure. 
Cupuie HRBor we stmis: w HRB i except that the tuel indang answied inly of highly enthhed mixed vide finule partale and ThO: ierike partaken in ultramen thermume:er wo uxed Io monilus the rut - en:Ial emperature. on in HRB-5, and the ritemn of

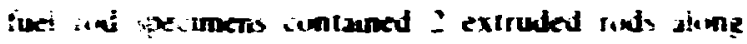

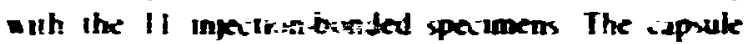

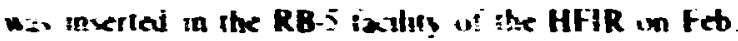

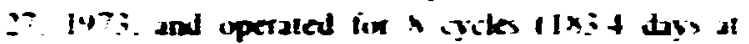

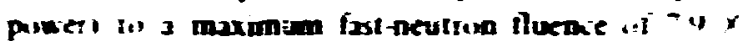

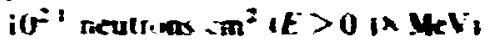

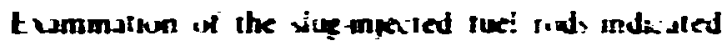

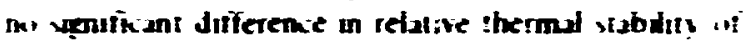

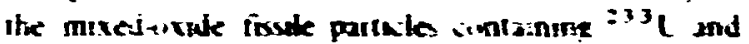

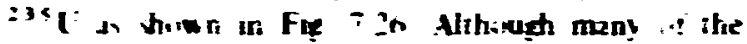

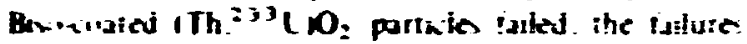
-ere selated th: the propertice of the cuating in th: butch Buil: types of kernd mystal uf ithe tempera. ture gradient + max'mum dstanie of 20 11 .5 pm. but n., wher suletse effeits wete muled (imparixnn wi the

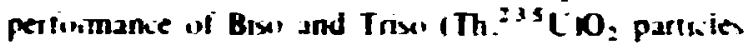

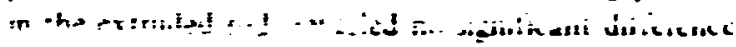

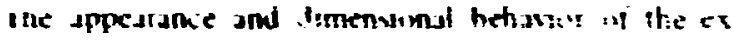

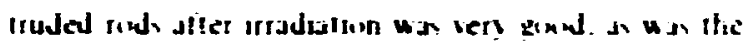

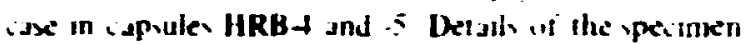
charniernth. apsule speration. and iuel periormance culualion ste being impaled in a xeparate report."

\subsubsection{Capsoles HRB-7 and 8}

\section{R L. Hamner}

The seventh and eighth iapsules in the series of HT GR.HFIR experimeits in remivable beryllum (RB) ixiluties are xhedule; fin insertion in early 1974 afier presriddation in a permancnt beryllium (PB) faility for Iwo cycles. The preirradiation was considered necisary beiause of the high initisl power densitics calculated fir the rily enriched fissile parlicies if placed in in RB fach $y$ at the beginning of the experiments. To aroid this. the amules will oe irradiated in the PB facilits. whe:e $-500^{\circ}$ of the 2350 will be burned aut hefure reanusal wh the RB inility. The iapsules. Jesignated HRB 7 and $-*$. are similar to thase for previous HRB exporments in that they will be in:Irumented and swept with inerl gases in order to monitor fucl perfirmance and control lemperalures. The capsules are dentical with regurd io types of specimens. hut their

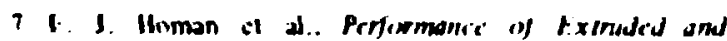
Sux-Inkifed fiud Rind Sperimens in Copsulc IRA.n. ORNI - TM in prepardikn)

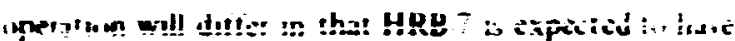

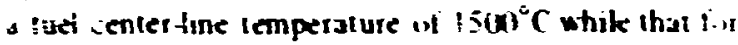

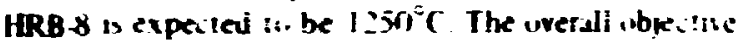
in thexe experanents is lu siter a relistrely latge number ui ispes of irsske partule tu periumanic $t i$

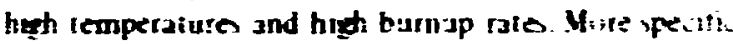
ibretives jue guven beline

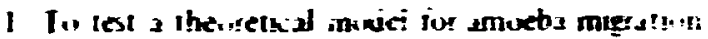

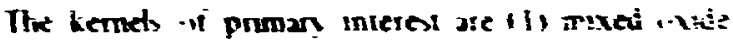

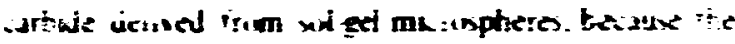

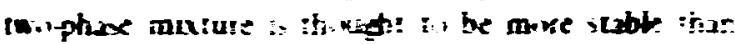

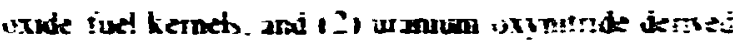

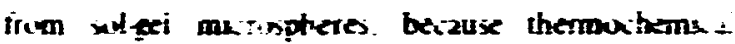

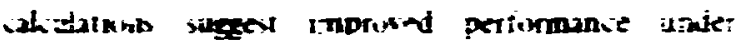
HTGR anditk in of therke ind temperature A wa

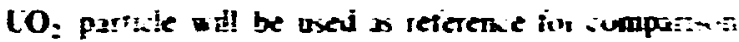
wit: ine wher !wingutikes

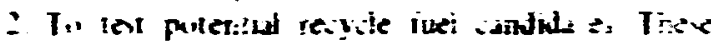

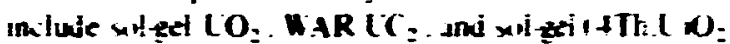

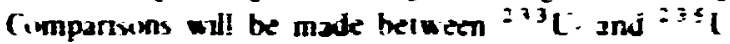

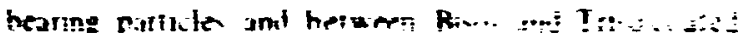
tras:icic

i. To sishlish the relative sisbility o: mixedunde

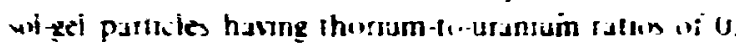

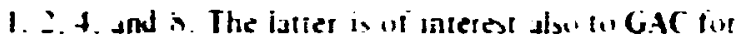
iirst core losadings.

4. I" tesi aduanced colting : iesigns trom GAC in which ZrC is substituted for in in their reference makeup particle

5. T. compare the performanice of a HAR $\mathrm{CO}_{2} \mathrm{CC}$ : particle to that "if the G.AC reterence makeup particle at very high iemperalures.

o. Tu resi mixed-ixide fissile particles prepared in a production-size : iater 15 in diam).

7. To test a multijunction lungsten-shenium thernus. couple fir meisuring ienter-line temperatures al dif ferent loxations in the capsule

\section{Desion}

Capsules HRB. 7 and -8 are identical and are similar to the capsules HRB 4 . -5 , ano 6 . The differ only in the iueied specimens. the graphite sleeve dimensions. and the use of a new central thermocoupie concept.

The apsules have 19 fuei specimens each I Fig. 7.27). Instead of adjusting the tivermal resistance of the gas gap to compensate for the axial sariation in thermal llux. we adjusted the specimen fissic and iertile material content wo as lo approximate a unifurm axial heat generation. With this type of loading " was parsible (1) use a uniform gas gap and eliminale the 

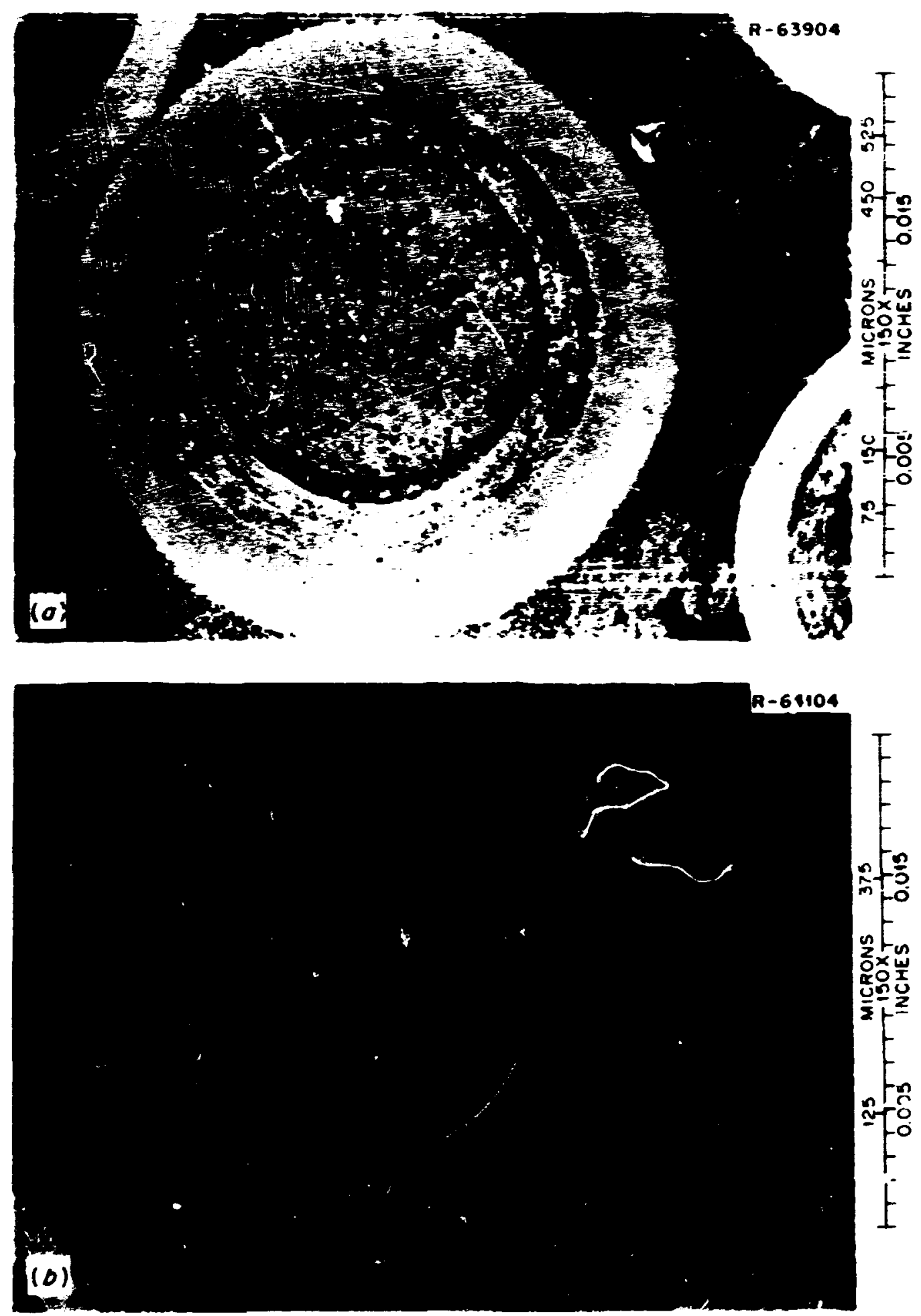

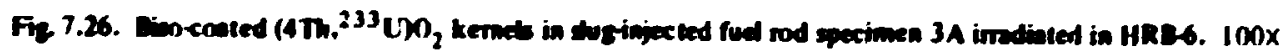




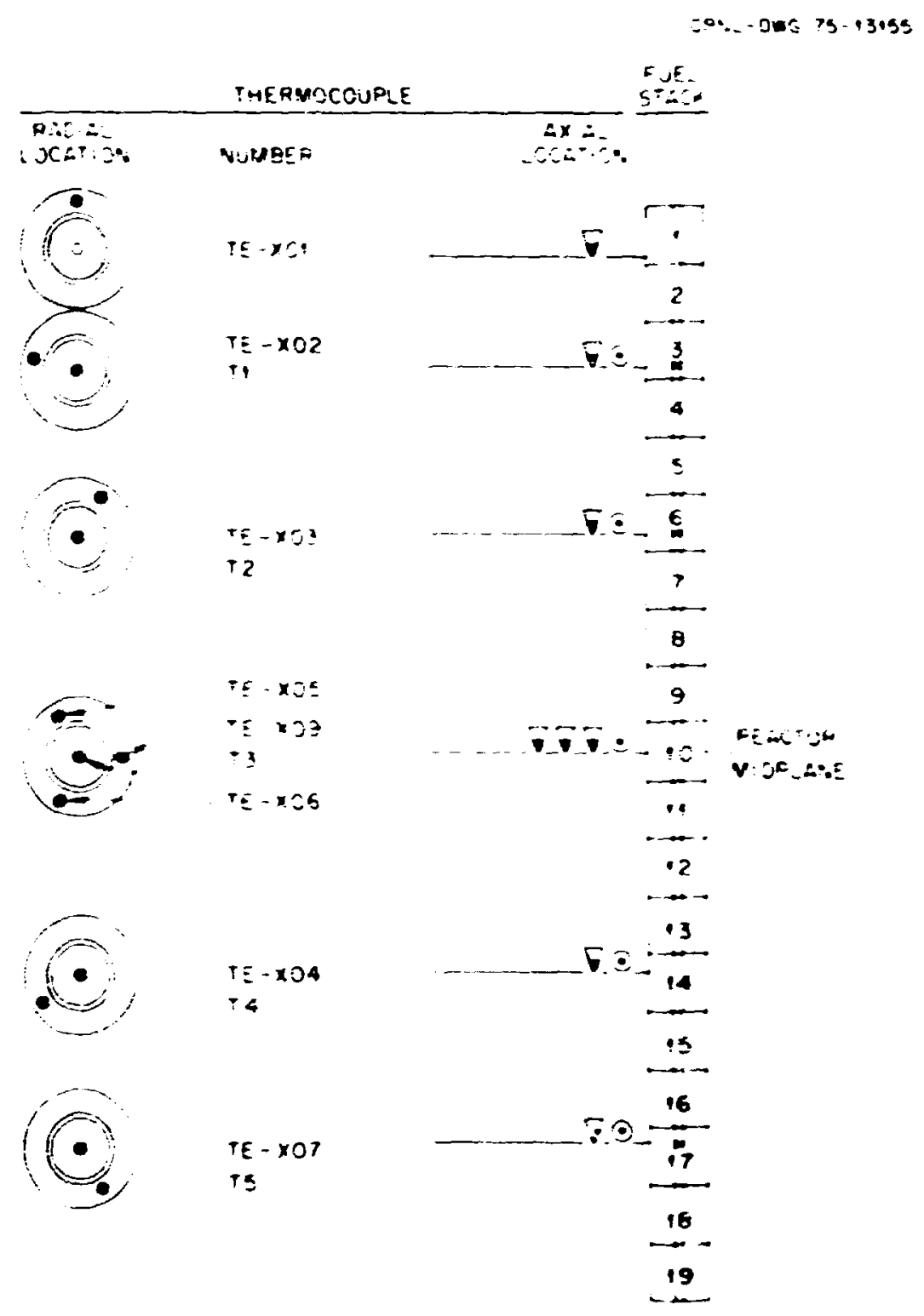

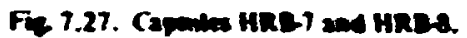

raper on the graphice slecve. The therminiouple lina. iuns are shown in iig 7.27. The graphile sleeve thermoxiuples are slarriess-sleel-sheathed Chromet Alu mel. as has been the care for the previsus HRB , apsules The central lempersiure is monitured hy a spenial five-junition $\mathbf{W}$ 5r: Re $\mathbf{W}$ 20: Re thermoxiouple. All ine fuel specimens have a ceniral hole for this thermocouple. and the junctions are distributed over the length of the fuel collumn. (See Section 7.7 (or delails.)

The propurad shedule fir insertion of earh iapule is
Is !idlows

HRS.7 In PB.1: mid-Deiember 1073 Ous PB-i: first of Fehruany 1974 In RB-7 first of Februan 1974

HRB.8. In PQ.13 first of Febuan jo7t Out PB-1iend if Mach 1974 In RB.5 end of Marih 1974

Insertiun .6: :4RB-7 in PB 1.3 was in sihedule 
The iapsules will be irradiated in the RB inality lo a fast tluence of $8 \times 10^{21}$ neutruns: ${ }^{2}{ }^{2}$ or until $د$ faluse of fuet purtikites as evidenied by bursts of issinnezs retease.

\section{Meparation and characterization of teat preciencess}

A brei desinption of the partictes involved. their purposes in the experiments. and their pusitions in the iarsiter are gren in Tsble $7 \|$ The itharsien/atum,

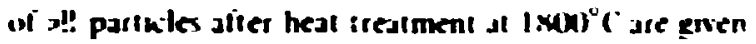
in Table 7.1 2. Par! uiles supplied by GAC were nor hest Ireated aRVL.

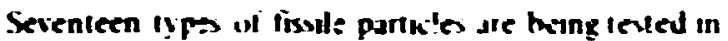
buth experiments. Adriver pantice. " $1 \mathrm{O}_{2} \cdot \mathrm{Cl}_{2}$ was imiluded (..) mannian the desured cmpersture as the

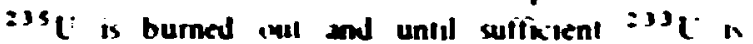

\begin{tabular}{|c|c|c|c|c|}
\hline Pomenes & Kereet tyre & 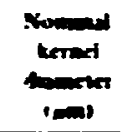 & Cowren ner & Popow a riperomet \\
\hline I & :35ex: $1=\mathrm{mb}$ & 200 & Ime & Cinc metertine \\
\hline 2 & 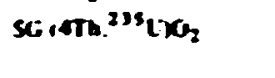 & 350 & $\rightarrow$ & 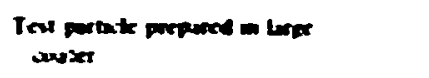 \\
\hline 3 & $S C=35 \mathrm{NO}_{3}+\mathrm{l}_{3} \mathrm{~N}_{3}$ & 900 & ove & 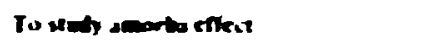 \\
\hline 4 & $c_{1}^{238} 10_{2} \cdot 1 r_{1}$ & - & m. & 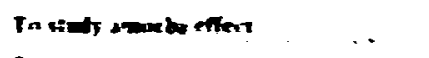 \\
\hline$s$ & $\operatorname{sc}^{3 \prime} \mathrm{vx}_{2}$ & $2 i j$ & مسm & " \\
\hline - & $\operatorname{sc}^{23+} \mathrm{uo}_{2}$ & 200 & on & 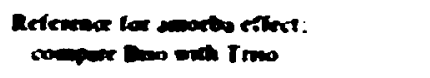 \\
\hline$?$ & $5 \sigma^{235} \mathrm{UD}=$ & 200 & $\operatorname{Tn}$ & 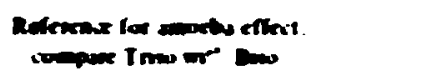 \\
\hline$\bullet$ & $56.2 \mathrm{Tm}^{213} \mathrm{U10}$ & 300 & טwe & 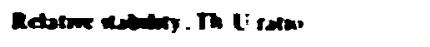 \\
\hline 9 & $5 G\left(4 \mathrm{TH}^{331} \mathrm{CHO}_{3}\right.$ & 350 & Im & Rerycte comber \\
\hline 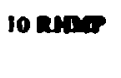 & 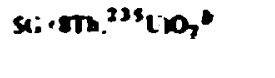 & (0) & $\operatorname{tmon}$ & 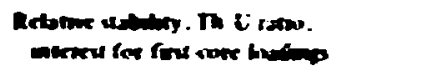 \\
\hline 11 & $5618 \mathrm{Tt}^{233} \mathrm{C}^{2} \mathrm{O}_{3}$ & 350 & $\infty$ & 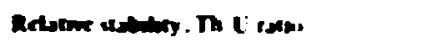 \\
\hline 12 & srim. $23 \mathrm{van}_{3}$ & 250 & wov & 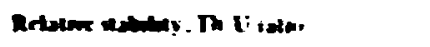 \\
\hline 13 & 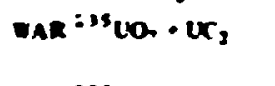 & $\infty$ & Tron & 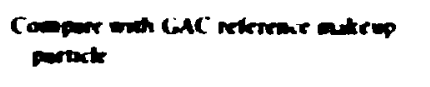 \\
\hline 14 & WAR " $\mathrm{U}_{3}$ & 300 & $\operatorname{Trm}$ & 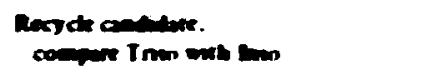 \\
\hline is & WAR "S" $\mathrm{O}_{2} \cdot \mathrm{UC}_{3}$ & 40 & mos & 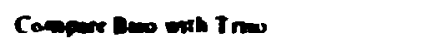 \\
\hline ie & wAR" ${ }^{38} \mathrm{CC}_{2}$ & 300 & $m$ & 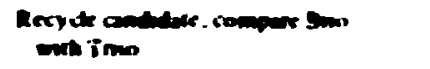 \\
\hline 17 & 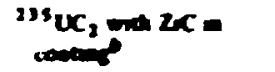 & 200 & $\operatorname{Trm}$ & 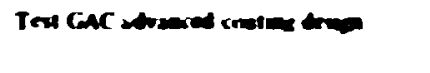 \\
\hline 10 & :3ses is mo & 200 & Trmo & Gac referme \\
\hline 19 & $\operatorname{sintm}{ }^{23} \mathrm{LtOH}_{3}$ & $3: n$ & $m$ & 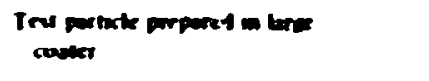 \\
\hline \multicolumn{5}{|c|}{ 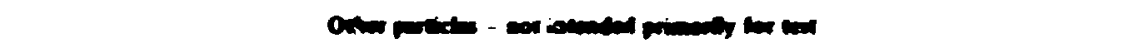 } \\
\hline & war $2310_{3} \cdot v x_{2}$ & סוס & סוn & 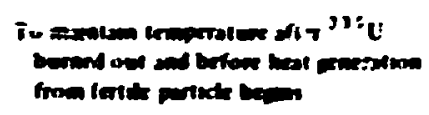 \\
\hline & $\operatorname{mog}_{3} 3 x_{0}$ & 500 & $\infty$ & Fentl morixte \\
\hline & 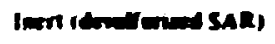 & 500 & mons & 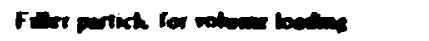 \\
\hline
\end{tabular}

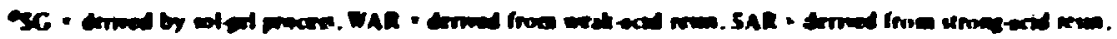

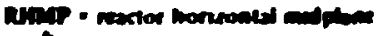

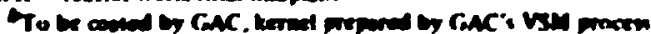




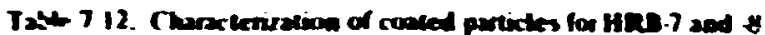

\begin{tabular}{|c|c|c|c|c|c|}
\hline 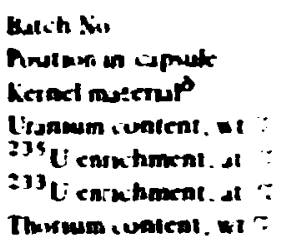 & 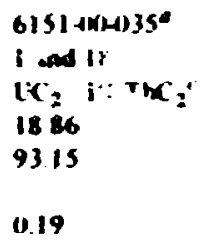 & $\begin{array}{l}1.263 \\
2 \text { and } 19 \\
\text { ithetion: } \\
725 \\
9317 \\
2974\end{array}$ & $\begin{array}{l}\text { On-2umn } \\
3 \\
\text { lion }+12 x_{3} \\
2365 \\
9317\end{array}$ & $\begin{array}{l}\text { OR-3497H } \\
+ \\
102 \cdot 1 K_{2} \\
24.91 \\
0317\end{array}$ & $\begin{array}{l}\text { Pu-303H } \\
5 \\
10 . \\
255 \\
98.05\end{array}$ \\
\hline & 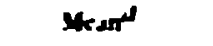 & Mx & Mesn & Mes! & Nen \\
\hline 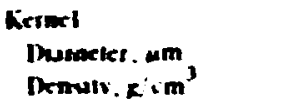 & $\begin{array}{l}196+161 \\
1199\end{array}$ & $\begin{array}{l}35381591 \\
4.8\end{array}$ & $\begin{array}{l}19251471 \\
99\end{array}$ & $\begin{array}{l}19381581 \\
105\end{array}$ & $\begin{array}{l}2268+1: 4110 \\
1000\end{array}$ \\
\hline 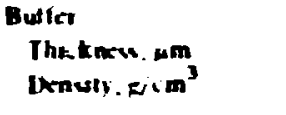 & $\begin{array}{l}991106 \\
107\end{array}$ & $\begin{array}{l}1012,138 ! \\
1.39\end{array}$ & $\begin{array}{l}7137.9 \mathrm{hl} \\
1 ?\end{array}$ & $\begin{array}{l}67+18.21 \\
119\end{array}$ & $\begin{array}{l}8+7,1691 \\
1,50\end{array}$ \\
\hline 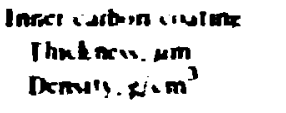 & $\begin{array}{l}33+351 \\
192(51)\end{array}$ & & & & $\begin{array}{l}3.11571 \\
20(\mathrm{ND})\end{array}$ \\
\hline 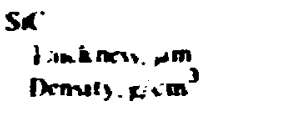 & $\begin{array}{l}3:: 30 \\
320\left(x_{A 1}\right.\end{array}$ & & & & $\begin{array}{l}271,151 \\
3193.00016\end{array}$ \\
\hline 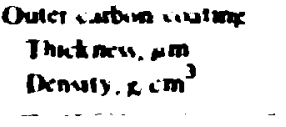 & $\begin{array}{l}38(5 \text { (1) } \\
1.85(., A)\end{array}$ & $\begin{array}{l}91.81961 \\
201+(1), 0071\end{array}$ & $\begin{array}{l}35.617 .21 \\
200010.0051\end{array}$ & $\begin{array}{l}78+1+91 \\
1.9980 .1014,\end{array}$ & $\begin{array}{l}40.712 .9, \\
2.02410 . \times 35,\end{array}$ \\
\hline 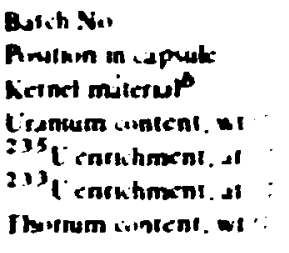 & $\begin{array}{l}\text { OR-ZRS9H } \\
6 \\
10_{2} \\
22+1 \\
4: 17\end{array}$ & $\begin{array}{l}\text { CQ.2114H } \\
7 \\
10 \\
i 6 \% 4 \\
4317\end{array}$ & 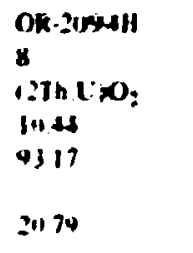 & $\begin{array}{l}\text { OR-2116H } \\
9 \\
145.610: \\
6511 \\
93: 3 \\
20501\end{array}$ & $\begin{array}{l}\text { A155n1+130 } \\
\text { i1) } \\
\text { 18Th.1102 } \\
5.33 \\
93.15 \\
+3.59\end{array}$ \\
\hline & لمתدي4 & Medn & Mesn & Mess & Wran \\
\hline $\begin{array}{l}\text { Kermel } \\
\text { Drumeles. um } \\
\text { Dhenviy. piom" }\end{array}$ & $\begin{array}{l}195+1591 \\
9.91\end{array}$ & $\begin{array}{l}17591521 \\
9.83\end{array}$ & $\begin{array}{l}282.011321 \\
10 \div 8\end{array}$ & $\begin{array}{l}3610111+71 \\
98\end{array}$ & $\begin{array}{l}02133.11 \\
477\end{array}$ \\
\hline 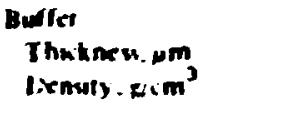 & $\begin{array}{l}748,861 \\
135\end{array}$ & $\begin{array}{l}850.981 \\
128\end{array}$ & $\begin{array}{l}3+51791 \\
126\end{array}$ & $\begin{array}{l}97.718 .71 \\
1.36\end{array}$ & $\begin{array}{l}100117.61 \\
124\end{array}$ \\
\hline 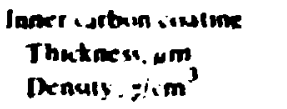 & & $\begin{array}{l}37(1 \times 1) 1 \\
20 \text { iND) }\end{array}$ & & $\begin{array}{l}3881291 \\
200801\end{array}$ & $\begin{array}{l}3214.31 \\
1911 \times 1 \times 1\end{array}$ \\
\hline 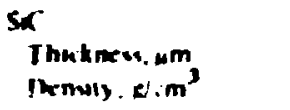 & & $\begin{array}{l}273(181 \\
317816(109)\end{array}$ & & $\begin{array}{l}3: 511.91 \\
3205110031\end{array}$ & $\begin{array}{l}31.671 \\
32 ?(\mathrm{ND})\end{array}$ \\
\hline 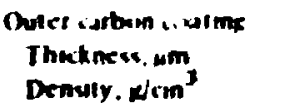 & $\begin{array}{l}77.11+71 \\
2.0110 .0031\end{array}$ & $\begin{array}{l}46.41231 \\
1.971100011\end{array}$ & $\begin{array}{l}89.01621 \\
2.006(0.003)\end{array}$ & $\begin{array}{l}22.91301 \\
2037(0.002)\end{array}$ & $\begin{array}{l}4216.11 \\
1.81 \text { (ND) }\end{array}$ \\
\hline
\end{tabular}


T21논 7.12 !

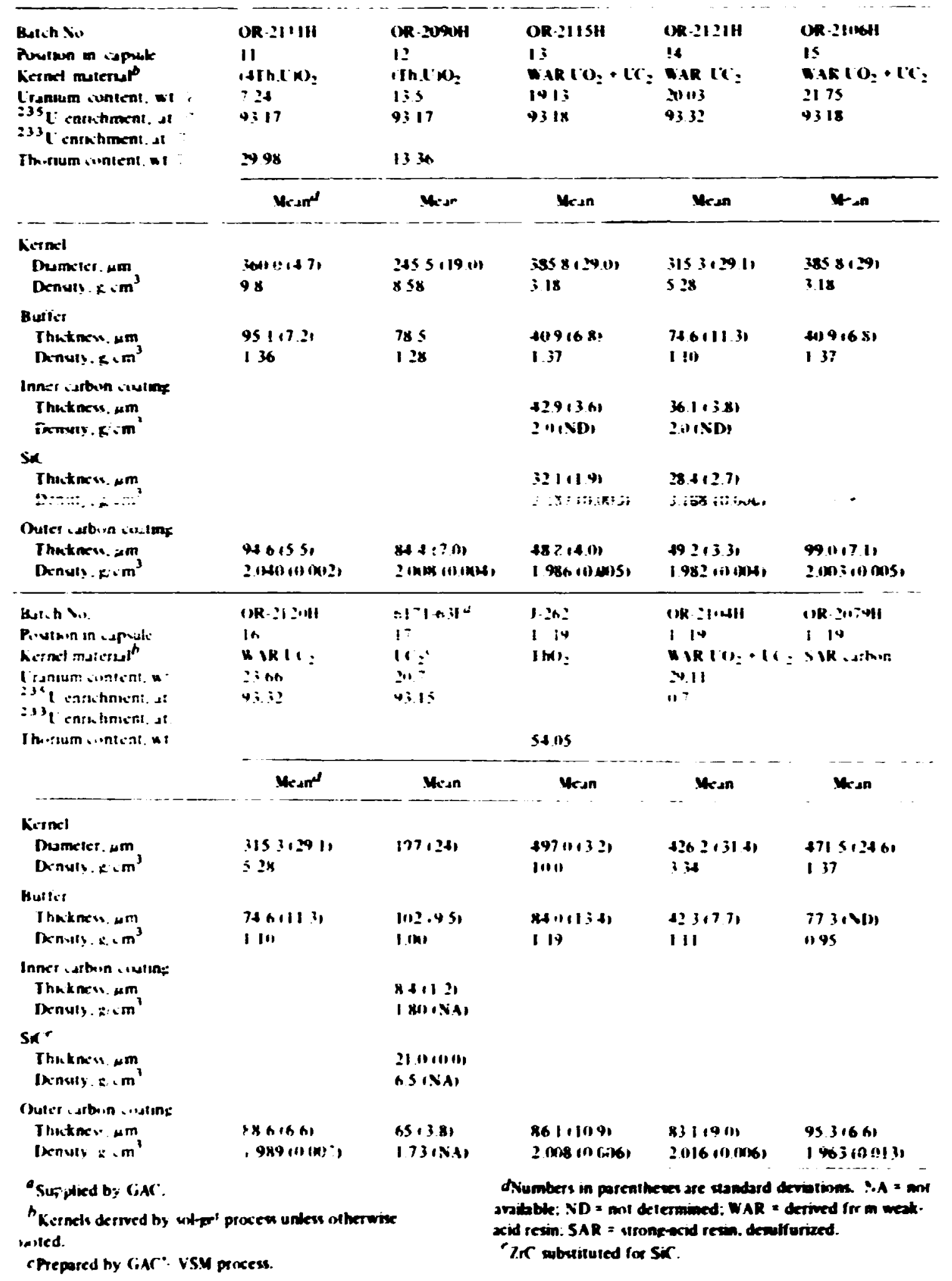




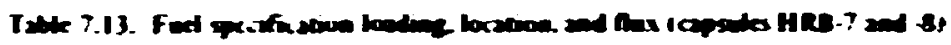

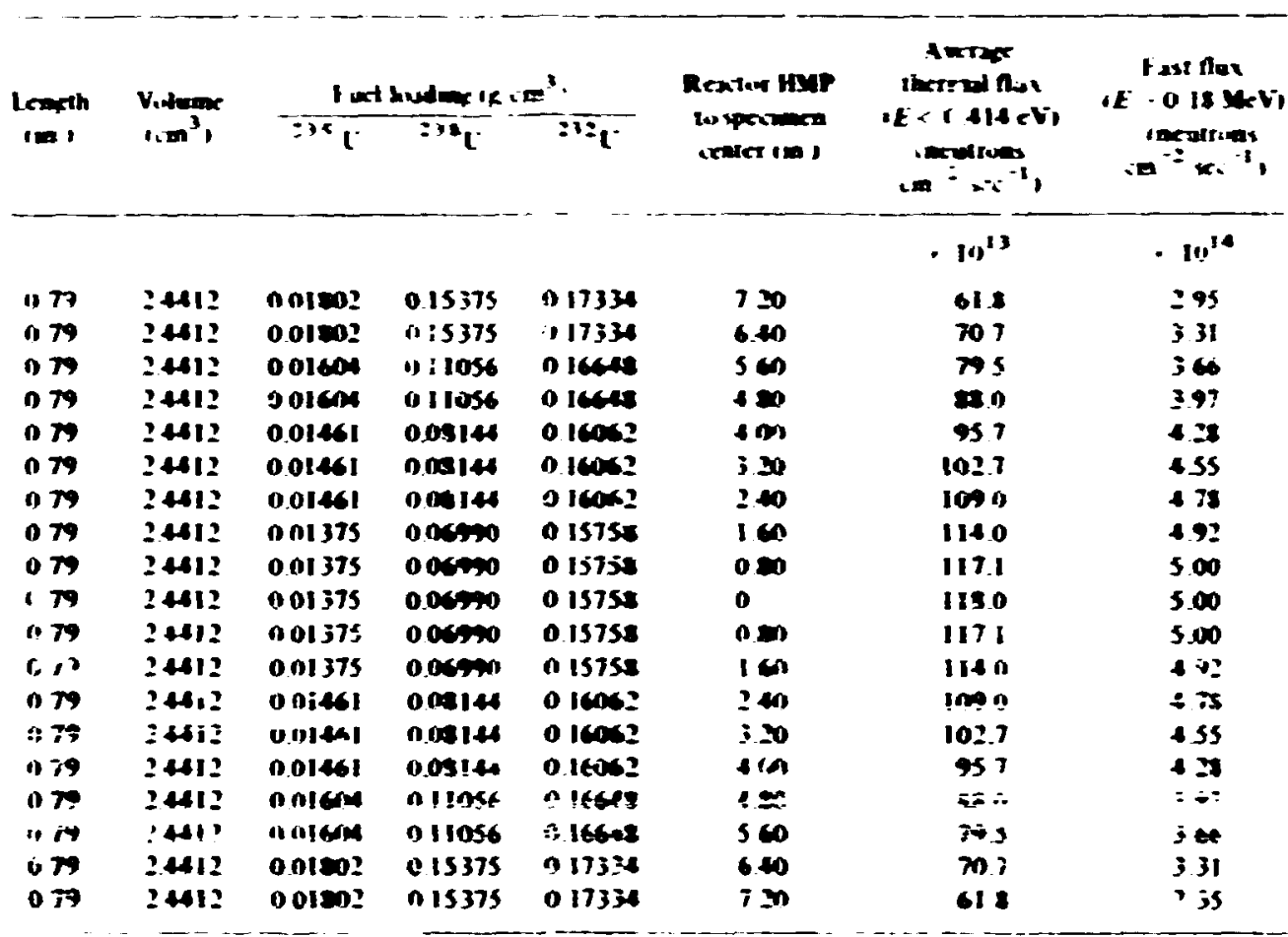

genersted in the feride partikle li mantain iempera. ture

The ingted parikten are inntined on stwe poiked

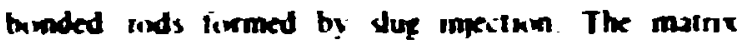
materials fix all speimens are $28 \leq$ wi A thury XF 3.5: graphite iilker in Ashland grade 240 pilih. Ex-h type of issik pariate was inienpirated in separate pectinens musally $0.490 \mathrm{~g}$. OD by $0 . x$ in how with a ceniral thite fon theimoicouple placemeat The sume fertik. "3A $C$ drwet. and inert partikles were wed in all pecmens as requred fir heary metio and parikile volume liadons. Approxmately 170 speimerns sere faorialed for the expenoments and tin the neciessary

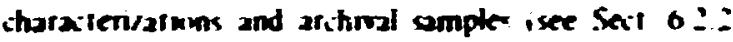
for detadk of fahricatim) titet fmat heat ireatment at $1800^{\circ} \mathrm{C}$. matnx sensities wete $0.61 \mathrm{~g} \mathrm{~cm}^{3}$ exiept iry the ${ }^{233}$ : thearial speimens. whih wete 0 ? $8 \mathrm{~cm}^{3}$. partikle ndume hodms were 607: ${ }^{23} \mathrm{C}$ lkodmp

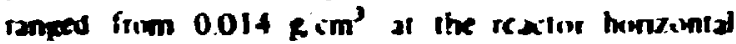
madplane in $0.019 \mathrm{fim}^{3}$ at the capsule exiremes: the 231 (I kading ranged from $0.7 ? \mathrm{~g} \mathrm{im}^{3}$ at the mudplane to $0.159 \mathrm{gcm}^{3}$ at the apsuke exiremes. and the ${ }^{31} \mathrm{Th}$ koding: rarked from $0.160 \mathrm{~cm}^{3}$ at the mudplane io $0178 \mathrm{im}^{3}$ at the sapule exire :es. Design hodme value are gren in Table 7.13

\subsection{DRADATION TESTS WN THE HFTR TAR CET FACTLTY}

A recions type of HF' $\mathrm{K}$ sposule is ine iaget. is HT. apulz. whith is 1 omd un:nstrumented device cinssst

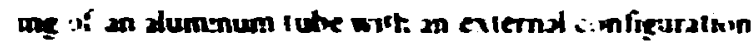
deritid to that of a HFIR laget tid Th: dexgn of

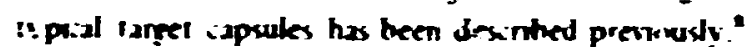
The apsuies cuntam small speizmens iff i vied par. th-te fucts ind iucteiemeni materuds on tise ing if

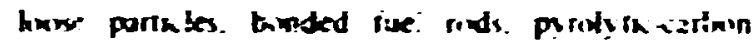
secmens. and experumental gaphites the spiriosom in be irradarad at remperaisures up $1 . .1$ ino0 ${ }^{\circ} \mathrm{C}$. depondane on the heat thot and speimen ispe. and in

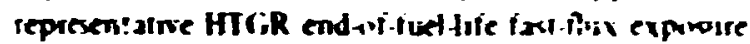
m doril three minihs The res speimens are. in

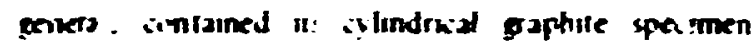
holder, ot mapannex whwh ixiups the centra! :0 in of the apsule the gaphite holde's are ientered aithin the sapsuk hy gosphite and nukel supports who'h. in

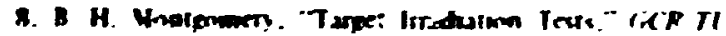

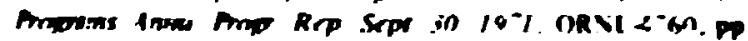
13436 


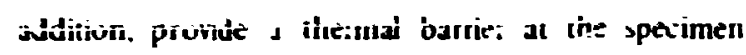
holver ends to mininize axial heat loses.

These iapsules have the advaniage of low $i \cdots:$ and shurt irradiztion time to dttain eprexinta'ive exposure. How ver. the capsules are sealed thus a gas sweep is not possible) and are nat instrumented. Tempiratures ian anly be determined by alculations based on the íssion and zamm3 heat values and capsule geometry and/or scduced by postirradiation evaluation of $\mathrm{n}-\mathrm{lt}$ wires or sis.en sarbile temporature moniturs. Also. only small specimens with verv sriall amounts of fissile .Laterial an be aciommodated.

The $\mathrm{HT}$ irradiations conduited during the reporting periud are summarized in Table ?.2. Irradiation and PIE in the series HT.12 through -15 and HT.16 uste completed. Irradiation of the series HT-17 through -19 was : ompleted and PIE initiated.

\section{7.i Capsules HT-12 through -15}

Capsules HT-12 through -15. described previously." were designed to test fertile-type particles with different brating parameters to conditions which would induce predictable failures and thereby establish mineral coating design criteria.

Desion

Each iapsule contained four tubular graphite specimen holjers or magazines. Exh holder in ium contained 13 ssnall graphite containers with an ar.sular cavity which held 50 to 75 coaied particles each (Fig. 7.28). Two $d i$ ihe tubular holders we desianed to develop a $930^{\circ} \mathrm{C}$ temperature in the particle :ontriners and the otter iwo a $1250^{\circ} \mathrm{C}$ particle contain r tenpera. turs.

if the 13 ;article containers in ear.s holder, 8

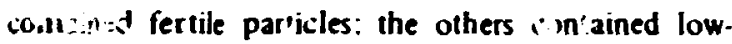
enriched $\mathrm{UO}_{2}$ particles. The type of esimen, $\mathrm{ThO}_{2}$ and $U C_{2}$. were alternated along the $r \cdot r^{\prime}$ iule length. The U6, was added scecifically to r.roduce a more uniform power generation and hence spiximen temperature over the life of tha experiment. It takes considerable tinis hefore power generation fro:n ${ }^{233} \mathrm{U}$ bred from the thorium reaches equilibrium. By adding Iowenriched U. one can minimize tise variation in specimen tem: erat ure with time.

9. GCR Progrems Annu. Proxp. Rep. R:e 31, 1372. ORNL $4911.5 . ! 13$ - IS.

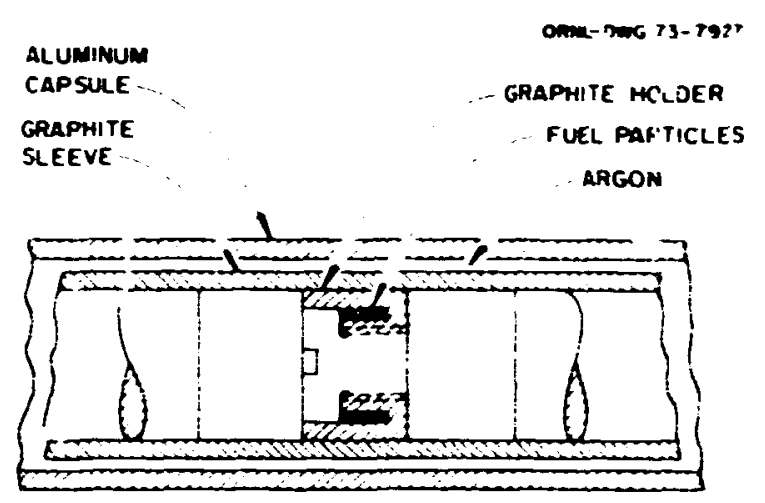

Fie 7.28. Crosesection of HT-12 throm-15 conted partide indintion capale.

\section{Operation}

Target capsule HT-12 was inserted in targ ": position F-3 on Sept. 10. 1972, and was removed in O.t. 23. 1972. afier 38.62 days at $100 \mathrm{MW}$ rt $e^{\circ}$ :ur power. The peak fast fluence was $3.9 \times 10^{21}$ neutrons $/ \mathrm{sm}^{2}|E\rangle$ $0.18 \mathrm{MeV}$. and the peak fertile particle burr.up was 2.9\% FIMA.

Capsule HT-13 was inserted in target position G-6 on Oct. 8. 1972, and was rerroved on Jan 10. 1973. after 85.5 days at $100 \mathrm{NW}$ reactor power. The peak fast fluence was $8.6 \times 10^{21}$ neutrons $/ \mathrm{cm}^{2}(E>0.18$ $\mathrm{MeV}$ ), and the estimated peak fertile particle bumup was $9.7 \%$ FIMA.

Capsule HT-14 was inserted in target position F.3 on Nov. 20,1972, and was rem:oved on Apr. is, 1973. after 137.0 cays at $100 \mathrm{MW}$ reactor power. The peak fast fluerice was $1.4 \times 10^{22}$ neutrons $/ \mathrm{cm}^{2}(E>0.18$ $\mathrm{MCV}$ ). and the estimated peak fertile particle burnup was $17.3 \%$ FIM.A.

Capsule HT. 15 was inserted in target position A-2 on Nov. 20, 1972, and was removed on May I1. 1973, after 159.96 davs ai $100 \mathrm{MW}$ reactor piwer. The peak fast nuence uas $1.6 \times 10^{22}$ neutrons $/ \mathrm{cr}^{2}{ }^{2}(E>0.18$ $\mathrm{MeV}$ ). and the estimated peak fertile particle bumup was 20.3\% FIMA.

Table 7.14 gives the fast fluenice and fertile particle burnup for each sample hclder in each capsule. No attempt was made to calculate the fissile particle burnup. Table 7.15 gives the operating history of the reactor during the irradiation of each capsule. 
Table 7.14. Particle fast nuonce and featife particle hurnup (capsules IrT.12 through - 15)

\begin{tabular}{|c|c|c|c|c|c|c|c|c|c|c|}
\hline \multirow{3}{*}{$\begin{array}{l}\text { Simple } \\
\text { hulder } \\
\text { No. }\end{array}$} & \multicolumn{4}{|c|}{$\begin{aligned} & \text { lasl-neutron nuence, } \\
& f>0.18 \mathrm{MeV} \text { (necutrons } / \mathrm{tm}^{2} \text { ) }\end{aligned}$} & \multirow{2}{*}{$\begin{array}{l}\text { liast-neutron nux, } \\
\quad t^{\prime}>0.18 \text { MeV } \\
\text { (neutronx } \operatorname{com}^{-2} \text { xec }\end{array}$} & \multirow{2}{*}{$\begin{array}{c}\text { Distance } \\
\text { from holder center line } \\
\text { lo HMP (in.) }\end{array}$} & \multicolumn{4}{|c|}{ lertile parlic:: burnun $(\cdot 1)(M A)$} \\
\hline & $11 \mathrm{~T}-12$ & $11 \mathrm{~T} \cdot 13$ & $11 \mathrm{~T} \cdot 14$ & IIT-15 & & & $H T \cdot 12$ & $111^{12}$ & $117 \cdot 14$ & $117 \cdot 15$ \\
\hline & $\times 10^{21}$ & $\times 10^{21}$ & $\times 10^{21}$ & $>10^{21}$ & $\times 10^{19}$ & & & & & \\
\hline 1.52 & 1.9 & 4.1 & 6.6 & 7.7 & 0.56 & 9.199 & & & & \\
\hline 2.51 & $? n$ & $4 . J$ & 6.9 & 8.1 & 0.59 & $\$ .909$ & 0.95 & 4.53 & 9.56 & 11.91 \\
\hline 3.50 & 2.1 & $\Delta x$ & 7.4 & 8.7 & 0.6 .1 & 8.626 & & & & \\
\hline 4,49 & 2.2 & 4.9 & 7.9 & 9.3 & 0.67 & X.344 & 1.06 & S.M & 10.45 & 1.3 .010 \\
\hline 5,48 & 2.3 & 5.2 & 8.3 & 9.7 & 0.70 & 8.601 & 1.10 & 3.20 & 10.90 & 13.50 \\
\hline 6.47 & 2.4 & 5.4 & 8.6 & 10.1 & 0.73 & 7.779 & & & & \\
\hline 7.46 & 2.5 & 5.6 & 9.01 & 10.5 & 0.76 & 7.496 & 1.21 & 5.62 & 11.67 & 14.42 \\
\hline 8.45 & 2.6 & 5.4 & 9.4 & 1110 & B.̈us & 7.214 & 1.26 & 5.84 & 12.05 & 14.90 \\
\hline 9,44 & 2.7 & 6.0 & क.? & 11.3 & 0.82 & {$[0.931$} & & & & \\
\hline 10,43 & 2.8 & 6.2 & 10.0 & 11.7 & 0.45 & 6.644 & 1.37 & 6.22 & 12.75 & 15.7 \\
\hline 11,42 & 2.9 & 6.5 & 10.4 & 12.2 & O.NK & 6.366 & 1.40 & 0.40 & 13.08 & 16.10 \\
\hline 12.41 & 3.0 & 6.7 & 10.8 & 12.6 & 0.91 & $6.0 \times 4$ & & & & \\
\hline 13,40 & 3.1 & 6.9 & 11.0 & 12.8 & 0.93 & 5.801 & 1.50 & 6.75 & 13.70 & 16.82 \\
\hline 14,39 & 3.5 & 7.7 & 12.4 & 14.5 & 1.05 & 4.194 & & & & \\
\hline 15,38 & 3.5 & 7.8 & 12.5 & 14.6 & 1.06 & 3.909 & 1.71 & 7.70 & 15.30 & 18.72 \\
\hline 16,37 & 3.6 & 7.9 & 1.7 & 14.9 & 1.08 & 3.626 & & & & \\
\hline 17,36 & 3.6 & 8.1 & 12.9 & 15.1 & 1.09 & 3.341 & 1.78 & 7.90 & 15.67 & 19.12 \\
\hline 18.35 & 3.7 & B 2 & 13.1 & 15.3 & 1.11 & 3.1361 & 1.80 & K.00) & 15.82 & 19.32 \\
\hline 19.34 & 3.7 & R.J & 13.3 & 15.5 & 1.12 & 2.770 & & & & \\
\hline 20.33 & 3.8 & 8. 3 & 13.4 & $i=x$ & 1.13 & 2.496 & 1.82 & 8.15: & 16.10 & 19.65 \\
\hline 21.72 & 3.8 & 8.4 & 13.5 & 15.7 & 1.14 & $2.21:$ & 1.86 & H.21 & 16.21 & 14.80 \\
\hline 22,31 & 3.8 & 8.5 & 13.6 & 15.9 & 1.15 & 1.931 & & & & \\
\hline 23,30 & 3.9 & 8.5 & 13.7 & 16.0 & 1.16 & 1.649 & 1,90 & 8.33 & 16.42 & 20.0 .3 \\
\hline 24.29 & 3.9 & 8.6 & 13.8 & 16.1 & 1.16 & $1.3 \mathrm{nh}$ & 1.91 & 8.38 & 16.50 & 20.15 \\
\hline 25,28 & 3.9 & 8.6 & 13.9 & 16.2 & 1.17 & 1.084 & & & & \\
\hline 26.27 & 3.9 & 8.6 & 13.9 & 16.2 & 1.17 & 0.801 & 1.92 & R.43 & $|h . h|$ & 20.30 \\
\hline
\end{tabular}




\begin{tabular}{|c|c|c|c|c|}
\hline $\begin{array}{l}\text { HFIR } \\
\text { - y.k }\end{array}$ & $\begin{array}{l}\text { Begen } \\
\text { cyik }\end{array}$ & $\begin{array}{l}\text { Ind } \\
\therefore ; i k\end{array}$ & $\begin{array}{c}\text { Iay, } \\
\text { uperstion }\end{array}$ & 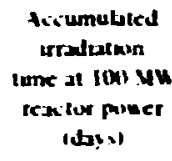 \\
\hline \multicolumn{5}{|c|}{ (appede HT-12 } \\
\hline$x 2$ & 41972 & {$[0 / 3] 72$} & 23 & 23.4 \\
\hline $\mathbf{3 3}$ & $10 \times 3=$ & 102372 & 15 & is 6? \\
\hline \multicolumn{5}{|c|}{ Capite HT-13 } \\
\hline 83 & $10 \times 77$ & $10 \div 23 ? 2$ & 15 & 15.18 \\
\hline 844 & $10 / 2472$ & $11 / 1172$ & 18 & \\
\hline $\mathrm{BEB}$ & $11: 1372$ & $11.19 / 72$ & 5 & 38.55 \\
\hline s5 & $11 \div 20 / 72$ & 12,$15 ; 2$ & 23 & 94.14 \\
\hline 864 & $12: 13 ; 72$ & $17 \div 3$ & 24 & 490 \\
\hline 874 & $1: 473$ & $1: 1073$ & .1 & 35.50 \\
\hline \multicolumn{5}{|c|}{ Capole HT-If } \\
\hline is & 1120172 & $12: 13 ; 72$ & 23 & 23.09 \\
\hline $\mathbf{n b}^{2}$ & $12 / 13 / 72$ & $1 / 7: 73$ & 24 & 46.35 \\
\hline 874 & $1 / 9 / 73$ & $1 / 10: 73$ & $\therefore 1$ & \\
\hline $97 B$ & $1 / 12: 73$ & $23 \%$ & II & 68.4. \\
\hline ss & $2: 3: 73$ & $22 n=3$ & 33 & $91+1$ \\
\hline 39 & $2 / 27173$ & $3 ! 22 / 73$ & 23 & 114.14 \\
\hline 90 & $3: 23: 73$ & tits?is & 23 & 137.00 \\
\hline \multicolumn{5}{|c|}{ Caponke HT-IS } \\
\hline 85 & $11 / 20 / 72$ & $12 / 13 / 72$ & 23 & 23.09 \\
\hline 86. & $12 / 13^{172}$ & $. / 7 / 73$ & 24 & $\div 6.35$ \\
\hline $87 \mathrm{~A}$ & $1 ; 9: 73$ & $1 / \mid 0,7\}$ & $\therefore 1$ & \\
\hline $87 \mathrm{~b}$ & $i / 12 / 73$ & $2 / 3 i 73$ & 21 & 68.86 \\
\hline 88 & $: 13 / 73$ & $2 ; 26: 73$ & 23 & 91.41 \\
\hline 89 & $2 ! 27 / 73$ & $322 / 73$ & 23 & 118.14 \\
\hline 90 & $: 23 / 73$ & $4 / 15: 73$ & .3 & 137.00 \\
\hline 91 & . $9 / 18 / 73$ & $5,11 / 73$ & 23 & 159.96 \\
\hline
\end{tabular}

Includes two days at $50 \mathrm{MW}$.

\section{Postirradiation examination and analysis}

Capsule HT-12. HT.12 was irradiated for two cycles (39 days) in the HFIR (1) a fast-neutror. evponsure ranging from $1.910 .3 .4 \times 10^{21}$ neutrons $/ \mathrm{cm}^{2}$ i>0 !9 ateV). When opened. the capsule and magatines were observed (1) be remarkably free of the sorty material previously found in most targel capsules. No evidence of pitting or corrusion on the graphile magazines was rbserved. This is allributed io the gettering action of airconium foil disks used between the specimen holders in the magalines.

The ORNL samples performed witho!! failures except for one that had a $\mathbf{2 4} \boldsymbol{\mu m}$-thick isotrepic carbon coating and a flash buffer on o $402-\mu m$ diam kernel.
Failure of $55 \%$; ( 41 of 75 particles) was not unexpecied and is consistent with assumed values of 25.000 psi tensile strength and a creep rate of $5 \times 10^{-2 \mathrm{~s}} \mathrm{psi}^{-1}$ Ineutrons in $)^{-1}(t>1.86 \mathrm{eV})$ in the $\mathrm{LTl}$ couting

Capsule HT-13. HT-13 ws irradiated for fiour sycles 185 days) in the HFIR to a fast-nioutron exposute ranging from +.1 to $8.6 \times 10^{21}$ neutrons $/: 1^{2} 1>0.18$ MeV). When opened. the apsule and magasines were observed to be free of sowt as in HT.12. Howerer. an impurtant observaiton from this examination was the degradation and swelling of the Poio graphite sample holders exposed in the high-temperature region. Even though there was no evidence of oxidation or mass transport in the sealed capsule. the graphite was so weak and friable that the screw caps could not be remuvad without drilling out the threads.

At i $250^{\circ} \mathrm{C}$. al! ORNL samples with $400 \mu \mathrm{m}$-diam bernels and thin coatings for which the calculaled stresses exieeded 25.000 psi showed complete or a high rate of failure. while similar samples with conservalively designed coatings survived. Oie sample (proposed reference) with a $500 \mu \mathrm{m}$-diam kemel and a conservalive coating design also survived completely, while a similar sample with thinner coatings failed almost completely. At the low temperalure. all ORNL samples survived exiept for $13 \%$ failure of one that had an ir.termediate coating design. With this one excention. the performance of these samples is consistent with assumed values of 25.000 ps: tensile ruplure stieng.. and a creep rate of $5 \times 10^{-28} \mathrm{psi}^{-1}$ (neutrons $\left./: \mathrm{m}^{2}\right)^{-1}(E>1.86 \mathrm{eV}$ ) in the outer coaling.

Capsule HT-14. HT-14 was irradiated for six cycles (1.37 days) in the HFIR to a fast-neution exposure ranging from $6.61013 .9 \times 10^{21}$ neutrons $/ \mathrm{cm}^{2}$ (>N18 MeV). W..en opened. the capsule and magazines were reiatively free of sool and showed no evidence of corrosion. The iwo low-temperalure magatines Idesign temperature $900^{\circ} \mathrm{C}$ ) were unloaded without difficulty. and the sample. of coated particles were easily re. covered. However, he two magarines and associated graphite holders ir, the high-temperature region $c x$ hibited extreme swelling. Diametral expansion of sample holders designed lo operate a: $1250^{\circ} \mathrm{C}$ was as great as 7.5\%. Unloading of these holders was difficuit because the graphite was very weak. The esireme swelling nearly clised the gap between magaine and apsule walk. which made the operaling temperatures during the latier part of the irradiafion lower. bist quite uncertain.

The unloading palters for HT.14 was simila, in that of HT-12 and -13. The cosr.piete or Figh survival rates at 
the low temperature were anticipated. and the massive

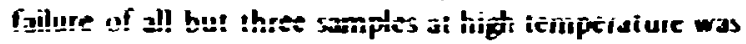
expected. It is noteworthy that the propused reference design survived completely.

Capade HT-15. HT-15 was irradiated for seven cycles (160 days) in the HFIR to fast-neutron fluemie exposures ranging from 7.7 to $16 \times 10^{21}$ neulrons $\mathrm{cm}^{2}$ 1>0.18 MeV).

This capsule was withdrawn after seven cycles of irradiation because ext:eme sweting of the Poio graphite holders and magazines was observed in HT-14 after a six-cycle irradiation. In HT-15. this swelling had compietely closed the initial gap between high-temperature magazines and capsule walls. and the capsule had to be slit open to remove the magazines. Diametral expansion of the magazines was more than $6^{\circ}$. and swelli: 6 of the sample holders was about $9 \%$ at the highest exposure. In addition to the swilling. the sample holders were severely distorted. Man; had hourglass" appearances. having expanded about $4: z$ in the midsection. where the fuel particles were located. and at least 87 at the end cap.
The unloading pattem for HT-IS was similar to that for the previous inree capsules. The gaphite sample holders in the high-lemperature regior were very weak and greal care was necessary. Of the nine samples of ORNL panictes. four survived compleiely in the lowtemperature region and the others had high survival rates. At the higher temperalure. the proposed reference design survived well. showing 39 (1wo particles in 75) failure rale. Table 7.16 is a summary of particle design and surviral rates.

\subsubsection{Care HT.16}

\section{Desige}

HFIR target apsule HT-16 was designed primarily to evaluate the effects of radiation expowuie on the physizal properties of different graphites. The capsuk vessel itself was identical to previous tanget capsules. but the internal design was different. The specimens consisied of 0.4-in.fiam graphite cylinders with a 0.125 -in. central hole and raried in lengh 112 wers $1 / 4$ in. ind 24 were $1 / 2$ in.). The specimens were mounted

\begin{tabular}{|c|c|c|c|c|c|c|}
\hline \multirow{2}{*}{$\begin{array}{l}\text { Botch } \\
\text { No. }\end{array}$} & \multirow{2}{*}{$\begin{array}{c}\text { Cocsted portink } \\
\text { decipe }\end{array}$} & \multirow{2}{*}{$\begin{array}{c}\text { Holder } \\
\text { No. }\end{array}$} & \multicolumn{4}{|c|}{ Survival rale (T) } \\
\hline & & & HT.12 & HT-13 & 1TT-14 & HT-15 \\
\hline \multicolumn{7}{|c|}{ Al secre deim pemperature $900^{\circ} \mathrm{C}$} \\
\hline OR-1837 & $+02-1-24.4$ & 51 & 100 & 100 & 100 & 91 \\
\hline OR-1830 & $402-1-38.1$ & 48 & 100 & 190 & 100 & 96 \\
\hline OR-1846 & $402-20.3-21.2$ & 5 & 100 & 100 & 98 & 100 \\
\hline OR.1826 & $402-21.4-30.2$ & 45 & 100 & 100 & 81 & 79 \\
\hline OK-1840 & $402-24.6-50.1$ & 8 & 100 & 100 & 100 & Ino \\
\hline CR-1749 & $402-32.9-36.4$ & II & 100 & 87 & 96 & 87 \\
\hline OR-1838 & $402-32.3-63.8$ & 42 & 100 & 100 & 100 & 100 \\
\hline OR-1849 & $508-79.4-74.7$ & 13 & ICO & 100 & 100 & 100 \\
\hline OR-1850 & $508-44.5-48.1$ & 4 & 100 & 100 & 6 & 94 \\
\hline \multicolumn{7}{|c|}{ 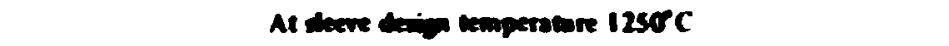 } \\
\hline OR-18.77 & $402 \cdot 1 \cdot 24.4$ & 38 & 45 & 0 & & \\
\hline OR-1830 & $402-1-38.1$ & :s & 100 & $\mathbf{0}$ & & \\
\hline OR-1846 & $402-20.3-21.2$ & 18 & 100 & o & & \\
\hline OR-1826 & $402-21.4-30.2$ & 32 & 100 & 23 & II & 44 \\
\hline OR-1RAO & $402-21.4-30.2$ & 21 & 100 & 100 & 100 & 7 \\
\hline OR-1749 & $402-32.9-36.4$ & 24 & 100 & 100 & 7 & 100 \\
\hline OR-1838 & $402-32.3-63.8$ & 29 & 100 & 100 & 97 & 100 \\
\hline OR-1849 & $508-79.4-74.7$ & 26 & 100 & 100 & 100 & 97 \\
\hline OR-1850 & $508-4.548 .1$ & 17 & 100 & 3 & 0 & 0 \\
\hline
\end{tabular}

'Numbers pve kernel liameter. buffer thicknexs, and I.TI thickness, reapectively, in micrometers. 
on hoilow grapinte rinis willè passed througi ine ientral : perimen hutes. The rods were in turn supported und centered in the iap ule by 0.010-in.-thik stainless steel supports.

To minimize axial hast . ix frum the specimens to the supports and her.ce 2sis temperature variation in the specimens. gamn.a hes. susiepter" in the form of stainless steet disks were fitted or. the graphite rods adjacent to the supports. The heat suisieptors were sired suhh that there woild be little or no axial temperature variation in the graphite iid and hence no axial heat Mux from the spe:imen into the rod. All specimens (36 in number) were designed to operate at $700^{\circ} \mathrm{C}$. Instead of varying tie ga' gap I in this case helium \& Io compensate for 2 ial variation in gamma heat. the hollow support rinis were litted with sillein carbide temperature monitors and tungsien icds distributed so as II produce a uniform axia' heat get eration wer the length of the capsule despite the axial gradient in gamma heat ratc.

\section{Operation}

Capsule HT. In was inserted in target pusition E.7 on Ftb. 27. 1973. and was remexed on July 29. 1973. after 1 jo. 91 days a $100 \mathrm{MW}$ reantur purver. The peak fist fluence was $1.39 \times 10^{22}$ neutronsicm ${ }^{2}$ (F: $>0.18$ MeVI. The individual specimen fluerice is given in $T$ ible 7.17.

\begin{tabular}{|c|c|c|c|}
\hline $\begin{array}{l}\text { Spechinen } \\
\text { No. }\end{array}$ & $\begin{array}{l}\text { Axd positum from } \\
\text { rextor HNP } \\
\text { (n) }\end{array}$ & 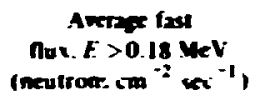 & $\begin{array}{l}\text { Fast nuever. } \\
E>0.18 \text { veV } \\
\text { incutronsicm? }\end{array}$ \\
\hline & & $\times 10^{15}$ & $\times 10^{22}$ \\
\hline 1075 & +9.63 & 0487 & ว.58 \\
\hline I I88 & +9.375 & 0.523 & $0.6 ?$ \\
\hline 1824 & +3.000 & 0570 & 067 \\
\hline $177 \mathrm{~B}$ & +8.250 & 0.670 & 0.79 \\
\hline $176 \mathrm{~B}$ & +7.750 & D 730 & 0.86 \\
\hline 181A & +7.000 & 0809 & 0.9 \\
\hline 1798 & +6.500 & $\overline{0.8<7}$ & 1.01 \\
\hline 940 & +5.750 & 0.925 & 109 \\
\hline 1001 & +5.250 & 2.965 & 1.14 \\
\hline $9 \%$ & +4.500 & 1.016 & 1.20 \\
\hline 572 & +4.000 & 1.046 & 1.24 \\
\hline 991 & +3.250 & 1 ons & 1.28 \\
\hline 1077 & +2.875 & I. 104 & 1.30 \\
\hline i 190 & +2.625 & 1.115 & 132 \\
\hline 900 & +2.000 & 1.140 & 1.35 \\
\hline 979 & +1.500 & 1.157 & 1.37 \\
\hline 1828 & 40.750 & 1.174 & 1.39 \\
\hline $176 A$ & +0.250 & I.IBO & : 39 \\
\hline I77A & 0.500 & 1.177 & 1.39 \\
\hline 1236 & -0.875 & 1.172 & 1.39 \\
\hline 1098 & 1.125 & 1.165 & 1.38 \\
\hline 245 & 1.750 & 1.152 & 1.36 \\
\hline 941 & 2.250 & 1.138 & 1.35 \\
\hline $101 \mathrm{~A}$ & -3.000 & 1.108 & 1.31 \\
\hline 1298 & 3.500 & 1.085 & 1.28 \\
\hline $\operatorname{loc} A$ & 4.250 & 1.045 & 1.24 \\
\hline $128 A$ & -4.750 & 1.013 & $1.2 n$ \\
\hline 1291 & -5.500 & 0.955 & 113 \\
\hline 249 & 6.000 & 0.913 & 1.08 \\
\hline $179 A$ & 6.750 & 0.842 & $1 \mathrm{~m}$ \\
\hline 1238 & -7.125 & 0.805 & 0.95 \\
\hline 1097 & -7.375 & 0.778 & 0.92 \\
\hline 1076 & .7 .875 & 0.722 & 0.185 \\
\hline 1189 & .8 .123 & $0.69 \%$ & 0.12 \\
\hline 1237 & -8.375 & 0.663 & $0.7 \mathrm{n}$ \\
\hline $10 \times 6$ & $-8,525$ & 0.630 & 0.74 \\
\hline Megrine & 9.500 & 0.516 & 0.61 \\
\hline
\end{tabular}




\section{2 .3 Costes 4.17 thost -19}

\section{J. M. Robbins W. P. Eatherly}

Exiensive tulures of the CAC parlikies in HT-12 through - I $5 \mathrm{~d}$ imonstrated. unequivinally. that the must sensitive parameter in particle coating design is the anisotiopy." Consequently, the HT-17, -18 and -19 series was daigned as a lopial sequence to the earlier series of apsules to better define the behavior of dense pyrulytic-carbon coatings on large $\mathrm{ThO}_{2}$ kernets a a function of preferred orientation. The preferred urien. tation was masured by the BAF lechnique. and attempts will be made to correlate with OPTAF measurements. The preferred orientation was varied between 1.0 and 1.7 .

A peripheral experiment involved one particle type with an anisotropy gradient through its outer coating to test the effect of such a gradient. A second particle type was coated using $\mathrm{CO}_{2}$ instead of argon as the carrier pas. With $\mathrm{CO}_{2}$. less soot is produced as an inclusion in the coating. The third particle in the peripheral experi.

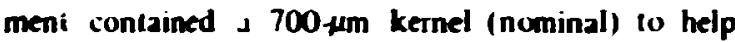
define the larges: kernel that it is ieasiole to use.

\section{Experiment desiga}

This experiment consisted of three HFIR target capsules designated $H T-17,-18$, and -19 respectively. The format was similar to that of HT-1 2 through -15 in that the experimental samples were loose cuated partiiles contained in small graphit: holders with the entire assembly enclused by a raphite sleeve. The graphite holders were designed 1.3 hold the particles in an annular array. The experiment was designed io test a series of Biso-iuated $\mathrm{ThO}_{2}$ particles at graphite holder surface temperatures of 900 and $1250^{\circ} \mathrm{C}$ to burnup and fast-netiton exposures up to at least $1 \frac{1}{2}$ limes the HTGR design requirements. These surface temperatures correspond to particle temperatures of about 1100 and $1500^{\circ}$. respectively. Each capsule contained two sam. ples lexcept as ncied in loading diagram (Table 7.18)] of each of the coating batches being tested. One set of samples was expoxed at $1500^{\circ} \mathrm{C}$ and as near the maximum dose rate around the target midplane as possible. The corresponding set of samples was exporsed at approximately $1100^{\circ} \mathrm{C}$ and at a lower exprosure at the ends of the target. Also, 7,5 entihed uranium was included in each capsule to smosth out heat generation curves and an maintain a more constant temperature throughout the test. A porous graphite heat shield separated the lemperalure zones. and a range of flux existed over the experimental sumples.
The experimen: contained eigit particle batihes trom GAC and ien frum ORNL. All measurements and charriterization of the GAC particles were peiformed by GAC. As in HT-12 through -15. the ORNL partikies were Biso cuatings in large sul-gel-derived $\mathrm{ThO}_{2}$ kernets. Parameters of the partibles are listed in Table 7.19. The ThO: kernels and coated partiles were arefilly sized and thoroughly iharaiterized so that effect of these variables would be minimized.

The ORVL particles were prepared from iwo kernet batches: nominally 500 and $700 \mu \mathrm{m}$ in dameter respecitively. The buffer and seal coatings were applied Io the $500 \mu m$-diam batch by $w$. J. Lackey of the Fual Cycle Engineering and Development Group. ${ }^{10}$ The outer coating on the $500 \mu \mathrm{m}-\mathrm{diam}$ batih and all cuatings on the $700-\mu m$ diam batch were applied by $R$. $L$. Beatty of the Carbon Development Group. After the buffer and sealers were applied. the particles were sized on a roller mi-rometer to eliminate exiessively thik $k$ or thin coatings. After all coating were applied. The partikles were again sized on a roller mictometer. The sized fraction of the particles with $500-\mu m$-diam kernels was poured over an x-ray holder with 144 holes that captured one particle in each hole. From the radingraph of these 144 particles. 99 were chosen and identified to be rested. The 99 particles were separated in a nonspecific manner into samples of 58 and 41 par! $k$-les for testing in the high-temperature high-flux region and the low-lemperature low-flux region respectively. A similar selection technique was used for the 700\% $\mathrm{um}$ diam kernel batich. except unly 16 and 22 particles were selected for testing in the two temperature-tlux zones. The smaller number of particles w's reyuired because of the larger amount of thorium in the larger diameter $\mathrm{ThO}_{2}$ kernels. All particles to be tested were heat ireated at $1800^{\circ} \mathrm{C}$ ?or $30 \mathrm{~min}$ in an atmosphere of argon.

After the particles were fabricated. characterized. and heal treated. they were loaded into annular graphile holders and assembleJ into magazines. All graphite parts except the nickel bearing positioners were heat trealed to $1500^{\circ} \mathrm{C}$ for $30 \mathrm{~min}$ in an argun aimusphere befor loading.

\section{Operation}

Capsule HT. 17 was inserted in I rrgel position A.3 o: July 22. 1973. and was removed on Sep1. 8. 1973. afie: 46.42 days (two HFIR syiles) at $100 \mathrm{MW}$ reactor

10. See Sect. 3.5. . this report. 
Table 7.18. Looding diogren of purticles

in 4 -17, - 18. and -19

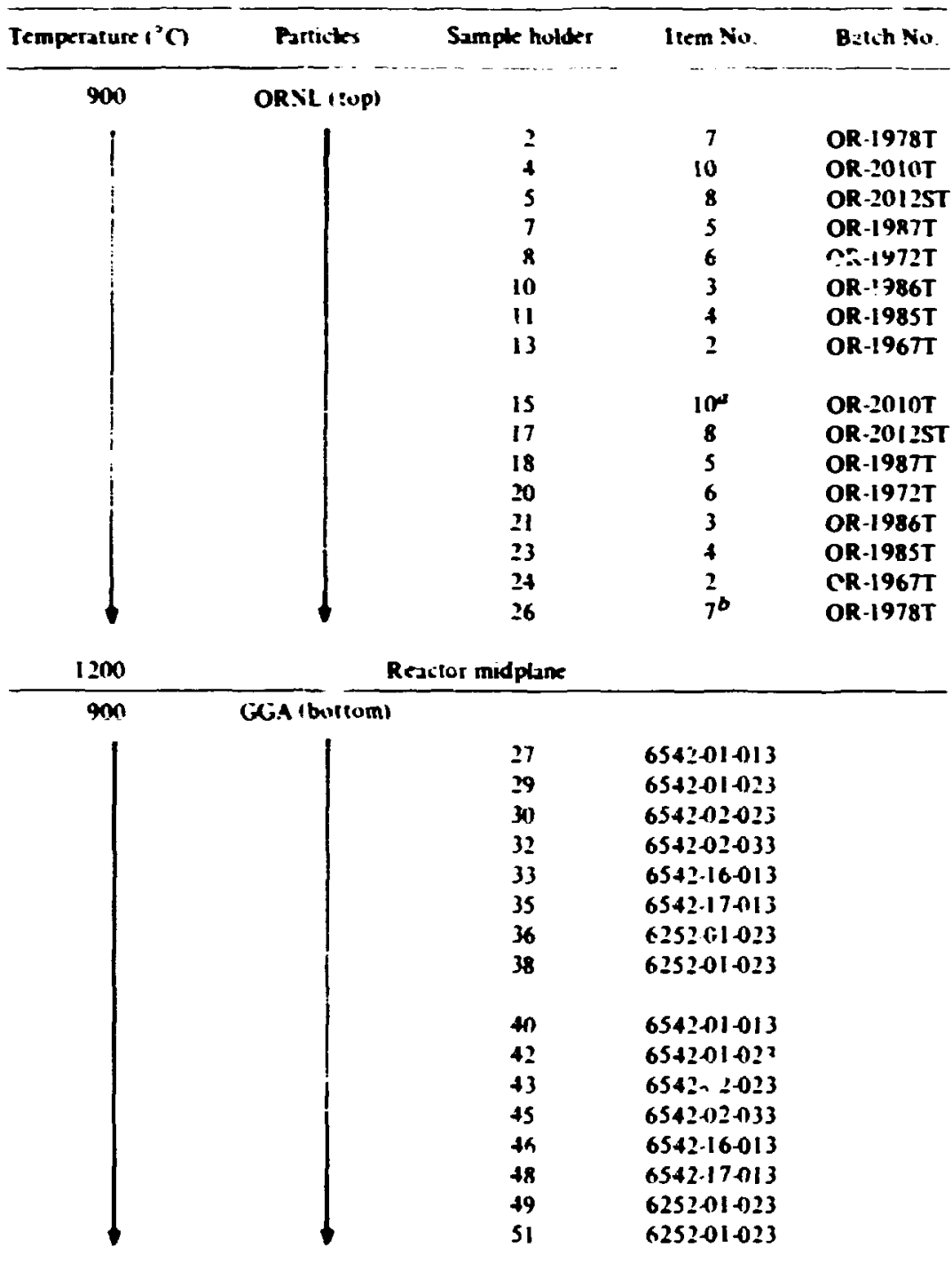

This particle wili be repluced by item I. OR-1975T, in HIT-19.

OThis particle will be replaced by Irem 9. OR-201 3ST. in HT- 18 and - 19 .

power. The peak fast fluence was $4.73 \times 10^{21}$ neutrons $\left./ \mathrm{cm}^{2}(f)>0.18 \mathrm{MEV}\right)$, and the peak fertile particle burnup was $2.8 \mathrm{Z}$ ? FIMA

rapsule H I.18 was inserted in target position E-20n July 22. 197.3. and was removed of $O=1.28,197.3$, after 92.94 Jays (four HFIR cycles) a: 100 iN reactor power. The peak fast fluence was $948 \times 10^{2}$ ! neutrons $/ \mathrm{m}^{2}$ (F: $\left.>0.18 \mathrm{MeV}\right)$. and the peak fertile particle burnup was $9.7 \%$ FIMA
Capsule HT.19 was inserted it larget position, F.7 on July 22. 197.3. and was removed on Dec. 17, 197.3. aller 1,39.27 days (six HFIR cycis) af $100 \mathrm{MW}$ reaclor power. The peak fast fluence was $1.4 \times 10^{22}$ neul. irons $\left./ \mathrm{cm}^{2}(E)>0.18 \mathrm{MeV}\right)$. and the peak fertile particle burnup was 17.247, FIMA.

Table 7.20 gives the fast nuence and fertils particle burnup for each sample holder in each capsule. Nis attempt was riade to calciide the fissile particle 
Table 7.19. Deposition conditions and property measurements on ORNL particles for MT.17, Ix, and 1 ?

\begin{tabular}{|c|c|c|c|c|c|c|c|c|c|c|c|c|}
\hline \multirow{4}{*}{$\begin{array}{c}\begin{array}{c}\text { Butch } \\
\text { No. }\end{array} \\
\text { OR-1975T }\end{array}$} & \multicolumn{3}{|c|}{ Deposition cinditionso } & \multirow{4}{*}{$\frac{\begin{array}{c}\text { Depusition } \\
\text { ralien } \\
(\mu \mathrm{m} / \mathrm{min})\end{array}}{11.8}$} & \multicolumn{7}{|c|}{ Meusured mopenties } & \multirow{4}{*}{ H.AF: } \\
\hline & \multirow{3}{*}{$\frac{\begin{array}{c}\text { romperilupe } \\
\text { (C) }\end{array}}{1313}$} & \multirow{3}{*}{$\begin{array}{c}\begin{array}{c}\text { Propylene } \\
\text { nux } \\
\left(\mathrm{cm}^{3} \min ^{-1} \mathrm{~cm}^{-2}\right)\end{array} \\
4.00\end{array}$} & \multirow{3}{*}{$\begin{array}{c}\begin{array}{c}\text { Prupylent } \\
\text { concentration } \\
1 \%)\end{array} \\
33.3\end{array}$} & & \multicolumn{3}{|c|}{ Buffer } & \multicolumn{4}{|c|}{ Ouler Conatimy } & \\
\hline & & & & & \multicolumn{2}{|c|}{$\begin{array}{c}\text { Meiun } \\
\text { (hicknisss } \\
(\mu 1 n)\end{array}$} & \multirow{2}{*}{$\frac{\begin{array}{c}\text { Mran } \\
\text { denuity } \\
\left(\mathbb{w} / \mathrm{sm}^{\circ}\right)\end{array}}{1.19}$} & \multicolumn{2}{|c|}{$\begin{array}{c}\text { Mean } \\
\text { thickness } \\
(\mu \mathrm{In})\end{array}$} & \multicolumn{2}{|c|}{$\begin{array}{c}\text { Mean } \\
\text { density } \\
\left(x / \operatorname{com}^{d}\right)\end{array}$} & \\
\hline & & & & & 68.5 & 17 & & 83.0 & $(3.5)$ & 1.982 & $(1) .(3017)$ & \\
\hline OR.1967T & 1300 & 2.00 & 16.7 & 5.2 & 75.6 & 15.21 & 1.19 & 78.4 & 13.71 & 2.0000 & $10.007)$ & 1.115 \\
\hline OR.1986T & 1250 & 1.10 & 9.2 & 2.1 & 69.2 & 17.21 & 1.19 & ins & $(3, n)$ & 2.102 & $(0.310)$ & 1.10 \\
\hline OR.1985T & 1275 & 1.25 & 10.4 & 2.9 & 71.0 & (7.6) & 1.19 & 76.4 & $(.3 .9)$ & 2.065 & $(0.008)$ & 1.12 \\
\hline OR.1987T & 1250 & 0.90 & 7.5 & 1.7 & 72,4 & $(9.8)$ & 1.19 & 84.9 & 14.31 & 2094 & (1).00s) & 1.17 \\
\hline OR.1972T & 1250 & 1.00 & 8.4 & 2.0 & 69.4 & (6.2) & 1.19 & 78.7 & $(4.3)$ & 2.116 .3 & $10.009)$ & $\cdots$ \\
\hline OR-1978T & 1240 & 0.50 & 42 & 0.8 & 69.8 & (4.1) & 1.19 & 83.9 & 13.61 & 2.072 & (0.00) & 1.73 \\
\hline OR-2012ST & $1200 \quad 13511$ & 1.50 & 12.5 & 3.7 & 74.1 & 16.3) & 1.19 & 100.4 & (3.0) & 1919 & $(0.0(19)$ & Cirudiens \\
\hline OR-201 3ST & 1325 & 4.00 & 33.3 & 11.5 & 80.4 & 16.91 & 1.19 & 84.5 & $\{3.9\}$ & 20102 & $\{0.009\}$ & l.mer \\
\hline OR.2010T & 1335 & 9.00 & 33.3 & 22.5 & 96.6 & $(8.6)$ & 1.08 & 105.4 & $(5.4)$ & 1.980 & $(11.009)$ & $1.00^{\prime}$ \\
\hline
\end{tabular}

- Ouler coaling unly; hulfer cojling deposited from aci yleno.

PDiluled with argun. except OR.2013ST, which was dithted with (CO,

"Si:in:mury irum MET CER.DS.2.

tNumbers in parentheses ale standard deviations.

Calculisted. includes wal cosaliny.

festi naiod from coutina run conditiuns. 


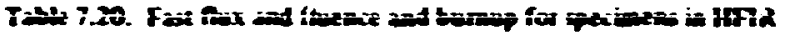

burt copeles HT-17. - 18. and -19

\begin{tabular}{|c|c|c|c|c|c|c|c|c|}
\hline \multirow{2}{*}{$\begin{array}{l}\text { Sumple } \\
\text { tolket } \\
\text { Niv }\end{array}$} & \multicolumn{3}{|c|}{$\begin{array}{c}\text { Fase heutron flucence. } E>0.18 \mathrm{MeV} \\
\text { incutrunsite }\end{array}$} & \multirow{2}{*}{$\begin{array}{c}\text { Fast-neution flux. } \\
E>0.18 \mathrm{geV} \\
\text { incutruns } \mathrm{im}^{-2} \mathrm{ec}^{-1} \text { ) }\end{array}$} & \multirow{2}{*}{$\begin{array}{l}\text { Destame } \\
\text { from } \\
\text { hulder ienter } \\
\text { co reactur } \\
\text { midplase (an.) }\end{array}$} & \multicolumn{3}{|c|}{ Fertuk portinte trmep if FIMA } \\
\hline & $\mathbf{H T}-17$ & HT.18 & HT-19 & & & HT-17 & HT-18 & $H T-19$ \\
\hline & $\times 10^{21}$ & $\times 1 ?^{21}$ & $\times 10^{21}$ & $\times 10^{15}$ & & & & \\
\hline I. 52 & 2.24 & 4.51 & 6.75 & 0.56 & 9.199 & & & \\
\hline 2.51 & 2.37 & 4.74 & 7.10 & 0.59 & 8.909 & 1.40 & 5.25 & 991 \\
\hline 3.50 & 2.54 & 5.09 & 763 & 0.63 & 8.626 & & & \\
\hline 4.49 & 2.72 & 5.44 & 8.15 & 0.67 & 8.34 & 1.57 & 5.78 & $10.8 ;$ \\
\hline 5.48 & 2.83 & 5.68 & 8.50 & 0.70 & 8.061 & 1.63 & 6.05 & .30 \\
\hline 6,47 & 2.95 & 5.91 & 8.85 & 0.73 & 7.779 & & & \\
\hline 7.46 & 3.07 & 6.14 & 9.20 & 0.76 & 7.496 & 1.81 & 6.53 & 12.10 \\
\hline 8.45 & 3.21 & 644 & 9.64 & 0.80 & 7.214 & 1.90 & 6.78 & 12.52 \\
\hline 9.44 & 3.30 & 6.61 & 9.90 & 0.82 & 6.931 & & & \\
\hline 10.43 & 3.42 & 6.85 & 10.3 & 0.85 & 6.649 & 2.03 & 7.20 & 1325 \\
\hline 11.42 & 3.56 & 7.14 & 10.7 & 0.88 & 6.366 & 2.10 & 7.43 & 13.60 \\
\hline 12.41 & 3.08 & 7.37 & 110 & 0.91 & 6.084 & & & \\
\hline 13.40 & 3.74 & 7.49 & 11.2 & $0.9 j$ & 5.801 & 2.22 & 7.82 & 1421 \\
\hline 14.39 & 4.23 & 8.19 & 12.7 & i. .05 & 4.199 & & & \\
\hline 15.38 & 4.26 & 8.54 & 12.8 & 1.06 & 3.909 & 2.61 & 8.88 & 15.88 \\
\hline 16. 37 & 4.35 & 8.72 & 13.1 & 1.08 & 3.626 & & & \\
\hline 17.36 & 4.41 & 8.84 & 13.2 & 1.09 & 3.344 & 2.70 & 9.11 & 16.27 \\
\hline 18.35 & 4.47 & 8.95 & 13.4 & 1.11 & 3.061 & 2.72 & 9.22 & 1643 \\
\hline 19.34 & 4.53 & 9.07 & 13.6 & 1.12 & 2.779 & & & \\
\hline 20.33 & 4.55 & 9.13 & 13.7 & 1.13 & 2.496 & 2.80 & 9.40 & 16.71 \\
\hline 21.32 & 4.58 & 9.19 & 13.8 & 1.14 & 2.214 & 2.81 & 9.48 & 1685 \\
\hline 22.31 & 4.54 & 9.30 & 13.9 & 1.15 & 1.931 & & & \\
\hline 23,30 & 467 & 9.36 & 14.0 & 1.16 & 1.649 & 2.85 & 9.60 & $1: .03$ \\
\hline 24.29 & 4.70 & 9.42 & 14.1 & 1.16 & 1.366 & 2.87 & 9.64 & 11.12 \\
\hline 25.28 & 4.73 & 9.48 & 14.2 & 1.17 & 1.084 & & & \\
\hline 26.27 & 4.73 & 9.48 & 14.2 & 1.17 & 0.801 & 2.88 & 9.10 & 17.24 \\
\hline
\end{tabular}

burnup. Table 7.21 gives the operating history of the reaclor during the irradiation of each capsule.

\section{Postimadiation eximination}

(J M Robbins. V. P. Eatherly)

Capsules : $1 \mathrm{~T}-17$ and -18 have been opened and visually ex:mined: HT. 19 will be opened in early 1974 When ope.ed. both !IT-17 and -18 were observed in be free of son.y material. as was the case for HT.12 through -15; this is attributed to the gettering action of zirconium foil disks used between the particle holders in each maga:ine. The graphite porticle holders in the low-lemperature region from both HT-17 and 18 were removed and opened without much difficulty: however. the mas atines in the high-lempersiure region of HT. 18 had in be slit to remove the particle holders. and the holders had to be broken to remove the particles. The graphite holders were observed to break easily and we re quile friable; this was not so in $\mathbf{H T}^{-17}$. Table 7.22 shows the survival rates for both ORNL and GAC particles in HT. 17 and -18 .

The table shows that in HT-17, all the GAC particles survived well except the Trisocoated batch: in HT-IR. the GAC particles strvived well in the low-temperaltire zone but began to show some failures at high temperature. Again. the Trisozioaled balch failed. No altempt was made io evaluate the GAC particles beyond visual examination: they have been relurned In GAC for final evaluation.

The general trend for ORNL particles in HT-17 was that particles with BAFs gieater than 1.10 survived at low temperalures and failed at high temperature. An exieption was that sample OR-2012ST. with a BA.r of 


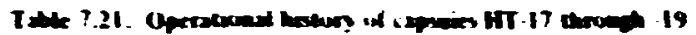

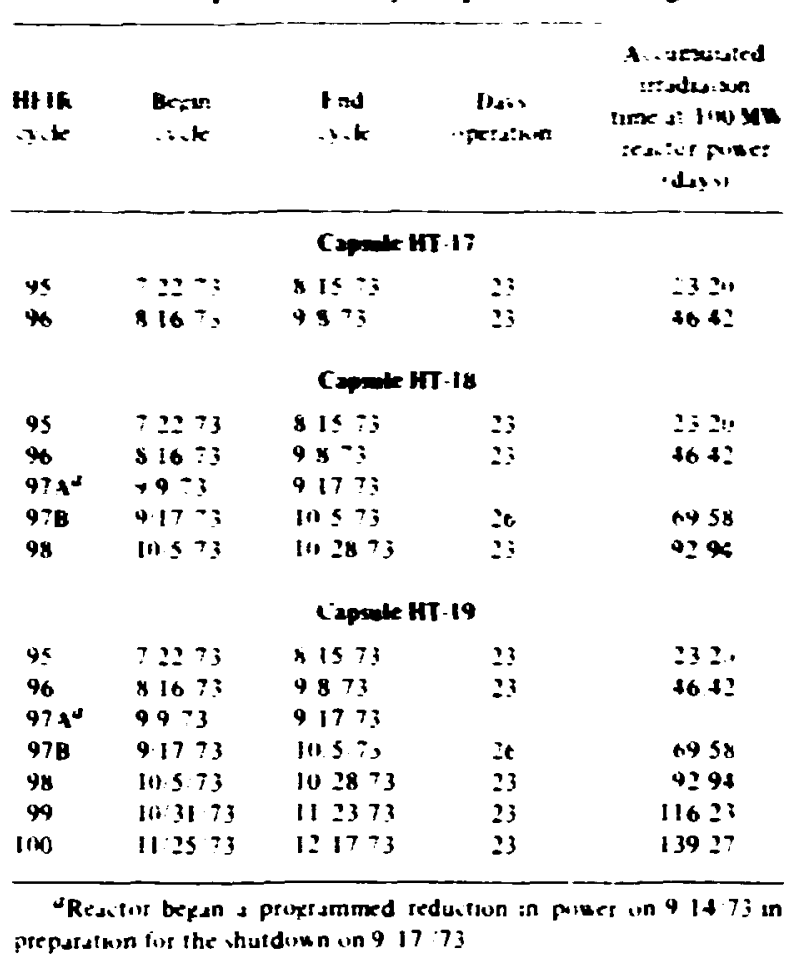

Table 7.22. Servival rates for ORVL and GAC partictes in $\mathrm{HT}-17$ and -18

\begin{tabular}{|c|c|c|c|c|c|c|}
\hline \multirow{3}{*}{$\begin{array}{c}\text { Batct: } \\
\text { No. }\end{array}$} & \multirow{3}{*}{ Source } & \multirow{3}{*}{ E SF or OPT AF } & \multicolumn{4}{|c|}{ Suntval rate (;) } \\
\hline & & & \multicolumn{2}{|c|}{ HT-i7 } & \multicolumn{2}{|c|}{ HT - 18} \\
\hline & & & $900^{\prime} \mathrm{C}$ & $1250^{\circ} \mathrm{C}$ & $900^{\circ} \mathrm{C}$ & $1250^{\circ} \mathrm{C}$ \\
\hline OR-2GruT & ORNL & 1.00 & 100 & 100 & 100 & 86 \\
\hline OR-1967T & ORNL & 1.05 & 100 & n & 0 & 0 \\
\hline OR-20I2ST & ORNL & 1.08 & $10 n$ & 84 & 0 & 0 \\
\hline OR-1985T & ORNL & 1.12 & 93 & 0 & 0 & $\mathbf{0}$ \\
\hline OR-1986T & ORNL & 1.10 & 24 & lno & 0 & n \\
\hline OR.1972T & ORNL & 1.22 & 100 & $n$ & 0 & $\mathbf{0}$ \\
\hline OR-198T & ORNL & 1.17 & 100 & 0 & 0 & 0 \\
\hline OR-i978T & ORNL & 1.73 & $\because 9$ & 0 & 0 & $b$ \\
\hline OR-20I 3ST & ORNL & 100 & $b$ & $b$ & $b$ & 100 \\
\hline OR-1975T & ORNL & 100 & $b$ & $\boldsymbol{b}$ & $b$ & $\boldsymbol{b}$ \\
\hline $6542 \cap[013$ & GAC & I.n6 & 100 & 100 & 98 & 1 \\
\hline 651201023 & CiAC & 1.10 & 100 & 100 & 54 & 98 \\
\hline 6542112023 & GAC & 1.06 & $\operatorname{In} 0$ & 100 & 85 & 100 \\
\hline 6542112033 & GAC & 1.12 & $: 9$ & 100 & 66 & 19 \\
\hline 6542.16013 & GAC & 107 & $\operatorname{lm}$ & 86 & 93 & 0 \\
\hline 6542.17013 & GAC & 1.27 & $\ln$ & $\operatorname{lno}$ & 93 & $s$ \\
\hline 625201023 & Car & 108 & 0 & 0 & $12^{d}$ & $12^{d}$ \\
\hline 625201023 & GAC & $1 \mathrm{ng}$ & 0 & 0 & $n$ & $14^{d}$ \\
\hline
\end{tabular}

"GaC values ite OPTAF. ORNL values dre BAF

OThis particle butch not in this position in th. " mapasine

CTrin-cosied pursictes

These parficles wall be checked apan for fallure al GAC. 
I Un. wevived betiet than OR-1407T IBAF I 051

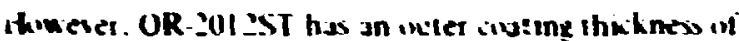

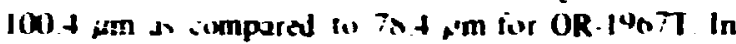
HT-Is. ORSil particlo isled inm tetely except fin the new partkle IOR-20I:ST) and so": af tha parkiles IOR-20IOT, with ihe large 164? $\mu$ m-diam l kernets and low 1100 ) BAf. The survisl of thex iwil partik baliches was not unexperiled.

tthinugh mast of the ORNL particles iaked in

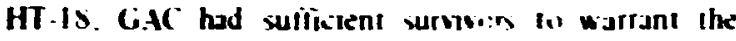
intinuation of apsule HT-19.

\section{2.t Capsule idT-29 through .23 \\ w. D. Eatherly J M Rubbirs}

Impurlant changes mit ixiur in seterat piepperlies of bonded fuel rods durng ir:adiation. To assess these changes on ierlain parameters. we have designed an irradiation test series of foui HFIR larget iapsules In measure the shange in thermal conductivity. elect nical resistivity. Inermal expansion. and dimensions of stmulated bonded fuel rods as a function of fuel partick volume hasding and tast-neutron tluence. The iapsules will be irradiated for one. iwo. four. and six cyiles. respectively. at a temperature of $900^{\circ} \mathrm{C}$.

The samples for irradiation wili be selected in the basis of electrical resistivity mejsurements. This will ensure that each type of specimen for one capsule will have the same characleristics as the similar specimens for th: companion ispsules. Alsi, companion specimens will be selected for preirradiation determiration of thermal conductivily and ixefficient of thermal expansion. After irradiation. the coefficient of thermat expansion. electrical resistivity. dimensions. and thermal condu:tivity vill be determined. These measurements wil! be made al temperatures up Io $700^{\circ} \mathrm{C}$. A mathematical analysis of the data will be made using the following equation:

$$
\lambda=\lambda_{m}-\begin{array}{cc}
1 & f+f\left(\frac{3 \lambda_{s}}{2 \lambda_{s}+\lambda_{m}}\right) \\
1 & f+f\left(\frac{3 \lambda_{m}}{2 \lambda_{s}+\lambda_{m}}\right)
\end{array}
$$

where

$\lambda=$ thermal conductivity of the composite.

$\lambda_{m}=$ thermal conduclivity of the matrix.

$\lambda_{s}=$ thermal conductivity of the imbejded particles.

$f=$ volume fraction of ' nbedded particles.

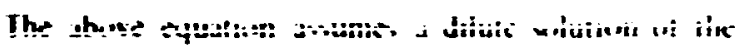
pherkil partsich in the isthint matris and bhould the

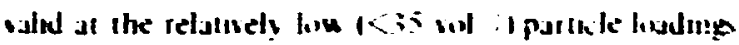
"li the speiamers in this experument

\section{Exp eriment dosiga}

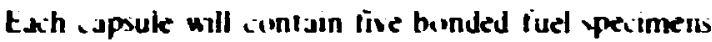

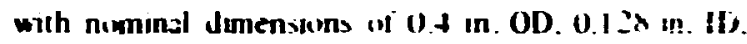
and 2.0 in long. simmetriked stout the restor midptane. The remainung space in elther end if the arsula will be uxd to test expetinkentul gisphiter fir pinsible use in vrunlural parts in gisionsled resilurs. One wi the live spicimens in the primary exper:nkent will be fabrialid by the slug-iniection tedinique and will contain approximately (n) sol $\because$ Bixcivaled inert partikles. This speimen will be pesituoned ahout the midplane of the reditur with iwo of the remaining firur specimens on each side of It. Thex four specimens will be formeal by ex/rusion' ' and w!l hate Bosocioated arbon particle losdings varying from 0 (o jhout $35 \mathrm{vol}$ $r$ in iour spproxinately equal increments. The linur extruderl specimens will have the sune matrix compusi. tion and approximately the sume matrix density. uhich

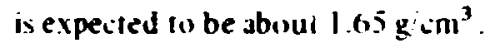

\subsection{IRRADIATION TESTS IN ORR IN-CORE FACILITY}
K. R. Thoms
A. W. Longest

Two high-llux facilaties were prepared in the ORR for joint ORN' GAC irradiation lesting. These facil:-ies. which oricupy the $C-3$ and $E-3$ core positions, ate apoble of irradialing fully instrumented capsules ho:ving temperature sontrol capability achieved by the use of mixed sweep gases. The ORR tore loading lias been adjusted to produce a fast-neutron flux in these iacilities sufficiently high to give representutive HTGR exposures of about $\times 10^{21}$ neutions $/ \mathrm{cm}^{2}$ in one year. One facility. C.3. was icicpied by a graphite uradiation capsule designed and fistricated by GAC. The secind facility is presently oxiupied hy a joint OR.VL-GAC fueled experiment which was designed and consirucled principally al ORNL.

\subsection{Dexign and Operation of OC.1}

The first capsule. Jesignated OC-1. was designed and built by GAC and irradialed in the ORR ( -3 porition.

11. See Sect. 6.2.3, this sepori: 
The apule was insisled in the ORR in June ix. in:

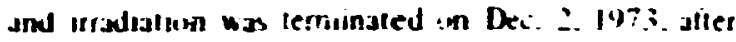

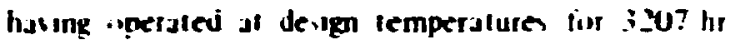
This apule contisined 10 grophite irucibles that

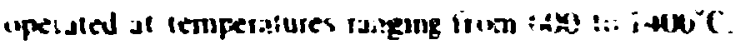

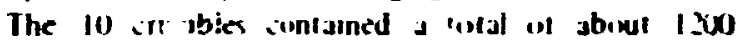
specimens. wme "li which were irradialed in previlus Cic experimenl, und sume of which will be reiriad! sied in the nexi ORR graplute uradiation test. capsile or: :

The incore xitin an this apsule was divided into iwal iells: the upper cell s:tritained vevrll cruishles and the luwer cell cuntaned liree irusibies. The temperature of eish cell was controlled by ais irctependent sweeptas system at mixed helium and arge on Since this was the hirs of a series of similarly je.igned in-core apsuiex. it served as a pront text of the bavic desiâl a. well as a hasis of support for a previous test': perfurmed (1) estumali the gamma healing rate of the inil incore facilities.

The initial operation of capsule $\alpha_{j}-1$ was very ersouraging. We fiouno that the desired operating temperatura could be chtained essily with approxiinately the same gas mixture preduted in the thermal analysi.s. Since l'ie sole source it heat in this capsule was gamms hea. this initisl operatiun confirmed that our prediction of the gamma heating rate in the $\mathrm{C}-3$ core posilion was fairly jicurale.

The most serious problem enciountered in the operstion of capsule $O G . I$ was the failure of the thermucisuple lead tuhe. The fube was replaced with tygon tubing. which remained intact during the duration of the test. We found that the resistivity of the -eactor pool water is high enough to prevent shorting of the thermosiouples even though the top of the hermeti: sasi to the capsule was completely exposed to the pool water. This hermetic sest prevented the pixll water from entering the seciondary contairment ans :herefore the failure of the lead twhe proved to be more if an inconveriserce than a ha/ard to the experiment.

The secind graphite irradiation test . capsule OG-2. is presently atheduled in be iirstalled in the ORR during the July 14. 19\%4, shuidown of thr. ORR.

\subsubsection{Dexign and Operation of OF-1}

The joint ORNLGAC fueled experiment designated - OF. I (GAC designation PI.3Q I is also divided inlo two

$$
\text { .......... }
$$

12. K. R. Thoms. "Irrudiaicion it GPR Cince Facilieves," GCR Proxroms Annu. Prux Rep. Dir 31. 19: $\therefore$ OPNL-4911, pp. $115 \cdot 16$

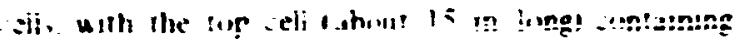
lifl tuel ypectmen. and the bultum cell tabuut $s$ in

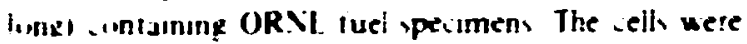

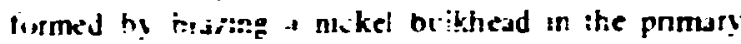

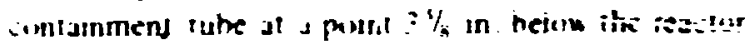
mudplane tach iell has $b$ akn sweepgas system aliuwing irdependent iempersture control and hisson-

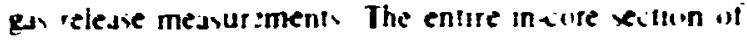
the ispsu'e is shown in Fig.?

The upper cell jexigned ind iabriated by $G A C$.

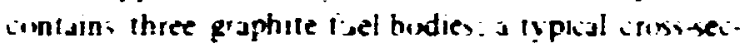
ilosn whour: in Sect' in A-A if Fig. 7.39 . There ate three U.'?:-In-diam aval holes for fuel rods and ti:ree 0 500-in diam tules for graphite samples. There is a 047 in diam hole in the center of exth sruible that antins a graphite spine contining thermuiouples. dusimetry. Ind the inlet sweep-gas lires. There ste six Otrisin diam tules is. the sraphite body which also contan the mociouples and do simerry. There are a total "if $1^{7}$ themmosotples in this celi. Inciuding three Chromel tlumel and it iungsten-rlienium in :? Re W 25, Rel. The uperation of the GAC :ell innsists in adjusting he iweeptas mixture 10 mainain thernoinuple $\mathrm{K} / \mathrm{I}$ shown in Fig. 7.291 a $750 \mathrm{C}$

The kiower cell. designed and jabricued by ORNL. contains a ingle graphite fuel hody whose iriss seition is shown in Section B.B of Fig. ?.29. There are tive $0+09$.jn diam holes one ientral hoie and iour peripheral holes. Two of the peripheral holes are to test the intolok istbonication process. Wilite the :enual holes and the other two peripheral holes are fortest the paikedbed arbonized fuel rods. There are ien 0.096 -in diam holes containing various tlux monitors. As can be seen in Fig. 7.29. thete are thermiciouples in the fuel hody web beiween the peripheral fuel rods and the graphite OD. Theri? are three additional t!ismocouples in the lower $2 \because$ in. of the fuel body evenly spaced around one peripheral fuel rod. Thess thermocouples are intended to provice information on the effective thermal conductivity between the fuel center line and the graphite fuel body.

Centering of the graphite fuel body was acomplished by wo differeri! methods. At the top end of the fluel biejy are eighi 0.125 in.diam holes in to which "Lucalox. $\left(\mathrm{Al}_{2} \mathrm{O}_{3}\right)$ pins were placed. These pins were machined sn as fo provide essentially point inntact with the stainless steel primary containment tube Th: bollom end of the fuel hody was machined in the shape of an octagon. again providıng essentially point contact between the graphile and the primary containment.

Both ends of the fuel body were insulated with 0.500 -in.thick Palarite.C (fibrous carbon) insulaii in 


$$
1
$$




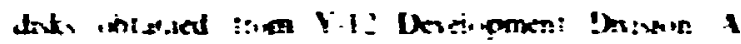

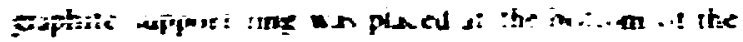

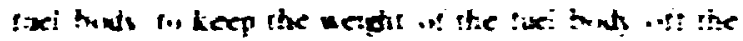
Psimer andu:

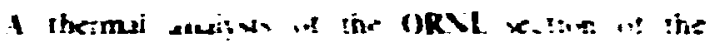

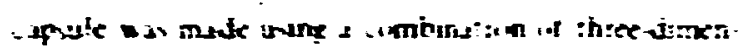

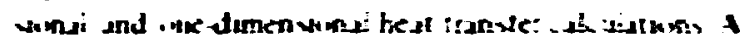

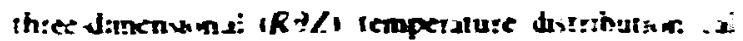

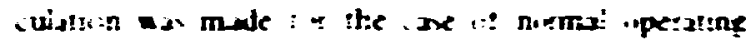

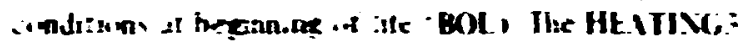

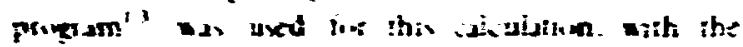

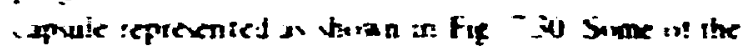

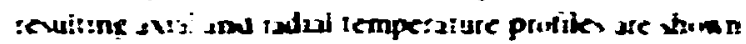
In Fin - is and $-:$ The inedursenstur.e hes:

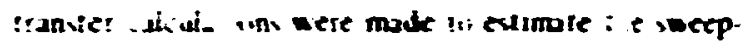

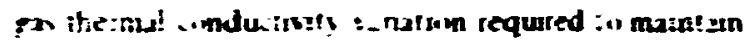

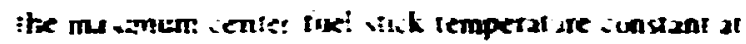

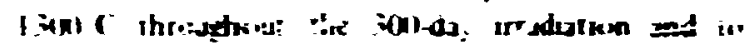

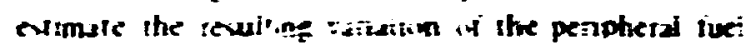

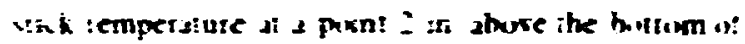
the tuet sink The rewiis of the unedimemand

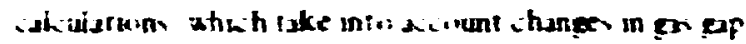

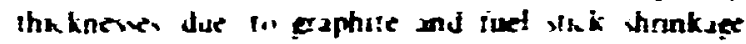
with isi-pxuitun elpunure and thanger in t:est geme:s-

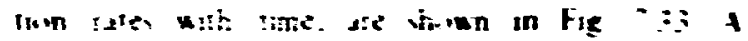

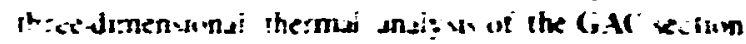
if the OF! aphise wh pertinmed ho Gill

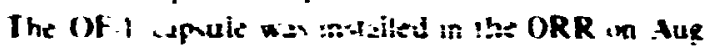
$\because$ (1)

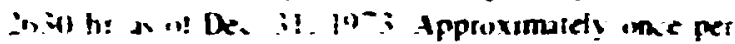

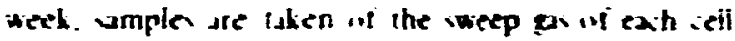

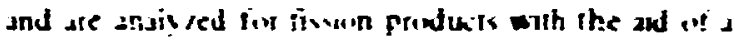
commstas speitrmeter The andysus of the amples from the CiAC ieli cisnsists in thising insum product indentration at the iuel These tesults ste then iepurted in Gifl. where iney die cunverted in rejeare.

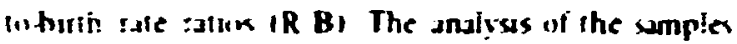
firm the ORNI + ell censsis in Jetermuning the $R$ B value dreilly f histong of the $R$ B vilues for the OR.VI. sell :s presented in Table $; .23$

\subsubsection{Preparation if Speciodens for OF.I Imadiation Test \\ R A Hodley W J Laikey}

Ine OF.I Ifisdiation lest innianed eigit Iypes af fuel rinds The :erf valubles inlinded the finvic kernel

13. W. D. Tumer and $M$ Siman-yiw. Afterive? in

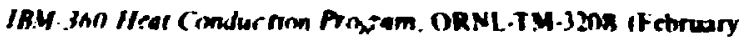
19711.

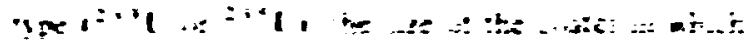

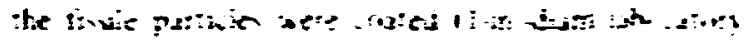

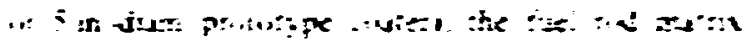

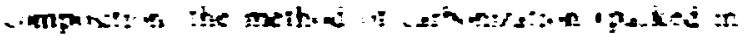

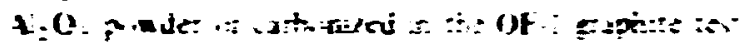

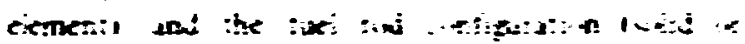

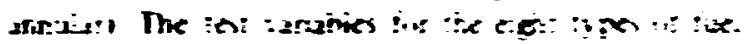

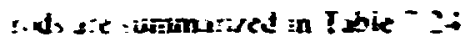

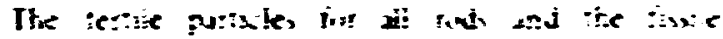

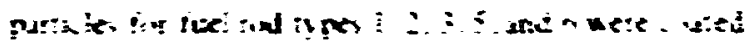

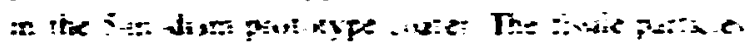

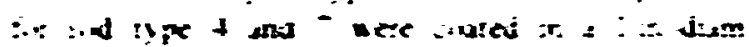

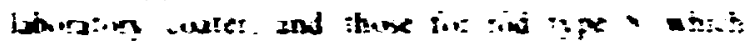

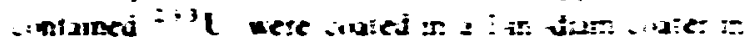

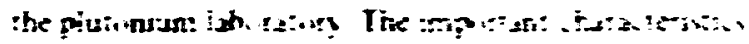

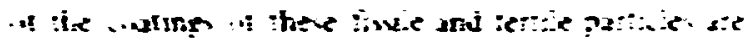
sumersed in !hil: - is

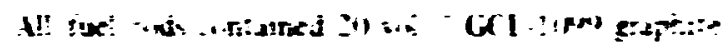

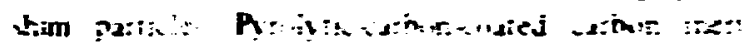

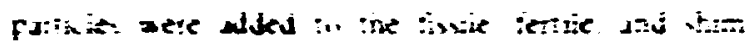

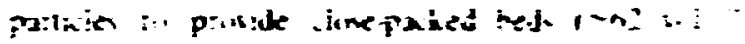

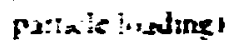

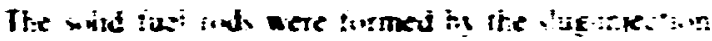

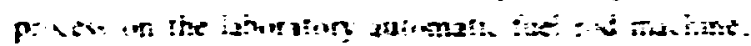

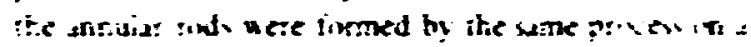
monus: pies

The riad were athonuzed enther in paked $+i: G, \ldots$

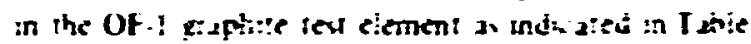

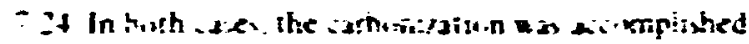

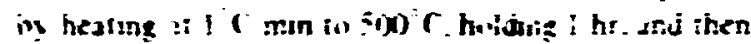

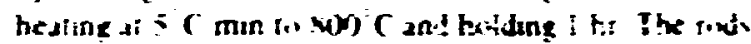

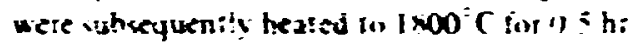

The weras: ..isinx demsily and mith . rlike ykit if eah igne ind sie jemmarised in Tahie - in In: mins densty i: linearly seiated to the pitits . "the seld whik te!: into biut alegries

i rind athinizted in staphice eiement.

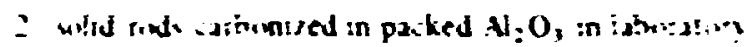

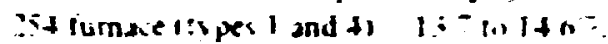

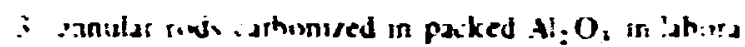

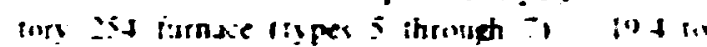
:I:

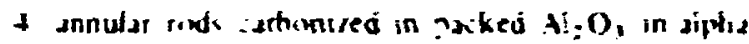

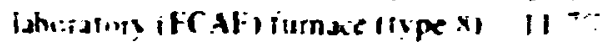

The dif̈erences in pifici coike sieid of rinds artmmired in paked $\mathrm{Ai}_{\mathrm{U}} \mathrm{U}_{3}$ in different furnares are apparen!ly Jue io srimil diffe:enier in heding rates

Hetallographic exanundion of these rods showed that all rods arthonized in naked $A: O$, had maillier urth 

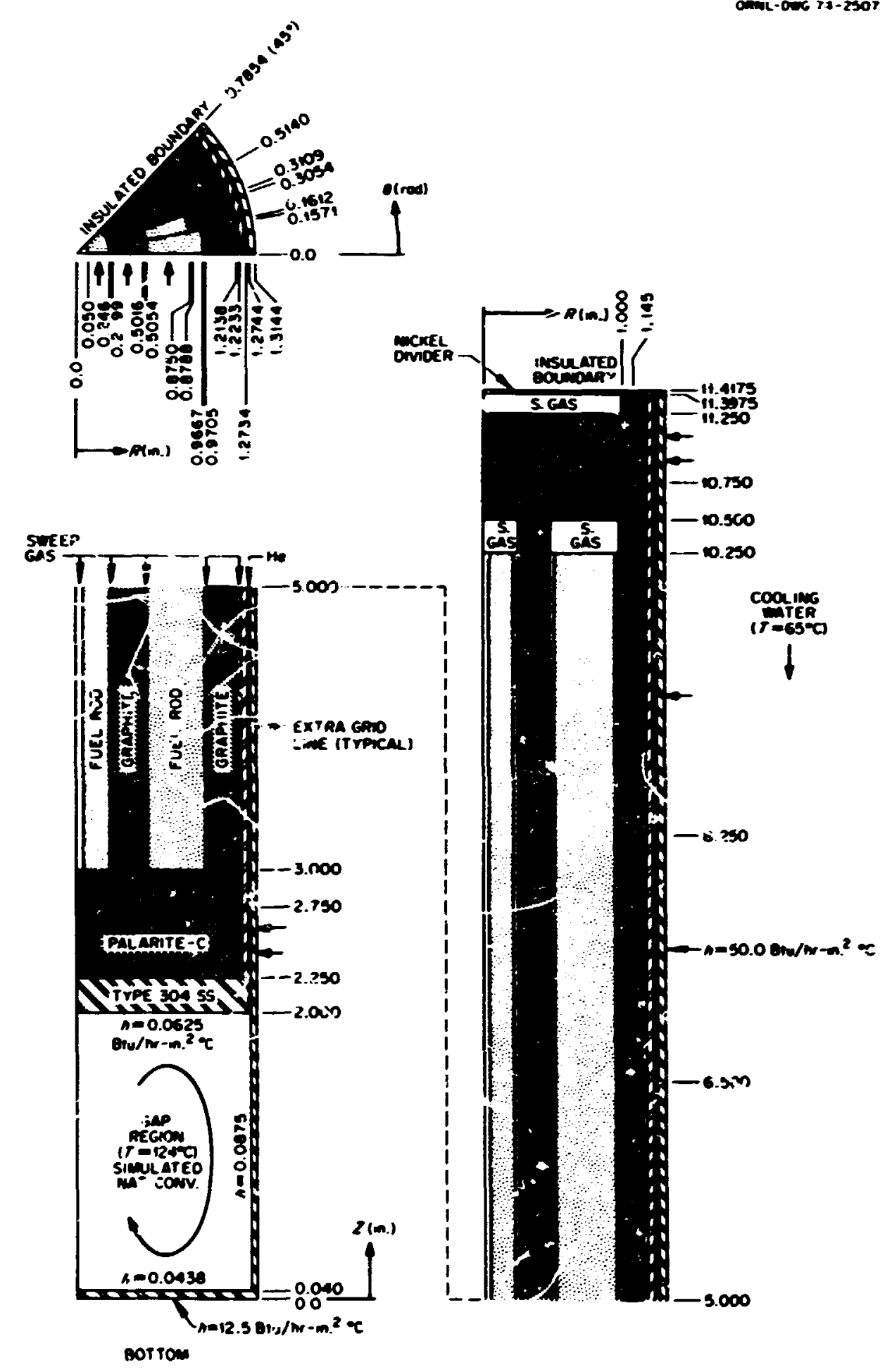

$0001-00678-2507$

Fig. 7.30. Representation of capark OF.1 for the HEATINri3 propan. 


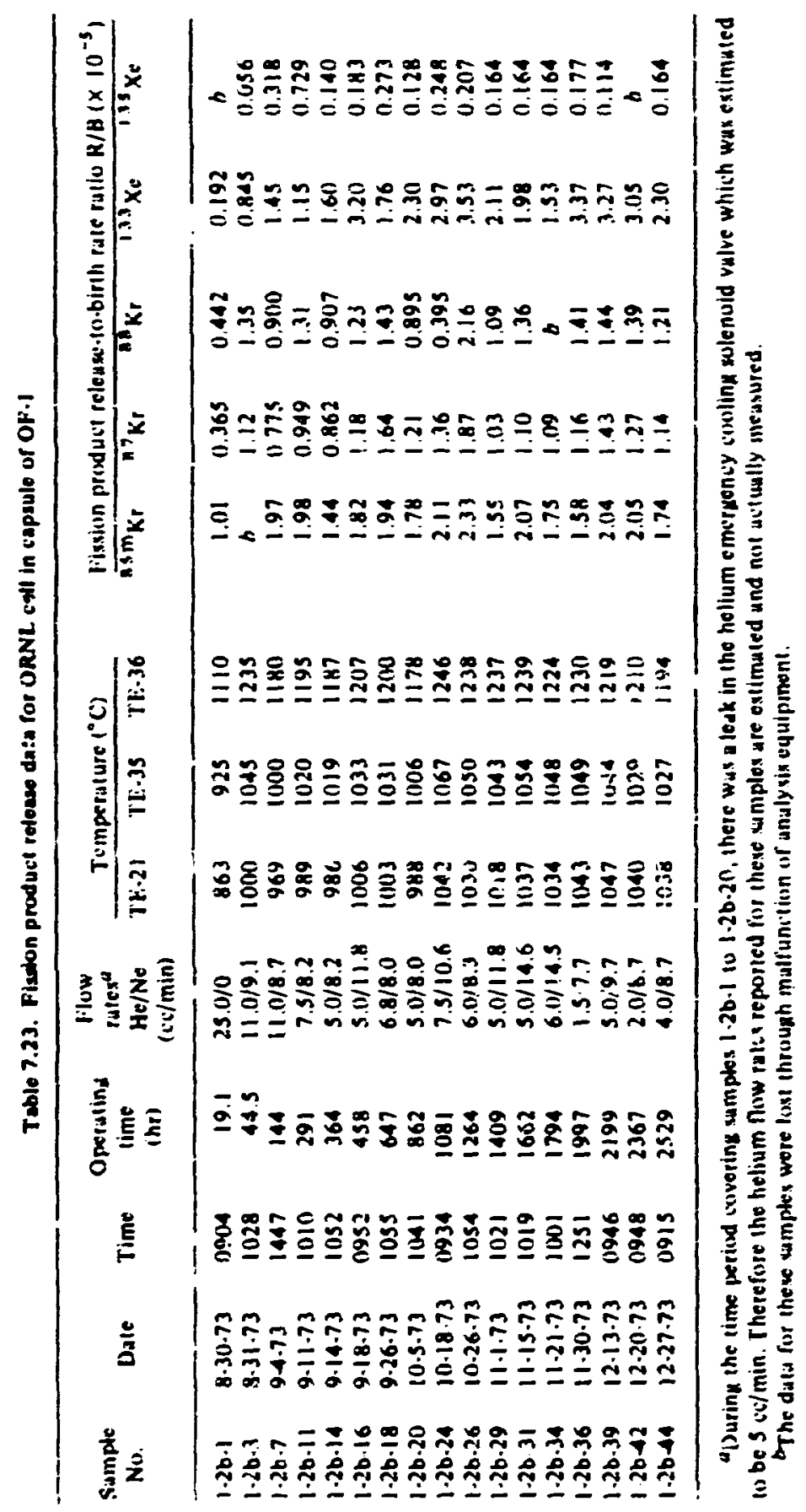




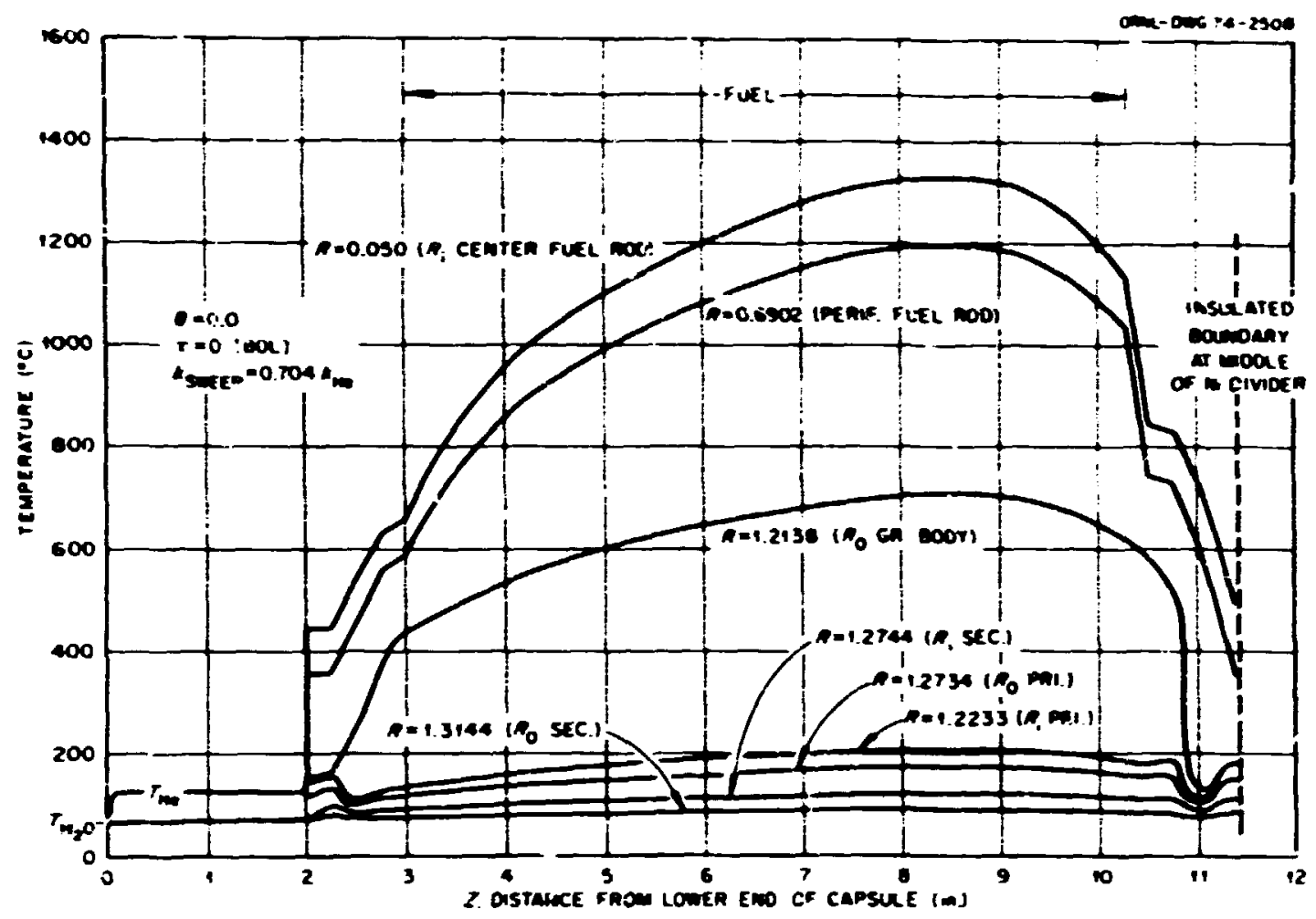

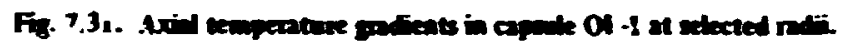

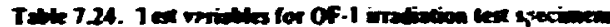

\begin{tabular}{|c|c|c|c|c|}
\hline $\begin{array}{l}\text { Fuel rod } \\
\text { type }\end{array}$ & $\begin{array}{c}\text { Froule } \\
\text { por: ic iype }\end{array}$ & $\begin{array}{l}\text { Motmx } \\
\text { filler type }\end{array}$ & $\begin{array}{c}\text { Carbombinon } \\
\text { method }\end{array}$ & $\begin{array}{l}\text { Foed rod } \\
\text { cumperaraton }\end{array}$ \\
\hline I & $\begin{array}{l}\text { Protityp: } \\
\text { oiter }\end{array}$ & Abery $6353^{\circ}$ & $\begin{array}{c}\text { Pucted a } \\
\mathrm{Al}_{2} \mathrm{O}_{3}\end{array}$ & Solid \\
\hline 2 & $\begin{array}{l}\text { Prrionype } \\
\text { coater }\end{array}$ & Adber 6353 & $\begin{array}{l}\text { In groptrie } \\
\text { etewaent }\end{array}$ & Solvd \\
\hline 3 & $\begin{array}{l}\text { Prosorype } \\
\text { coster }\end{array}$ & GLC loss & $\begin{array}{l}\text { In prophute } \\
\text { element }\end{array}$ & Solnd \\
\hline 4 & $\begin{array}{l}\text { Laboralory } \\
\text { coveter }\end{array}$ & Abor 6353 & $\begin{array}{c}\text { Paxtied in } \\
\mathrm{Ai}_{2} \mathrm{O}_{3}\end{array}$ & Solves \\
\hline 3 & $\begin{array}{l}\text { Prototype } \\
\text { coulet }\end{array}$ & Astorr 6353 & $\begin{array}{c}\text { Pacted } \\
\mathrm{Al}_{2} \mathrm{O}_{3}\end{array}$ & Anaubr \\
\hline 6 & $\begin{array}{l}\text { Prototype } \\
\text { cosiet }\end{array}$ & Astoury 63;3 & $\begin{array}{c}\text { Factus in } \\
\mathrm{Al}_{2} \mathrm{O}_{3}\end{array}$ & Annubr \\
\hline $\boldsymbol{T}$ & $\begin{array}{l}\text { Lowaton } \\
\text { contes }\end{array}$ & Abory 6353 & $\begin{array}{c}\text { Paxted w } \\
\mathrm{Al}_{\mathbf{2}} \mathrm{O}\end{array}$ & Anabr \\
\hline 8 & $\begin{array}{l}\text { To buboratory } \\
\text { cosiet }\end{array}$ & Abey 6353 & $\begin{array}{c}\text { Pekt }=1 \text { in } \\
\text { A! })_{3}\end{array}$ & A numbr \\
\hline
\end{tabular}

-Coated in Sin. diam protolype coarer. betch I 2:i3

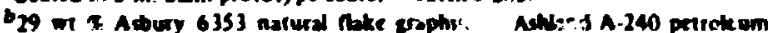
pirch.

(39 का G G. 1099 (10 4. um) gaphule cowder in Ashland A-240 petrokum pitch

"Coated in 1 in dinm laboratory conter batch OR 1977

eaj' I kernal conted in 1 th diam conler in plulowium baboratory 


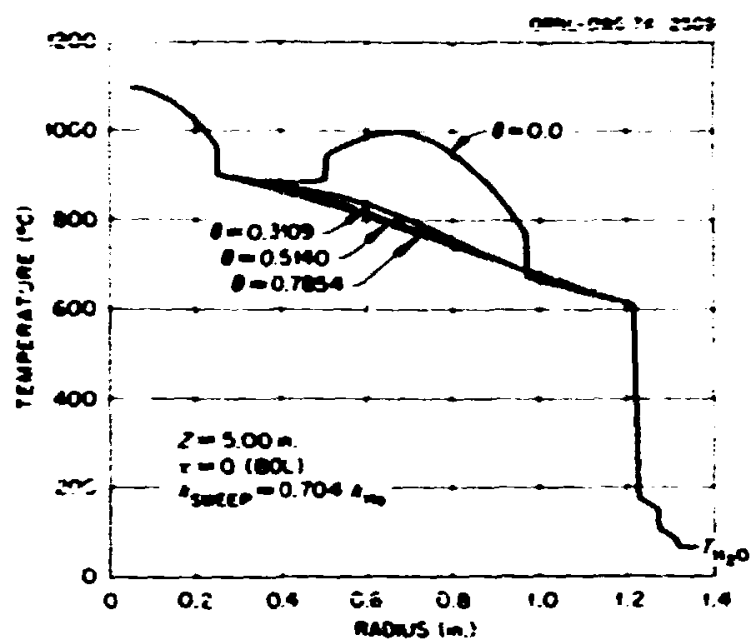

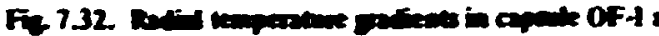

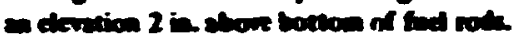

very upen. porous microstruitures. This is the type of miniosiructure that would have been expecticd based on the pirch coke yield. On the other hand. the misirspheres of the rods arbonized in hlock were mich mure dense. In the rod containing GLC-104t sarbonized in bionix (1ype 3). we lound six particles in which the LII cooting was torn. apparently due 10 a matrixparticie interaction. Wo tearing was found in the rod containing Asbury 6353 cartonized in block. but from the appearamie of the matrix it would not be surprising to see tearing afier ir radiation.

The results of broken particte analyses are giten in Table 7.27. These data indicate that the rod conlaining GLC-1089 carbunized in bloct (rod iype i) contained about iwo broken fissile particles and two broken fertile particles. One annular rod containing Asbury 6.353 sarbonized in paiked $\mathrm{Al}_{2} \mathrm{O}_{3}$ (rod iype 7 ) also appeared to have about two broken fissile partikles.

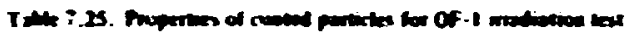

\begin{tabular}{|c|c|c|c|c|c|c|}
\hline & \multicolumn{2}{|c|}{ reentr } & \multicolumn{4}{|c|}{ Inste } \\
\hline & I. & Arect & \multicolumn{2}{|c|}{ 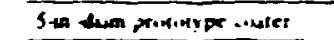 } & \multirow{2}{*}{ 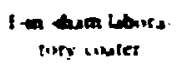 } & \multirow{2}{*}{$\begin{array}{l}\text { Pu lebustion } \\
\text { instet }\end{array}$} \\
\hline & Choline & 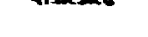 & Inpmorded & Anareled & & \\
\hline $\begin{array}{l}\text { Lernet domares } \\
\mathrm{um}\end{array}$ & $4 \times 5-96$ & & $3938 \div 10$ & & $35^{*}$ & $35 r^{2}$ \\
\hline $\begin{array}{l}\text { Buffer thu laten } \\
\text {-n }\end{array}$ & $860.1 ?$ & & I01 ? & & 93 & In: : \\
\hline $\begin{array}{l}\text { Buffen den unt: } \\
x \text { im }\end{array}$ & I ins & & $139 \cdot 1+05^{b}$ & & $1 \mathrm{Is}$ & 10 \\
\hline $\begin{array}{l}\text { Soskes the threw } \\
\text { mm }\end{array}$ & 34 & & Sine & & Sine & Sinne \\
\hline $\begin{array}{l}\text { Outcr couturs } \\
\text { shut ness. mm }\end{array}$ & $861 \cdot 22$ & 821 & \$1 : : ? ? & & 1106 & 850 \\
\hline Denuty. $\operatorname{com}^{3}$ & 1860 & $1921^{d}$ & ; & 10270 & $196^{\circ}$ & $198:$ \\
\hline $\begin{array}{l}\text { Open purroury' } \\
\text { sol ? }\end{array}$ & 4 & +1 & 34 & +2 & & \\
\hline Deproutminn rste. & 83 & & $1=$ & & & \\
\hline $\begin{array}{l}\text { Purthte sumeter. } \\
\text { um }\end{array}$ & $8392 \cdot 49$ & $827+5:$ & $7 \mu n=61$ & $: 175: 96$ & & \\
\hline Den w1y $x^{x} \times: m^{3}$ & $3355 \cdot 0 \mathrm{~m} 7$ & $3415 \cdot 0007$ & $2640=0107$ & $(69) \cdot 0007$ & 244 & 2665 \\
\hline $\begin{array}{l}\text { Cinth cunien! } \\
\text { ceporicik }\end{array}$ & $05405 \cdot n 0006$ & & $03704: 00006$ & & $\begin{array}{l}\text { C.00616 } \\
T 1.0275\end{array}$ & $\begin{array}{l}\text { tousol } \\
\text { tho: } 2381\end{array}$ \\
\hline$\underset{\text { Ppm }}{\text { Expoused } \mathrm{t} \text {... Th.h }}$ & 4.10 & 11.16 & 2.1 & 22.39 & & \\
\hline
\end{tabular}

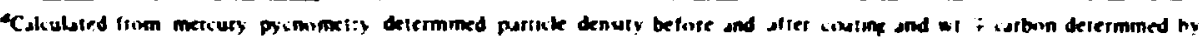

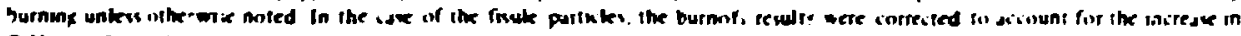
O L rotur durnes burnanse

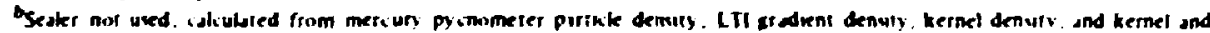
couting dimenume

- Calculbied

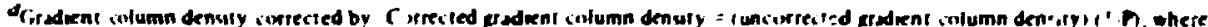

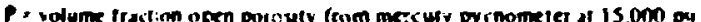

'Gedien' column denty i not coprested.

'Mercury prommeter al is.00n pu

TMercury pinomerer 250 pu

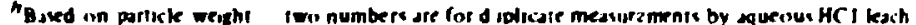




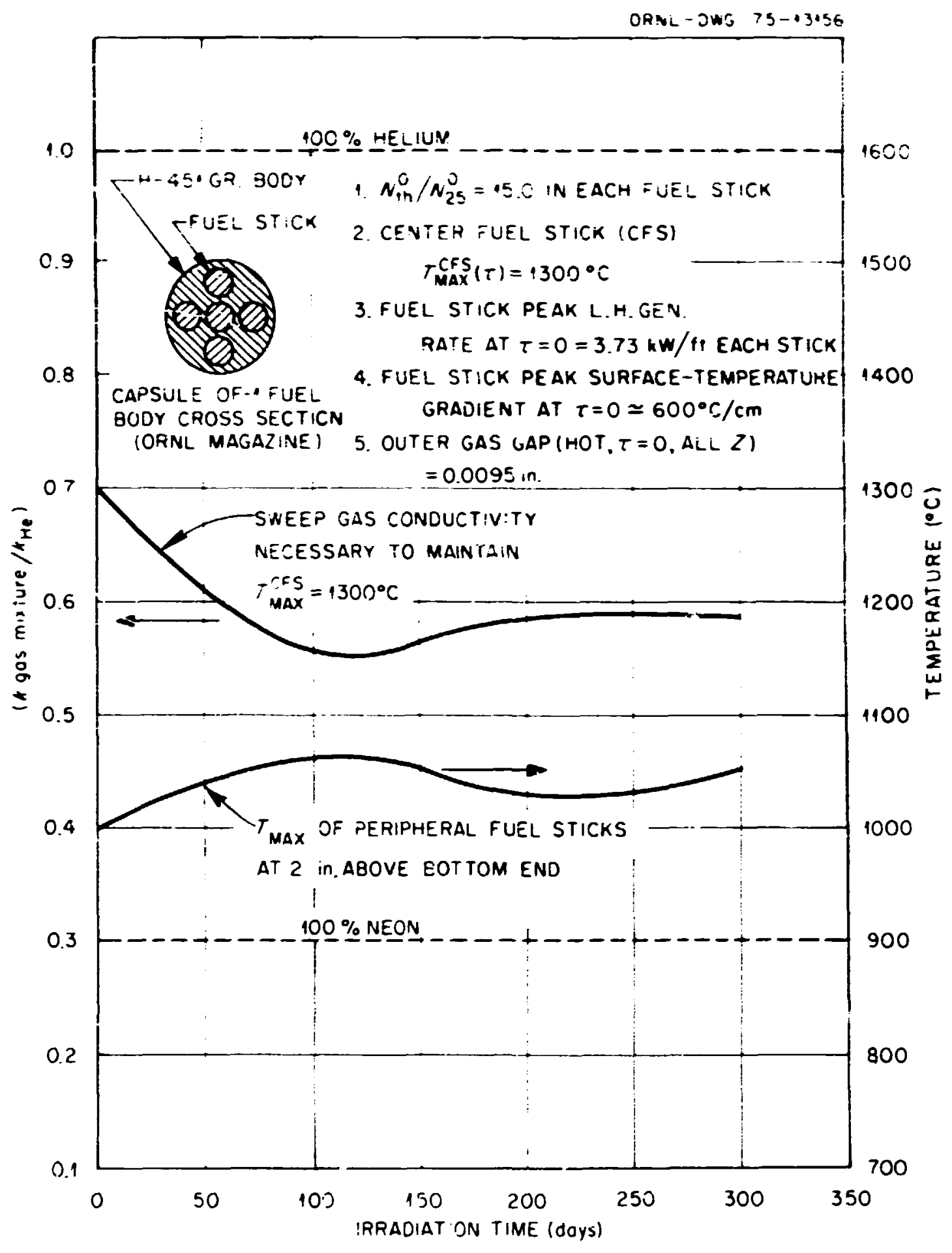

Fig. 7.33. Results of one-dimensional thesmal deaign calculations for ORNL magaine of ORR capoule OF-1. 


\begin{tabular}{|c|c|c|}
\hline Rod type & $\begin{array}{l}\text { Matrix } \\
\text { densily } \\
\left(E^{\prime}=m^{3}\right)\end{array}$ & $\begin{array}{l}\text { Pitch } \\
\text { colte yictd } \\
(=1 \text { \&) }\end{array}$ \\
\hline I & 0.473 & 13.7 \\
\hline 2 & 0.732 & 44.9 \\
\hline 3 & $N D^{2}$ & ND \\
\hline 4 & 0.491 & 14.6 \\
\hline 5 & 0.553 & 21.0 \\
\hline 6 & 0.540 & 19.4 \\
\hline 7 & 0.573 & 21.2 \\
\hline 8 & 0.464 & 11.7 \\
\hline
\end{tabular}

Not determined due to in bility to obtain accurate weyghts of rods after removal from gaphite element.

Table 7.27. Realis of brokew partick andysis on thet rods for OF-1

\begin{tabular}{|c|c|c|c|c|c|c|}
\hline \multirow{2}{*}{$\begin{array}{l}\text { Rod } \\
\text { type }\end{array}$} & \multirow{2}{*}{ Matrix fallere } & \multirow{2}{*}{$\begin{array}{l}\text { Carbonization } \\
\text { method }\end{array}$} & \multicolumn{2}{|c|}{$\begin{array}{l}\text { Heary metal keached } \\
\text { (g) }\end{array}$} & \multicolumn{2}{|c|}{$\begin{array}{c}\text { Fraction } \\
\text { (g/z) }\end{array}$} \\
\hline & & & Th' & u & $\mathbf{u}$ & Th \\
\hline & & & $\times 10^{-6}$ & $\times 10^{-6}$ & $\times 10^{-4}$ & $\times 10^{-4}$ \\
\hline 1 & 29.0\% Asjury 6353 & Paxked $\mathrm{Al}_{2} \mathrm{O}_{3}$ & $<\mathbf{i} 3$ & 13 & 1.1 & $<0.1$ \\
\hline 2 & $29.0 \%$ Asbury 6353 & In block: & $\varepsilon$ & 1 & $<0.1$ & $<0.1$ \\
\hline 3 & $38.5 \%$ GLC 1089 & In biock & 1613 & 68 & 5.5 & 10.3 \\
\hline 4 & 29.0\% Asbury 6353 & Packed $\mathrm{Al}_{2} \mathrm{O}_{3}$ & $<8$ & 3 & 0.24 & $<0 . i$ \\
\hline 5 & $29.0 \mathrm{D}$ Asbury 6353 & Packed $\mathrm{Al}_{2} \mathrm{O}_{3}$ & II & 4 & 5.34 & $<0.1$ \\
\hline 7 & 29.00 Asbury 6353 & Packed $\mathrm{Al}_{2} \mathrm{O}_{3}$ & 311 & 99 & 7.4 & 1.9 \\
\hline 8 & 29.0\% Asbury 6353 & Packed $\mathrm{Al}_{2} \mathrm{O}_{3}$ & 7 & 4 & 0.5 & $<r_{, 1}, 1$ \\
\hline
\end{tabular}

CAshland A240 piich used as buader in all rods.

bOre ferite perticte contains spproximately $558 \times 10^{-6}$ of thorium.

Cone fir-ik particle contains ipproxinately $38 \times 10^{-6}$ of uransum and $161 \times 10^{-6} \mathrm{~g}$ of thorium.

\subsection{IRRADIATION TESTS IN THE ETR CAPSULE FACILITIES}

\subsubsection{ETR Capsules H-1 and -2}

\section{K. A. Olstad}

Varinus aspects of the design. operation, and postirradiation examination of the capsules $H \cdot I$ and -2 have heen reported previously. ${ }^{\text {4-16 }}$ Resuits of the analysis

14. A. R. Olsen. "Capsule Tests." GCR.TU Proxmems Sem.onnu. Prop. Rep. Sepr. 30, 19/I, ORNL4637. pp. ilo 11.

15. A. R. Olsen and R. F. Fitts. "Capsule Tests," GCR-TU Proxpams Annu. Pron. Rep. Sept. 30. 1971. ORNL4760. pp. $67-68$. of the flux monitors in the capsules have also been reported previously. ${ }^{7}$ The thermal analysis of these capsules has since been completed, as descrihed in Sect. 7.8.1. Results of the analysis of kemel mig:ation data obtained from this experiment were reported, ${ }^{18}$ and a topical report on these capsule irradiation tests has been

16. A. R. Oisen and R. B. Fills. "FTR Capsules $H-1$ and H-2," GCR Protrums Annu. Prox. Rep. DeC. HI. 1972. ORNL-4911, Pp. 116-24.

17. H. T. Kert, "Nuclear Analysis in Support of Imadiation Experiments," ikid., Pp. 138-41.

18. T. B. Lindeniet and R. A. Olstad, HTGR Fuel Kemel Migration Data for tive Th.U.C.O System as of April I. 1974. ORNL-TM4493 |June !??:! 
isued : The abstrat frum this repert follews

Cinged HTGR iucl porinke were itrdisted uader serere

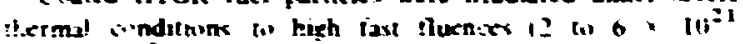
ikutrons im $\mathrm{m}^{2}$. 11 . Is Meli and burnups +25 in $+5^{-}$unanium burnup. 1 - thorium burnupl in the FIR in the H-I ind H-: ipruk uraliotun text from May 197: to M.y 1972. The test

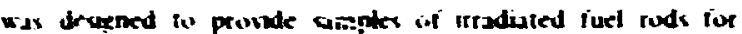

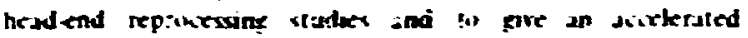

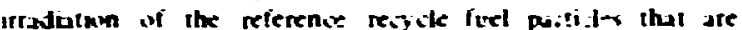

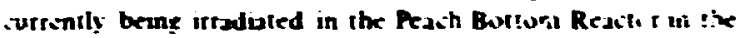

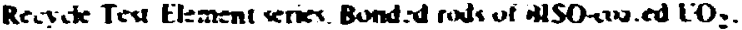

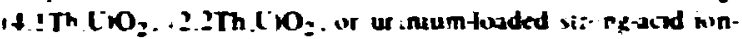

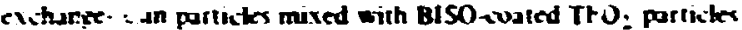
and rod, of TRISO-oated $C_{\text {: }}$ mixed with Bisu-wited ThC: parthes were irradiated. The inizial insile iwlope was $23{ }^{2} \mathrm{C}$ in sll wmpkes. The couted partikes were bunded in a chxe-packed anf zuration with a arbunaceuis matrix to form rods aporoximetely $\%$ in. in dameter $x ?$ in. bng. Fach ar -ist wax surreunded by hainium sleeve to dectease the thetsal thu in the fuel. Abuut hali the ompler operated at much atove deugs temperatures durins the last of ihe four irradianon cyctes because the espsukt were indvertentiy irradiuted in an inverted pusition during this period. The alcabted -eniet fine temperatures of the bunded rods soried from 900 to 1500 ' $C$ at the bezinning of the test and from 600 ) to $2600^{\circ} \mathrm{C}$ at the beginning of the Last $;$ sk. Pustirsadiation examination showed that the rods that operated at normal temperalures throughout the rest were largely fragmented or debunded. porsibly because of high ihermal gradients or betause of repeated thermal cycling durng the test. The particks themseives sunived the irradiation in excelknt condikion. A small amo"zi of kernel migatiun was sberved in $\mathrm{CO}_{2}$ - $14.1 \mathrm{Th} . \mathrm{COO}_{2}$, and 12.2Th.li) particlex in normal-iempirature inds but was not observed in the $\mathrm{ThO}_{2}$ partictes. The tods that opetaled at very high temparatuies during the bast syte were sevetely damaged and contained a centra! region of reddish powder with no recionnissble particles remaining. Substantial maxtion of the mixed oxide and $\mathrm{CO}_{2}$ keracls as well as the $\mathrm{ThO}_{2}$ kernels was observed. Ninne of the arbide or resinderived partivies have been examined ractalIneraphically at the time of writin:"

A large amount of kernel migration data was obtained from this text because of the relatively high fuel temperatures during normal operation and hecause of the very high temperatures in some of the fuel rods when the capsules were irradiated in an inverted position. The calculated remperatures nave a large uncertainty (see Sect. 7.8 ) but the relative stability of the different kernel types wis weil demonsirated in this test. Examples of the relative thermal stability of different fissile and fertile particles at different irradia-

19. R. A. Olsiad et al. An Irradiation Tert of Condidare IITCR Recyrle Furls in the $\| .1$ and $\| .2$ Capsules, ORNI.TM. $\$ 397$ (July 1974).

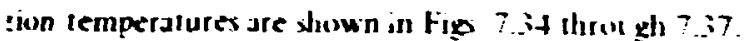
Figure 7. it shows a $\mathrm{CO}$, kernel which has migrated a small distance into the buffer soiting under inenderate temperature conditions and a thoria hernel which has exhibited no migration under the sume conditions. Figure 7.35 shous a 14.1 Th.L:O2 kernel whili has migti: :d a small distance into the buffer couting and. again. a ThO, kernal which has exhibited no nigration Lnder the sanie conditions. Figures $7 . .30$ and 7 : 7 show ! $\therefore$ Th.LY, kernels which have migrated th rough the pirticle cuatings at high temperatures and temperature gradkats and ThO: particles which have migrated only partially into the buffer coating under the sank inditions. The migration istes observed in this test were correlated with the operating temper itures ind temperaiure gradients. as described in Seit. 11.1.

\subsubsection{Postimadiation Examinatson of ORNL Fud Rods from ETR Capsule PI IN}

\section{E. I. Long. Jr}

Two ORNI stury-blended wam-m:!lucu tuel rod specimens were irradizted in two compartment. of a fivecompartment instrumeriled ETR apsule (PIBN) along with tweniy other fuei rud specimens fojicialed by G.AC. This ispsule was designed by GAC is a part of their thermal stability tesis; their results are reported separately. ${ }^{26}$ The ORNL fue! rud specimens contained the same fuel (strong-acid-resin-derived fissile parlicles and thoria fertile particles) and were fabricaled with the same matrix as the molded rods in HRB.: The results from the iwo experiments are thus being reported logether ${ }^{2}$ I In general. the molded fuel rods in PISA performed as well as those in HRB-3. However. the much higher bu:nup of the high.ly enriched fissile parlicles and the high operating temperatures for a sibstarial part if the irradiatmon in PI $3 N$ combined (o) produce directional migration of fuel ard severe allack hy fuel compounds in the SiC layer of Triso conatings. On the other hand. few conopletely failed coatings were observed. which confirmed the low fission-gas-release data. In addition. no amoeba migration of the fertile parlicles was ohserved in PI $3 N$. in contrast ta HRB-3. Details of the examination and performance analyses are given in Ref. 21.

20. ITTKR Rase Propam Quar. Proxt. Rep. Iicg. 11. 197. Gull G.A-A 12725, pp. 190234

21. F. J. Unoman el al., Imadiation Performance of IITCR Fivel Rods in HFTR Fixperiment IIRB I and ETR Fixperimen' PI: $\because$ ORNI.TM-4526 (Octaber 1974). 


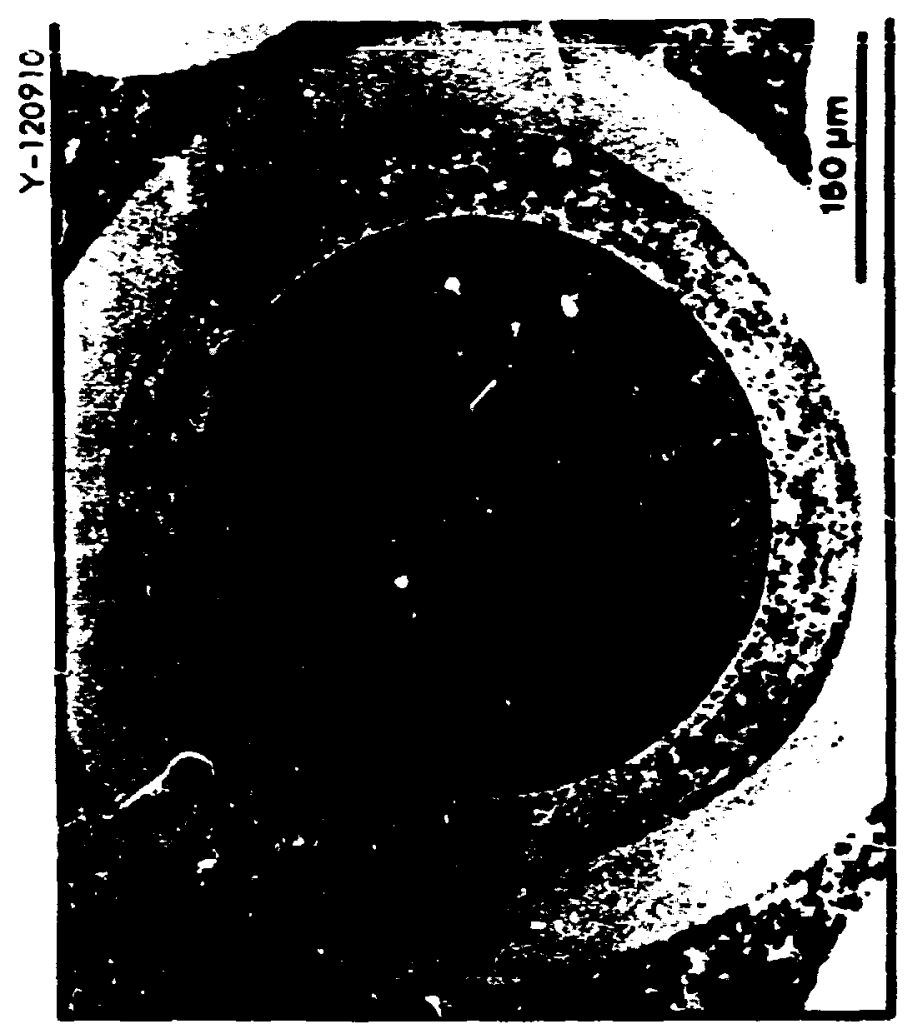

ล5

흐

吾宣

돌

흔

흘

案文

高芒

홀

흘

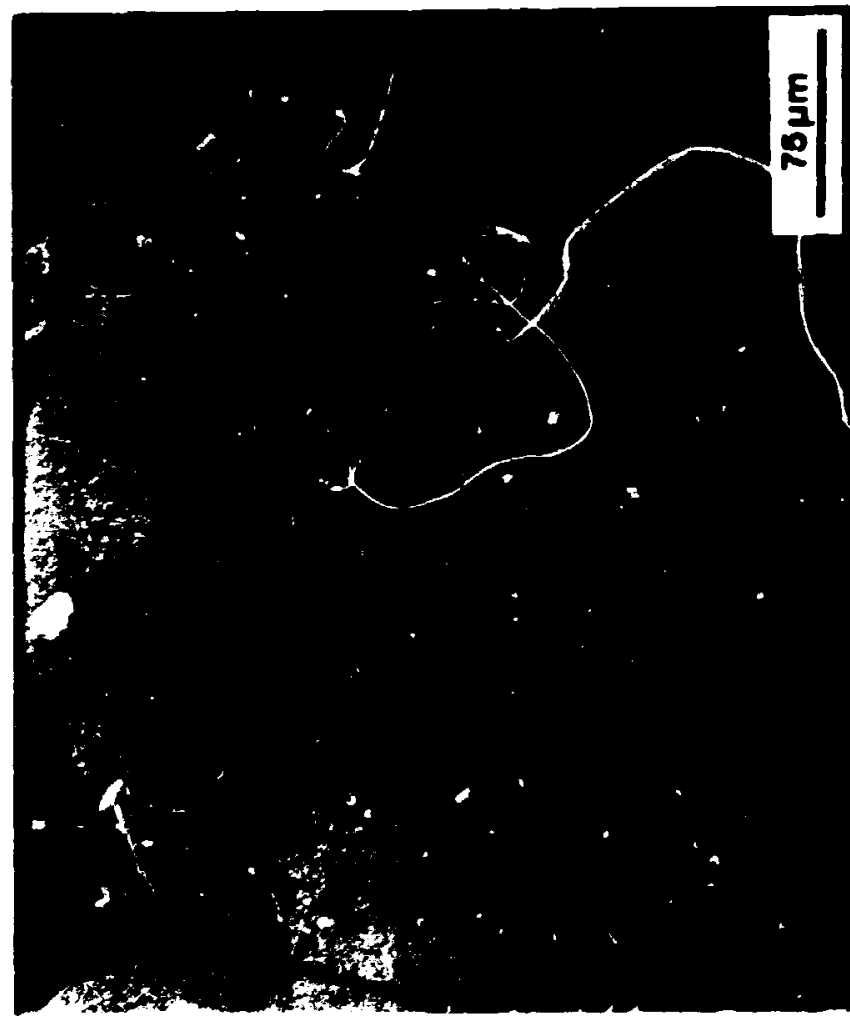

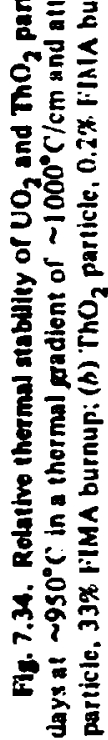



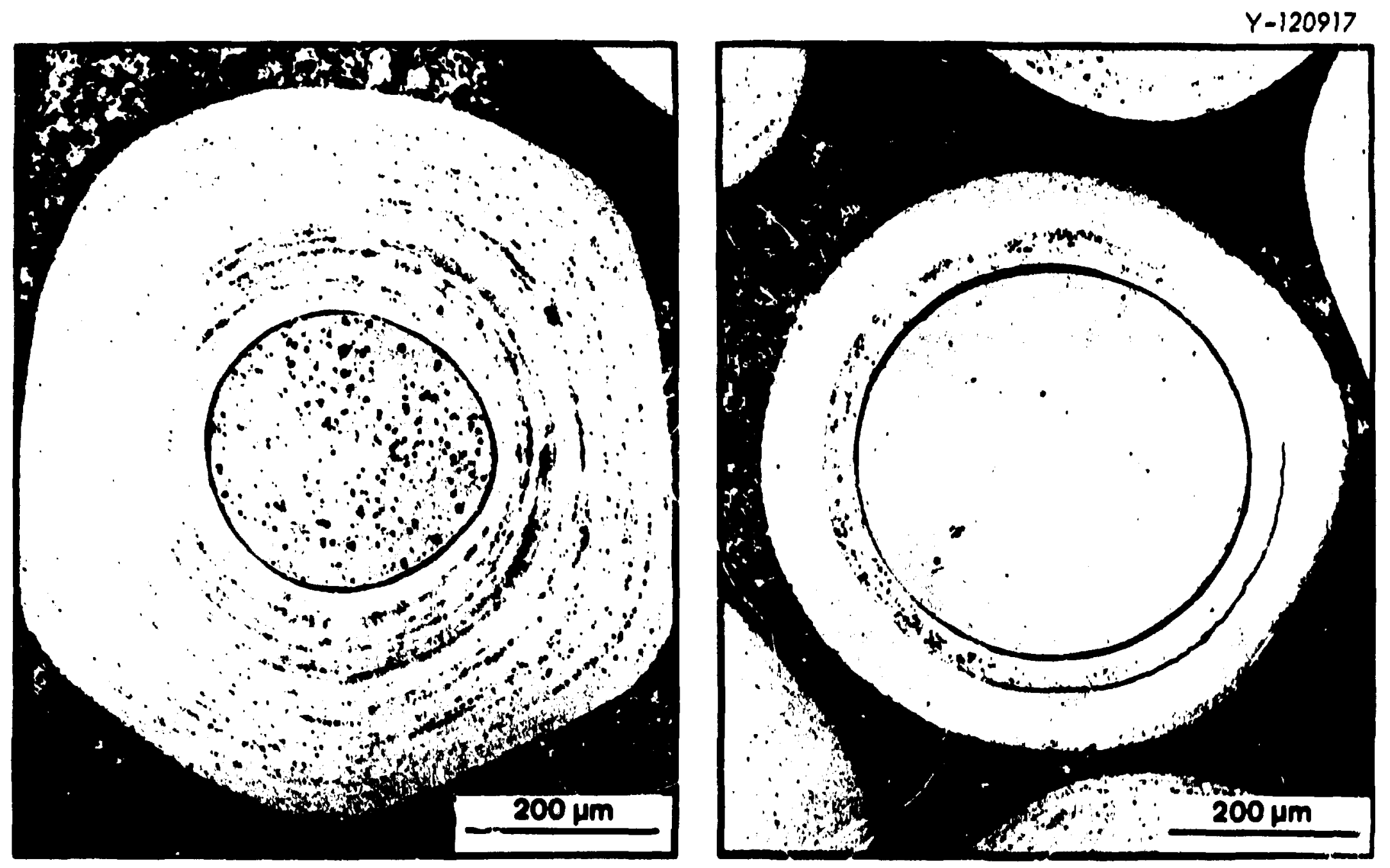

Fig. 7.35. Rolative thermal atabulity of $(4.1 \mathrm{Th}, \mathrm{U}) \mathrm{O}_{2}$ and $\mathrm{ThO}_{2}$ particles irndiated in nod 11.14 . Tiese particler wore irndiated

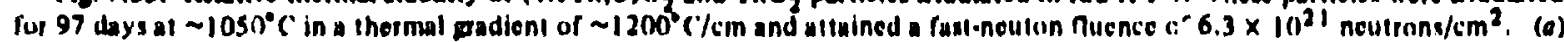
(4.1 Th,U)O, partkle, 8.2\% I:IMA burnup; (b) ThO, purlikle, 0.4\% I:IMA burnup. 
$Y-120909$

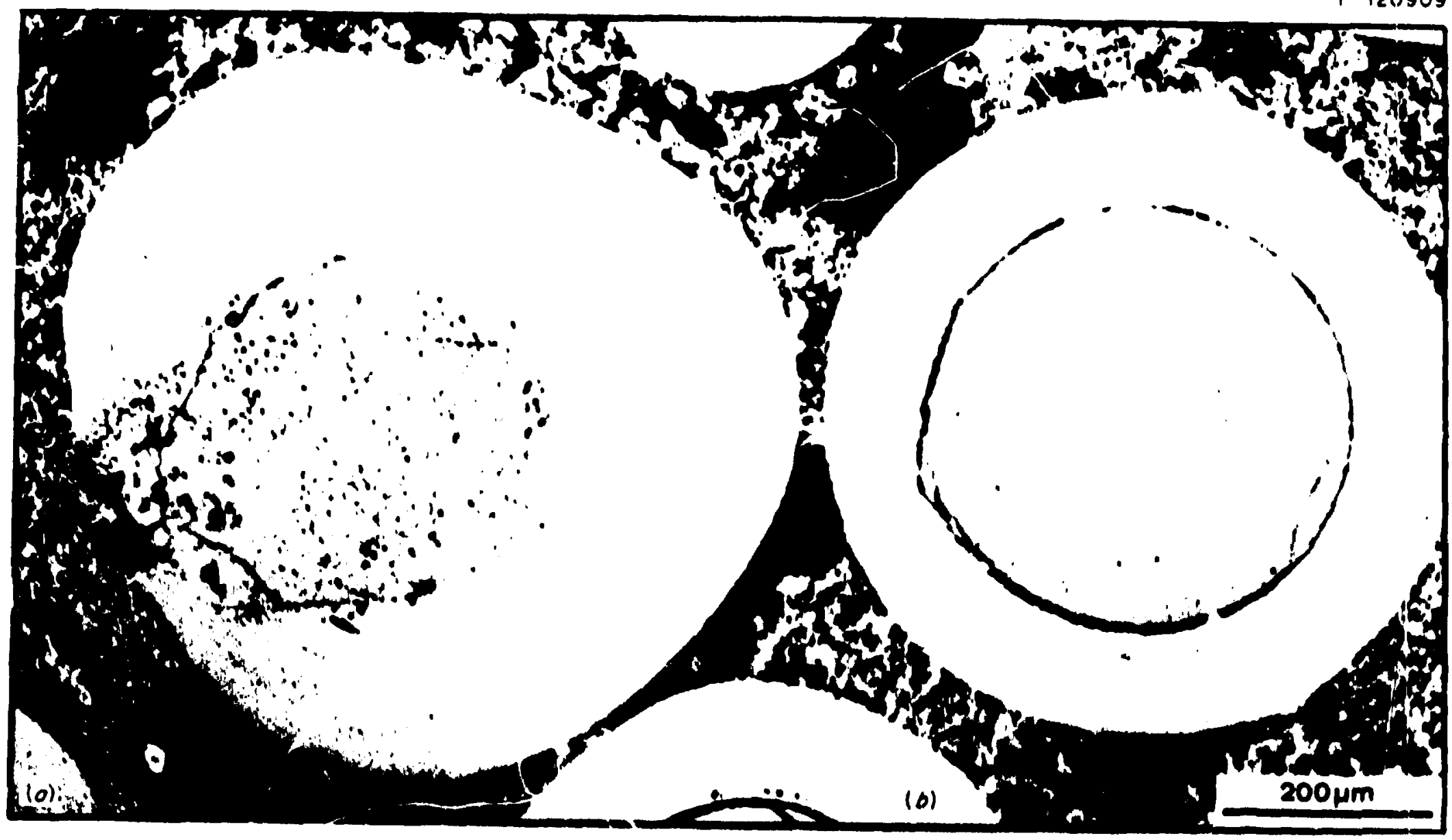

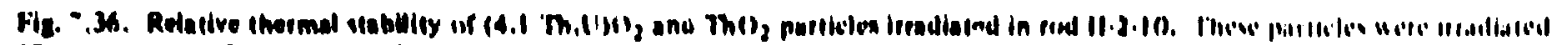

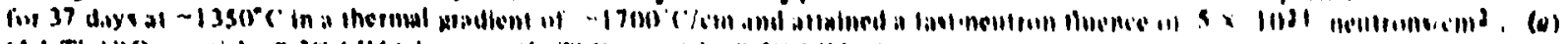

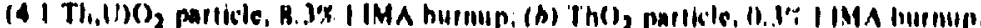


$Y=1209 \times 1$
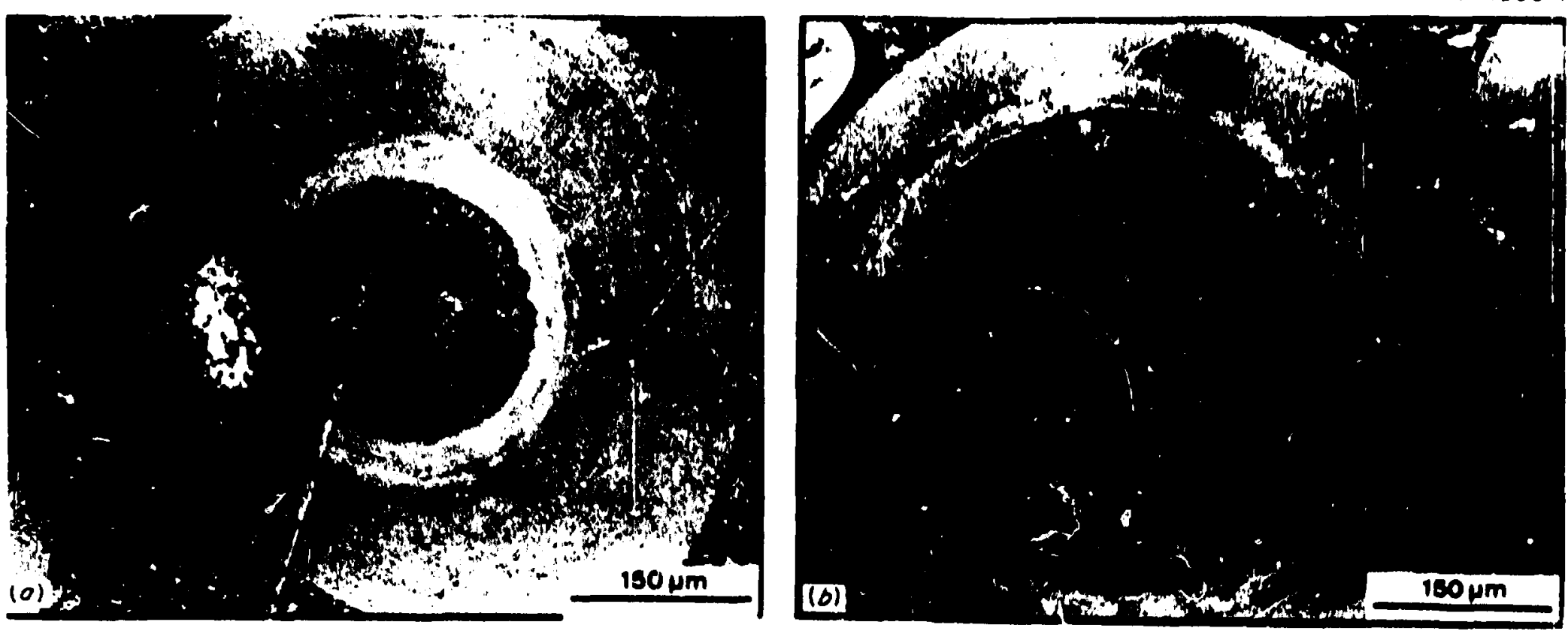

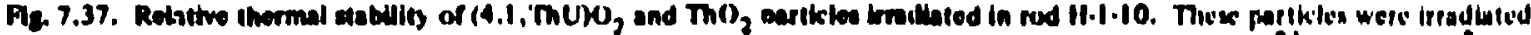

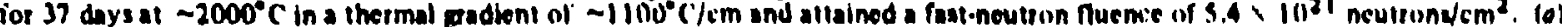
(4 ITh,U)O, parick, 8.6\% FIMA: (b) ThO, parikle, 0.4\% I:IMA. 


\subsection{RECYCLE TEST ELEMENTS IN THE PEACH DOTTOM REACTOR}

\section{E L. LC.Ig. Jr.}

A xel if xeren test fuct elenkents. known as recyle test elements (RTE). s heing urracidial in tto Peach Butlim Resitis. Each RTE contains s:x $1:-$ in. fong gajphile fuel budkes. earh of which lias eight $1 / 2-$ in. Jiam heles io aicommudate fucl sampies: thus. to separate bre: fuel sumples are irradated in eat. RTE. Thexe elements were labriated in a cimperative effior: by ORNL and GAC as part if the Nisiona' HTGR fuel Recyile Develuphisen! Program. The elemcists con!ain bunded fuel rinds and lexse teds of partiles made from vereral combinations of iertile and tisvic partictes of unlerest for use in the HTCR. Iin portum vi tine luel prepared by OR.NL has been desiribed in detisi in an ORNL.TM reputt: 2 which. In conjunction with a ĆAC repurt 23 comprises a cimplete fibrlication desiriptiun "'the test elements.

The urraliation of the first six RTE began in the Peach Bullom Reacior in July 1970. and the tests have progesssed without initent since that time. ${ }^{24}$ In April |'7l. the first of these elements was dixiharged from th: reditor (RTE-7). and an a'situnal element IFTE-11. previnusly designated $\mathrm{KT} \Sigma-11$ was inserted. After 25: equivalent fuli-power days of operation. a peak fast ilsence of about $i 0^{21}$ neutrons $\mathrm{im}^{2}|E\rangle$ a. 8 MeVI was achieved in RTE.7. The secund recycle iest elemcin! IRTE + , was removed irom Peach Gotinm in eariy January 14? : afier ist equivalent full-power days of irradiation. The pask iasi !lueace exposure was sboul $1.9 \times 10^{21}$ neu?rons $\mathrm{im}^{2}$. and the average fuel hurnup was sboul \$.5\% FIMA.

Itie resulti from examination of these iwil :est elements have also rien reportis in detal ${ }^{22}$ Briefly. the fuel performes very well. as expected at the low exposures. but di.r:ensional data indicated gieater irrat: aliun-induced shrinkage of the fuel rinds inan antici pated from atieierated iest data at higher exposures. The reasons for such incredsed shrinkage may beciome

22. F. L. Long. Jr., R. B. Fitts, and F. J. Homan. Fahncatiom of OR.V. Fuel inm jaied in the feoch Bolfom Rein in and the Porturgdestion tixaminarion of Recycle Tesr filements 7 and 4. ORNL-Tint 6477 (September 1974).

23. R. P. Morissetie and K. P. Sieward. Recvcle Test tiement Proxam Desipn. Fatrication. and Assembl). (;A-10109 (Septe: b)et 1971$)$.

24. (iCR Proprams Annu. Progr. Rep. Dec. 11, 1972. ORNL 4911 , Fig. 7.11,p. IN4. exdont during examination of the remaining rest elemen!s. Itic 'nurd recyile elemeni. RTE-2. was remuved from the Peach Bottom Reactor in midSeptember 197 ; afier 701 equralent full-puwer days. and the postirradiatisn examination is sihedisted tu bxun in early $c y ; 4$. The remaining four rejycle test stements will remain in the rexitur untii the termination of reatot operatıuns sheduied fur fall CY.74.

\subsection{NICLEAR ANALYSUS IN SUTMRT OF IRRADIATION EXPERIHENTS}

H. T. Kers

Vimfear analyss support required for irradiation experiments generally ian be desiribed as follows.

I. Estimater of neutrim-induced reaction rates and neutron fluxes are needed during the design of an experimental apsule to determine fuei loadings, heat rates and tempiarature p.itiles. neutron lluenies. and wher Jesign parameters. These estimates are based on infirmation from computatuonal analysis and da from previces experiments

2. Cosintetry support is available for each irradiatmon experiment. Dusimeter paikages irradated with the apsule provide activation data fior use in evaluating the preliradiation desig: estimales and in making comparisons with other experiments.

The neutronic characteristics of an experimental iapsule are determined primarily by the characteristics if the irradiation facility and to a much lesser extent by the iapsule design. For this reason. the primary abjective of the nuclear analysis effort has been to completely iharacterice each irradiation fa:ility. Specitic ansule design variations are then evaluated for each irradiation facility. The following facilities are used for GCR program irradiaiion experiments.

1. The peripheral targel positions in the HFIR target region are used for the HT capsules.

2. The RB-5 and RB-7 facilities in the HFIR remorable beryllium region are used for the HRB capsules.

3. The VXF.13 facility in the HFIR permanent beryllium region is used for initial low-fux irradiations of some HRB capsules

4. The C.3 facility in the ORR sore is used for GAC experimen's. The OG-I capsule was irradiated in the C. 3 facility.

5. rlic E.; facility in the ORR core is prescontly shared by GAC experiment P13Q and ORNL experiment $\mathrm{OF}$ 1. h 'wever. GAC will assume exclusive "a ., 
the $E$ - facility, and two new iacilites will be udded to ihe ORP. curc in oRNiL experiments.

The neutronic itiarat: asties which h-ye been Jeteria : : $:$ f for each of these facilities are presented below.

\subsubsection{Paptucri Pration in the HFIR Ioget Reyour}

The neutron tharacteristics in the HFIR tais: :rgicn were established by severai :onnputationa! anjiyses a a::: experimental efforts. Caliz:ated soatial and cims variations of the neution fluxs within the target region save been subsisntiated with ditz f:om irradiatis. experimants. Fluxis in the poripheral target fidiliti.. are shown in Figs 7.38 and 7.39 and: should be used for analysis of HT capsules. Table 7.28 provides typical reaction rate data for the 17 apsiles

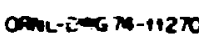

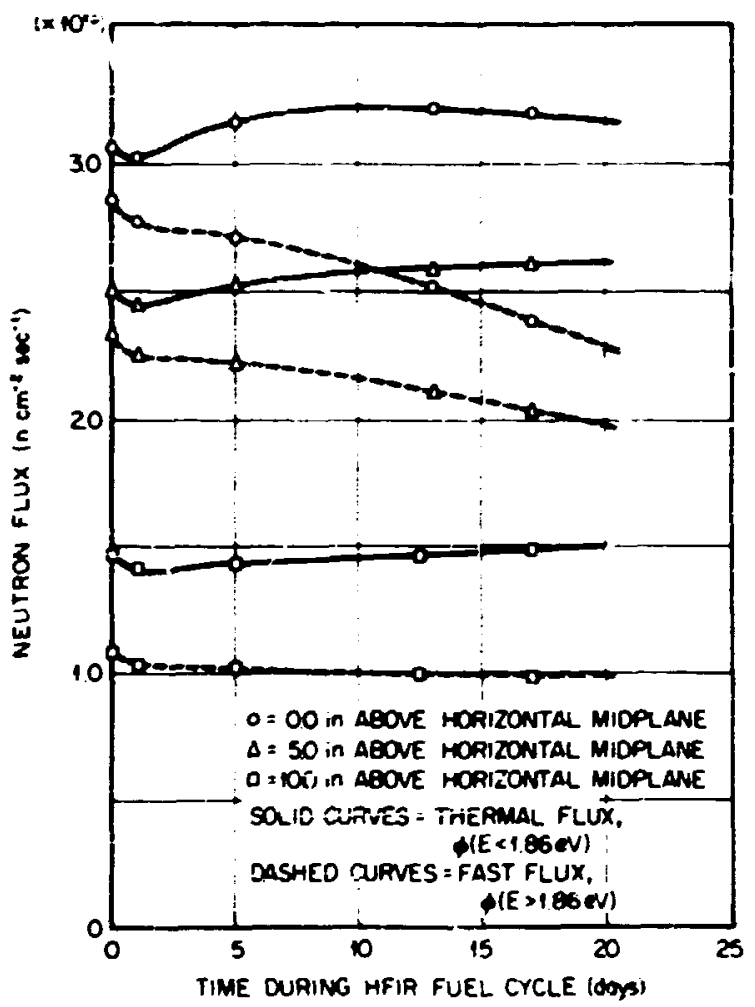

Fig 7.38. Time-dependent neutron fuxes for three axial poxitions in the A-2 taget fecility of HFIR (capaule-dependent perturbations omitted).

\subsubsection{The RB-5 and RB-7 Facitities in the HFiR Remorable gerylliam}

Calculated neutrun fluxes in the remu-jic: th: !!nm regron show large spitial gradients and lime variations whish result from the cluse proximity of these izilities to the HFIR core and control plates Daximeter data from the HRB capsuks and other experiments in these facilities in be interpreted as multiycile averages if the alculated fluxes. but a direct expenmental meas. :-rment of flux variatiuns in the removable beryllium is extren:-:- difficuti and has not been dine Caliulated fluxes tior sio: RB facilities are presented in Figs ? H and 7.41 , and typh.: unit rexition rates are given in Table 7.28 .

The HRB-3. 4. 5. and to capreles were irradiated fir five or more fuel iyctes and wa. repusitioned in the

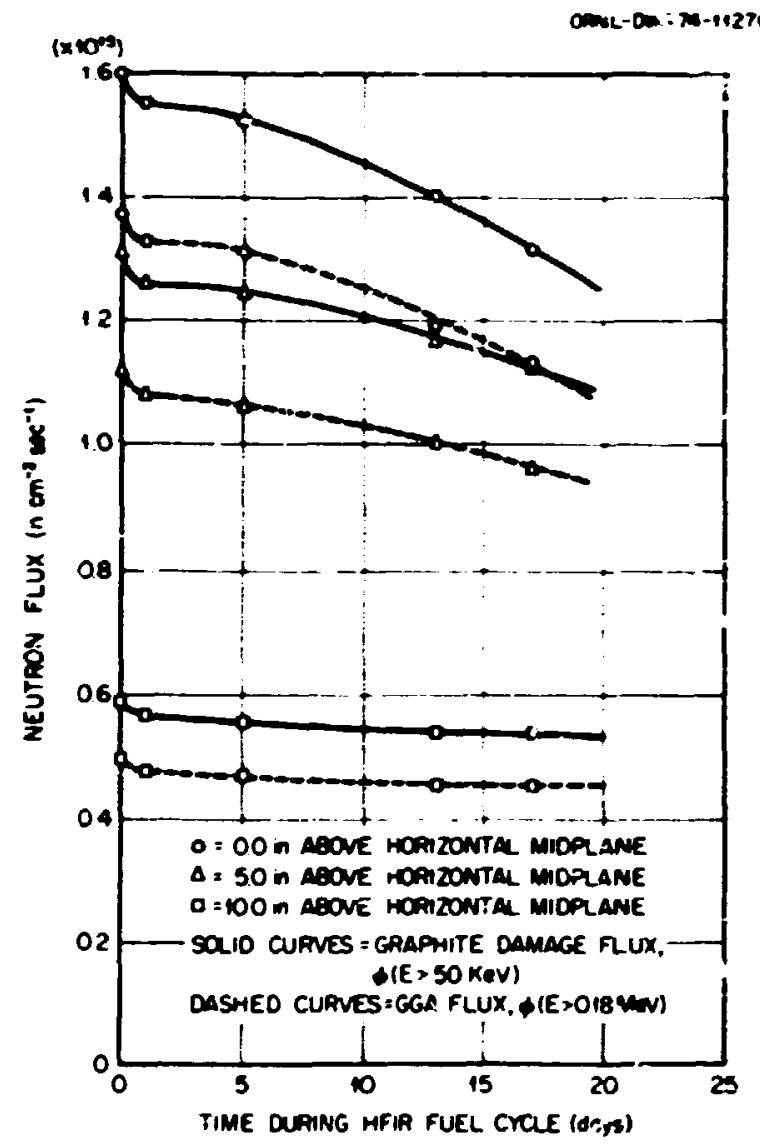

Fig. 7.39. Time-dependent neutron damage fires for three axial pocitions in the A-2 targ $t$ lacility of HFIR (apouledeper. dent perturtations omitted). 


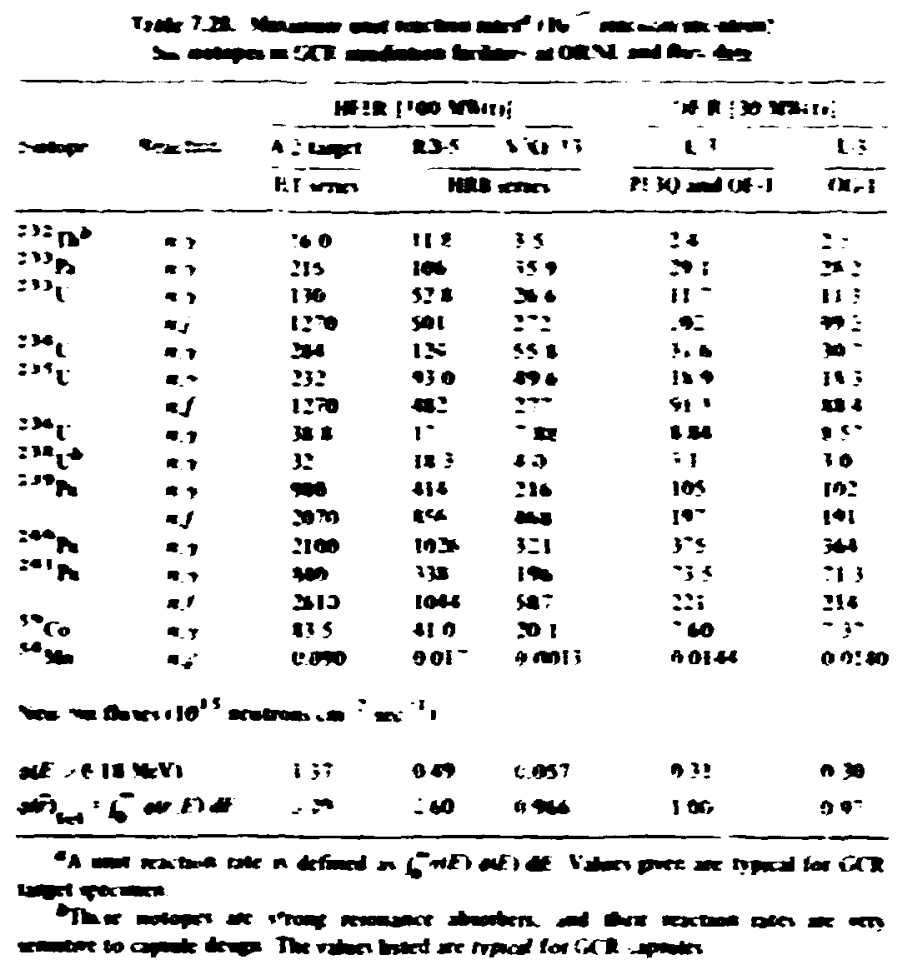

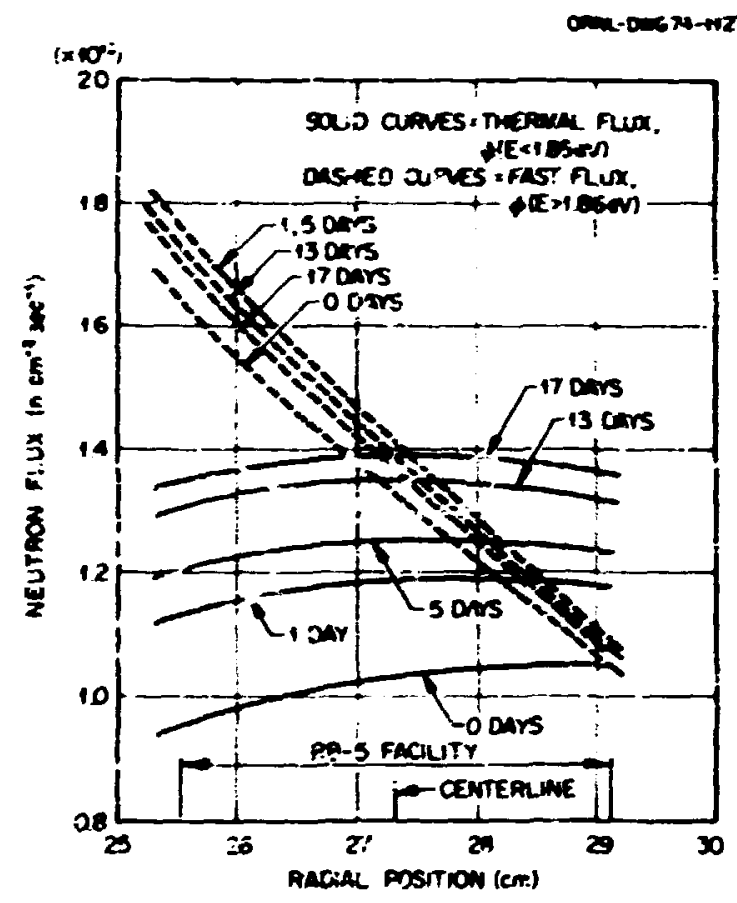

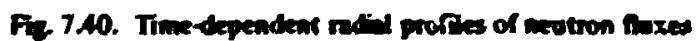

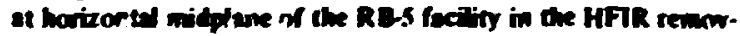
sule baytim. faility one or more :imes during irsadiation. Consequently. the axtivation datz írom these apsules must be inlerpieted $x$ a tixce intezial involviag neutron fuxes whish are orientation dependent. However. un-ertainties in the apsule oneristion histogies produc $=$ large umiertainties in the pises derived from the arivation data. Dosimeter packages in future HRB arsules are designed to eliminate the orien:ation probiem.

\subsubsection{The VXF.13 Facity in the HFIR Penuareat Berylliom}

Neutron fluxas for the VXF-! 3 faility have not been measured iscetly, and the fluxes calculated for the permanent beryllium region are strongiy dependert on some assumptions in the compulational modei. Significant effort will be expended during FY-1775 in acuracely sharacterize the VXF-13 facility.

The design of the HRB.7 and 8 iapsules required sume estimate of the neutron, fuxes and reaction rates in the VXF.13 fasility. Some activation dara were available from dosimeter irradialed at the horizontal midplane of the VXF.? fa: $:$ ity. and the nuxes derived from these data were assumed to be equally valid for the geometrically similar VXF. I 3 facili'y. The axial and 


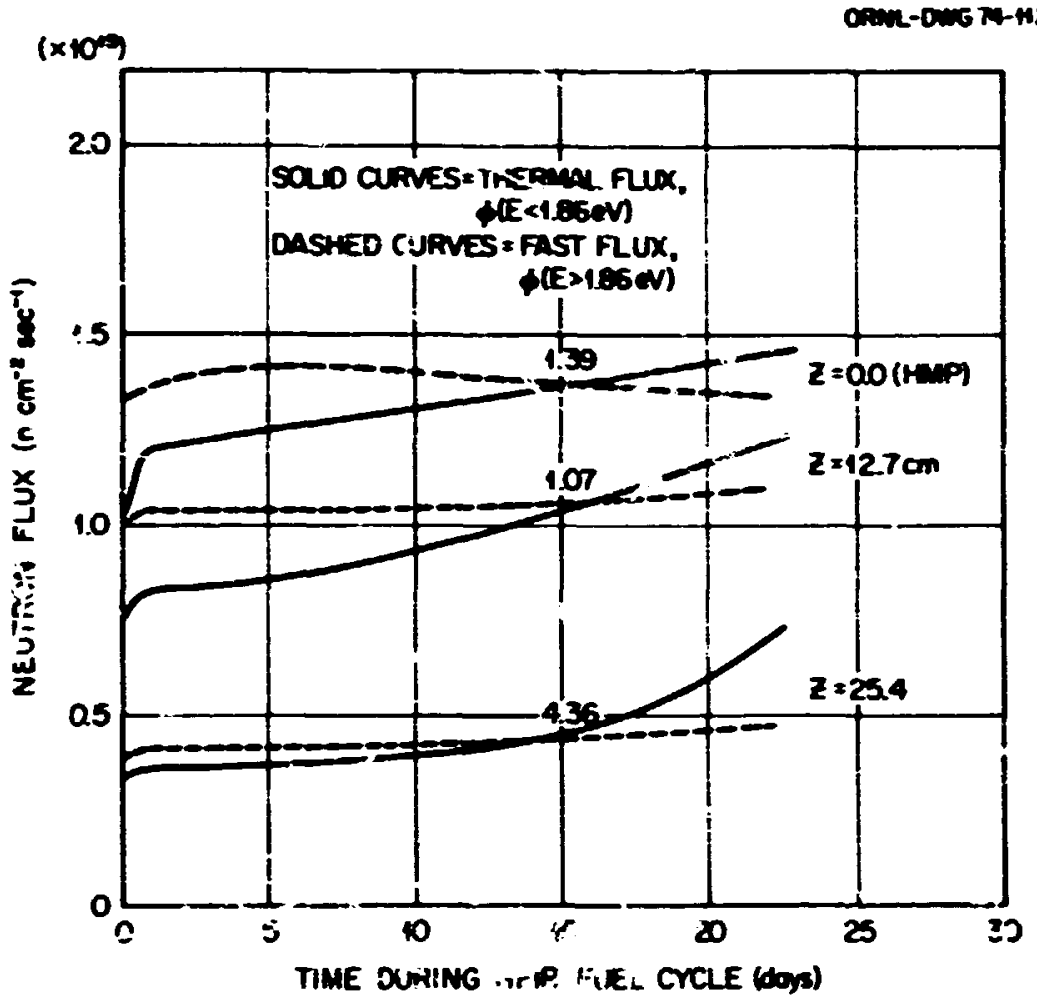

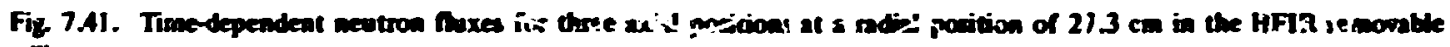
berytium.

time dep indence of fluxes in the VXF-13 (and VXF-7) pu.ition were obtained from computational models and normalized to the ey'xerimentai data. The resulting fluxes are $\cdot a$ in Figs. 7.42 and 7.43. and prelıminary :eaction ricie dista for HRB capsules $i_{3}$ the VXF-1 $j$ facility are given in Tatle 7.28.

\subsubsection{The C.3 Facility in thr. ORR Cone}

The neutronic characteristics ni a given ORR coie position depend heavily on the rativ. positioning of fuel elements and beryllium rilestor sments in the iverali core configuration. Consequently, neutron fluxes for each core lattice : osition iavi be cittermined for each uniqua core configuration.

The OG.1 experiment was irrarliated in the $\mathrm{C}-3$ prisition of the ORR core configurations sh',wn in Fig.
7.44. The resu.'ts of computational analyses and dosume in experiments were combined to determi:e neution fuxes in the GG-1 experiment as shuwr in Fig. ?.4;.

\subsubsection{The E-3 Facility $i_{2}$, the ORR core}

The capsuse containing ORPiL ixpert nent . $F$.I and GAC experiment PI3Q was placed ir: th: c-3 tacility. Severa: preirradiation estimates were made of reaction rates and neutrun fluxes, and some dosimetry results were obtaines from monitors 'oaded into the E-3 aiur libum core piece. Reconiunended values for neutron flu::es are presented in Figs. 7.46 and 7.47 , and reaction rates are presented in Table 7.28. Appreciably more ;iin rmation will be available when the dosimeters are recivered from OF.I. 


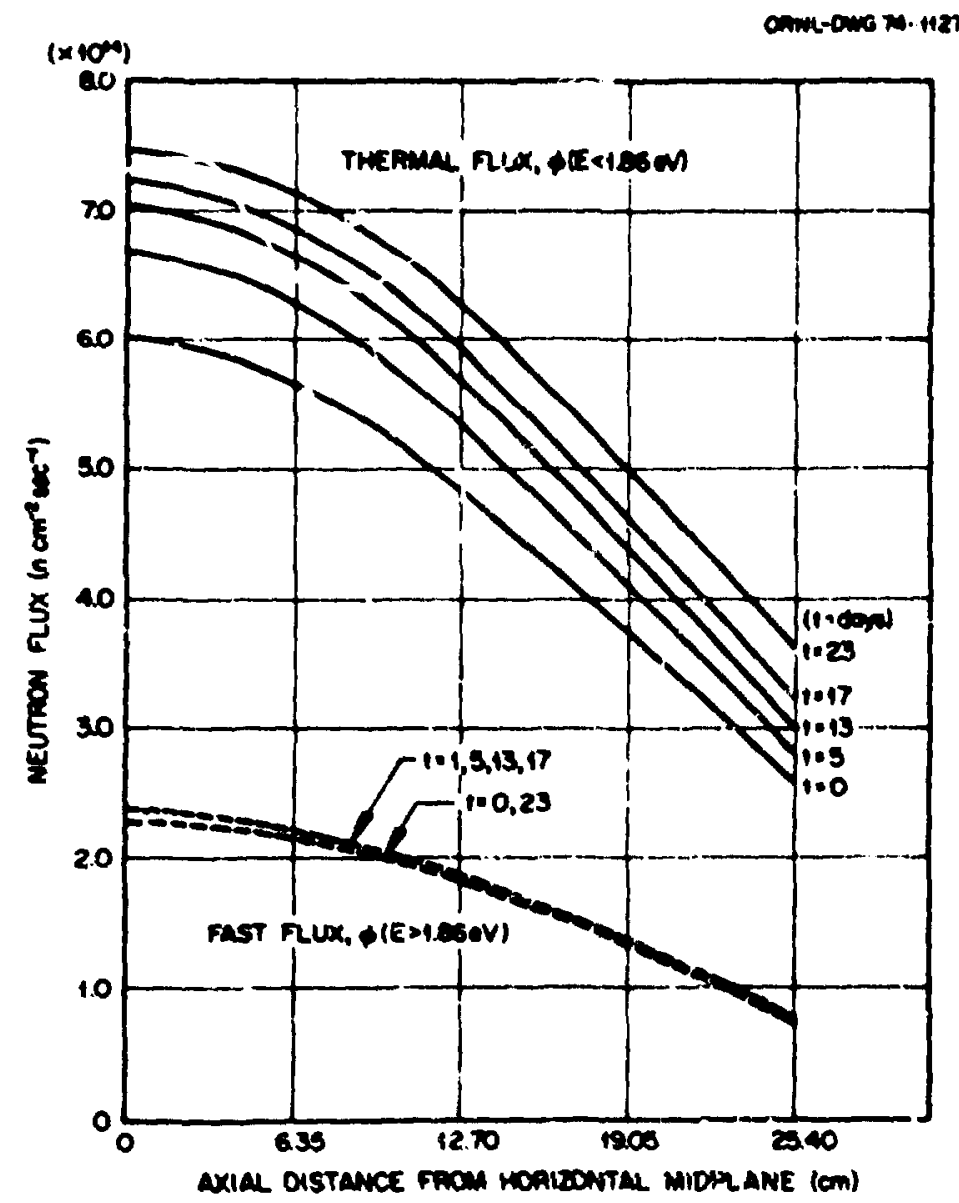

Fig. 7.42. 'ilme-dependent extal profles of neutron Muxea for the VXr-13 fecitity in the HFIR permanon, beryllium.

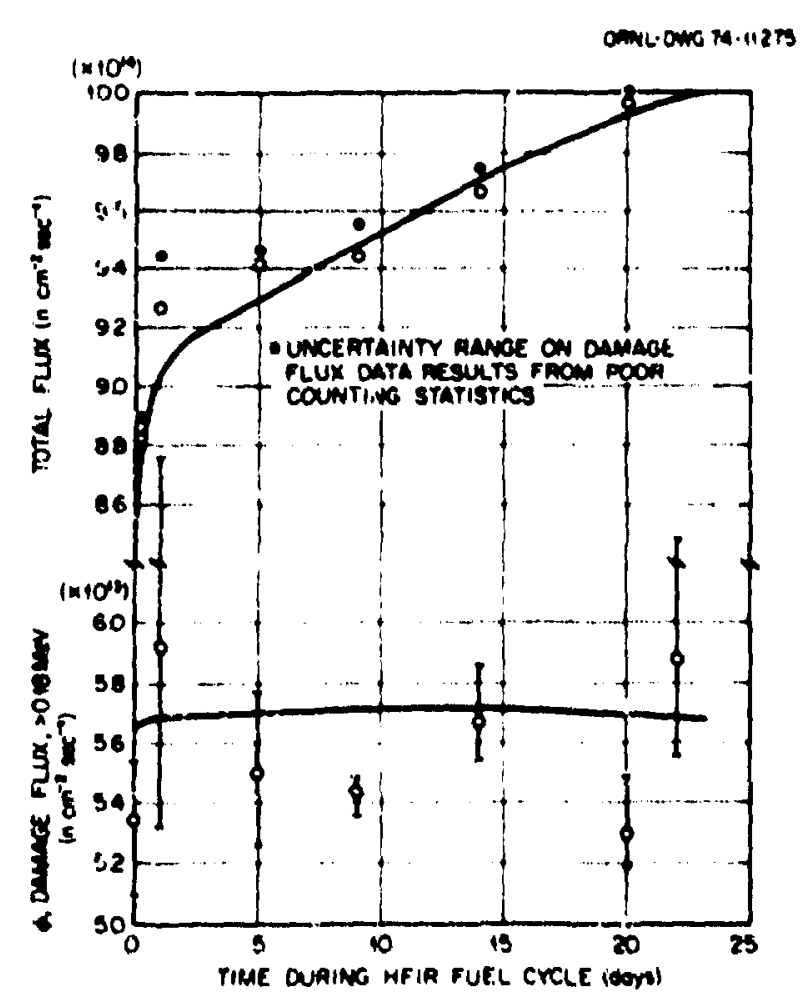

Fin. 7.43. Ciompariacon of calculated and expertmontally de.

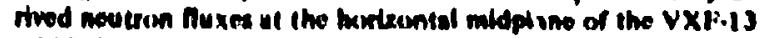
nbell fecilliy in IIIIR pormanent beryllium. 


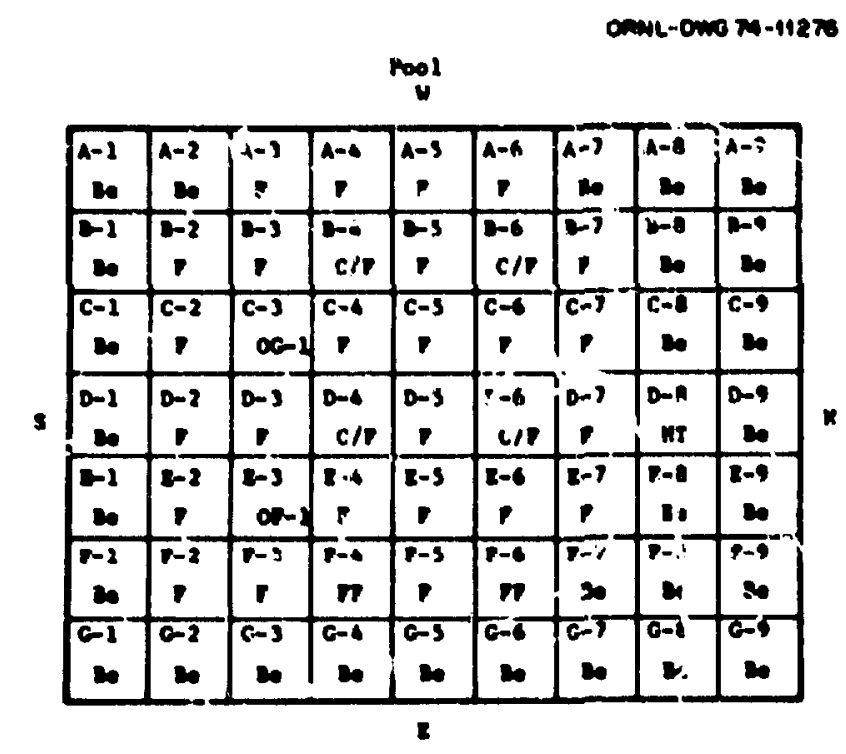

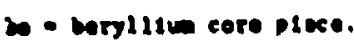

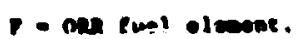

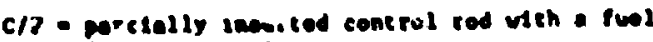
Pollower ocetion.

IT - Mydraulle eube foellsty.

$n$ - iel sollemer of fully vithdien conerol rod.

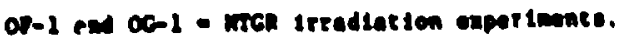

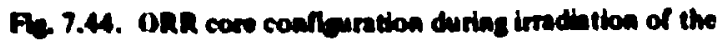
oGi and or . expentuente.

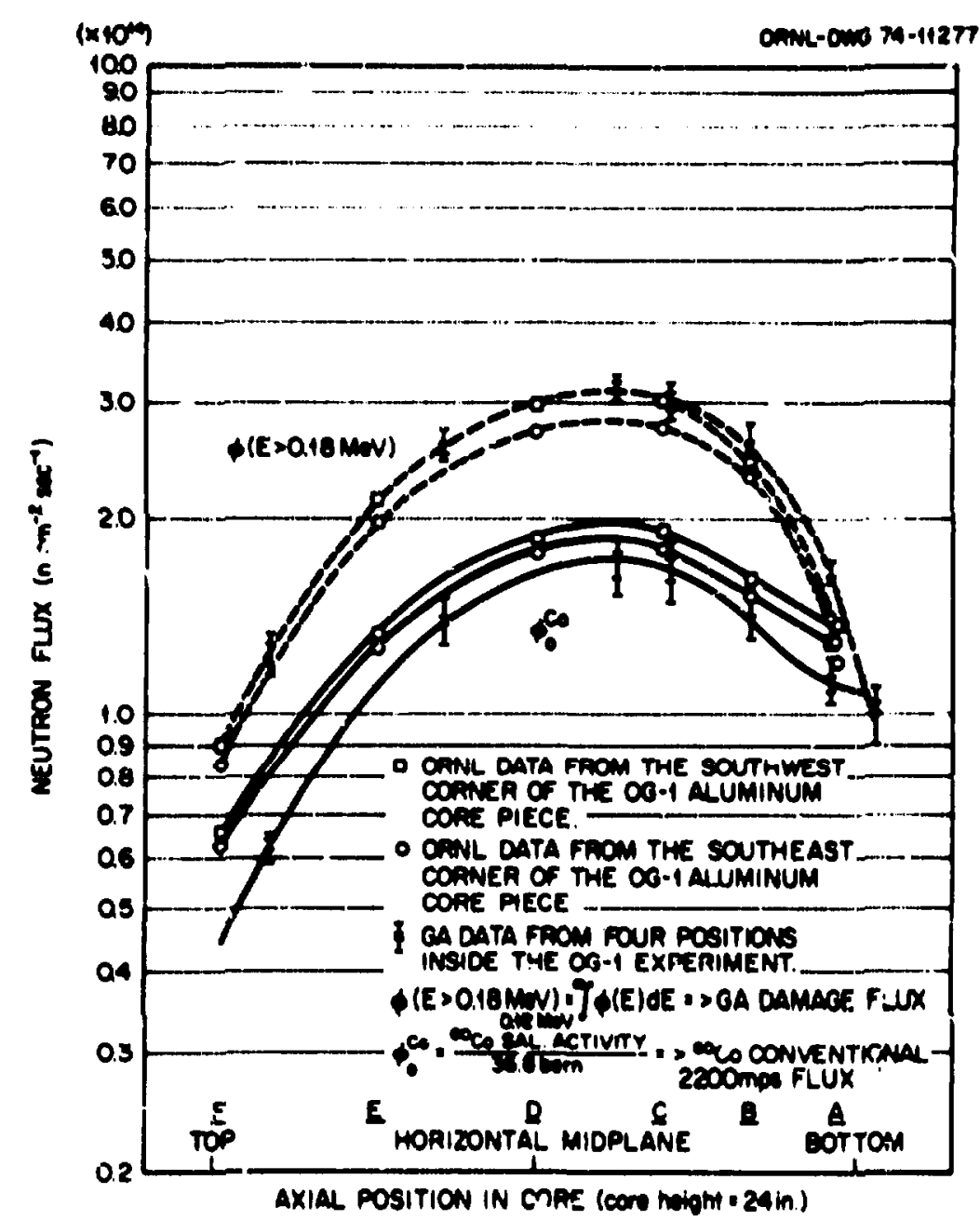

Fig. 7As. ORNL and GAC Hux date for the OG-1 experimont in the C.3 mellity of tho ORR. 


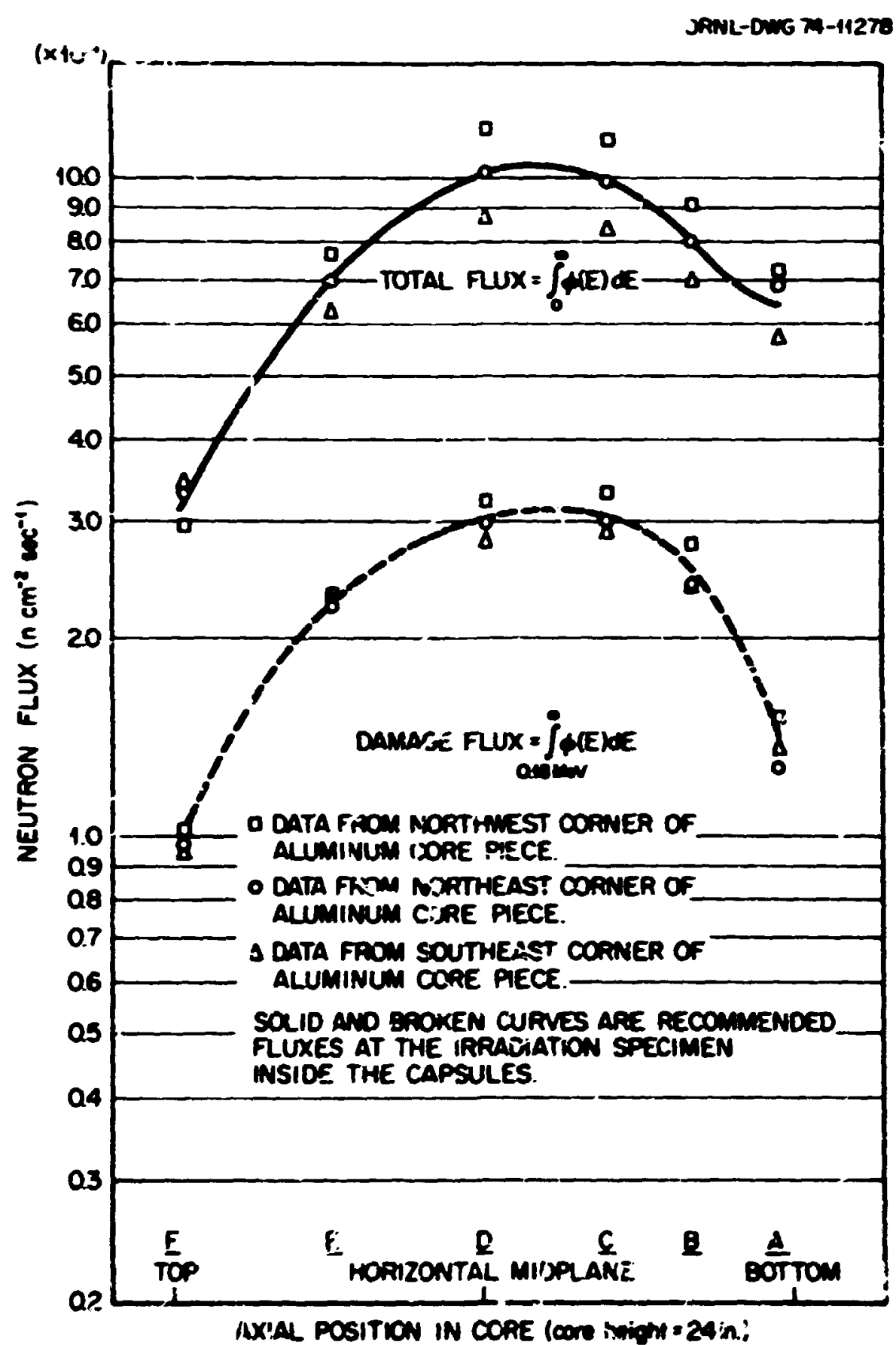

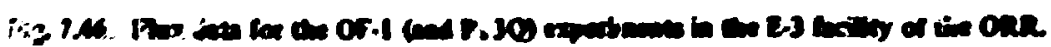




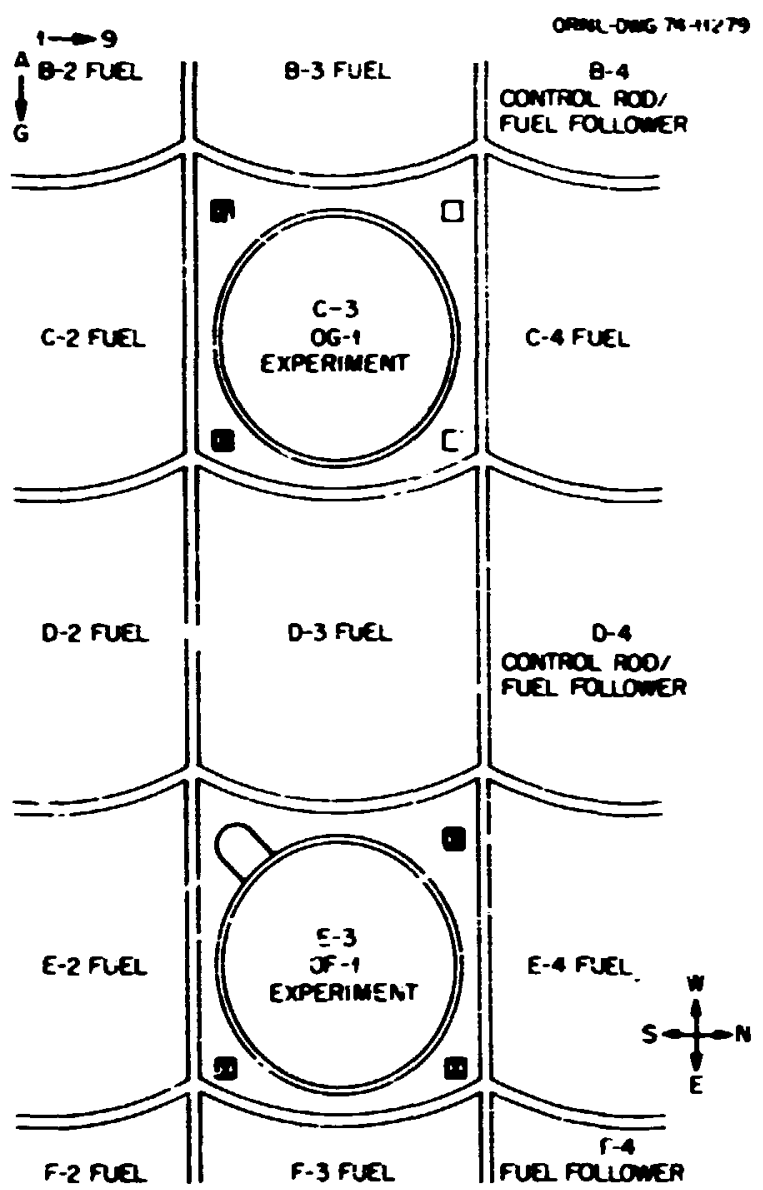

- inOICATES dosimeter Capsule POSTION

Fi, 7.47. Hention expevisient pocitions in ORR core.

\subsection{CAPSULE THERMOMETRY}

\section{R. L. Shepard R. M. Carroll J. K. East}

\subsubsection{HRB-3 Center-Line Thermometry}

\section{Desipon}

The fyel centertine temperature in HRB.? was measured with a $\mathbf{W}$. 3\% Re/W-25\% Re thitrocouple made by stripping about $I \mathrm{ft}$ of the strinless steel sheath and magnesia insulation from sheathed material and replacing the magnesia with hard-firer. BeO insulators and an overwrap of rhenium foil. Thi: thermocou. ple junction (TE-112) was located al it.e same axial position as three shealina Ch: nmel/Alume: thermocou. pies and one sheathed $W-3 \%$ Re:W $\mathbf{W}$. Re thermocouple in the peripheral graphite sleeve (thermocuuples TE-105. - 106. - 109. and -108 in Fig. 7.48).

The sheathed W-Re and Chromel/Alumei tinermorioupie material was brazed through capsule bulkheads and :unnected to thermocouple extension wire about $10 \mathrm{ft}$ sbove the fuel, extending 2 bout 30 ft to i se experiment instrumentation connector a! poulside. Heavy copper wire was used for $\$$-Re extension to reduce the tutal circuit resistance between ponlside and the data-iolle:tion system. In addition to he usual compensating th mocouple extension wires. a pair of copper wire: was attached to the connecter terminals on thermscouples TE-108 (peripheral W-Rei. TE-109 (perip!eral Chromel/Alumel), and TF-1 12 (central W.Re). These additional wire pairs pronder means for prassing a smal! (4 mA) de cursent through the therrociouple livop. inereby measuring the loop resistamia by subtracting

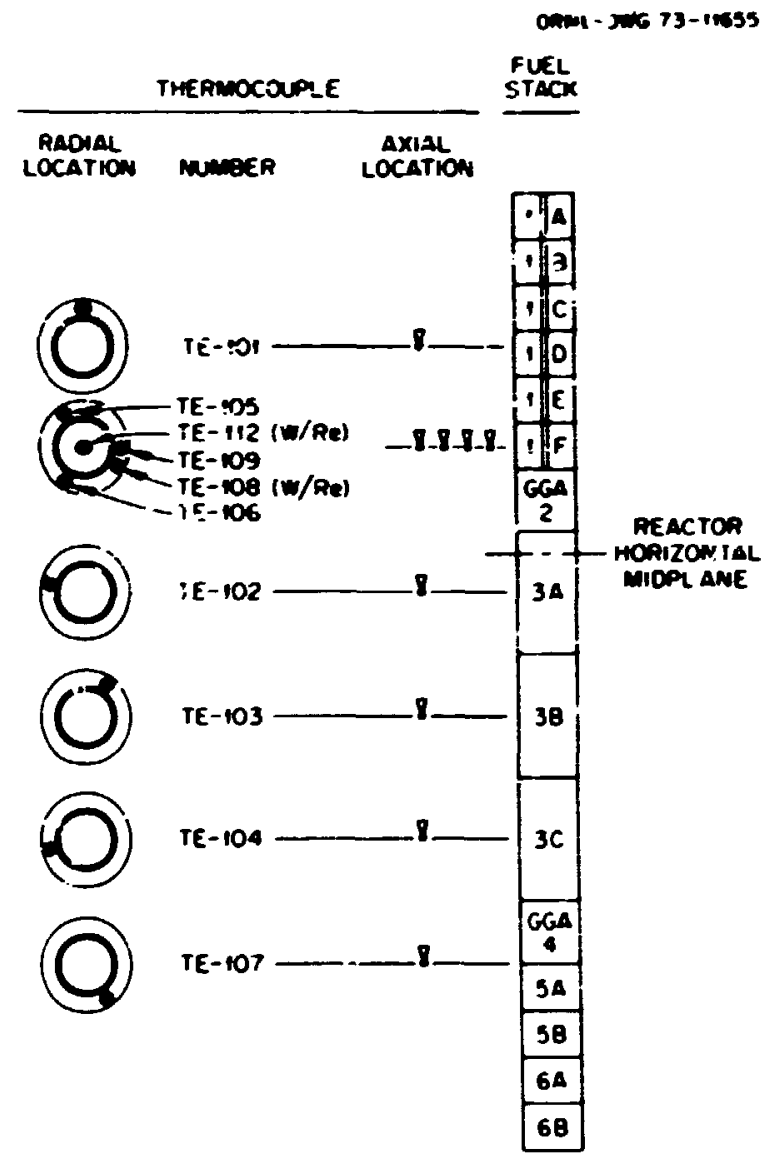

Fi2 7 A8. HRE-3 fed specinen and theomoconple locutiona 
the thermal emf (no current) from the thermal emf plus IR drup (with currer. . This ioop resistanie measurement was perforr ed routinely during the course of the experiment. using the Dextir data systen to switih an extemal current suppty and to measure terminal emfs for the three thermocouples. Buth forwaid and reverse di currents were employed.

\section{Peforiance}

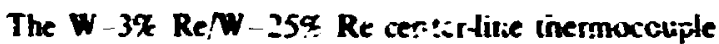
survived the entire 6100hr irradiation al temperatures to $1100^{\circ} \mathrm{C}$. accumulating a thermal-neutron fluence of about $2.6 \times 10^{22}$ an and a fas $>0.18 \mathrm{MeV}$ ) neutron fluence of $7.8 \times 10^{-1} \mathrm{nv}$ in an inert atmosphere but exposed to carbon and fission products. As sho:-n previously. ${ }^{24}$ the thermucoupte output decreased about $300^{\circ} \mathrm{C}$ during the 6100 ty irradiation. This deirease in output was accompanied by $m$ increase in loop resistance of $\$ .4 \Omega$, or $17 \%$ of the total in-fitong thermocouple loop. R.duced to that fraction of the thermocouple within the high-flux highten:perature iucked region. the resistance change amounts to severalfold increase.

A plot of values and the mesured lowp ressiance is the indicated temperatures (Fig. 7.49 ) taken during the

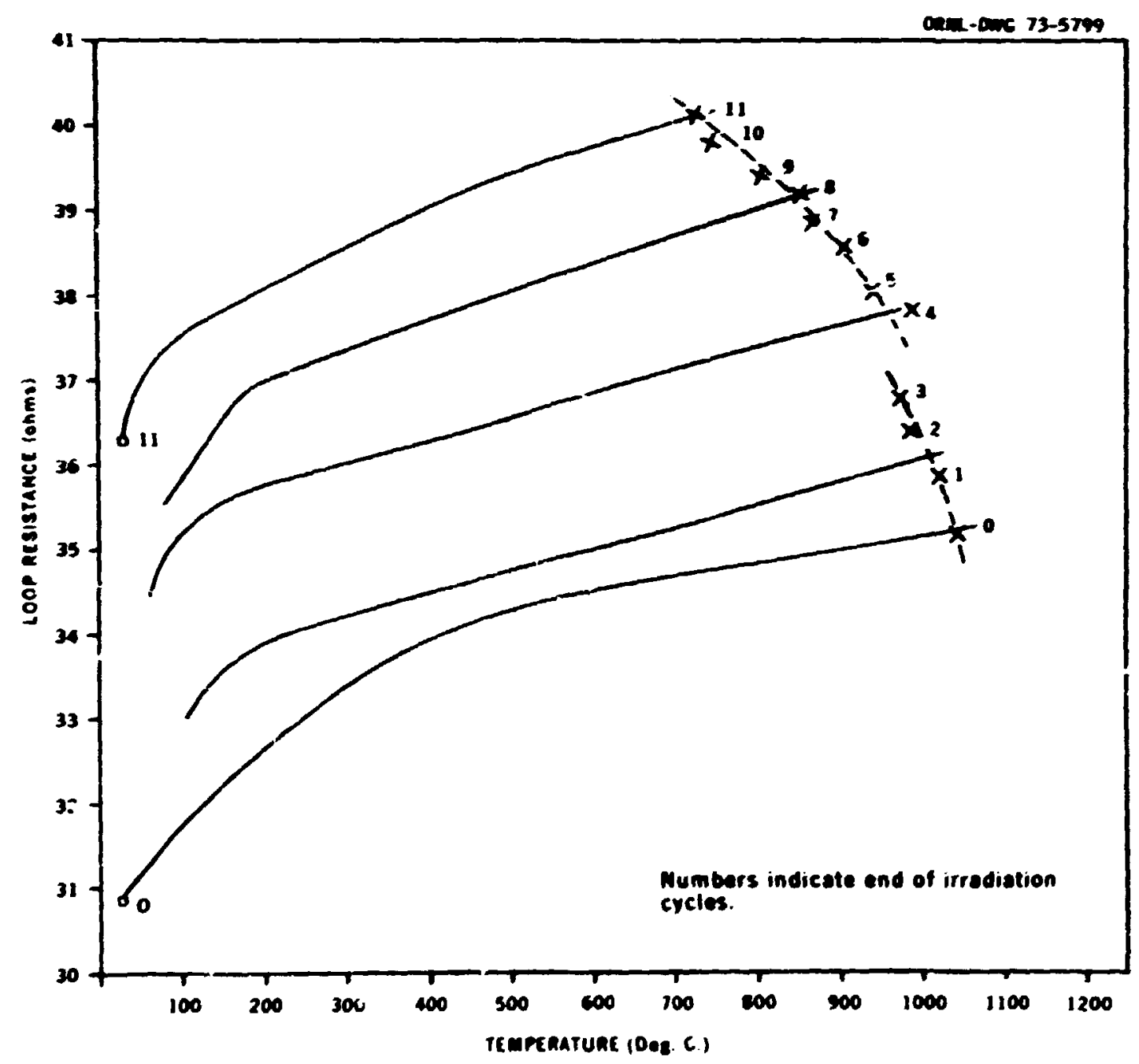

Fig. 7A9. HRB-3 W-3* Re/W-25\% Re center time thermocouple loop resintunce is tempernfure. 
start of $t$ of the 11 reaitur iycles and the last shutdown shuws a progression of the thermucuuple condition frum one of high culput and luw resistance to one of reduced outpul and higher resistance. It also shows the $5 \Omega$ increase in ambient !smperature resistance. The dashed line conneiting $\boldsymbol{X}$ 's idertifies the normal uperat. ing condition during each cyci: and is assumed to de note equal temperaturs. If so. this plot shows a shift of tiernocoupt. uutput of more than $300^{\circ} \mathrm{C}$. from the $1100^{\circ} \mathrm{C}$ indizatet initially to about $700^{\circ} \mathrm{C}$. at the end of 11 syiles. This evaiuation of the thermocouple decalibration agrees to within aboui $50^{\circ} \mathrm{C}$ with that ubtained from heat produitior calculations. 24

\section{Postiradiation examination}

The $\mathbf{W}-3 r^{6}$ and $\mathbf{W}$ 25\% thermocouple wires were retrieved from the HRB-3 capsule in postirradiation hot-ill examinations. Dimensional changes in the wire were ilearly tow small to aciount for the large observed resistance ihanges. Cumpusitional changes. due to calculated $W$-co-Re transmutation snd the separation of a seciond phase observed in metallographs of the wires. ate believed to have caused both the decalibration and resistance incre: $e$ of the thermocouple wires.

This experiment showed the feasibility of determining that the calibration of ihe thermccouple was changing by correlating :tanges in loop resistance and thermal emf. a method independent of any hezt production and transfer calculations or assumptions about the true cenle:-line temperature.

\subsubsection{ERB-4 Center-iexe Thermometry}

\section{Design}

The $\mathbf{W}-3$ r $R e ; W-25 \%$ Re fuet centertine thermocouple for HRB4 was fabricated from the same materials and by the same method as the one used in the HRB-3 experiment. Sheathed thermocouples in the peripheral graphite sleve were located in similar positions (Fig- 7.48). except that no sheathed W-Re peripheral thermocouple (TE-108, was used. is siguif:cant differerice was the connacion of the additional loop current-araying pair of leads. As shown in Fig7.50 . the $300 \mathrm{P} / 300 \mathrm{~N}$ current-carrying pair was connected to the thermocouple loop just inside the primary bilkhead. detining a lowp about 5 in. long. instead of the 10 to 30 ft-long loop used in HRB-3. Loop resistance measurements made during the course of the irradiation could be made to a precicicn of betier thar $0.03 \Omega$ and showed much greater sensitivity to changes in reactor power and to degradation of the thermocouple.

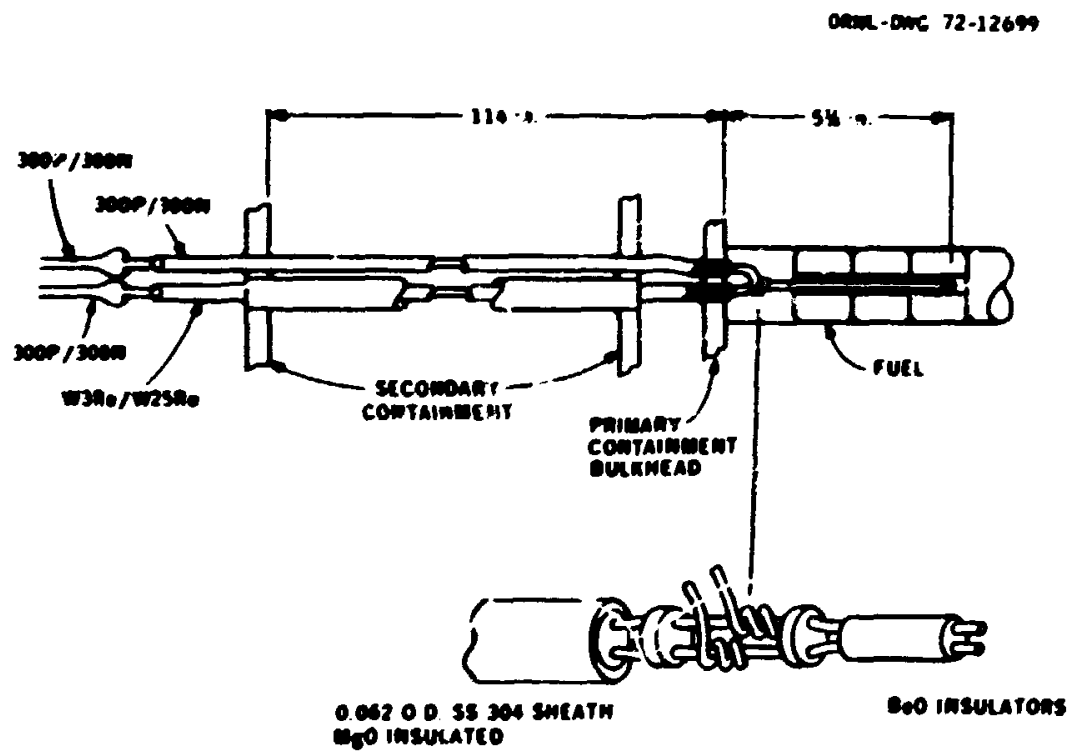

Fig 7.50. Four-wise W-Re thermocouples in HRE-4. 


\section{Performance}

The fuel cencer-line $\mathbf{W}-3^{\circ} \mathrm{c}$ Re $\mathbf{w}$ 25\% Re themo couple in HRB-4 failed open circuit after $2213 \mathrm{hr}$ at temperatures of 900 to $1005^{\circ} \mathrm{C}$ during a capsule temperature increase sreated by adding neon to the heliun gas flow. During this irradiation. the the'mocouple showed a $75^{\circ} \mathrm{C}$ decrease in indicated temperaute Ifrom 925 to $850^{\circ} \mathrm{C}$. xsuming constant true cencer-line temperature) and a 0.0- $\Omega$. or $18 \%$. increase in the themoccuple loop resistance. The resistance increased at an accelerated rate during the 40hr period preceding the failure, and erratic output was observed in the hour before failure.

The data for loop resistance and indicated tempera ture for the startup of each of the first four irradiation cycles (to $2011 \mathrm{hr}$ ) are plotted in Fig. 7.51. In contrast with HRB.J, these data show straight-line dependence of resistance on temperature (due io the shorter loop used) and pe mu quantilatime estumaes lo be nade of the dealibratron The methud assumes that all powits on a line perfendkulas so the imtigl lo-hel resisence. iemperature lin $n$ ixi represen the cac true senter line temperature. The dexibritin an then be determined praphically for varrus irndative times. If ach determinations are made. we observe (I) 2 hanear inirease in kop resisiansic a anbieat temperature (reator shutdown) and (2) a linear decalibration nie of abrut $50^{\circ} \mathrm{C}: 1000$ ht at an operating (true) temperzture of $1100^{\circ} \mathrm{C}$. This decalibration rate is about $30 \%$ geater than the estimate obtaned above by the assumption of constant centertine temperature. When these data are converted from time to fluemie and compared with data oblained by Sandefur er al:s wing copper melting

25. N. L. Sandefur, J. S. Stcibet. and R. J. Grenda. EMF Drif's of Chromel/Atumel and W3\%Re/W25\%Re Thamo couples Measured In-PRz 10 High Neutron Exposures, GULF. GA-AI2SOI (May 24. 1973).

ORAT-OWG 74-6843

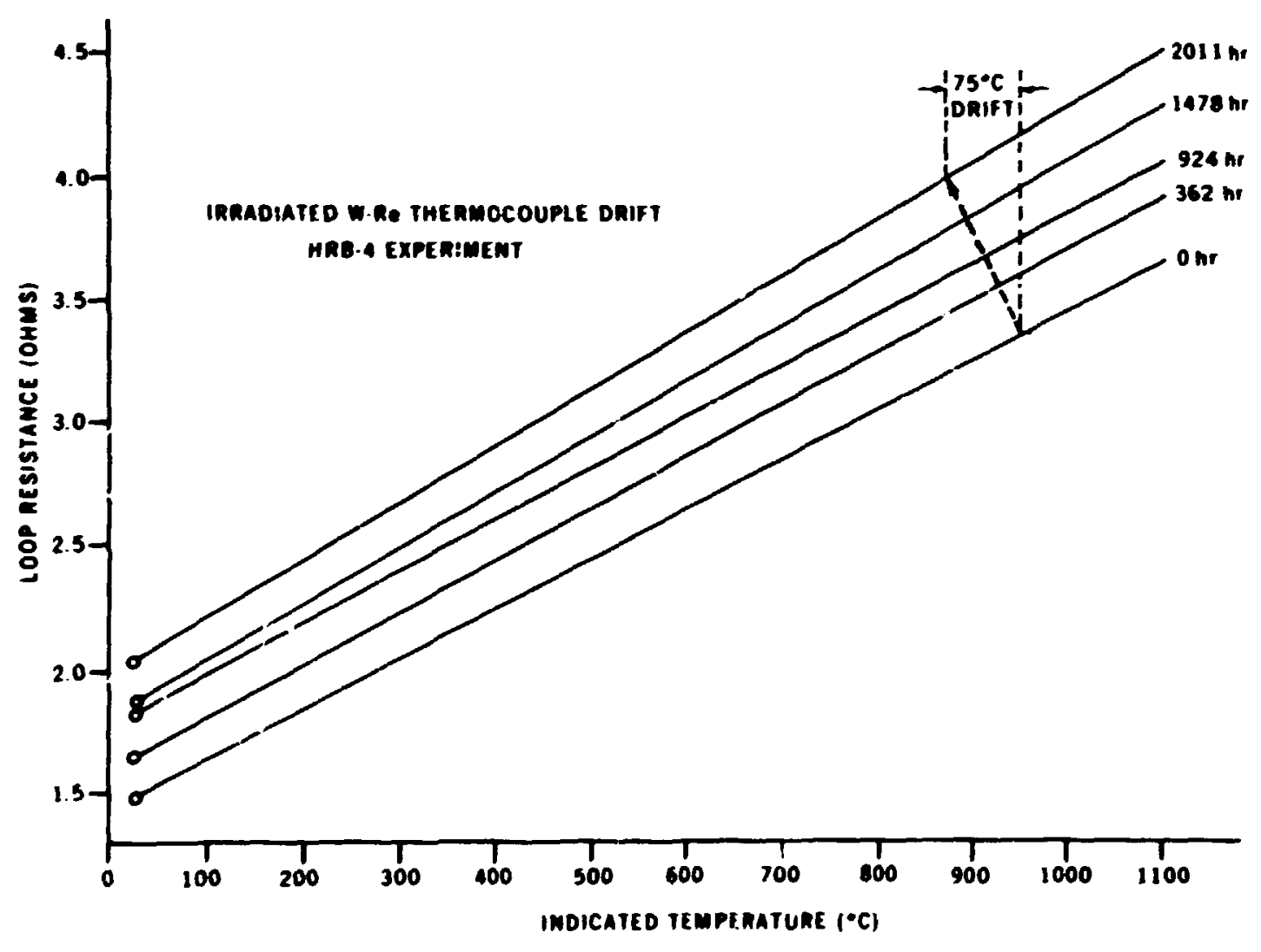

Fiz 7.51. bmdinted W-Re thermocouple diff in HRE4 expertiment. 


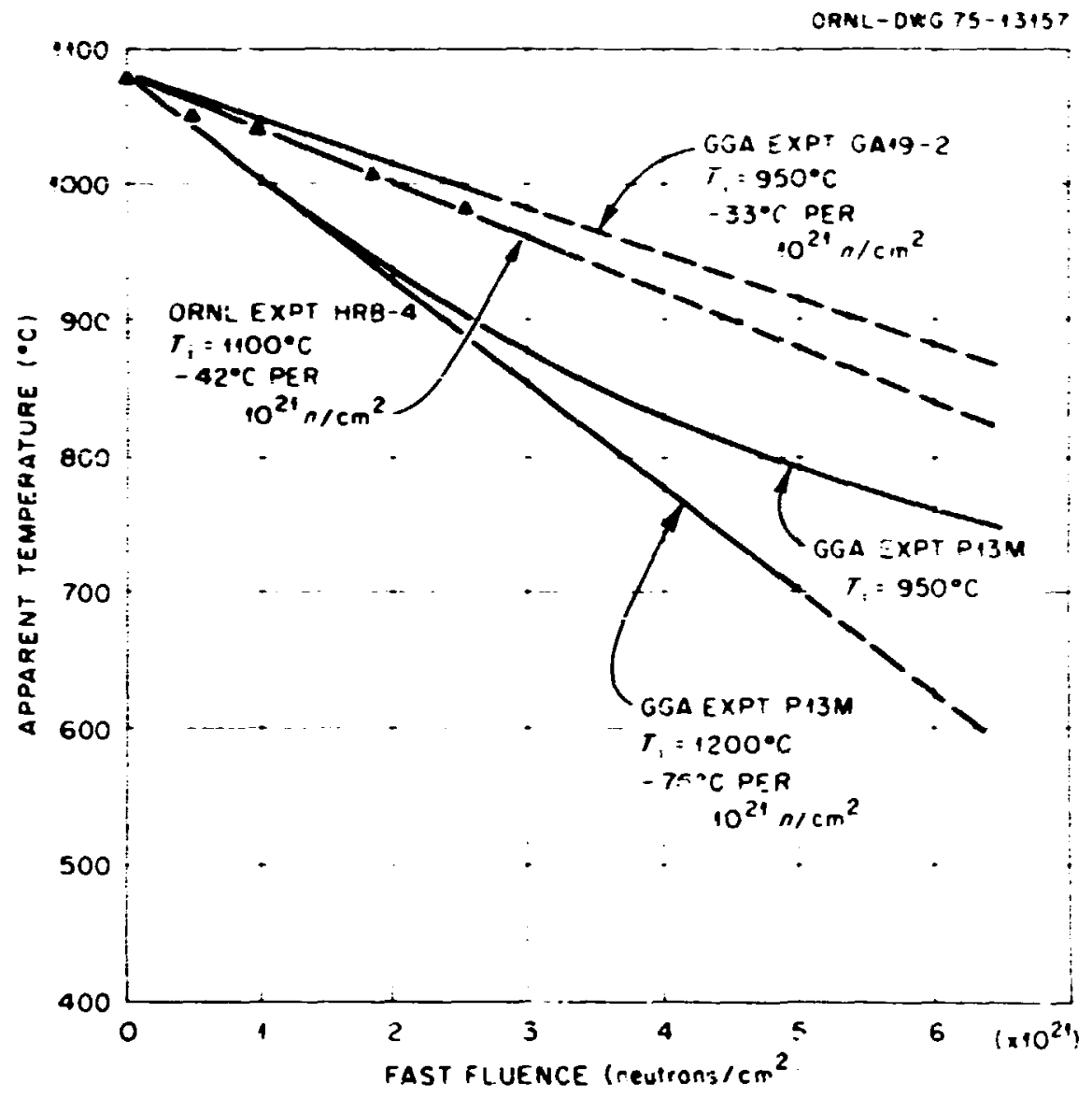

Fiz. 7.S2. Decalibation of W-3\% Re/W-25\% Re therwoconple is HFIR experienent HRR4.

point in reactor !emperature standards. good agieement is obtained das shown in Fig. 7.52) for irratiations conducted at atout the same tempera ure.

\section{Postisadiation examination}

In hot-cell examination of the W-Re therinocouple materials recovered from HRB 4 , it was determined that the thermocouple bead had broken off nedi the weld and that the BeO insulators had lengthened with r.'spec! to the thermocouple wires by as much as 3\%. Apparently, insulator swelling foiced the bead off the thermocuuple.

This experiment demonsliated a quantitaiife cores.tion for irradiated $W \cdot R e$ thermncouple decalibration by accurately measuring thermorouple loop resistance, and thermal enif and using a graphical me:hod in rbiain true temperatures. The method assumes a nomal shift in characteristics with irradiation tume.

\subsubsection{HRE-S Center-Line Utrasonic Themometry}

\section{Design}

The 10-ft-long $1 / 16$-ir. $\cap D$ shesthed center-line thermociouple used ir cap:ules i'RB:- and 4 was replaced in HRB-S by a $1 / 16-i n$. On stainless steel guide tube. This tube contained an ultrasonic lead line terminated by a 2 -in.-long rhenium ultrasonic sersor shown in Fig. 7.53. The end of the thenium sensor was localed in about the same posit: in in the fuel capsule as vas the thermocouple junction in HRB-4. Conlainment for the sensor was provided by a welded sensor enclosure terminating the upper end of the guide tube. 


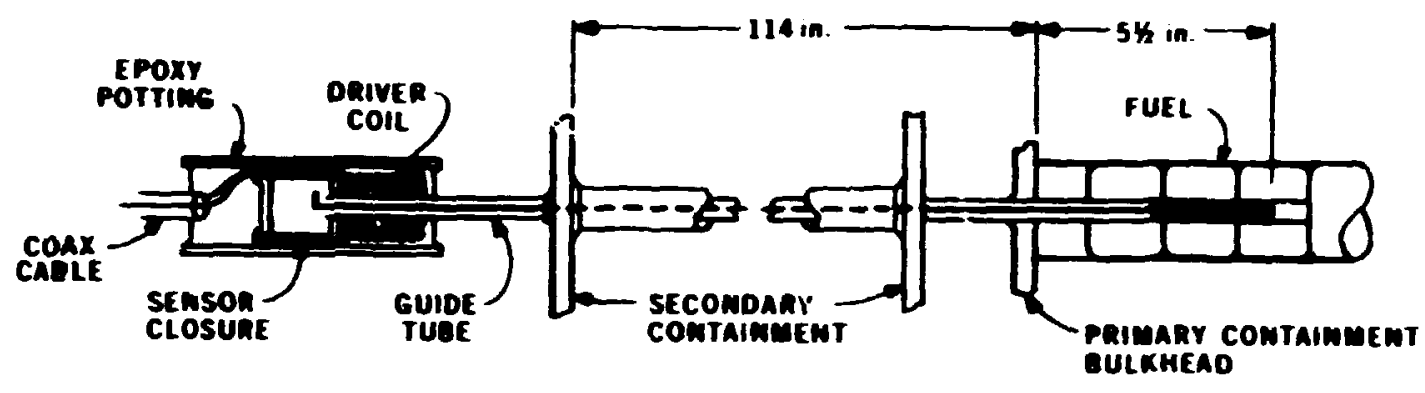

FUEi PIN CENTERLME I.STALLATION

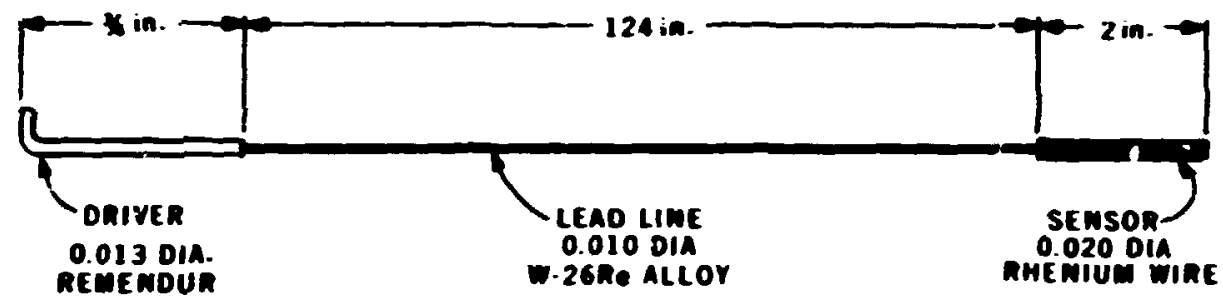

SENSOR UNE

Fig. 7.53. Ulansonic thermometer in HRB-S.

The ultrason: ihermometer (UST) determines temperature by measuring the time interval between acous. tic echos reflectio (I) frum the joint between the lead line and the seasor wite and 12) from the ead of the sensor wire. Thus it measures the tunsil time in the rhenium wire of a mecharical pulse produced by and then sensed by the driver :ovil and the magnetostrictive Remendur driver inside the coil. This transit time is a direcl measure of the $v$ hrily of sound in the rhenium and is $a$ well-known and reproducible function of temperature. Rhenium wire was chosen for the sensor material because it represents a material whose thermal pronerties are well known in ver; high temperatures (10 $-\sim 0^{\circ} \mathrm{C}$ ). Its comparatively large liemal-neutron cross section of 85 bialom makes it unsuitable for the hign thermal-neutron flux environment of th: HRB-HFIR experiments. but its colerance fir absorbed carbon is a parially compensating factor in its choice for this experiment.

The cisnplement of sieathed ChromeliAlumel theruno:ouples in the peripheral graphite sleeve were tiu same as those used in HRB-4. The 2-in.-long rheniun sensor almost exacily covered the span from TE-101 to the plane of TE-J05. -106 and -109 .

\section{Performance}

The rhenium UST in HRB.5 operated satisfa:torily for the entire 2,70hr capsule irradiation at iempera. tures from 900 to $1100^{\circ} \mathrm{C}$ accumulating a thermal-neu. tron fluence of $1.1 \times 10^{22} \mathrm{nvt}$ and a fast-neutron $(E)$ $0.18 \mathrm{MeV}$ ) fluence of $32 \times 10^{21}$ nvt. A pronounced shift in the pulse interval for transit lime! during reac:tor shutdown isothermal conditions was noted after each 23-day reactor cycle. The points plotted in Fig. 7.54 show a decrease in transit time from about $43 \mu \mathrm{sec}$

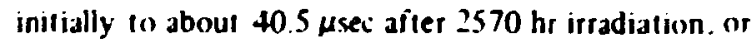
a $7 \%$ decrease. The decrease shows a straight tine dependence on time or fluence. Also, lotted in Fig. 7.54 is the initial calibration of the lis $\mathrm{I}$ (solid line) made before capsule assembly and a inal calibration made in thic in-ponl whole-capsule furodes !shown in 


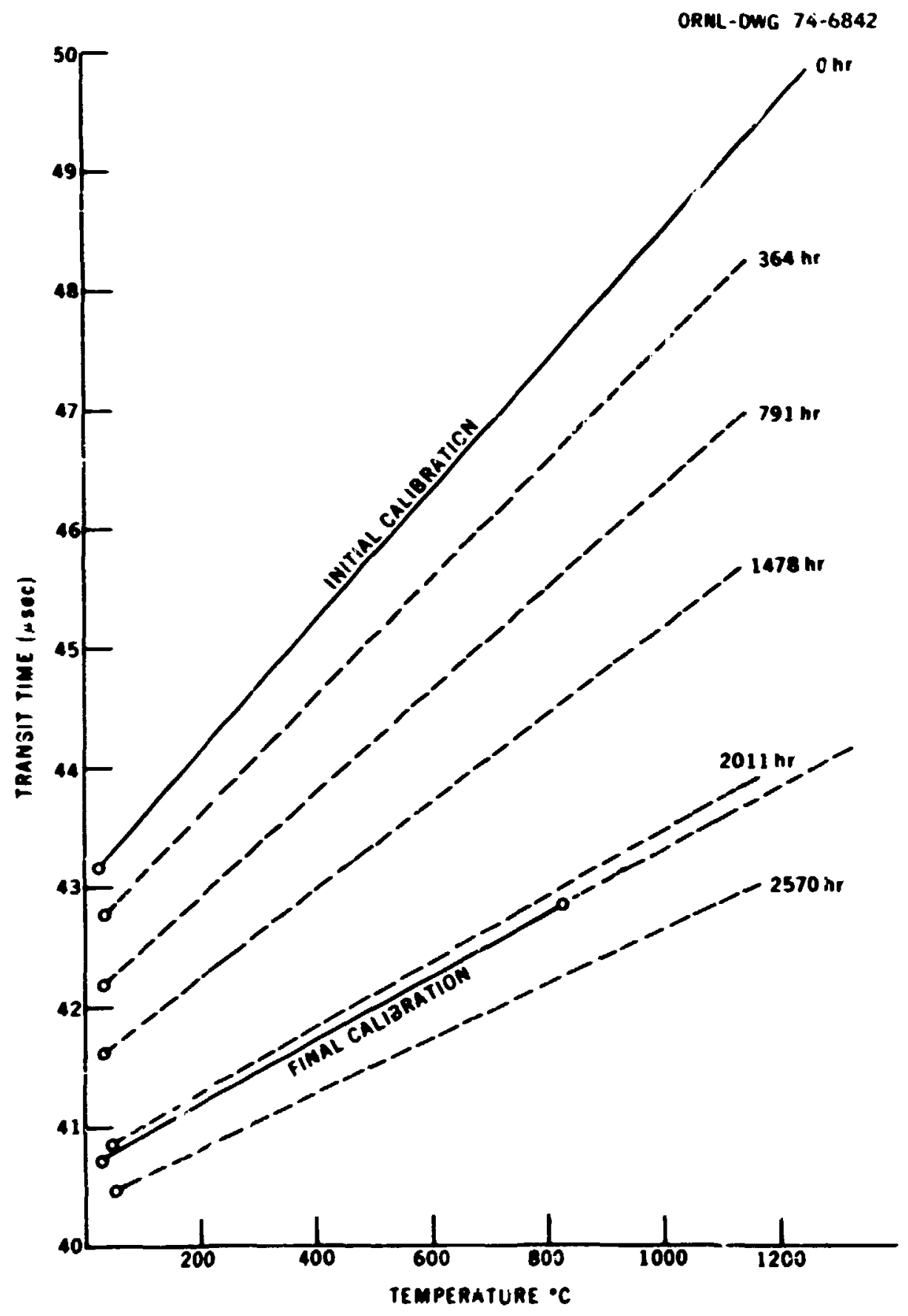

Fif 7.54. Imdited thriem wltrasonic thermometer drift in HRe-S experiment. 
Fi. 7 .i) after rernoving the IRB-S capsule from its position in the HFIR RB irradia: s? facility

The dashed lines is:erpolated between tice initial and final calibration curves in Fig. 7.54 are suggested intermediate calibrations based on the known values of the ambient iemperature transit times. Using these interpolated calibration curves, the data obtained dur ing itse irradiation may bs updated and corrected. Corrections for data 'aken during $100 \%$ helium cooling pericats, seven days into each of the reactor cycie. are given in Table 7.29.

\begin{tabular}{|c|c|c|c|c|c|}
\hline & \multicolumn{5}{|c|}{ Crete } \\
\hline & 83 & 8 & t5 & 86 & 87 \\
\hline LET transit tim $=\infty \times$ & 47.4 & 4.6 & 45.5 & 4.5 & 4.0 \\
\hline Unconered lean o.. "C & 817 & 625 & 450 & 270 & $\mathbf{2 0 0}$ \\
\hline Correcte I tup., 'C & 90s & 910 & 930 & 990 & $1320 ?$ \\
\hline Periphenil uesp." "C & 600 & 600 & $\cos$ & 610 & $\leq 32$ \\
\hline
\end{tabular}

Anerra of TE-105. -106. and -109.

An unexplained result oicurred at ti: 2 end of the test The ambient temperature value of transit time appeared is shil, back (recoser) toward its unirradiated value. The shift is opposite to what might have appeared with gradual reduction of deiay heal after end of irradiation.

\section{Postimadiation examination}

A piece of the ultrasc.ic sensor li: 2 several feet long was recove' "' intact in the hot iell when HRB-S capsule was dissected. A .nechanical measurement of the W-Re lead line and the !nniurn sensor showed no charge in diameter of as raluch as $: 0001$ in. The sensor wire was broken and the fractured surface examined with a scanning electron microscope. Numerous voids were visible (Eig. 7.55) at 4000X clustered near grain boundaries. The wire was cnemically analyzed and found to contain $50 \%$ os;nium, having heen transhiuted from 100\% rhenium by the intense themal-neutron flux. This composition may be predicted by daugin!e: element decay schemes such 2 : that described by Brat."in et al. ${ }^{26}$ The shift in corrposition from i00\%

26. C. B. :. Brantion, D. N. Hall, and C. M. Ryall. The ristimorion of the Composition and Volune Chantes in Nothe and Refromiony Metal Alloys Due po Neismon Imadiarion. AERE-R:- 19.76 (Seprember 1968). thenium to $50 \% \operatorname{Re}+50 \%$ Os shculd redua the transit time. as we observed it did. according in t3i- sit rhenium-osmium atloys published by Paperiakis et al. ${ }^{2 \text { - }}$

This experir.1ent denonstrated the feasil ility of $x$ sing an utrasonic thernometer. installe' as a siruple rep'dicement iur a themocouple. to s.easure fuet center-line temperatures in an irradiation capsule $t:$ assi howed the sensitivity of th: rljbration of the L'SI to thermal-rieulı in transunutation of the high cross-section thenium sensor material. tut provides - means for correcting for the decalibration. The test prompted the fabrication of a unique whole copsisle calibration furnace winich may be used to verify (or lisprove i many ideas about it $z$ behavior of irradiate. 1 the:mometers.

\subsubsection{IIRB 6 Center-Line Utresonic Thermometry}

\section{Desigo}

The menium ultrasonic thermometer used in the MRB-6 was identical to that used successfully in HRB 5. However. the 1/1,-in.OD stainless steel guide tube material was changed and found later to have been of a so'ter temper and to ivie veat itoroughly cleaned during capsule fabrication.

\section{Performance}

The UST sensor worked satisfactorily during capsule fabrication but failed during the first reactor startup and operated only intermittently thereafter during the $\mathbf{4 0 0} \mathrm{hr}$ irrad stion at $\mathbf{9 0 0}$ to $1170^{\circ} \mathrm{C}$. The difficulty was identifis:d as a pinched guide tute where the flexiule norition of the capsuie assembly was clamped above the eactor cre. Removal from core ar.d straigl: eaing the experiment after the second irradiatiun: cycie restored performance of the UST to some degree. and it was possible 10 make a midterm calibration to $600^{\circ} \mathrm{C}$ in. the in-pool furrace. The calibration obtained fails between the 1478. and the $201 \mathrm{i}$ in curves in Fig. 7.55 (the calibration aurves for HRB-5). apparently too low a value fo; the transit time for only $1100 \mathrm{hr}$ of irradiation The data are som?what suspect, however. due to the severe degradation of the pulse shapes by the kinked line and may well be off in absolute value by several microseconds. An end of -life in-pool calibration to $750^{\circ} \mathrm{C}$ was made on HRB-6 following $4400 \mathrm{hr}$ irradiation. It also shows values lower than expected by

27. E. P. Papedicis el al., Cionsonic Themomemy for LMF2R Systems Find Re,art. NYO-3306-13. p. 113. Fig. 40 (June 1977). 


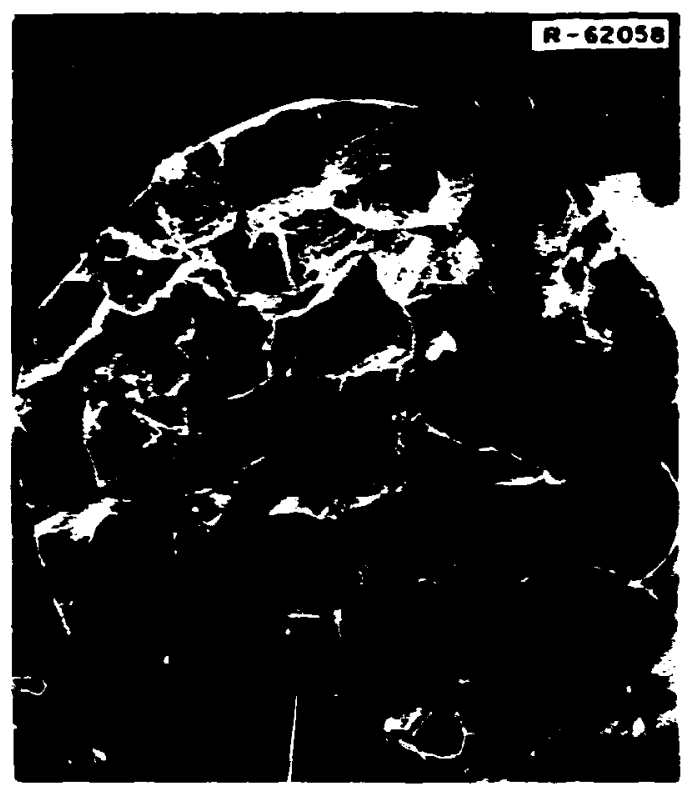

RHENIUM FRACTIJRE - ARCHIVE MATTERIAL $150 \times$

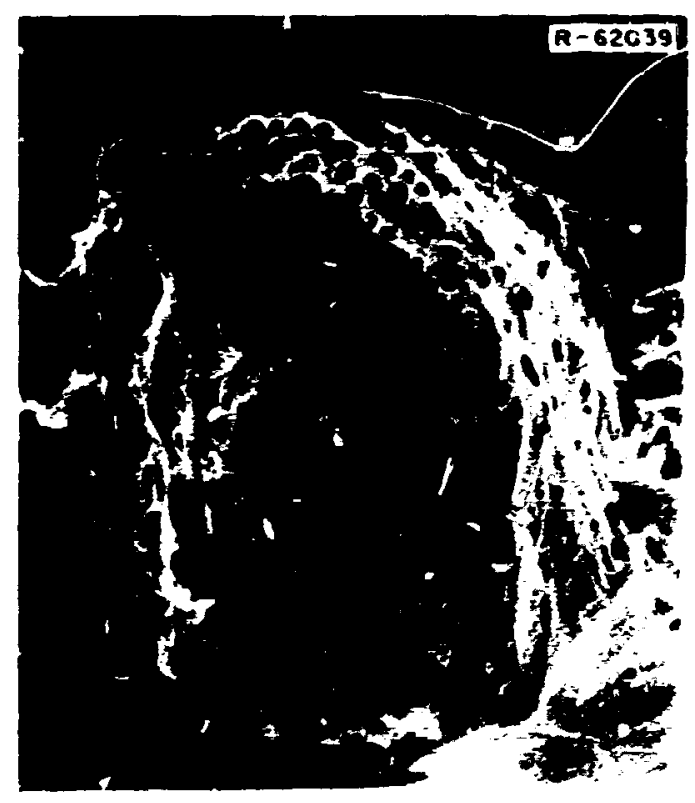

VOIDS IN IRPADIATED RHENIUN $4000 \times$

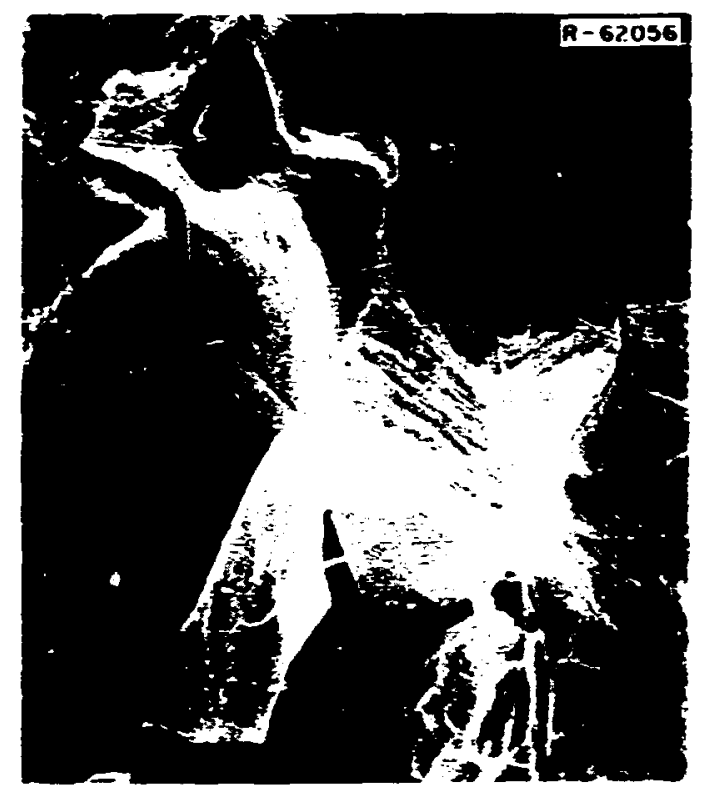

RHENIUM FRACTURE - ARCHIVE MATERIAL $1000 \times$

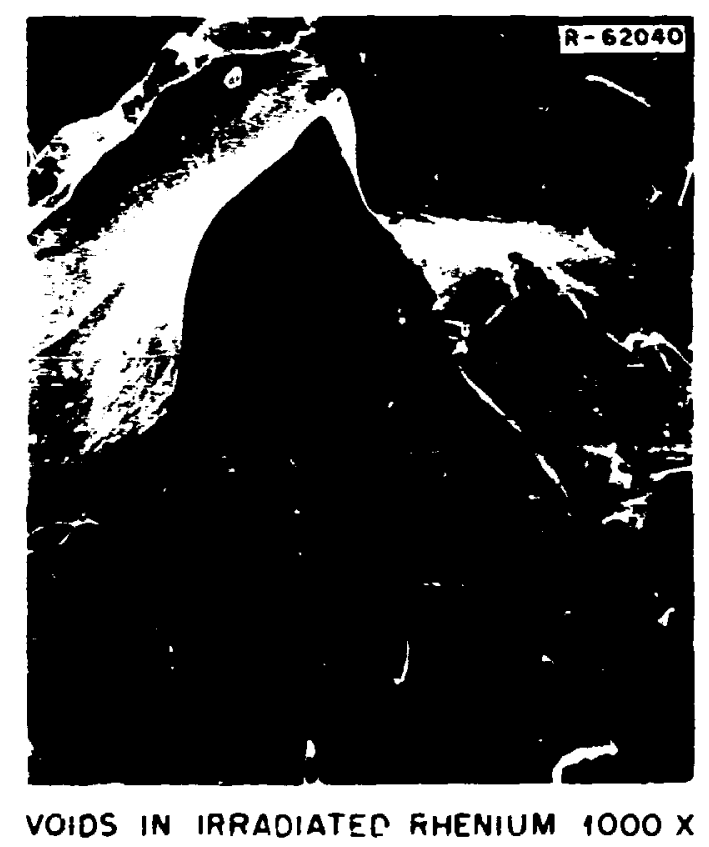

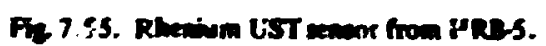


about 2 $\mu s x:$ a temperature dependence similar to the first in ows. alibration but steeper than that foind for the HRB-S LST sensor.

\section{Fostirradiation examination}

Examination of the thenium sensor recomed in the hot cells from the HRB-6 irradiailion capsule apin showed an intact bul easily bratien thenium wire specienen. Voids clu tered near gair ' munciaries were again observed by sianning dictr ma asiopy. Mkrohardness meas'ireme its made un i isdised and archive rhenium wires showid an inctease in h-:dness from 215 DPH before to 55? DPH after irradiation. A sanpi: has been submitted for ch mical compusition analysis.

This iest demonstlater the sulnerability of the UST io mechanical interfe en:e alone the acoustic transmission line but suggests that with caire such problems can be aroided and satisficitory operation realized is i.i HRE-S. Calibration shifts were not rcprindured well between the two experiments. and further studies would be requited bx.fore belisilor can be predicted with good accuracy. The in-pens turnace offers the pussibility of obtaining interim midt $\mathrm{xm}$ calibrations. s!

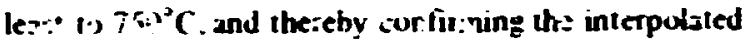

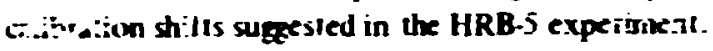

\subsubsection{HRB-7 and 8 Center-Line Thernometry}

\section{Desige}

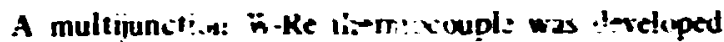
for use in t.reasuring axial tem, pratcre gad s...s nt fuel centertine experimet:!s. This a sembly. shown in tig. 7.56. utilizes three theathed pais of $\mathbf{N}-5 \%$ : Re $4.26 \%$ Re thermuruuple wire materai hrazed tiurcugh the apsale bulkhead. Fe sinpped uires. abis 16 in. long. are insuiale: with sx-hole nard-fired : :eO insulaturs 0.090 in. in cutside diameter and ivined by wapping one wire aroulad another i.. make five thermocouple iunctions. Or.e additional pair of sheathed extension wires $(G$ and $H)$ is attahed to the nain thermocouple loop wires (A and D) so inat the luop $r e:$ tan: an ta measuret. By applying the lowp current to suce pairs of wite (G-H. B-C.F.E.C.E. and $F \cdot B$ ind measuring in each eave the (witput oi the man loop A.D. resistanie may he funnd for the whole thermoxouple loxp. two-thirds of the inop. sne-third of
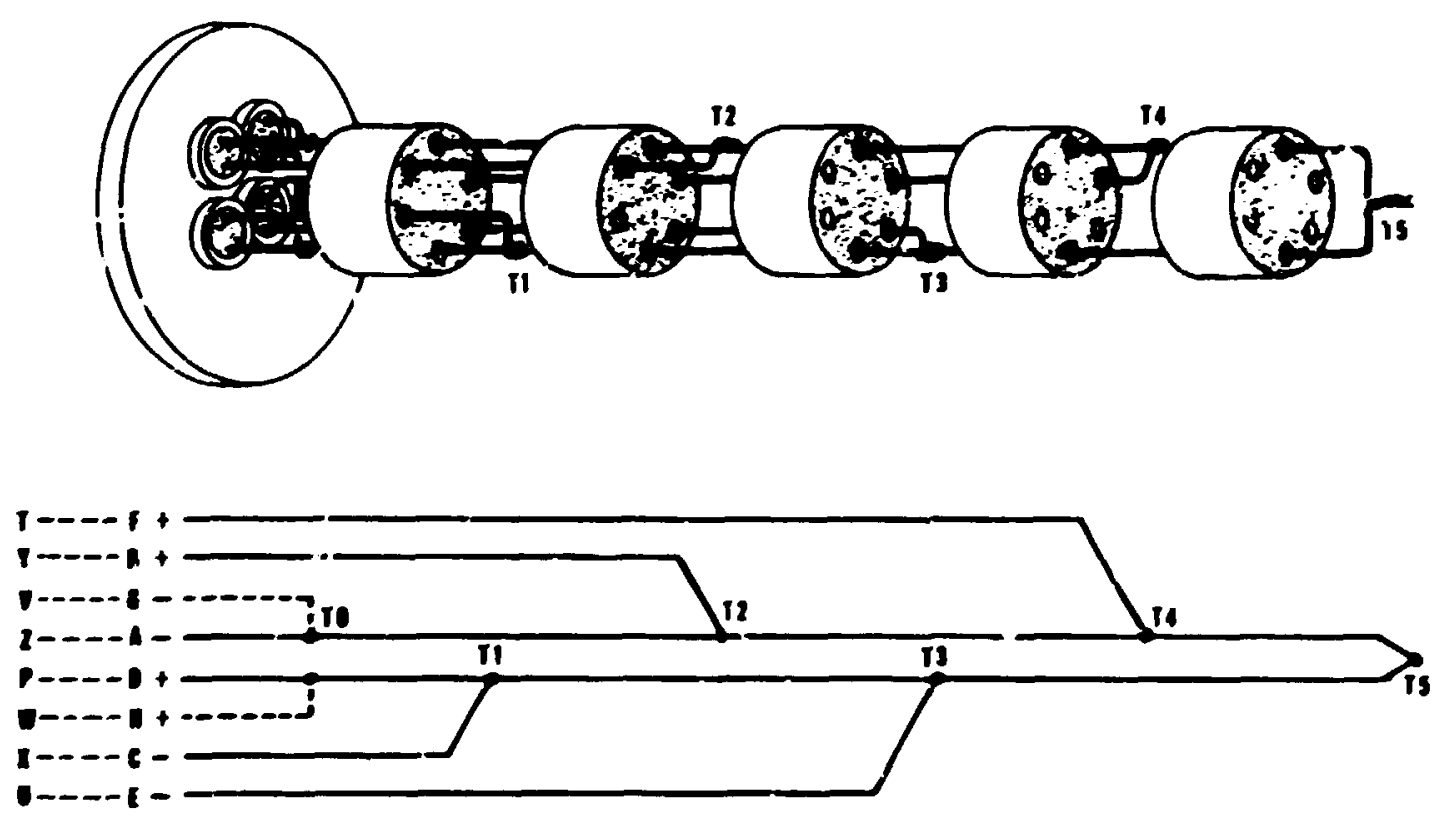

Fif 1.56, Mulfijunction multiloop thenmocouple. 
the lixup. and the pexsitive wire (D) and :he negalive wite $(A)$ individually. The enlire assetibly was designed l1 be buile. Wispped wish thenium foll is peven! insulator-tu-graphite contait. and insetted in 33.130 in.-ID liut element sijik. Ascemblies were tabicaled and itstalled in HRB.? and ox experimerits seheduk.1 "1" start irradiation in Deiember 1473 and Fehruary 1974.

\section{Performance}

The obje't of this experiment is 0 be able 10 measure the iemperature gradient along the iut center-line and along the thermocouple: to measure the effects of time. temperature, and radiation on different portions of the thermo-oupt: to deternine whether the low- or highthenium alloy wire is the principal contributor (o) resistance changes and thermorouple decalibration; and to be able to arrive al a model of thermociouple decalibrations which takes temperature and flux gradients into account.

\subsection{PERFORMANCE EVALUATION CF FUELS}

\section{R. A. Olst3i}

A surnmary ard seferences for this irradiation test are given i: Sect. 7.4.1. The thermal analysis of these capsules was complicated because the :apsules were uninstrumented and because in the umertainte in the fision heat rales and gap widihs arter the capsules werc inverted. The iemperature ialeulainns werc made using the axial profiles of $: 35$ fission rale shown in Fie 7.57. These profiles were delismined fro:n the profiles if thermal flux measured culside the capsules during exh sycle by ETR persinnel and were normalize 1 in the ${ }^{235} \mathrm{U}$ lission rates measured in the ETR Critical Frility. In the top section of the capsules. the ${ }^{25} 1$ : fission rates /fissions/sec per ${ }^{235} \mathrm{U}$ alum! were roughly three times as large after the apsule inversion as before. Similarly. the ${ }^{235} \mathrm{U}$ fosion rates in the hot tom section of the capsules were muxh lower after the capsules were inverted than before. It was this large increase in ${ }^{235} \mathrm{U}$ fission rate (or equivalently. the therinal fiux) in the up section of the capsule that caused very high operaling temperatures and subsequent damage (1) the fuel during the lasi irradiation cycle. T!.e reaction ra!es of the other nuclear transformations were calculated relative io the 235 (I reaction rate, and the nuciear transformation equations were solved to determine the fuel comparition and subsequent lission heating rates during the entire irradiation.

The temperatures that were calcuialed from these fission heating rates are shown in Figs. 7.58 and $7.59 \mathrm{at}$ the beginning of the first iycle and at the hegirning of the last cycle (during which the capsules operated in an

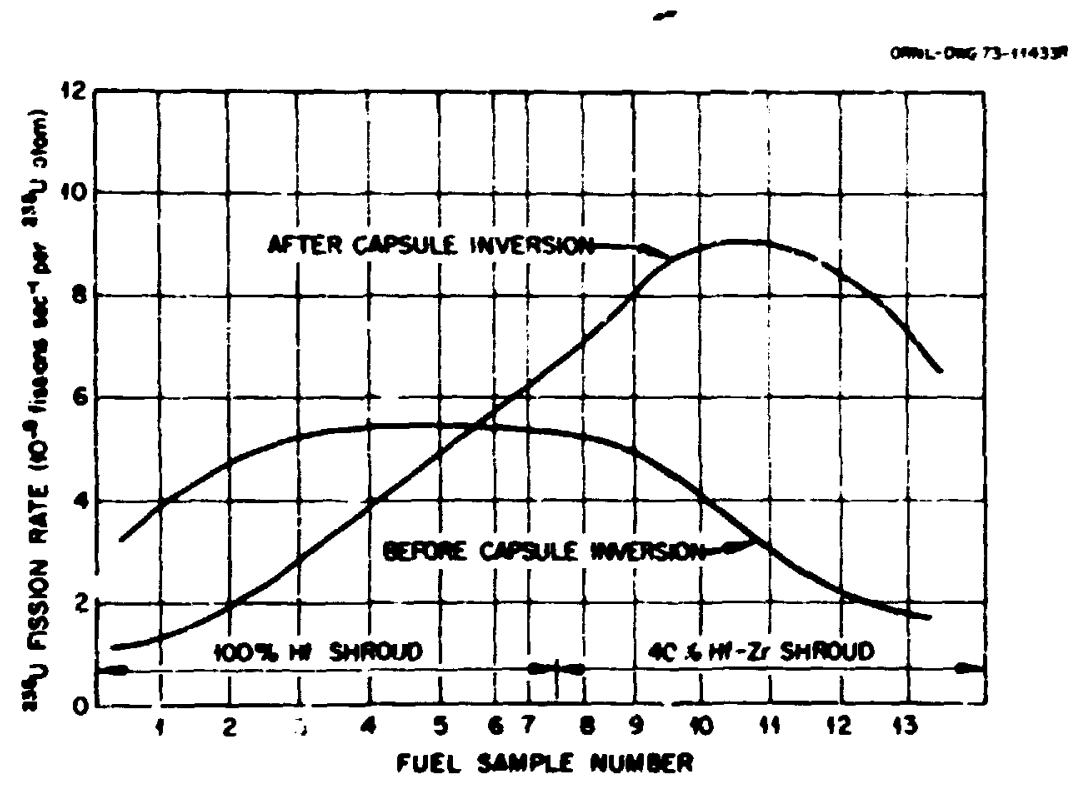

Fig. 1.57. 23! U fiavion mie in Heapales before and after the capaule inverion. 


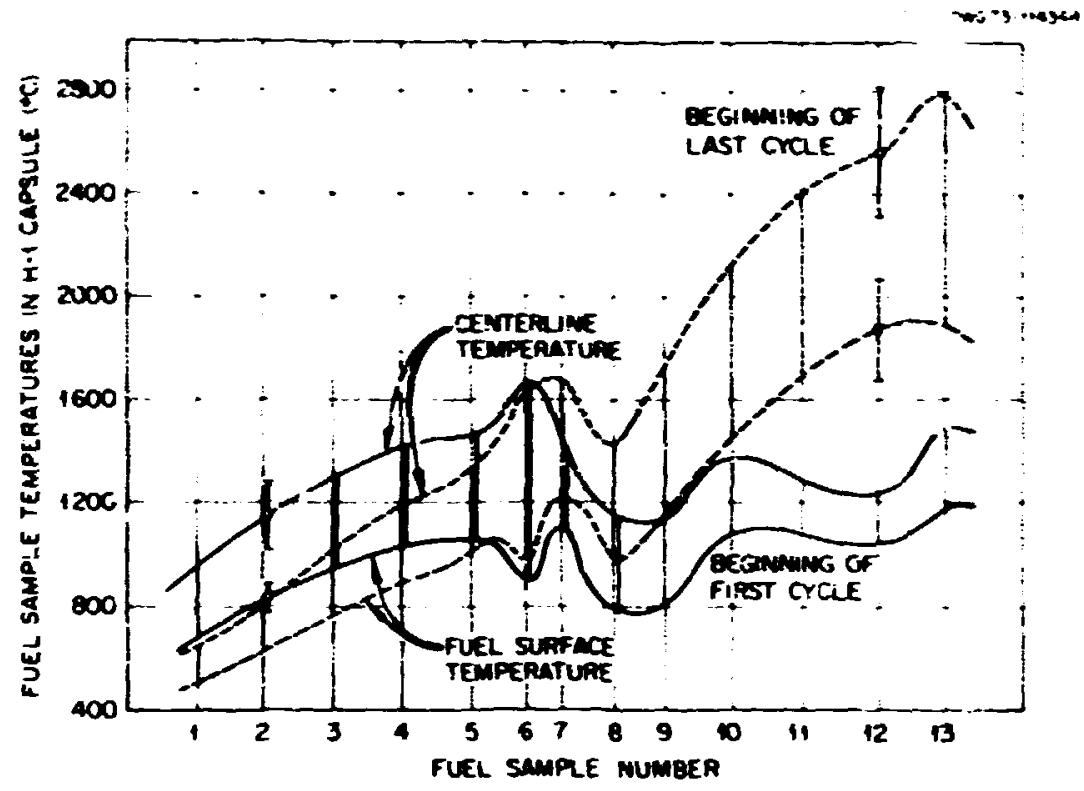

Fiz. 7.S8. Fued samale lemperaturs in H-I capale at beginaing of first and lad cycles.

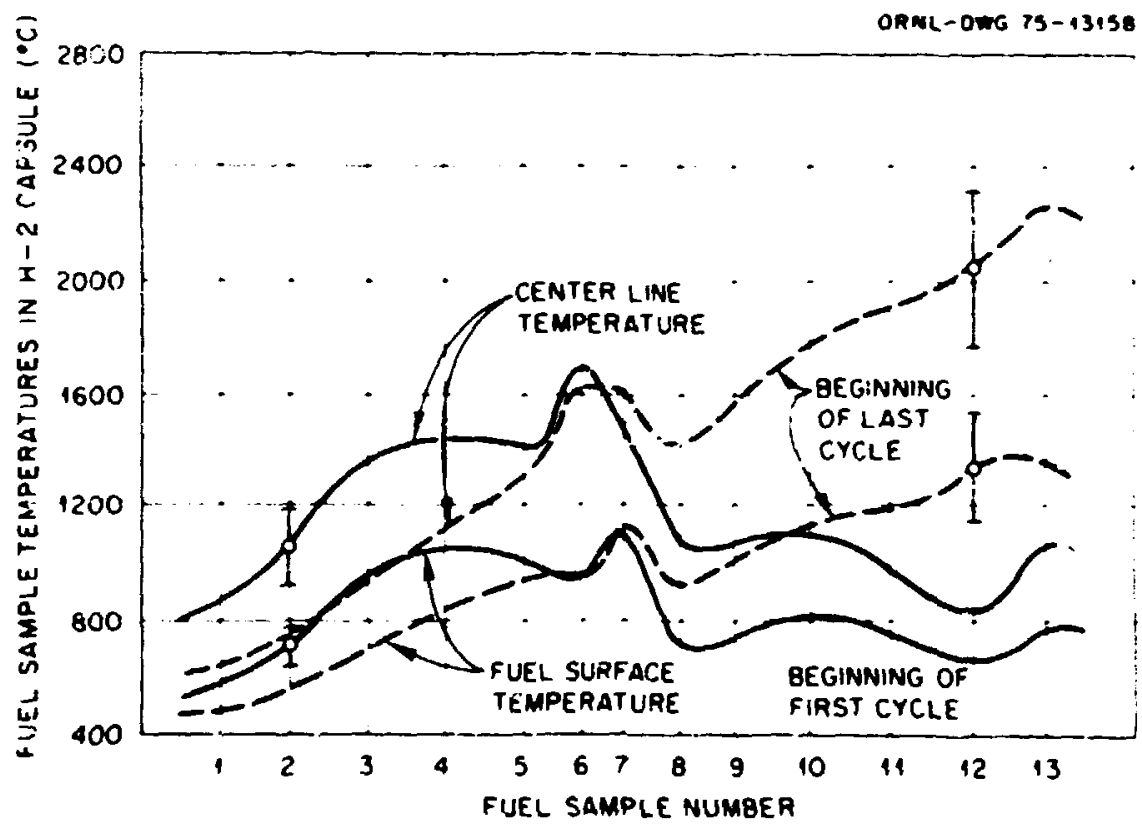

Fig. 7.59. Fued ample tempentures in H-2 capale at beginning of fint and lact cycles. 
inverted pusition). Samples $\because$ and 13 were blended $b$ :ds of particles. Since blended oeds have a lower thermal cor:tuctivily and smaller cuelgraphite sleeve gap than bonded rods. the: cperated at lower surfia temperaturt, but higher center-line temperatures. The :ritial center fine temperatures of the bonded rods in the H-I sapsule vaned from $950^{\circ} \mathrm{C}$ for rod H-I-I to i $450^{\circ} \mathrm{C}$ for rod $\mathrm{H}-1 \cdot 5$. However, beazuse of the apsitk inversion. the enter-line temperatures of rads H-I-I0, H-I-II and $\mathrm{H}-1.12$ werc geater than $2000^{\circ} \mathrm{C}$ during the last iycte. The cente: tine iemperalures of the $\mathrm{H}$-2 samples were generally lowe: than thuse of the H-1 sampies. buth before and aiter the inversion. The initial zer:terline temperatures in the rods in buth apsules are uncertain by approximately \pm 100 to $\pm 150^{\circ} \mathrm{C}$ becouse of uncertanities in fision heating rates and fuel iui thermal anductivity. The center tine temperaturts of the rods that operated a: very high temperatures during the last ock are uncertain by approximatel: $\pm 250^{\circ} \mathrm{C}$ because of large uncertainties in the gap between the fuel rods and the graphite sleeves as well as uncertaintes in the fissum heat rates and fisel conductivity.

The initial temperatures wete aliulated assuming a bonded-rod thernal conductivity of $0.07 \mathrm{~W} \mathrm{in}^{-1}$ $\left.1^{\circ} \mathrm{C}\right)^{-1}$ and all gaps at their initial values. The temperstures during the last escic were calculated assuming a rod cond in:tivity of $0.05 \mathrm{~W} \mathrm{~cm}^{-1}\left({ }^{\circ} \mathrm{C}^{-1}\right.$ and assuming itat gaps hetween the graphite sleeves and the stainiless steel capsite were at their final valıes. as determined from post:rradiation dimension measurements. The g: $p$ between the bunded ruds and the gaphite siceves during the wost cycle were assumed to be at their initial values (i.e.. 5 in:its) Thix zin aption wis made beisuse: there was a brge uncertainty as lo whether these gap widths decreased or increased during the irradiation. A zomma heating rate of 15 Wig was assumed in all calcubtions. The tuermal conductivity of the blended beds was assumed (1) be $0.0 .35 \mathrm{w} \mathrm{cm}^{-1} 1 \mathrm{Cl}^{-1}$ throughomit ihe irradiation. 


\title{
8. Prestressed Concrete Pressure Vessel (PCRV) Development
}

\author{
G. L. Witu:man
}

The misor portion of the presiressed concrete reatit pressure vessel developmer I progeram consisted in th: disussembly and examination of the thermal eylinder moviri and evaluation of experimental da:a and calculated results. The thermal ylinder experiment was designed is utilize information obtained from the concrete materials charicterication. triaxial ireep. insirumentation evaluation. analysis methods develop. nkint. Inci sticuctural model studies of the PCRV divelupment program. The purpuse was lo provide reliable resi dala fron. a fairly complex i!lindrical model for use in evaluating the sapability of a finite. ciement compute: unaly is in conjunction with snallspecimen conisete test di.d to calculate the type off rime-dependent PrRV hehavior to the expecied in a iumnercial HTGR power plant.

Dis further researih has been undertaken under the inncrele tiaxial crecp iudies: however. the applied ioadings have been mantained on the liniversity of Texas long-ierm crecp specimers and strain readings taken perlodically A series of tinal sur.imary reports are heing prepared in triaxial creep studies conduited at the linversity o: Tcxas and the Waterways Experiment Station. LS. Army Corps of Engineers. A report is also heing prepared on lixe Wateiways Experiment Station :oncrete muisture nugtation experiment. Completion of these reports has tieen delayed both by a lack of available personnel a id funding.

\subsection{THE THERMAL CYLINDER TEST}

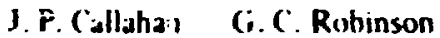

The thermal yylinder experiment was designed to provide a means fir evaluating the present capability to predict temperature and time-dependent stress-s'rain behavier of a relatively simple prestressed inncrete sliuciure using dieepted methuds of analy sls lugether with bhuralun st!ength and ireep test data. The model also proviced an opportunity for evaluating lung-term slability. acuray. and reliability of a variety of stre, and stran-measunng devkrs.

The thernial evlinder mu'el is approximately 3 one-sixth-siale representation of the central barrel seition of a singleravity-lyp: PRRV sush as was employed in the Fort Si. Viain Sidclear (Fenerating Statwn. The model is $3.75 \mathrm{ft}$ in inside jameter. + it high. and $1.5 \%$ in wall thickness. Tesing of the model was cumpleted in December 1972. and preliminary results wore reported.' For refereilice purpuses. a shemstle : apresentation is shown in Fig. 8. !. The cest stiuclure and th: model assembly are desiribed in detail in Ref.: Z and 3 respectiveiy.

During this reporting period. we have completed icte iswning of the model prestressing conduited pus:-nortem siudies of cincietic cruss seitions and axial presiressing lendons. and completed an analysis of the model test history

\subsection{Analyticul and Experinental Resalts}

Thermal cylinder model tex. A time-dependent ireep arialysis of the entire uperational history of the thermal iylinder model was conduc:ed using the SAFE-CRACK

1. J. P. Callo'azn. R. S. Valnchovic. and G. C. Robinson. (iCR Programs innu. Pmorr. Rep. Dec. 31. 1972. ORNI.4911. DP. 181209.

2. 1. M. Co im, 1. P. Callahan. and M. Richusdson. GCR Prorrums Srmuinu. Atog. Rep. Sepr. 3n. 1970. ORN1.4637. pp. $70-71$.

3. J. P. Callahan. J. M. Corum. and M. Rxhasdwen. GCR.TU Aograms Annu. Ano. Kep. Sepl. 3n. J971. OPNL4760. pp. 79.91 


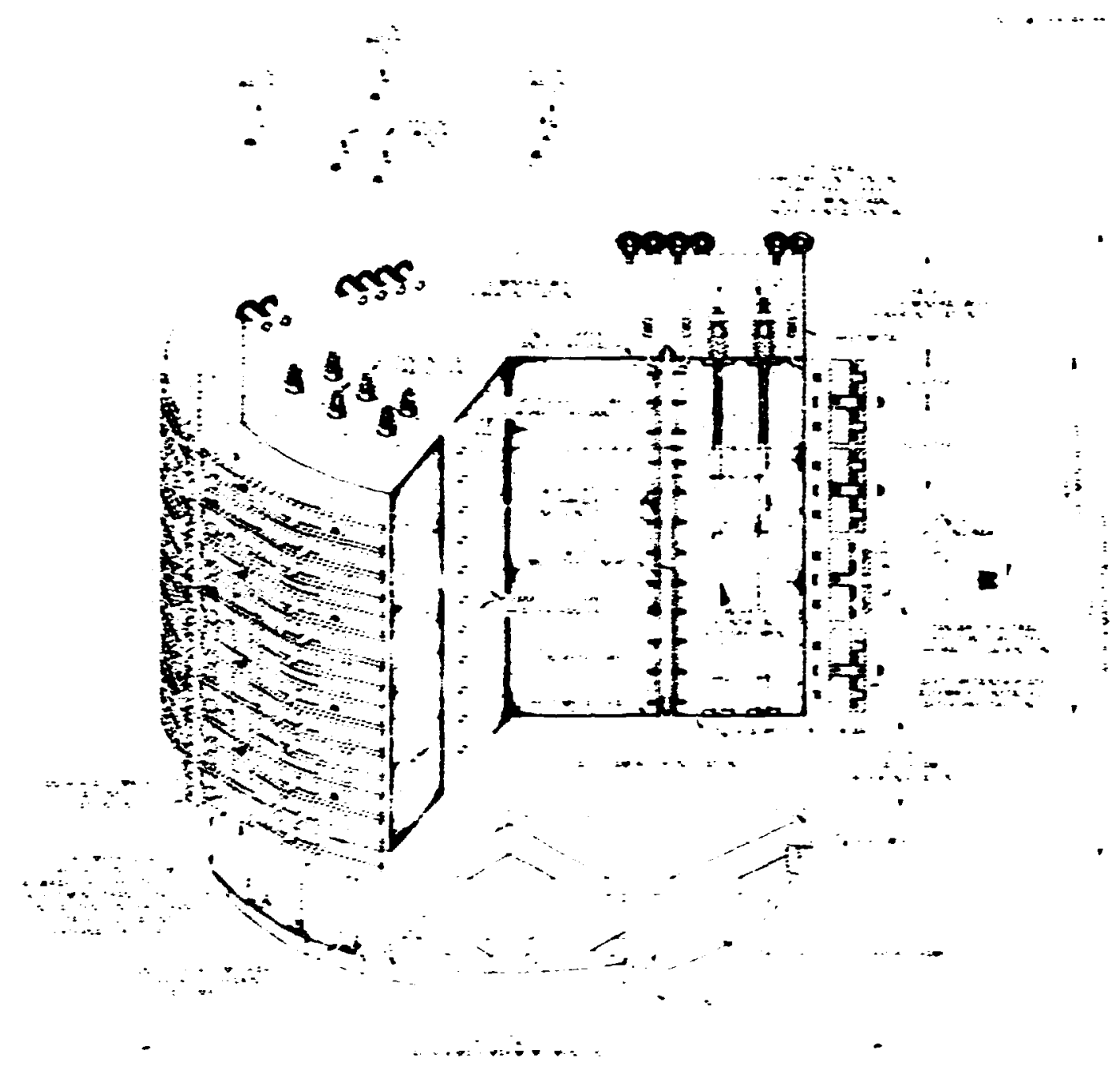

Fy 8.1. Isometric of thereal cylinder test sirecture.

cumpuler prugram" together with cuncrele matcrials properties data chiained under the overal! OR.SL PCRV research and development program. The model was analy sed initially' for inly a purtion of its icst histury and usir.g materials properties data avalable in the literalure fin! a similar cencrele. The complete analysis employed t7 tume sieps cureriag ixs days alter completion of presiressing.

The analylical medel is an avisymetric thisk-walled cylinder having dimensions and $i$ ennetry of the test model. A total of 56,4 elements are used. consisting of

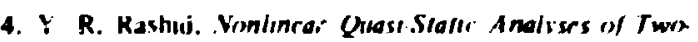
Inmensingal (onrtele Sinuctures. (iA-9994 (Mar. 23. 1970). triangular ring =kements to represent the soncrete and membrane shell elements to represent the liner or heat exchangers. The circumferenlial presiressing is represented as uniform pressure applied to the outer harrel sc:tion. and the axial prestressing tendons are treated as uniaxial clision elements. Oh .c the specified failure interia ar: exceeded. the :itrected concrete elenient is allowed "w erast. ard new sliffness and load matrices arc compuiced in the analysis. The resuliing new cquilibr...m equations are then solved for new displace. ments.

We have compaied the analylical results iblained using SAFt.CRACK with experimental data fiom the 
therma iylirder movel. Table X.I lists the 155 gages incleded in the reodel. Althurght t.e table indi:atis percent strvival of cach gage type, it dues nut pros nide : $n$ evaluation of gas: reliability and aciuray. The remainder of this section disiusses the relative per $:$ a: ance of the valiu's gians.

The radial pusitions of the various gages are shown in Fig. X... Cenerally. the initial kette: of the age designations used in the fipure indicats the quadrant in which the gage is lvated (A. B. $\therefore$ or D). This is followed hy une or two ketters or a ktter and a number designating the gage type. The fiast number of the three-number series that follows the letters indicates relative radial pusition from the inside of the rest seitkn. and the last number indicates the orientation (i.e.. $1=$ axial. $2=$ radial. and $3=$ circunferential $)$. The mildk number is used to further identify individual sensurs.

Ot the estiuns cuncrete embedment gages. the singlefilament resistance type provided the must consisterit and meaningful data. Cumparisuns of analytial and experimental resulis for axialy and radialy oriented eages linated in pusition 1 arc given in Figs. 8.3 and $x .4$. respeitively. In both cases. the prestressing and pressuriation strains :ste overiestimaid. white strans produced during bestup weic underestimated. The behaviot of the axial gages Juring hul-spot hesting appears crrati. sine a sirain jump was recorded shorlly at:er repressurization at 497 days. This effect could have resulted from observed faitures of prestressing tend;ns. as diciussed later. The cause of the sharp 'luctuations in the andyical results duning hot-spot l cating will be studied further.

The analytial and corresponding experimental results for eages in the second rusette position are given in Figs. 8.5 to 8.7 . The same behaviural trends seen for the gees in pusition I were recurded by these gages as well. with prestressing and pressurization strains being overestimated and heatup strains underestimstea. As ex. peited. the recurded stiains during hot-spot heating were less deviant. since these gages were farther away from the heated zone latenter rosette pessition of Fit 8.2). Huwever, signilicant strain jumps wete apin monitured by the aud gases. and the anaiytical curves showed sharp fintuations during hot-spot keating.

Singe-fitament-type embedinent strain gages were also partioned in the comiete directly adjaient to the hut-spot heaters. as shown in Fig. 8.2 for the "D" secikun. Figures $\$ .8$ and $\$ .9$ are comparisons for racial and circumferential gages al the hut spot. The presiressing strains agreed exieptionaly well for these two Rats: althuugh. 2: seen previcusi; the iritiai heatup stizins differed significantly from the calculated values. and the experimental pressurization strains were consiatently low. With the exieption of three questionable calulated data points in Fig. $X . X$. the experimental and

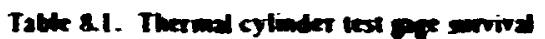

\begin{tabular}{|c|c|c|c|c|}
\hline Ciapt typ: & $\begin{array}{c}\text { Letter } \\
\text { dexpmation }\end{array}$ & $\begin{array}{c}\text { Total } \\
\text { number }\end{array}$ & $\begin{array}{l}\text { Number } \\
\text { faled }\end{array}$ & $\begin{array}{l}\text { Percent } \\
\text { survival }\end{array}$ \\
\hline \multicolumn{5}{|l|}{ Imbedment papes } \\
\hline $\begin{array}{l}\text { Single filament ressidance } \\
\text { Vibr ating wite }\end{array}$ & $\mathbf{P B}$ & $4 i$ & 18 & 617 \\
\hline Type A & D) & 27 & 21 & 22 \\
\hline Type B & $\mathbf{P}$ & 9 & 3 & 33.3 \\
\hline Typec & lix & . & I & 0 \\
\hline Wound we resstance & & 6 & 1 & 83.3 \\
\hline Siress cells & & & & \\
\hline Trtanium resstance & $\mathbf{T}$ & A & 3 & 62.5 \\
\hline Prescure diaphraqm & PSK & b & 6 & 0 \\
\hline \multicolumn{5}{|l|}{ Siran farss } \\
\hline Weldathe (huner) & & 17 & 6 & 68.4 \\
\hline A tal iendons & 13 & 12 & 3 & 750 \\
\hline Circuntere.tial tendons & (C; & $\star$ & 0 & $\ln .0$ \\
\hline \multicolumn{5}{|l|}{ l.oad cells } \\
\hline Avul endons & TH & 12 & $\mathbf{I}$ & 91.7 \\
\hline Iotal & & 155 & n3 & 59.4 \\
\hline
\end{tabular}




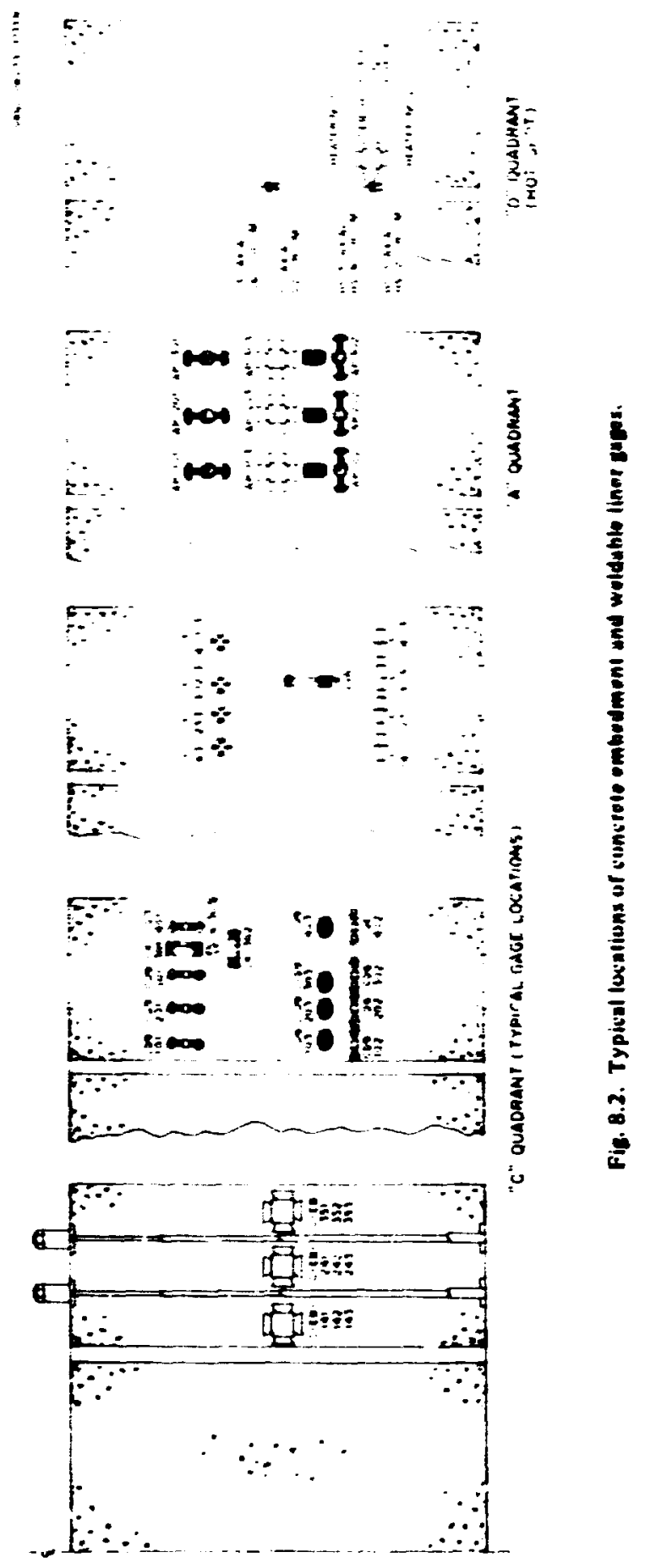




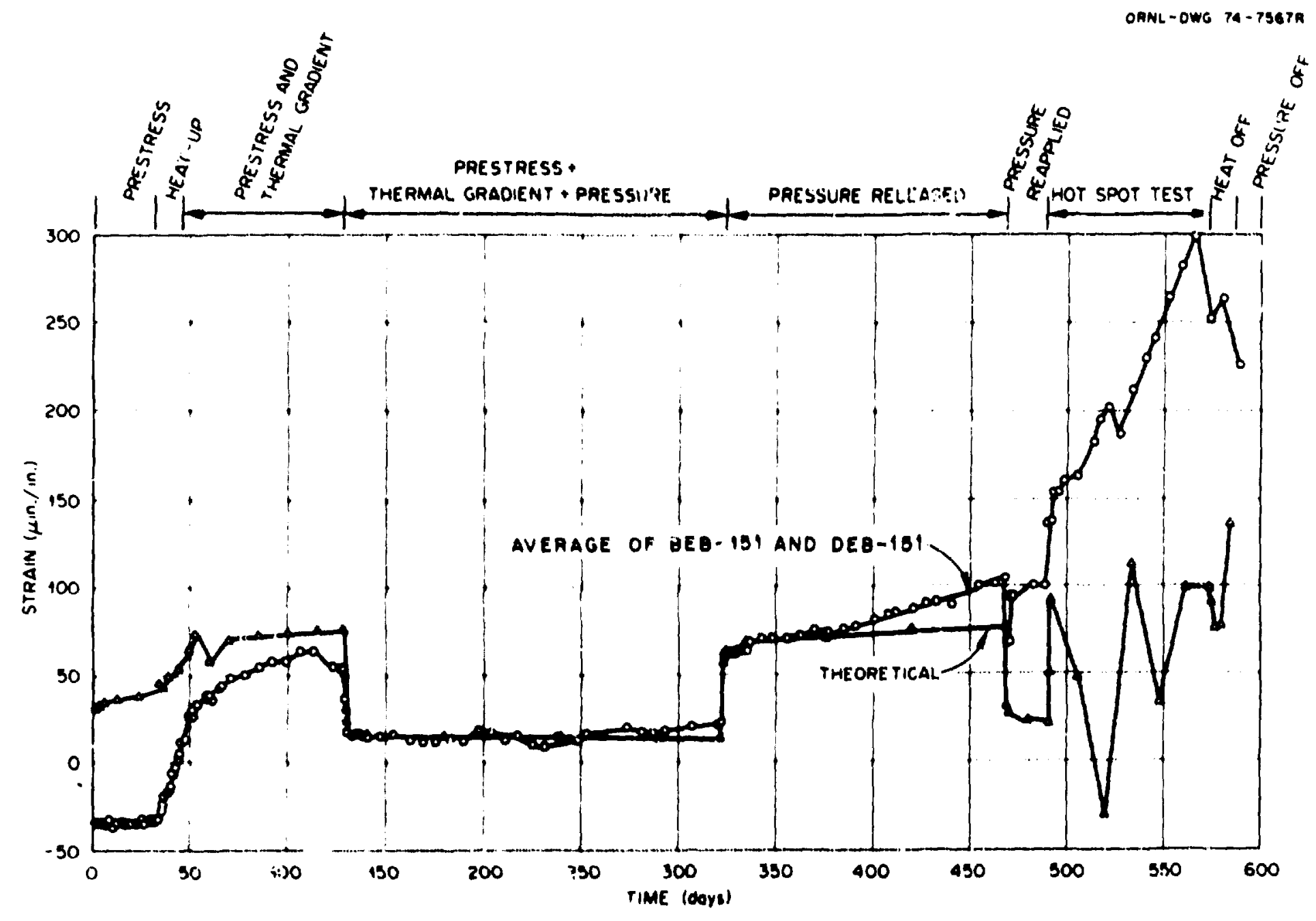

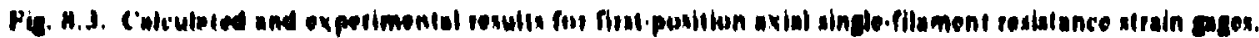




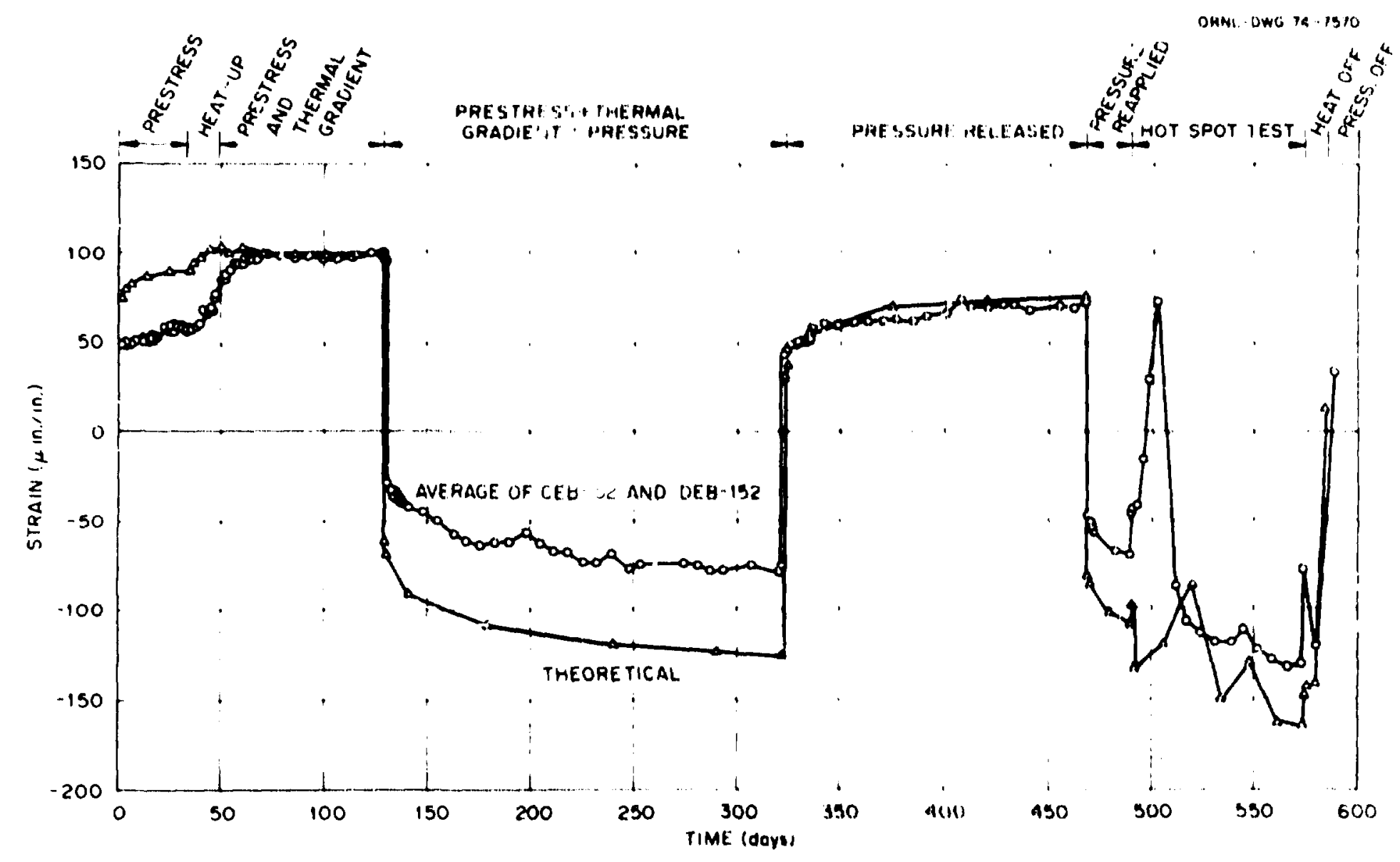

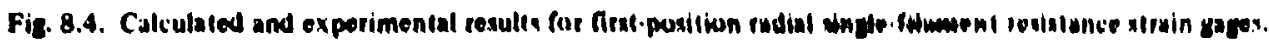




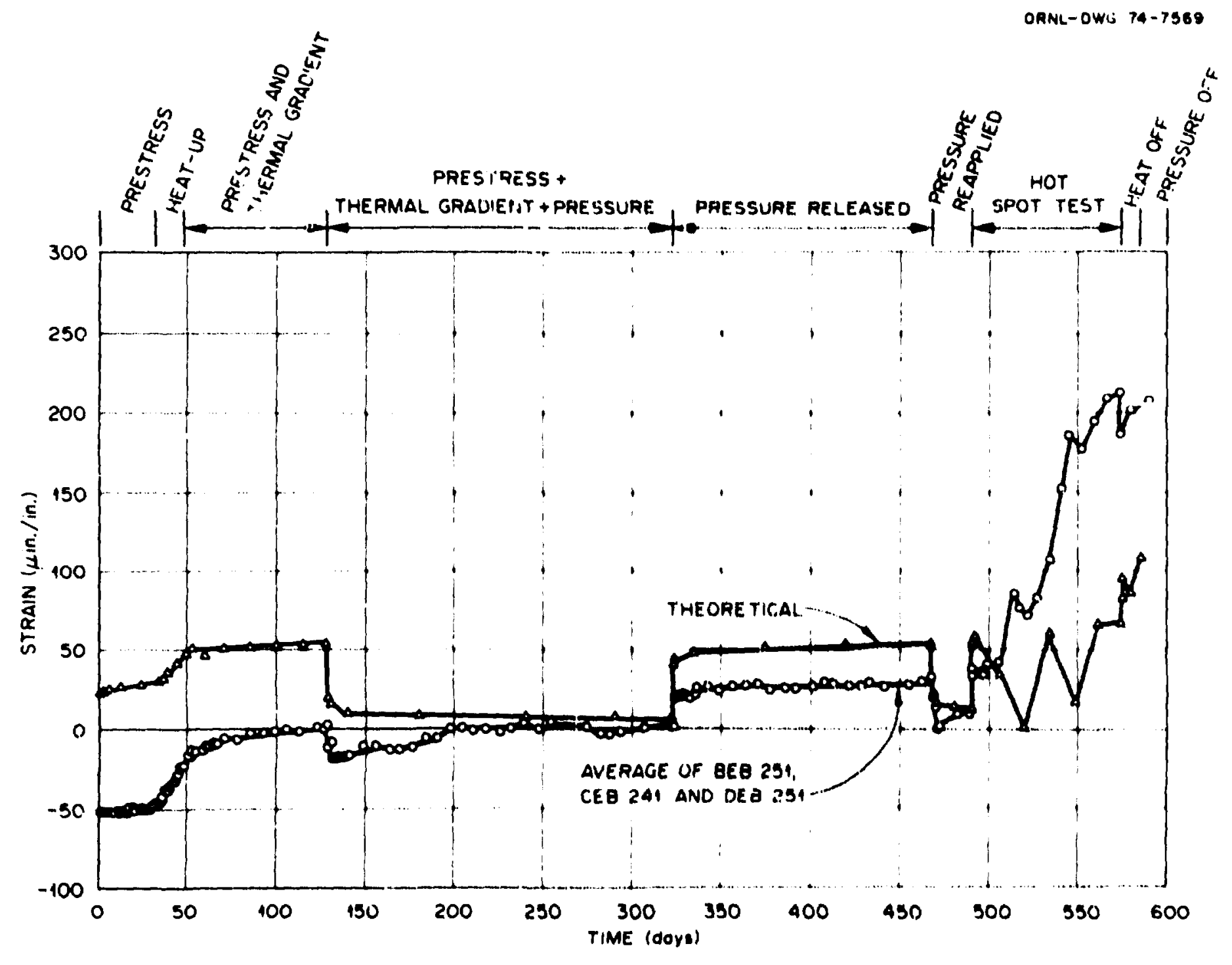

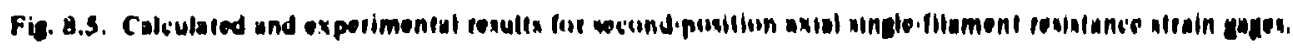




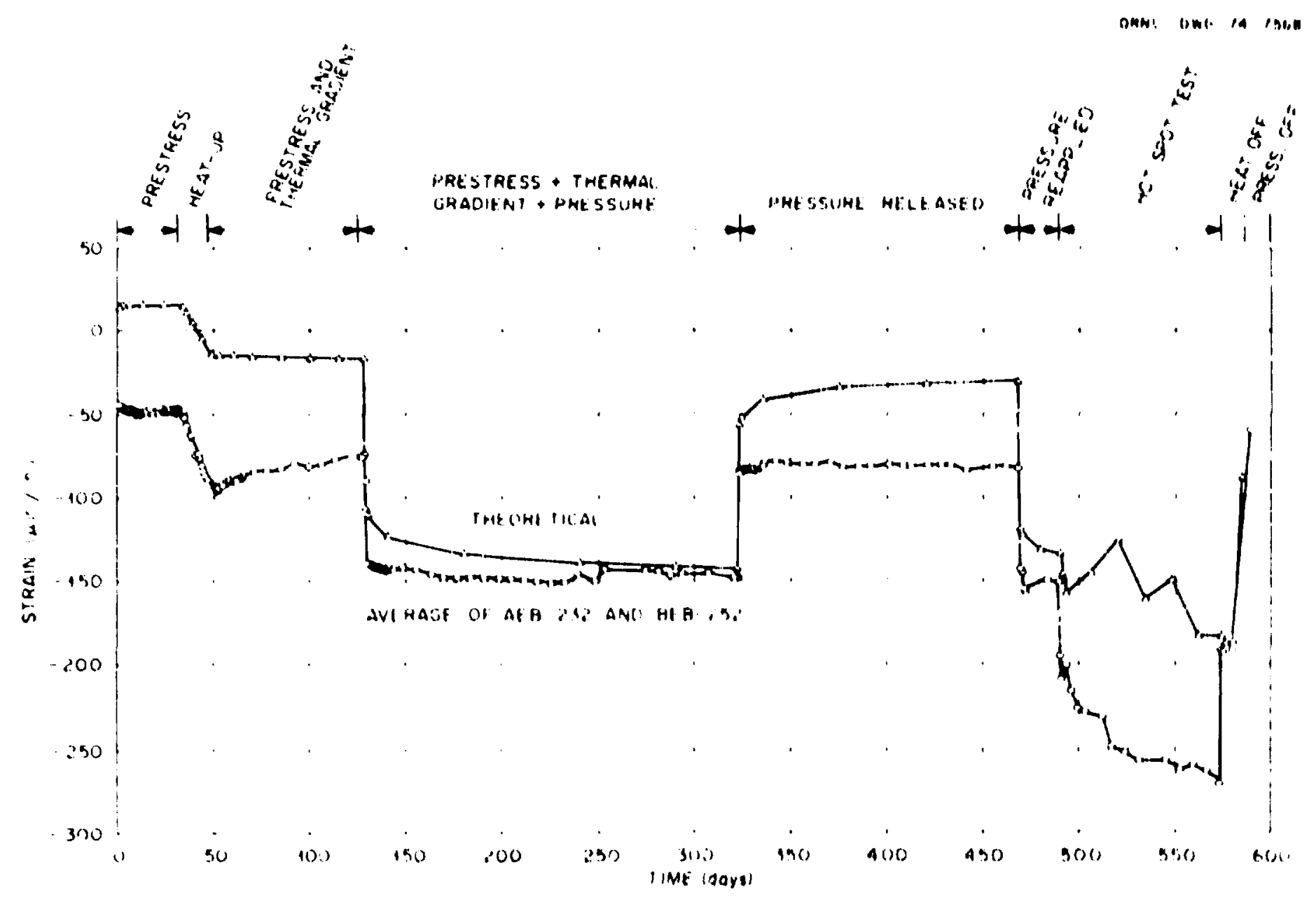

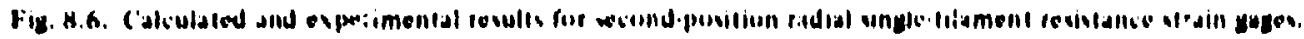




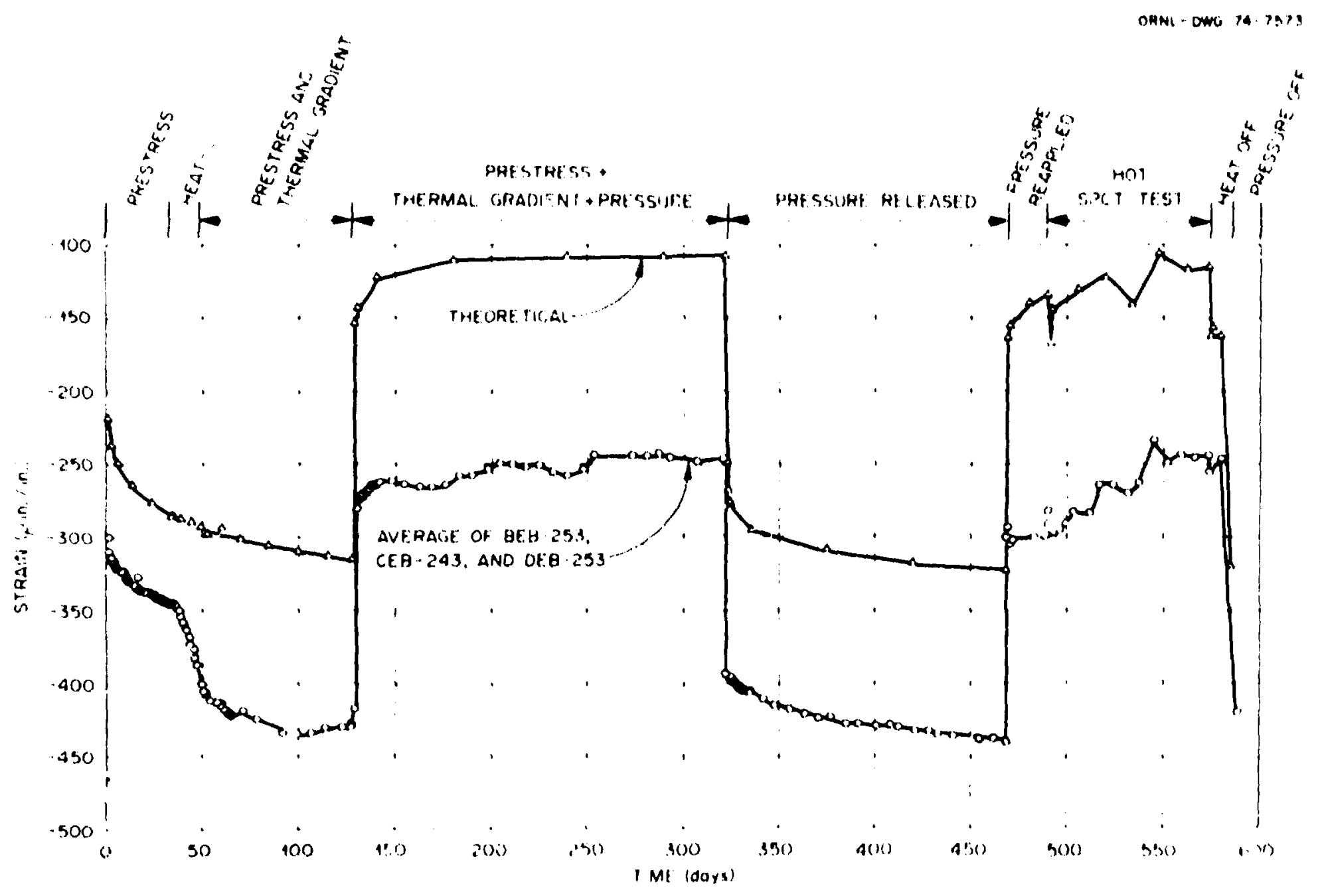

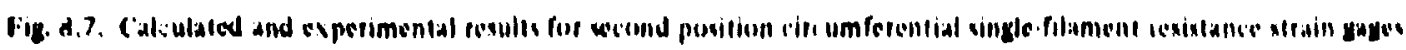




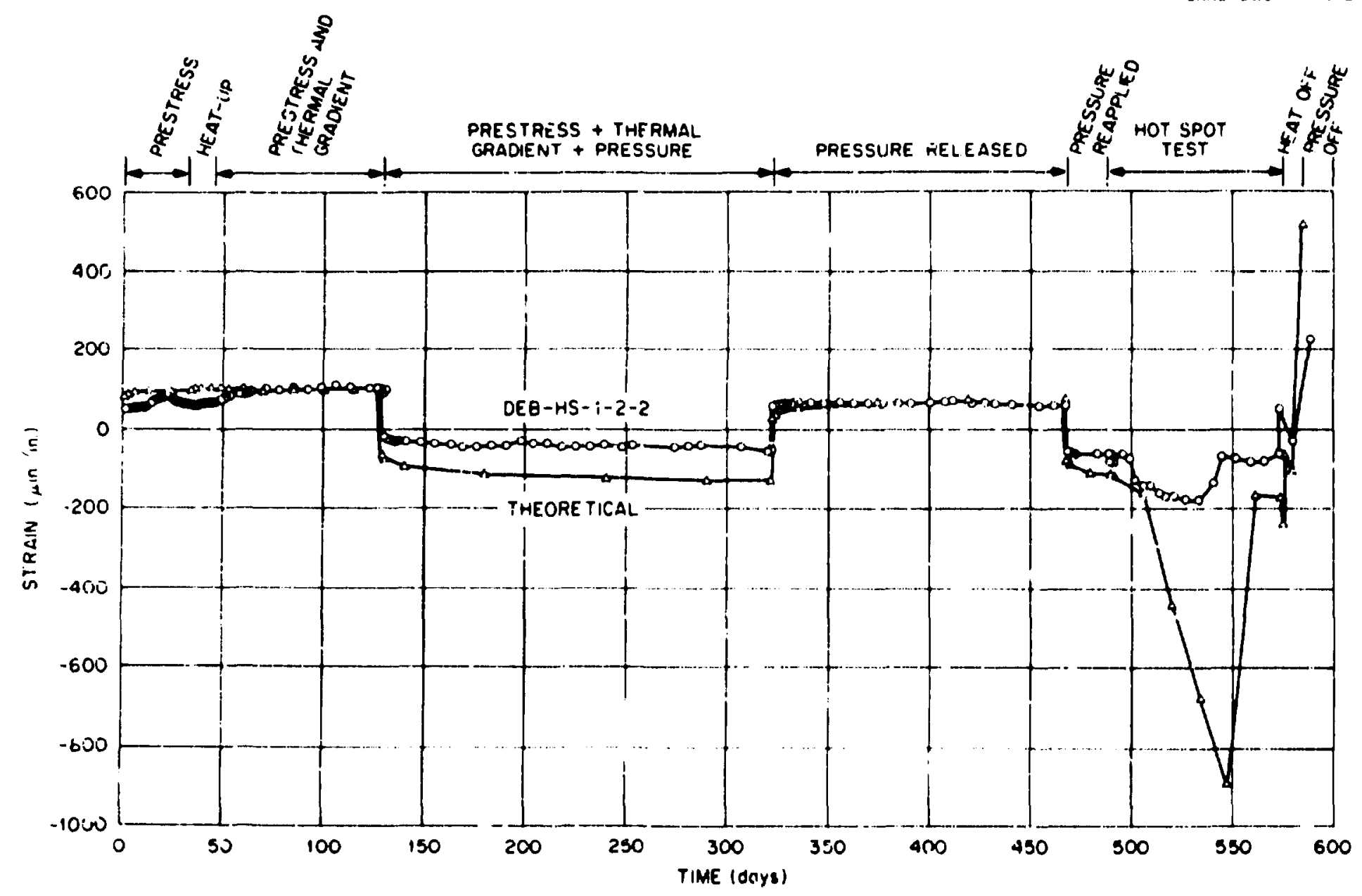

Fig. 9.8. Calculzted and experimental resultw for hot spot possitio: radial sinde lin: ineni resistance straili gaye. 


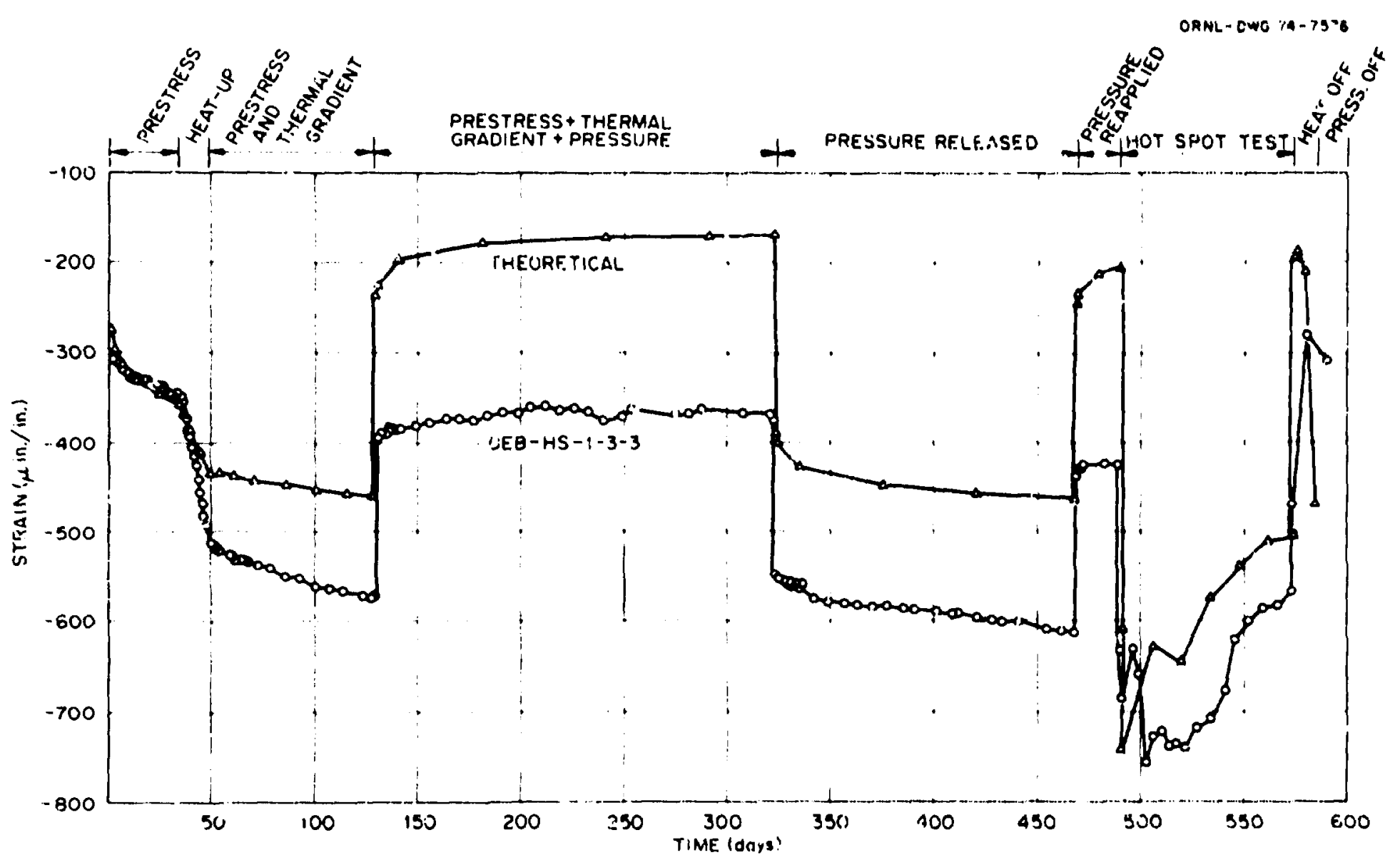

Fig. 8.9. Calculated and experimental cesults for hot-spot-porition clicumforential singlo. filament rodintance atrain gase. 
analytical curves folluwed exh other excedingly well during the hot-spot test.

Average comparisons for the type A vibrating-wire strain gages in radial pusition I (see Fig. $\$ .2)$ are stiown in Figs. \$.iO to 8.1 2 for axial. raciai. and circumterential directions respectiveiy. The same geneizi trends disiussid for the single-filament typ gaes shown in Figs. 8.3 and $x .4$ were recurded by this entirely different type of conirete embednent strain guge that was (ast dire:tly into the thermal tylinder model curcirete, ihat is. overezination by the analyses of prestressing and pressurization strain; and underestiniztion of heatup strains. Since the sibrating-wire str.in pages will function satistaivrily oniy at temperatures less than about $150^{\circ} \mathrm{F}$ the gages iziled at the beginning of the hos:-spot test. The missine data in Fig. $\$$. iO from 270 to $\mathbf{3 9 0}$ days was aused by problerns with the gage readucl equipment. Although fiv: vibrating-ire gags positions were used airuss the test section. the pasition 3 gage results. shown in Fig. 8.i3. can be cumpared from the behavioril standpoint with the single-tilament gage da:a shown in Fig. $\times .7$. with the same basic ufferer.ces betweer experianental and analyticai resul:: being seer: for both gage ty pes.

Of the nine $1 ;$ pe $\mathrm{B}$ ribrating-wire embedment strain gages used in the no del. six contin'sed to operate durin: ite experimert: however. the readings in many isses were incounsistent becaduse prohicms with the readoul equipment. The vibrating-wire gage frequericy monitor used for the study was designed spacifically for use with type $A$ zages and frequently gave inionsistent readings wher, used with type $B$ and $C$ gages.

Comparisons for two circumferential type B gages ate given in Figs. 8.14 and 8.15 for the first and second gage pusitions. Although better agreement occurred for nrestressing strains. the same basic Irends are again seen for this gage type: that is. the calculated it ain during pressure steps arc larger and heatup strujns snaller than the experimental values.

Only one of the type C vib:ating-wire sirain ga,es was included in the model. 4lthough this gage is far superior in basic design than the other two types of vibrating. wire gages, it requires precasting to insure satisfactory performance. (This was not done in this experiment.)

The wound-wire resistance emberime:st strain gages also failea to periorm satisfactoii,y, although only one Jid not ......in operational during the experiment. (Hwwever, the gages of this type incluced in the companion concrete specimens did function satisfac. torily. The unsatisfactory perf.rmance of these gages is altributed to abserice of bonding between gage and concreic. It Is felt that the present gage deficiency couid be corrected with unly inum muditiantions of the bending surfacts of the gate huusing.

Experinkental and ialculated stresses for three iricunterentially oriented tianium stress Eits are shown in Figs. 8.10 to $\times .18$ ior the first. sechnd. and tiurth poxitions oi Fig. $x .2$ repectlvely. Thise ce!ls funitioned solisideturily until atter the antial pessurization lowd. ing. (ell 25: performed spasmodkally to.,m that puint intil the pressitic was rideased. and cell i-i i-i nicilltored ar unexplainable stross drop di ito lays. This test was the first attempt to ux: a str. is ceil of this particular desugn: furth: reinenkeat will be requircd io insure reliability and long-term stability.

The presourc diaphriger. Ispe st stress cell corisssts of 14ri single-fitament embedment stian gages pusurimed in parallel in uniform sitess lexations. with one having a relatively thin sheet metal pressurc diajt:agin altikited. It: st:ess is determired by measuring Ith: appitied diaphrazn pressuce required to balasic the siraln readines of the two gages. Aithough itis tichnique appe :-d apable af measuring stresses develuped dut ing short-term luading (see following disiussion it companion spcimen tests). it wa incapable of detei mining time-dependent strejses in the thermal cyiinder inoulel. To dos this wiold quire individua diaphizgm pressure cuntrol and train gage readout sysiz'ns.

The calculated and expirimentai strains !or axial :nd circumferential weldahle strair gages are shown in figs. 8.19 and 8.20 for the concrete pressure annulus $:$ des inf the inside heat excharger (b heal exchanger) respectively. The sinc senctal cubservation made fo: the aisbedment instrumintation also applics to these gages; that is. except for the hoi-spot experiment, the strains produced by mechanical loadings were slightly uverestimated by the analysis 5. . 1 ihose produced during heatup were underestimated. The sharp luctuations in caisulated rasults noted previously for the embedment gages durng iot-sput heating were not seen on the liner, but the gratest disagreement occuired during the hot-spot part of the experiment. This was especially true in the case of the circumferestial gage.

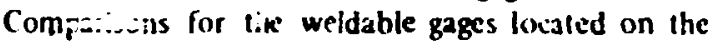
annuli: ije of the heat exchanger or liner. Fig. 8.20. show connsiderabiy greater disagreement. This trend was consistent for all lour sets of liner gages. The strains produced by healup were disiorled considerahly; however, pressurization strains were consistent with the reajings for the concrete side. A post-mortem examination of the annulus side gages, which did not have integral leads. showed that the resistance of th: gages charged during the experiment while that of t'ie gage: on the concrete side, which were equipped witl integral 


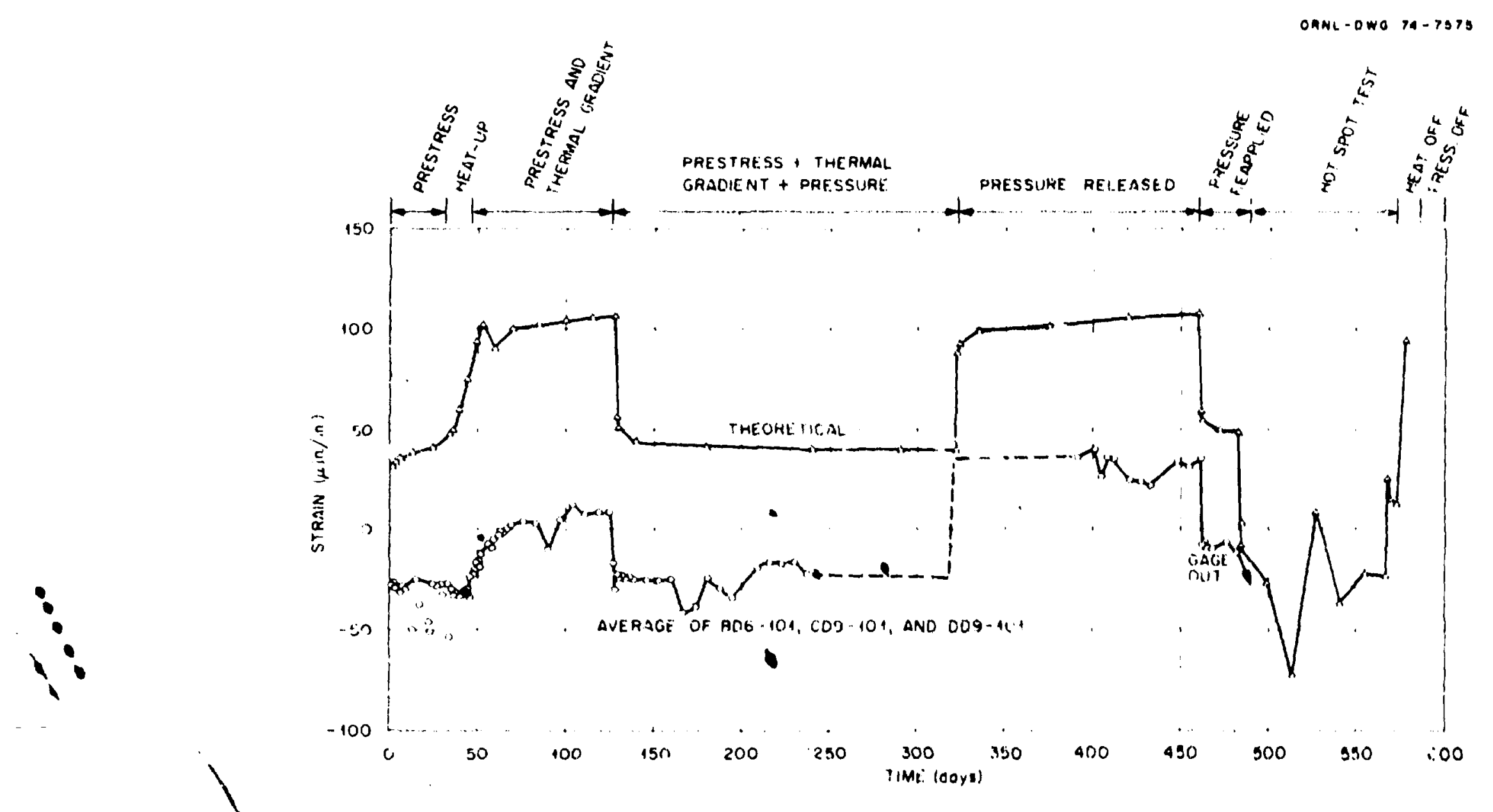

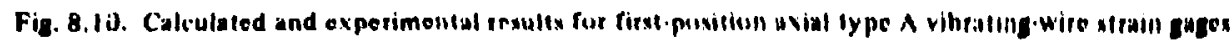

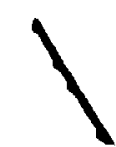




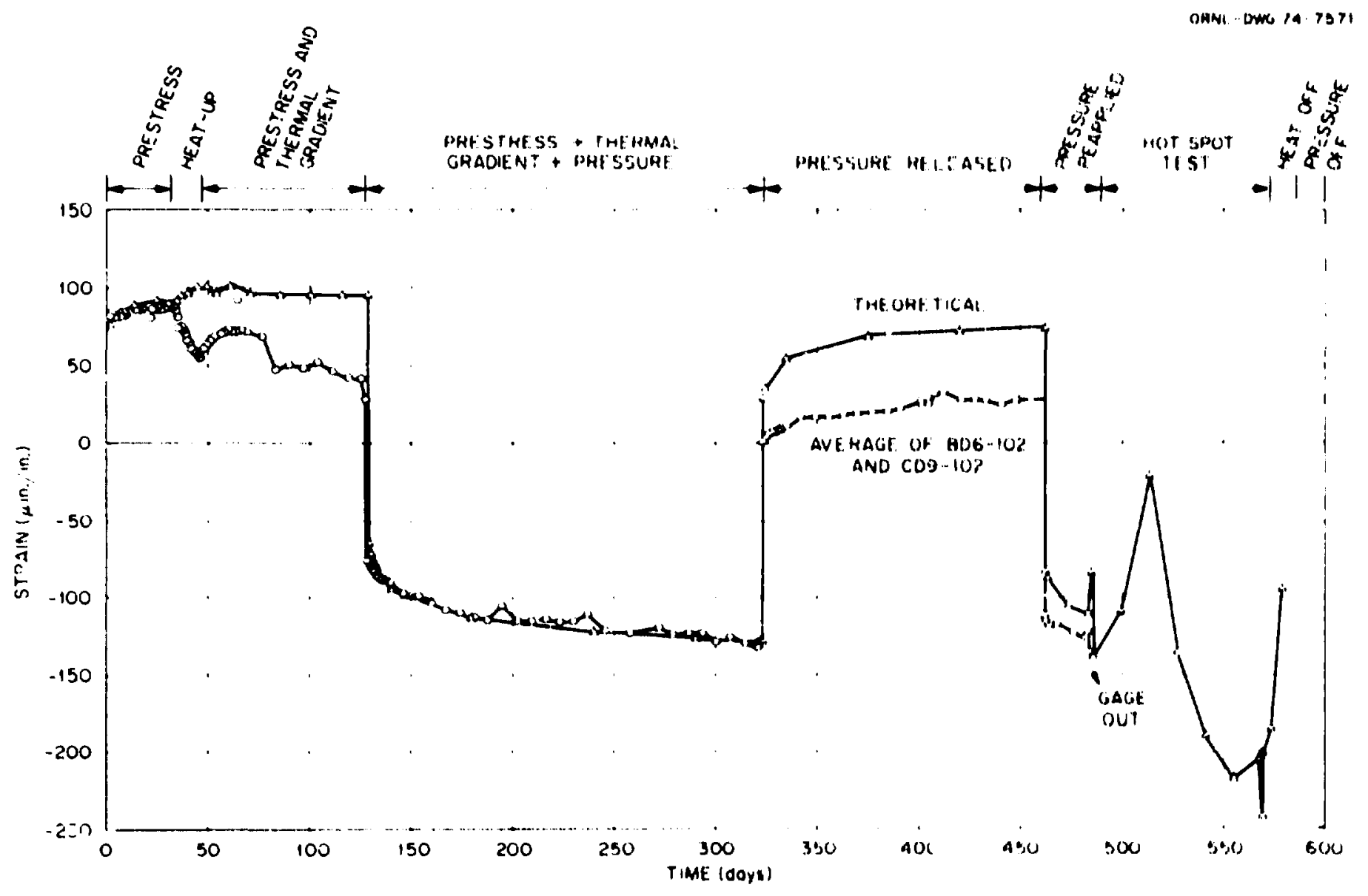

Fig. 8.11. Calculated and oxperimental rosults for first.poxition radial lypo A vibraling.wire sliain guges. 


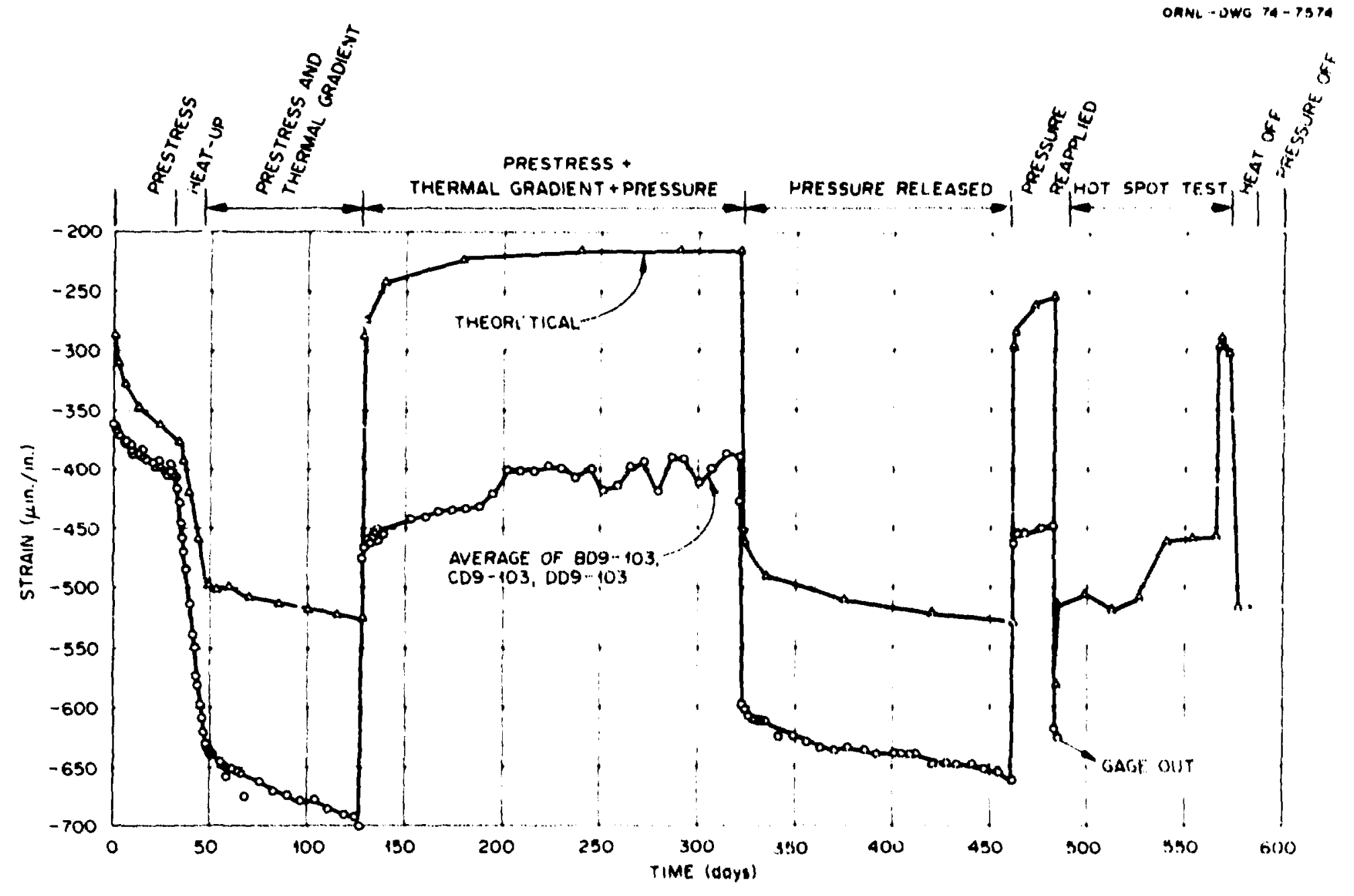

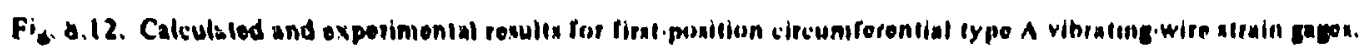




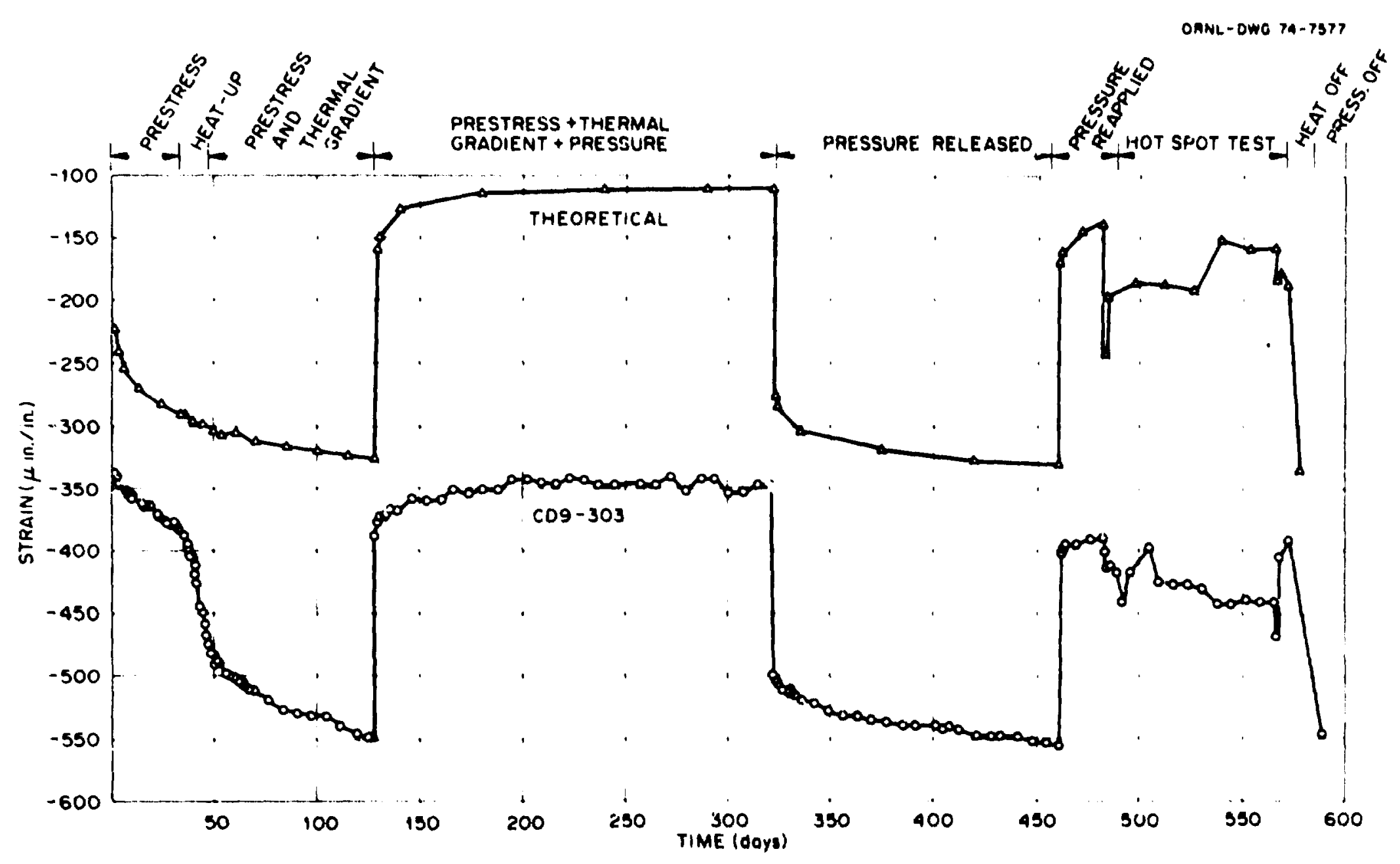

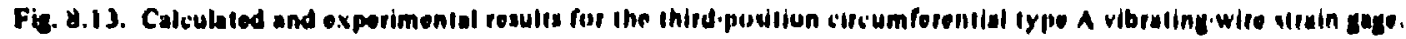




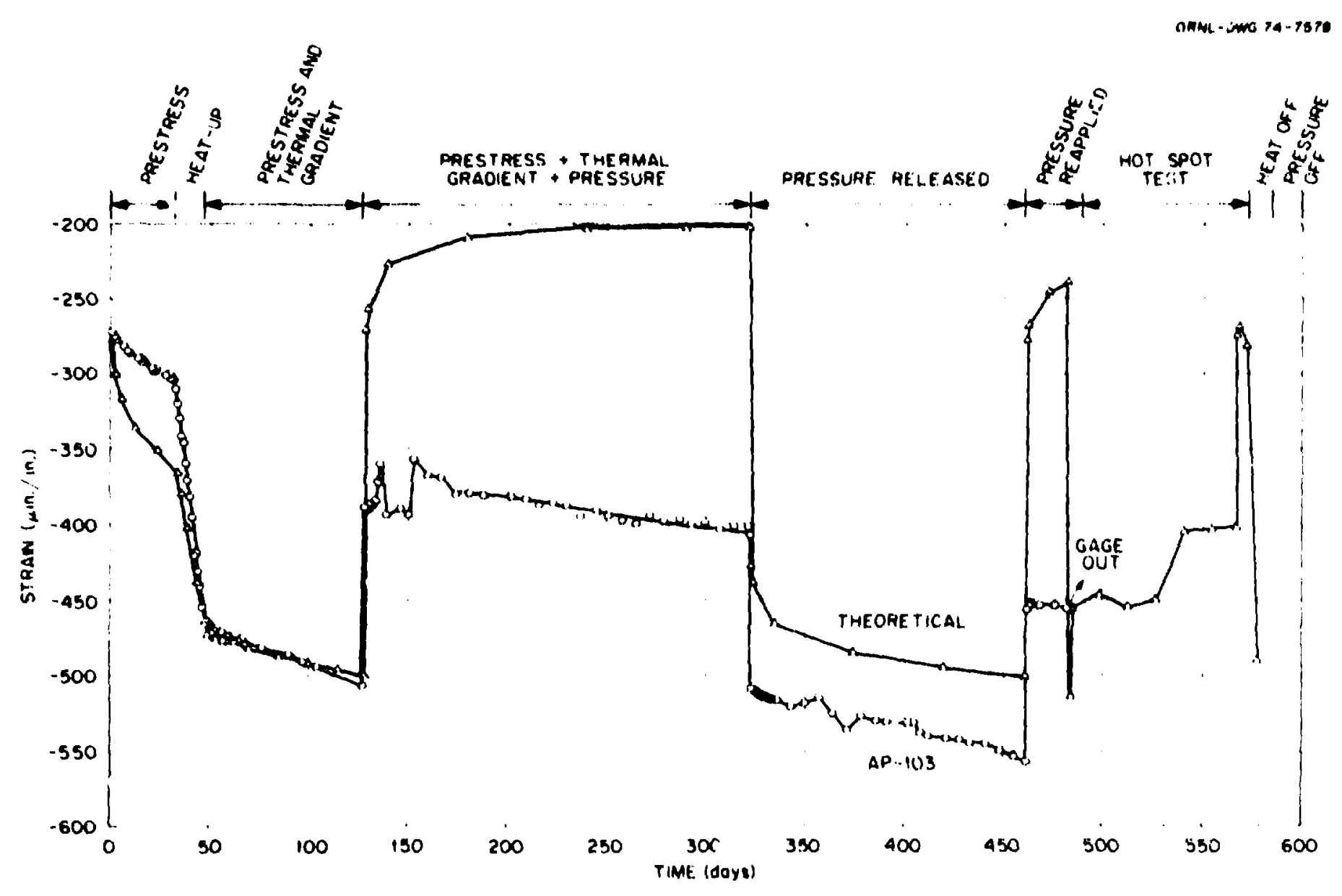

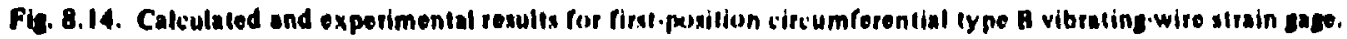




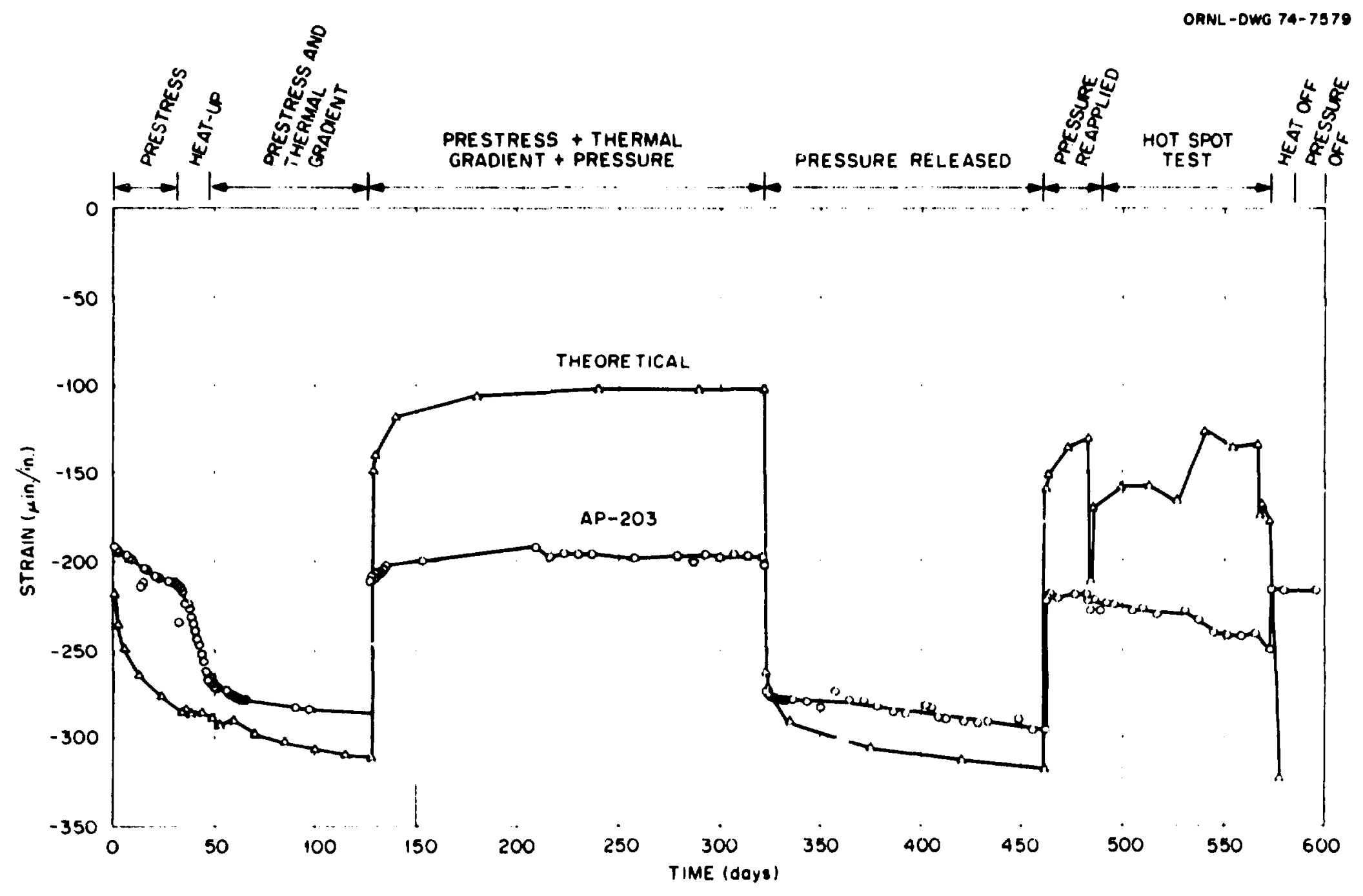

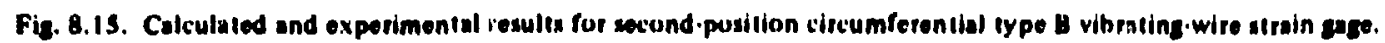




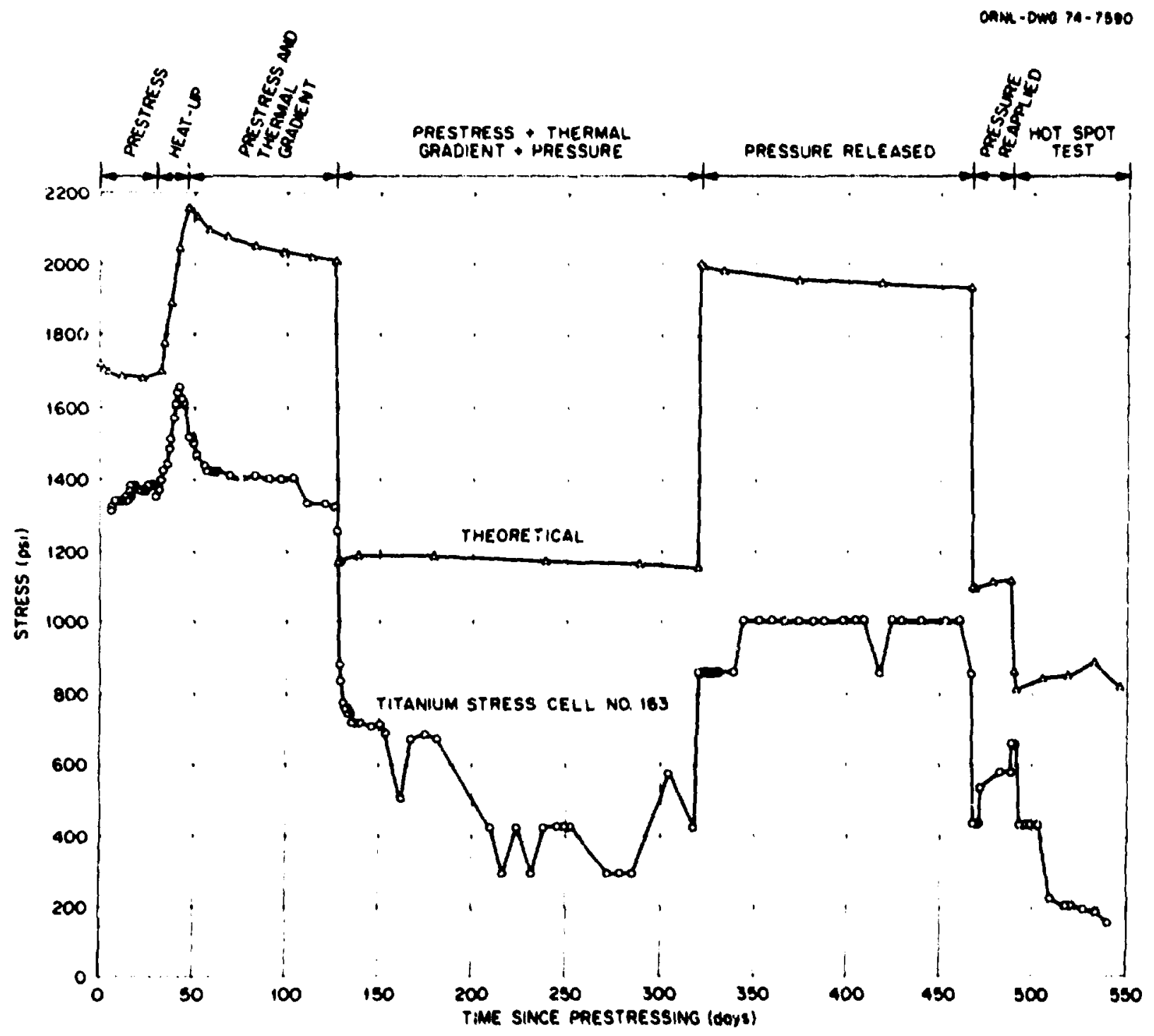

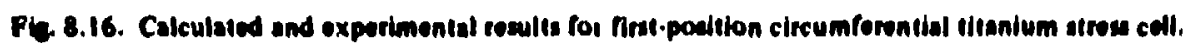




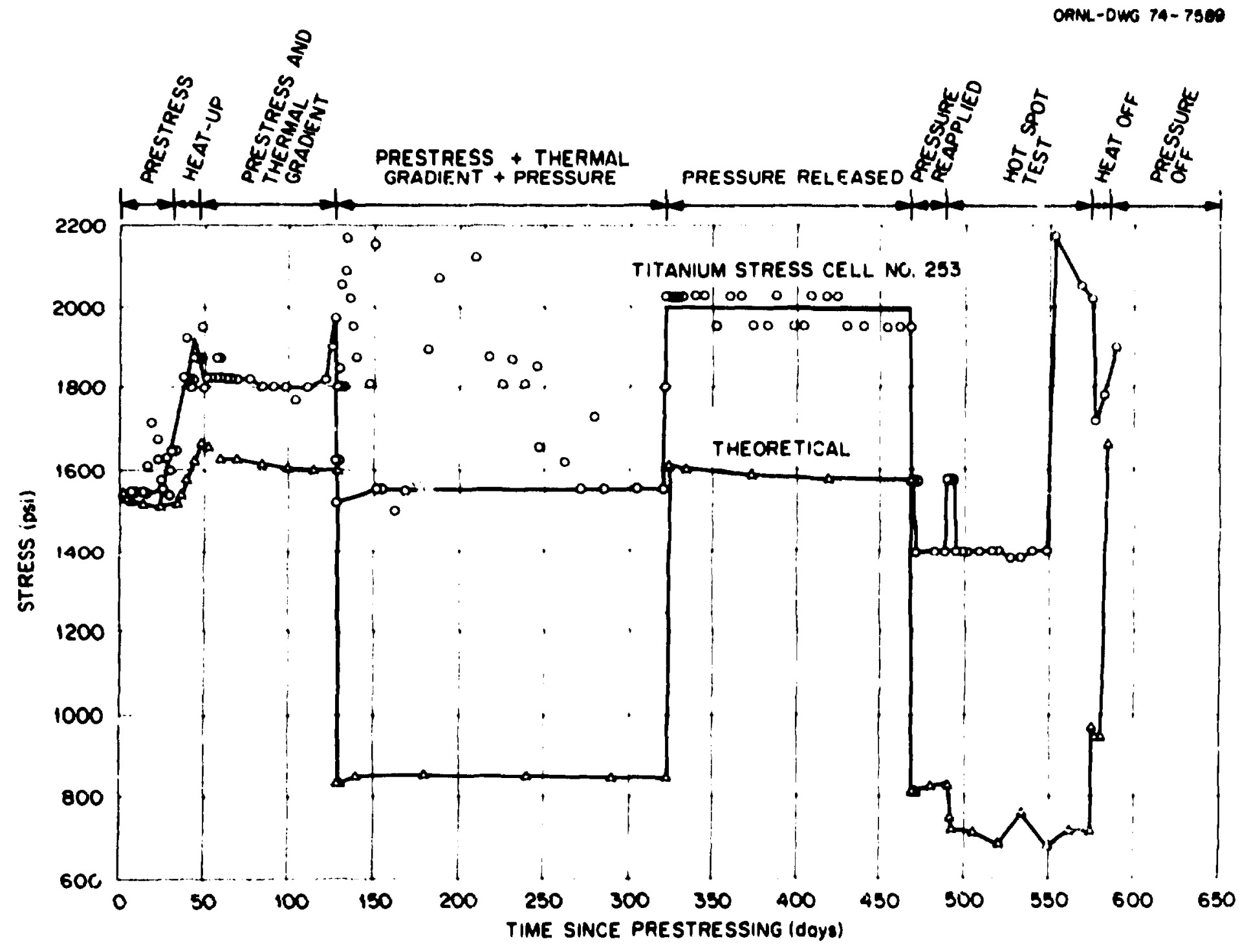

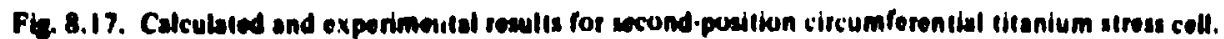




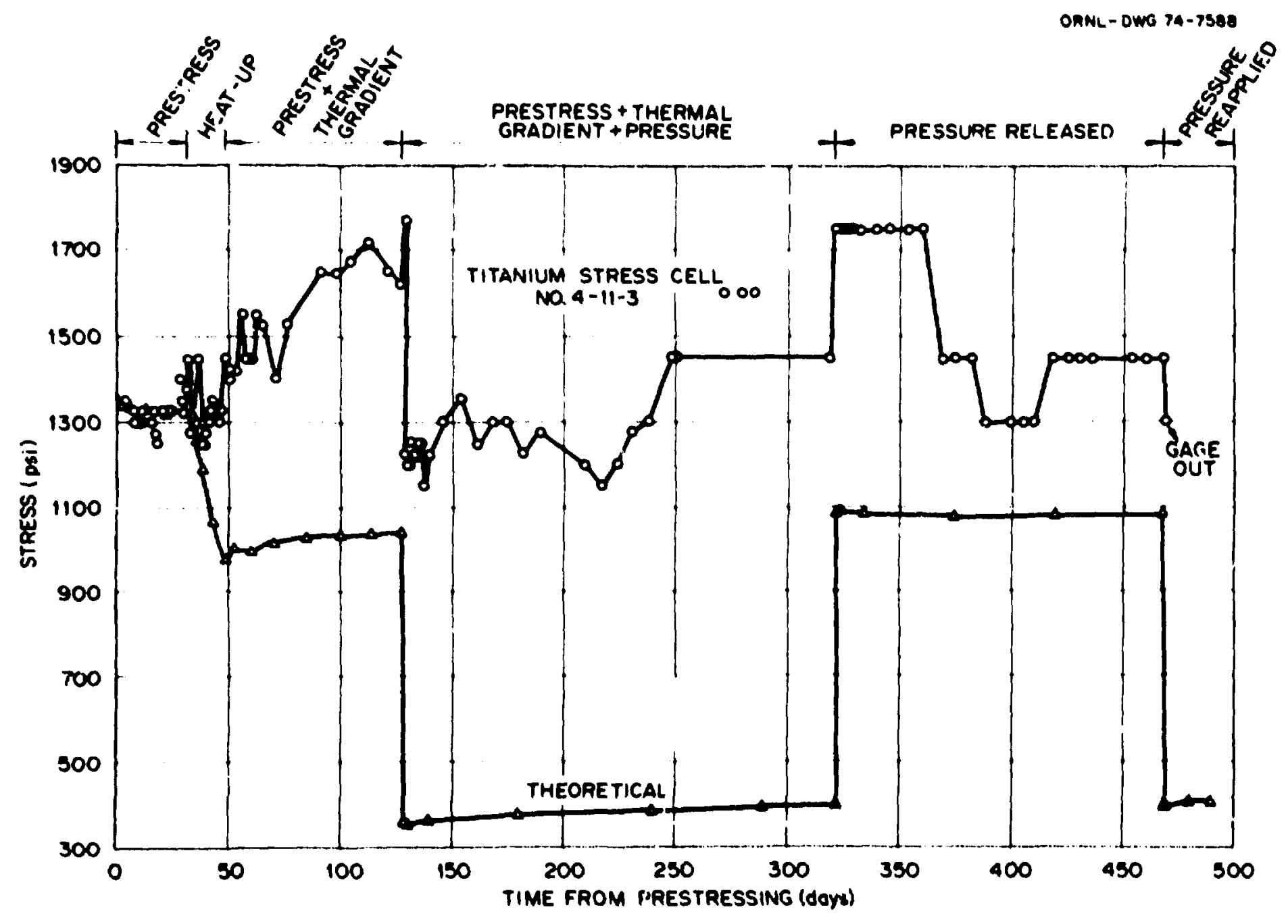

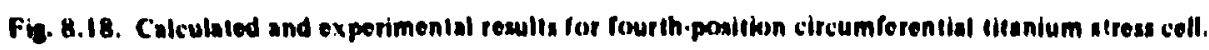




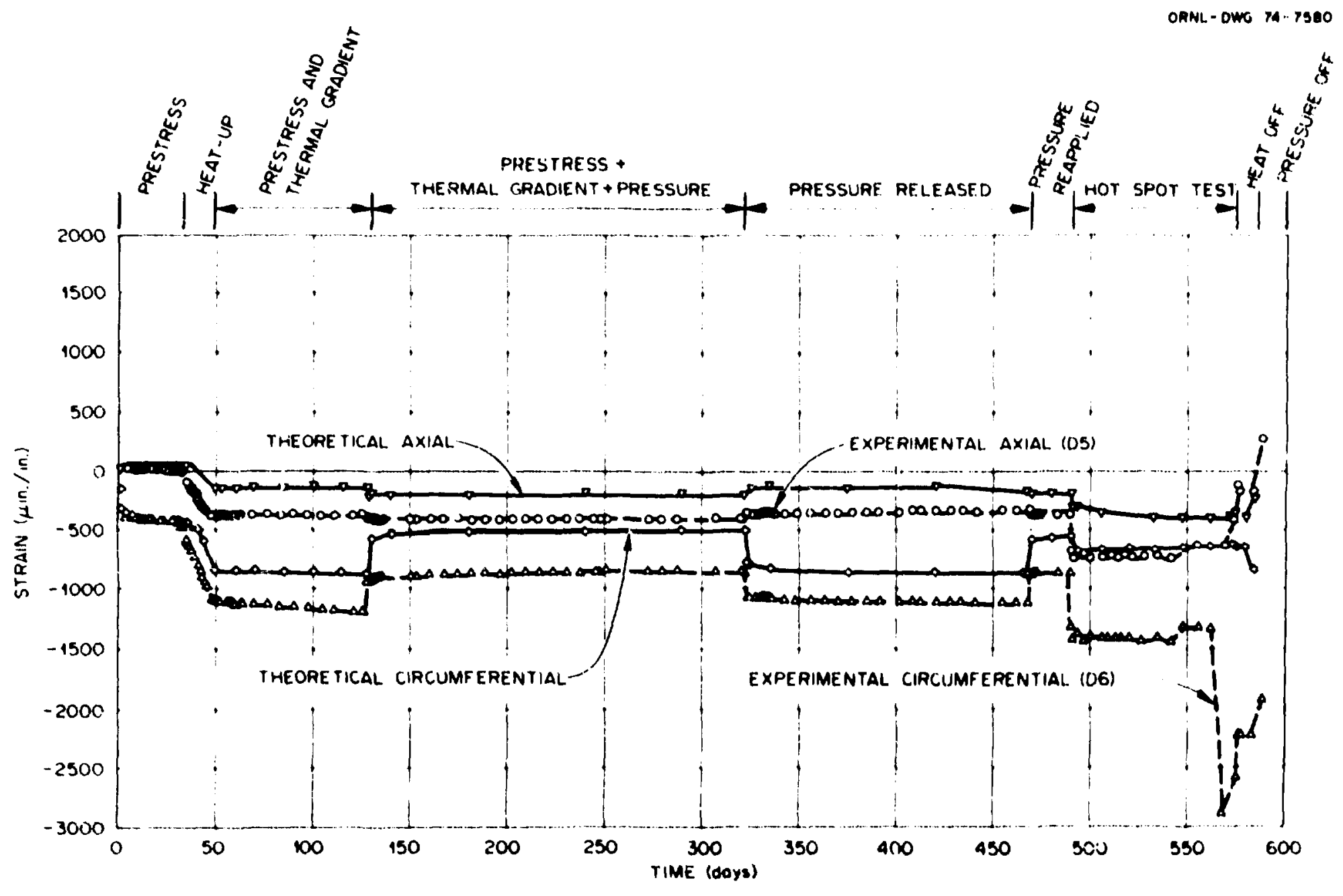

Fi9. 8.19. Calcubted and experimental results for axial and circumferential woldable slrain enes allached lo the cuncrele side of a heat exchanger. 


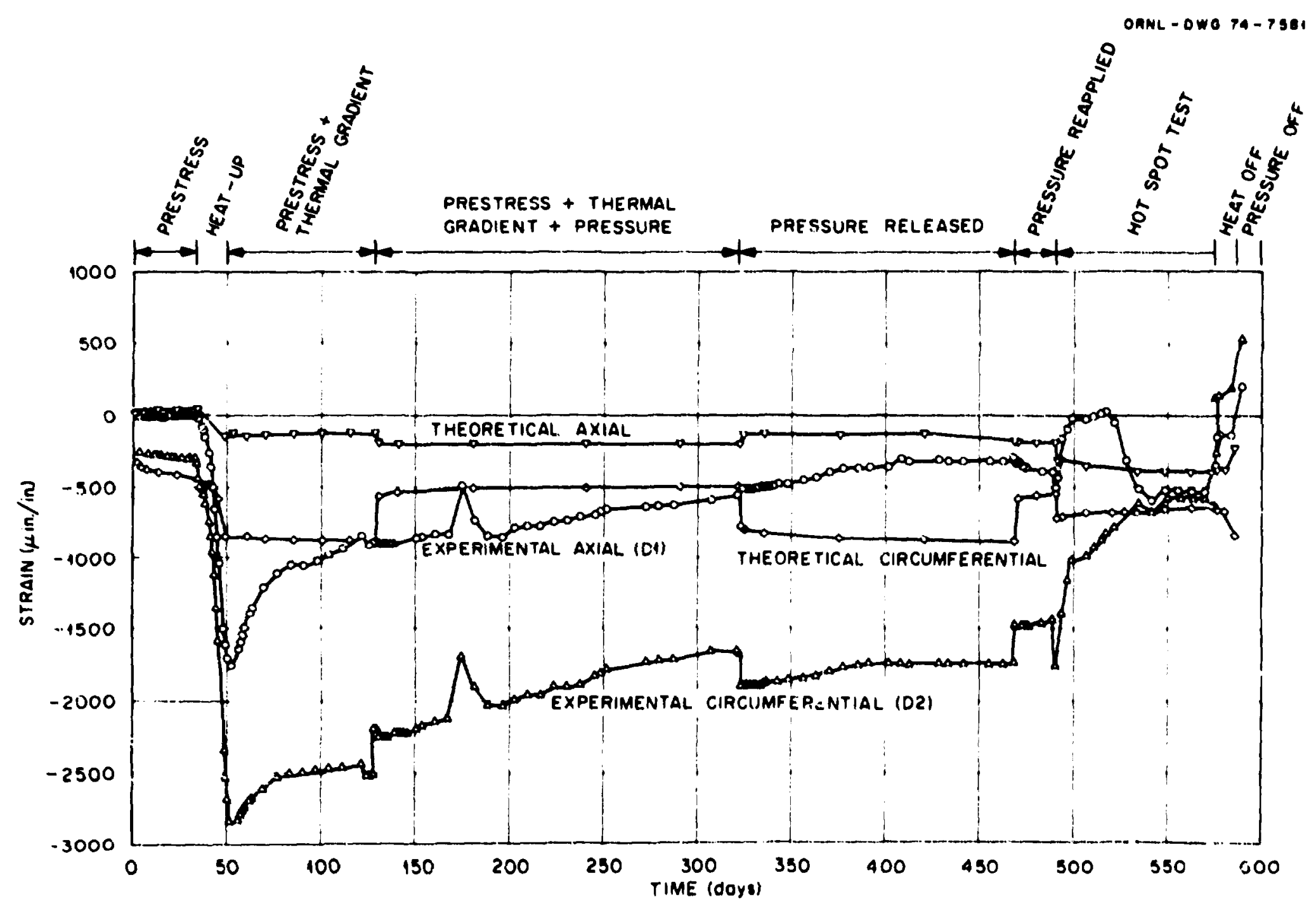

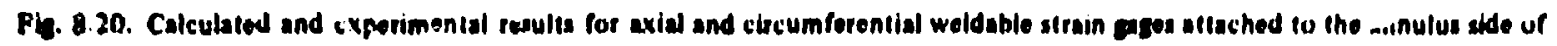
8 houl oxchanges. 
leads. remained unchanged. It was thus cur:ciuded that the Fig. 8.19 gage datu representev the bet.aviur of the heat exihanger and that stiain distortions scill in Fig. 8.20 resulted "on instrumentativn problems rather than iiner behavior.

Tik results for veldable geges alladhed at the level of the rot.spot heaters are shown in Fig. 8.21. For cuoparison. the irure shows plosts for circumlerential ganes attached to both sides of the hedt exchanger. Altbough the hot-spot heating strains were much greater than thuse in Fig. X.19. the same general trend il shuwn: however, in this ease the circumferential gat: aid not exnibit the previously noted strain jump toward the end of the hot-spo: hisating period.

Individual strands of 12 axial aid 8 circumlerentiai prestresing tenciuns hcis instrumentei with conventiunal fuil resistar:ie strain gages. and cuinpression loal ceils iere attached in series with th: axial rendons. Results for threc axi. 1 tendon strain gages are shown in Fig. 8.22. The inner row lenduii suffered a bonding failure pritr to prestressing and inust therefure be disiounted. Th: two vuler row tenden gages pusitioned as shoun.., in the small inset of rig. 8.22 indicated stable corditions until initiation of the bot experiment. At that ime, yage CíB-2 shuwed a gradı:د sirain decrease followed by a discrei: jurnp. The load-vs-time plot o! axial terdon load cell CTR.? is slown in Fig. 8.23. This transducer, which was altached to the CCB-2 instrumented tendon. indicated a stable loading during the hot-spoi heating period. It is therefive duubiful that the strain gage recorded a real tendon behaviur. On the uther hand. load transducers CTR-I and CTR-3. whicil were coupled to inner row tendons. measured periodic step-load diops during the experiment. Recent pust-mortem studics gave stron! eviderice that the load changes were produced tis progressivs sorrosion railure of inner row terdons. The corrosion pron':-7 is discussed in Section 8.1.4.

Strain gage vata for two circumfierent:al tendons are shown in Fig. 8.24. In contrast to lic axial iendons, these tendins were located outside the concrete test section and constrained as shown in Fig. $X 1$. Based on the :trair gage data, the circumferential tendon; appar-nily performed satisfactoily

Companion specimen tests. Two ls. hy 4 (tin. conerete cylinders were instrumented with every type of embedment stress and strain incasuring device sillployed in the thermal cylinder in order :o provide a be:ler understunding of hasic gage hehavior. These companion test aylinders were cast. scaled. an! hea'ed. and one was ioaded uniaxial!y in accordance witl; the idrge-model ti.ne s:hedule. Both cylinuers were main- tained a 150 F tempera!ure daring the thike-dependent portion $0^{\circ}$ iik study. Cylinder $11-1$ was sthjicted to a itho-pst aniaxial lowding 50 day from the limk ot th-rmal eylinder model prestressing. and iylinder $\mathbf{~ 1 - 2}$ retiailued anstressed during the model lesting periud. The unabridged strain hislory of the ampanion speci. men siligle-filankent resistanic stisin gayes is shown in Fig. 8.25. The axial gages in buth iyinders experienced excessive drift quite early in the experiment. and the unstresied M-Z eylinder Iateral gage began drifting severel at +20 days. On the uther hand. the stressed M-i specinien lateral gage performed cunsistently for the diration of the experiment. The excessive namber of gage failures was probaily isused by the relatively high temperature seen by thrse gages.

In :dótion to the sustained :-ating peried, the M-I specinien wa loaded and un'uaded in steps buth at 75 and $150^{\circ} \mathrm{F}$ : the M-2 specimen was alsu short-tine load tested at $75^{\circ} \mathrm{F}$ to prowide additional page data. Typical st.ess-vs-strain plat- tor these short ferm tests art shown in Figs. $X .26$ and 8.27 for axial single-fitament resistance gage MI-SEB-ill and type B vibrating-wire gaye M2-P-101 respectively. The cuncrete properties oh. tained for ti:c operating gages vi each type are shown in Tr.ble X.2, where the iña values are verage 140-day strength test results for moist-cured or tiy $12-\mathrm{i}^{2}$. iylinders. Since the much larger companion speciniens were sealed to prevent muisture loss and were at least I80 days of Jye. the 180-day compressive strength test data were used as the hasis for comnarison of gage pe-formance. The $150^{\circ} \mathrm{F}$ dats wer: oblained after apfroximaleiy 550 days of heating consequeat!y. The modulus of elasticity whuld be slightly higher ihan the 180-day vaiue. Alt the gages could not be evaluated heciause of premature iailure of sume oi $t_{i} \wedge$ companion specimen gages: however, based on the aviliable data. certain conviusions can be made.

The single-fiament resisiance and type B vibratingwire enibedment gages gave the must aciurate readings. The wound-wire resistance gagas alsr: perfomed satisfactorily at both iomperature; w!lich was surprising since the therr.al sylinder model gagis of this type were unsulisfaclury. The type $\mathrm{C}$ vihrating-wire gage gave reasonable cesults ot room temperatise. hut the $150^{\circ} \mathrm{F}$ readings were significantly low.

The surface resistance gage; listed in Tahle 8.2 were ex,erimental gages develuped as part o" the OKNL biaxial ireep test apparatus. 5 Three gages were allached to pairs of small steel pusts protruding from the surface

5. R. I: Denkins. CKR Proktain Scminnnu. Mokr. Rrn. Ma: .1J. /9KУ. ORNL.4424. pp. 12738. 


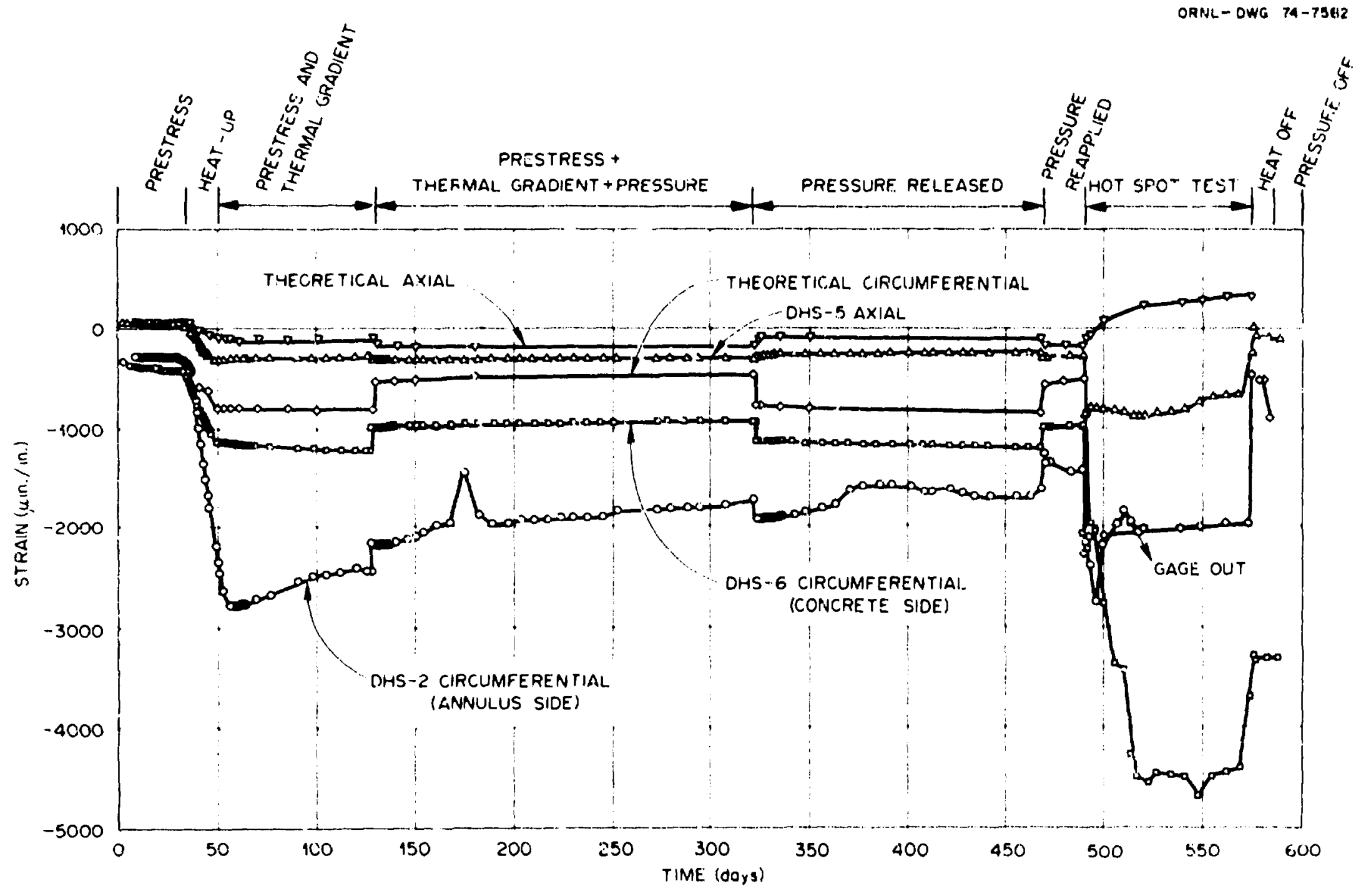

Fig. 8.21. Calculated and experirrental results for axial and circumferential weldable struin gugex altached to cuncrete side and for circumferential gase allached to annulus side of b heal exchanger. 


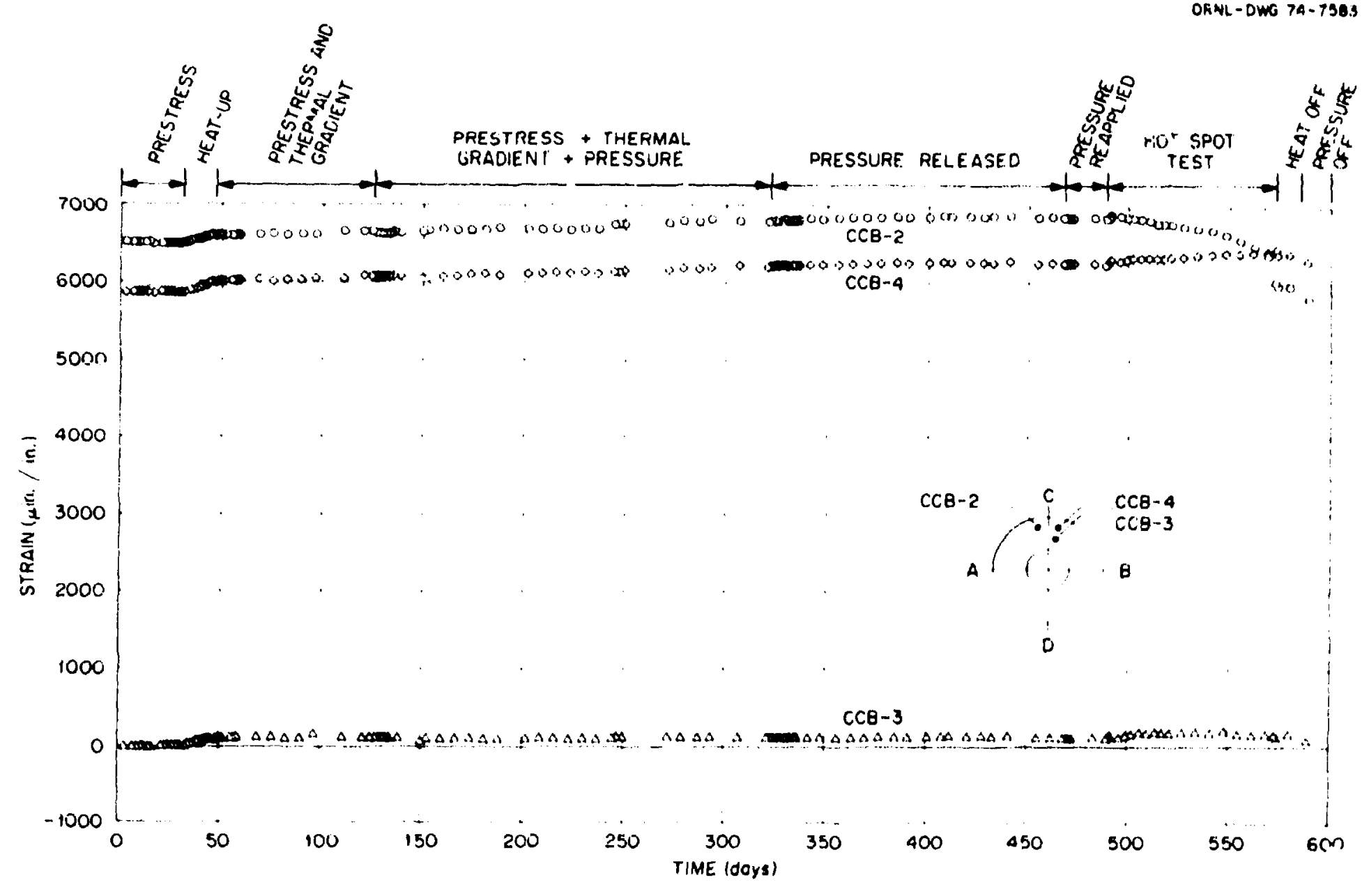

Fig. 8.22. Experimenral results for foil.tyme strain gugeu altached to axial prostressiug lenduna. 


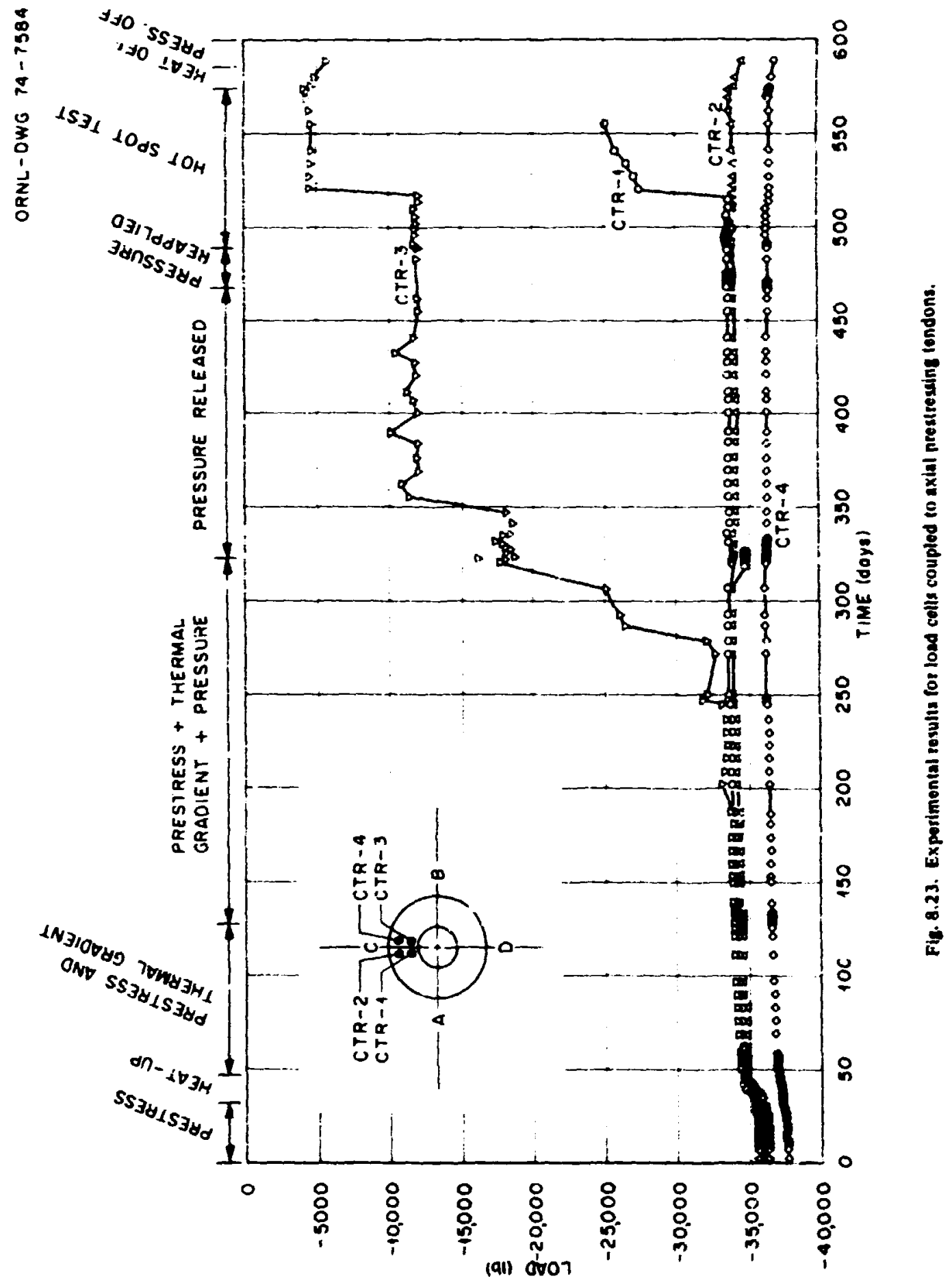




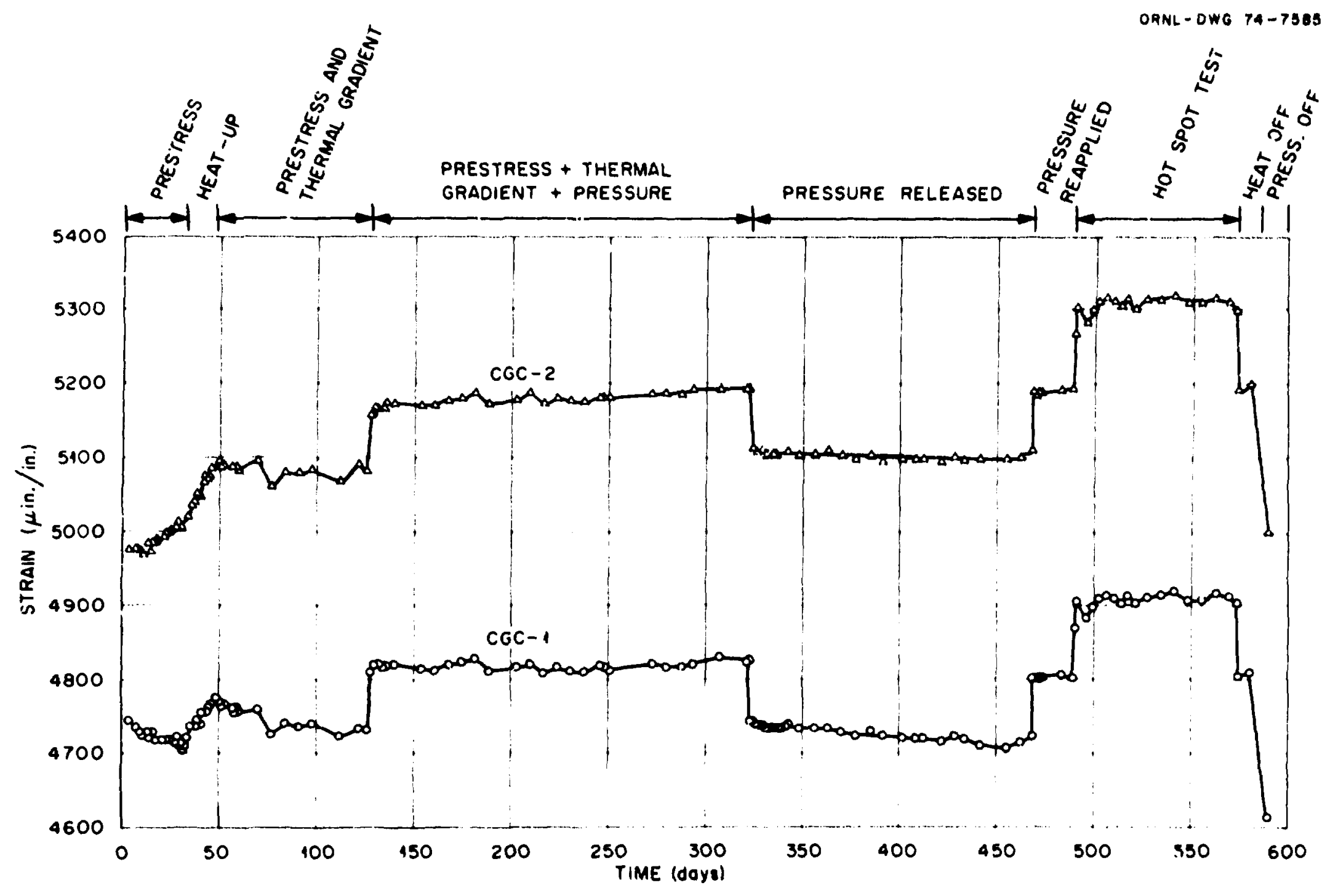

Fin. 8.24. Experimental resulls for foillyype strain gages ullached to circumforential prealrosuing tendonx. 


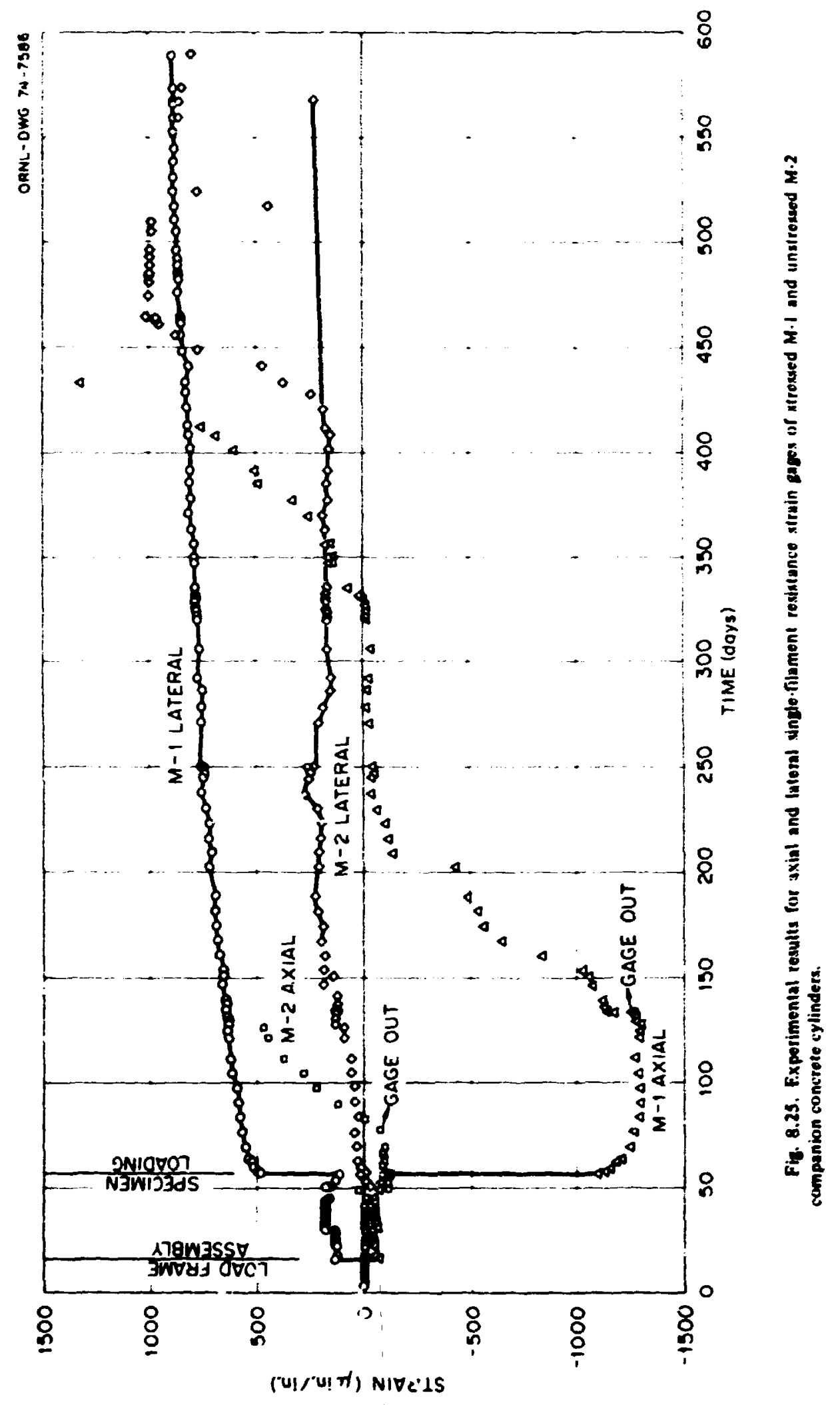




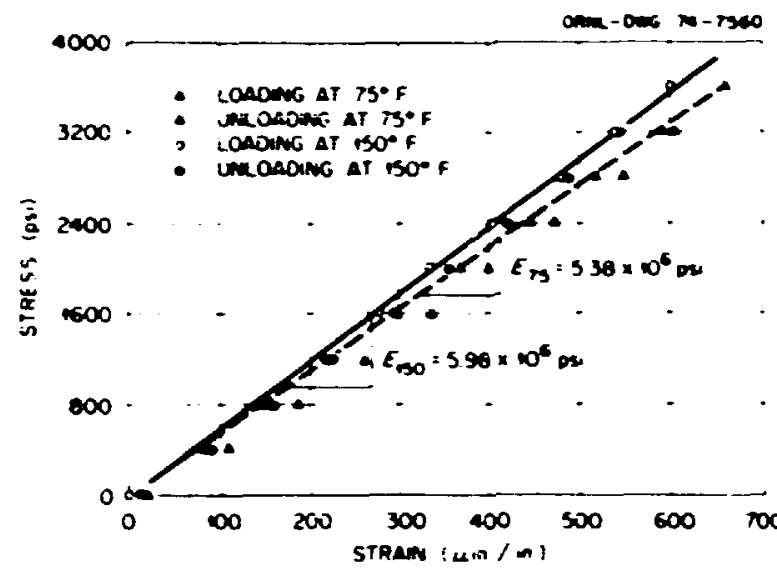

Fo 8.26. Short-time $Y-1$ specinen losd test results for axid

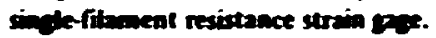

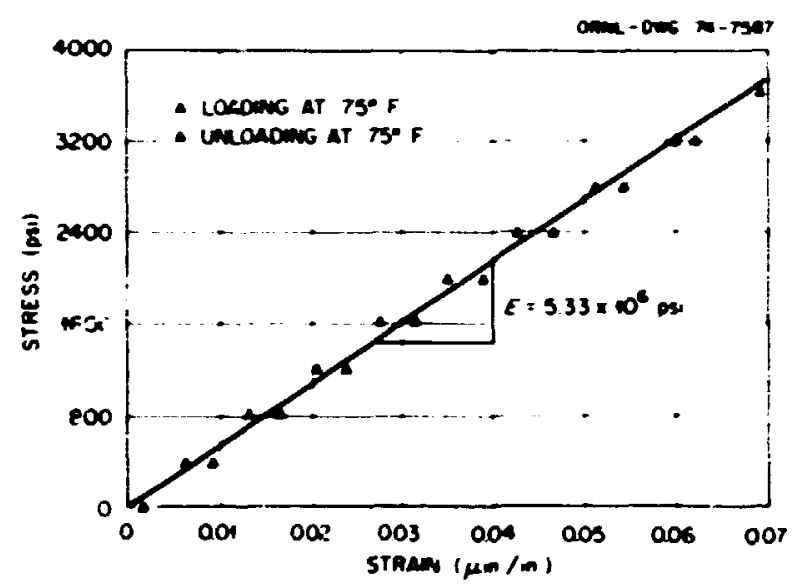

Fiz 2.27. Short-time M.2 specionen lond lest results for axial ype $B$ vikrating wire strain gre.

of each cylinder at equal angular spacing. Although these gages were not operational during the room. temperature test, they performed satisfactorily at $150^{\circ} \mathrm{F}$.

The results of the uniaxial compression testing of the litanium stress cell are shown in Fig. 8.28. In addition to the cumpanion specimen tests of the cinbedded gages. each stress cell was load calibrated under uniaxial compression. The results indicated that the embedded stress cell reading must be muli:plied by 1.19 to obtain the actual stress in the concrete.

We also atlempted to monitor the embedded pressure type stress cells during the companion specimen tests
Table 8.2 Companion specianen cumpresciun test resilts

\begin{tabular}{|c|c|c|c|}
\hline \multirow[t]{2}{*}{ lage II } & \multicolumn{2}{|c|}{$\begin{array}{l}\text { Mudulus ol } \\
\text { clasikil! } \\
\text { (poi) }\end{array}$} & \multirow[t]{2}{*}{$\begin{array}{l}\text { Puswen } \\
\text { (dIm) }\end{array}$} \\
\hline & 751 & 1501 & \\
\hline & $\times 10^{\circ}$ & $.10^{\circ}$ & \\
\hline Single filament tesistance & 5.38 & 5.98 & \\
\hline Type B vibratune wire & 5.33 & & $0 \geq 8$ \\
\hline Type C vibratung wue & 4.67 & 4.74 & \\
\hline Hound wire resistance & $\$ .90$ & 6.41 & u.jI \\
\hline Suriace resistance & & 5.80 & \\
\hline Concrelc strength teslst & $5 .+0$ & & $0 \geq 0$ \\
\hline
\end{tabular}

but. owing to a need for additional and more sephollaled instrumentation. wete able to obtain only the folluwing three readings:

$\begin{array}{ccc}\text { Acted stres } & \text { Stres cell presure } & \begin{array}{c}\text { Aercent } \\ \text { (pis) }\end{array} \\ 402 & 700 & 74 \\ 795 & 1500 & 89 \\ 3666 & 4200 & 15\end{array}$

This device was able to determine the maximum specimen stress to within $15^{\text {r }}$ but was unable io measure the lowei stress fevels to : reasonabie acuiasy.

Although both of the types of strexs-nxeasurement devices used in this experiment offer some promise. considerable work will be required to develup a satisfactory embedment stress cell that is capable of monituring lime-dependent stresses in prestressed cuncrete structures.

\subsubsection{Disanembly of the Thermal Cylinder Modet}

The thermal cylinder model detensioning was completed on May 30. 1973. which was 771 days from the time of the original tensioning of the prestressing system. The circumferential tendons were completely detensiuned first; then the axjal tendons were deten. sioned in unc step in sets of 13 in a quadrant at a lime using a rrerse of the original loading sequence. One significan system failure was revealad during the detensior :ng operation. The axial tendons shown in Fig. 8.29 were equally divided into an inner and an outer row of the moxici test section. Hydraulic pult rans were coupled to the tendons. and the loading was rasied i.. 45,000 to $47,000 \mathrm{lb}$ to lift off the restraining nut which was then loosened. The first inner row tendon was 


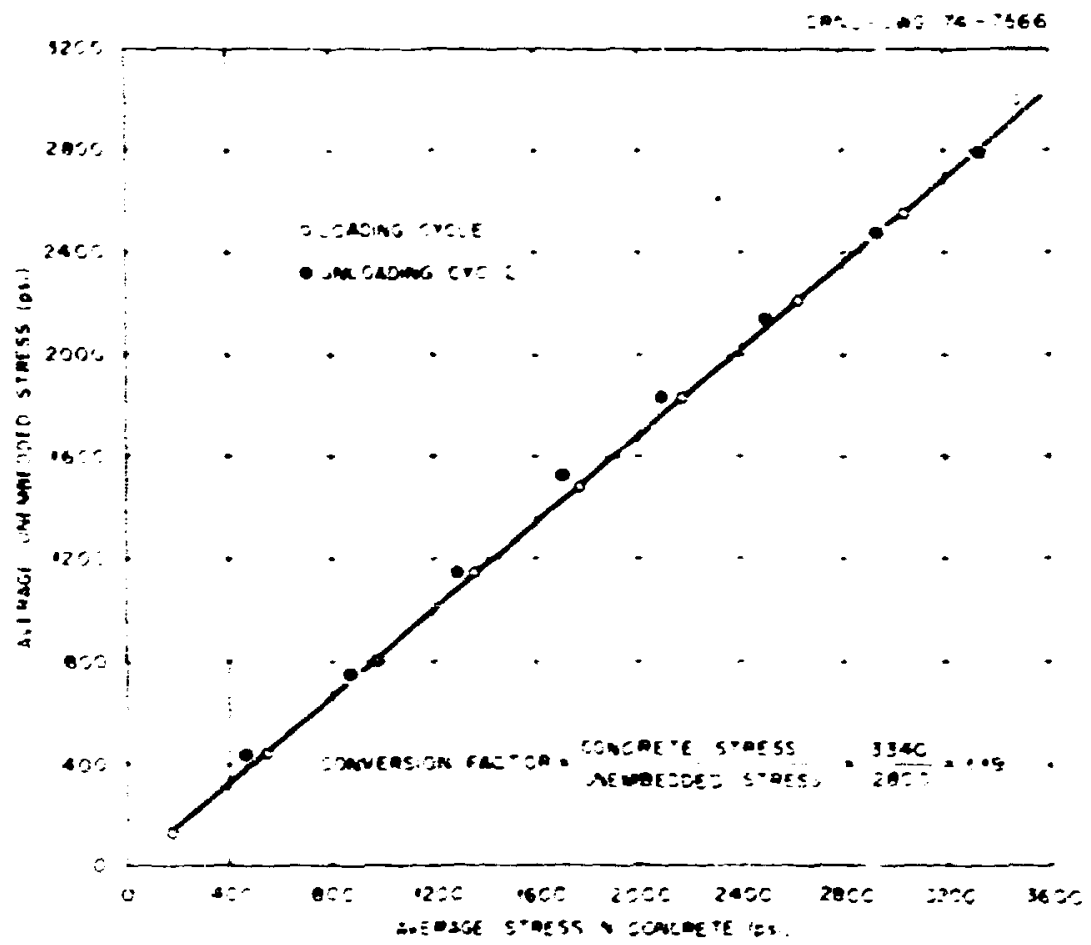

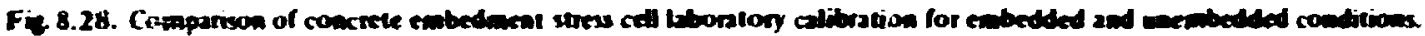

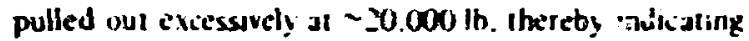
falure. All the ovter lendons required al kas: a pressure of $45.000 \mathrm{lb}$ to lousen the restraining nut. white all but two of the inner row tendens required onjy a low ram pressure tu unseat the nut.

lipun completion of the detensioning uperatiun, ume of the lisiled lendons was remored. It appeared wo have iailed nest the hollow ditchur. and as indicated by the darkened appearanic of wome of the fiature surtizes. the wires had evidenily fiuled prior to detensioning. The investigation of the meatunism of these tendon failutes is disiussed in Section X.1.4.

Afice the cifcumferential prestressing assenblics weri removed, the modei was stripped and the inner conctete core (shown in Fig. 8.1) removed. A visual cxamination of the liner did not reveal any huikling. craking. of othe; probicms. Portions of the steel liners wire removed at the six locialions desigated as cut sections in Fig. 8.30. and the expused porticins of the axial tendun assemblies were capped and sealed as shown in Fig. 8.31 '11 prevent contaminalion during sectioning of the concrete. The model outer ring was transported to a commercial marble company for sectioning. The ring was first cul in half using a water-cooled Inonchlorinated well water d damund wire saw: additicnal sa-ronung was dunc using a diamond sircutar suw. The portion of the test section iabeled is "musture blowh" in fy. $\$ .30$ was further sectioned as shown in Fig $\times .32$ to provide $a$ ! $\times 1 \times 1$ it moisture test cube intanne a stankess slecl muislute prote aicess tube at the center. The use of this lest athe in alibrating tik rijsture probe is Lexiribed in Section X.1.5.

Visual inspectituit of the exposid cross sation: revealed no siguinant defects or st. uitural iraiks in the concrete. The slices made a: it: inctrumentation section showed that a good bind existed berween the variuus pages and the concrete.

The section produced by iut 15 (see fig 8.30 ) is shown in Fig. 8.33. The centerusos! age label is to the right and below 2 precast three page rosetie of singletilament resista ze strain ages. A closeup of the excellent bend whieved between the precast page issette and the reniaining concrete is shown in Fig. 8.34. The upper gage shown in Fig. 8.33 is 27 axially oriented lype $A$ vibrating-wire gace. and the lower is the xitivalor coil housing and one end anchor of a radially onerited of the same type. The crack shown to the right of the upper gage occurred duning 


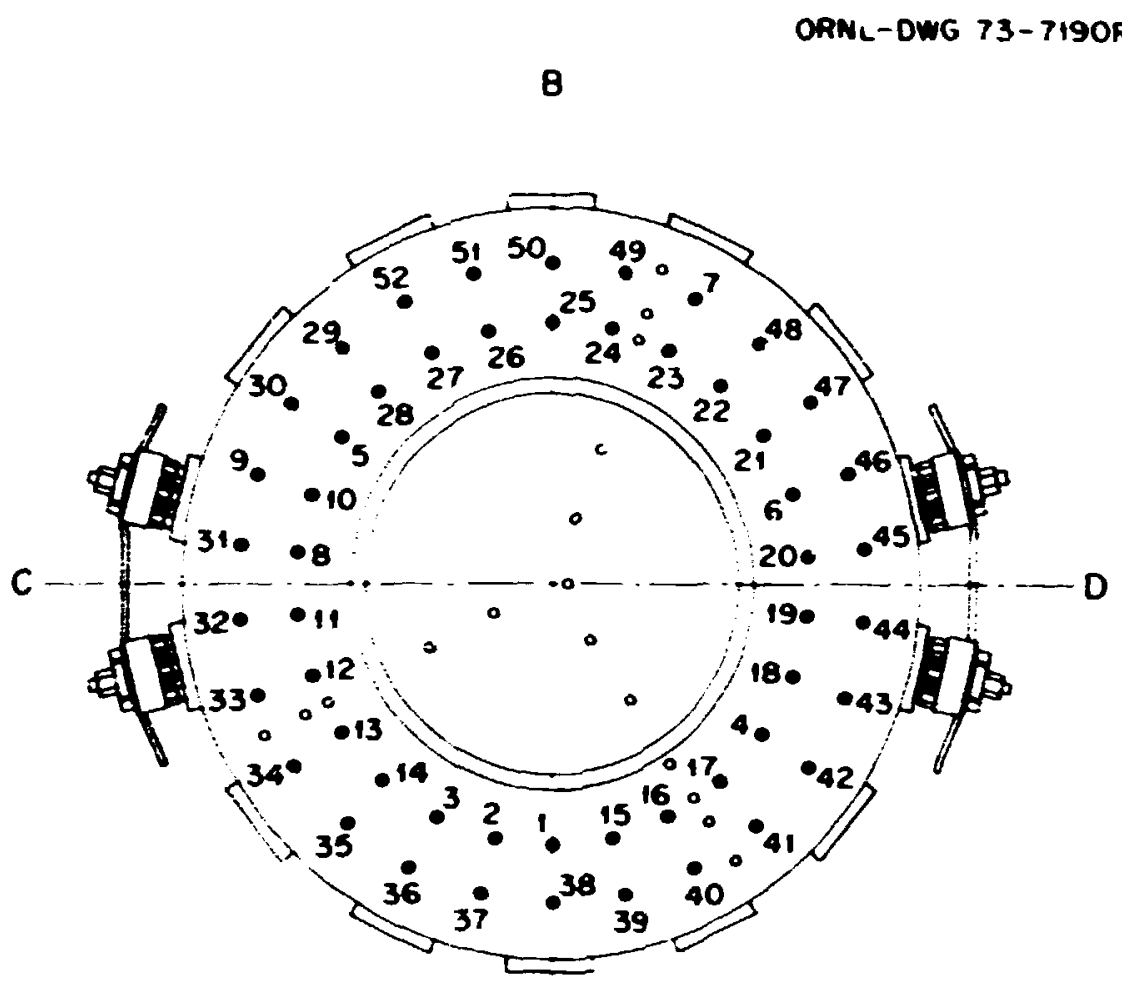

A

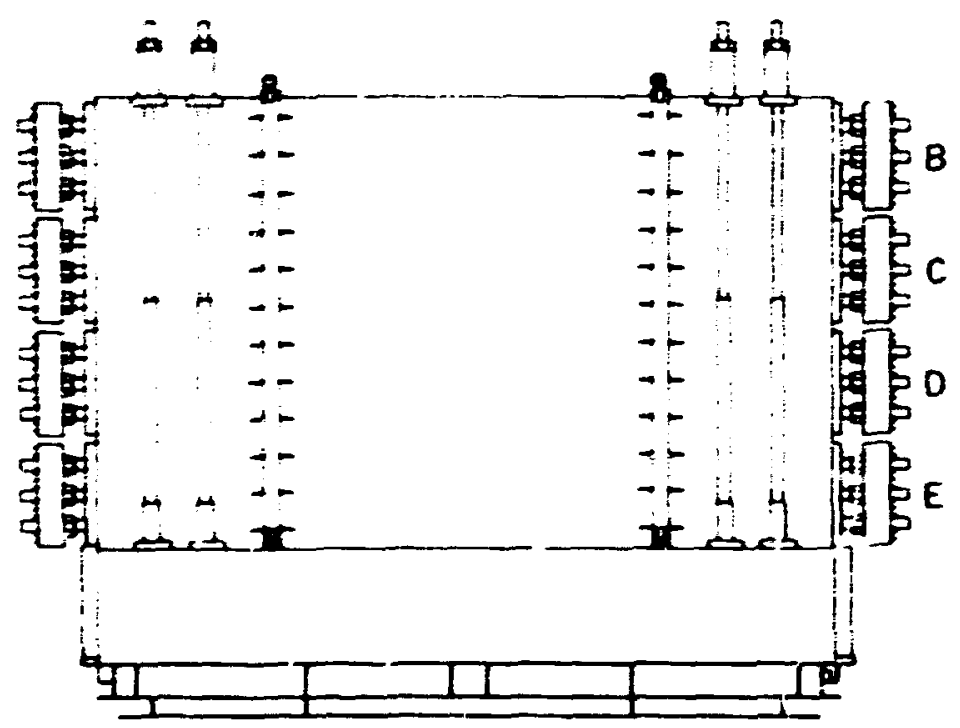

Fa 8.29. Therinal cylioder prestrescong system. 


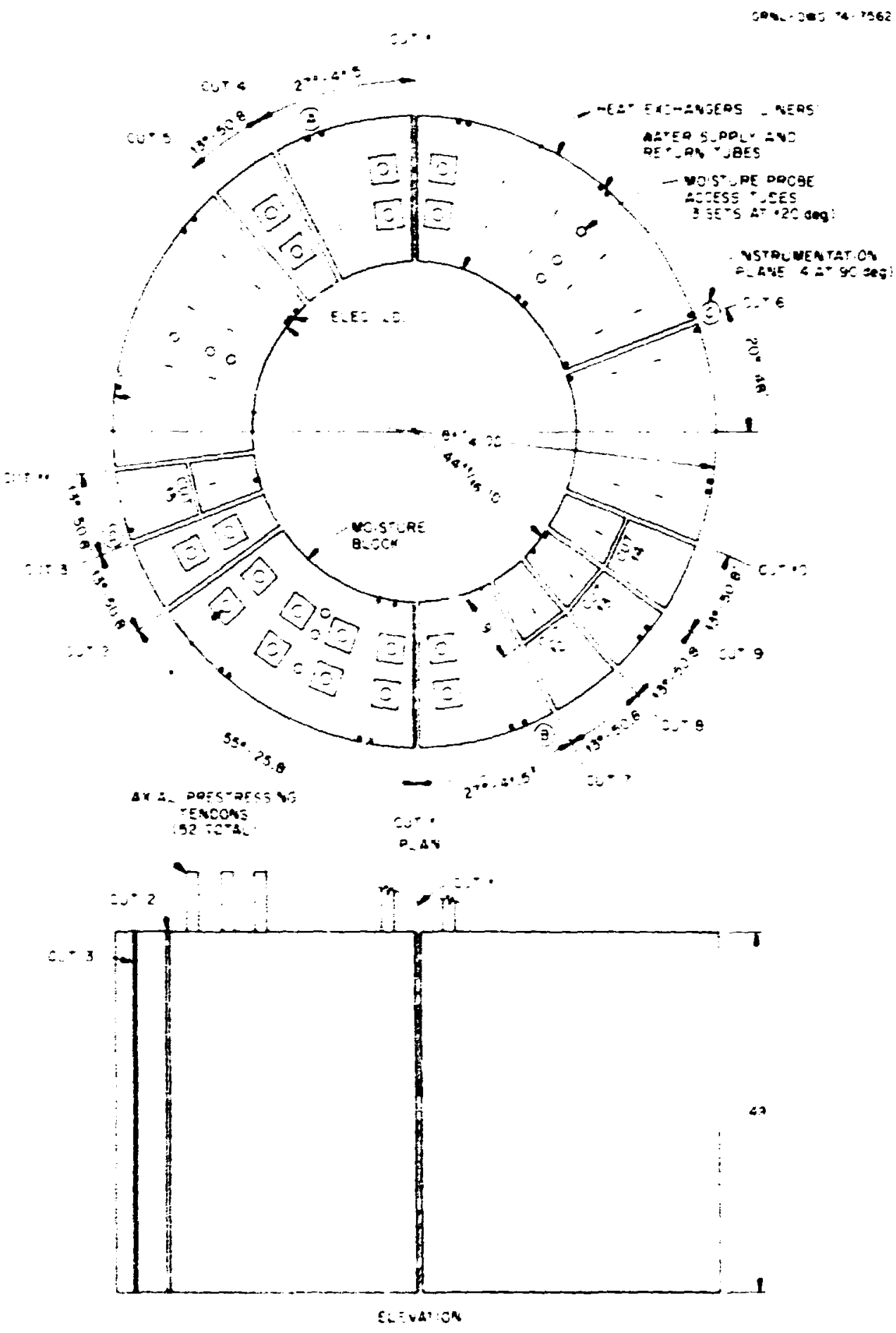

Fic 8.30. Themal cylisset model sectioning plan. 

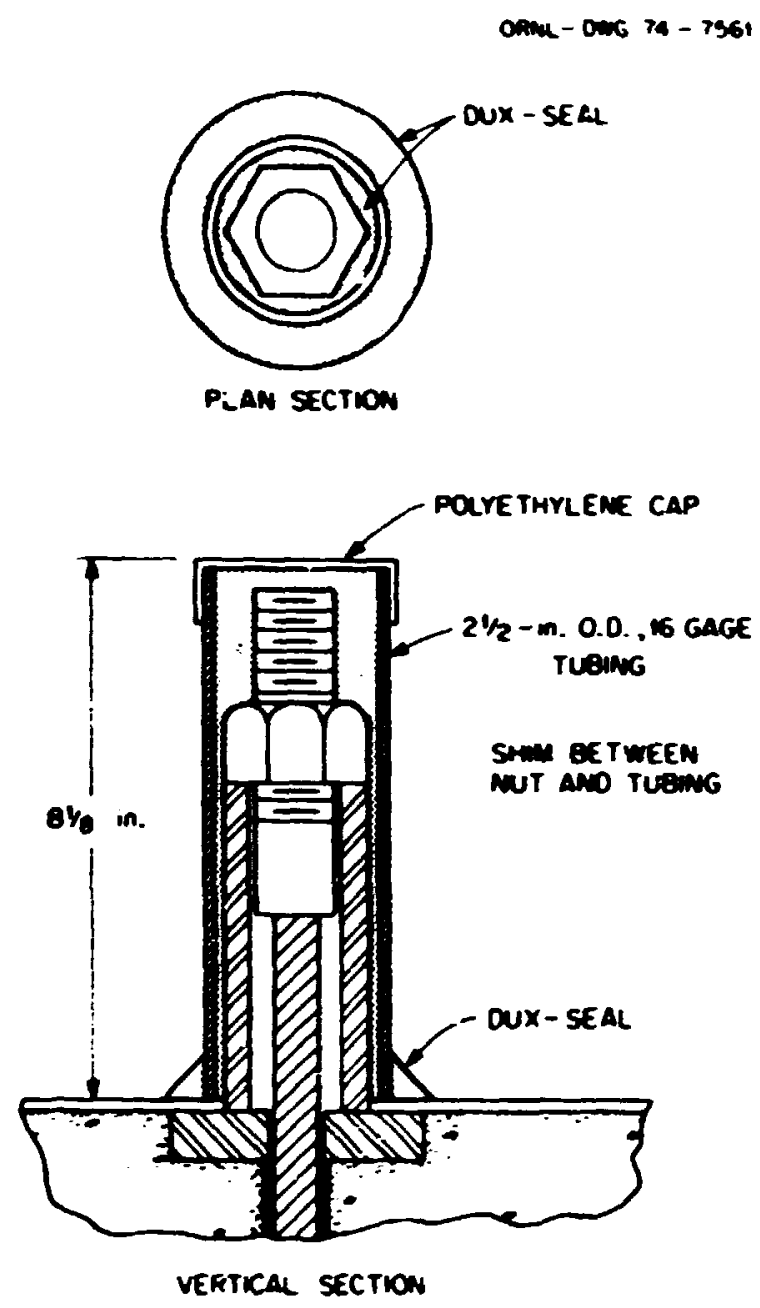

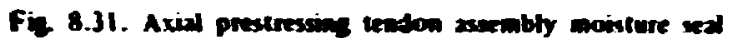
for concrete sectionion.

the ulting opetation. and the remaining inctussons seen in the concrete are primarily secilioned instrumentation kads.

\subsubsection{Rebound Hammer ix:- Results}

Although there were no signifficant defecits seen in the cut surfaces, the cincrete immediaiely iurrour.ding the hot-spol healing elements was darkened as shown in Fig. 8.35 . which indicates that some thange ociurred in the concrete due to the $450^{\circ} \mathrm{F}$ hot $-s p$ t heating. A series of readings were made on the concrete fixies using an impact hammer (or sclerumeter). This test is based on the principle that the rebound of an clastic mass depends on the hardness of the surlace against which the mass impinges. (ounpressive s!rength of the n:aterial ian be determined from this hehavior. The test appara. tus comsists of a spring-luaded mas having a fincd amount of energ imparted to it by extending a spang to a predetermined compression. The mass is then rekeaced. and the distance traveled by the rotheunding mass. expressed as a percintage of the unifial exicnsion of the spring. is illed the rebuund number. This number is an arbitrary measure. silice il deperds on the energ stured in the given sping and on the sise ut the mass.

The test is sensitive to koval variations in the curricte: lor example, the presence of a large prece of aggregali: inmediately bencalh the plunger wisuld result in an unurmully high rebound number. In contrast. The presencic of a void in a simila pusilion would result in a relatively low number. A correlation of rabound num. bet with ur:-unfined cumpressive strength is wiven in the lextbunh by Neville for a con:rete make wih c:ustics limestume segregate. Figure $x .36$ is a repriduitis $n$ if this iurve with the straght lime extendied is incluste a compressive sirengih of $8000 \mathrm{psi}$.

The results of a rebeund lest of the seitioned thernial iylinder mudel are shown in Table $x$. 3 . Rethound readings were iaken in the four faces of the iross seitkily ar the A and B yualrants. Reading wete made along lines consinacted perpendiculat to the inswli surfiac of the cylindrical lest sections al iwis elevatuons as shown in Fig. 8.37. One base sel wa laken in the upper part of the reudel approximatcly I it frum the (up. and one was taken through the vertical center of the lusi-spul heated rune. The distances shown in the rabke were taken from the unside suriace of the seitiun. The "at heater" readings were taken directly adjacent (1) the panil civil heaters. As can be seen on the nght hand sick of the table. consuderabl: cumpressici strenath reductions were measured in the laval hea! affected ane. This ane was easly distingursiced by the distimit color change when compared with the rest of the iross section. On the uther hand. the hase readings Iaken at a cunsiderable dislance from the heat-afiected gune show very little sisength variation. The average strength decermined frum the base readings wa 750) pai. There is litile dubht that a sigoifuant strength decrease was experienced in the heal-affecied rone. Tive thermal cylinder had a 24 -day unconfined compresurve strength of a proximately 7000 pos. which might iend (1) indicate that :he rebuund reading strength correlatuon may be slightly luw. Inwever. these readisps were

b. A. M. Neville. Rroperters of (imarerer. Widey. Now Yark. 


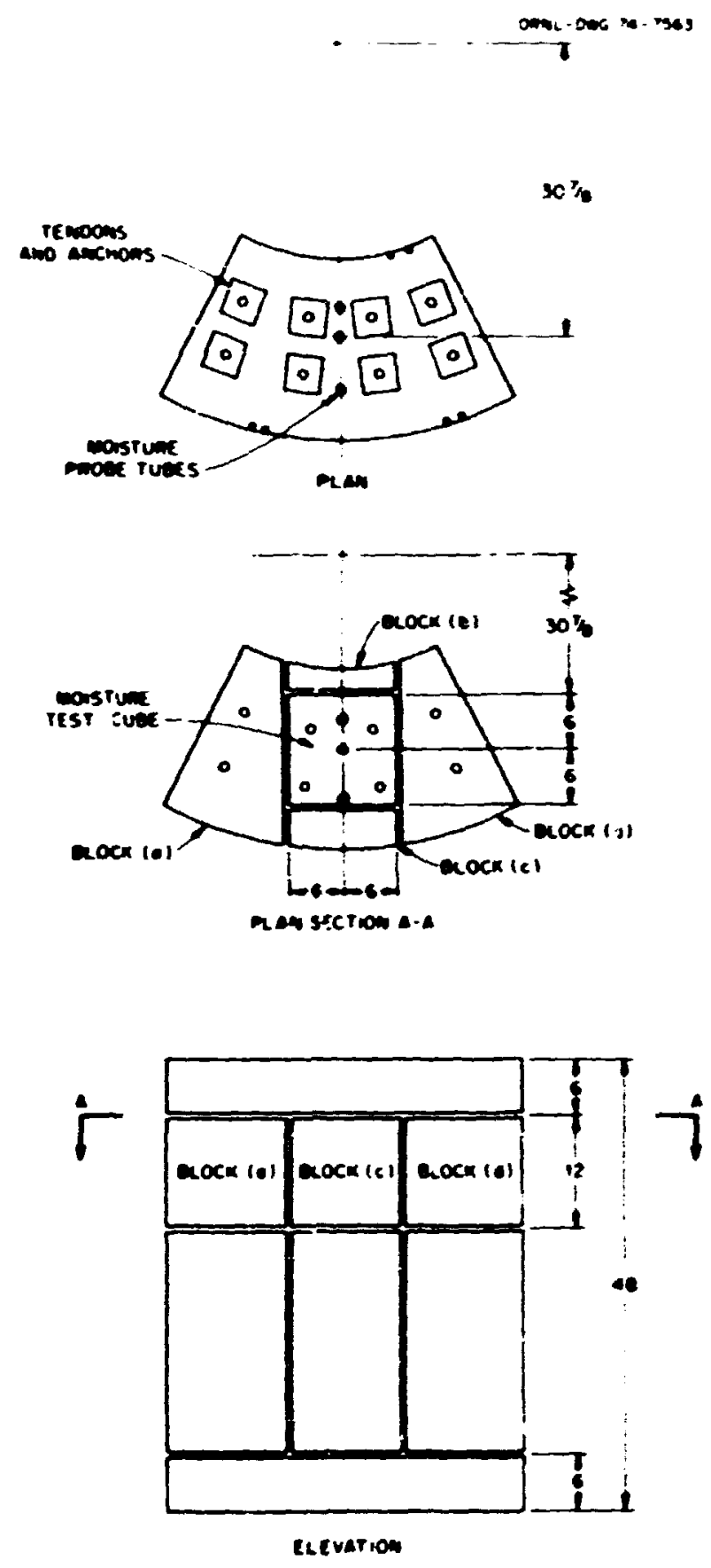

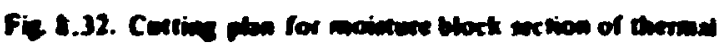
rivines moded.

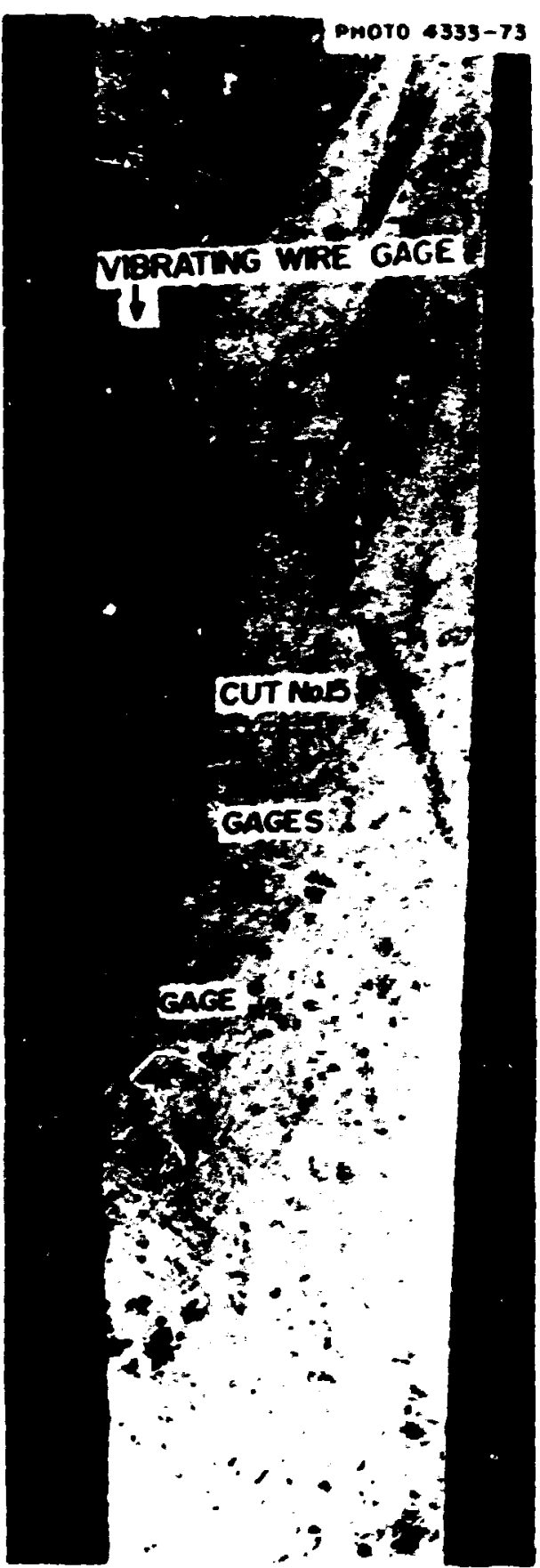

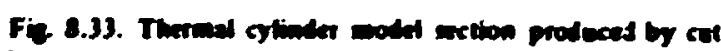
13. 


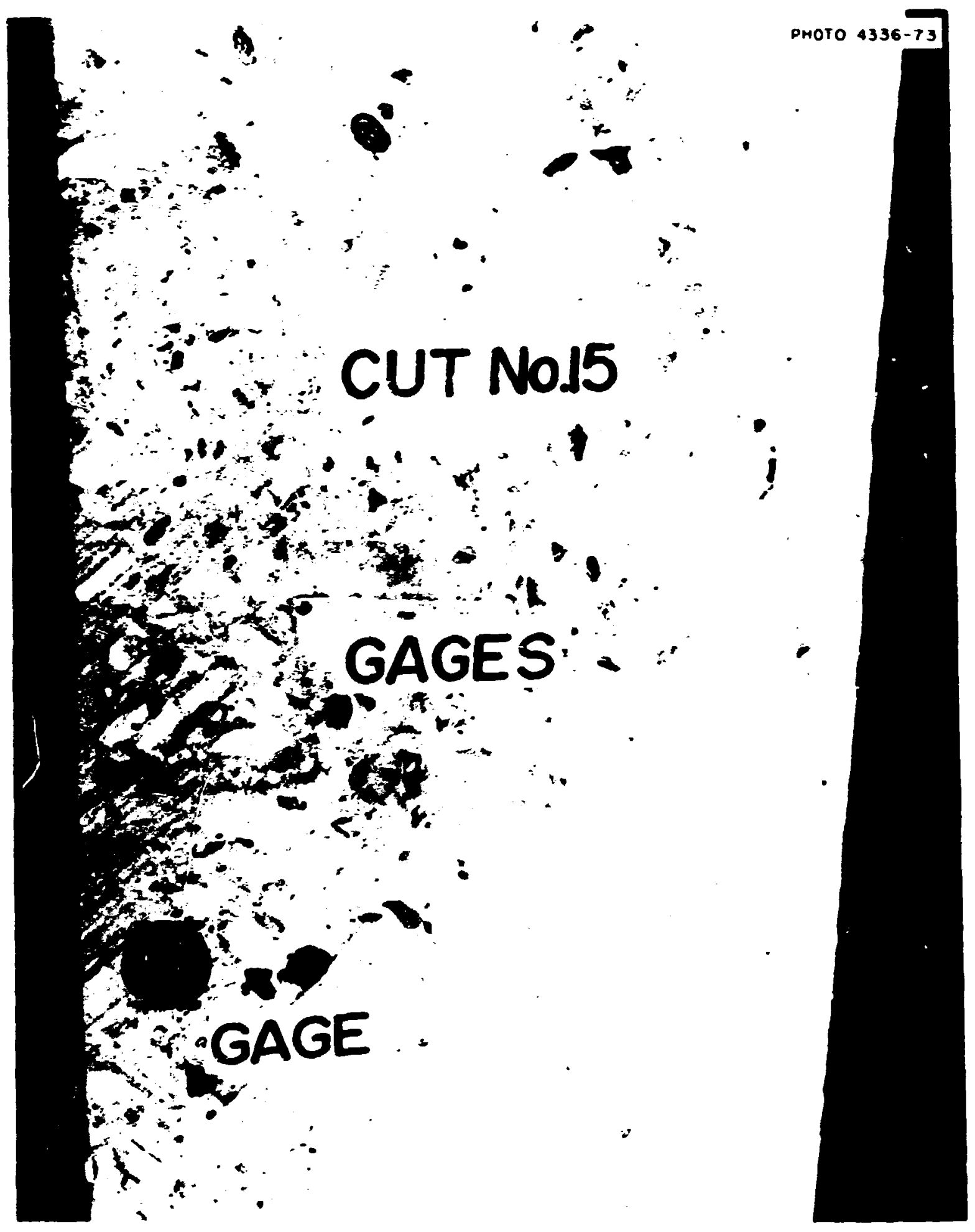

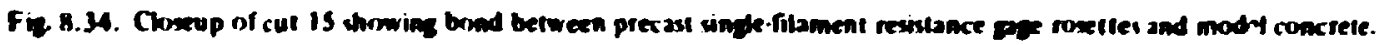




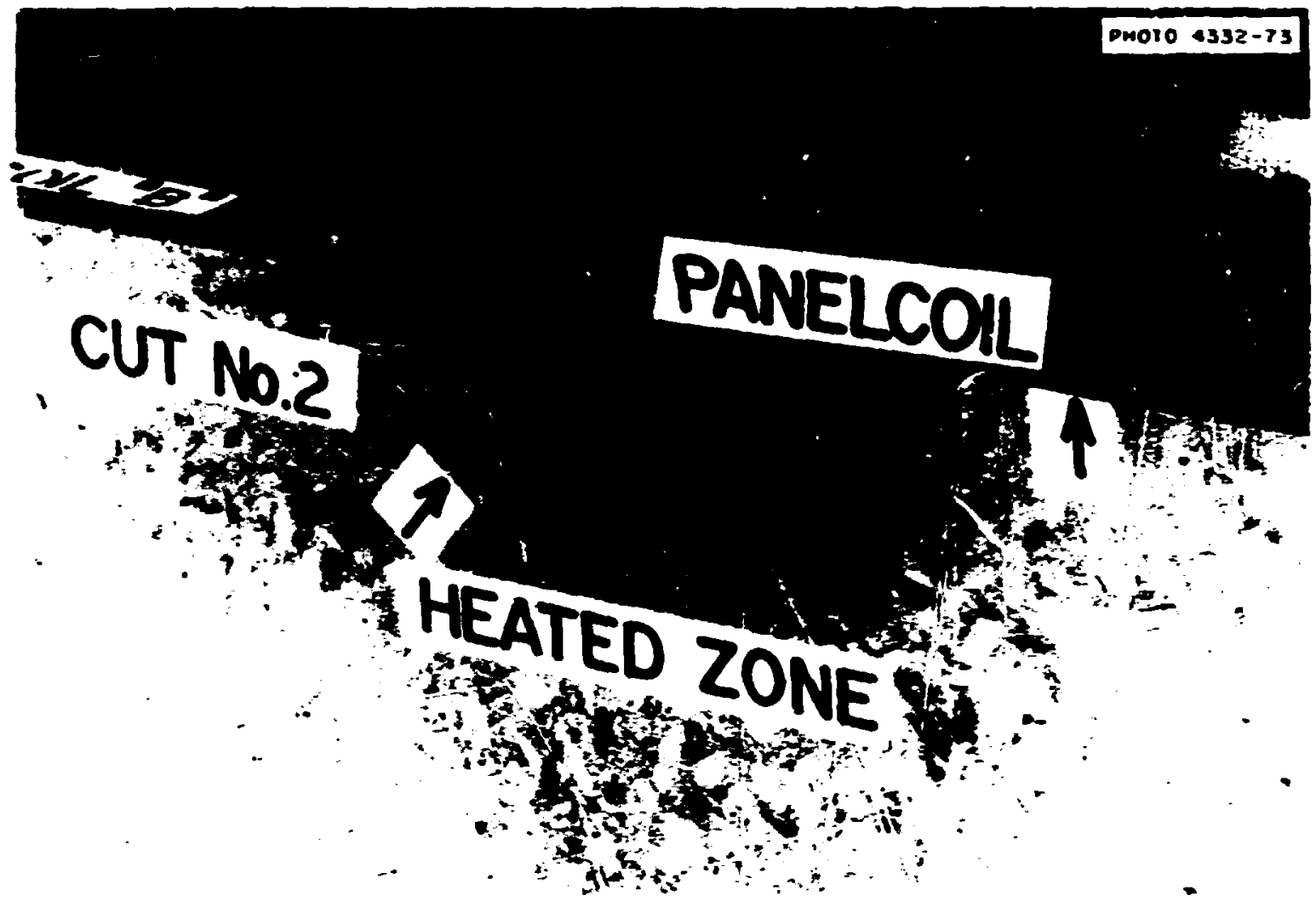

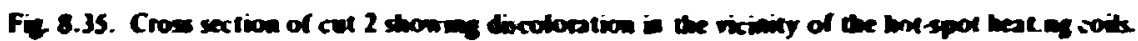

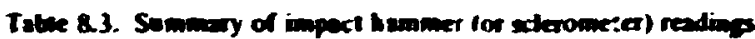
on therind cylieder modet cross sections

\begin{tabular}{|c|c|c|c|c|c|c|c|c|c|}
\hline \multirow{3}{*}{$\begin{array}{l}\text { Distencic } \\
\text { (m.) }\end{array}$} & \multirow{2}{*}{\multicolumn{3}{|c|}{ Bace readings }} & \multicolumn{6}{|c|}{ Readings at hot-por kvel } \\
\hline & & & & \multicolumn{2}{|c|}{ Axcition } & \multicolumn{2}{|c|}{ B rection } & \multirow[b]{2}{*}{ Avetape } & \multirow{2}{*}{$\begin{array}{l}\text { Compressive } \\
\text { streneth } \\
\text { (ps) }\end{array}$} \\
\hline & $A$ & B & Average & 1 & 2 & I & 2 & & \\
\hline At heatet & & & & 31 & 3 & & 30 & 28.00 & +600 \\
\hline 1 & +3 & +1 & 42 & 38 & 40 & 38 & j4 & 37.50 & 6300 \\
\hline 3 & 43 & 4 & $43 \leq$ & 42 & to & 43 & 39 & +1.00 & 1900 \\
\hline 5 & 45 & th & 45.5 & +1 & 40 & 40 & $4:$ & +1.00 & $6: 00$ \\
\hline 7 & $\$ 3$ & +3 & $\$ 3.0$ & $\$ 1$ & +1 & +3 & +3 & $\operatorname{t200}$ & 7100 \\
\hline 9 & $H$ & 43 & +3.5 & 48 & +1 & 42 & $H$ & +3.75 & 7500 \\
\hline 11 & 43 & $H$ & $\$ 3.5$ & 43 & +3 & +3 & 45 & +350 & $75 m$ \\
\hline 13 & 4 & 4 & 43.4 & 12 & 45 & 4 & +5 & +3.75 & 7500 \\
\hline I! & 4 & $\$ 5$ & 4.5 & $\$ 9^{\circ}$ & $\$ 3$ & 4 & 4 & 43.70 & 7500 \\
\hline$! 7$ & $\$ 3$ & +4 & $\$ 4.5$ & 42 & $\$ 7$ & 42 & +4 & 43.75 & $75 n 0$ \\
\hline
\end{tabular}

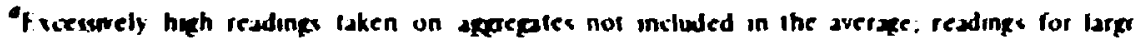
aperegate inclusons were sil 


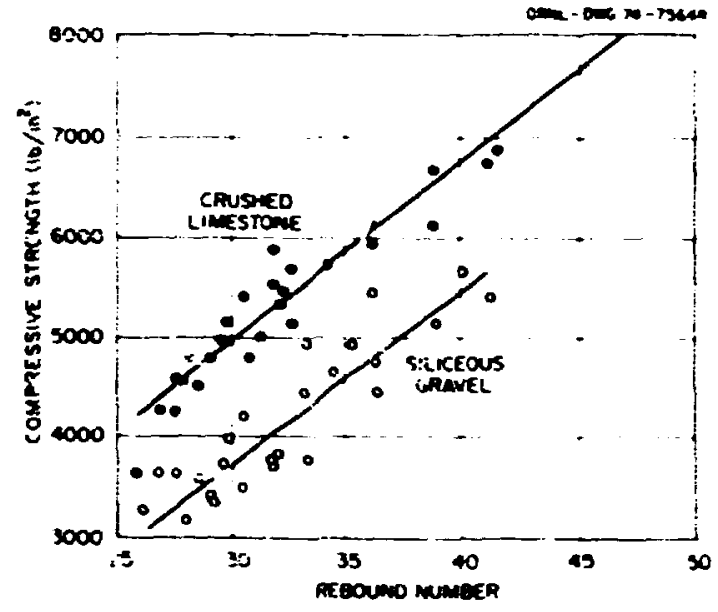

Fin 8.36. Retacion between compressive strength and re boum. number for concrete cyliaders made with different aer-atex. IReadings taken on the side of a cylindet witl the hammet hurizontal.) iskin Un the nialrix rather than on the iggregales whenever pussible. The r. bound readings nade un lerge agregates were significantly higher.

\subsubsection{Teadon Corrosion Srudy}

A thorough inrestigation is being condusted to determine the cause of causes of the tendon tilures desinbed in Section 8.1.2. The status of the 26 innci row and 2 of the oriter low tendons is summaized in Table 8.4. The locatioti in tixe model of eich tencion listed is shown in Fig. 8.29. For a cumplete iescription of the thermal cylinder model fatrication and testing. the reader is referres to Refs. I and 3 The followin: discussiun protides a detaled descnption of the axidi tendon prest ressing system.

Each tendon was a 0.5-in.-diam LOK-STRESS - iono strand consisting of seven wires and having -EEE anchurs allached to both ends. These strands were manufatured in acordance with ASTM A416 and

Table 8.4. PCRV thermal cylinde, modei - stutus of 2xid tendon exanination

\begin{tabular}{|c|c|c|c|c|c|}
\hline $\begin{array}{l}\text { Tendon } \\
\text { ve. }\end{array}$ & $\operatorname{Row}^{2}$ & $\begin{array}{l}\text { load cell } \\
\text { designation }\end{array}$ & Filure location & Dispusition & Remarks \\
\hline 1 & I & ATR-II & Broke nei: bottom ancho: & OR.YL (Metsls \& Ceramics) & Failed at time of detensioning \\
\hline 2 & I & Vione & Broke ar tu: :enm aninor & Stressied Corporation & Failed at time of detensioning \\
\hline 3 & I & Sone & Broke nis nultom anthor & Cieneral Acomic Company & Faled al time of detensioning \\
\hline-3 & 1 & Nune & Broke near buttom anchur & ORXI. ftested single wires) & Failed at time of detensioning \\
\hline 5 & $\mathbf{I}$ & Sone & Broke nesr boitom anchor & CRYI & Failed at time of ditencioning \\
\hline 6 & 1 & Nuns & Broke neal boitom anchur & ORNL Mctals \& (cramics) & Failed al time of detensioning \\
\hline$;$ & 0 & Sunc & Fulked a' top & OR.VL IMetals \& (eramies) & Faled at 57.500 ib \\
\hline $\mathbf{8}$ & 1 & CTR-3 & ailed near ienter & ORNL (Metuls \& (eranics) & Failed at $8400 \mathrm{lb}$ \\
\hline 9 & 0 & Nons & $\begin{array}{l}\text { Wirc pulled througin top anctor } \\
\text { (1)-in. wre in anchor }\end{array}$ & Loft in concrete & $\begin{array}{l}\text { Stopped at } 60.000 \mathrm{lb} \text {, wire } \\
\text { sipping in anchor }\end{array}$ \\
\hline 10 & : & Vione & & Left in concrele & Failed at time of detensioning \\
\hline 11 & $\mathbf{I}$ & CTR-1 & & Left in conirste & Failed during lest (see load cell data) \\
\hline 12 & 1 & Yone & Broke near top anchor & ORNL (Met"n (cramies) & Failed at $6200 \mathrm{lb}$ \\
\hline 13 & I & None & & Left in sontrate & Failed at time of detcasioning \\
\hline 14 & 1 & Yone & & l.eft in concretc & Failed at time of detensioning \\
\hline 15 & I & None & & l.eft in -or. efte & tailed at time of detensioning \\
\hline 16 & I & None & & Lefi in concrete & Failed al $43,000 \mathrm{lb}$ \\
\hline 17 & $\mathbf{I}$ & Vinns & & Leil in conerete & Fatled at time us fel :nsioning \\
\hline Is & $\mathbf{I}$ & Vone & & Lefi in concrete & Fialed at 23,000 D \\
\hline 19 & I & $1[5.3$ & Falked near lop : 'a hor & (OR: : & Iailed at $60.000 \mathrm{lb}$ \\
\hline 20 & 1 & ?] R-7 & & Leit in concrets & Nin indication of failure \\
\hline 21 & 1 & Sion: & Iraled nes butfom anchur & ORNI. & $\begin{array}{l}\text { Failed at } 57.200 \text { lb (one wis: } \\
\text { shows cracks) }\end{array}$ \\
\hline $2 Z$ & I & $v_{i}$, & & Left in consrete & Irailed at time of detensioning \\
\hline 23 & $\mathbf{I}$ & None & & Leff in curicicte & Iailed at 31,000 ib \\
\hline 24 & I & Nonte & & Lafi in sweresc & Fulicd at 29.000 ib \\
\hline 25 & 1 & HIR-S & & Lefit in concrete & I ailr d during lest (se. l.)ad cell data) \\
\hline 26 & $\mathbf{I}$ & Vione & & L.eff in concrete & Fixcessive yiclding at $32.500 \mathrm{lb}$ \\
\hline 27 & $\mathbf{I}$ & vione & & Lete in concrese & Falled al :imc of deiensioning \\
\hline $2 *$ & $\mathbf{I}$ & Yione & & I,eft in iuncrete & Ixcessive yicldine d $3,3,0$ ih \\
\hline
\end{tabular}




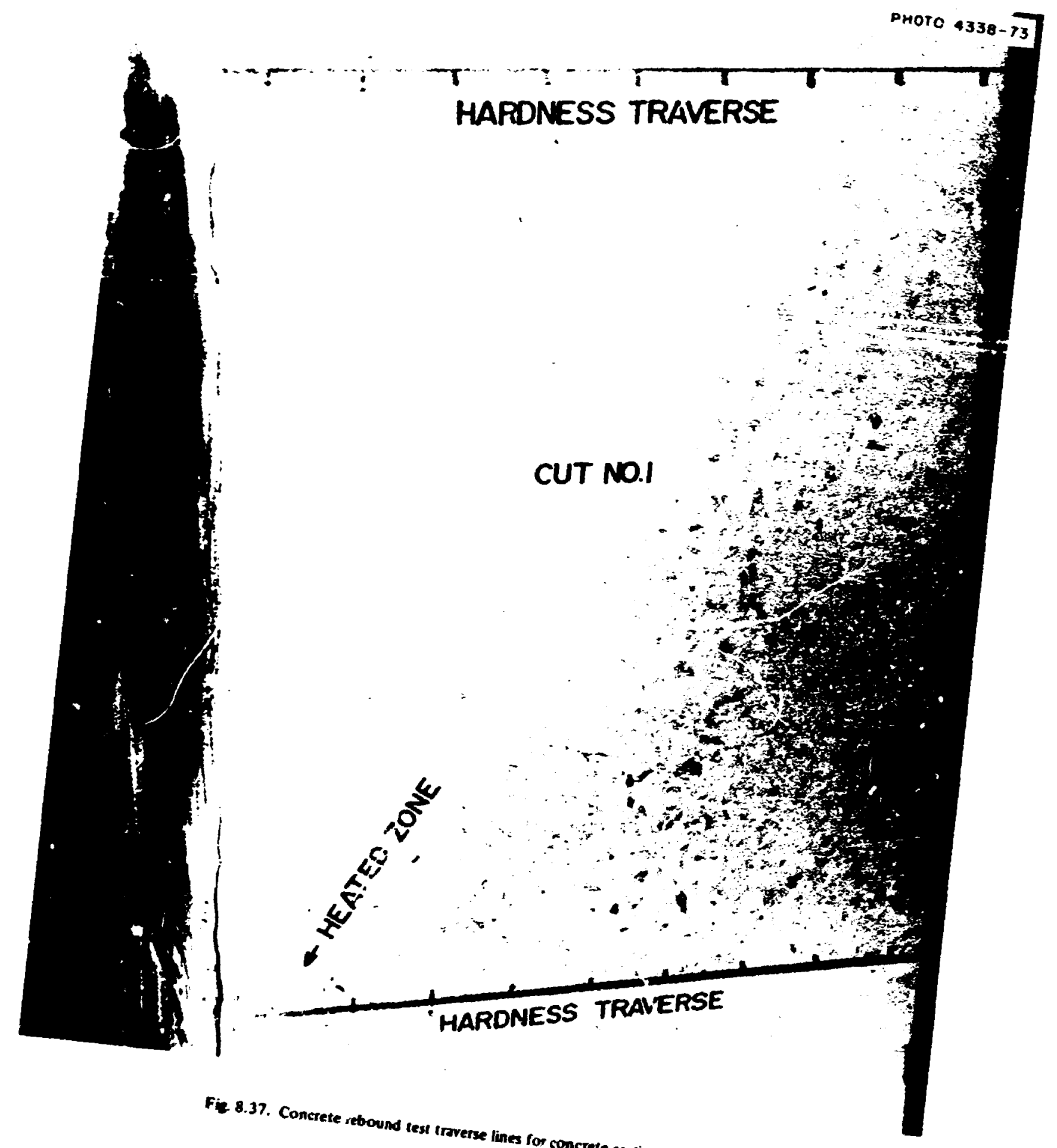


were specified in this case to minimize possibie relaxation lusses. They lave a moduius of elasticity of $28 x$ $10^{6}$ psi and a bresking strer:gth of 250,000 psi.

The lenduns were cuated with a widely used cominercial iurrusion protection material when received from the manufacturer. A total of 12 tendons. 6 in each riw. were instrumenled with looj cells at the top ar: ho: and with fuil-type electrical resistance strain gage: on one wire of each strand. It was necessary to remove the original protective coating from ap approximately 12-in. section of the instrument:d wire iv install the gage. These were the only ienduns frum which any of the uiiginal corrosion protection was remuved. Once

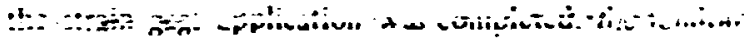
was waterprooted with a commerial wax using methuds recummended by the Portland Cement Assucistion.' The specific wax erroluyed is generally reciug nized to provide effective corrosion protection. The tendons were housed in two-piece lelescioping ducts in the manner shown in Fig. 8.38. The joint at the boltom anchor fitting was first sealed with heat shrinkable "fiexile" tubing. and itre lower duct section was filled with melted wax. The upper joint was then sealed with llexite : whing. and the upper duct section was filled with relted wax. The known volume of wax required Io fill each tendon assembly was used to indicale whether it was completely filled. Also, when properly filled, the flexite tubing bulged slightly. Finally, the lower end of the bottom anchur fitting was sealed with melted wax.

The sealed tendon assemblies were positiuned in the structure as shown in Fig. 8.1 , and the bollom anchor plates were tack welded onto the bottom sheet metal scal. The assemblies were held in place at the top by a fixture. and a final epoxy seal was applied to the buttom anchor plates and lower tendon sleeves prior (i) castiig. Upon completion of casting. the exposed concrete surface was sealed with an epoxy-iopper layer. A final epoxy seal was applied to the top surface at the completion of the tendor pusttensioning operation.

During the 15 -month period simulating normal PCRV operation. the inner row of stressed axial tendons was subjected to approximately $125^{\circ} \mathrm{F}$ anci :t:e outer row to $100^{\circ} \mathrm{F}$. During the subsequent 3.,nonth period of the hot-spol test, the peak !emperature was abrut $225^{\circ} \mathrm{F}$ at the inner row and $130^{\circ} \mathrm{F}$ at the outer. Figure 12.15 in the last progress rejort' shows the data for threc of the

7. N. W. Hansen and O. A. Kurvits. "Instrumentation for Structural Testing." J. PCA Res. Divelo)p. Ioh. 7(2). 33 (May 1965).

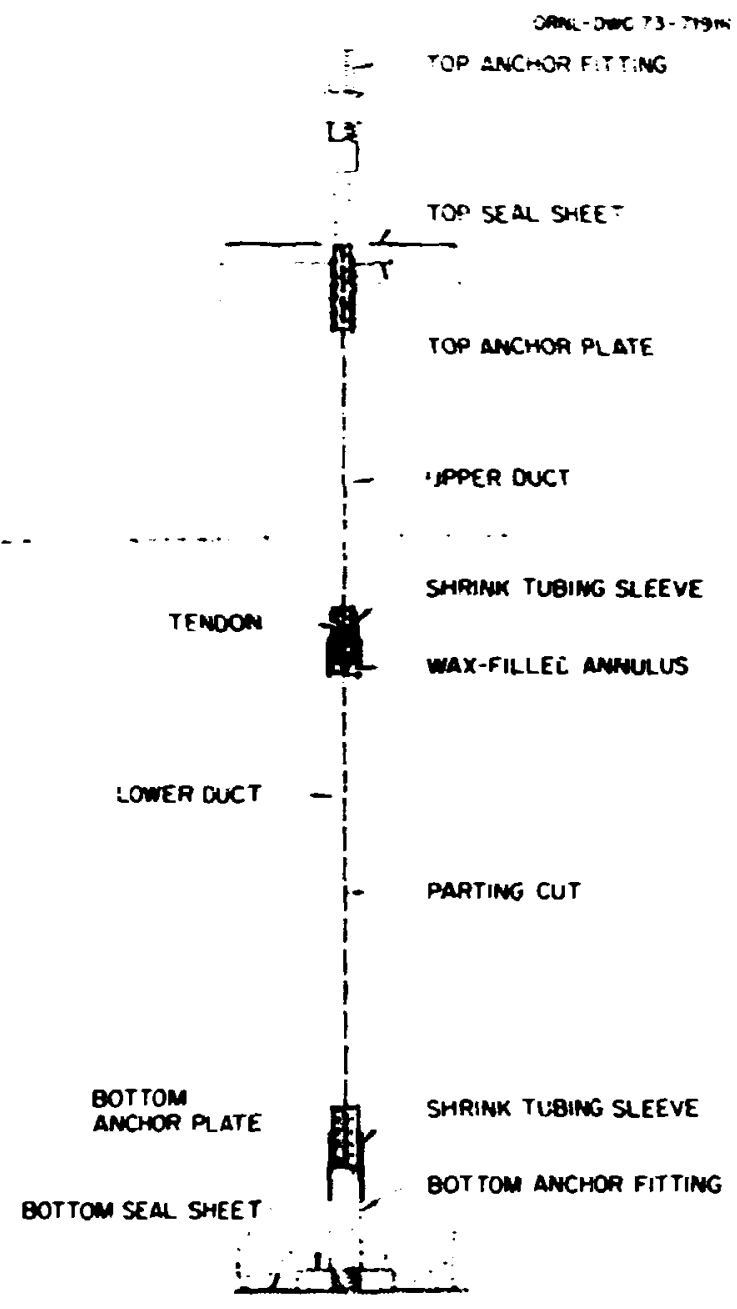

Fig. 8.38. Axial tendon assembly detal showing the parting cut employed in disassembly of ducts.

axial tendon transducers during the period simulating r.ormal vessel operation. In the figure iransducer CTR-3 was indicated as having malfunctioned begioning at about 190 days from prestressing. Fur'hcr examination of the data from this transducer in light of observed tendon failures has shown that the previousl: unexplianable shifts in load readings were apparently pro. duiced by failure of individual tendon wires. Figure 8.23 includes an unabridged histury of the same transducer. Of the four transducers in this quadrant of the model for which load-time histories were obiained. (TR-3 was the only one exhibiting a substantial step change in loading prior io the hot-sx)t test. Although the data for 
(TR-3 indicats that some wires tailed starting at 250 days. which o prior to tive nut-sput experiment. the luss of terden load appears to be generally associated with the period following the hot-spot lest.

During the course of the experiment. noises were reported which appearec to have eminated from the model. During one of these incidents, an inspection was nade of the circumferential prestressing system; however. no problem was discovered nor was the sovice of the noise identified. In retruspect, it could be concluded that the sounds were made by failing axial tendon wir:s.

During detensioning. which is desisioed in Section 8.1.2. the outer row of tendons 4 ll required the full ram load of about $45.000 \mathrm{lb}$ to unseat the tretrainin na: :-

- Gurctrasi. il bul ilice of the inner row teadons indicated failure of some or all the wires in the st:and by virsue of the low ram pressure required for detensuning.

Thus far. a total of : I tendoris. 10 from the inner row and I frum the outer. have been removed from the thermal cylind ar model. Durirg a selective rejoad: $z$ of outer tow tendon 6. the top anchor fitting shown schematically in Fig. 8.. 8 was pulked almost through the entire length of strazd to which it was swaged without inducing wue fail: $r e$.

Of the 10 in:or row tendons this far removed from the model. ? railed neas the tottom an hor. I failed near the middle of its le.seth. and 2 fai:ad near the top anchor. One of the tendons thai railed near the bottom

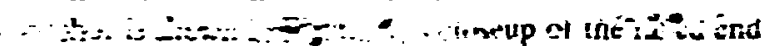
is shown in Fig. 8.40. Figurz $8.4 !$ is a photomicrograph

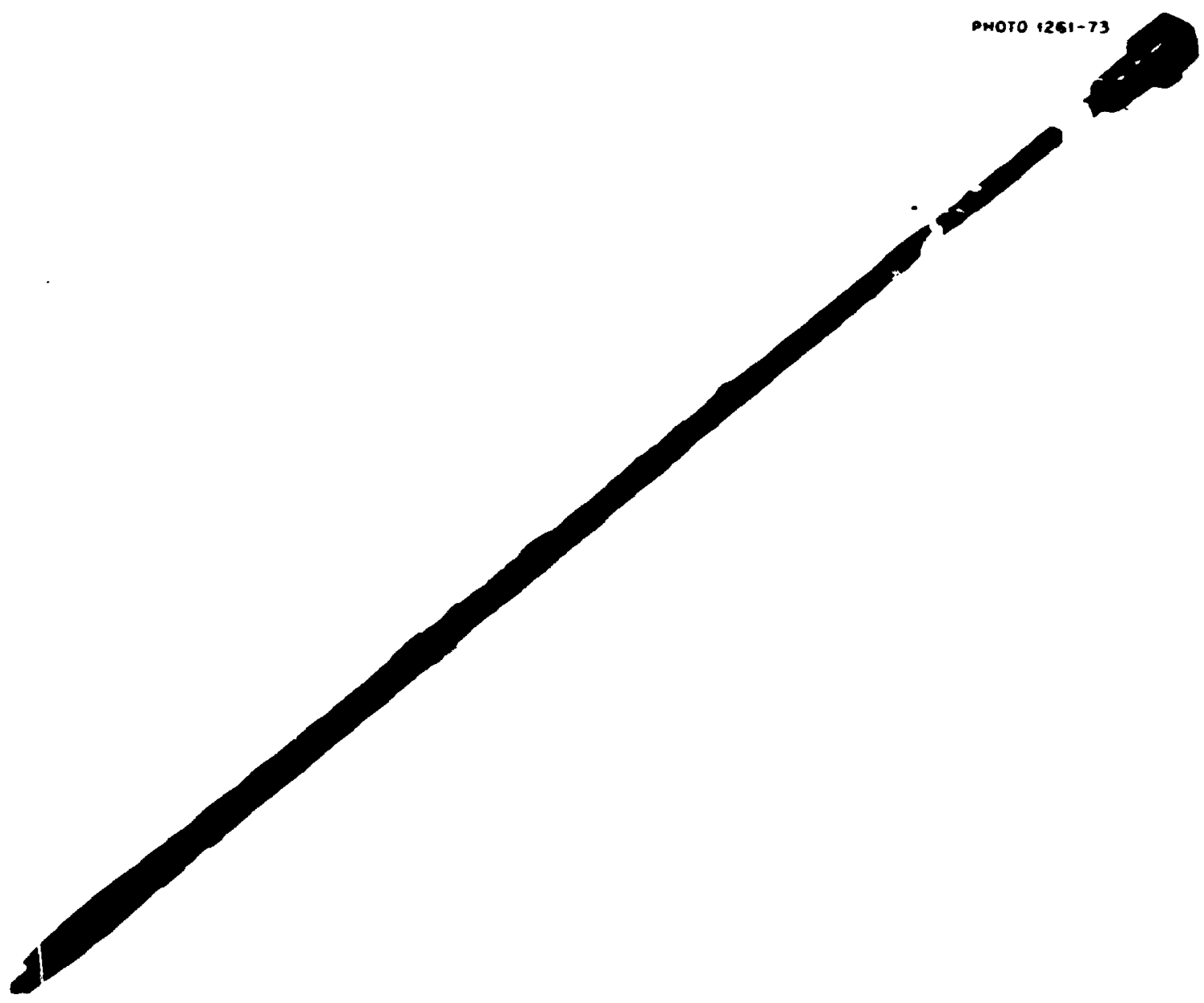

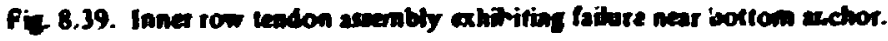




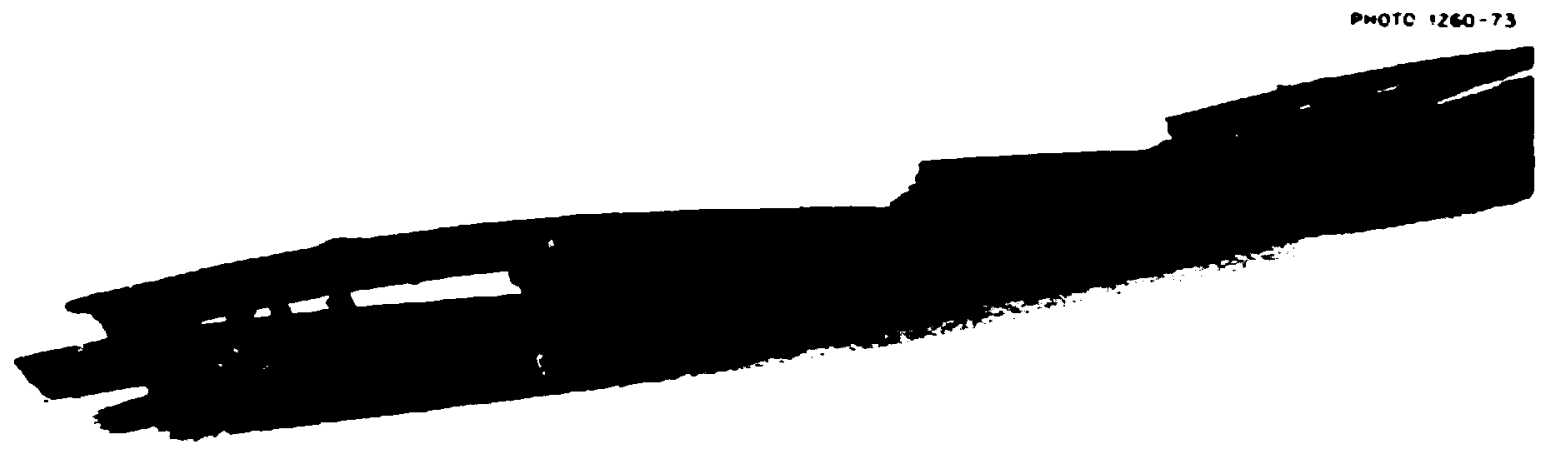

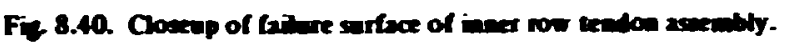

showing transverse eraking in the region of the wires adjacent to the failur:? surface.

Tendon 8, which apparently experienced wire failures near the midpoint of the experiment. required a load of $\mathbf{8 4 0 0} \mathrm{lb}$ so fail the strand. This tendon failed near midlength, and four of the wire failures appeared to be old breaks. Tendon 12 broke near the top anchor under a ram loading of $6200 \mathrm{lb}$.

Inner row tendons 19, 20, and 21 required design loads for detensioning. Tendon 21, which failed near the bottom anchor, displayed previous craking in one wire. and tendon 19 failed near the top anchor at a wad of $00,000 \mathrm{lb}$. Tendon 20 remains intact in the conctete section in that no distress was revealed by the attached load cell.

The single outer row tendon that was pulled to failure required a maximum ram loading of $58.400 \mathrm{lb}$ at $4 \pi$ elongation. Cup and cone type fracture surfaces were produced in al: ziven wires.

Chemical analyses performed to date indicate that samples of the unused protective wax contain 0.40\% sulfur: however, there are no significant amounts of water-soluble chlorides. sulfides. or nitrates present. Wax and corrosion pruducts taken from a failed tendon and tendon ducts show significant quantities of iron. zinc, chlorine, and sulfur. The cherrical and metallurgical studies of the failed tendons and tendon assenib!res will be continued.

\subsubsection{Mositure Heasurements}

A direct calibr:::on of the Truxler probe-lype neuIron and gamma-ray backscallering instruinent was conducted at the Waterways Experiment Station
(WES). Corps of Engineers, U.S. Army, Vikksburg. Miss. Twelve I-ft-diam by I-fitong cylinders were ast using the Tennessce limestone concreic mixture designed at WES for the ORNiL concrete program basin stidies and used to cast the thermal cylinder model. Shurt sections of the 1 -in. $-0 D$ stainless steel tubing used as moisture probe aciess tubes in the thermal cylinder model were east into the center of each calibration specirner. The sive of these specimens was chosen in aciordance with reciommendations made by the probe manufacturar.

The calibration procedure consisted in weighing and laking a set of three independen: I-min prown curnts immediately after casting and after demolding lone day). The demolded specimens were divided into four sets of three specimens each and placed in constantenvironment chambers maintained at a temperature of $75 \pm 2^{\circ} \mathrm{F}$ and having relative humidities of 100.90 .80 . and 707 respectively. The specimens were removed from the chambeis and weighed. and counis were made at 7. 28. 35.42.49.57.76.87. and 112 days from easting. The results of the calibration lests are shown in Fig. 8.42. Inconsistencies were found between recior led weighis and probe reading of the specimens subjecled to the $100 \%$ relative humidity when compared with ihe remaining nine specimens: consequently, only two set: of these readings are shown in the figure. No discemible difference was seen between the rate of moisture loss of the remairing thice sets; the average values are shown in Fig. 8.42. Of the two curves shown. the upper curve and data points rexesent total moisture content (bsed on calculated dry weight), and the lower curve represents evaporable moisture content (based on the ovendried specimen weights). The circled data poinis on 

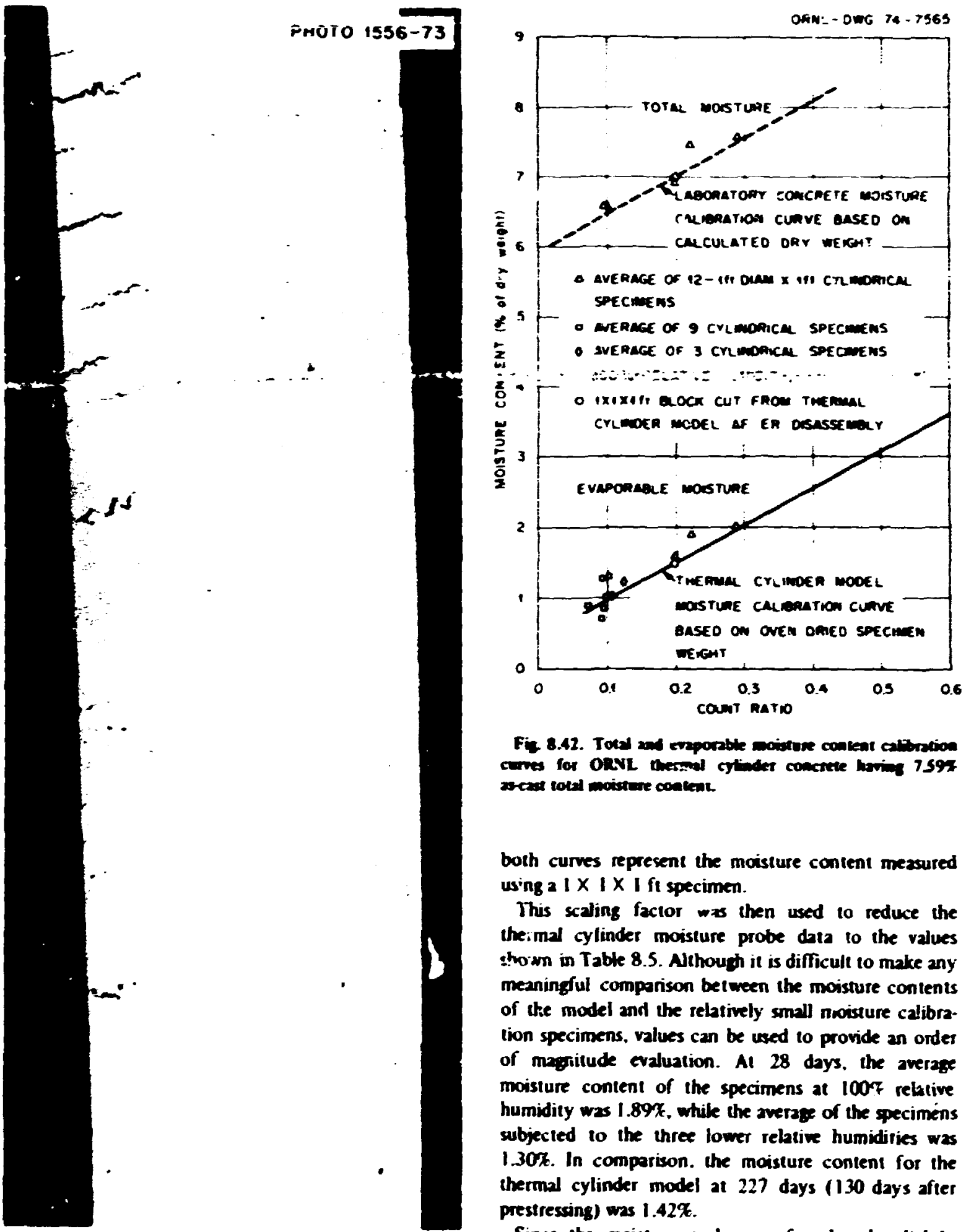

Fiz 8.42. Tots and eraporable moivture content calbracion

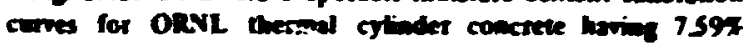
arcad total moisture content.

both curves represent the moisture content measured using a I $X$ I $X$ I f 1 specimen.

This scaling factor wis then used to reduce the the:mal cylinder moisture probe data to the values shown in Tabte 8.5. Athough it is difficult to make any meaningful comporison between the moisture contents of the model and the relatively small noisture calibra. tion specimens, values can be used to provide an order of magritude evaluation. Al 28 days, the average moisture content of the specimens at 1007 rebative humidity was $1.89 \%$, while the average of the specimens subjected to the three lower relative humidities was 1.30\%. In comparison. the moisture content for the thermal cylinder model at 227 days $(130$ days after prestressing) was $1.42 \%$.

Since the moisture probe was found to be slightly

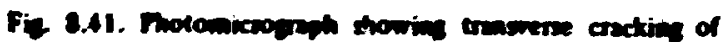
temperature sensitive. the slight increases in malues coniciding with temperature changes applied to the 


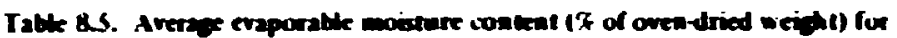
verious ratid positions in ORVL thermed cyliader moded

\begin{tabular}{|c|c|c|c|c|c|c|c|}
\hline \multirow{3}{*}{$\begin{array}{l}\text { Dst. vanie } \\
\text { mestrevase }\end{array}$} & \multicolumn{6}{|c|}{ Rudud dusar.se isum center in.) } & \multirow{3}{*}{ Siatus of lest sertwon } \\
\hline & \multicolumn{3}{|c|}{ +1.5-2n - doam curce } & \multicolumn{3}{|c|}{ 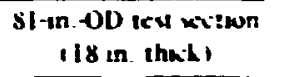 } & \\
\hline & 1.5 & $\mathbf{S . 0}$ & 15.5 & 27.5 & 30.5 & 35 & \\
\hline $1 \mathbf{3 0}$ & & 1.87 & 1.4 & 141 & 1.40 & 1.37 & $75^{\circ} \mathrm{f}$ unsde. $75^{-} / \mathrm{w}$ wisude \\
\hline $1: 3$ & 1.48 & 1.33 & $1 .+6$ & $1 .+5$ & 1.16 & 14 & 105 f mude. $75^{\prime} \mathrm{t}$ cursude \\
\hline ito & 1.49 & 1.53 & 1.40 & $1+7$ & 1.16 & 1.45 & 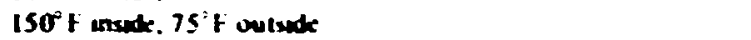 \\
\hline 15 & 1.51 & 1.55 & 1.48 & 1.47 & $1 .+9$ & 1.47 & $150-75 * f$ \\
\hline$\therefore 3$ & $1.5 !$ & 1.55 & 1.47 & 1.46 & 1.48 & 1.47 & $150-75^{\circ} \mathrm{F}$, beliore preswruativn \\
\hline$: 00$ & $i+7$ & 1.51 & 1.46 & 1.4. & 1.16 & 145 & $150-75^{\prime}$ f. pressurued to 700 pos \\
\hline 315 & $1.5 !$ & 1.54 & $1+7$ & $1 .+7$ & 1.28 & 1.47 & Same as for: :16 days \\
\hline +1) & 1.54 & i.57 & 1.5 & 1.4 & 1.4 & 1.4 & Samc as for 236 dar \\
\hline$\because$ & $\therefore:$ : & $\therefore$ & $\because \because$ & $\therefore \vdots$ & $\therefore:=$ & $\therefore:$ & 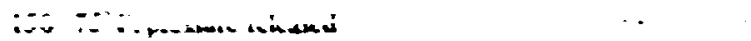 \\
\hline olt & 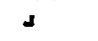 & \pm & 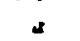 & $1.65^{*}$ & 1.52 & 1.48 & 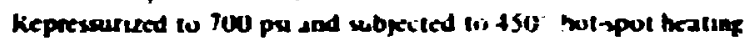 \\
\hline 056 & 1.20 & 1.31 &. .20 & 1.16 & 1.50 & 1.50 & Arket coublown to $150-75^{2} \mathrm{~F}$. di presiure \\
\hline is & 1.23 & 1.29 & 1.19 & 1.43 & $1+8$ & 1.48 & After complete cooldow a is is $-75^{\circ} \mathrm{l}$ and pressure rekesed \\
\hline
\end{tabular}

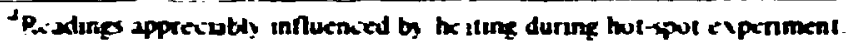

model are the result of the cemperature in-reases. It these (emperature effects are taken ints consideration. It in be concluded that the cepper-epuxy muisture sea! was adequatc lor conditions simulating normal PCRV uperation. Examination of the moislure readings made In the core region alter the hot-spul experiment shows that a small amount of moisture was lost during heating. This is a reasonable conclusion based on the measured temperature profikes. which shiow that a large purtion of the core was subjected to temperatures of 175 to $200^{\circ} \mathrm{F}$.

A similar examination of probe readings for the model test section indicates that the moisture content remained cunsiant during or after the hut-spol experiment. It should be noted that a relativety small portion of this test secitive was subjected to elevaled temperatures ouring the hot-sput heating: in fait. a farly latg portion of the section was iusled to temperatures of $10 n^{\circ} \mathrm{F}$ or lower. which should aicount for the differemies of musture contcnt in the core and test ring. There is also little evidenic of appreciable migration of moisture from insude to outside of the lest section during the course of the experiment exiept for the readings made after the hot-spot heating whikh show a sliph increase in muisture in the outer iwo probe positions in companson with the innermost pusstion. 


\title{
9. HTGR Structural Materials Investigations
}

\author{
P. L. Rıtientiouse
}

Many of the metallic components in the pomany circult ot an HTGR are expusec to temperalures and exwronments of suficient xeverity to result in tumedependent bethivior 11 c. creep. corrussion. or long-term thermal stabulity may be the limiting izitors in theit use). The objectives of this propram are to provide information w improve the bases for 111 determinip: the response of these matenals to loading- 121 ilentifing the influeace of envilunment on tehavior. and 131 formulating siruit. al design methods and falure in. teria. The program was inilated and rlanning begun in the last tixu montis of 197:

\section{I MECHANICAL FRONERTIES OF HTGR STEAM-GENERATOR AND FRIMARY CIRCUIT MateRIals}

\section{$\begin{array}{lll}\text { C. R. Brinkman } & \text { W. R. Martm } & \text { P. L. Rittenhouse }\end{array}$}

The putpose of this work is to generate the elevated. temperature meshani:al property data needed for validation of the structural design technoling of the HTGR siram generator and frimaryirituil cominunents. Creep behavior will be studied in stress-nupture and long-term ireep tesis conducted in helium atmospheres contaminated with $\mathrm{H}_{2}-\mathrm{H}_{2} \mathrm{O}$. $\mathrm{CO} . \mathrm{CO}_{2}$. and $\mathrm{CH}_{4}$ to leveis consustent with these expected in the primary coolant. Fatigue. creep-fatigue interactions. stress relaxation. and irat growit dynamics will also to investigated. and the effeits of thermal aging on properties will be determined where appiopriate. Materials cutrently scheduled to studied in approximate urder of priority are Incolos 800 . $21 / 4 \mathrm{Cr}$ I Mo steel. HastelIos X. 1010 1020 steel. Ininnel 617. Hastelloy S. and high-alloy ferritu steels.
Wirk was initaled in December 1973 to study subiritial iraik-prowth sates in incoxy 800 and $21 / 4 C_{r} 1$ Mo steel in approprate atmospheres at temperatures to $760^{\circ} \mathrm{C} 1: 400^{\circ} \mathrm{Fl}$.

\subsection{WELDABILITY OF HTGR MATERLALS AND MECHANKAL FROTERTIES OF WELDMENTS}

\section{P. L. Ritienhouse C. M. Slaughier}

This phase of the program will evaluate the weldabilit! of HTGR primary ircuit materials. Weidments of Inichoy 800 in Inioloy $\mathbf{8 0 0}$ (with Imonel os and 18: fuler metalst and Iniolur 800 to $2 / 4 \mathrm{Cr} / \mathrm{Mo}$ sicel (with Inconel 8 2 filler mela!) will recerve emphasis early in the program. Later studes will be direited to the welding of $21 / 2 \mathrm{Cr} 1$ Yo steel to Inwitarbon steel and to the welding of the Hastelloy and Inire: s 17 . In all cases. the weldments (weld and heat-affected rones) will be evaluated by nondestruitice examinations and through tensile and siress-rupture tests. Sil uficant effort will be directed to this work beginning in mid-1974.

\subsection{STRUCTURAL DESTEN METHODS FOR HTGR COMPONENTS}

This segment of the proteram wull develop design analysis methods ior evaluation of the performance of HTGR primañiricult iomponents. Specifically. modets will be formulated f.,r predinting the behavior of materials under viting mullaxial loading and thermal conditions. Further. tesis will be inducted to validate these models. This work will become aitive late ir 1974. 


\section{CORROSION OF HTGR STEAMGENERATOK MATERIALS}

\section{J. H. DeVin HS Isas) P. L. Ritteathurse}

One of the roure intizal immponeats of the HTCR ?humal ariall is the stam enerator. and. Is in m! steam supply sostem. the cortuxion betinim of the steam-eneratur materals is of grear imporiagic Plans are to estuate the general. pitimg. and stress corroswon of HTCR stean-exretalor materals throwin a senes of

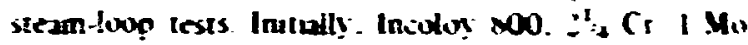
steel. and approprate weldments of these maternsi, will be tesced under supetheal. erapuralur. and diemating

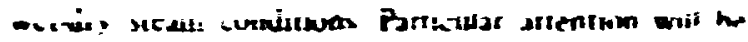
Gen to the pertiomance of exparator-seition maienals under iuctioivas of boding heat tramier The refereace water themustry for the steam-urrosion tests aill be Iypual of HTCR feedwater. but isis will also be conduited mith additions of $\mathrm{Cl}^{-}$. oxygen. and $\mathrm{Na}^{*}$ to evaluste corrosion behanor under off-desygn iundttruns. Potential materials for future HTGR steameenerator applikation lez. Ferntik steels wih $\psi$; and gealer chromium and Inionel 61 ? I wall be examined as this program progresses.

Durng this repon pernod plans were developed for

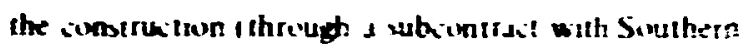
Su-ies: Enpaneeringl of a h:gh-iempegture si:am corruston lum at the Burim stem pian? in Flond. This lony is designed $x$ that if whe pusubic i.. Insirument tik curroshn speimens A maxumum ire.

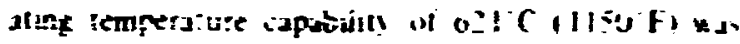

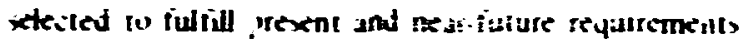
lix the corrosion testug of HTGR seam keneistw materuals. This combunaikn of high temperjture $\mathrm{And}$

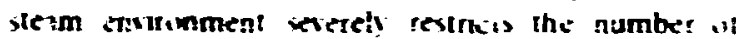
sulibble applkable mutcrabs iog insiruilline of th: lowp. Imimei of was thusen beisuxe it 11 manserses the best balance of stength trot therma: subitit . 1 ,

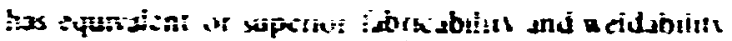
stal $i: i$ is ienz chasuered ion ux on HIGR vicum enerators

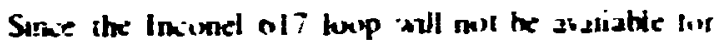
opetation untal iale 19?4. intul cortosinn tests of FTCR materials will be cinducted in two custing lioups opersicd by Sivuthern Vuikear Ingencerung Onc of these loups will be run uraki syth super. heal saturated seam inndirors and the wher with superhealed steam. Fabridten si the curstatitind pressurved-tube speimens to be employ ed in insth ot these lexps is under ais 


\title{
10. HTGR Fission Product Technology
}

\author{
H. J. de Sirtudil
}

Fissinn produst dwersbuim studiev ensole HTGR

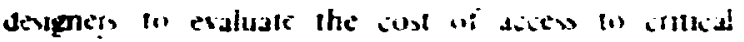

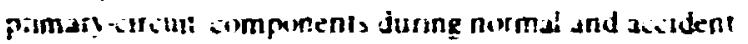

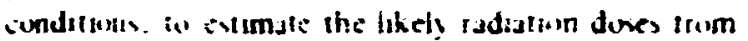

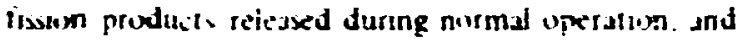

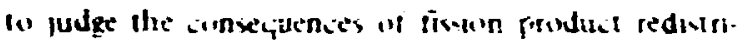
buttom, fullowing duidents

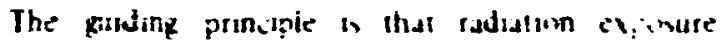

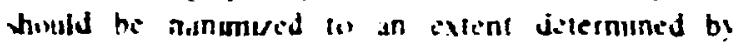

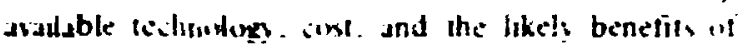

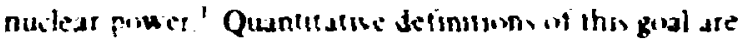
stili in implere: particularly with reterence in the integrated dine that mat be aiquired during thane rate

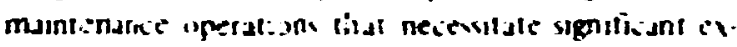
puxure of a larger than normsl populsturn wi wivker. Also. ciunomi pendiles sivilated witl: the prexenct of gamma emiters in the curiur have ind been assessed Howeres. !f would seem prudent in altempt wing cintine the maximum proportion of lission prodist, to the core in arde: (1) sumultaneously minimuse putential deaiands on the outer fissun pruduct batriers of the plant wich as the prestressed simitele reaitur sexsel IFCRV i liner und the xiondary innisnment cionimic and radiologesil impaits of the inventury if amms emitters in the primaty ericult. and the siuice term of the designbasss aident. At the sunt lime. une would be maximiang inspectability and aciessibulity befior: and after :-..dents in which fissm products mat be distributed heyind the PCRV

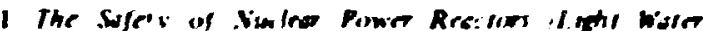

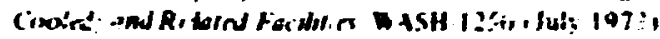

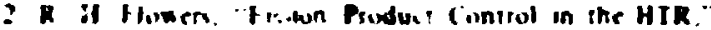

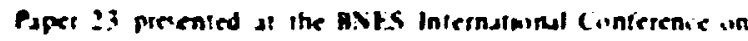

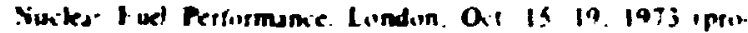
iedings to te publisheds
The eurrent reterence flet is a Tru-Bi: combination in which $-5 \sigma^{-}$, wh the fiswin sucur in the less-setentive Bis tuel We are curtersi: : ncerned with determining the retentsce sithls of a low-empersture isotropic IIII Binmasied ThO: luel as that the ant-benefit esuation an be mure fully disiused

Oiner work an finslem prods at conterd is dexrrbed in Chupter 1:

\section{I MATHFMATICAI. AN.ALYYSIS OF FISSION PRODUCT RELEASE FROM PYROC ARBOACOATED FUEL PARTICLES}

\section{R. B. Erons III M. T Morgan}

The ulumali sbicince of the phax of the propsum I: a) desise a vald "ururic term" that wil reflest the insempronduci-release beharior of costed parlicies ande: reaciors cinditions. This requates consucieratum at isrint solutums if the heal equalion. expressed ir. icrm, of xelected mass iransier parameters. in order $1 "$ velrit + suisble "diffusion model." Ii the mudel will derivibe release within a rexitor it should alsu desinbe release as it is measured under less inmplicaled labora. iny ionditions Our curreat apprasth has heen to conienirale on releaxe as if ixiurs under imtralled Iborstory sondilums. with the realwation that the results must be refined io imilude additional ano mure itmplicated isclors assilated with hiph-temperaturt Irradision

Since a release-vs-ime curve fof a laboralon annealing expenment must eventually indicate depietion effecils. our inital efforts ioncerned prosible applizainn of in' intepaled-rate equations that were tharai. terized by a cintinuiridy decteaung droving mitential 


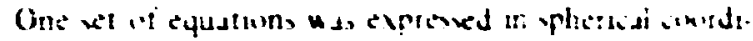

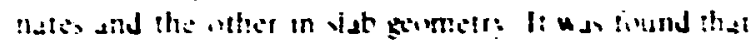

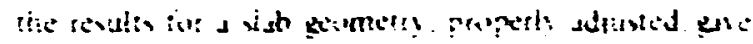

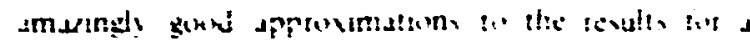

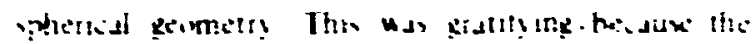
imples vab geomells resits isn be axed for intisl

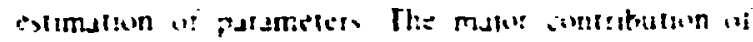

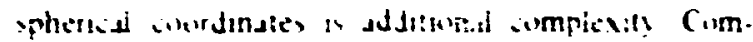

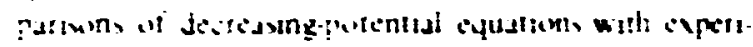

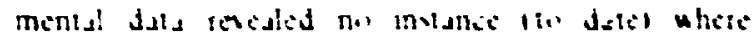

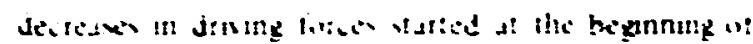

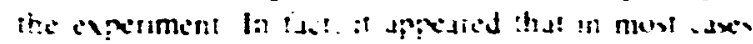

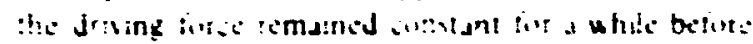

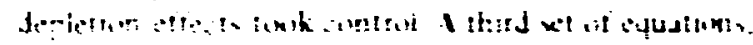

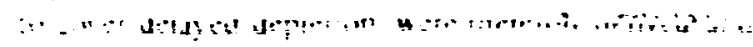

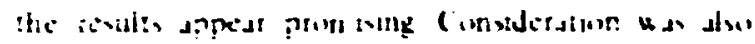

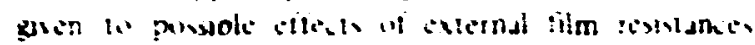

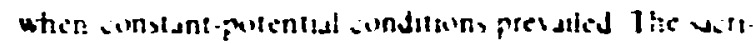

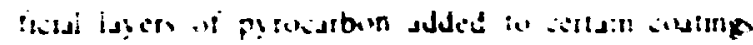

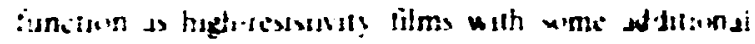
ipsitt?

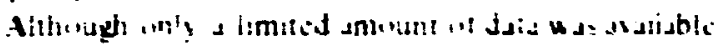

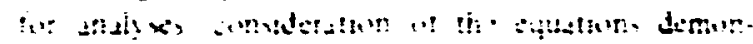

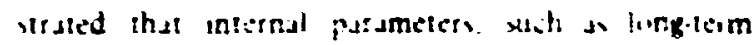

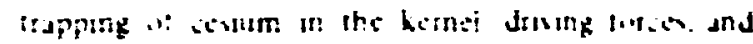

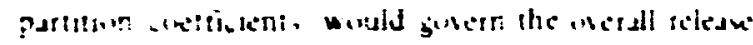

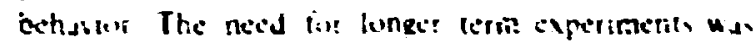

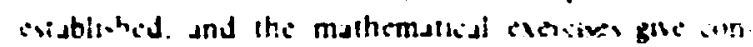

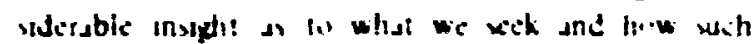

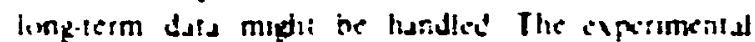

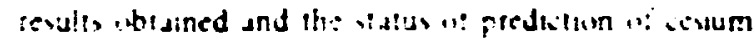

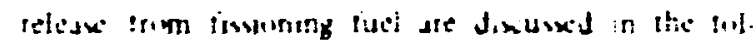
i, initig xituns

\subsection{FOSTIRRADATION MEASLREMENTS OF CESIUM RELEASE}
II T Ningan
K B Esmillt
R L. T, Mns
L. L Fur.luld

ixperimental work has conicritraled on the notision if sesum. besisce. of the metslik fissorr prodicts cevum. slronlium. and bar:um. scsum pribably tas the

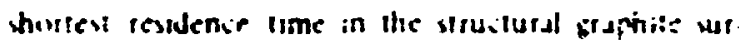
rounding the fisel Cevum retention by the stre whus iikels $\ldots$ be Jetermined 1, a gredier evtent by the

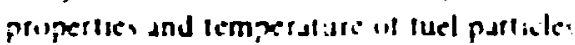

A Jislingushing listur: "l uur experimenial lects. nique for studying cestum reles is ine lime requited in pe:firm the experimen' st teslioth temperstures This.

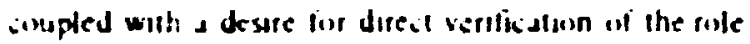
of varusus paramicrs and compunents. prompled de

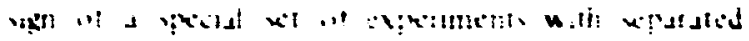

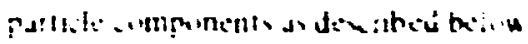

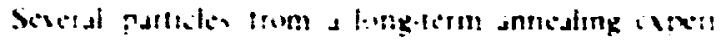

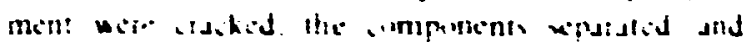

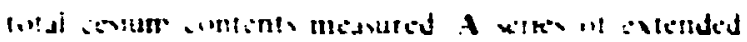

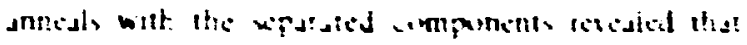

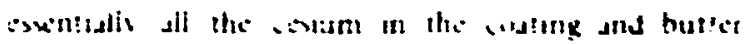

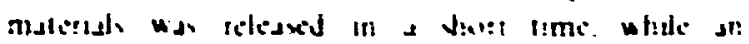

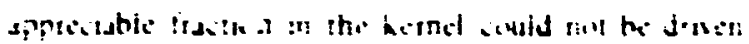

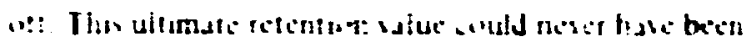

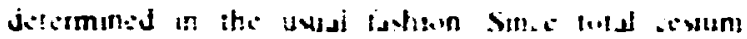

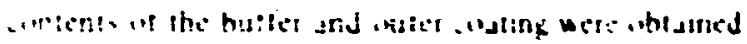

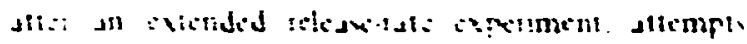

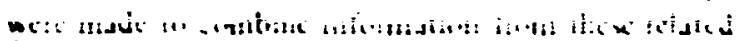

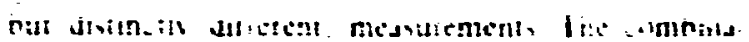

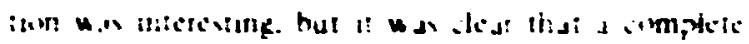

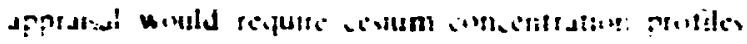

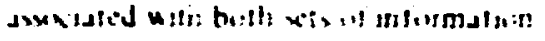

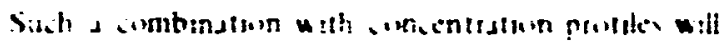

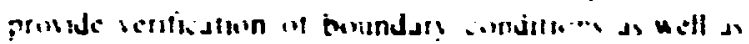

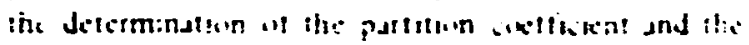

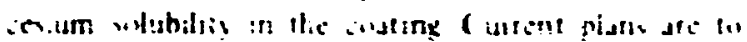

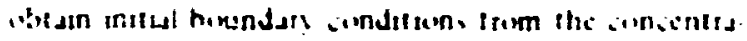

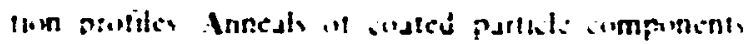

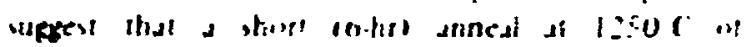

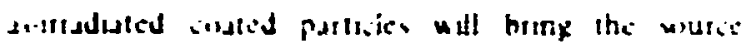
rep:" on (n) cquilibrium

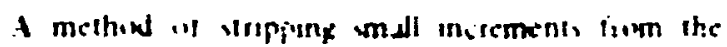

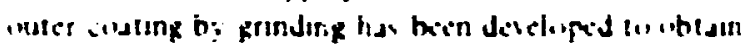

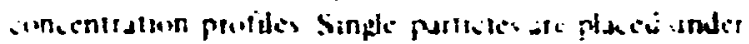

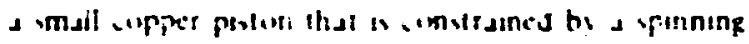

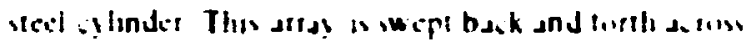

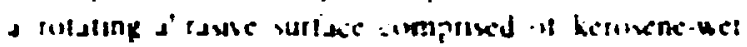
emer! paper inov tl semented in, that Jisk. The

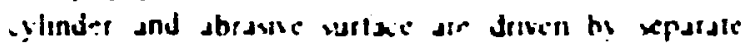
molors Entraduled partkies nat. been pround up i".

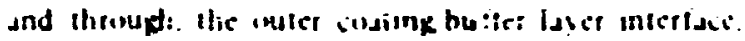
and spherkil! has ben maini. and up li. but noll

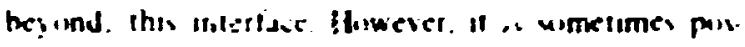
stble w tepan priseskil! w the kern butter intertsite Nepproset.:d

Anwher maper patl of eut elint in the yed wall

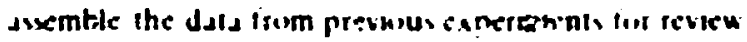

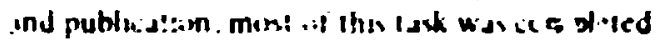

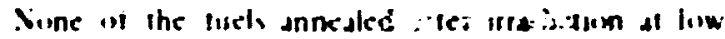
Icmperstures relesxed all their in:onsl it. in Between is and 'w": il the colum we' dppostly being retsined in slles irum whith reledse $x_{\alpha}$ a ther inipun. sible is very Jow. wnic these experimenis la od resetal thousund hisur: This lisniling release phen : venun is illustrated in $F: R$. 101 , whese the reledse-vi-liore curve 


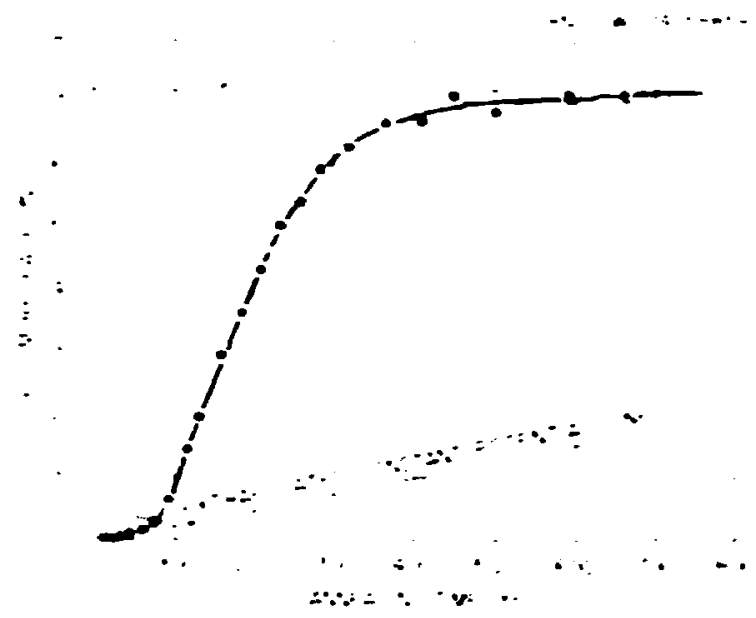

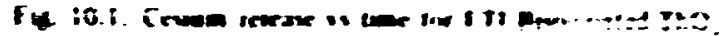

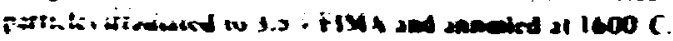

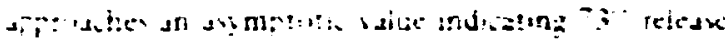

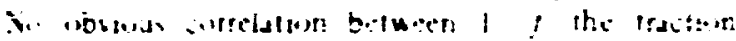

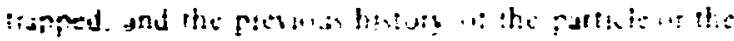

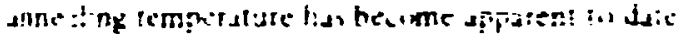

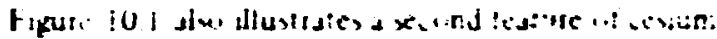

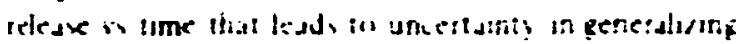

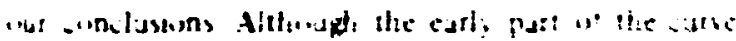

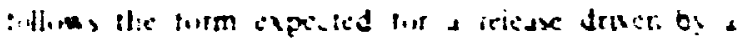

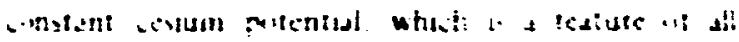

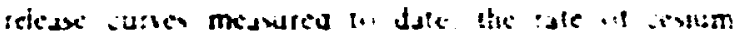

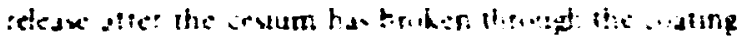

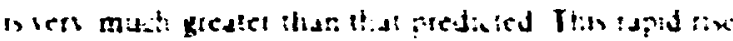

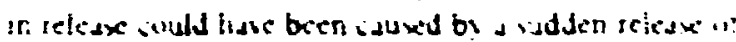

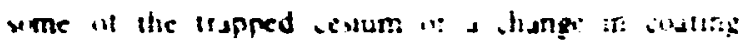

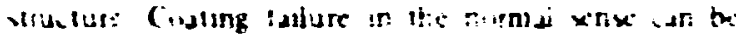

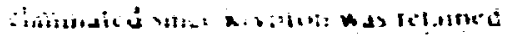

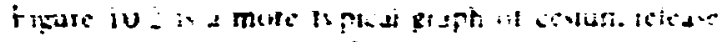

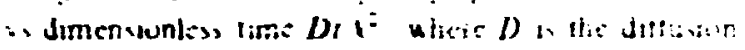

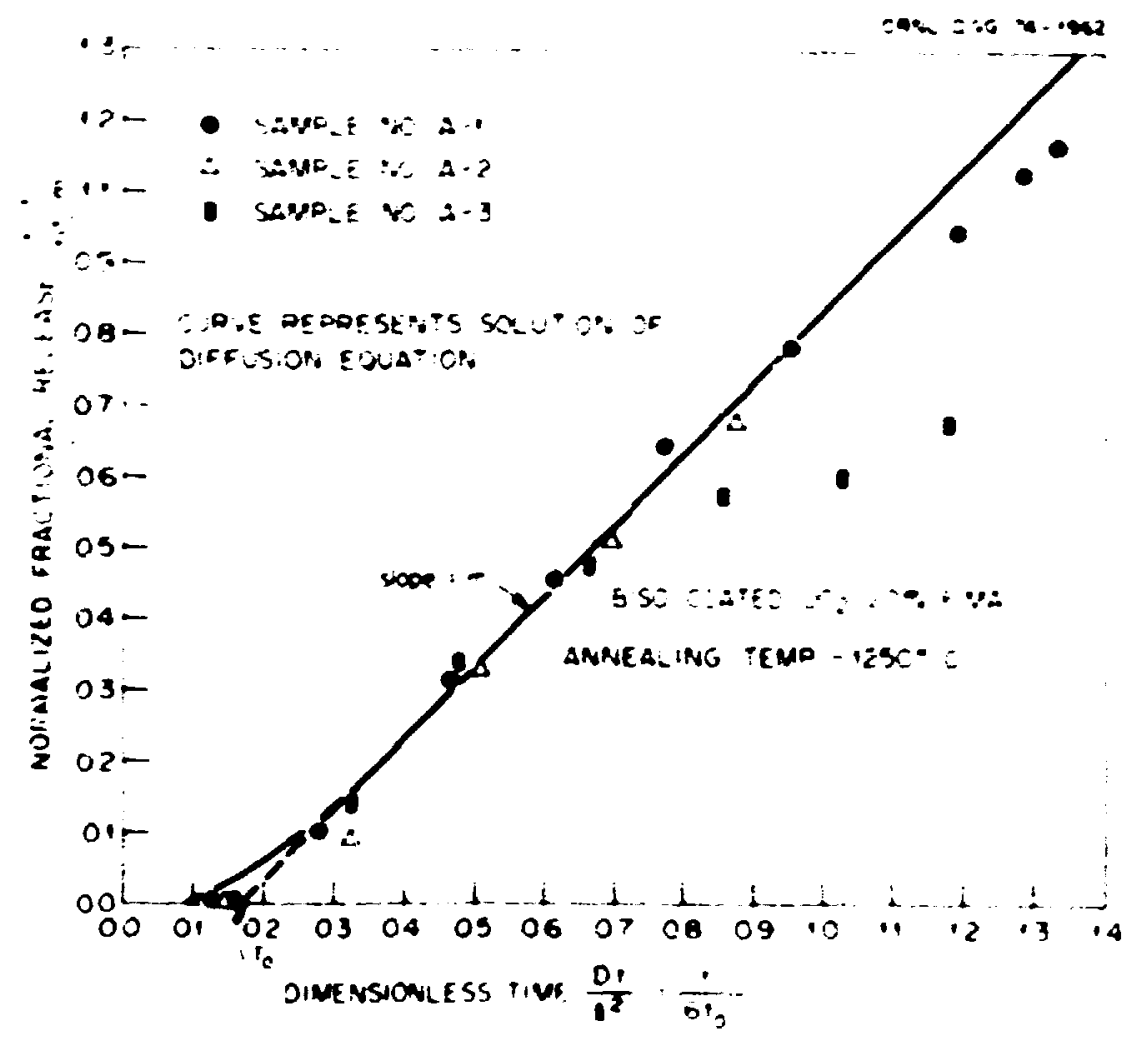

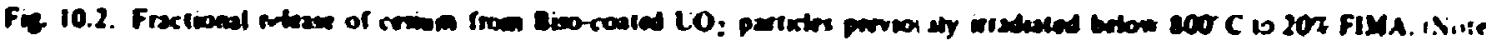

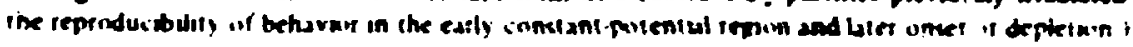




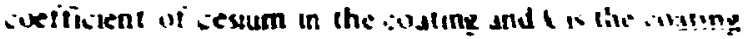
thiskness. This reledse follows a cinstunt-putentul line fir sume tume and then drops oft as a result if sepletion of the kernel. Mathematial Jexiption at this curve requires dentification of the purnt $\mathrm{dt}$ which depierion of the surarite regum bezans and the partition cietilikent of sesum between the kemel and the cuatung when thi cestum potental is ni" ionstant. Approprately nomalired reicuse surves have bern cirund tube quite reproducture in the constant-potential reginn

The release of sestum irom particles ivated wrt.1 high-temperalure isuttuph (HTII pyrurarbon was s:0stantally belin that wi low-temperature isutropk (LTI) sora irbingiouled fuels abine $1: 50^{\circ} \mathrm{C}$.

\section{ig.3 STATUS OF ESTLMA IIUN OF CESUM RELEASE FonM Eged COATẼ FUELS DURING IRRADAATION}

\section{H. J. de Sorduidl R. B. EusnsIII M. M.rean}

It is stestly premsture to sigue that the ThO a kerned wall play ampartan" part in contrulling cevum reledex" irom a Btsmates tho: iuel wnit there is no, published exidence to support the propusilion that irspping wall be mantaned durng hugh-temperature irradiatiun. S.Ald-siale phenimend such d trapping are known io be sensitive to irr didation

Seciund. we annot sel detine a unsenative trapping irditun that would be significantly usetul fice. gredict then rerot.

Therefire. one is foried th estimate sesium reledse using a model in whish only the coating ion!rols release. Cimbination of the amplemeritan resulis ab:aned b! Burnetle and file suthors : ields the fillimine selustion tior $D_{1}$, in LII pyrisiabion

$$
\text { MC, }=053 x_{1}-\text {, nookr }: \mathrm{m}^{*} \mathrm{~N}
$$

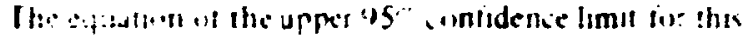
xineri, date wllectun w

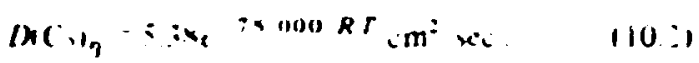

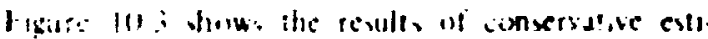

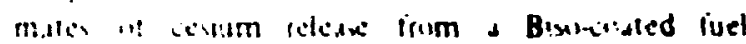

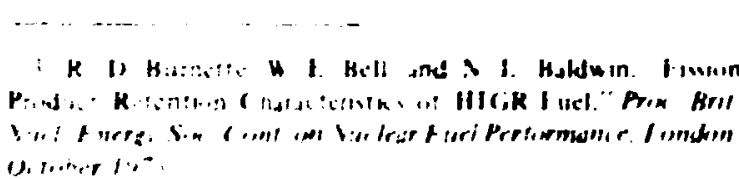

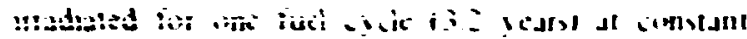

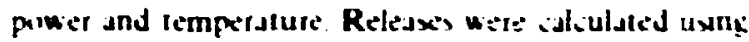

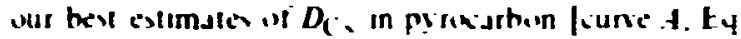

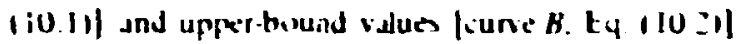

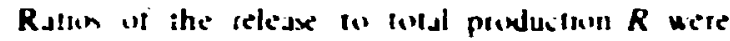
imputed in sish geometry usng a correciled solutun

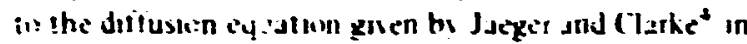

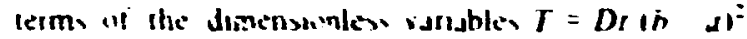
ind $t=$ it $h$ ab d

$$
\left.R=1 \quad \frac{I+Z}{I} ; \frac{1+11 . T}{T}\right)
$$

whet: $f_{i}$ is a tabuluted funclesn of $l$, and $T$. Ihe rewa:"

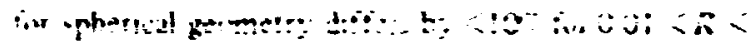

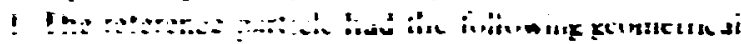
harkiterislis kemel dumetes. $\$ 00 \mu m$. butier that

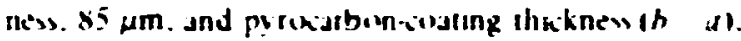

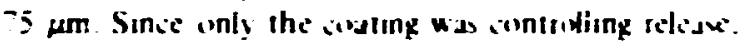
the y urice was reprexented as a well-sturred iluid os thickness a $1 \vdots: 3 \mathrm{uml}$ in which long-lised cevum was being senerded at a cinstani Idic The patum

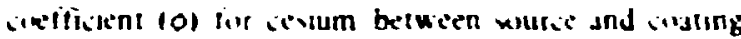
was raken d unas. A ker" andentration was muntuned at the uuler ha:undars

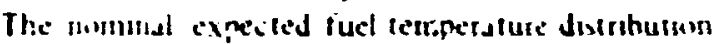

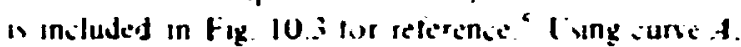

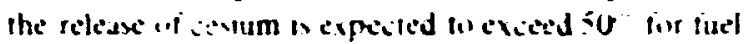

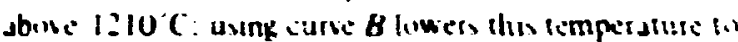

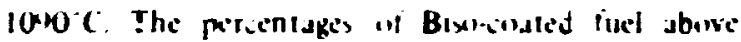

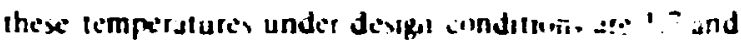
4.5 respestively. The sverdge ${ }^{13}$ C, inventures"

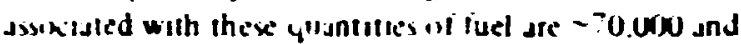
- 1 w0.000 CI. The retentwn uf ceutum by the struituid gtapille varrounding thes relatnely hot luel is expected tw be sgnificant. bus :alsulations! methods remun unprosed

Relienturn wi cesum by the kernel could lower curves $f$ and $B$ in Fig. 10.3 by from 3 lo is time baxd on

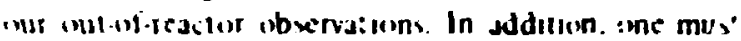
insider that real fuel particles du not spend 3.2 years at content lempersture. The beneticial ellect of a redu-iun in the lime spent di anen temperature may

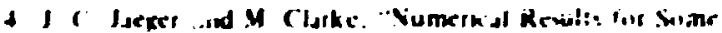

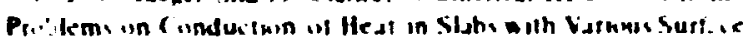
( inditums" Phul Mor 38. 314 1 1447,

5 Detmand Power a Lant (iv. Summa Power Statkin.

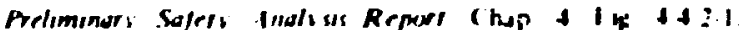
Dinket $511+511,19731$

"Ihd (hap 11. Tsbke II I I: 


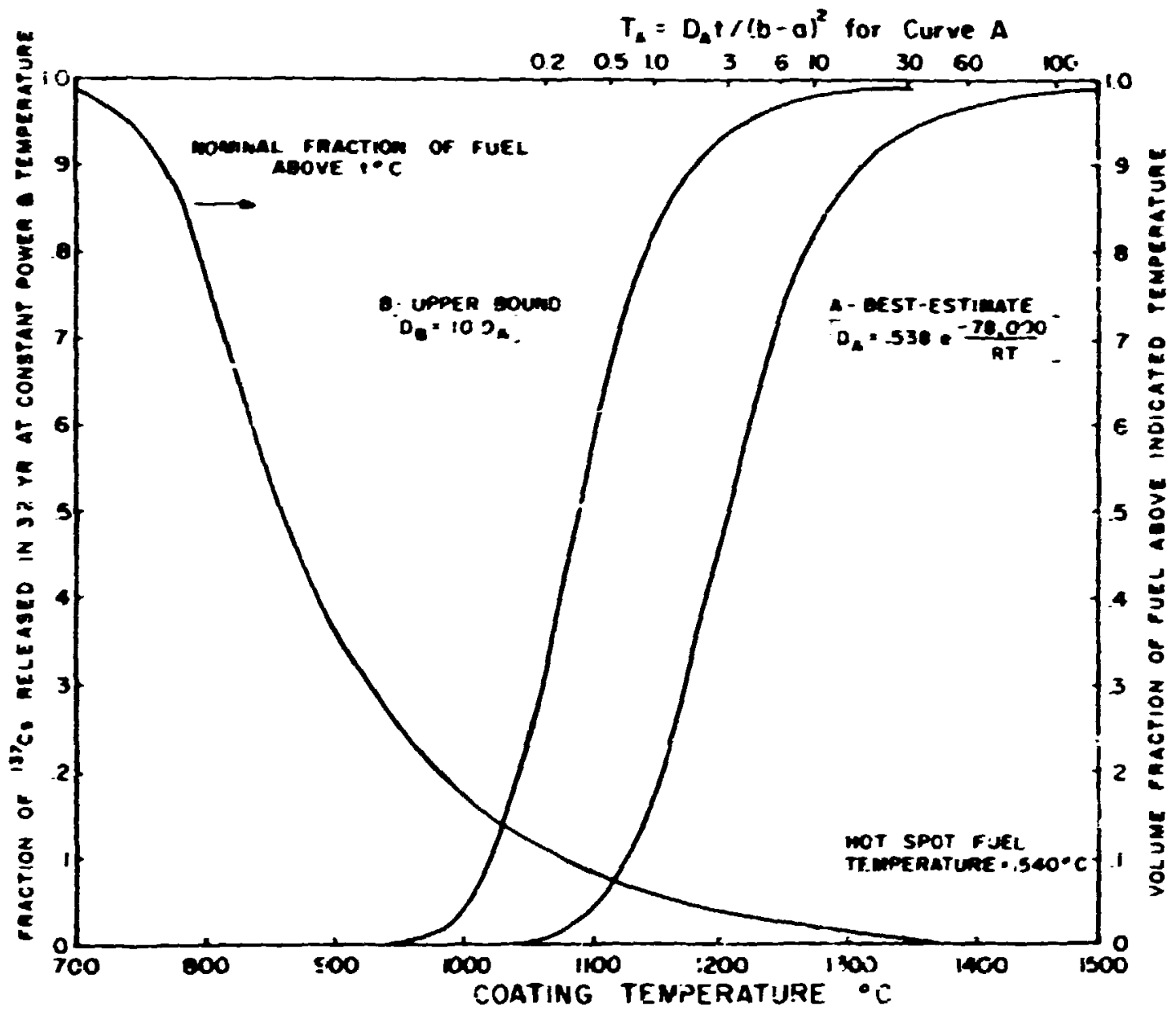

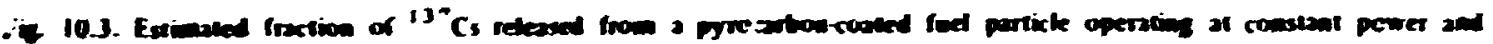

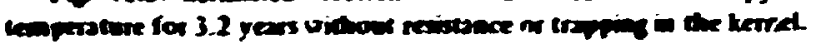

be vasualued using the values oi Dr $\sigma^{*}$ a: the top of Fig. 10.3. Secind. consiant-purtentul conditions that would prevent lursher increases in the cesaum drinng force with tume may iccur. Substitution or diffusion data for prostuction cooling ian be expected to reduce une of the pap between curces $A$ and $B$. However. not enough data are presantly avalabh is determine whether Bisu-cinated Tho: luet ian control cesium release well enrigh to meet potental requirements for pnmary. incuil ancess.
The goals of iurrent research and development are in determine the significance of the role of the ITh.CDO: ker:et in cesium retention. to imprive whit: core rek ase estimates. and to define realistli guals for the cortrol of iesium release from the core. Other paris of tho program are engaged in reduing thermal resistanies in oloxik-lype elements which could lead in lower finel temperatures. 


\title{
11. HT(iR Fül Chemistry
}

\author{
H. J. de Nurdwall
}

This isk is dewoled to the underst.snding. yuant: isn.. and wh:re appropriate. developiza techniques to inilust: this shemical ellects that could lireit the nertiormarle if HTGR fi.-t particis. The work : ear has desalt manly with theor. ial and experimental analyses

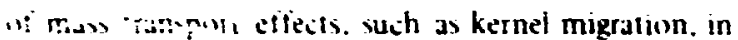
!iTGR oxide tueb. These inalyxes wete advanied ?tunticantly hy the suitability uf experimental measurement, is is nel migration from the lucls irradiation pregram dersibed in Se:tion $7 . t$ In-rederor experinients with arhide- $\cdots$ r:tride-containing LO: particles were initaled lo eva uate the possible atitigation of Rerriei migration b: heve means. A progi $m$ liur the miessarement of gas pirssure and ixygen potential in

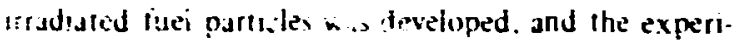
men!: appuratur wa, constructct and resled. Literature

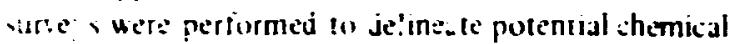
inesn. fir imfroving the rate:tion of cesium. Jariur.: and virontium by oxide kernzis.

\section{II.I MASS TRANSRORT IN FUE_ PARTIC!'s's IN A TEMPERATURE GRADICA}

\section{T. B Lindem:}

The phenomeron of fuel kernel anigration in a ifictmal grdulent is widely whicrved in the ax:de and ab:de funl partales uxed in HTCRs. The rate of migralun i. ger erally abserved to be sufficient to establish uperatic nal limits on the time temperature puwer-denuty re's'wnships that can: specified in the design of an HTGR core. It has heen difficult io wablish the at:-controlling mechanism of migraturn and hense te propese silubie mears of mitigation. During ions. method that an be uxed in establish :xperim:ntally the rato-cuntrolling mechanien were: developed and applied to $\|$ a analysis of in-reactor kernel migratio: obsenced in coated partciles of $\mathrm{LO}$ : $\mathrm{Th}_{1} \mathrm{l}_{2} \mathrm{O}_{2}$. and $\mathrm{ThO}_{2}$.

Thice iasses of migration mectanism were :an. sidered: gas-solid reactions. the widely proposed $\mathrm{CO}^{-\mathrm{CO}_{2}}$ gaseous diflusion. and solid-state diffusion actoss the fuel kernel.' Expressions for the:r ratcs of migration were developed. : Ill rate expressions had the Arrhenius form. but with temperature-depertent pre. exponential trerms. All suffered from a practical insufitciency, that is. the values of many of the constants had not been meastied. However. esimales of the rale of carbon transfier by $\mathrm{COCO}$, diftusion in fission gas and by a reaction-controlled mechanism were made. Breach-

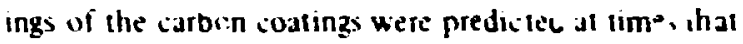
were orders of maguilude iess than those bisierved experimentally.

Further theorecical inaly ses led to a geineral experimental methud for est blishing the rate:onirolling mechanism. The ration the predicted kernel migration in a particle locales at any radius in a fuel rod cross section to that .. \& raterence position. sonveniently the midradius. conta.n: only the activation energy and the cal-ulable teroerature and temperature gradient: the preexporiential constants cancel. The shape of a plot of this :at.o vs radius turns aut to be tharacteristic of a given nechanism and relatirely insarsitive in the activation energy. The plut may thereforc be used to distin'guisiti different meahanisms if sufficicntly precise data are avalabic.

1. T. B. Lindener and $H$. J de Nordwall. An Analisis of

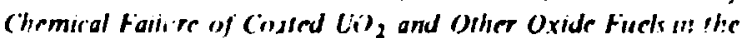

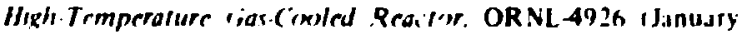
19741 
The hirst xt wi un-redius expermmental kernel migr:a

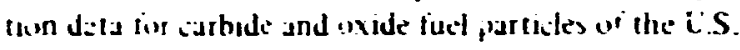
de tgen meisme arail:ble in 197:: these metallingraphwally derives data were arialyged by the exhniques axiribed abowe. ${ }^{3}$ Tle analyes for the arbide fuel rids. in wht it the arbolde migration is known to be cintrolled by solid-state diffusion. "s demonstrated that it : rato : :chnique for analysis of kernel migration indered ytelded :.e theoretically predicted beilavior. The subseyuent analy is of the $\mathrm{LO}_{2}$. Th, $\mathrm{I}_{2} \mathrm{O}_{2}$. $\mathrm{Jr}_{\mathrm{ThO}}$ oxude kernel migla!ion exrablished hat the migraii in rate was definitel: not controlled by the rate of $\mathrm{COCO}$ : diflusion $\mathrm{a}$ : long as the pressure of arbon monoxide wis not buitired b: some speritic themial equilibrium. Furthermore, the dats indicated that a solid-state ditfusion mechanism was most likely controlling the kerael migr: ion rate.

A solid-state "kernel rigiztion coefficient" (KMC) was ialculaled for each paiticle in the several irraliation experiments. The K:IC is detined as

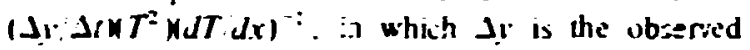
migration in time $\mathcal{J}$. These cun ifi-ients. obtained from 400 to $2000^{\circ} \mathrm{C}$. are shown in Fig. $: 1.1111 .3$. The order of stability was $\mathrm{UO}_{2}<\mathrm{Th}_{1}=\mathrm{L}_{2} \mathrm{O}_{2}<\mathrm{ThO}_{2}$. with th: EMC for ThO, being aboui the sime as that published ${ }^{3}$ for unirradialed ThC. The K.Me fir ThO, wid net exhibit any burnun dependence in the burnup ringe 0.3 to 14;: FIMA flissions per initial heary meta? atum). Considerable additional in a whr fue! testing is under way lo improve the statistics of these correlations and to prove their applicatility at irradiation times beyound the present raige of 30 to $27+$ days

Out-ri-renctor studies of mass iransport in unirradiated siated particles placed in a temperature gradient have just begun.

Another area of interest is the use of secund-phase addition: to oxide kerncls to reduce the rate of kernel migrafion. parlicularly in $\mathrm{LO}_{2}$. The basic. though unsubstantiated. working premise has been that lowering of the oxygen chemical potential $\left(P_{C}\right)$ within the

2. R. A Olvi.d el al. An Imodiasion of Candicale HTLiR firls in the H.I and H.2 Copsulr. ORNL-TM+397 IW be issuedi.

i. T. B. Lindemer and R. A. Okisd. HTGR fium Nernel Migration Dato for : he Th.U.C.O Sirsem as of A Anl 1. 1974. O)NLL-TM-4493 (II' te issued).

4. T. D. Gulden. "Carbon Thermal Difiuson in the UC, $f$ Syvem." J Amer Cersm. Sor 55. 14 181;972).

S.C. B. Sicofl and O. M. Sisnsfield. Siability of Irrodiated isoud.Particle fiuels in a Temperalure riradicnt. GulfG1.A!?181 11972). uxide njrticles b; themical butfering will lead to lower

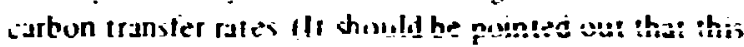
ation may be in conflict with the requirements for retention of the fission products. whikh oxygen polential: there a aighes $P_{C O}$ is desiratle.) Buffering additives such as $\mathrm{CeO}_{2}$ : $\mathrm{Sr}$ have beer prop,used in the literature. while we have in-reatior tests (HRB-? and HRB- $/$ ) w i coated particles containing $\mathrm{CO}$; and seiond-phase $L C_{2}$ or $\mathrm{U}_{2} \mathrm{~N}_{3}$ Such testing is a basic requirement of these investigations becuuse it is presently not possible to predict the shemikal beh:-ing of $75 \%$ FIMt wxide fuel. th:t is. fuel with a fission product to uranium ratio of 6 at the end of life.

\subsection{GAS PRESSURE MEASUREMENTS IN COATED PARTKLIES}

\section{T. B. Lindemer}

An experimental program has been intiated t. measure the axygen reiesse (as carbon monoxide) fro'n irradiated oxidecoated paticles as a function of fission derejty and temperature. The measurements will be unique $f . u$ oxide fuels of the L.S. design a:1 will provide 3 direct ineans for establishing th: overall themical bchavior of cis axide-forming fision prod. ucts. Such information is needed boun for the theoretical analysis of mas: tansport and fission product in oxide fusls and for th: hydraulic design of the particie coating. The reiease of krypion and xenon will also be measuied.

An apparatis to r.:eastrre the number of moles af carbon munoxide and krypton nius xenon released an irushing a hol irradiatc! ioated particle has been built and tested. The correspor nding particle internal pressure is deiermined using an estimate of the totai aciessibie volume in the kernel ard buffer regio:s made from particle dimensions.

A diagrarl of the apparatus is snown in Fig. 11.1 . The various chanbers were built from slandard high-vdiuum parts. A measurement is nade by heating the particle in vacuo 11: the desired icmperalure, which nay range up to $2000^{\prime} \mathrm{C}$. allowing it to degas. and then imultarie. susly er:shing and cooling it rapidly (1) a temperature at whicl no further reaction between uxides and carbun can tak: place. The heat from the small particle and the light graphite heater is dissipated by radiation or absorbed by the conl anvil and the crusher. The otal quanitity of released gas, now held in $1385-\mathrm{cm}^{3}$ calibrated volume. is determined by measuring the pressure with a sensitive capacitance manometer. Reac. tiv: gases are then removed using a titanium filament at 


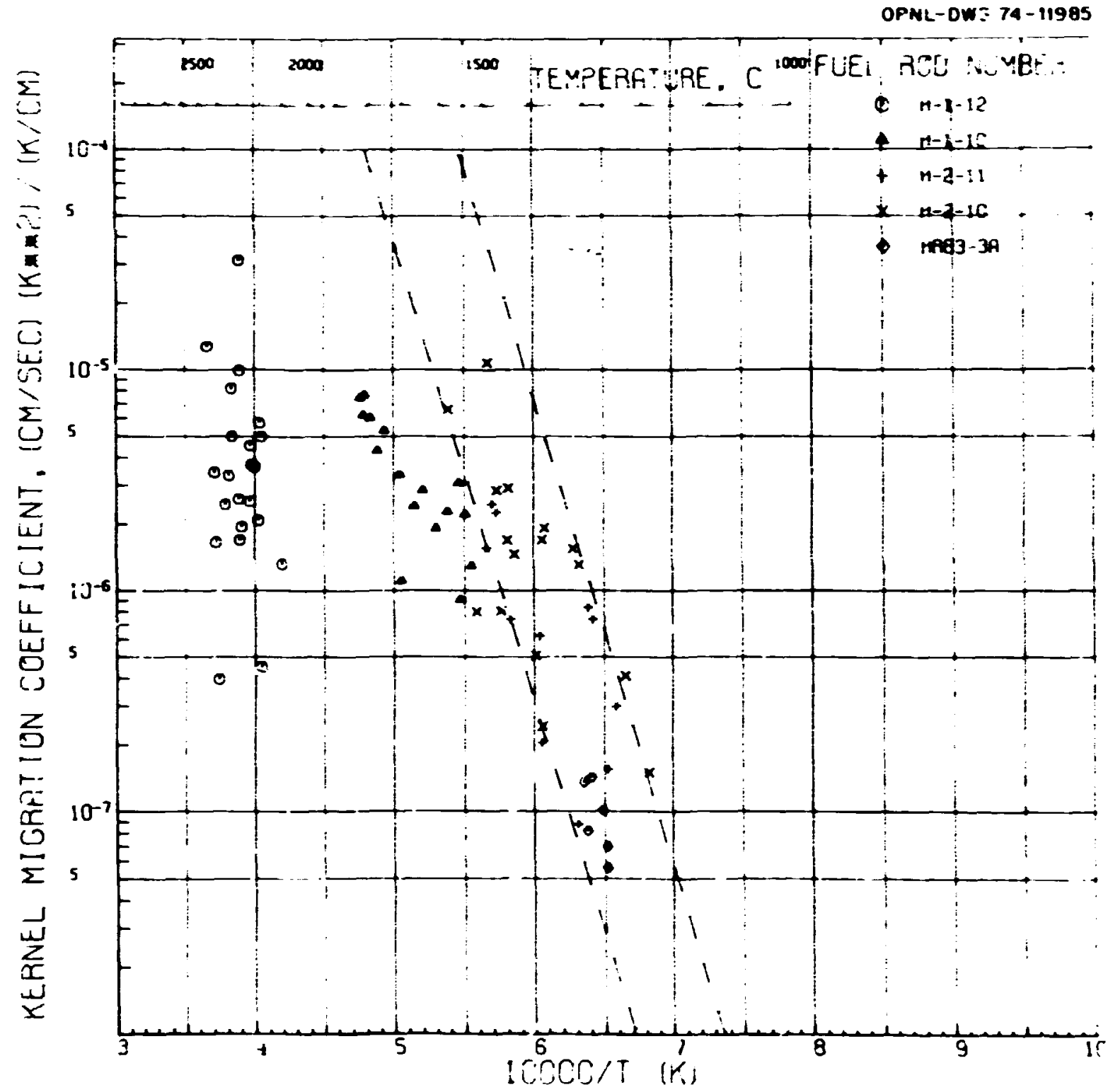

Fi. I I.I. In-reactor kernel mimption coeffetents for Bisocoated TMO, irradated in the HFIR and ETR facilities. Alwo shown for comparion are the 95 ; confidence limits for out af-reactor miptation of unirradated ThC 2 (Ref. SI. 


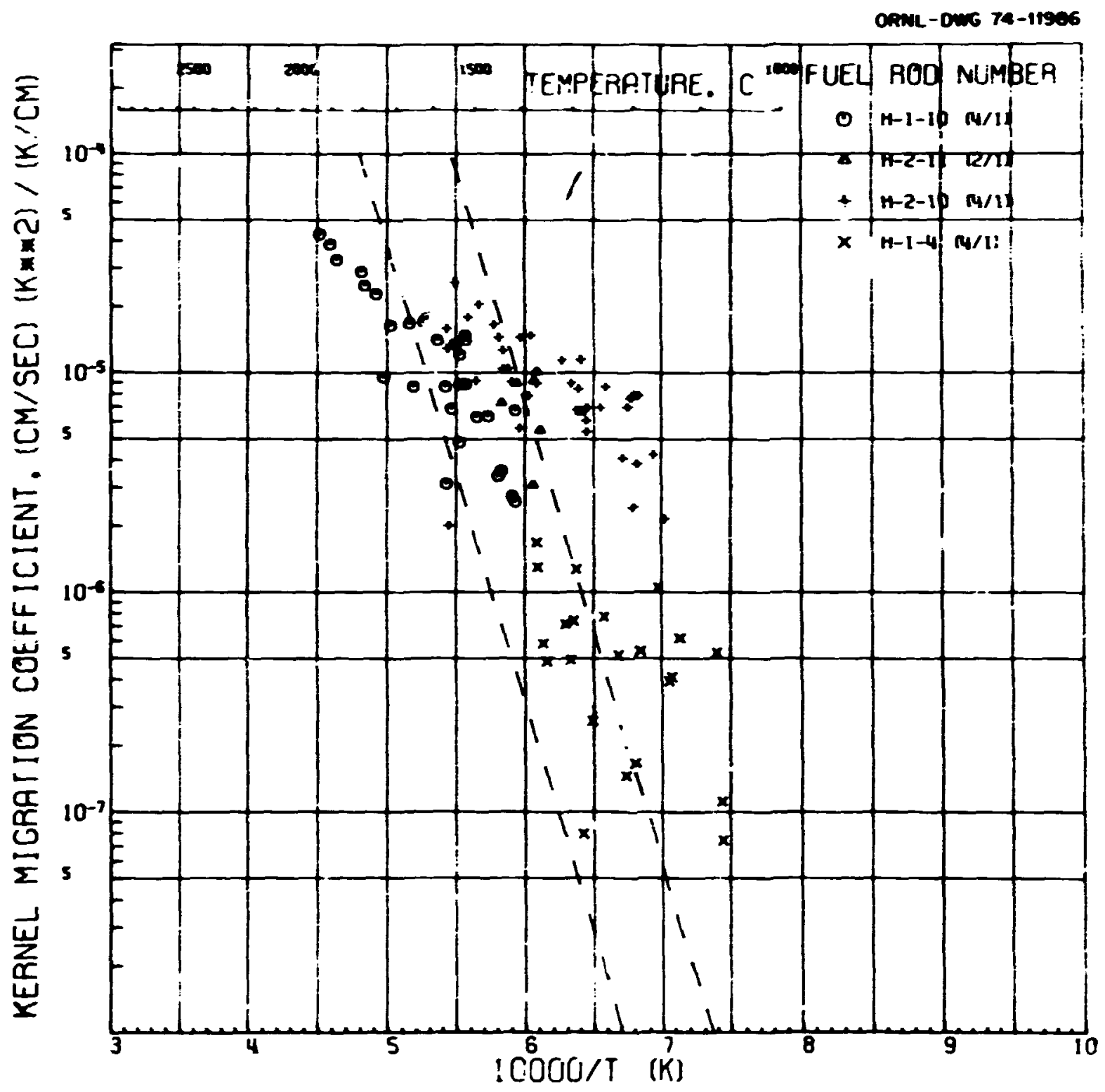

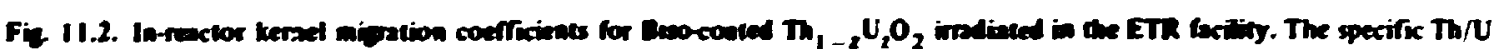
ration are piven in the kegend with each fuet ind mumbet. Alo shom tor cosuparison are the $95 \%$ confidence binits for out-of-rexctor mingation of unirractuied $\mathrm{ThC}_{2}$ IRef. 5 ). 


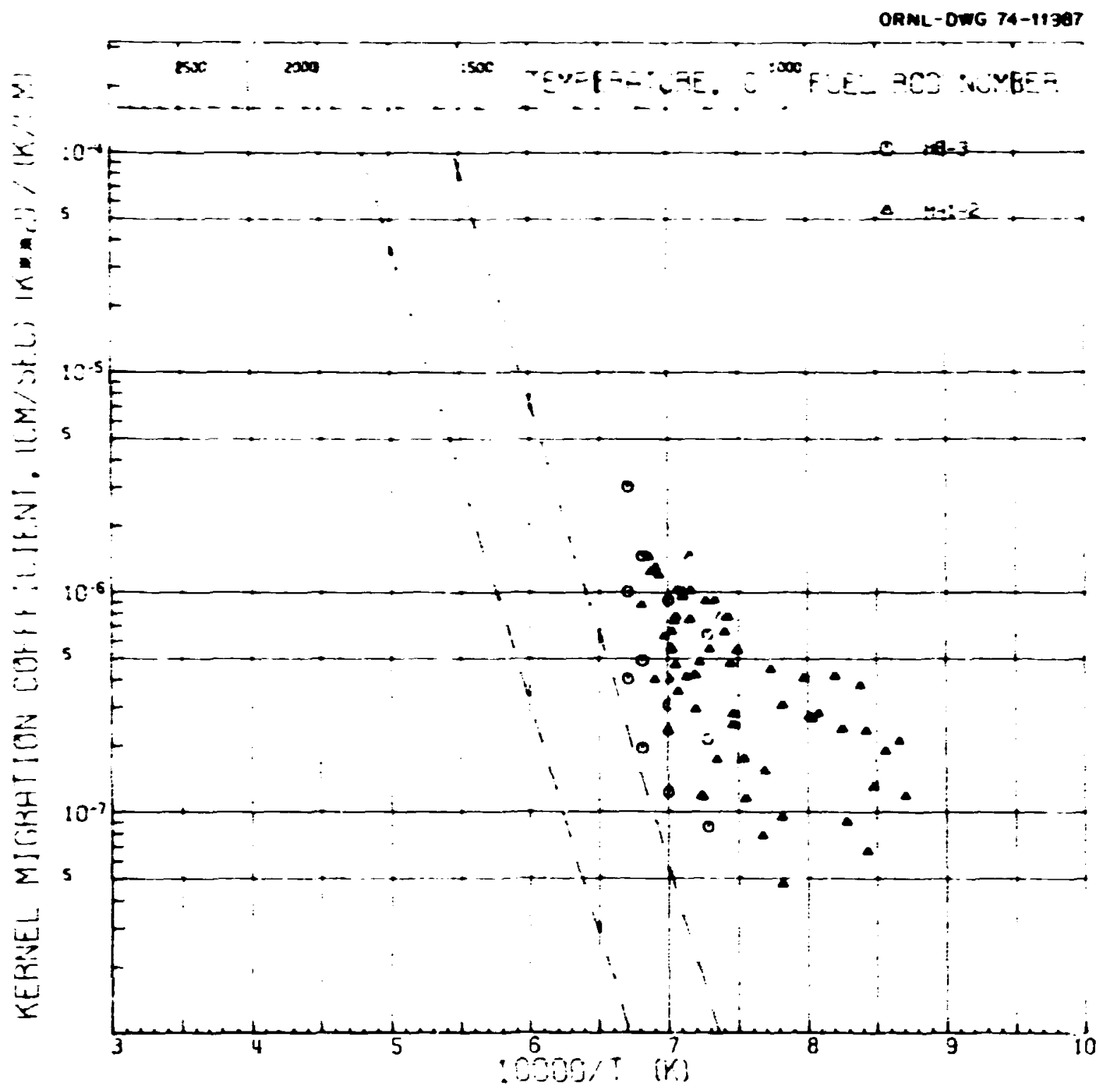

Fy. II.3. In-reartor kernel migation coefficieats for Biso-coaled CO, irradiaced in the ORR and ETR facilities. Alwi whown for

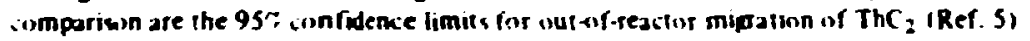


OANL DWG 73-12785

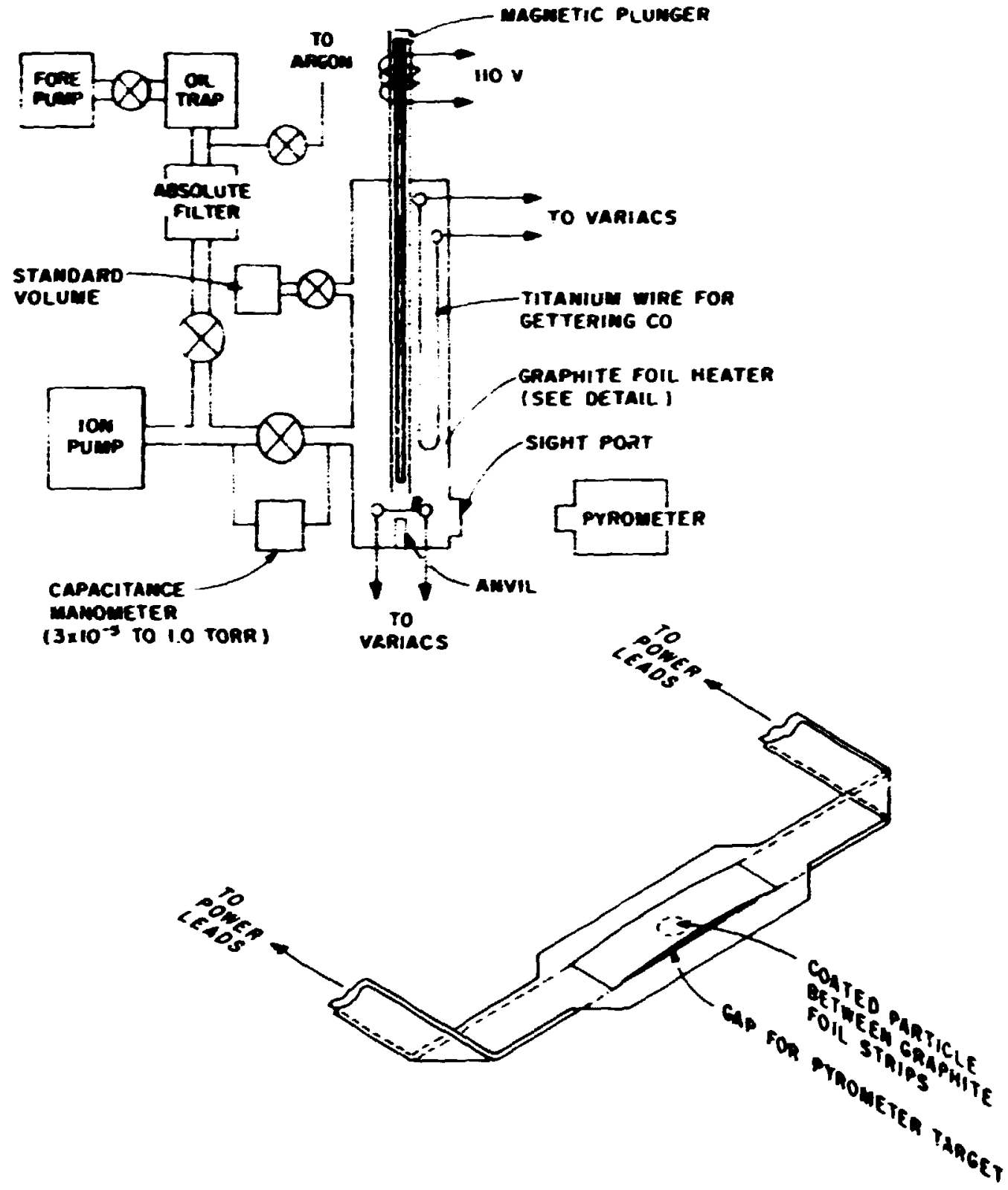

Fin 11.4. Apparatus for measuring the pes conteat of cooted fuet partucies at his temperatures. 
$-1000^{\circ} \mathrm{C}$ as a getter leaving trypton and xenun. The knption and xenoa are determined by a secund pressute measurement. The number of fiscions that hase orcurred in the partikte. winth is required to nomalize gas refo: messuremen:s. is measured by gamm sperirosiopy:

Extensive testins has demonstrated that degssing can oe adequateiy conirolled. the separation of reative gases from knjpion and xenon is complete. cooling is rapid envugh to prevent ic prosinction zitier crushing and the nuruber of mules of $g$ s in the system can be measured $10 \pm 5 \%$ accurary.

\section{:1 3 ChIBACAL COMPA THaLTY Of FUE AND FLSSHON RRODUCTS WTH COATHHGS}

\section{T. B. Lindemer M. T. Murgan}

Literalure reviews have been perform od to asceriain whether coating-kemel interation $z: 1$ be redicted by them:-al modifination aimed furard confinung reative iossion products within the kernet.

A cumplete survey of knumn phase equdibrrum data indizated that adtitives of $\mathrm{Al}_{2} \mathrm{O}_{3}$ and ax pursbly $\mathrm{SN}_{2}$ might combine effectinety with cesium. struntium. and barium. Concurrent experimental work by German researchers indizated that these additions sere inteed effective at reator temperaiures." Large reductions in fission: prudict retease were al iv reponted

6. R. Forthosan et al.. "Devetopeneat of Couted fuct Partickes for Inureased Safety Requerements." Paper IAEA S4-169:40 presented at the IAE.A SY:nposium on Primiples and Stantards of Reactor Salet;. Hebruary 1973. See also Repurt GE.RHTR-72. 


\title{
Part III. HTGR Safety Program
}

\section{HTGR Systems and Safety Analysis}

\author{
J. R. Engrel A. M. Perny
}

The systems and safety analysis task is the central. integrating task of the HTGR safety program. gathering and utilizing the information from other lask areas in a combined analysis of postulated HTGR accidents aird afely-related issues. During 1973. the principai activity in this program was the preparation of an overall HTGR Safety Program Plan. Work was also carried forward on a formal approach for the description. cataloging. and analysis of accident sequences. No quantitative overall acident analyses were undettaken during the year. but a method ivas imflemented for calculation of fission product transport in HTGR cotes. and fission product inventories in the Peach bottom Reactor were calculated for comparison with measured values in discharged fuel.

\subsection{NATIONAL HTGR SAFETY PROGRAM PLAN}

\section{J. R. Engel}

A mzior activity for the HTGR safety program during 1973 was the preparation of a National HTGR Safety Program Plan. The plan was originally intended to include research, developinent, and analysis in all phases of HTGR technology that telate to the evaluarion of HTGR safety. A program was laid out covering the ren-year period FY-1974 through FY.1983. a penod expected to see the introduction of the first several commercial HTGRs. Mlanned levels of effort were heavily concentrated during the first part of the period, with more than 80 \% of the effort sitheduled for completion by 1979. The plan was prepared by ORVL. with substantial assistance from ine Gereral Alomic (company !GAC). along lines approved by AFC's Division of Rezilor Research and Developroent.

A prelimsinary draft of the plan was compieted in July 1973 and sibmitted to AEC for review and comment. Follo:ving this review. an extensive revision and expansion of the document was underiaken. and a new diaft was presented to the Commission in December.

The plan was organized into seven principal areas: (I) HTCR systems and safety analysis. (2) Iission procinct rechnolozy. (3) primary zoolant technolozy. (4) seismxi and vibration technolozy. (5) confinement components (reactor vessel and containment structures). (6) primary-system materials technology. and (7) safety instrumentation. These areas included an extensive program for surveillance of operating reactors (Peach Bottom and Fort St. Vrain) and postoperntional observations of core and components. In each area. the current status of technology was reviewed and a detailed list of tasks developed, the successful completion of which would faiditate the andysis of postulatei accident sequences and improve the evaluation of safety margins.

It has subsequently been determinev ihat most of the research and development activities identified in the plan belong properly in the HTGR base program. In order to make generally available the detailed review of technology contained in the plan, while signilicantly 


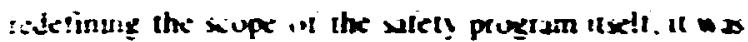

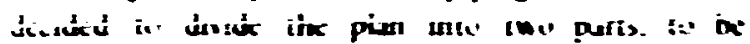
astisthed as \& Plannme Gusct ive HTGR Satet! ard s:etb-Relised Rexearith and Devetupment" The gurde

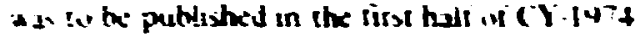

\subsection{S:STENS AND SAFETY ANALYSS}

P. Rutri

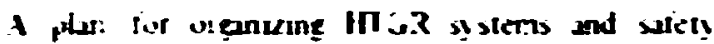

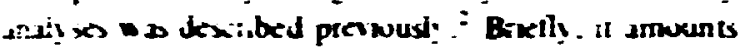
$\therefore$ Hexinbiris puten:ul aichten: progeressiuns by means

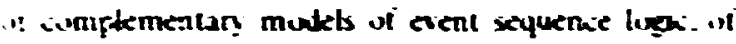
:asior and piant $t$ answent behaver. of cimpunent jumase mechansms a 1 of fisswon product reterse ard irdispurt provesses Suh maly ses are subyeil to initsumal resision and reinement wo that the an repte. xen! the bas aralable miormation from the vartusus supponturig rechnoluges.

During 1473 . additiunai work was dune tuward develupine provedures and furmats i.gr dexiribing air Jeni sequenies. Fulluwing the methud of Tieisen." the primany (coarse-struetured) aident event iuger is to be expressed in a iew main decision trees. saih of which proveeds irum a majur plant cuntungemy condition turward vanious possibic outiomes. As now envisuned. the ir.tixi inntingences will correspond to the catesuries of potentialy sernous aicidents identified in salety disiussions in the pian: licensing dourents: exh of these alegories aitually represents a class of events that may ran widely in degiec and circum. stanic. A !ypical alcgury is "water ingress." which civild range frum barcly deicilabke to quantitics ausing prestressed cinnirete reator vesse! pressure-relici axtuation. The aovent of each initial contingency is to be t:aied to the originating causes by fault tree analyses.

Since eah primary decision tree in this siheme is really a cimpusite of a number of trees ti.e.. ine fo: eah significant ariant of the initual cuntingen:yl.

1. Slaffs of Oak Ratze Tatonal aburatiry ard (ieneral

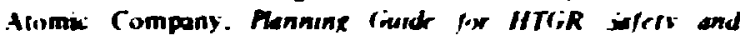
Soletr Resisted Resecech and Derekpment. ORNI, 4968 1.4uy $1974 \%$

2. P. Rubel. "Systems and Safety Analysts." Gick Frowoms

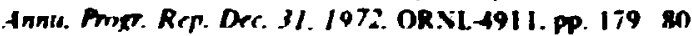

3. I). S. Vielsen. "The Cauke (ionsequence Ihapgan Melhod 2: 2 Bass for Ouantalate Redability Analyss." Faper pre seifed at the FNA,CRFSI meeting on Apolkability at Ouantsiative Raliability Analysis of Cumplex Systems and Yerkes Fants in its Rclation to Safety. Munkh. Yay 2623.1971.

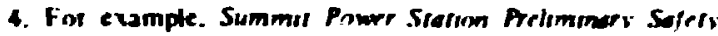
indyes Report. INelmarva Power and Laht Company

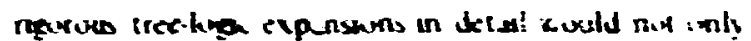

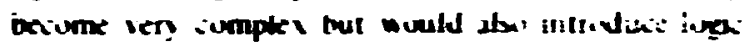
smmales The sompleaty wuld be geatl instedoct

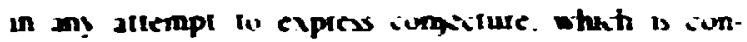
wered neicosin in early tentatre luge mertels the

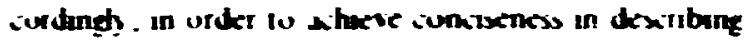
we ranges of crenis ind -onfiturs a matri lurmat wo devised as an unkrum ad in the first-steng e epanyun

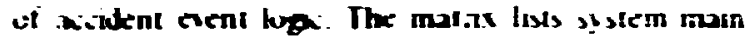

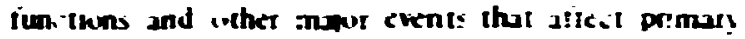
funcunal whectwes tes. 2 compunent ialues in the beliun sucult my sase sume solunt bypass then arouni the sore). These cients are setected to represent

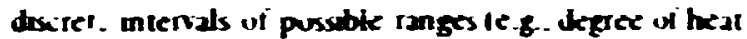
remund defikeny I othere appropnate and ase greped ciudung to respunsuble swbsy stem or mays iumpunent. Combenatuns of cuents are then seteited. whe the sedeturn proxias ciould be buth arbitran and subjeitive. these abjeztuns an be iveriume partly by ioniensus and partly thrungh probability evalutions. In the incetest of con-isetess and abulity of the dagrams to anecy essential intormation. il may prove advantageaws in dride the event sequetice arrays into phases. erther by time or at atuial decision points.

Further expansion of the aident coents identified in the matries is to be by subsedary fault irees. These will interizec with sysem reliability analyses. to which they wil introduce speitic acident circumstances thal aftect the equipment isponse prosperts. Som of the carlkest expanswons. ho'vever. mas be iunjectural and merely indialc incentives and appropriate sbritives fir further investigation.

In close relition to. and in support oit. the aicideri event sequeme deariptions. It is planned to evaluate systemis and compor.ent qualifications to meet speitic inallenges. Conrinikual relubility is one aspect of such investigaluons. Mure directly involved with the uverall safely program. however. are the capabiluties of compuments (1) withstand envirunmeni- and xicideatinduced stresses. The organization of the analysis is intended (t) highight such matiers and help define the assiviated aident conditions to which the componer: may be expased.

A preluminary analyss of the event sequences in the conling irterruption class of acidenis was conducted in injunction with the methods developmert. This helpec io identify the pratical problems and require. ments ior event descriptions in peneral and to demonsirate the utility of the methods. Since so much of the analysis content is still speculative. It is not intended for publication in the near future. 


\subsection{FLSSON RROUCT TRATSORT L HTGR CORES}

\section{R. J Kedl}

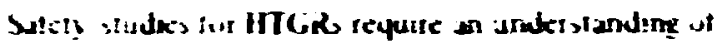

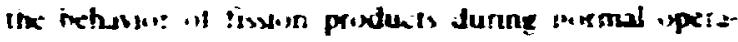

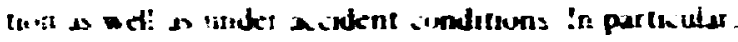

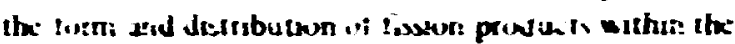

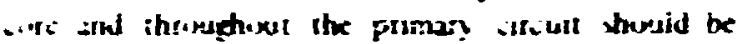

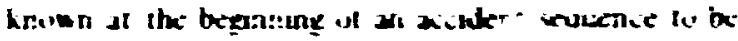

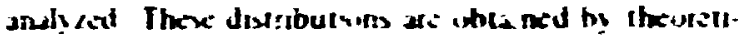

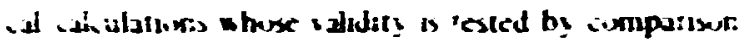

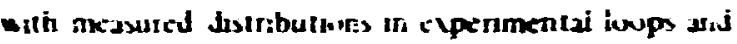
21. . pertaling fexiturs

To develup th- apability tivi perturmng sech salicuiaIII

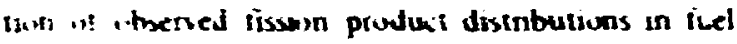
chemeints remusid from the Pexih Butum Reailu!. We angured irom Gil the fisstun product transpurt code FIF $R-0$. a verson of the C.AC cude FIPER-X.s FIPLR

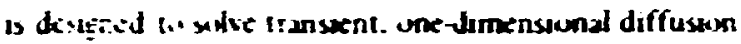
problems in stab. islunjnical. or spherical geumetr. with unteus uptunal busundary ionditions to desiribe Iranster of isssen produits from the wid grapinite mixkerstor (1) the helium coviant. In additwn. a

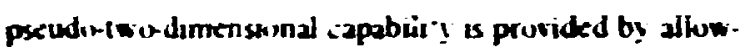
Ing the souplung of shicessive 210 reguns ot the rexity through the fisswon product concentrations in the hilur. cindant stiezm.

The inde was dergened for use on a eviliaC $110 \mathrm{~s}$ compruter. Consdeiable cilort was desuied Woth in understanding thr code in detal and to adapting : 1 for uperation is the IBM $\mathbf{3} 60$ computers at ORNL. From anatyss of the FORTRAX programing and by applical.un "u test problems fior which analy ti.al sulutions may be obtained. the basi mathematlid tratment of the physial prinesses cunsidered tas been validated. Several addituns to the progam and (o) its output were make. including the pnnting of current reicase to birth rate ratwos and fission product inveniorkes in tuel par. ticles. in graphice. and in condant as absoluce am:-ints Imikrumoles and cunes) and as frations of the :ota' invenions. The progerm conversion was exsentid.; ampleted and tested. with the exception of certa:n options not needed for our work.

A ceries of five bench-mark problems was composed. with which it is hoped to compare FIPER-Q with FIPDIC. a similar code used in the Lrizied Kingdom. as

5. R. Forutanpour and B. Rows. FIFYRX. A fortsen 5

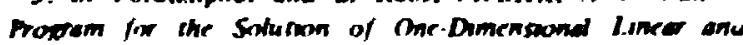

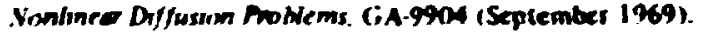

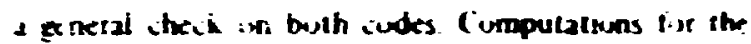
ine proioiems wete umpieted at (SRVL. but iomparzbe FIPDK, aluiatuns scte nos set 2tallabic at the erat i"? the s:ar

\section{Calcllation of fission FRODLCT INVENTORLS IS: THE FEACH DOTTOM REACTOR}

M. L. Tubus

The HIGR sunet:ante prepam tnciude: measure.

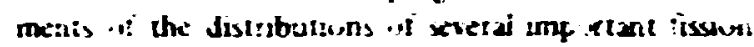
provluits at: ihe Peah Butlum Reaitu: sore and

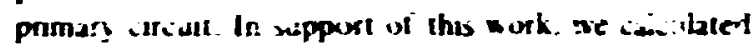

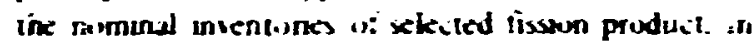

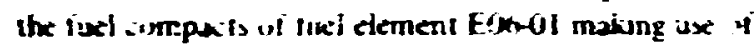

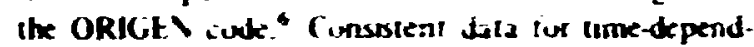

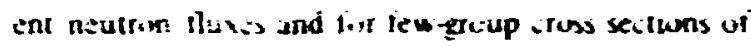
the principal fuel nustides were ubiarned li.m thit dimenswani fuel depletum caivilatins: by CAC for in aitul poster holong af iure 2 uf the Peach Butlom Rexitur Th: purpuse of the tume-depencent inventu:y caliulations. un cunfunition with the related fusturradiaren enventeng measurements. was iv establish the suric term l.r subsequent tisstun product retease and iranspirt izhoulations.

The measured and cakiaited aitivities in element EOo-jul at the end of the irradiation period arr impared in Tabk 12.1. The mesured and calculated

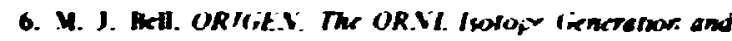
Depletion Cinde. O.NiL-6628 1 44y 19731.

7. Prvate commenuatoun from Cemerd Atomir Company.

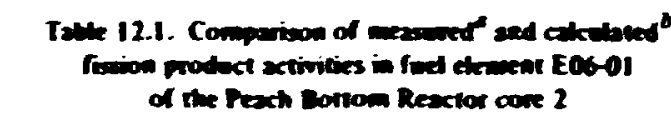

\begin{tabular}{|c|c|c|c|}
\hline \multirow{2}{*}{ Sus inde } & \multicolumn{2}{|c|}{ Acturty $\left(\mathrm{Cu}^{6}\right)^{6}$} & \multirow{2}{*}{ Rutm } \\
\hline & Mescured & Caliubled & \\
\hline & 5634 & 5180 & $0.9 ?$ \\
\hline${ }^{103} \mathrm{Re}$ & 2128 & 2600 & 1.25 \\
\hline${ }^{106} \mathrm{Ru}$ & 231 & 196 & 0.85 \\
\hline & 9. 7 & 6.5 & $0.6 ?$ \\
\hline $134 \mathrm{Cs}$ & 129 & 161 & 1.25 \\
\hline $137 \mathrm{C}$ & 186 & 168 & 0.91 \\
\hline $144 \mathrm{Ce}$ & 3155 & yMn & 1.01 \\
\hline${ }^{154} \mathrm{fu}$ & 3.1 & 33 & 1.07 \\
\hline Av & & & 0.99 \\
\hline
\end{tabular}

See Sert, i] 2

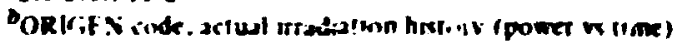

r virmalized to 30 compacts, end of uradu.ixon 
results are in resonably gud greement: the average devation is 1\% and the iargest deviation is $33: i$. We cunctude that the ahulated ume-dependent lissun product enventures on the fied sinuld be adequale for

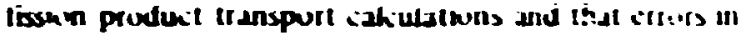
the siurce terms will usudly be small cumpaled with thuse asuniated wh mezurements of ite liswers pruvdel Iranspurt stself. 


\section{Fission Product Technolog:}

If. J. de Niorduzll

The iwerall gials of the work desuribed here ale sinilar to thuse stated in Chapter 10. However. sinci support had been derivec from the HTGR Sifely Prugram. emphasis is on th- behrvior of iodine. the mosi toxic volatile fissior frodist elemer.t. and on integral ralidation experiments that seek to determine whether nathematical mudels of fission product iranspoit do : $:$ fact predint the distribiltions ubse ved in operating renctors conservatively and adequately

Ir vine adsorption and desorption studies are : ned toward determining the apacity of the primary coolant circuit for iodine under norral operating conditions and the rates at. .hich deposited iodine can be desoroed during acident; involving deprassurization. sleam ingress. or overhealing of the steani generalor. A knowl. edge of the capacily of the sircuit for iodine is an important factor in determining whether the very useful decontamination of the pnmary coolant by "plate-oui" an he sustained throughout reartor lifetimes. Knowl. edge of desorption rates permits the calculation of time-dependell: iodine comientrations in the contain. ment throughout the course of ar, accident. However. it should be pointed out that if the containment isolation valves close a: designed and aciess to the con!ainmerit for postaci.tent mairienanca is not reuuited. ai lic iodine that is anticipated to 'se present in the primary citcuit. iuclusive of the "design" safet; margin. may be released without breaching faderal regulations.

Our experiments usiny the Peach Bottom HTGR are aimed toward exploiting the unique charaiterictics of that reactor. namely. its aciessible primary circuit and its relatively uniformly loaded ccee. Specifically. Wi: seek in measise the rates of fission product ielease from the core a a function: of time and :a relace these measurements to the distribuider of fission products within the sure. Given adequate samping of core comporents. one should then be able to test the FIPER cute on a reasonable siale. In addition. meisurements of the distributions of deposited fission products yield information aboul deposition and reentrainmert.

\section{3.: 10MIVE ATYSORPTION AND LESORPTIC N STUDIES}

\section{t. L. Cor.ipere :A. F. Osborne}

\subsubsection{Factors Limition Iodine Concentration in the Primary Coolant Cirsuit}

The prissible release of fission product :odine from an HTGP. during normal operation or as a result of postulaied acidents is directly dependent on the inventory in the primary coolant circuit. elther in the as phase or deposited on system surfaces. Limits on thes: inventories can be derived from the regulatory limits on radiation dose tc the public ,esulting from any such reliases. The inventory levels are a balance between production in fuel particles and release to the coolant. and removal from the coolant system by various processes. The faciors affeciing the chemical relationships between gas-bome 1.xtine and that held in suriaices are of particular interest, both with respect to deposition and to desorption. or liftoff.

Derived release limits. The possible dose to the public as a result of a posiulated accident is tegulated ay 10 CFR 100. which requires tha! an exclusion area boundiry be located such that. in particular. the dise to the thyroid of any individual cannot exceed 300 rem. 
The thyroud dose to an aduit irom 1311. Ihe Jominant indine nus-lide. is $1.27 \times 10^{6} \mathrm{rem} \mathrm{Ci}$ inhule. '. : Assumung an aiceleraled brearhing rate ${ }^{3}$ oi :

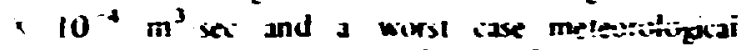

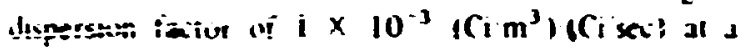
reptoxinisitis: distance of $\$ 00 \mathrm{~m}$ betv $i=r_{1}$ the plant vent

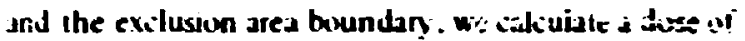
$0.7 \mathrm{rem} \mathrm{Ci} 131 /$ vented during an acident. Thus the Jerwed plant release limit corresponding to 300 rem to the thy ruid is $300 \times+0.74=410 f^{\prime} \mathrm{C}:$ : 'I, where $t^{\prime}$ is the firation of toral thyruid dose that results from ${ }^{13}{ }^{1}$ I inhalation. The coulant systera incentory limit $x_{c}$ depends then on the liftulf. or desurptios. fration $I_{\text {. }}$ appropriate to the postulated acident and the fraction II. $s$ ' that is released from the secondary containment system.

$$
\left.(.)_{c}\right)_{\max }=410 f^{\prime}:\left(L_{c} L_{s}\right)
$$

where $x_{C}$ is the inventory of 131 in the cuiviant jystem both un the surfices and in the gas. and possioly that released to the :covlant circuit in the course of the acident uncier consideration. Valves to isolate the seionidary system should close promply, and any indine that is transported into the secondary containment will be removed by absorption in internal recircutating filiers and deposition on the walls and nour of the cuntainment. The isolated secondary cuntainment leak rate is expected to be 0.257 iday. For the 2 -hr interval frequently eniployed. $L_{S}=0.002512=$ $0.000 \mathrm{z}$. which indicates inat $\left(. V_{C}\right)_{\mathrm{m}, \mathrm{x}}$.ould he greater thr: $2 \times 10^{6} \mathrm{Ci}$ even if $l_{\mathrm{c}} \mathrm{C}=\mathrm{J}$. As will be shown below. such vuantities of activity cannol wicur in the primary coolant system. Thus the dose iimits of 10 CFR 100 could not be exceeded if the isolation valves cluse as designed.

If the secondary isolation valves de not close. materiai released into this secondary could pass through ( $L_{s} \sim$ 7). However. it is possible that the desorption fraction $\therefore$ witlun the coviant system will be constrained 10

1. C. F. Hastetly, ORNL Health Mysic: Division, persomal armunicalion.

2. F. J. Soldat, N. M. Robinkon. and D. A. Baker, Models and Compiter Codes for Evalualing Environmental Radiation Doses. BNWL-175 (Fehruary 1974).

3. Meteoroloni and Alomir Finerny 1968. D. H. Seade.el.. TID-24190. p. 366 .

4. Delmarya Power and Iight Company. Preliminary Safery Analysis Report for the Summit Power Station. Doxkel 50-450. as amended through liebruary 1974.

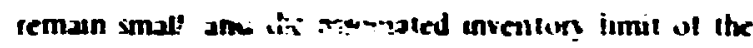

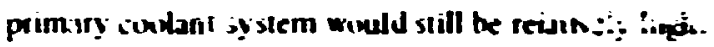

In it ase of release ur:cter nurmal uperaline cionds. fins. I thyrued dusc limi if $15 \mathrm{mrem}$ year is in thisted $^{3.5}$ if the propased limits of 10 CFR 50. Appendix I ipresently propesied for lighi waler reaiturs is!ly ! are applied. The air-grass-iow-milk zhild pathway is limiting. and i:! is sto deminant rikfick. An

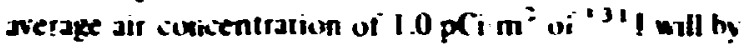
this pathway result in a kbsa of in a mrem yeat to a thild using I lier of milik per Jay. An appropriale sverage meteororngial dispersion fatur of $(x)=$ $10^{-5}\left(\mathrm{Ci}^{3}\right.$, $6 \mathrm{a}$ sec: $\mathrm{min}$ result in a derived :missien limit fio $131 /$ of 0.01 if Civear. whete $f$ is the fration of all thyreid derse : $t=1$ would he contritused by 131 thruagh the milk pathway.

Thie primary system leakaty rate for tt.e Summit Power Station HTGR was estimated to be $0.01 \%$ /day." and the lumped decontamination ixtor for the prestressed corkirete reacitor vessel (PCRV) cor:-rete and seconciary containment wo, assumed" 10 be 100 for all iudicie species. all paths. and all velucities.

On the basis of these assumptions, the denied limiting ${ }^{1} 31$ I content of the primary coolant system gas during normal operation (assuming $f=1$ ) is

$$
\left(N_{G I_{\mathrm{mi}}}=0.013 \times 100(10.001 \times 365)=36 \mathrm{Ci} .\right.
$$

This corresponds to $1.3 \times 10^{18}$ anoms of ${ }^{131} 1$ or a partial pressure of $10^{-10} \mathrm{~atm}$ of : i1 1 .

Various other estimates of leakage rales and decontamination factors have heen made for other reactors (subject (1) wthe:- limits). Leakage rates for HTRs have been taken is irssir/yeat" with no subsequent decontamination: howevri, a coviant content of $5 \times 10^{-5} \mathrm{Ci}$ was indicated. resulting from the implicil assumption of very rapid deposition on surfaces from the primary coxlant gas.

Audebeau ${ }^{7}$ and co-workers assumed a leakage rate of $0.2 \%$, day and no further decontainination (1actor $=1$ )

5. Interinı Licensig Aolicy on as Low as Practicable for Craserus Rn.tiowtin Releases from light-Warer. Cooled Vuclear Power $R$ actors, it: Regublory Guide 1.42. June 1973.

6. H Bonka and K. Brussermann. Indine Release from Viucl or Power Plon's and Reprocessing Plants os Well as Cottamination of the timironnient in the Future. Jul-997-RC; (Augus! 1973).

7. J. P. Audebeau, R. L. R. Lefevre. and M. S. T. Price. "Ouality Manapement fos HTR live!s." paper prexented al Britid) Nurlear Finigy Suciefy Conference. London. Ot. I5 19.1973 (proceedings in be published). 
on axessment of the efien:s of ivel yuadity contred in

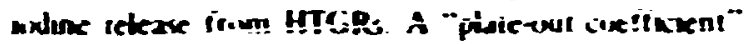

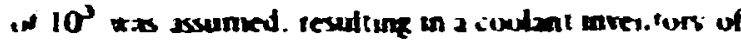
O.ax (in then momki.

The sthwe irarsier retms provide the telatwongh heiveen primary system enventunes and duxe. Nie num furn lo cinuderatners of the factors serving to fix the mentern in the primary syem cumbant gas and on the system surtines.

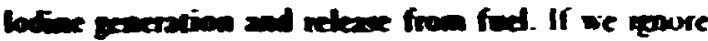
the delals of precursun chains and asume mat the

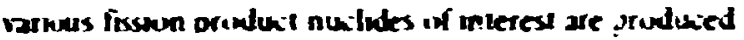
irretly. Ihe turth rate $B$ of any nikinde is ielate $i$ to

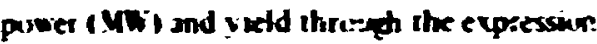

$$
B=3.1: \times 10^{2} \times \text { MW } \times \text { yield. alıms sec }
$$

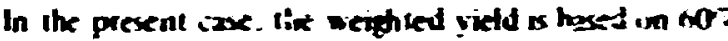

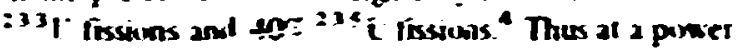

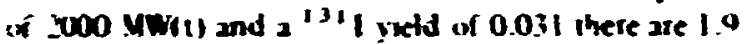
- $10^{12}$ alums of "'I genersted in the core per scioris. The sicaty-sizic inventor: of ${ }^{131} 1$ is thereby $1.9 \times$ $10^{2+}$ al ims. in 5.2 $\times 10^{7} \mathrm{Ci}$.

Cse of the pricedures outlined in the 5".nmut Power

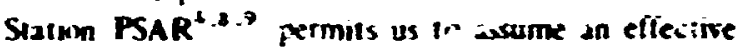
reicase-tobith atto $\left(R\right.$ B) for: $: 31$ of $1.7 \times 10^{-4}$. This resialt. and an estimater. value of 0.99: for the average

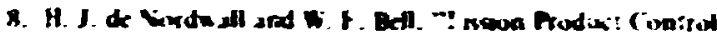

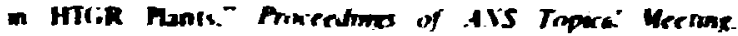

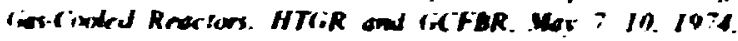

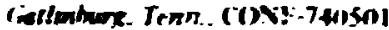

9. R. D. Burmetic. W. F. Bell. ad X. L. Buburm. "t moun

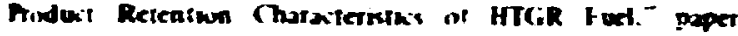

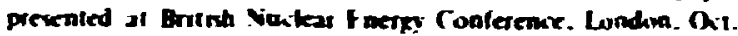
is 19.1973, procredmas to be puthinedi.

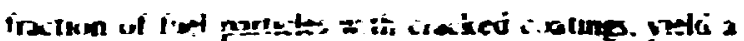

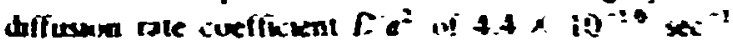
fon undare retease itum iratied fuel partutes. Pelease

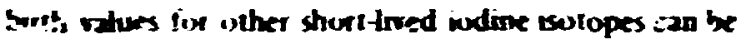
cblarned by usene the ralue of $D d^{2}$ in the approximate Burh formula.'

$$
P B=i \sqrt{D a^{2}}
$$

Wete $\lambda$ is the halfite of th: paythula: b-ispe. In the bere of lonztived $x$ shable suiopes. the cumulati te iraituonal relese $F$ al tume $t$ sut be sblained from il $e$ rebitwon

$$
F=\frac{4}{v=\sqrt{\frac{D}{a^{2}}}} \quad \frac{3}{2 a^{2}} .
$$

It is neciessan to aicunt for the rarwis annial fued relood segments of the cure separately for the longtred

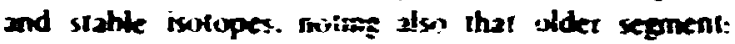
rave lower purser densities and doubless somewhal lower fuel ienuperatures.

An invention of the amounts of various wdune nu-lides released in'o the primary cumbant system of a 2000NWill HTGR as shown in Table i.3.1. An xo: cervice fater was ised for the slable iso:ones.

Al the end of ine year of operatum. for exmpie. the invening of lodinc released in in the priman system is abnu: $1.4 \times 10^{22}$ alums: in three sears it is 2 hoil $x \times$ $10^{2}=$ atoms. eli. At seady state the system contans

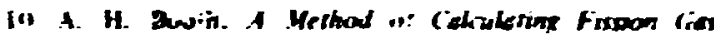

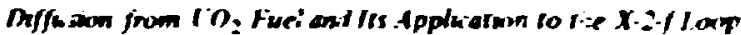

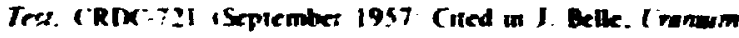

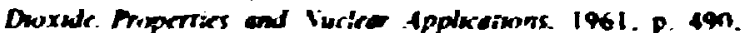
IStic

\begin{tabular}{|c|c|c|c|c|c|c|c|}
\hline boxs moctule & 127 & 129 & 131 & 132 & 133 & 130 & I3S \\
\hline Hartace & senvir & $1.6 \times 10^{7} y$ & $193.5 \mathrm{~h}$ & $2.28 \pi$ & $20.2 \mathrm{n}$ & osen & $6 n$ \\
\hline$Y=10^{\circ} T$ & 0.411 & I.35: & 2140 & 4 ass & c.2n & 6412 & 5.371 \\
\hline 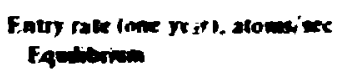 & $\begin{array}{l}2.0 \times 10^{14} \\
3.7 \times 10^{14}\end{array}$ & $\begin{array}{l}6.8 \times 10^{34} \\
1.2 \times 10^{15}\end{array}$ & $32 \times 10^{34}$ & $\begin{array}{l}5.0 \times 10^{13} \\
5.0 \times 10^{13}\end{array}$ & $\begin{array}{l}2.2 \times 10^{14} \\
2.2 \times 10^{14}\end{array}$ & $\begin{array}{l}46 \times \ln ^{13} \\
46 \times 10^{13}\end{array}$ & $\begin{array}{l}9.5 \times 10^{13} \\
9.5 \times 10^{13}\end{array}$ \\
\hline $\begin{array}{l}\text { Reteand atom momeaton } \\
\text { I rear } \\
3 \text { yous } \\
40 \text { reas }\end{array}$ & $\begin{array}{l}4.3 \times 10^{31} \\
1.8 \times 10^{22} \\
3.0 \times 10^{23}\end{array}$ & $\begin{array}{l}1.4 \times 10^{22} \\
6.1 \times 10^{22} \\
1.0 \times 10^{24}\end{array}$ & $\begin{array}{l}3.2 \times 10^{30} \\
3.2 \times 10^{20} \\
3.2 \times 10^{20}\end{array}$ & $\begin{array}{l}6 \times 10^{17} \\
6 \times 10^{17} \\
6 \times 10^{17}\end{array}$ & $\begin{array}{l}2.4 \times 10^{10} \\
2.4 \times 10^{10} \\
2.4 \times 10^{10}\end{array}$ & $\begin{array}{l}2 \times 10^{17} \\
2 \times 10^{17} \\
2 \times 10^{19}\end{array}$ & $\begin{array}{l}2.7 \times 10^{10} \\
2.7 \times 10^{19} \\
17 \times 10^{30}\end{array}$ \\
\hline
\end{tabular}

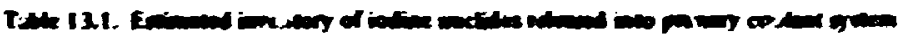

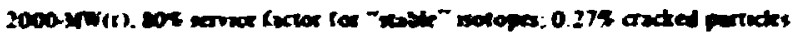

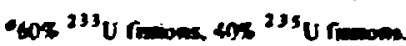


about $8600 \mathrm{Ci}{ }^{1+1}$, along wit:. somewhat smaller but appreciable quanities of the other radusias: indine nuclides. The entr: rate of iodine ir to he f rimiry indari sys:en is ?2: one year' $1.0 \times 10^{1}$ ' atomsisec: 20\% of which is 131 I. The entry rate of stable isotopes in reases as they build $u_{t}$ in the elemr:ts: ;ust prior to replacement the total lodive entry rite is $23 \times 10^{15}$ atomsisec. it? of which is $1: 11$.

Priary coolant system lodine atoms entering the primary ciolani system ari r.pidly ci.culated with the hested helium ciolant gas t roygh the sieam generat ds and back through the cors. Any w seral forms of indine removal by: sysiem suifaces mav ocur. Part of the circulating it: am is passid through a helium purifi:ation syste:m Som: parameters recently listed" fo: one ol two ren'tu s o the Summit Power Station of the Jelmarva Povar and Light Company are given below.

Pro...

Nomini 20.70 MW(t)

Trimary He in:ent. . ior mixing 9329 tb at 4 ? ath

Coolant circulation rate $2016 \mathrm{lb} / \mathrm{sec}$

PCRV leak rate

$0.01 \% / d a y$

Melium purification plant thow rate

$2070 \mathrm{lb} / \mathrm{hr}$

The various rate ionstants for the remova! of jodine from the primary cuolant gas are

$$
\begin{aligned}
& \text { Decay } 1^{131} 11 \quad \lambda=0.795 \times 10^{-5} \mathrm{xec}^{-1} \\
& \text { Purification } \quad r_{p}=0 . ; \times 10^{-3} \mathrm{sec}^{-8} \\
& \text { PCRV leak } \quad r_{1}^{-} .1 .16 \times 10^{-9} \mathrm{sec}^{-1}
\end{aligned}
$$

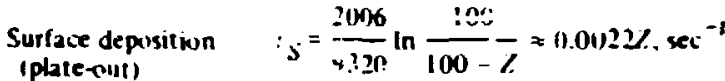

The term $Z$ is th: recceit removed pat pass by plate-out. The lumpect removil rate constant obtained from the above.

$$
S(r, \lambda)=6.27 \times 10^{-3}+r_{s} .
$$

is evide.tly strongly ationted by the surface deposition rate.

At steady state the amounts of a given iod:ne nuclide in the gas $\left(I_{1}\right)$ and on ' e surface $\left(. V_{s}\right)$ are given by

$$
. V_{C}=R^{\prime} / \mathbf{S}(r, \lambda)
$$

and

$$
v_{s}=v_{r} ; \frac{r_{s}}{\lambda}=\frac{R^{\prime} r_{s}}{\lambda s(r . \lambda)}
$$

'there $R^{\circ}$ is the entry rate of the nuilide into the primary coolant, which is aken as equal is the release iate fr. in. fuel, as disiussed earlier.

The leak rate from the primary sysiem is shen

$$
L^{\prime}=X_{G} r_{L}=\frac{R^{\prime} r_{L}}{S\left(r_{0} \lambda\right)}
$$

Using the entry rate of 131 : to the primary system of $3.2 \times 10^{14}$ ator $/ \mathrm{sec}\left(8.6 \times 10^{-3} \mathrm{Ci} / \mathrm{sec}\right)$ with no surface deporition. Ine ${ }^{13}$ I content of the primary system gas al sieady sinte is $140 \mathrm{Ci}$. above the derived limiting content of $36 \mathrm{Ci}$. wherse $\mathrm{a}$ value muilt below this is to be desired. Clearly some surface deposition (more than 0.1\% per pass) is desirable and essential. As discussed later, deposition his been found to ociur at ample rates (up (o thr per pass) in reactors where the sur'are: thad noi bectme covered with iodine-Larger arsounts of iodine will need to be deposited on unit primary " $y$ ' $m$-faces during the lifetime of power reaciciss. Consec.sently, it is neiessazy to evaluate the nat'ure of sistia: deposition and the capacity of system surfaces fi $7-c_{i}$ :n product iodint.

The nat ire of he deposition will strongly affect the . are of remc.:-i uncier acident zonditions.

lodine deposition. Sritice depusilic, or plat:-out nav ocur by (I) reac: an with metal surfaces (I) produce a volatic iadide and subsequent permaiknt deposition of the reacti . protuit al some point in the sysiem or (2) adsurpition on suifaces. The iature of the surfaces will require definition.

If the condilions for the fitst possibility - formation. vapor tran'po: $:$. and permanent depusition of a volatile iodide at: fulfilled. it is certainly possible to continice the plate-sut indefinitely. On the other hand. $i$ plate-out involves immobiizing the iodine on the surface by adsorption (or reacition). the exieni of the system surfaces could produce a imit to the continuation of plate-out. Other options to control iodine release, not defined here. would then have to the exercised.

If a fairly rapid exchenge of iodine between gas-borne ard adsorbed ponases oncurs. a sufficipl' surface should provide a long ennugh holdup to peririt adequate decay of radiuasilive iudine.

\subsubsection{Surface Composition}

The major materials of the primary coolant circuit that could contribute is iodine plate-out are heal exchanger surfaces, core and reflec: ir graphite clanncls and pores. and system walis. Interacion belween 
graphite and iodine will no! be constzied if inis report.)

lodine in the HMGR primisy coolant may react with bare metal surfaces to form metal iodides. but this must compete with porssible oxidation of the surface by impurities in the helium, largely the result of a slight water ingress. In the set of exploratory thermochemical calculations to be described, it was assumed that an impurity concentration corresponding to 10 (or 20) ppm of $\mathrm{H}_{2} \mathrm{O}$ at $50 \mathrm{~atm}$ total coolant pressure existed in: the circuit prior to equilibration with graphite at the temperatures considered.

Subiect to this assumption. the thermochemical calculations ${ }^{21.12}$ indicate that oxidatinn of iron to $\mathrm{Fe}_{3} \mathrm{O}_{4}$ can occur up to about $400^{\circ} \mathrm{C}$. whereas $\mathrm{Cl}_{2} \mathrm{O}_{3}$ can form at all temperatures of interest. At temperatures up to aboul $500^{\circ} \mathrm{C}$. iron can be oxidized in the presence of $\mathrm{Cr}_{2} \mathrm{O}_{3}$ to form $\mathrm{FeCr}_{2} \mathrm{O}_{4}$. Increase of the hydrogen-10oxygen ; $\mathrm{H}(\mathrm{O})$ iatio $b ;$ a factor of 10 would reduce the temperature below which $\mathrm{Fe}_{3} \mathrm{O}_{4}$ is stable by about $50^{\circ} \mathrm{C}$, with lirtle effect on $\mathrm{Cr}_{2} \mathrm{O}_{3}$ or $\mathrm{FeC}_{2} \mathrm{O}_{4}$ formation. Increase in water content, or reduction in the $\mathrm{H} / \mathrm{O}$ mitio. sightly increases ine ismperature below which $\mathrm{Fe}_{3} \mathrm{O}_{4}$ is stable. Radiation icactions or othe: sources of hydrogen. such as oil leaks ( not evaluated), might cause tive ges to become more ristucing. The relationships are preier:ted graphically in Fig. 13.1. In this figure the proportionate excess or deficiency of free and combined hydrogen relative to free and combined oxygen in the phase is exp-essed in terms of a ratio

$$
R=\left(P_{\mathrm{H}_{2}}+P_{\mathrm{H}_{2} \mathrm{O}}\right)\left(P_{\mathrm{H}_{2} \mathrm{C}}+P_{\mathrm{CO}}+2 P_{\mathrm{CO}_{2}}\right)
$$

such that $R=1$ if the only source of $h$; drogen or oygan is water.

Based only on equilibrium considerations. there appear to be livw if any combinations of metal compocitior and iemperature in the primaiy system that wouic not be susceptible to metal oxide formation. particularly if eno shh time were available for sufficient onfomium to firfuse to the metal surface in alloys containing low proportions of chromium. It is recog. nized that manganese, which is present in the alloys to 1\% c: less, also forms relativily stable nxides.

11. O. Kubachewai. F. L. Frans, and C. B. Alcock. Welsilunicd Themochemisery. 4th ed.. Table f.. Petpomon. 1967

12. D. R. Siull. SANAf Themochemical Tables, Thermal Revarch Iaburatoey. Dow the mi al Company, Midband. Micn. 1264.

\subsubsection{Adsorption Equitibria and Surface Capocity for lodine}

Since some experimental data for the adsorption of iudine on iron already existed, 13 materiais representative of oxidized surfaces were chosen for initial study.

Adsorption of iodine on $\mathrm{Fe}_{3} \mathrm{O}_{4}$. The determination of the adsorption coefficient of iodine on $\mathrm{Fe}_{3} \mathrm{O}_{4}$ by the bithermal equiliuration method described previously'4 has been . umpleted. Determinalions at a particubar smple temfer_aure were generally made at iodine source vapor pressures of $10^{-11}, 10^{-10}, 10^{-9}, 10^{-8}$, and $10^{-7}$ atm. The first sample used $\mathrm{Fe}_{3} \mathrm{O}_{4}$ prepared by Sweeton and Baes; ${ }^{5}$ measurements were made at 200 and $300^{\circ} \mathrm{C}$. A second sample of high-purity $\mathrm{Fe}_{3} \mathrm{O}_{4}$. obtained from Rocky Mountan Research Co., was used for determinations at $250,350,400$, and $450^{\circ} \mathrm{C}$. The first sample had a surface area (BET) of $0.16 \mathrm{~m}^{2} / \mathrm{g}$ and a crystallite size of $222 \mathrm{~A}$ : the second had a surface area of $0.25 \mathrm{~m}^{2} / \mathrm{g}$ and a crystallite size of $216 \mathrm{~A}$.

The vapor pressure of iodine at low temperatures was obtained by interpolation from values listed by Honig and Hook. ${ }^{16}$ The partial pressure of iodine at the sample was calculated laking into account the dissociation of $l_{2}$ into iodine atoniss (which becomes doninant at the higher temperatures and lower pressures) and tije thermal transpiration effect. '?

Since the temperature and. correspondingly, the dissociation of $I_{2}$ varies around the $H T G R$ circuit, while the pressure of helium remains effectively constant, the funition $\left(P_{1}+2 P_{1_{2}}\right)$. called the "iodine burden" and denoted by $\boldsymbol{P}_{\text {urden }}$, is a more usefui parameter than either $P_{1}$ or $P_{1_{2}}$ for plotting isotherms showing the amount of iodine adsorbed on unit surface. Such a plot is shown in Fig. 13.2.

It may be saen that 1 limiting value of adsorption in the vicinity of $2.0 \times 10^{14}$ atoms $/ \mathrm{cm}^{2}$ is indicated. sugesting that this may represent monolayer saturaion. A closely packed monolayer of iodine z:oms $(2.2$

13. E. Honnkis. A Review of the Adsomption of Jodine on Welal and Its Betwrior in Loops. ORNL-TM-2916 (May 1970).

14. M. F. Osborne. "lodine Adsorpion and Desorption." GCR Prowem Anm. Prop. Rep. Dec. 31, 1972, ORNL-4911 PP. 168-70.

15. F. H. Sweeton and C. F. Bace. Sr.. "The Solubilily of Magnetile and Hydroly ix of Ferrous Iron in Aqueous Solutions at Flevated Temp ralures." $f$. Chem Thermadyn. 2.479-500 (1970).

10. R. F. Honig aid H. O. Hook. RCA Review. pp. 360-68. September 1960.

17. C. F. Milstead. W. E. Bell. and I. H. Norman. "Deposition of lodine on Lon Chromilm-Alloy Steels." Nucl. Appl. Tech. 7. $361-66$ (1969). 


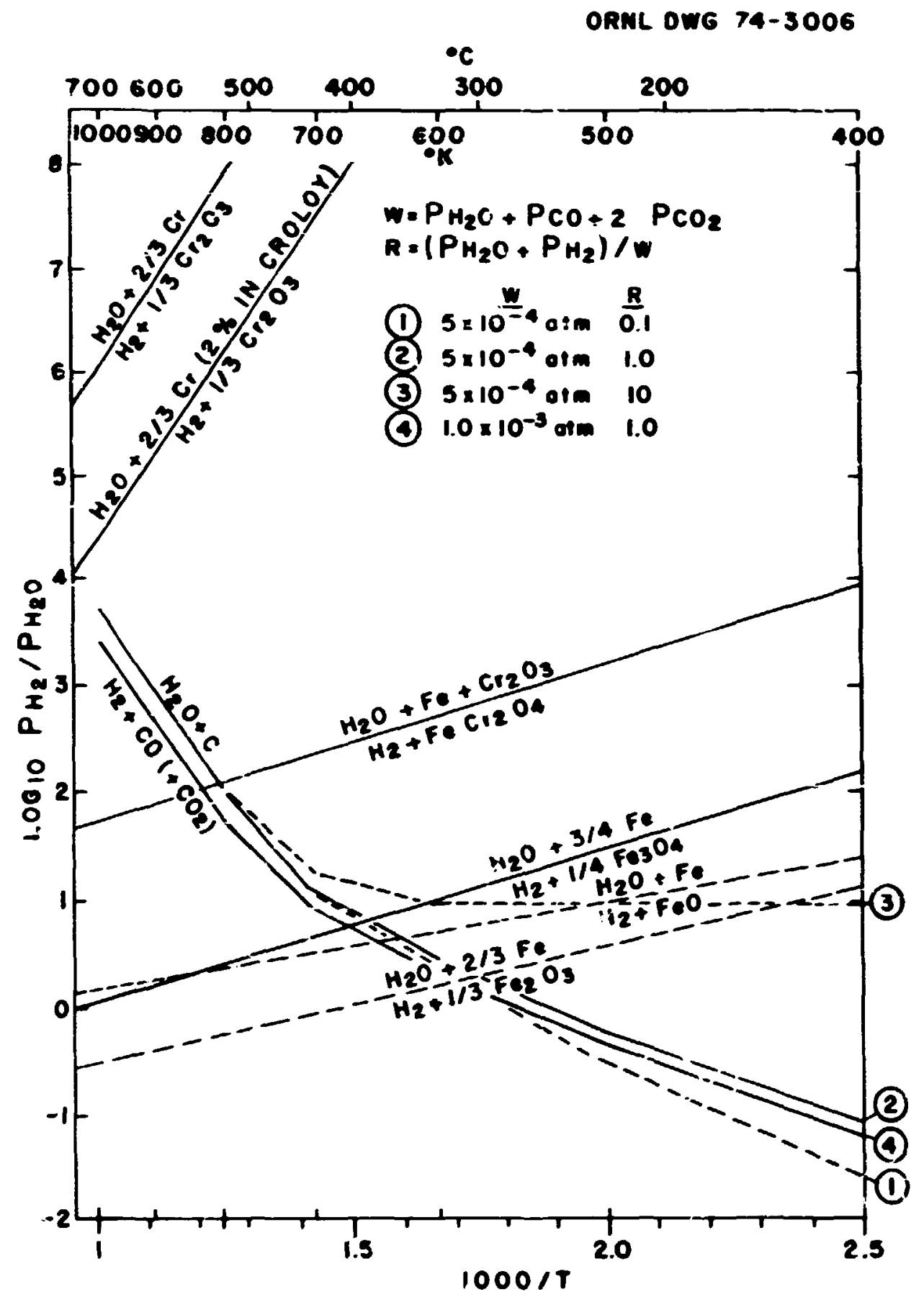

Fig. 13.1. Oxidation of iron and chromium vs zemperzture by $\left(\mathrm{H}_{2} \mathrm{O}+\mathrm{H}_{2}+\mathrm{CO}+\mathrm{CO}_{2}\right)$ in equilibrium with carbon. 


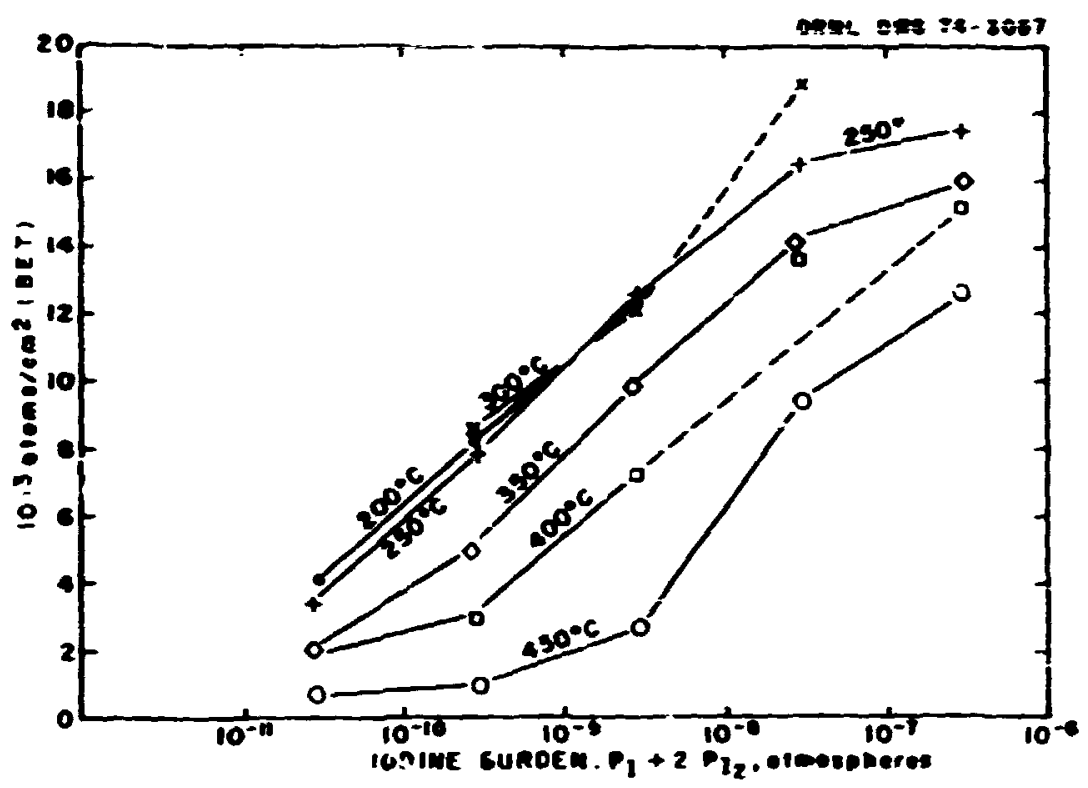

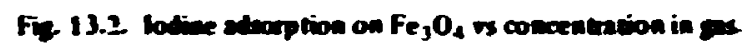

A ionic radius) wuld result in abcut $6 \times 10^{14}$ sites/im ${ }^{2}$. However. chemisorption implies specific bonds to particular substrate atoms: thus the capacity would appear to be related to the spacing of iton atoms. possibly divient iron. in the $\mathrm{Fe}_{3} \mathrm{O}_{4}$ su.faces. An $\mathrm{Fe}_{3} \mathrm{O}_{4}$ unit cell $\left(a_{3}=8.7,24 \mathrm{~A}\right)$ contains 8 molecules arranged ${ }^{18}$ in an inverse spinel structure: $\mathrm{Fe}^{3+}\left(\mathrm{Fe}^{2+}\right.$ $\mathrm{Fe}^{3+} \mathrm{O}_{4}$. The $\mathrm{Fe}^{2+}$ ions on this structure are indicated to be arranged in pairs with approximately $\mathbf{2 . 9 7}$ A sparing betwen the two: this is too close io hold an iodin atom or: each. The closest distance of adjacent pairs is indicated to he about $4.9 \mathrm{~A}$ : there would be no more than abour $2.8 \times 10^{14}$ such sites per square centir ieter, and quite possibly less, depending on exposs $t$.

Chemisorption: of iodine on all exposed atoms of elerinental iron (bec. $\sigma_{0}=2.8664$ A) again is not possible in any single plane. Th.-closest feasible regular spacing of iodine chemisorption sites appears to be on alternate iron aioms in the 110 plane. pirmitting aboul $4.1 \times 10^{4}$ sites $/ \mathrm{cm}^{2}$.

The inventory of iodine atoms released into the primary coolant syster., was indi.at? 2 to be $1.9 \times 10^{22}$ aloms at the end of the first year. The capacity of

18. H. Krebe (Tr. P. H. L. Walter), Fundomentols of Inorenenk Crystal Chemisiny. pp. 266-67. MeCiraw-Hill. Londen. 1968.
$\mathrm{Fe}_{3} \mathrm{O}_{4}$ surfaces for iodine at a partial pressure of $5 \times$ $10^{-10} \mathrm{~atm}$ (previously indicated to be an upper limit) and at temperatures in the range $20010300^{\circ} \mathrm{C}$ is about $8 \times 1 \mathrm{c}^{13}$ ioms $/ \mathrm{cm}^{2}$. Thus. these data imply that if permanent adsorption on $\mathrm{Fe}_{3} \mathrm{O}_{4}$ were the only deposition mechanism, within a year the jies on shout $2 \times$ $10^{\circ} \mathrm{cm}^{2}$ o microsiopic surface would be inieded. The superficial surface area of steam generator surface below suct emperatures is of this magnitude.

Since the expected life of the reactor is $\mathbf{4 0}$ years. other means of removing ' ${ }^{\prime}$ ' I and other shorter-lived iodine isotopes from the primary helium require consideration.

\subsection{4 lodine Deposition and Exchange}

The existence of an adsorption equilibrium requires concurrent evaporation along with deposition, resulting in an exchange of isotopes between gas and surface phases. If the rates are adequate. the surface area needed to provide enough holdup for sufficient decay of radioactive species to occur could te considerably less than that required if adsorbed atoms were mcre or less permanently fixed io adsorption ites. The partial pressure of stable iocine at steady state would be determined by the rates of entry and of removal by the purification plant. The ensuing partial pressure would determine the fractional surface coverage: this, and the available surface area, would deiermine the average 
residene time. and the residen: ime would determine the reduction by deray of the system content. and consequently the gas cuntent. of radiuactive iudine.

A simple model for steady-state isothe rmal adworption of a single rativaitive species and a sinde stable species le.sts to the following expression for ine area needed to mantain iodine isotope concentration in the coolant at a given level:

$$
A n=\left[\frac{C_{1}^{\circ}}{C_{1}}-1\left|\left[1+\frac{r_{P}}{\lambda_{1}}\right]\right| 1+\frac{\lambda_{1}}{e}\right]\left[\frac{y}{k}+\frac{R_{2}^{\prime}}{r_{P}}\right] .
$$

where

$n=$ number of adsorption sites on unit micresiopic area. sites $/=\mathrm{m}^{2}$.

$A=$ system micrustiopic area $\left(\right.$ BET). $\mathrm{cm}^{2}$

$C_{1}=$ radioaitive isotope concentration in gas, atom/ $\mathrm{cm}^{3}$.

$C_{1}^{\circ}=$ radinactive isotope concentration in $g 5$ in $\mathbf{a b}$ sence of adsorplion, atoms $/ \mathrm{cm}^{3}$.

$r_{p}=$ rate constant for removal from primary sjstem to purification system $\left[6.17 \times 10^{-5} \mathrm{sec}^{-1}\right]$.

$\lambda_{1}=$ isotope decay constant $\left[1 \times 10^{-6} \sec ^{-1}\right\}$,

$e=$ surface evaporation rate constant, $\sec ^{-1}$ (assume $e>\lambda)$.

$V=$ gas system volume $\left[9.7 \times 10^{8} \mathrm{~cm}^{3}\right]$,

$R_{2}^{\prime}=$ ingress rate of stz'sle atoms $19 \times 10^{14}$ atoms! seci.

$k=$-angmuir coefficient : n concentration units $\mid \theta=$ $k C(1-\theta)]$ for siable nuclides $\left[4.8 \times 10^{-11}\right.$ $\mathrm{cm}^{3} /$ atom, bas":d on Fig. 13.2]

The values in brackets apply to the syster: discussed earlic: : also, $C_{1}^{\circ}, C_{1}=140 / 36 \approx 3.9$. We then calculate $A n=6.3 \times 10^{21}$ sites. If the value of $n$ is $2 \times 10^{14}$ atoms $/ \mathrm{cm}^{2}$ (Fig. 13.2). then $A \approx 3 \times 10^{7} \mathrm{~cm}^{2}$ (BET)

Since the superficial area in the steam generators. in particular the economizer and evapnrator regions. will be somewhat above $10^{8} \mathrm{~cm}^{2}$, it appears that iodine remowal by adsorption on $\mathrm{F}: \mathrm{O}_{4}$, with relatively rapid exchange. could be marginally sutiicient to ensure an iodine pressure below $10^{-10} \mathrm{~atm}$. Exchange rates have nol been neasured $\mathrm{f}^{\prime \prime r}$ iodine on $\mathrm{re}_{3} \mathrm{O}_{4}$. However. relatively rapid excrange was reported by General Atomic Company ${ }^{19}$ at $400^{\circ} \mathrm{C}$ for iodine on mild stcel surtaces loaded with iodine at relatively high iodine pressures $\left(\sim 10^{-7} \mathrm{~atm}\right)$.

\section{i3.1.5 Removel of lodine from the Primary Coolant as Nexw lodides}

It is possible that metallix areas will be avadabte (particulariy if the $\mathrm{H}_{2}: \mathrm{H}_{2} \mathrm{O}$ ratio is high for any reason) and that consequently as-bome iudine could reat with metals to form volatile iodides. Condensation of these iodides on the cooler parts of the circuit cuuld provide an unlimited sink for iodine removal. They would alsu constitute a majoz localized source of iodire that would require consideration in the analysis of acidents involving fission product redistribution.

The thermodynamic data assembled by Hoink is ${ }^{3}$ have been used to calculate the equilibrium compositions at various temperatures for a constant iodine burcin of $2 \times 10^{-10} \mathrm{~atm}$ if c:m.ntal iron is always present. The results are presented in Table 13.2.

Steady circulation with equïibrium at all points around the circuit and with metallic iron available at alf points will result in a Van Arkel type process. ${ }^{20}$ (As the jodine-bearing gases are cooled. iron will react to furm gasenus iron iodides: as the iodides are heated, iron will be precipitated.) Also, as the temperature approaches $500^{\circ} \mathrm{K}$. iron diiodide partial nressure will exceed the vapor pressure and Fel: could deposit.

We have indicated earlier that $\mathrm{Fe}_{3} \mathrm{O}_{4}$ should exist in the system below $400^{\circ} \mathrm{C}\left(673^{\circ} \mathrm{K}\right)$. If elemental iron is not available to the gas below such a temperature, the iron hurden at this temperature would limit the iron diiodide partial pressure at lower temperatures, and the gas temperature would have to increase to about $183^{\circ} \mathrm{C}$ $\left(456^{\circ} \mathrm{K}\right)$ befure condensation of iron diodide could occur. (Ir this and other discussions the "burden," in atmospheres. of a given ato:n will be defined as the sum of the partial pressures of each gas-borne species containing it multiplied by the number of the given kind of atoms in the species. At constant system pressure it is independent of temperature and reactions in the gas phase, unless additions or removal from the gas phase ocicur.)

Two factors actually operate against deposition by conciansation discussed above. First. : tal surface tempratures are nut believed to get as low as $183^{\circ} \mathrm{C}$. and possibly not as low as $227^{\circ} \mathrm{C}$, except behind the

19. "Sorption of ledine on Metal Surfaces (Dynamic Method)." Pubic Srnice Company of Colorado 330 . HW(r) Wheh. Trmperafure lias.Conled Rrartor Rrsearsh and Develny. ment Proxtam Quort. Prnzr. Rep. Sept. 30. 1967. GA-8270. pp. 14355.

20. R. F. Rnisten. Iodids Metals an I Metal Iodides. Wiley. New York. 1961 . 


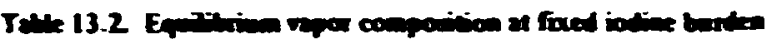

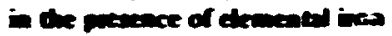

\begin{tabular}{|c|c|c|c|}
\hline & \multicolumn{3}{|c|}{ Temperature $(\mathrm{K})$} \\
\hline & 1000 & 673 & 500 \\
\hline Vapor presurure of Fel $2(s)$. arim & $2.5 \times 10^{-2}$ & $2.1 \times 10^{-6}$ & $7.22 \times 10^{-11}$ \\
\hline 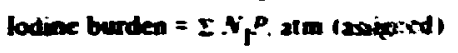 & $2 \times 10^{-10}$ & $2 \times 10^{-10}$ & $2 \times 10^{-10}$ \\
\hline Iroa buiden $=\Sigma N_{F} P$. atm & $3.9 \times 10^{-1 .}$ & $1.49 \times: 0^{-12}$ & $7.76 \times 10^{-11}$ \\
\hline$P_{1} \cdot$ atm & $2.00 \times 10^{-10}$ & $197 \times 10^{-10}$ & $1.98 \times 10^{-11}$ \\
\hline$P_{\mathbf{I}_{\mathbf{2}}, \text { atm }}$ & $1.14 \times 10^{-17}$ & $8.95 \times 10^{-14}$ & $1.25 \times 10^{-11}$ \\
\hline$P_{\text {Fel }_{2}} \cdot$ atm & $3.9 \times 10^{-16}$ & $1.49 \times 10^{-1:}$ & $7.74 \times 10^{-11}$ \\
\hline$P_{\mathrm{Fe}_{2} \mathrm{~L}_{4}}, \mathrm{~atm}$ & $17 \times 10^{-29}$ & $7.3 \times 10^{-20}$ & $3.15 \div 10^{-14}$ \\
\hline$P_{\mathrm{Fel}_{3}}, \mathrm{~atm}$ & $1.3 \times 10^{-23}$ & $2.6 \times 10^{-17}$ & $134 \times 10^{-13}$ \\
\hline
\end{tabular}

thermal barricr, which is effectively inaccessible. Second, the reaction rates with high-temperature surfaces would have to be faster than is deemed likely. so that equilibrium concentrations may not develop arount the circuit. Some data indicating iron iodide transport at higher iodine pressures $\left(\sim 10^{-8}\right.$ to $\left.10^{-7} \mathrm{~atm}\right)$ have been presented by the General tatomic Company. ${ }^{9}$ "

In addition to $\mathrm{Fe}$, the metals of HTGR primary coolant circuits include Ni. $\mathrm{Cr}_{r}$, Mn. and small proportions of oth er elements thit are also capable of forming volatile iodi les, principally the diiodides. Calculations related to the behavior of iren were reported by Hoinkis ${ }^{13}$ and by Milstead et al.. ${ }^{17}$ that of chromium has been reported by Osborne. ${ }^{21}$ anJ the stability and

21. M. F. Osborne, "sodine Adsorption and Desorption," GCR Program Annu. Progr. Rep. Dec. 31. 1972. ORNL4911. Pp. 168-72. volatility of various metal iodides have been discussed by Rolsten. ${ }^{20}$ We have calculated equilibrium constants for the formation of $\mathrm{Fel}_{2}, \mathrm{Nil}_{2}, \mathrm{Crl}_{2}$, and $\mathrm{Mnl}_{2}$, as gas and condensed phase, at 500 and $1000^{\circ} \mathrm{K}$, using thermodynamic daia presented by Brewer. 2.23 These values and .heir differences (which sorrespond to the logarithm of the vapor pressure of the condensed diodide) are shown in Tabic 13.3.

The vaiues indicate unambigu yisly that where manganese is available to form the indide. it will be the

22. L. Brewer. G. R. Somay ajulu, and E. Braisett, "Thermidynamic Prodetl es of Caseous Metal Dihalides." Them Rev. 1964, 111-2i

23. C. N. Lewis and M. Randall, Thermodynamics. id ea., revised by $K$. S. Pil et and $L$. Brewer, McGraw-Hill, New Yik, 1961 .

Table 13.3. Logrithm of equilibrium comants for the resction $M(s)+21(\theta)=H_{2}(s$ or $g)$

\begin{tabular}{|c|c|c|c|c|c|c|}
\hline & \multicolumn{2}{|c|}{$\begin{array}{c}\text { Log } K \\
\text { (condensed state) }\end{array}$} & \multicolumn{2}{|c|}{$\log K$ (gas) } & \multicolumn{2}{|c|}{$\log V P\left(a(m)^{a}\right.$} \\
\hline & $500^{\circ} \mathrm{K}$ & $1000^{\circ} \mathrm{K}$ & $500^{\circ} \mathrm{K}$ & $1000^{\circ} \mathrm{K}$ & $500^{\circ} K$ & $i 000^{2} x$ \\
\hline $\mathrm{Hel}_{2}$ & 23.23 & $6.92^{h}$ & 12.72 & 5.15 & 10.51 & $-0.87^{b}$ \\
\hline $\mathrm{Nil}_{2}$ & 18.47 & 2.79 & 0.28 & 1.74 & -12.19 & -1.05 \\
\hline $\mathrm{rrl}_{2}$ & 26.59 & 7.54 & $10 . n 7$ & 4.08 & -16.52 & -3.46 \\
\hline $\mathrm{MnI}_{2}$ & 35.78 & $12.53^{h}$ & 24.04 & 10.50 & -11.74 & $-2.03^{b}$ \\
\hline $2 I=I_{2}$ & & & 21.11 & 5.76 & & \\
\hline
\end{tabular}

${ }^{a}$ Fqual in $\log K$ (kas) $\log K$ (condersed).
${ }_{\text {Liquid. }}$ 
Joninani sidid or vapor species (despite low concentration in the alloys): the risurijied iog $\boldsymbol{K}$ value is much the highest. This is con isteat with $a$ statenent by Rivisten $=0$ that the high siability at mangonese iudide will prevent the produition of manganese by the iodide priviess.

Beciuse if. liR iuldunt systems are likely to contain much more oxyen fas $H_{2}, 0$. $C O$. and $\mathrm{CC}_{2}$ : th:an iodine. it is likely that buth manganeze aisd shrumium will (where avalable at the surface) be bound as oxiutes.

\subsection{6 lodiae Behavior under Arr ineat Conditions}

The effectiveness of depusition on primary circuit surtiaces is best assessed in terms of the ratio of the amount of iodine deposited on surfaces to that in the gas phase at steady state. which. from equarions presented in Section 13.1.3. can be seen io be $r_{s}: \lambda$ for 3 system in whith deposition is not limited by surface apacity. For the example employed, $r_{s} i \lambda$ is $\sim 2200$. but values in excess of $\mathbf{2 0 . 0 0 0}$ have been measured in operating HTGRs with relatively clear circuits. ${ }^{24.25}$ In assessing the release of iodine during an aciident. one must therefore pay careful attention to the rate at which deposited iodine can become gas turne cilher by evaporation. as the result of themical reaction. or beiause the surface itself is inherently mobile. as in the ase of a dusi film. io date. we have heen concerned with physical desorption and desorption due to themical reaction.

Four scouting experiments made with portions of a sample of iron powder on which iudine had been adsurbed at $400^{\circ} \mathrm{C}$ to a surface concentration of $7.4 \times$ $10^{1+}$ atoms $\mathrm{cm}^{2}$ (BET) are reported below. IThe iron powder had a specific surface area of $0.14 \mathrm{~m}^{2}$ is (BET).)

Isothermal desorption into a flowing helium stream containing $3 \% \mathrm{H}_{2} \mathrm{O}$ was examiired at $250^{\circ} \mathrm{C}$ by placing one-fourth of the sample (alout $0.4 \mathrm{~g}$ ) in a heated $\mathrm{I}$-in.-diam tube and passing th: heliunt-steam mixture over it at I liter (STP)/min. After 5 hr. about $13 \%$ of the original ionine was desorbed.

Three desorption experiments were conducted using the temperature-ramp technique. In two of thesc experiments, a helium $3 \%$ steam mixlure was passed over a separate portion of the sample while the

24. P. R. Rowland. W. F. Browning. and M. Carylyle, Behavior of lodine Isofopes in a High Temperature lias Rractor Covlani Cincuir. I).P. Repurt 736 (N vember 1970).

2.5. II. J. de Nordwall. F. F. Dyer. J. O. Kolb. and W. J. Martin. Sect. 13.2, this reprort. temperature was increased steadily at a rate of ${ }^{\circ} \mathrm{C} \cdot \mathrm{min}$. Fiows of 2.2 and +.5 liters (STP) min, respectively. were used. In the third experiment. pure helium flowing at 2.2 liters (STP) min was used, with the same rate of temperature increase $12^{\circ} \mathrm{C}$ min). The amount of iodine remaining on the specimen at any time (or temperalure) was determised by in-situ gamma spectrometry. Figure 13.3 is 2 giaph of the conrse of desorption in the respeciive experiments. which was consistent with list-orcier kinet es.

First-urder iesorption rate cisilicients $\left(k\right.$. $\sec ^{-1}$ ) oblained hy differentiating the curves are sinown in Tatle 13.4 for temperatures of 250,400 . and $550^{\circ} \mathrm{C}$. alung with the single value obtained from the isothermal experiment.

Veill ${ }^{26}$ repor ed that at $400^{\circ} \mathrm{C}$. iodine at a surface concentration of about $8 \times 10^{15} \mathrm{atcms} / \mathrm{cm}^{2}$ on bright steel was desothed under vacuum with an initial rate constant of abou $7 \times 10^{-5} \mathrm{sec}^{-1}$. about twice what we observe: into tlowing helium. However. evaporation into vacuum and into a flowing gas stream may not be limite- 1 by the same factors.

It may be seen that in the experiments using moist helium. the desorption rate coefficients were propo:tional to llow. This suggests that desorption may depend on partition between the surface and gas phases. A partition coelficient $Z$ (atoms/liter)/(atoms $/ \mathrm{cm}^{2}$ ) can be calcuiated threugh the use of the expression

$$
Z=\frac{273 \cdot 1 k A}{T F}
$$

where $F$ is the rate of flow [liters (STP)/sec]. $T$ is the temperature $\left({ }^{\circ} \mathrm{K}\right)$ at which the first-order rai $=$ coefficient $k\left(\sec ^{-1}\right)$ is evaluated, and $A$ is the BET surface area of the sample $\left(\mathrm{cm}^{2}\right)$. Values of $Z$ for the various experiments and conditions are also shown in Table 13.4. It may he seen tha: values of $Z$ at a given temperature are consistent for the moist helium expcriments.

If we assume that the desorption rate into pule helium can he similarly treated. the partition coefficien's are less than those for moist holium at 250 and at $400^{\circ} \mathrm{C}$. indicating less desorption under the given (4) nditions.

A. equilibrium partition ratio can be calculated at $400^{\circ} \mathrm{C}$ for the static procedure in which the sample was

26. F. H. Neih, Adsorption and Desomplion of Iodine on Mild Sirel, OR.NI.-TN.276.3 (April 1970). 


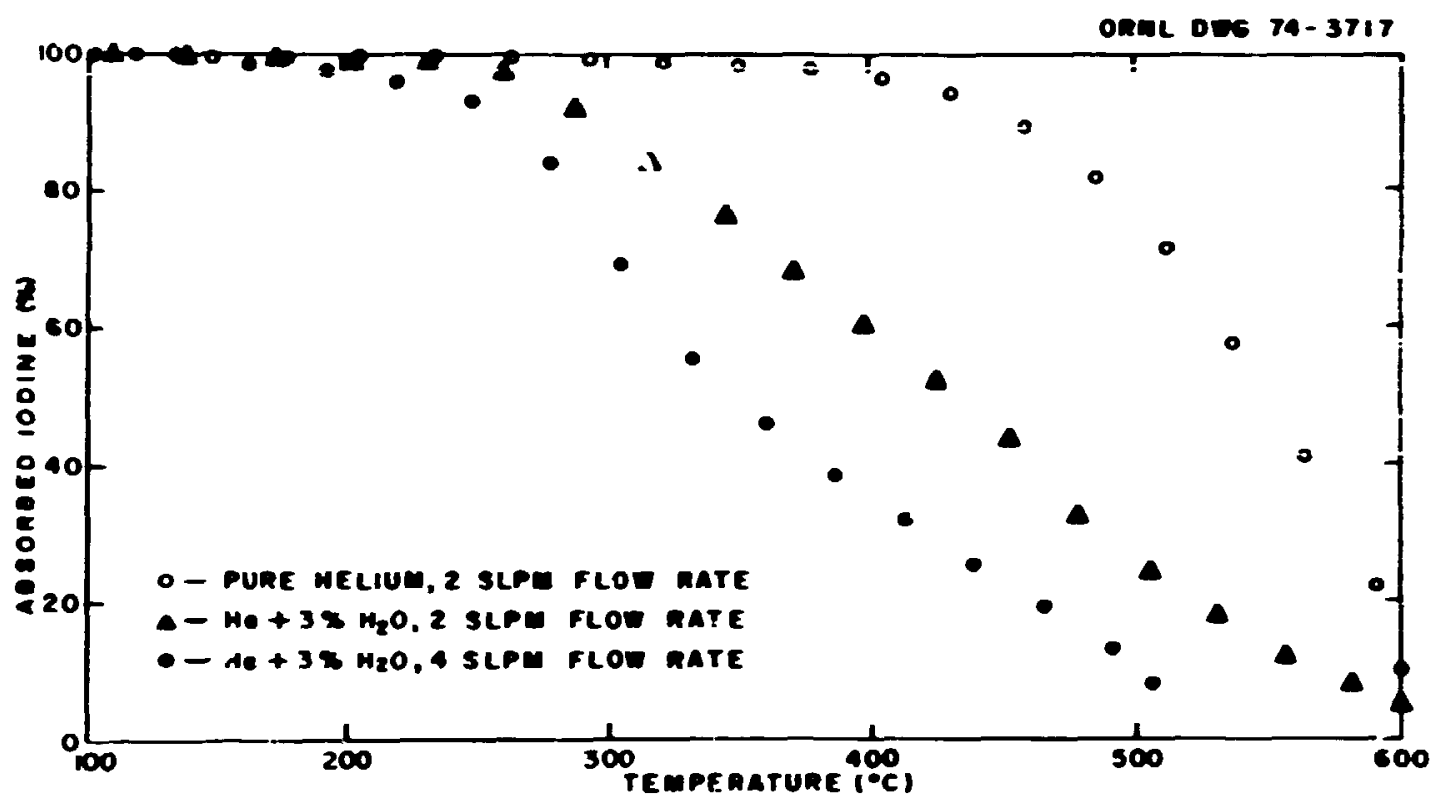

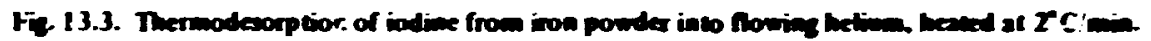

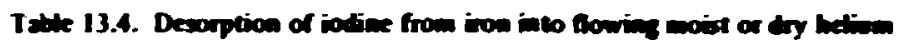

\begin{tabular}{|c|c|c|c|c|c|c|}
\hline Type & $\begin{array}{l}\text { Fkow } \\
\text { [liters (STP), } \mathrm{min} \text { ] }\end{array}$ & $\begin{array}{l}\text { Fraction } \\
\mathbf{H}_{2} \mathrm{U}\end{array}$ & Coeffinient" & $250^{\circ} \mathrm{C}$ & $\div 00^{\prime} \mathrm{C}$ & $550^{\circ} \mathrm{C}$ \\
\hline Isothermal & 1. & 0.03 & $\begin{array}{l}k \\
Z\end{array}$ & $\begin{array}{l}8 \times 10^{-6} \\
0.14\end{array}$ & & \\
\hline k.mp & $\therefore 4$ & 0.03 & $z$ & $\begin{array}{l}.0 \times 10^{-5} \\
0.10\end{array}$ & $\begin{array}{l}1.5 \times 10^{-4} \\
0.9\end{array}$ & $\begin{array}{l}5 \times 10^{-4} \\
2.6\end{array}$ \\
\hline Ranip & 4.2 & 0.03 & $\begin{array}{l}\hbar \\
Z\end{array}$ & $\begin{array}{l}4 \times 10^{-5} \\
0.16\end{array}$ & $\begin{array}{l}2 \times 10^{-4} \\
1.2\end{array}$ & $\begin{array}{l}1.1 \times 10^{-3} \\
2.5\end{array}$ \\
\hline Ramp & 2.2 & 0 & $\begin{array}{l}k \\
7\end{array}$ & $\begin{array}{l}2 \times 10^{-6} \\
0.016\end{array}$ & $\begin{array}{l}3 \times 10^{-5} \\
0.19\end{array}$ & $\begin{array}{l}4 \times 10^{-3} \\
2.0\end{array}$ \\
\hline
\end{tabular}

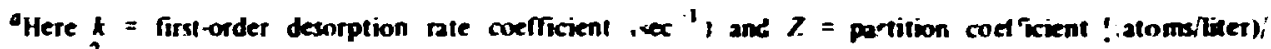
(atoms $\left./ \mathrm{cm}^{2}\right)$.

prepared by depositing iodine on the sample surfaces.

$Z_{\text {eq }}=\frac{6.02 \times 10^{23} \times P}{S R T}=\frac{6.02 \times 10^{23} \times 2.5 \times 10^{-8}}{7.4 \times 10^{14} \times 0.082 \times 673}$

$$
=0.37 \frac{\text { atom/ititer }}{\text { atom } / \mathrm{cl}_{1} \mathrm{1}^{2}} \text {. }
$$

where $S$ is the original surface concentration $(7.4 \times$ $10^{1+}$ atoms $\left./ \mathrm{cm}^{2}\right), P$ is the iodine piessure at the sample $\left(\sim 2.5 \times 10^{-8} \mathrm{~atm}\right)$ after thermal transpiration and dissociation are taken into account. and $T$ is the sample temperature $\left(673^{\circ} \mathrm{K}\right)$.

Comparison with the experimental value at $400^{\circ} \mathrm{C}$ in the dry helium experiment. $Z=0.19$, indicates that the values are in reasonable agreemeni. the value obtains." by live kinetic method indicating a little less relase than that derived using the static method. The closeness of the agreement indicates that the experiment with dry 
hetrum probably did depend preduminantly on partitiva equalibrium Quite possibly this ws also ince for the experiments with muist helium. but mass tansfer analy sis ( not attempted) appears desirable.

It may be shown that if a substance is partitioned between grs and surface phases with 2 partition ptio of $y^{*}$ atoms on surfacs/atoms in gas. and the pas is isot rmally bled off (depressurized). then

$$
j *+1 ; \ln \left(\frac{v_{f}^{*}}{F_{s}}\right)=\ln \left(\frac{P^{*}}{P_{1}}\right)
$$

where $N_{s}$ and $V_{s}$ are the number of stoms originally and biet in the system and $P^{\circ}$ and $P_{l}$ are the corresponding system pressures. By definition.

$$
M *=(A / V) Z
$$

where $A$ is the (miiroscopic) surface area of the system on which ioduc is adsorbed ant $V$ is the effective volume of the $z$ in the system. in order to estimate the effects of full depressurization in an HTGR. ve coume an area $A$ holding iodine of $2 \times 10^{\circ} \mathrm{cm}^{2}$ and an effective volume equal to that occupied by $9320 \mathrm{lb}$ of helium at $47.6 \mathrm{~atm}\left(P_{0}\right)$ (i.e.. $V=0.95 \times 10^{6}$ liters at $250^{\circ} \mathrm{C}$. etc.). We thus calculate ine fraction lust at the various temperatures to be $0.0003,0.005$. and 0.056 at 256. 400 . and $550^{\circ} \mathrm{C}$ respectively.

The complete release to the environment of several percent of the primary coolant circuit inventory of i 3 'I may be required in order to exceed 10 CFR 100 limits. This material is likely to have been deposited in the cooler region of the steam generalor. The abov. values sugest that in a siry system. a heatup of these regions would have to occur before potentially intolerable relezse of 13 'I would occur. even in the case of complete depressurization completely released to the environment. In the moist system this may also be the case (as indicated b: similarly calculaled values). bu! mass transfer effects may need to be -onsidered.

\subsection{FISSIOA PRODUCT BEHAVIOR IN THE PRIMARY CIRCUTT OF THE PEACH BOTTOM HTGR}
J. O. Kolb
W. J. Martin
F. F. Dyer
L. L. Fairchild

\subsubsection{Experimented}

The experimental measurements that were made as part of this program involve sampling the helium covlant leaving and teturning to the cure and measuring the ouffar : : products depasited on accessible pirinus of the primary coolant circuit.

The coulant samplers were designed to i'l peimit helium to enter the sampler at reaitor coular. veluxity to minimize perturbation of partikte flow paths (isokinctio sompling). 12) separate molecular speries from particulate malter. and (3) separale and cullect particuhte matter azording to size while avuiding agdumeration on collating surfares and conseyquen! obsiruring of prticulace features.

Lesor and material limitations were imposed by the sizes of the arilabte openines in the ciriuit boundary. ine esperature of the helium being sampled. and the necescity for the upsiream smpler to in-orpurate a thermocouple. Upsiream and downstream (netative to the steam gensrator) samplers are therefore different in deta. The downstream sampits is shown schematiolly in Fig- 13.4.

Cas enters the samplet through, an intet nozze and flows through three silver diffusion tubes in parallet. a fivestage cascade impactor. a siver membrane filter. a fitergass "absolute" filter. and. finally. silver z"viice and treated charcoal traps to remove any r-maining iodine and organic iodine compound. 2" After the sampler is removed. eat componer. is analyzed separately. External surfaces axpose; te hot croblant are examined to determine the exient of any coolant-metal interations.

The order of the active components in the sampler was determined by a desire to prevent condensable molecular specie: from passing through a filter. In a system containing a relatively large amount of dus.. there are advantages in trying to remove dust first. particularly if the dust particles are large enough to be removed centrifugally. Where the dust particles are small. deposition of some dust in diffusion tubes is unavoidable. The resulting confusion depends or the relative proportions of a given nuclide $p$ sent as dust and molecules. An ideal sarr.pling station would include three samplers: (1) the type described above; (2) the type used in the Dragon Project, which is designed to remove heavy particles first: and (3) a short charcoal trap and filter to remove everything to permit easy and rapid analysis of the total inventory of the gas being sampled.

27. R. D. Ackley and Z. Combs, Applicebility of Inorponir Sorbents for Tropping Radioiodine from IMFBR Fuel Re processing Off-(ias, ORNL-TM-4227 (May 1973). 


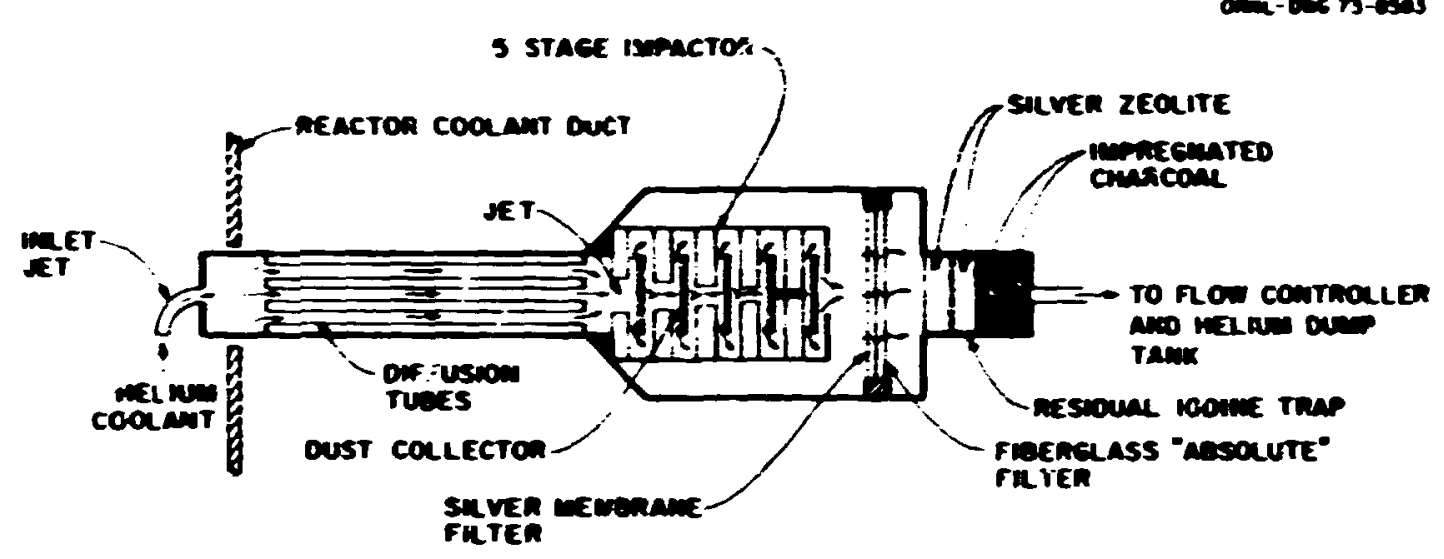

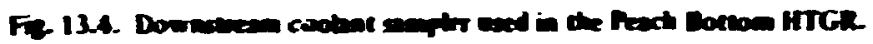

In the downstrean sumplet. sibver was chosen as the fabrication material for the diffusion subes and the first filter element because (I) it would not tarnish in a reactor atmoxphere. (2) stable silver is not songht in the coolant circuit dure, and ( 3 ) its etectrical conductivity and bright metallic surface fixilitates examination of deposits by electron and optice microscopy.

The upseream sampler consis:ed of two units. one containing diffusion tubes and one containing filters and absurbers. The filter unit was separated from the diffusion lube unit by a few feet of pipe; the diffusion tubes weie made from slainkess steel. paitly because sufficiently small silver tubes were unavailable and partly to avoid risk of silver vapor entering the reactor.

Although the coolant samplers were in place throughout each entire reactor opersting period. they were operated only toward the end of the cycle to minimize dust accumulation and to make the collected fission produr's relate as closely as possible to the reactor downime at which the samplers were removed. Even so. the amount of dust collected caused actomeration on the impactor plates and filter surfaces.

During reactor shutdown. deposition of gamma-rayemitting radionuclides on different portions of the primary coolant ducting was measured by gammsspectroscopy using a $\mathrm{Ge}(\mathrm{Li})$ detector surrounded by 2 shield designed to Iransmit gamma rays from only a limited area on the duct. The detector was moved manually around the primary circuit cavity, the analyzer remaining in the reactcr air room. This exercise has been carried out three times: in June 1971 and 1972 and in September 1973.

In order to estimate the contributions of raregas decay in the primary circuit to observed activities of rarezs daughters sich as $139 \mathrm{Cs}$ and ${ }^{\circ} \mathrm{Sr}$, the concenuations of shortined krypton and xenon isolopes were measured by nowing the coolant directly through a specially desizned counting cell.

\subsection{2 bocine Delumior}

Tne distribution of iodine between samplet compo ner to is given in Table 13.5 for the pair of samplers remowed in May 1973.

Talle 13.5. Lutine didtribtions in cootant mapless (My 1973)

\begin{tabular}{|c|c|c|}
\hline \multirow{2}{*}{ Component } & \multicolumn{2}{|c|}{ Iodine concentration :(w) } \\
\hline & Lpsiream & ivownstream \\
\hline Diffusion tubes & 0.047 & 0.034 \\
\hline Dust & 0.0014 & $<0.018^{a}$ \\
\hline Special traps & 0.00014 & 0.0036 \\
\hline Total & 0.048 & $0.038 \cdot 0.056$ \\
\hline
\end{tabular}

Apper limit; no ' 31 ! peaks actually observed.

Since no ${ }^{131} 1$ was found in the last inpregnated charcoal an.1 s:iver zeolite traps. one has some assuranie that a substantial fraction of the iodine entering the samplers was collected. The apportionment of the totals between different species was made using the observed distribution of 13 'I between sampler components.

"Organic iodides." which are characterized by their ready passage through the diffusion tubes and dust filters and subsequent deposition on the adsorbers. were 
prexent unly at retativeiy low comienteations. The

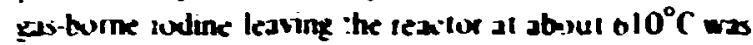
inl 0.:; "urgani watuk." wheteas that kaving the sejm generatur al shuut $310^{\circ} \mathrm{C}$ contaned between o Ind 5 of organk indide. Approximately $90 \%$ of the ensuni whlice enternge the core was apparently being insiruged by passupe through the core. Sime the fiters in both sumplers operated at similar ambient temperaiure. Mreani iodide gentratson in the somplets cannor sicunt lor all ai the ludine found in the specal traps. Oreanin ididz ismpuninds were apparently beung iurmed in the steam geracator. probably by recitiuns between deposited iodine and carbuniontainug anaterils on the steam generator surfacs.

The composstion of the dust .-iculating in the Peach Buttom HTGR indkates that it does not have a sinple sevurie. : During this sampling period. small quantities of ui irom the purified helium cumpressur were known to be leaking into ihe priman coolant ciccuit. That this had raised the dust conceniration was confirmed by 2 late, experiment (wtikn the oil kak had been stopped) in which almost no dust was delected in our samplers. May 1473 dust anpeared lo cuntain only iraces ci indine.

The larga iration of iodine in the diffusion luber was nus erturely consistent with the abserved fat-surface concentration profiles (Figs. 13.5 and 13.5 ) or the amount of dust visible. There was clearly not enough dust in the diffusion lubes to asiribe activity measured in that region to the iype of dust collected on the filters. The temperalure distribution in the sampler may also have influenced the iodine distribution. Unambigu. ous as.jgntrent of this iodine io definite molecular species inu:it await the resulis of further experiments.

In spite of this incertainty about the lodinecarrying species. iretwean 33 and 587 of all 131 / leaving the cure was teing deprosited on fixed surfaces between the samplers. which include the steam generator. If one excludes the organic iodide compounds from this eximate of life deposition rale. one oblains higher values (viz.. 41 to 60\%), but one must then describe the production of organic iodides separately. ITinis anay he verirable anyway, since organic iodides may behave differ: ntly in PCRV concrele and do behave differentiv in th: remainder of the chain learing to man.) We haster to add that the Iransiation of these conclusions (1) z.nother reactor is only valid if residence times.

28. F. F. Dyer el al. (iCR Prontam Annu. Prokt. Rep. Dec 31. 1972, ORNL.49II, p. 172.
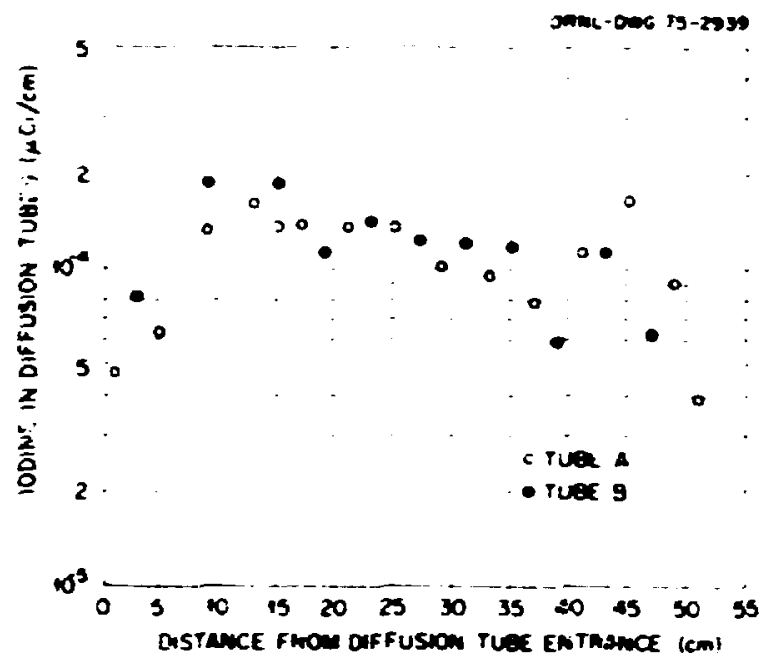

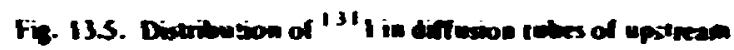
ander.

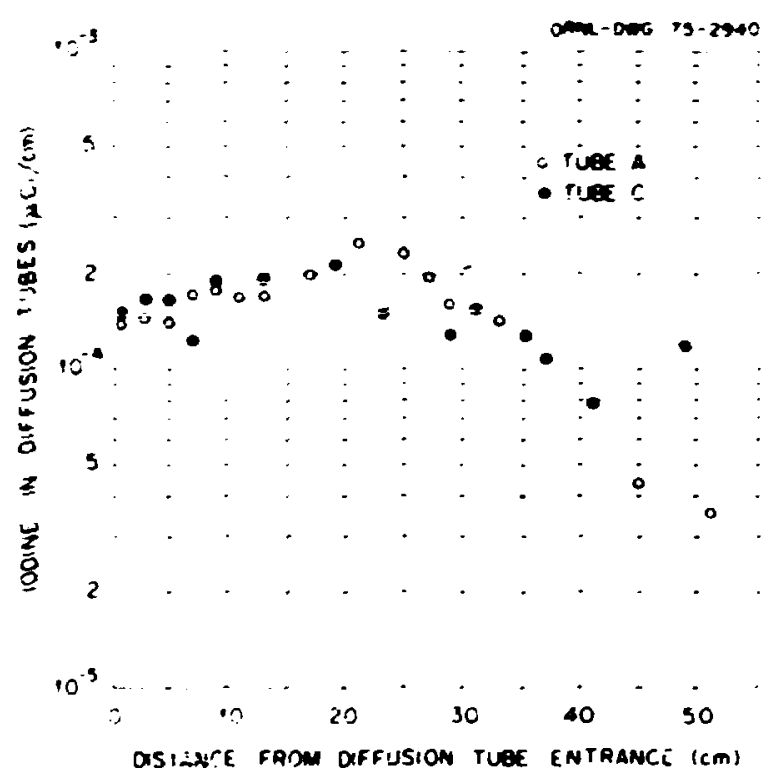

Fiz 13.6. Distribution of 1311 in diffusion rebes of dowar stream sampier (May 18. 1973).

temperatures. temperature distributions. and deposition rates are similar and if adsorption isotherm, are linear.

The possible deperdence of the deposition ratio in the iodine content of the primary circuit was discussed in Section 13.1. No attempl was made to measure 129 I and stable ${ }^{127} \mathrm{I}$ in our samplers. We expect that barely delectable amounts of these nuclides will the present on 


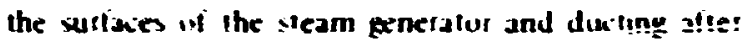
in rexilor is deciommissiume:

Surface comcentiations of 131 in the costd din't, as .xessured in September 1473 by gamma specitrusciops. are shown in Fig. 13.7. The corcentration was iound io van expunentally with disizoce along ihe duit. indicaing iha! upposithon was irreversibic The mass iransfer cixefluient $h$ for depoxilion was calculated to he 5.9 imicec by siling the equation

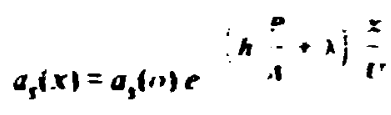

wo our resuls. In this -xpresion. $a_{\text {s }}$ is the surface atuvity $\left(\mu(1) / \mathrm{sm}^{2}\right)$ at pusint $x$. it is the mas !ranster cicfinient. $P$ is the duit perimeter. $A$ is the crosssectional area. and $\boldsymbol{l}$ is the :etoxity. Fis mass transic: axtifient iakulated by Hansun ${ }^{29}$ using the PAD cude $^{3 E}$ io represent the sepussition of an atoni of

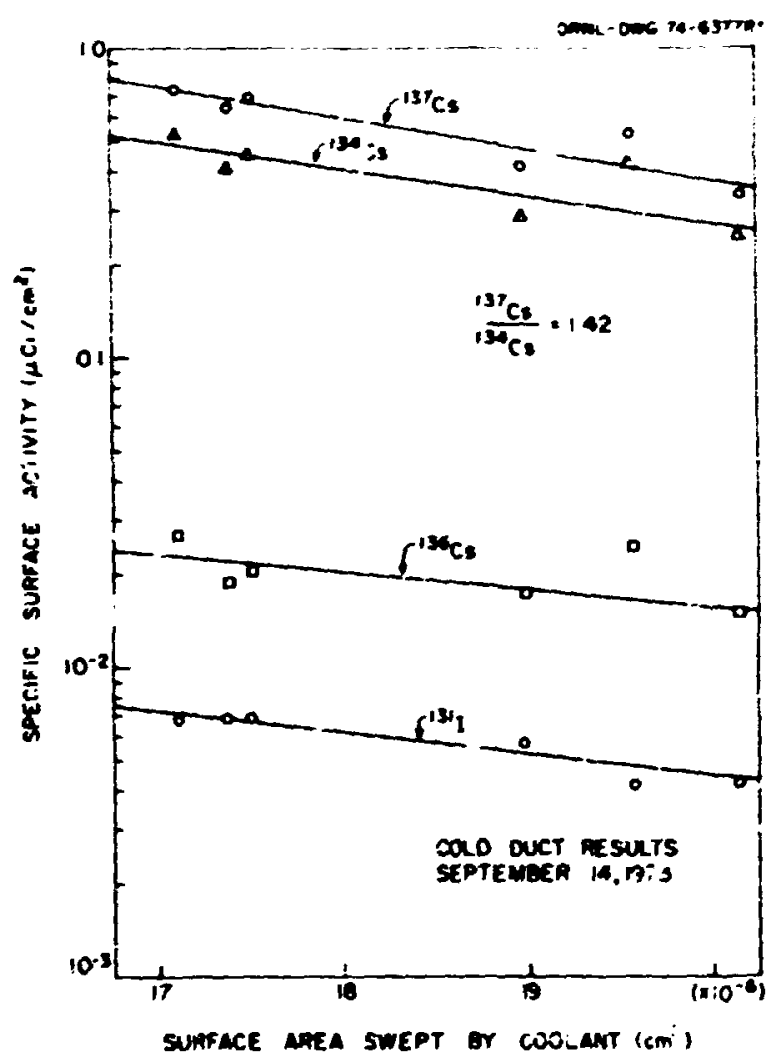

Fig. 13.7. Surface concentrations of $131 /$ in the cold dure (Sept. 14, 1973). smitai sice $i X e$ was about $5.7 \mathrm{~cm}$ ser: this tends to confirm that some elemental iodine $[1+1: 1$ was present in the gas leaving the steam gerretafor.

Iniegration of the expressior. above yielded an ailis. ity ity the cold duit of a single coulant loxp of 0.0047 (i. 0.0045 (i) of whikh was depasited in the regon between the steam generator and the duwnstieam gas samplers.

Wi '31/ was celeited on the hot duct. However. surface comienirations on the ho! dut comparable to that found on the cold auil wciad have been deteited.

ni:- ubserved leptetion of the coolant and he deposition in the coid duct were lised to calculatc the 13. $I$ inventory of the steam generator surticies anc the accessibte parts of the circuit (is.. the region from the hol valve to the end of the cold return dicil). The No. I steam generator and the loop were estimated to coniain 0.025 and 0.035 ( $i$ of ${ }^{13}{ }^{1}$ I respeciively. Assuming that both lougs conta- the same amount of iodine. that the gas plase contairs a nedigible amount of iodine. and tha: the inaciessible regions of the sholant circuit contair insignificant amounts of deposited iodine. elther because their surfaces are too hot of because deposition rates are $f(x)$ low. one alculates that $R^{\prime}: B^{13} \cdot I$. the rate of release from the core into the covlant ircuit to the hirth rate. was $2.4 \times 10^{-8}$. T, oblain the rate of ${ }^{13} 1$ ralease from the fuel. one must multipiv the rate of release by the purge altencation factor. which. : when !ast measured. was about $60 \mathrm{i0}$. This highe release rate $\left(-10^{-n}\right)$ is the one that should be compared with the expecied rels:ase rate for largir HTCRs.

Conclusiom. Helium leaving the core contains very liftle $\mathrm{C}^{\prime} \mathrm{I}_{3} \mathrm{I}$ and dust-borne iodine. The organic iodine that enters the core from the steam generator is a'most completely testioyed in the core. and temperatures are tow high for iodine to adsorb appreciably on the circulating dust leaving the core and pethaps on the walls of the hot duct as weil.

On entering the steam genelator. the iodine divides itself between the phase and a two-component surface consisting of a dust layer and the metal structure. Between 35 and $58 \%$ of the iodine leaving the core leaves the region between the samplers in a similar nolecular form. and $0.025 \% /$ hr of the iodine deposited

29. D. Hansin. (jene, a' Atomic Company. unpublis ied work. 30. F. F. Vanslapei and L D. Mears. PAD. A compro.er Code for Colculating the Plar-ous Actuvity Dislmibution in a Reactor Cidcull. GiA-10460 (JanLary 1971). 
helween the samiteis reenters the 1,2s phase after an unkining: delay as "organi- :odine."

A further. ics well-detined fraction of adsorbed iviin may beconce asuivisart with a dust layer that cuats the auriaces of the stean wi:erstor and rienter the gas phase on dist partickes. Alremasi.ty. iodine atoms my iest with dist in the ges phase. We cio iriot distinguish the two piocesses. However. we prefer the former model. beizuse it is kinetically more probable and because our resulis for cesium imply that some dust may remairi on the stram generator and duct surfaics for years. Dust passing. through the core would the almost completely freed if iodine.

We prefer to awail a sults from our seciond set of smplers, which were noi affected by oil decomposition? products. before recommending hu: the cencentration $o^{f}$ different circulating species dowrstream of a steam zenerator should be calculated. Clearly a single depusition rate for all iodines riust be selected with great gare if the conversion of organic anu dustcaris:d iudine in the core is to be sonservatively desirined.

Finally. we would caution the :eader that these data may only apply to Peach Bottom during a time wher oil is leaking into the circuit. Their general applicability remains to be established by further measurements in this and other HTGRs.

\subsubsection{The Behavior of Cesium}

Cesium in the cootant circuit. The disiribution of cesium between components of the upstream and downstream samplers is shown in Table 13.5. The axial surface concentration profiles measured in upstream and downstream diffusion t:ibes are shown in Figs. 13.8 and 13.9 respectively. Tnese profiles exhibit an expos. nential distribution followe? by a uniform distribution. with considerable scatter in the uniform values. We have ascribed the exponential distribution to the deposition

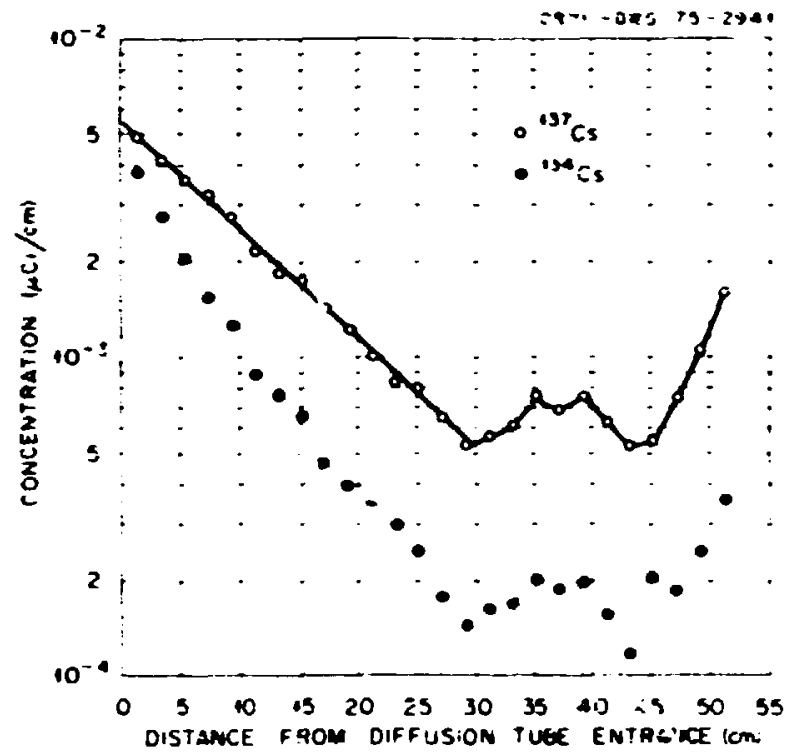

Fiz 13.8. Disuribucion of rediocesiun on difusion tuk $C$ epsean samplet (Xay 18. 1973 ).

of gaseous species that obey gas ciffusion principles ind the uniform distribution to the deposition of dus: particles that contain radioresium. We observed that the surface concentrations of cesium increased siveral centimeters from exit ends of all diffusion tubes. This anomaly remains to be explained. We assumed that the uniforni dist-horne cesium was constant alcng the entire diffusion tube bugtin aini have sublrach:d this total dust-horne cer.um from the total amouni ot cesium found on the diffusion tubes to ubtain a net fractional amount of gaseous cesium in the coolant. The concentration of cesium isotopes in the coolant derived from !!:ese observations are presented in Table 13.7.

Table 13.6. Obnerved distrioution of cesium activities ( $\mu \mathrm{C} i)$ in Peach Bottom gas samplers .'n May 17. 1973

\begin{tabular}{|c|c|c|c|c|c|c|c|}
\hline \multirow{2}{*}{ Component } & \multicolumn{4}{|c|}{ Upstream } & & \multicolumn{2}{|c|}{ !nwnstream ${ }^{a}$} \\
\hline & ${ }^{134} \mathrm{Cs}$ & $i 3 n c s$ & ${ }^{137} \mathrm{Cs}$ & $\left.{ }^{1.17} \mathrm{cs}\right)^{134} \mathrm{Cs}$ & $\because \mathrm{rs}$ & $137 \mathrm{Cs}$ & ${ }^{137} \mathrm{rs} /{ }^{134} \mathrm{cs}$ \\
\hline Diffusion cubes & 0.28 & 0.M883 & 0.55 & 19 & 12 & n 38 & 31 \\
\hline Impactor & & & & & 0.51, & i. 81 & 3.6 \\
\hline Filters & 0.33 & 0.0064 & 1.17 & 3.6 & 0.26 & 1.10 & 4.2 \\
\hline Total & 0.61 & 0.012 & 1.72 & & 0.88 & 3.29 & \\
\hline
\end{tabular}

${ }^{a} \mathrm{Nr}^{136} \mathrm{Cr}$ was found in the $\mathrm{dr}:$ antream somplers. 


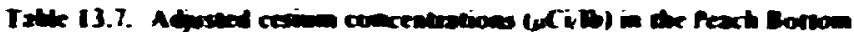
HFGR cuetion in ing 1975

\begin{tabular}{|c|c|c|c|c|c|c|c|}
\hline \multirow{2}{*}{$\begin{array}{l}\text { lwened } \\
\text { prext }\end{array}$} & \multicolumn{3}{|c|}{ iprrem } & \multirow{2}{*}{$=\frac{x^{2} p u s t e d}{64}$} & \multicolumn{2}{|c|}{ Duvenirem" } & \multirow{2}{*}{$I^{-2 d y=v i e d}$} \\
\hline & 1346 & $136 \mathrm{Cs}$ & 150 & & 1348 & 106 & \\
\hline (infes: & $1.9 \times 4$ & $7.115 \times 5$ & 23244 & 12 & 11905 & $4-6 \times 5$ & 30 \\
\hline (V)dert) & $3.82 \times 4$ & $547 \mathrm{ks}$ & $: 768 ?$ & 3.3 & $795 \times 1$ & $283 \times 3$ & 36 \\
\hline I.10l & $5.76 \mathrm{~N}$ & $1.25 \%$ & $149 \times 3$ & & $8.0^{-4}-4$ & $1 \times 3 \times 3$ & \\
\hline
\end{tabular}

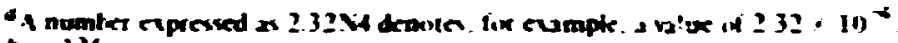

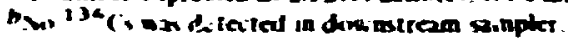

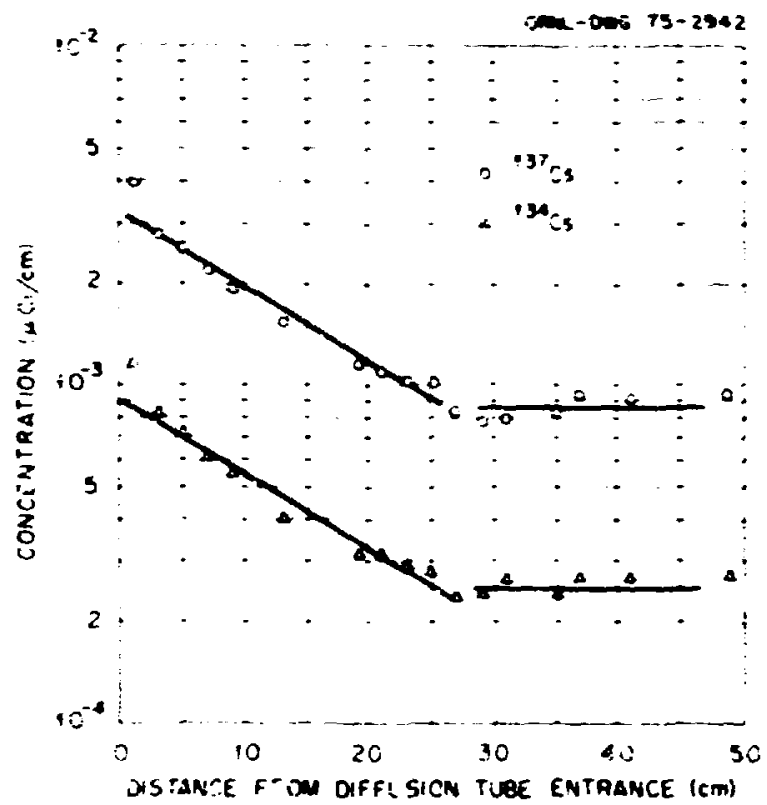

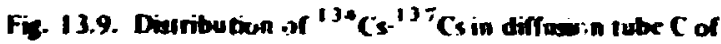
downatream samplet (May is, (473).

C:sium was also $m$ ascured in the cold return dict during the September 1973 shuidown. These restilis are shown in Fig. 13.7 and Table 1.33. Figure 13.10 compares the ${ }^{13}$ ' $C$ s distributions measured in 1971 . If;. 2. and 197321 approximately one-year iniervals

Unly an upper liniit of $0.2 \mu \mathrm{Ci} / \mathrm{cn}^{2}$ rou!d be mieasured on the hol duct ipstream of the steam generator.

As for iodine. the duct surface cuncentration data were fitted to an exponential equation of the form.

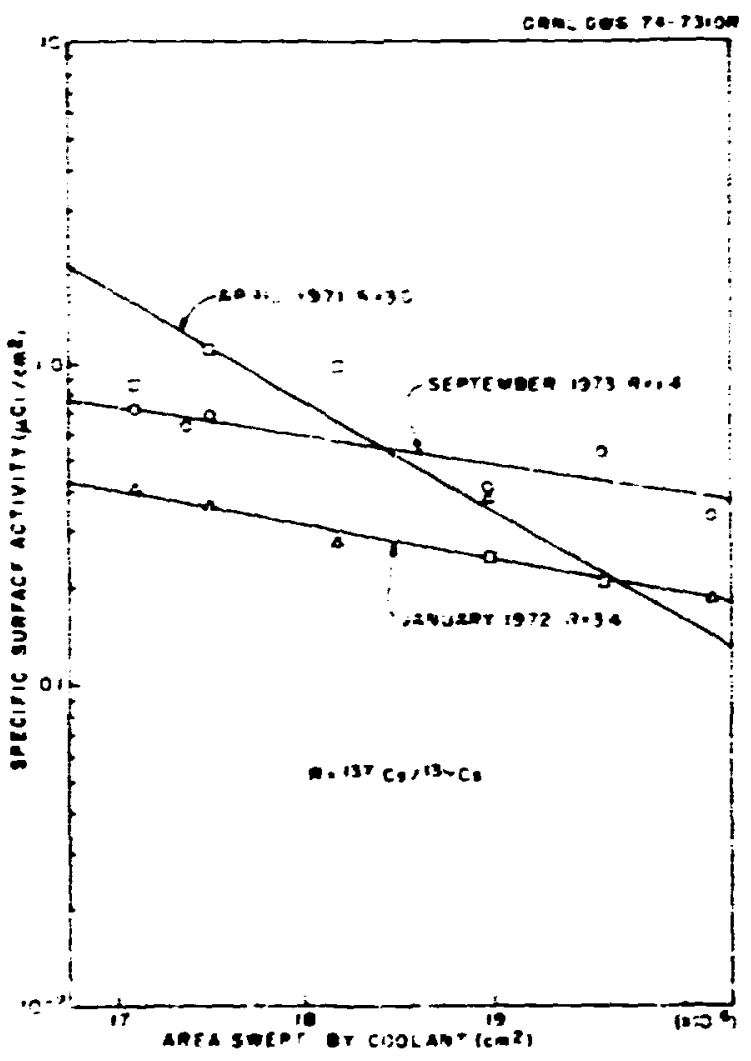

Fig- 13.16. Disfribution of ${ }^{13}$ i Cs on cold dacl.

$$
a_{s}(x)=a_{s}(o) e^{\left(h \frac{P}{A}+\lambda\right) \frac{x}{U}} .
$$

which was then integrated to yield $A_{s}$. the activity on the loop No. 1 cold duct surfaces. Values of $r$ and $A_{s}$ 
Table (3.8 Actinties : "Cics") on the coll netura chet Sepl 4, 1973"

\begin{tabular}{|c|c|c|c|c|}
\hline Pusction & 134 & ${ }^{137} \mathrm{Cs}$ & $130 \mathrm{c}$ & ${ }^{13} \mathrm{C}_{2}{ }^{134} \mathrm{C}$ \\
\hline Stesm generator Eu & 0.527 & 0.726 & $2.65 \times 10^{-2}$ & 1.38 \\
\hline 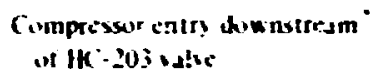 & 1. Ho4 & $0.64 t$ & $1.88 \cdot 10^{-2}$ & 1.59 \\
\hline $\begin{array}{l}\text { Cummessor entry by } \\
\text { owity ent? }\end{array}$ & $13+59$ & 0.649 & $2.05 \cdot 10^{-2}$ & 1.52 \\
\hline $\begin{array}{l}\text { Compressure coit by } \\
\text { avity entry }\end{array}$ & 0112 & 0.182 & $7.7 \cdot 16^{-3}$ & 1.38 \\
\hline 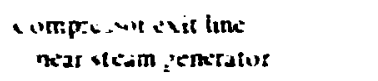 & 1.289 & $0+15$ & $1.72 \times 10^{-}$ & $1 .+4$ \\
\hline Yymazi ret'rt. be: & $0 .+2$ & 11.538 & $2+4 \times 10^{-2}$ & .2 \\
\hline $\begin{array}{l}\text { ¿innpresser tets n beture } \\
\text { bining cuncent. it dui! }\end{array}$ & 10.246 & 0.338 & $1.48 \times 10^{-2}=$ & 1.3? \\
\hline
\end{tabular}

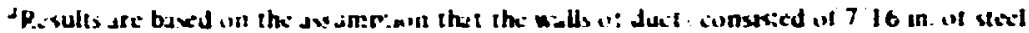
nios 3.75 in. of isctingi insule' :A

sre given ivelow:

\begin{tabular}{|c|c|c|}
\hline & $h(t m=c)$ & $I_{s}(C . i)$ \\
\hline${ }^{134} \mathrm{C}_{i}$ & +.1 & 0.69 \\
\hline isto. & 2.9 & 0.035 \\
\hline 137 & 5.8 & $i: 4$ \\
\hline
\end{tabular}

Discissim. The desiription of the be havic $r$ of cesium is complicated by the fact that ivel. cesiun containing graphite. and casium vapor were iteprosited in the steam generator and wither parts of tie primary circuit during the operation of the first corc. $\overrightarrow{:}$ : has resulted in the stearn generator funcioning as a nei siurce of cesium raiher than a sink. For exain, "s, the total concentration of 137 ( $s$ at the unstream sampler was 1.40$) \times 10^{-3} \mu \mathrm{C}$; per pound of helium and that $\|^{-t}$ ionnstian sampler was 2.8.: $\times 10^{-3} \mu \mathrm{Ci}$ ith. S. tcarly playing an important role in cesium :airibution. Phis difficuliy is partially resolvable by utilizing the fact that it has becn $3 \frac{1}{2}$ yeas since icte i ceaseo uperaition. Cesium from corp $I$ is relatively richer in 13 ? (s than that keing generated afier sol, ne 600 days of cire Il uperatius. We expect aure i cisium lo have a

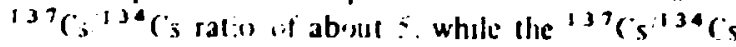
ratios found in May 1973 were as low as 19.7 on the inlet jet and 0.8 on the external surface of the upstream sampicer.

The variation of the cesium ratio in the diffusicn tubes, shown in Fig. 1.3 .1 !, indica,es that the molecular

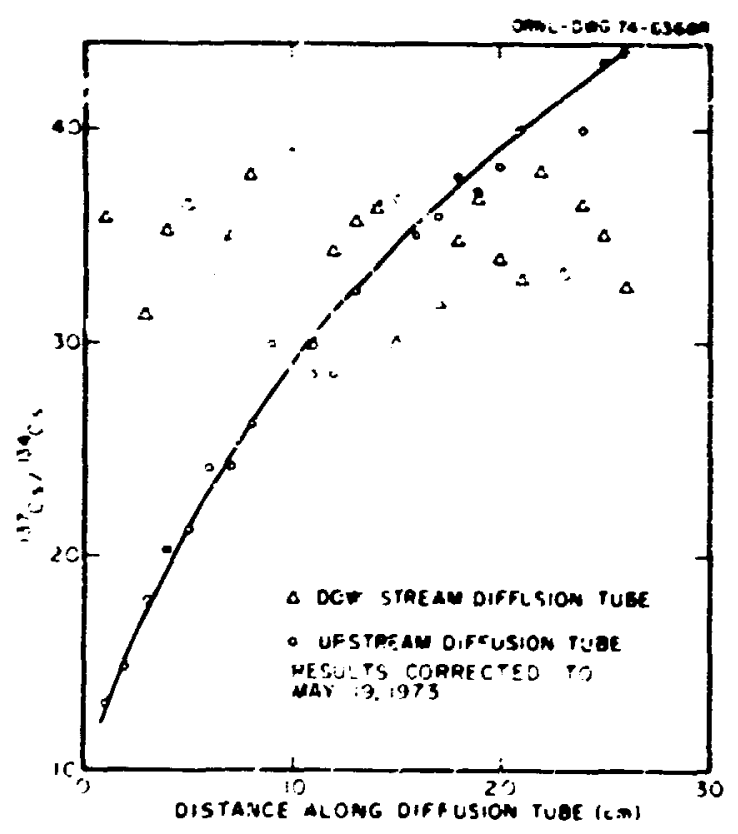

Iig. 13.11. Cesilem satio in the diffusion tubes (May 19. 1973).

iesium: deposited in the early parts of the upstream ditlusior. tuhes was predominanily new. Howeter, all cesiurr: in the downstream tube !...d sbout the same high: isotopic ratio. indica:ıng th.st the cesium was $\mathbf{r}$.'ich wder than that in the urst eam sampler and that partial 
isutopi exchange was criurring in the steam generator between Csigas' and Cxdust). There was alss sume interferenic from dust.

The dusl sompies contained cexium of similar apparent to that in the large die is in 1972. with a cesium ain) of about 3.5. The ${ }^{137} \mathrm{Cs} /{ }^{13-C s}$ ratio for cesium collected in both of the 1973 amplers is lower than the found earlier in the same locations.

In the cold duk drivnstream of the steam generator. the mean. " $7 \mathrm{C}^{\prime}$ ' 'Cs ratio fell from 3.4 in 197: to 1.4 in 1973 after rising previous year. ${ }^{21}$ these ratios are given in 10.13 .10 . Thex ctunges indicate that cesium is now being reteased by ecte II and that new cesium is now being carried to ali parts of the circuit. inciuding the repion dowrsiream of the steam generator. Both the slope of the deposition profuce in the cold cluit and the - listribution of cesium in tire downstreant diffusion tube amplet indicale that not all the cesium in i is regon is ascoxialed with dust.

Finally. The rate of deposition of cesiun: in the cuic duct now exceects the rate of the ientrammen. cosserved between 1971 and 1972. The ultinute cessuis sinix has nut bsen definitely identified. but cesium released from core I, as determined by isotopi ratio, has been found on the external surfaces of the EOrol element and in the putge inlat channei.

The percentages of alomic cesium [C $($ (as)] deposited per pass in the steam areralor ate 94 and $70 \%$ for $134 \mathrm{Cs}$ and $139 \mathrm{Cs}$. respectively. The differenct being auribable to the steam gexerator being richer in ${ }^{137} \mathrm{C}_{3}$ than :34's and able to exchange cexium with the coolant. Clearly the stcam generator is not a perfect sink even for cesium vapor.

Finally. il is interesting to assess the rate at which cesium is leaving the core. In order to do this one must know $\hbar$. the fraction deposited per pass. While $\delta$ can be ascessed for Cs(gas). it cannot be estimated fo- Cs(dust). Uluing the data in Table 13.7. we have calullated $A_{s}(1), \delta$. the annual increase in tile primary circuit activity. assuming that all molecular cesium in the circuit is from core II. Using th: rc!ationship

$$
\frac{A_{s}(1)}{\delta}=8.766 \times 10^{-3} a_{g}(0) F
$$

where $f$ is the flow rate and $g_{f}(0)$ represents tte gas ohase concentrai in, we calcilate th.' following upper limi: estimate ir. the annual increase in cesium aclivity for boll, lnops: $92 \mathrm{Ci} /$ year for ${ }^{13}$ " $\mathrm{Cs}$ and $0.98 \mathrm{Ci} / \mathrm{y}$.ar for 13 : Cs. frace cince release rates will be compared with calculated estimates when a whole core reiente calculation using realistic temperatures can be performed.

Cesing in the core. A fuel zlement was withdrawn from the reactor after 384 days of operation. and axial and radial dictributions of cesium. strontium. and tritium were meacured in the graphite components. Radiochemical analysis is apptoaching completion. Detailed interpretation of observations is being deferred until similar information is available from a 701 -day element. The most siznifican: observations for cesium are given below.

1. Cesium deposited on the top graphiv, reflector was able to penetrate below the sulface. thus increasing the apacity of the ieflector as a sink for cesium. Figur: $: 3.12$ shows radial concenitation 3 rofiles for ${ }^{134} \mathrm{Cs}$ and 13'C3. Analysis oi the lower reflector awaits disassembly of tive : sion prulluct trap.

2. The axial distributions of $1{ }^{77} \mathrm{Cs}$ in the fuel. sleeve. and spine are shown in Fig. 13.13. Although these radially averaged :oncentrations tend to follow the fuet cemperatwe distribution, there are two indications that zesium is being swept down th: purge channel. First. to peak cesium activity in the spine and sleere is further downstream than in the fuel. and second.

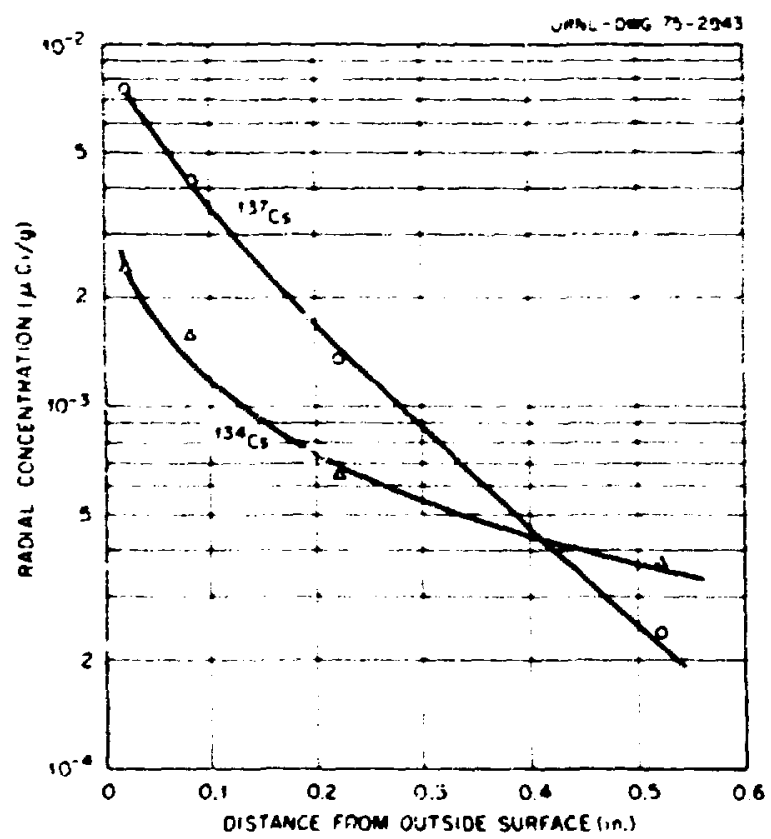

Fic. 13.12. Radial concentration of ${ }^{137} \mathrm{Cs}$ and ${ }^{134} \mathrm{Cs}$ in upper renector fuet ele ment EO6-01. 


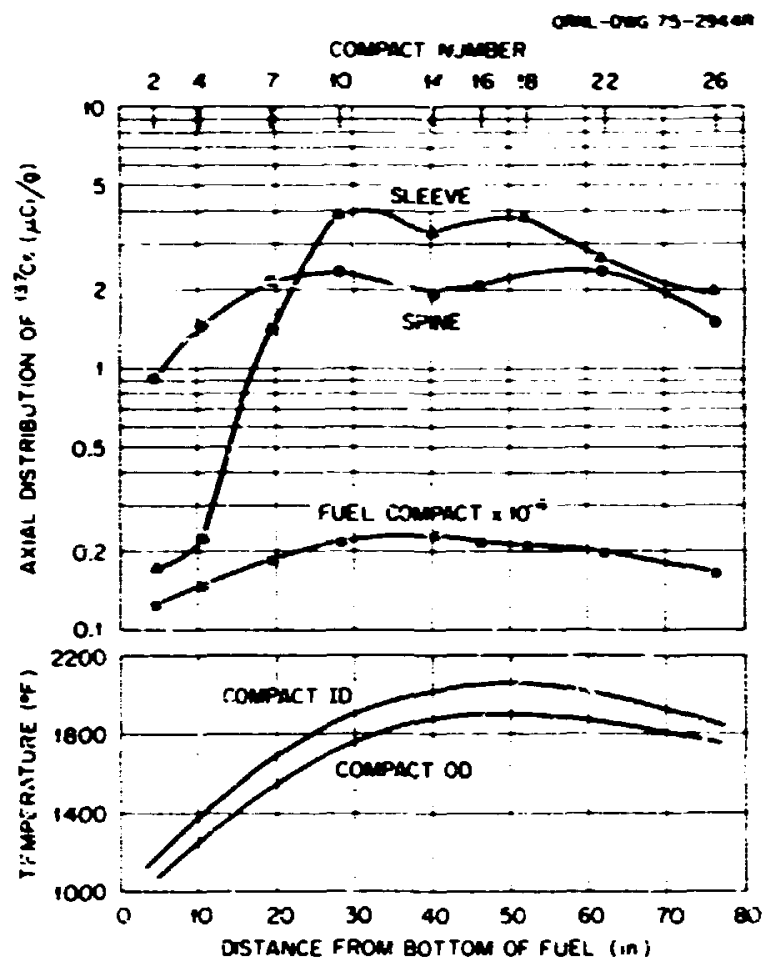

Fiz 13.13. Axial distribution of ${ }^{137} \mathrm{Cs}(\operatorname{lan} .6 .1572)$.

cesium appears to be pil..9g up about 25 in. from the buttom of the active core. This conclusion is reinforced by preliminary obscrvations on the 701 -day element. The fraction of the cesium generated in the fuel that is residing in the fuel sleeve and snine is shown in Fig. 15.14. A. - . from these results is $1.6 \times 10^{-4}$. Measurements have shown that very little of the released cesium is in the fissiun product trap.

The observed radial concentration profiles for ${ }^{137} \mathrm{Cs}$ in the sleeve at three axiai positions are shown in Fig. 13.15. The concave shape of the plot of concentration is raoius is inconsistent with a single simple diffusion process, although the steep concentration gradients imply a subjtantial attenuation and hence delay of cesium during passage from the fuel to the coolant. The ex;onential concentration profice could indicate that the helium be'ng suckec through the fuel sleeve by the purge was influencing the iransport prociss. but only if is steady state had been altrined.

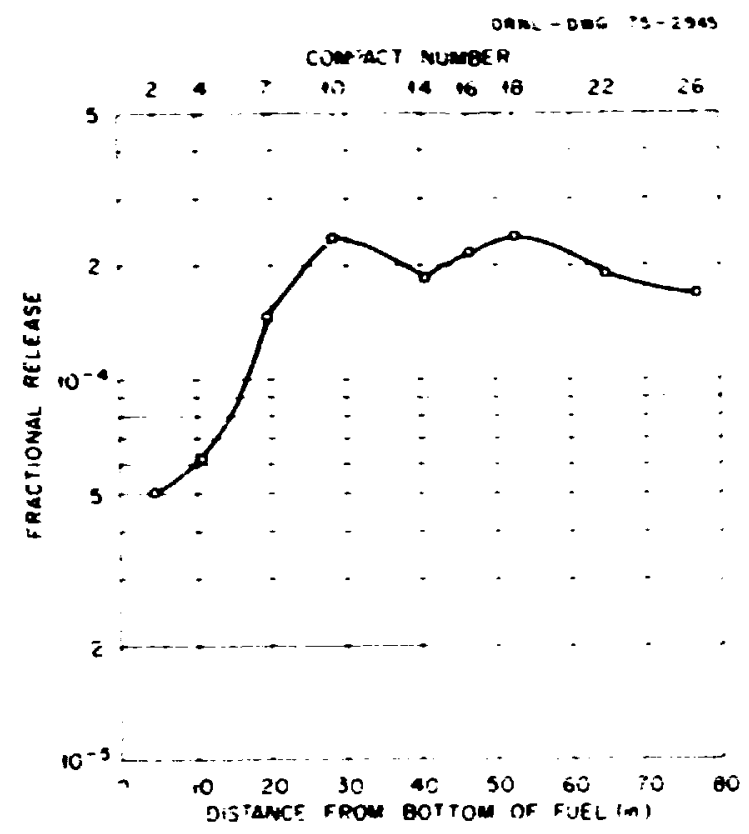

Fig. 13.14. Fractional release of ${ }^{137} \mathrm{Cs}^{1}$ rom fuet to spine and dueve of iuet elemeni :06-0I (Jan. 6. 1972).

Conctusions. Cesium from core il appears to be entering the primary cooiant circuit at about 1 Ci/yedr after about 600 effective full-power bys of oper. .on The significance of this observation. . : Bidisin is the behavior of a large reactor will depend to a great exient on a detailed compais.n of the ten:nerature history of a Peach Bottom elemen: and thar of a la.e 4 TTR.

Once in the circul. a sesium atom has the same options as an iodine atom. although the adsurption on both carbnnaceous and metallic surfaces are larget (not so large that a perfect sink deposition moial can be used uver the whole temperature range).

The relative role of surface dust, oxide films, and base meta!s in retaining deposited cesium and other fission product metals cannot be identified at present but will be examined when samples of circuit materials ate available.

Integration of the iota! amount of cesium in the circuit requires analyses of steam generator parts. 
255

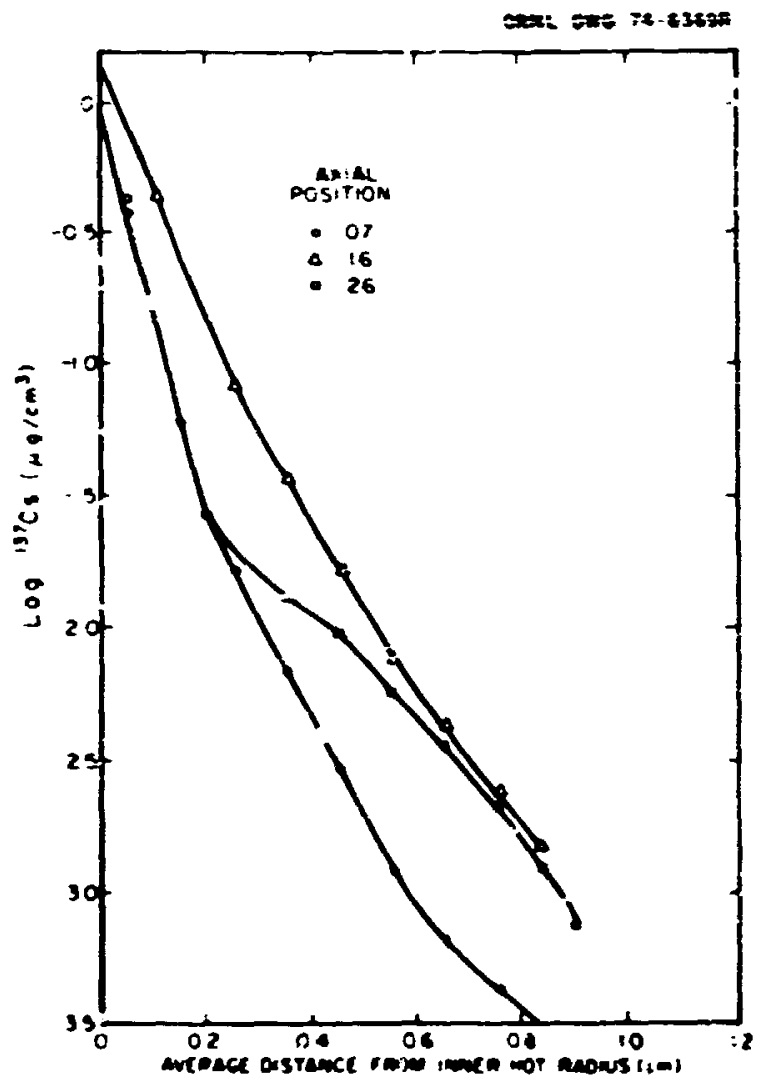

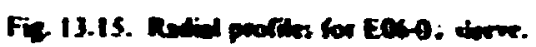




\title{
14. Printary Coolant Technology
}

\author{
A. P. Malinau:kas
}

The arbon and graphite that are emploved in the reactor as neutron moderalor. fuel cladding. and core structurai material are acieptably slable at the ekrated temperatures and tadiatior. intensities involved. However. al the lemperatures of of-ration. the materisls can be ieadily uxidized. therefore. su:ne altention must be gren to mantaining the c...smically inert cordani helium iree from uxidizing imp:itities.

Because of the operating cunditions involved. the mast likely oaldint of signifusince is stcam. and the muat probuble incurrences leading to steam ingress imivive ellhe: contunueus inieakage from small Jcaks in the steam enerator or the suduen introduction ai a idige amount of sleam thrength itr rupiure if a sleam seneralur lube.

Fislablisiviag the sinseg;enips of continumus but

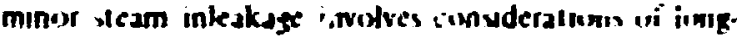
It"m tifecls. wherej: large. undwen steam ingresses ir sul! in effe: is af mure ummerlate inn:era. Bulh longand shortierm elie:is of sleam inleakuge sre being investigaled and. to linius in the anjiglical anecis of the problem mure ditedly, eitsily in this area ins been cuncenirated on the cretopment and use of sumiputa-

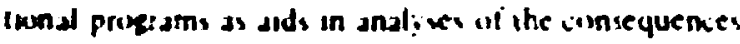
ili steam interses

\subsection{EVALU AnON OF COOLANT CORE IATERACTONS SND COOLANT COMPOSITION DURAN, roRT ST. VRAIN STARTUP}

$$
\text { G I. Tintes' }
$$

I.) estaten the effects at slesm ingress in the

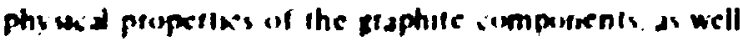

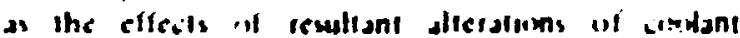

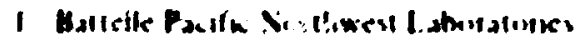

composition on the performance of metallic components. it is necessary io consider the kinetins of the chemical processes involved. These are quite complex and sre further complicat ad by the constont mixing and recitiulation of the gases through zones of varying temperature. effe:ts of radiation on the chemical riations. and the natuis of the souries (inleakage) and sinks (e.g. the purification system) for the impurity specines involved. Thus. iather sophisticated somputaInonal programs. such as GOP f for steady-state ciondi(ions) or OXIDE (fot transient conditions) are reyuired iir systems aralyses.

Considerable eifor! has been expended both in code levelopment and in providing experimentaliy derived input data for use in the codes. but tew opportunities have been provided to test the cudes and the input data against aitual measurement; frum an operating $H T S R$. Inil al starlup of the Fort St. Vrain Reactor will provide a unique oppritunity. not orily in this rega:d but also in the evaiualion of the signifisance of radiolylit reastiuns in $+\pi$ aperatiunal system. Because the COP code is the unly compulational propram presently avaiblate that includes radichyin realsons. Inis cinde ts to be u ed as bilh an ald in identriying parameters of particular sipnifianco and as a mechanism for startup data analysis

Most of the efiurl dusing the current reporting period hu been expended :r. updating and modifying the cude for use un a CDC CYA!? it sysicin. (The cinde had prevnusly been :ad on a UkilVAC I lOx system.I Several iesi caes have also been run to ideniify patameters that are parinularly sensitive to radiolytic resickiss. In this manner. we have ibserved that radiatum effe, is cause a substantial increase in the $\mathrm{H}_{2} \mathrm{H}_{2} \mathrm{O}$ talw and a lea:: an order of magnifude teirease in the $\left.\mathrm{CO}_{\mathrm{CO}} \mathrm{CO}_{2} \mathrm{rit}\right)$ a the remperatures of

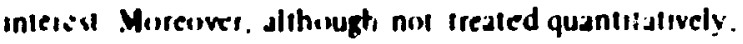


the formation of methane appears to result primarily from radiation-induied proiesses.

\subsection{COMPUTER ANALYSL OF THE EFFECTS OF STEAM INGRESS INTTO THE COOLANT CARCUT}

\author{
D.S. Joy
}

As indicated above. emphasis during this reporting period has been on the development and use of compuidtional programs for analysis of effecis of steam ingress into the primary coulant circuit. For this purpose. the OXIDE:- code, which had been developed for use on a UNIVAC 1108 computational system, has bren obtained from General Atomic Company and adapted for use on the IBM 360/9 I system.

Further work is to proceed in two directions: one of these will use the code. in its present or only shathily modified form. as an aid in the indentification $v i$ components that are particularly vulneratle to oxidative attack and to the sensitivity of the results to the inpui dz:= employed. The second direction will critiilly examine the mathematical aspects. assumptions. and physical phenomena that form the sinucture of the OXiDE:-2 code. 


\title{
15. Confinement Components
}

\author{
J. P. C.Jlahan
}

The initial effort under this new task area consisted of

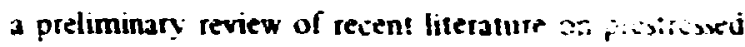
cuncrete reaitor vessels and rexitor containment strustures to provide background material for preparation of Chapter I2 of the HTGR Safety Program planning guide.' Chapter 12 ui the report brietly summarizes the present status of confinement component technolugy and outlines a comprehensive researih and develupment program. This initial review of the literature will te expanded to provide the information sequired for preps:ing an in-depth rechnology assessment of IITGR confinement components.

\footnotetext{
'Planning Guide for HTGR Safery and Safety Related Research and Development. ORNL-4968 (May
} 19741. 


\title{
16. Primary Systems Materials Technoingy
}

\author{
P. L. Rittenhouse
}

This program is concerrod with the materials used in the const mintion of the primary systems of HTGRs. Its objective is $t J$ develop information that will permit more precise definition of material response and behavior under abnormal reactor conditions and thereby provide improved bases for the evaluation of safety.

\section{I NATIONAL HTGR SAFETY PROGRAM PLAN}

R. G. Donally W.P. Eatherly P. L. Rittenhouse

During the final quarter of 1973, we developed a plan for work on the safety-related aspects of primarysystem naterials. The categories of materials covered in this plan are (1) primary loop metallic coraponents (duiting, steam generator. circulator, etc.):(2) graphite components (support blocks. reflectors, etc.) and (3) control components (absurber materials and humable porsons).

In each of these calegories, the primary emphasis is to study mechanical properties. failure criterid, and environmental effects (temperaturs, atmosphere, irradiation. etc.) as they relate to the assurance of safety during off-design reactor cor.ditions.

\subsection{TECHNOLOGY STATUS REPORT}

\section{W. $\mathbf{R}$ Mariin P. L. Rittenhouse}

The preparation and publication of a repurt evaluating HTGR metalic structural materials iechnology nas been authorized under the HTCR Safety Prosiam. This report. to be completed during FY 1974, will (I) identify all HTGR struclural alloys of interest, their apilications. Ind their environments under accident condinions: (.) describe the status of technology. including existing information on properties and ongoing programs; and (3) identify specific areas in which additional study could lead to a better understanding of mater.als behavior and therefore to quantification of margin : of safety. During the latter part of the year. we identifizd the scope of the information required for this report and have parsued this in detail through discussions with the General Atomic Company (GAC) and through literature review.

\section{PEACH BOTTCM METALURCICAL POSTMORTEM}

\section{P. L. Rittenhouse}

The Peach Bottom 40-MW(e) prototype HTGR has been in operation since 1968, and its planned decommissioning (to begin late in 1974) offers a unique opportunity to establish the effects of e-tended exposure to primary-and secondary-coolant environments on H.GR structural materials. The results of such studies would be relevant to both safety and tesign aspects of current and future gas-iooled reactor systems.

General Atomic Company and ORNL have cooperated with Philadelphia Electric Company (the Peach Buttom operator) and Suntac Nuclear Corporation (the decummissioning agent) to iden'ify the desirability. feasibility. and cost of removing various components from the reactor primar, system for examination. It is now proposed to remuve one of the steam generators essentially intact ( $\mathrm{i}$ \%.. tuber heet, tubing bundle. and shroud): samples of the ccicentric (hot) ducting in. cluding 'ire ho: valve: selected parts of the helium .llinlutur; and two sections of the cold ducting. Procedures and precautions needed in ccmponent re. moval. handling. and shipping have been identified and agreed upon by GAC and ORNL. Disassembly. seclioning. and metallurgical examination of these components will allow us to obtain evidence related to wear, erosion. corrosion, carburization, and metallurgical stability and integrity. 


\title{
17. HTGR Safety Studies for the Directorate of Licensing
}

\author{
J. P. Sanders
}

Support for this effiort was initlated in late Sivenither 1972 and continued throughous the year. The initia! struiture of the work was designed to place certin ORYL persunnel in a position to ait as ionsul asits to :he Giss-Covied Reactors Branch (CCRB) of the Directorate of Liensing (DOL) in support of the II response to licensing appications for commericial HTGR plants.

As a foundation fior this task. work was initiated in sollecting and evaluating certain basic property data and performance sriteria for materials and cornpon:nits. In September 1973. the tirst licensing tupical report' was received logether with a requesi from the cieneral Atumic rompany (G.AC) that it be reviewed so that it could be used 2 the bass for future license applicition;.

epon the receint of this request, the tiCRB stali asked that the effiorts at (ORNL be devinted maialy to the ev-luation of specitic ections of the ecp irl. This task composed the major eticit diring the remait:ler . If the year. The Summit PSAR: and iater the Fuiton PSAR $^{3}$ were used (1) provide detals concerning the system desgn ar:d operation in this ivaluation effiort.

\section{I AN ADIABATIC HEATUP MOUEL}

\section{H. D. Turner I. I. Sinian-T.n}

\subsection{Definition of Roblem}

Oile of the lirst probleris in be studied was the developmet.t of tenupersiures in the corre ui all HGK

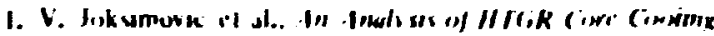

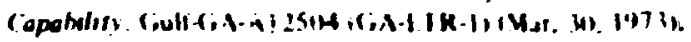

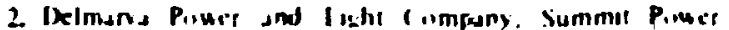

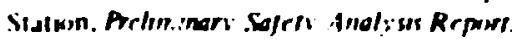

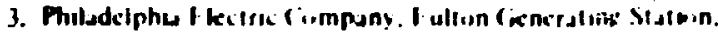
Arimmory idery Iralisus Arpurt. following simul(aneous loss of forced cooling (LOFC) and recitur trip. Under these conditions. the aftertreal rcmaining in the fuel is distrituted by conduction throughust the large mass of yaphite in the ctive cur: and in the reflector. Historically. 'hie :omputation w is of interest. since it had been determines thai, ler the Fort St. Vrain IFSV) design. this ultinate acident would result in maximum temperatures :hat would cause the insulation in the prestressed concrete reactor vessel (PCRV) liner to fiat and aiow all the afterheat io be conductesl to the PCRV liner conling system without catdstruphic das age to the containment vessel.

Natural convection loups withen the central core savity would be formed among the higher power and the lor er power refucling reguers under normai conditions. The formation of these inops would tend to redistritute the heat wi'nin the cititral core cavity. This etifect has been immiteu iront this series of calculations because the perating : pecifications. at least fior the commerical plants. reotare that the primary systen: be depressuried within a limited timz following the LOFf dicident. Depressurization of the primary system essentialy eliminates the cifectiveness of the natural convec. tion lineps.

The sequence of the 'ask was fil eval satc existung keneral heat induction cimputer propranis is) de. termine theit applicability fir this presblein. (1) evaluatc the appropriate model lor the iomposite core. (1) determme the appropriati physical property values for the core compinents. and 1 determine the most appropriate speili:atuns tor the boundary condituns and the initial conditions lor the computation.

ite task comminced with a sludy of the cioncept of the H tík and included a revicw of the therila analy sis 
presented in the Fort St. Vrain FSAR." Exising heat iranster wojs tron Oak Ridga as well as other installations hire sineyed. and HEATING4. a moditiiation of the seneralized heat conduction code HFATING3. "as thusen as the basic toul to be ised in the analysis." It was selected due to its texibility to handle a wide vanety of problems. its ease of input data preparation. its ready adaption to other problems. and the experience and knowledge that the staff at ORNL pussessed in its development and use. It was felt that this latter aspect would greatly facilitate making modifiations in the code to adapt it to a specific application.

\subsubsection{Representation of the Nonbomogeneous Core Structure}

In developing a model to predict the temperature tistributicn in the HTGR during a LOFC accident, it is impraitical to represent the reactor core in detail since the model inust be presented to the heat transfer code as a combisation of regions where each region contains a homogeneous material. This is a particular!y difícult protiem in describing the core of the reactor due to its nenhomogeneous nature.

Figure 17.I shows the geometry of one-twelfth of the siugle regular hexagonal elemient used in the FSV core, and Fig. 1,.2 illustrates the complete arrangement oi these elements in the core. It is obvious from these figures that a detailed "point-by-point" analy sis would require excessive computer core and timc; as shown later, this detailed analy sis is nut necessary. All acciurate representation of the effective thermal properties which appropriately depict the transient heat flow must be obtained in order to evaluate their effect on the lemperatures of inter:st. The effective density. specific heat, and volumetric heat generation iate are relatively easy to evaluate, since they depind only :pon the rolume fraction of each material in the zone. The stfactive conductivity of the core is inore difficult to evaluate. since it involves both parallel ar,d series heat now by conduction as well as radiation across the coolant channeis and the gaps separating fuel elements. As an additional complication, the thermal propertie: for each material may vary with temperalure. For various HTGR core designs, the ...teters of the fuel rods and the toried-conlant chanriels may differ and the fuel-coolant pitch may change from one calculation to

4. Fort St. Vrain Nuckar Fenerating Station. Final Sarety Anotysis Report. Publk Service Company of Colorado, Denver. Caic.

5. W. D. Turner and M. Siman-iow. IH.4TING: An IB.H 360 lleat (nnductwon Progrom. OPN! :-4-3?08 (February $1971)$.

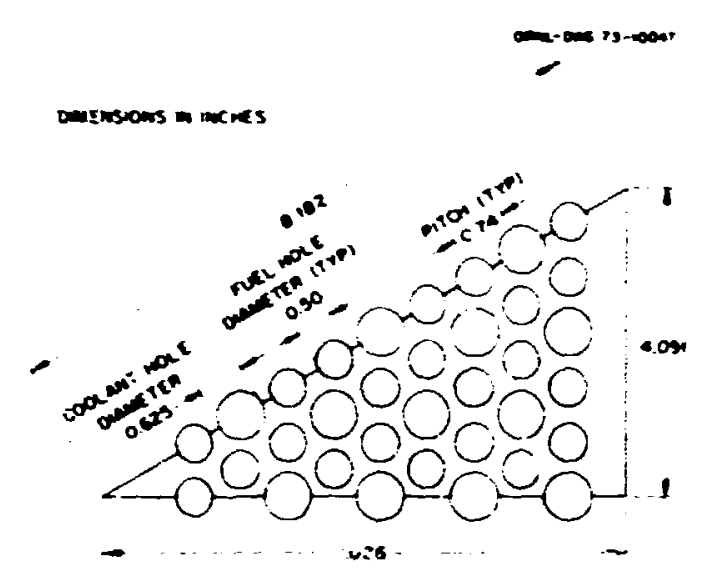

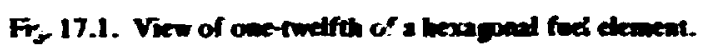

another. resulting in a change in the neat now network.

Thus, a study was made to dermine the effects of the racial thermal conductivity on the temperatures of interest in the HTGR core during a LOFC accident. First. the technique developed by Gulf General Atomic (CGA) to calculate the effective radial therma' conductivity of the active core of the reactor was evaluated. The unit cell repicted in Fig. 17.3 was devised as an independent check on this technique. The morkl consisted of a rectangle of graphite containing one-half of a coclant channel and a fuel rod. The ends of the rectangle were insulated, and one sice of the rectangle was maintained at a fxed temperature while a constant heat flux was asoumed at the other. This defines a typical unit cell at the horizontal midplane of the core of the reactor. The one-half coolant channel was approximated by three rectangles of decreasing size. and the fuel rod was approximated by five rectariales of varying sizes. The area of the approximated regions was equal to the actual areas. One-dimensional radiation parallel to the long axis of the approximating rectangies was considered across the regions defining the coolant channel. The steady-state sclution was obtained using the HEATING3 code, and the eifective cunductivity of the unit celf was calculated by

$$
k_{e}=q \frac{N}{\Delta T} \text {. }
$$

where $q$ is the constant heat 'lux. $\Delta:$ is the hickness of the unit cell in the direction of heat flow. $\Delta x d S T$ is the average iemperature drop acruss ihe viltt cell.

Calculations were made for a beundary temperature $T_{b}$ of $1500^{\circ} \mathrm{F}$. and comparisons were made with the results presented in thic For : $:$. Vrain FSAR. Calculalions cou!d have been made for several values of the 


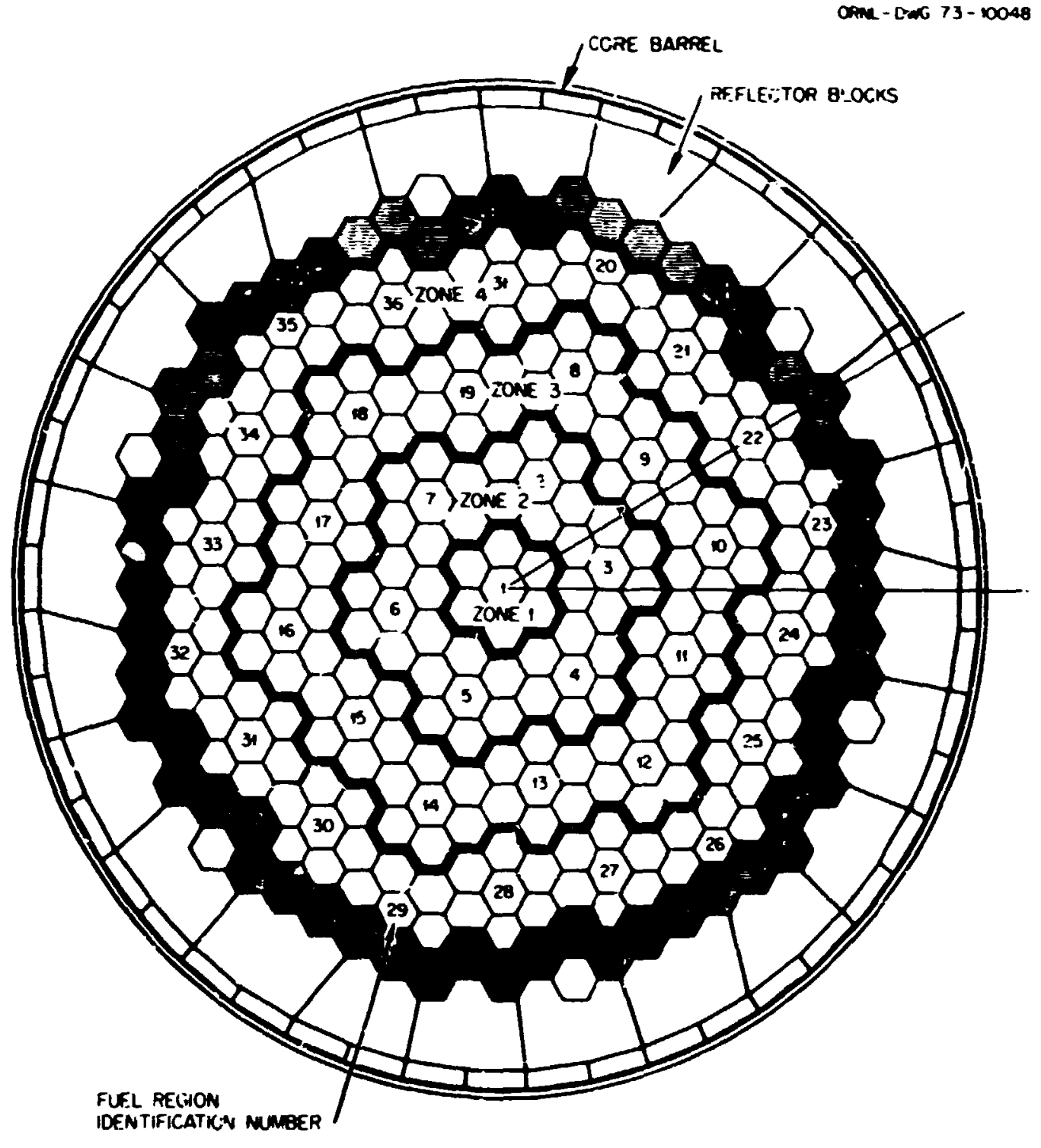

Fig. 17.2. Cromsactional view of all the elements. Arrang unent in the core.

boundary tempeiature to obtain the temperaturedependent effective radial thermal conductivity. but it was determined in the study that this was unnecessary. By considering both parallel and series heat flow. the following anslytical expression was also obtained for the model deficted in Fig. 17.3:

$$
\kappa_{r}=\frac{1}{w} \sum_{i=1}^{7} w_{i} K_{i}
$$

where

$K_{r}=$ effective radial thermal conductivity.

$W_{j}=$ width of the $i$ th heat flow path.

$\kappa_{i}=$ effective thermal conductivity of the $i$ th heat flow path.

$$
w=\stackrel{?}{2} w_{i} \text {. }
$$$$
i=\text { ! }
$$ 


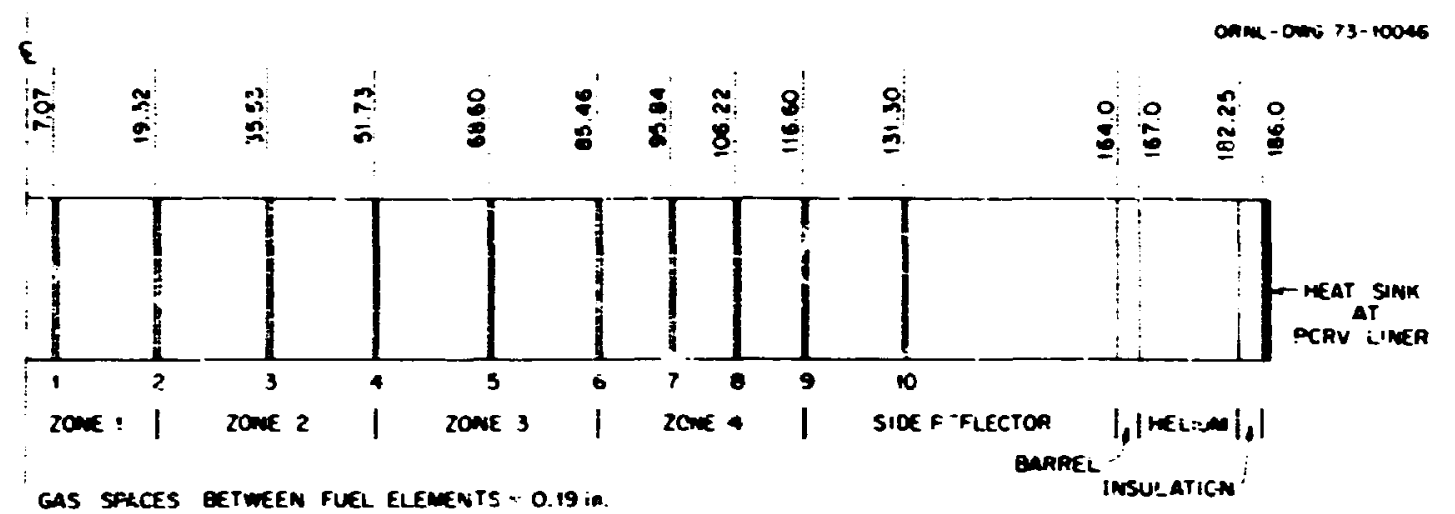

Fig 17.4. Onedincrsiond radil model of the HTGR core.

FSAR. An 3xiai midpiane power factor of 1.36 vas uxed with these radial power levels: this value was extropolated from Fig. $3 . j-y$ of the fort St. Viain FSAR. The power decay finction following the reactor Irip is introduced into the computation as a tabular lunction scrived from Fig. D.1-9 of this FSAR. In the one-uimensiunal radial model, consideration was given 1i) the relative importance of representing the respective $\therefore$ : volumes correctly as opposed to a correct repie*itation ol the heat transfer surface. Study led to the thoice of the acurate representation of the core rhimes. The regions were then constructed in such a way that their vol:smes were equal (1) the actual volumes of the elements represented.

This chuice ensured the correct representation of the average power concentration and heat ipacity of the reactor core. Most of the material properties. including those of the compusite fuel elements. were obtained frum Table D.3-15 of the Forr St. Vrain FSAR ${ }^{4}$ with the exciption of the thermal properties of helium." Ileat was transferred aross the heliun s?acis between fuel elements both by rodiation and conduction.

The first callon'ation using ihe geometric representa. tion shown in Fig. 17.4 was divided into four related ises that were tested. For purposes of identification these cases will he denote; I through IV.as follows.

\footnotetext{
(ise I Tix bassi case with effecive conctuctivitues derived analy (cally as described by Fal. 12 ) with all tile spaces beiween ilemenis replicented.
}

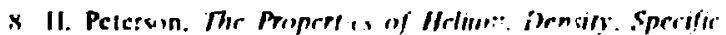

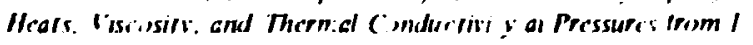

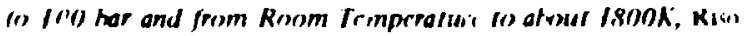
Repisi vis. 224 iseptember 19711
Cise II The same calculation with etfoctuve cunductivitis:s uken f., m Fir.. D. I-S of the Fort St. Virain :S.R. ${ }^{4}$

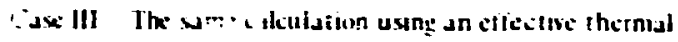
conductria: of 10.0 for the collipusite corte denkents."

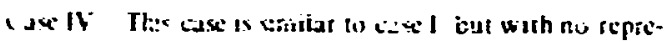
entation of the spitces between the fuel clements.

Three s.jditional modeis were iniruduced to 8 al:aste the temperatasic lior. across :he lucl rod and to evaluate the composite clifecive tinermal conductivities by using the IfFATINGit ode. These cases were labeled as follows.

Cuse $v$ This case is similai to cuse 1 : in addition, ore fuel rod aid the surrounding graphile were represented at the exnter of the corc.

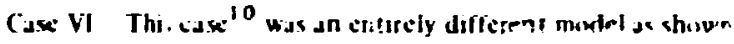
ir. Fig. 17.5. It as uniwied by wreng a steddy-stato: calculation of 1 emiersture : ::ider Iormul opes ding

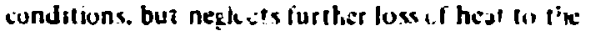
cioblant fijlowing I OFC and reactor tijp.

Caxe VII Thus case, wheh models is typical conducion radiation hedt transier element in the detive corce as

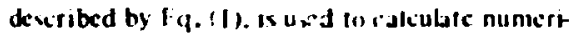
cally the cficiatec thermal c. nductsity in the acive cure

9. Since the numerical tecinnuge decs not dlow a con-

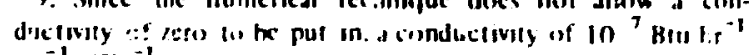
$\therefore-1,11^{-1}$ was uxd.

II). Ilws model wis nol a port ol the sludy. but the icsulis of

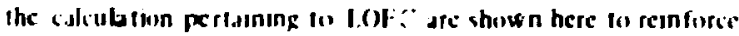
the results whlainc $J$ fromi case $V$. 


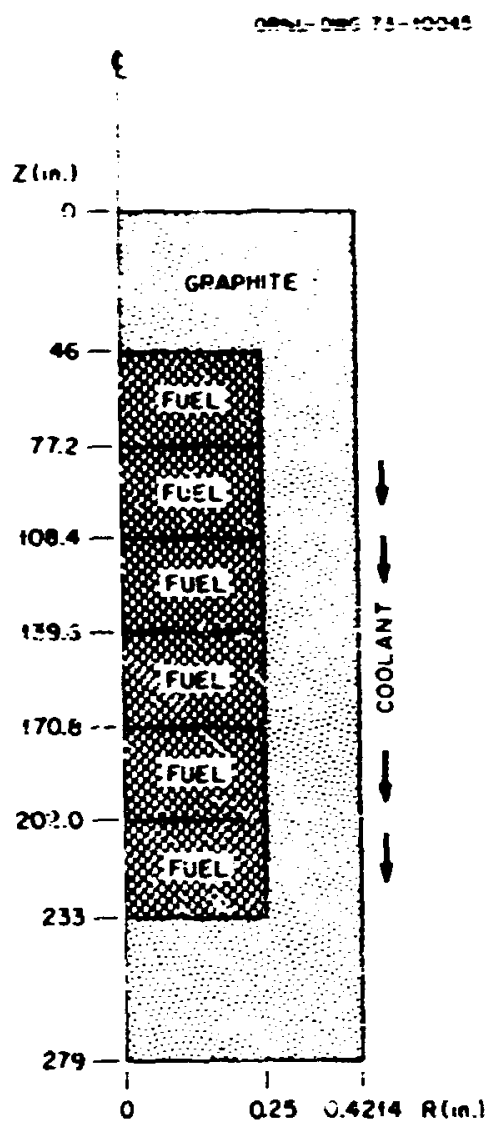

Fig 17.5. Twodimensional modet of a unit cell for consideration of now.

\subsubsection{Results of Evaluation of Effective Thermal Conductivity}

The results of cases I through IV are given in Fig. 17.6. The temperature of th hollest reguon in the core (at $R=60.3$ in.) shows vet. itlle dependence on the cfictive conduclt ity. For the first 5 hr after LOFC and reactor trip. ihe temperatures are essentially the same for : ic first inrce ises, and withen the first $10 \mathrm{hr}$ Ilic ditcicfic :- within less than 5 r of the overall remperaiure change. At the center line. cascs I and II still indicate good agreement within the first in hr; bilt for tle ease with the thermal conducivity equal to kero. the center !in: temperature is lower sinc: no hest is being tronserred to it from the hotfer regions. The same effect is seen at the mierfac between the active core and the side reflector.

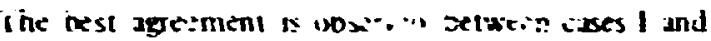

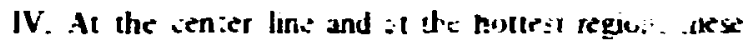

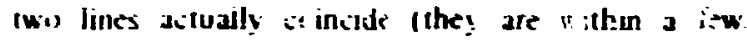
degrees of esih otherl: whit: at the wick reflector the temperature of ase IV is sightly tower due to the sightly better conduction to the sunk through the side ritlecior.

The irsults of asxes $V$ and Vl are given in Figs 17.7 and $I^{7} x$ respectiveis. (ase $f$ jom nstrates the timp*- Ith. choriges in a fur! rod situsted in the center of sx . Ir: urricunded by gr:tphite and the compuxite rore as in : 1 . Withiri 2 snir, the :mperatures of the tice'.

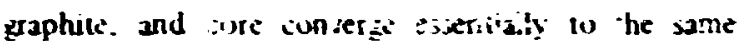
temperature." (dx ll uses = difiereat markel to :-diulate the fuel. igeprite. and ivolant temperatures. For this case. th: initi: Emperaiute tor th: is answent calcula:ion tue to : IFC and : eator trip is determined firm a steady-siate cai-ilation for the norm:al wperating

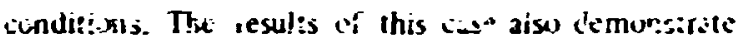
that witis:? inin lidicuing the reato! tisp. tile or-eratuin, if its :en:et lire, the tuel-yaphice

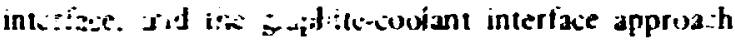
the s:ine if:?

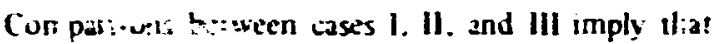
is : ative adisi thermal conductwity has very listle

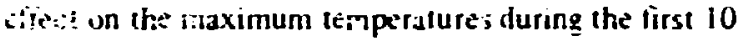
hr following a LOFC aicicient with subsequent reactor trip. The results of ascs I and II indicate that the temperature distributiuns in the first $10 \mathrm{hr}$ are not sensitive (1) a detailed representation of the chisctive thermal conductivity. A comparison of tine results of ases $I$ and $I V$ inulates that the gaps between fuel elentelts have litule effect un heat iranspors in the cort luring the first $10 \mathrm{hr}$ and that they are not the principal resistance in the heat iransfer of the generated heal (1) the sink.

The results of cases $V$ and $V I$ indicate tina: as soron as fissi on power in the fuel rods is reduced. :he temper: tures of the so rods approach that of the surrounding graphite. allowing one to trat i:c a:tive core as a homogeneous material with composite piopertics. This is die to the relative heat capacity and the graplitic conductrity. No contact resistance has been considered, but a value of $3 \mathrm{Btu}$ il ${ }^{-1} \mathrm{ft}^{-2} \mathrm{I}^{\circ} \mathrm{F}^{-1}$, nas used for the fuel conduclivity. This valus is liwe: than experimental thermal conducivities measuted for the fuel fods.

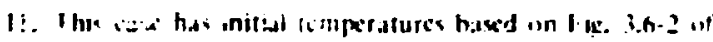

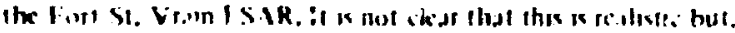

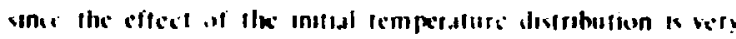

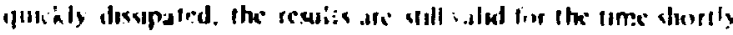

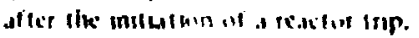




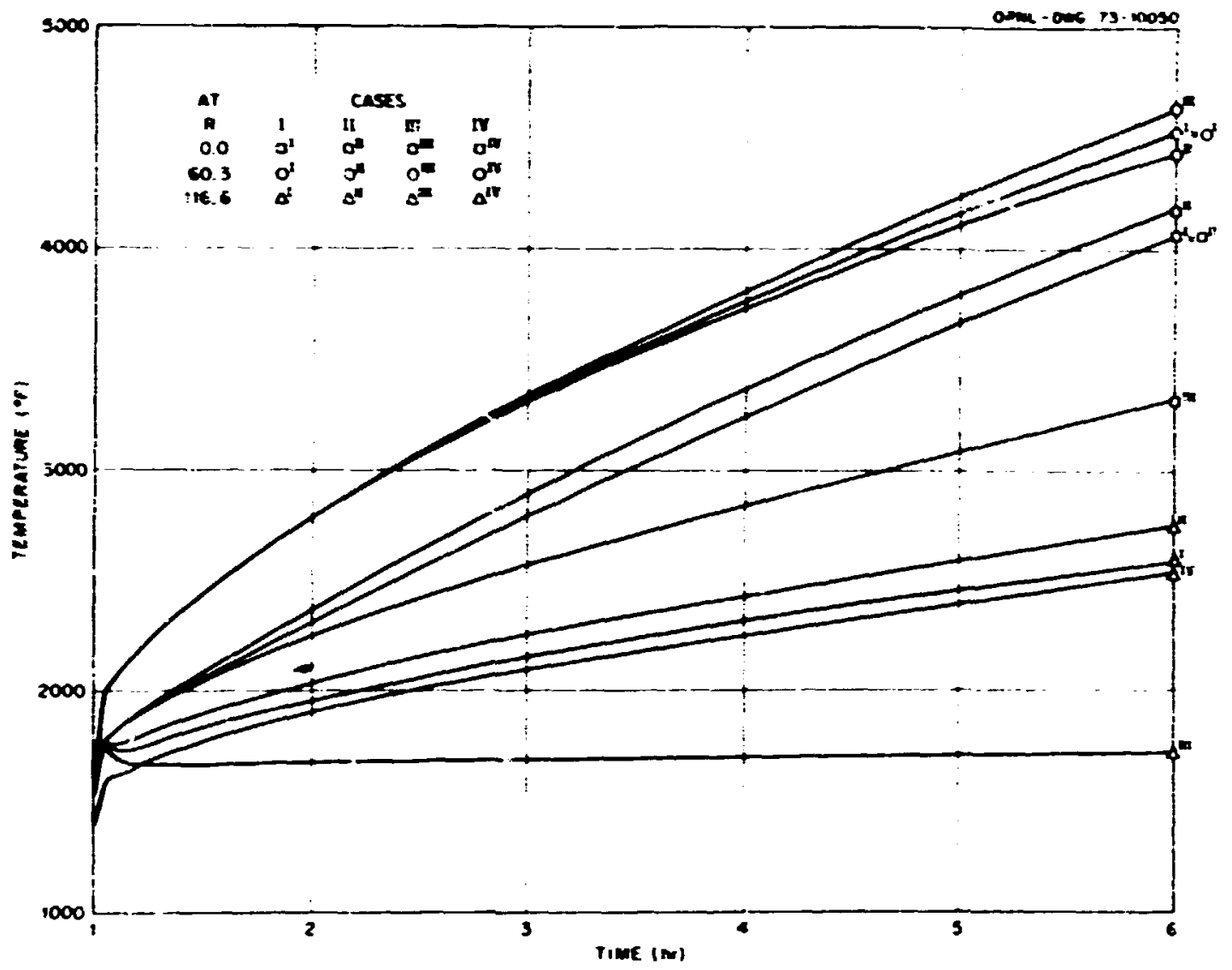

Fif 17.6. Compantive representation of reselts for cases I through iV.

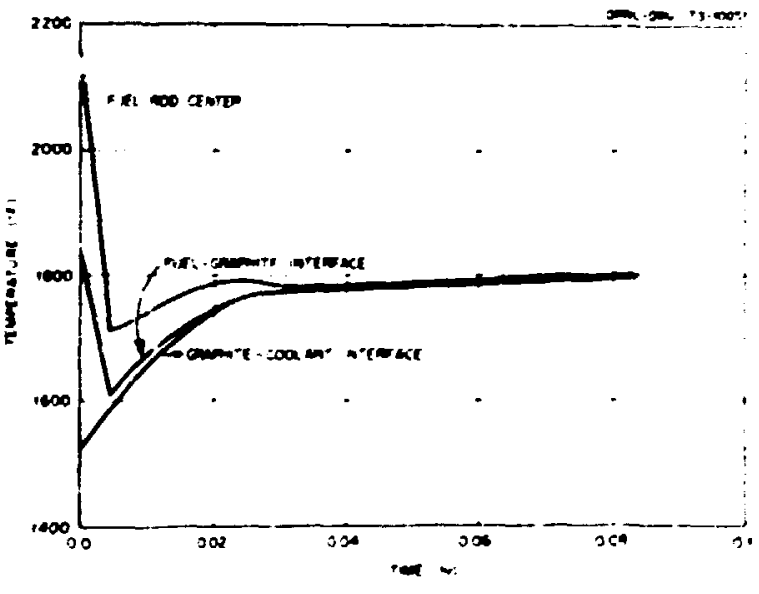

Fig. 17.7. Results for case $v$.

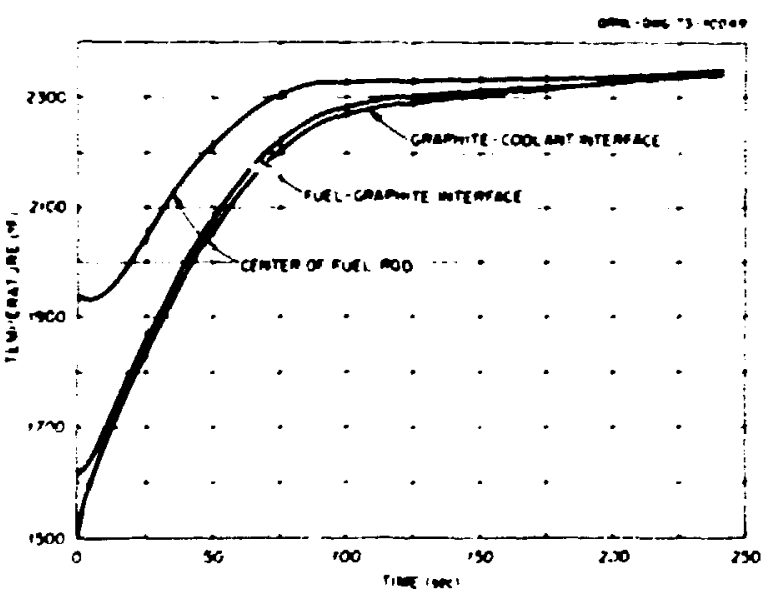

Fig. 17.8. Results for case vi. 
Becduse :he inal peneration is distributed inroughout the cure and because of the effecl of the annislar gas return duct in the FSV design and the PCRV laner insulation. fittle heat is iransparied through or out of the core during the first few hours after LOFC and reactor trip. Therefors. the temperature change ate mainly dependent wa the heat spacity of the :ure and the he:s generated in it. Although the heat leasing the ietive core during this time penud is smdl. the thernial properties of the core are such that the transient: are

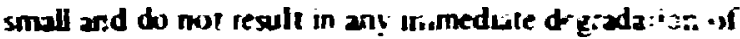
the cure materials.

In cvaluating the conclusions made by GGA in the
ESAR4 cuncerning these iransients. if was not necesson to have detaked and very aicurate values for the effectire thermal conduct: : ries of the composite core. F; calculations represenus. longer periud. when high tempratute, gadients will oe dev toped or when that PCRV liner insulation fails. this condusion dues no: apply.

\subsubsection{Development of Two-Dimensiswed Adiobatic bteatup Moded}

The one-dimescional radia' model was exlended to the Iwodiniensional RZ m: uel depicted in Fig. 17.?.

conc-owg is-trezo

E

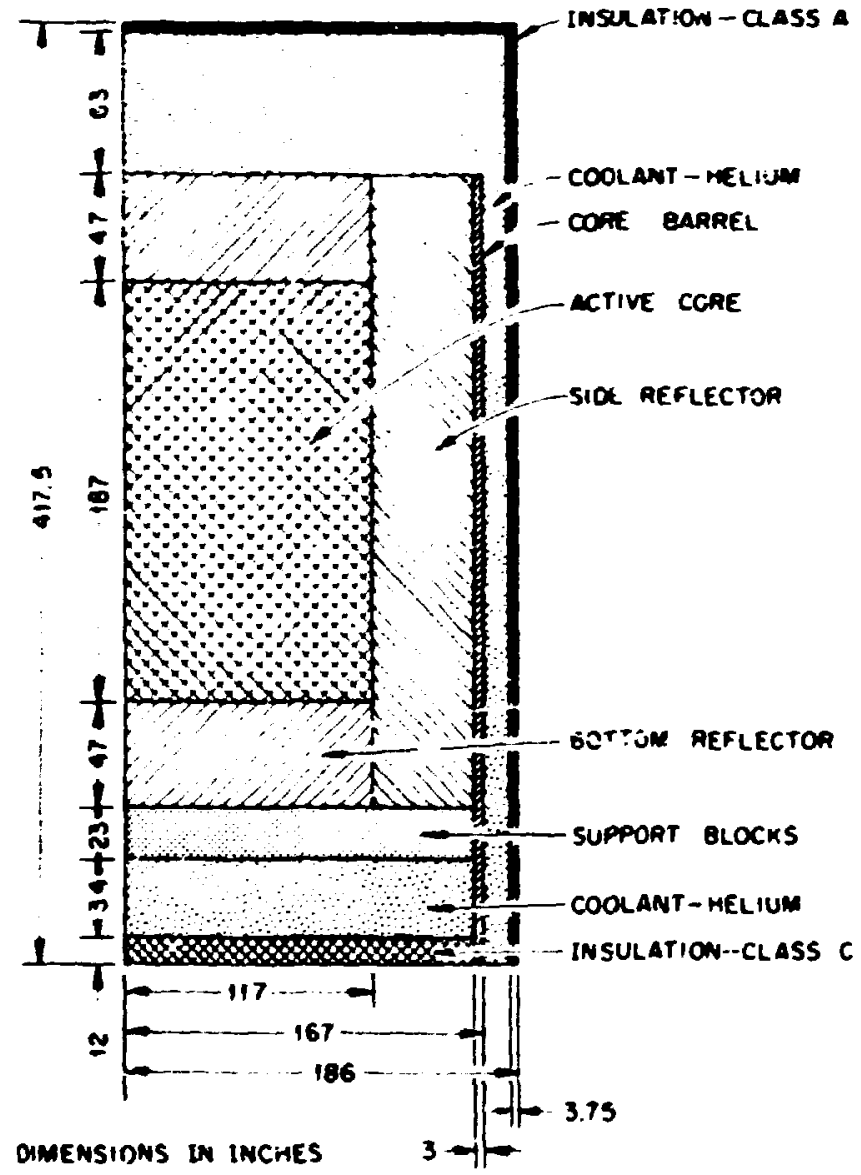

Fi 17.9. Preliniary $R Z$ racded for andyzine LOFC accident. 
This mudel was samilar to the one presented in the FSAR ior the Frti St. Vrain HIC,

The mudel included the sitive core with spatially distribused firsing product decay seneration; the top. buttum. and side graphite reflectus: the graphite core support blicks and pusts: the steel core barril surrounding the sinte rellectur; the thermal insulation cumersheets: and the helaum ilied funes. The thermol cundusitivity in the active core and graphite refleiturs uวs inisurrooki. The iemperatuie-deoendent radial thermal ionduitivity wa calculared by Eq. (2). whike the remperature-deperident axial thermal conductivity wos caliulated by

$$
k_{a}=\sum_{:=1}^{3} P_{k_{l}} .
$$

where $k_{d}$ is eflective axid thermal conductivity: $P_{,}$is perientage of axial iruss-sectional area associated with the fuel. :raphire. and helium respectively: and $\dot{\alpha}_{i}$ is remperature-cipendont thermit conductivity for the iue! saphite. and t.:lium respecitively. The cumpusite densities and specilic heats in the ative core and graphite reflecturs are alculated by a volumetri: average of the propertics of the malerials involved. The aitive cor: was modeied in the radial direction in the sume manner as line one-dimensional radial model presented earlki. Ikat was iransferted by buth sonwaction and radiation arross ihe heliam gaps. The biundary along $r=0$ was a no-llux surfiace. whereas the remaning butnciaries were held at a constant sink temperature of $130^{\circ} \mathrm{F}$ on the side wall and top head and $2 G$ ? $^{2} F$ on the inttom.

Resul:s were compatibic sith the results from the one-dimensional radial model as wel! as those reported in the Fort St. Vrain FSAR.

\subsection{COUPLED CONDUCTION-CONVECTION MODEL (CCCM)}

\section{W. D. Turner}

\subsection{Addition of Convection Algorithns to CCCM}

One prohlem that must be addressed during the sufety siudies of an HTC $R$ involves the determination of the Iransient temperatures in the active core and along the coolant chanicls during the system Iransients that wiould follow a reaclor irip or an abnormal transient condition. A model depicting this type of transient requues an analysis of the tutal heat iransierred to the gas by cunvection.

A version of the heat transier condes HEATINic was modisiced to inctuct the tlow of thid in a coulent chanxel. The andysis is restricted to a twodimensiunal RZ model or a three-dimensionsl ROZ model and assumes that the fluid flow is une dimensiunal alor; the $Z$ axis. The code yields the ste ady-state or transaent temperature ästribution in both the sulid materials and the coulant; the alkulation requines th: mass flow raie and inkt tenperaiure, pressure. and composition of the curlant as input. The eqration whith ietermines the temperatures in the coulant iry the steady-state proh$\mathbf{k n t}$ is

$$
\left\{\begin{array}{l}
G C_{p} A_{r} \frac{\partial T(z)}{\partial z}=2 \pi T \quad 0 \leqslant z \leqslant L \\
T(0)=T_{u}
\end{array}\right.
$$

where

$G=$ mass tluw rale of the coviant.

$C_{p}=$ specitik tieal of the ciowlant.

$f_{f}=i$ inss-sectiunal asea of the coxplant shar.nel.

$r=$ radius of the coulan i shannel.

$\varphi=$ heat flux normal to the surface of the comblant channel.

$T_{a}=$ inler remperisture.

$l=$ lengtn of the coxilant channel

For the iransient calculations. the giverning earation for the temperatures in the comlani channel is

$$
\begin{cases}\rho C_{p} A_{c} \frac{\partial T(z, t)}{\partial t}=2 \pi r q \quad\left(; C_{p} A_{c} \frac{\partial \pi z, I)}{\partial z}\right. & 0 \leqslant z \leqslant l, t>0 \\ T(z, 0)=f(z) \quad 0 \leqslant z \leqslant l . \\ T(0, t)=T_{1.7}(1) t>0\end{cases}
$$

where $\rho$ is the density of the $i(w) l a n t . f(z)$ is the initial remperature jistribution, and $T_{i:,}(t)$ is the limede ondent inlet temperature.

These aquations were written in, finite-di,fererice form compatitle with thr numerica! ichnique used in HE:ATINC;. The alcuiation of the film heat transfer coefficien. $t$, the helium flowing inside the coolant 
channels is deternimed by

$h=\left\{\begin{array}{l}0.019 \operatorname{Re}^{0.8} k / d \quad 4000 \leqslant \operatorname{Re} \\ 0.004 G C_{p}+\frac{14.9 k}{d}-0.004\left(i C_{p}\right) \\ \left(\frac{\operatorname{Re}-200}{1900}\right) \quad 2100<\operatorname{Re}<4000 \\ 0.656 G C_{p} / \operatorname{Re}^{2 / 3} \quad \text { Re } \leqslant 2100\end{array}\right.$

where

$h=$ ifln heat transier coefficient [Btu $\mathrm{hr}^{-1} \mathrm{ft}^{-2}$ $(\mathrm{F})^{-1} \mathrm{i}$.

$R e=$ Reynulds ri:mber (dimensiunless).

$k=$ temperature-dependent thermal conductivity of the helium [Btu hr ${ }^{-1} \mathrm{ft}^{-1}\left(\mathrm{~F}^{-1}\right.$ ].

$d=$ anmeter of the coolant channel (it).

$\left(;=\right.$ mass velocity of tixe helium $\left(\mathrm{lb}_{\mathrm{m}} \mathrm{hr}^{-1} \mathrm{ft}^{-2}\right)$.

$C_{p}=$ heat capacity of the helium [Atu $1 b_{m}{ }^{-1}$ $\left(\mathrm{Fi}^{-1}\right.$.

The secind part of Eq. (6) is a linear interpolatior. based on :he Reynolds number. betwen the ?ist relationship evaluated at $\mathrm{Re}=\mathbf{4 0 0 0}$ and the .hird evaluated ai $\operatorname{Re}=2100$.

\subsubsection{Addition of Implicit Trassient Algorithm to CCCM}

Preliminary ealculations indicated that the models which would be necessary in the thermal analysis of the HTGR safety studies would require an excissive amount of computing time on the HEATING code to determine the transient temperature distribution over the periuds of inierest. Many implicit numerical techniques exist which are capable of solving most transient problems faster then the classical explicit prucedure which is used in HEATING. Howerer, the adaption of most of them in the code would require extensive revisions as well as curtailments of important features.

It was determined thit both the Crank-Nicolson and the classical implicit 'backwards Euler) procedures could be incorporated ir.lo the current framework of the HEATING computer inde without drastically changing the structure of the program. Thus, both techniques were added to the code. The resulting system of equations is solved by point successive overrelaxation iteration, and procedures were incorporated into the code for estimating the optimum acoeleration parametes. An iterative proc:dure based on Carre's analysis 2 was included to estimate the optimum ziceleration parameter for problems involving constant coefficients and a constant time incremen: For uther problems. an empirival pruatdure was developed which monitors the number of iterations necessary to satisfy the convergence criterion. The aceleration parameter is then updated based on the change in the number of iteration as a suaction of time.

The implicit prucedure incorporated in the HTGR version of HEATING I:akes this cade considerably more efficient than the previous version. Eor exampir. the older version required over an order of magsitude more CPU time than the revised code to calcalate the transient temperatuies for a typical HTGR heat 'ransie: problem. Nu attempt was made to optimize thic isme increment for the solution using the implicit procedure, whereas the explicit procedure used the maximum time increment allowed tor a stable solution. Comparison of calculations indicated that the solution obtained using the implicit procedure was as eccurate as the one obtained using the older version of the code.

This version of the HEATINC4 code. which ircludes both the coupled conduction-convection calculations and the implicit procedure for transient problems as neil as other refinements. has been denoted as the Coupled Conduction-Convection Model (CCCM).

\subsection{Development of CCCM}

One of the models that has been developed to analyze the transient temperatur:s in the actin core and cosiant channels of an HTGR during an accident conditinn involving a reduced mass velocity is presented below.

A ty xical unit cell in an active core during normal operation and reduced flow of coolant is depicted in Fig. 17.10. The three vertical sides are considered to be no-flux surfaces since they represent lines of symmetry. This three-dimensional model can be approximated by the two-dimensional $R Z$ model depicied in Fig 17.5. Since the heat capacity is the dominant feature in the heat transfer characieristics of the active core, the outer radius of the graphite was chosen so that the volume of the graphite is accurately represented. The six fuel zones are used ( $)$ approximate the axjal power distribution. The bottoin of the cylinder and the boundary

12. B. A. Carre. "The Determination of the Optimum Accelerating F.clor for Successive Over-relaxation," Comp. J. $4.73 \ldots 78$ (1961). 


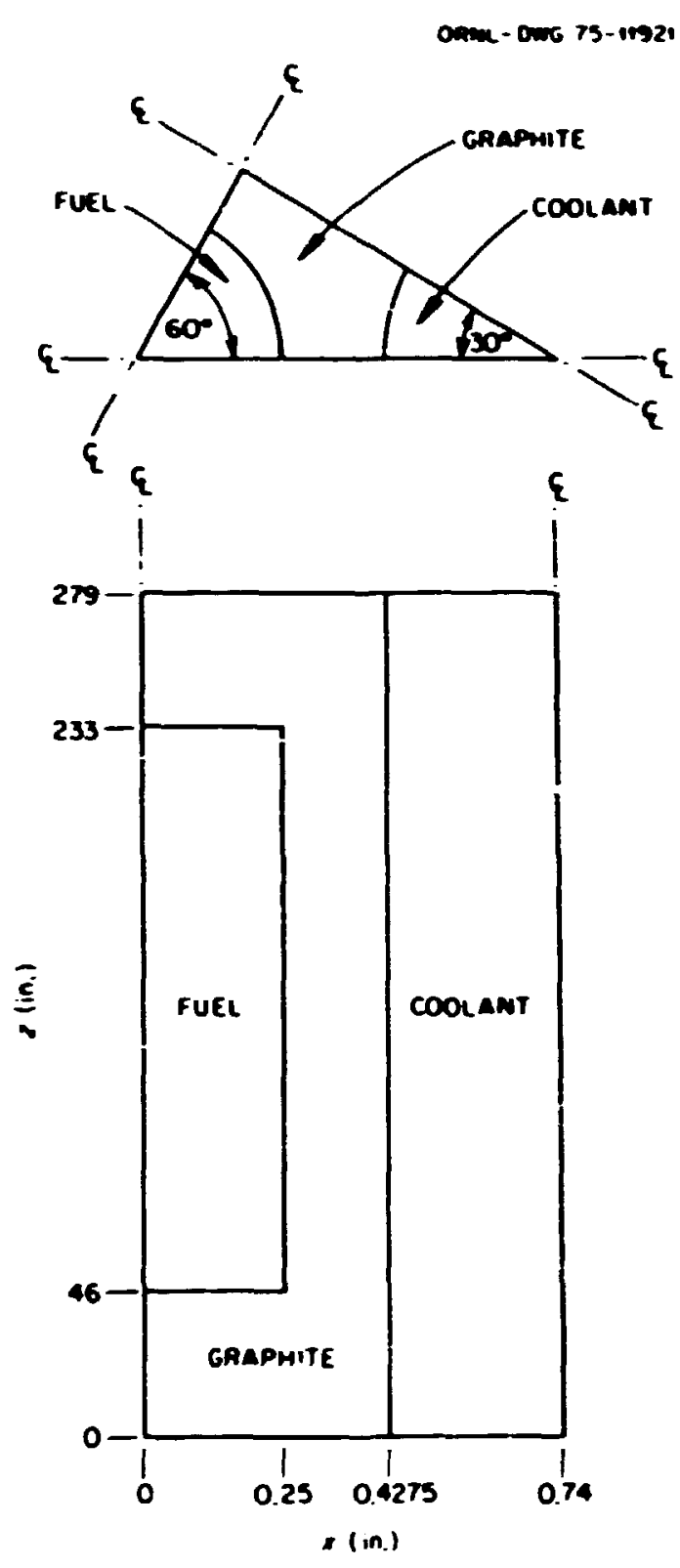

Fin 17.10. Treectimensionel unit cell in active core brime wormal operecion and reduces conlant how.

along $R=0$ are considered to be no-flux surfaces. At the top of thr cylinder. heal is Iransferred to the coolant by convection and to the sunerstructure above the active core by radiation. The inlet iemperature, the mass velocity. the pressure, and the composition of the coolant and the axial power distritution are represented as functions of time.

\subsection{Calculations Using CCru}

Bused un data received from GGA at our request. we make alculations to predict the transient respounse of the maximum ficel temperature and cudant exi! temm.apure using GGA's flow rates and inkt temperatures for the following cases involving the 2000-4wit) Delmarva Puwer and Light reactor:

A. Rezutor trip iron 1007 puwer (fig. 4.3 in Ret. i).

B. Innmediate loss of inain lonp conding (LOMLe) followed by sutduwn un me omre au iliary couling system (CA'S) i-rop with 1 t0-min dalay and vike main bop helium shutof rale tialed in upen pusitior: (Fig 4.20 in Rel. I).

C. Design base depressurization acident (DBDA) with couting on the man loops for $12 \mathrm{~min}$ and then couling with one CACS loop 1 ? $\mathrm{mm}$ after rezctur trip (Fis 4.28 in Ref. I).

D. DBDA and a LOMLC with couldown by ane CACS after 5 -min delay (Fig- 4.33 in Ret. 1).

Axial temperature profices for normal operating condiciuns are presented in Fig. 17.11. The temperatuac profiles are baed on the axiad power distribution gren by $\mathrm{CGA}^{13}$ and on a radial power peaking failor of $1 . n$.

Transient temperatur: respunses for ases A through $D$ are presented in $F$ ifs. 17.12 through 17.15 respectively. The maximum fuel temperature and the coulant exil temperature from the ORNL cakulations are drawn $x$ a continuoss function of tirse in each of the figures. Data at selected points from the appropriate figures from Gulf-GA-A1 2504 are also included.'

\section{Reults for cre A}

Fig.tre 17.12 shows the lemperalure for a reactor trip from $100 \%$ pwwer with a radial power peaking fator of 1.6. The volume overage fuel tempetalure and the averape cose outlet helium temperature from Fig. 4.3 of Gu!;-GA-A 12504 are also included. The results agree guite well through the I-hr time period. Note that the calculated fuel temperatures are for the highest power region and therefore should represent the maximum fuel temperatures as compared with averase fuel temperatures presented in Fig. 4.3 of Ref. I. Note: The calculations of GGA determine both maximum and average fuel temperatures and it:-se values are dumped on magnetic tape. It is the rifsice of the perr un who makes the piots from these aris as to which ralues will bx presented.) The same distinction is made between

13. R. A. Clark, ktter Io J. P. Sanders. Sept. 17. 1973. 


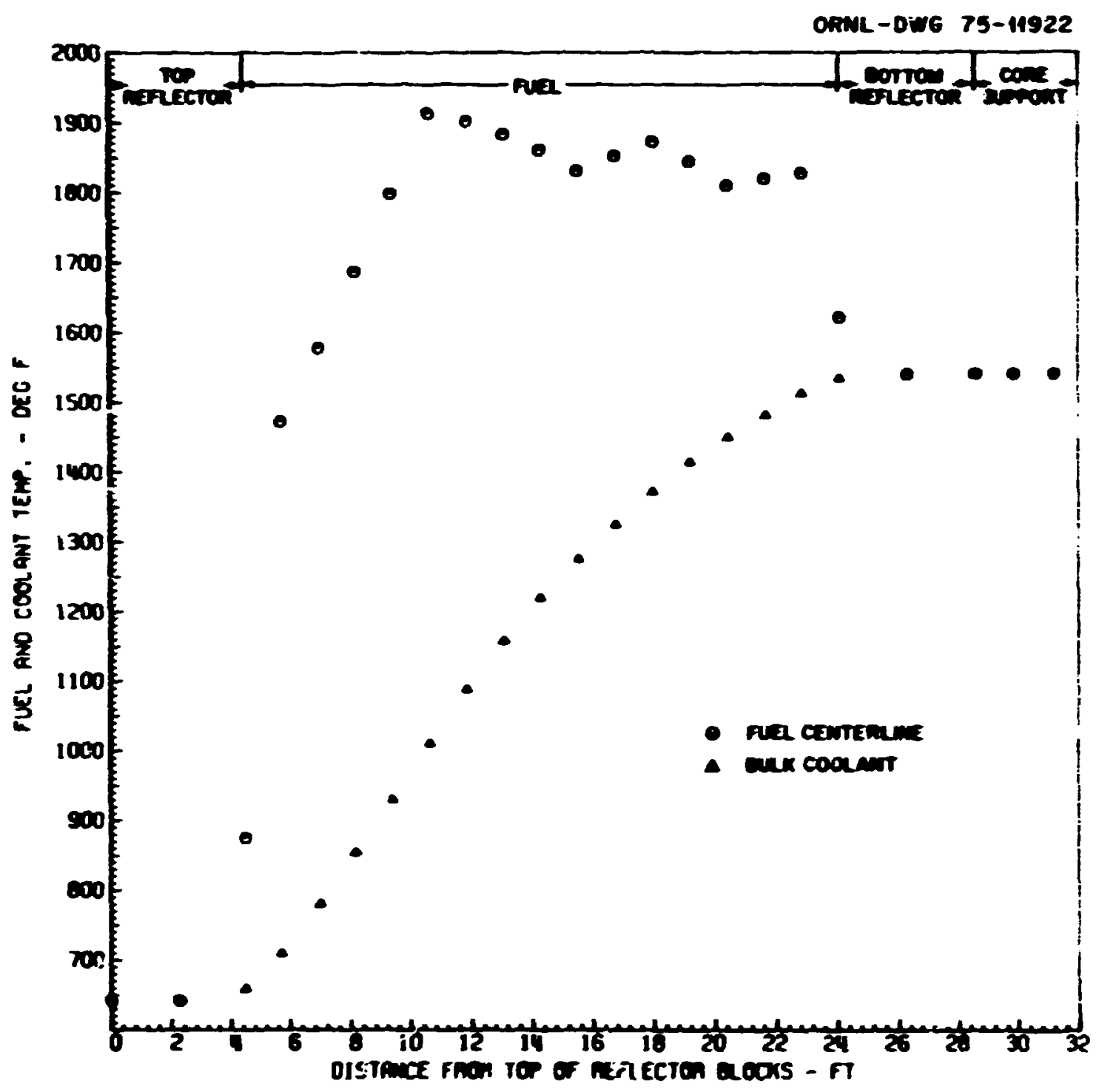

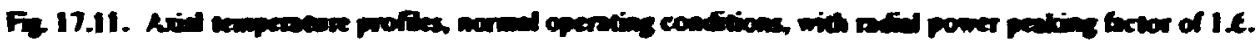

the two exit coolant temperatures: shown in Fig- 17.12: huwever, if the now orifices are still effectire at the lower now rates, the exit temperatures of the coolant from all channils shculd be about the same.

\section{Realis for cose B}

The temperatures for an immediate LOMLY followed by shutdown on one CACS loop after a 42,inin delay with one man loop helium shutoff valve iriled open are presented is Fif. 17.13. The inaximum fuel temperative and the core maximum coolant outlet temperature from Fig 4.20 of Civir.SA-A 12504 are indicated in the figure. For tiones less than $2.75 \mathrm{hr}$, the Reynoids nu:nbe: was determined to be less than $\mathbf{4 0 0 0}$. The ORNL calculations indicate that the maximum fuel temperature is $.914^{\circ} \mathrm{F}$ al normal operating conjitions: $30 \mathrm{sec}$ afier LOMLC. this maximum fuel tempe ature drops to a value of $1708^{\circ} \mathrm{F}$ and then increases to a maximum value of $2622^{\circ} \mathrm{F}$ at $40 \mathrm{~min}$ when oreratior of the CACS loop is initiated. After $6 \mathrm{hr}$. the raxim!: fuel temperature is $510^{\circ} \mathrm{F}$. 
ORNL-DWG $75-14923$

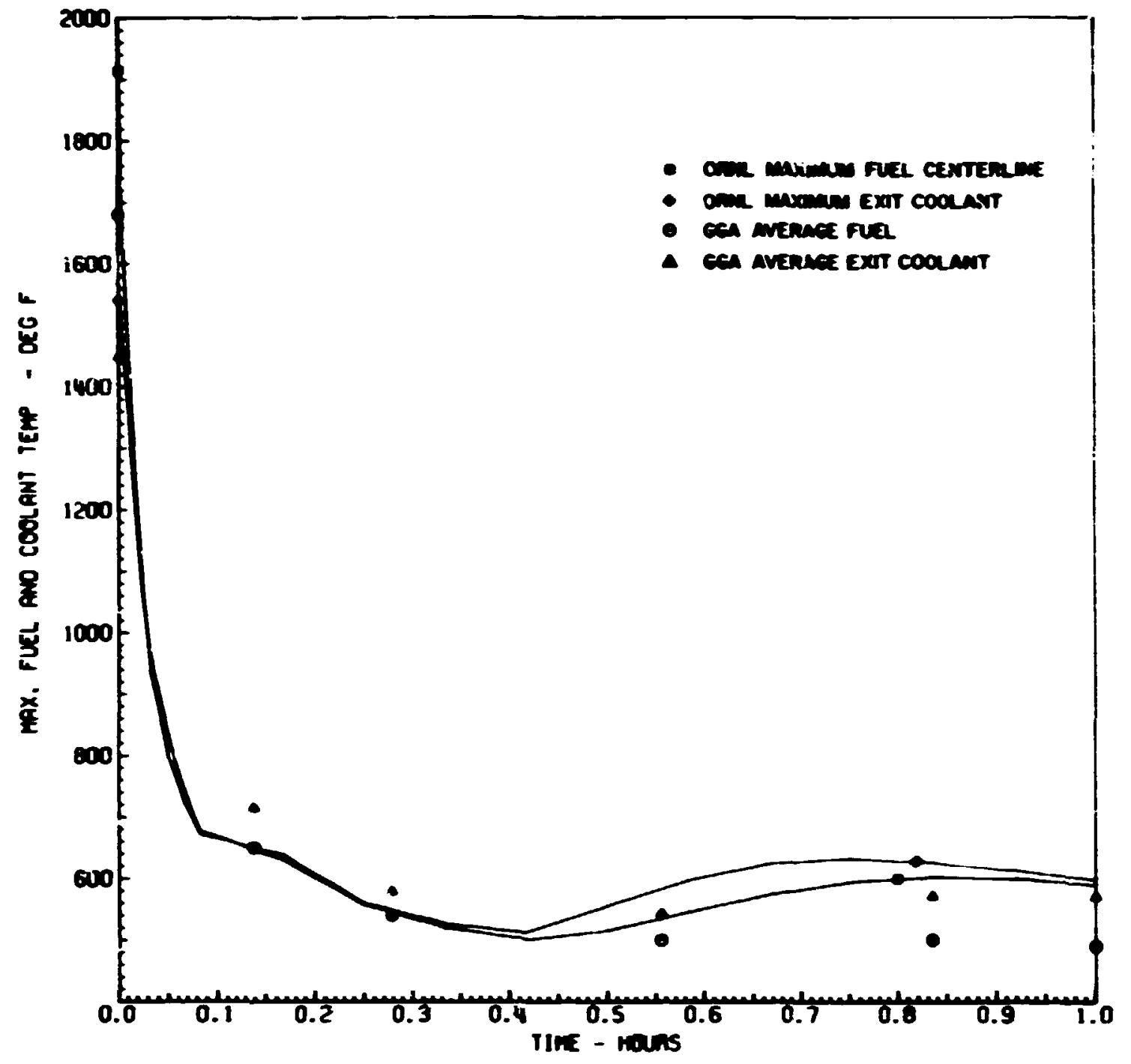

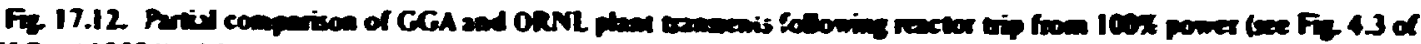

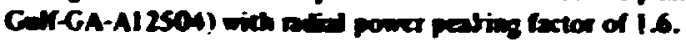

Bith the maximum fuel temperature and the maximum witet coolant temperature are below values calculated bi GGA for most of the transient. This is due to the fact that the GGA calculations include the buoyancy effect of the hot gas in the channal with a higher power Finsty cusinared with cooler $g$ in channels with lower power density. This effect, which is not presently included in the DRNL calculations, will be most prominent for those cases where the gas pressure is higher. the gas flow rate is very low. and the delay time to start of forced conve :tive now is long. All these characteristics are found in case $B$.

Nite that even though reverse flow is prohibited by the relatively low fow in this case. there is 2 "tendeniy" toward the formation of a natural convection lrop that impedes forcei convective flow in the 1.utter channels and enhances it in the cooler chaninels.

\section{Results for case C}

The temperatures for DBDA with cooling on the main loops for $12 \mathrm{~min}$ followed by cooling with one CACS 
OANL-DWG 75-11924

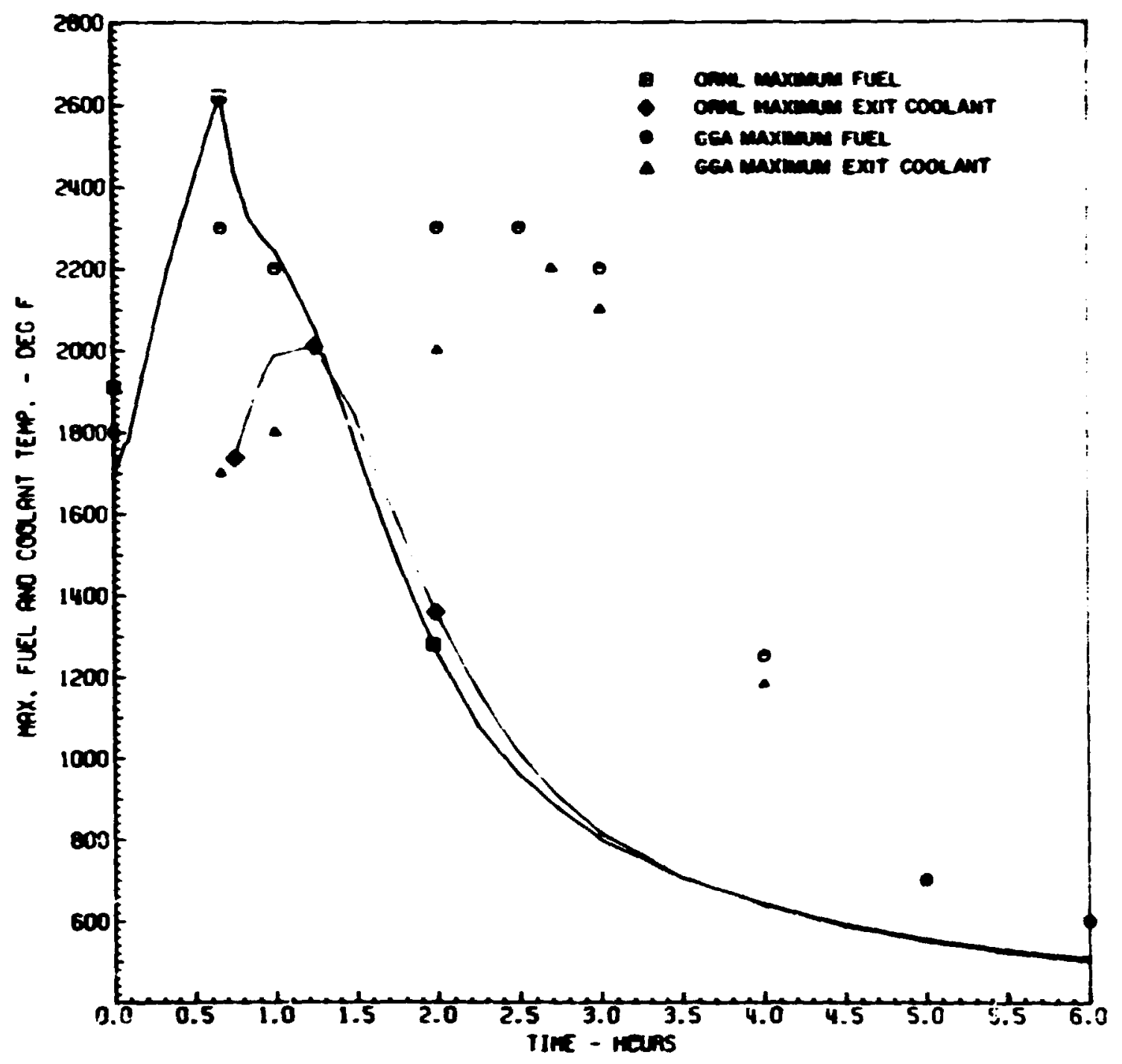

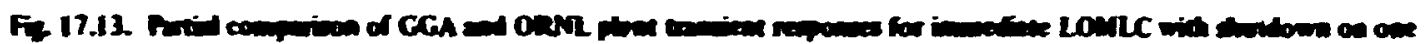

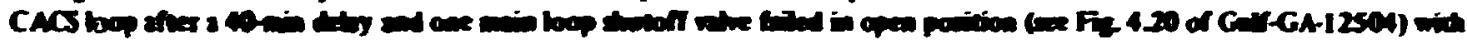

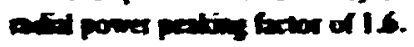

loop 17 min after reactor trip are presented in Fiz 17.14. The maximum fuel temperature and the core maximum coolant outkt temperature, taken fron Fit. 4.28 of Gulf-GiA-A1 2504. are identified. The maximum fuel temperature during normal operating conditions as caiculated by ORNL is $1903^{\circ} \mathrm{F}$. The Reynolds number drops below $\mathbf{4 0 0 0}$ at about $z$ min after initistion of the depressurization accident. The maximum fuel temperature drops to a minimum of $1347^{\circ} \mathrm{F}$ at $10 \mathrm{~min}$ and then increases to a maximum of $1727^{\circ} \mathrm{F}$ a. $1.5 \mathrm{hr}$. Ten hours after reactor trip. the maximam fuel temperature is $989^{\circ} \mathrm{F}$ and is decteasing-

The general curve indicated by the ORNL calculations is quite similar to that presented by CGA. Again. the remperalures calculated by ORNL are lower becrase the effect of reduced flow in the hot channel due to the buoyancy of the hotler gas is not included in the ORN: calculations at present. This effect is less than in case B 
ORML-OWG 75-11925

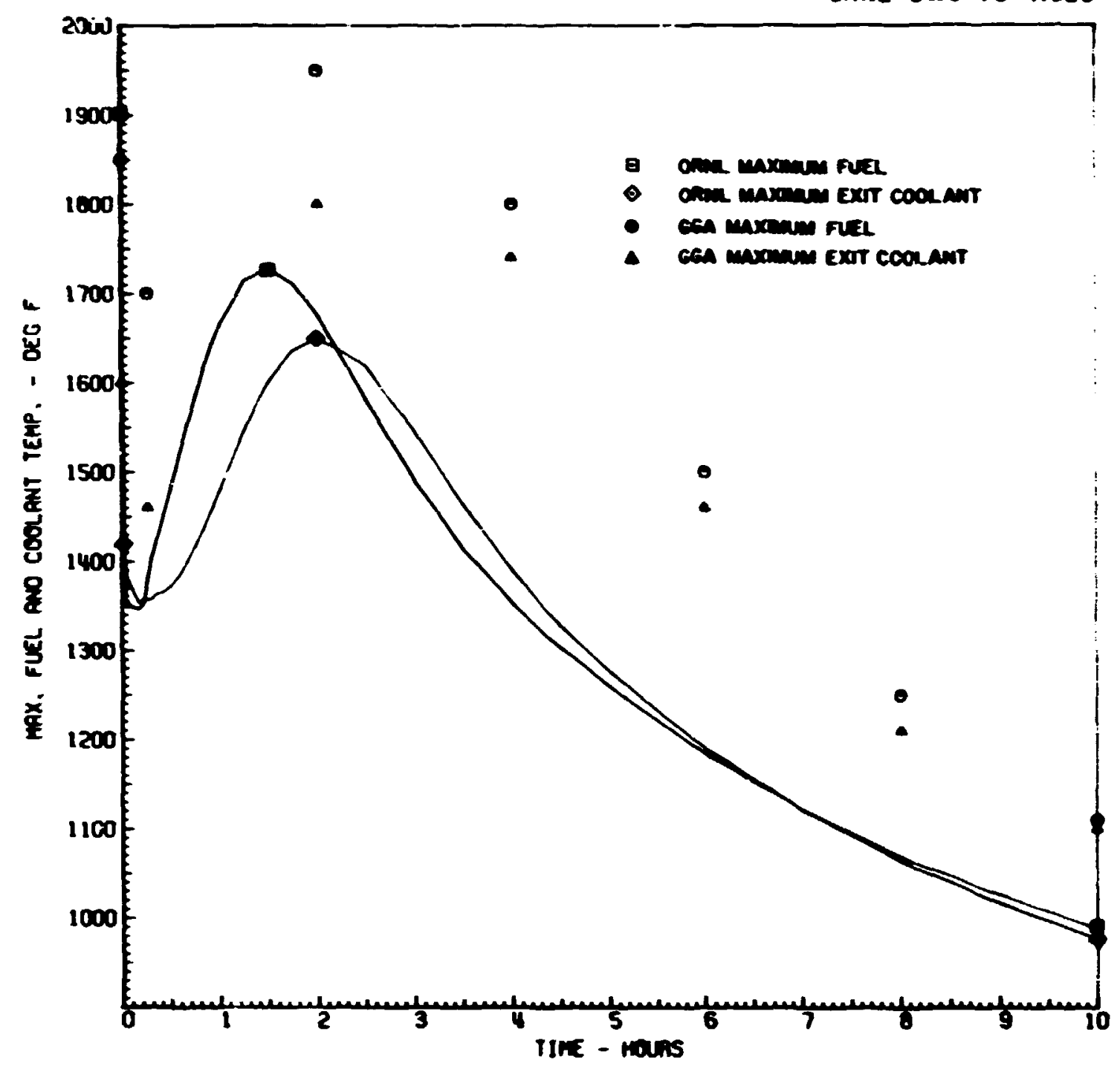

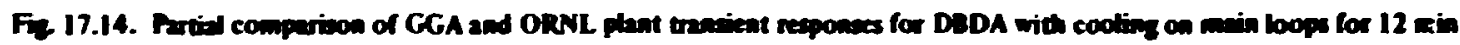

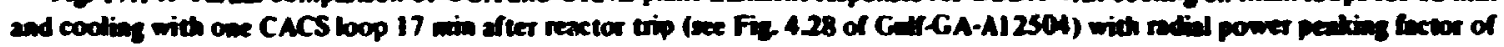
1.6.

due to the fact that the pressure is much lower, the gas density is lower. and therefore the density difference is less.

\section{Resalts for case 0}

The temperatures for DBDA and LOMLC with cooldown by one CACS after a 5-min delay are presented in Fig. 17.15. The maximum fuel tempera- ture and the cure maximum coolant outlet temperature, as presented by GCA in Fig. 4.33 of Gulf-GA-A12504, are indicated. The ORNL calculations show the maximum fucl temperature during normal operating conditions as $1914^{\circ} \mathrm{F}$. The maximum fuel temperature drops to a minimum of $1708^{\circ} \mathrm{F}$ at $.30 \mathrm{sec}$ after initiation of the accident, increases to a maximum of $2095^{\circ} \mathrm{F}$ at 1 $\mathrm{hr}$, and drops to $1403^{\circ} \mathrm{F}$ at $6 \mathrm{hr}$. When the CACS is activated, the Reynolds number is below $\mathbf{4 0 0 0}$. 
ORNL-OW6 75-11926

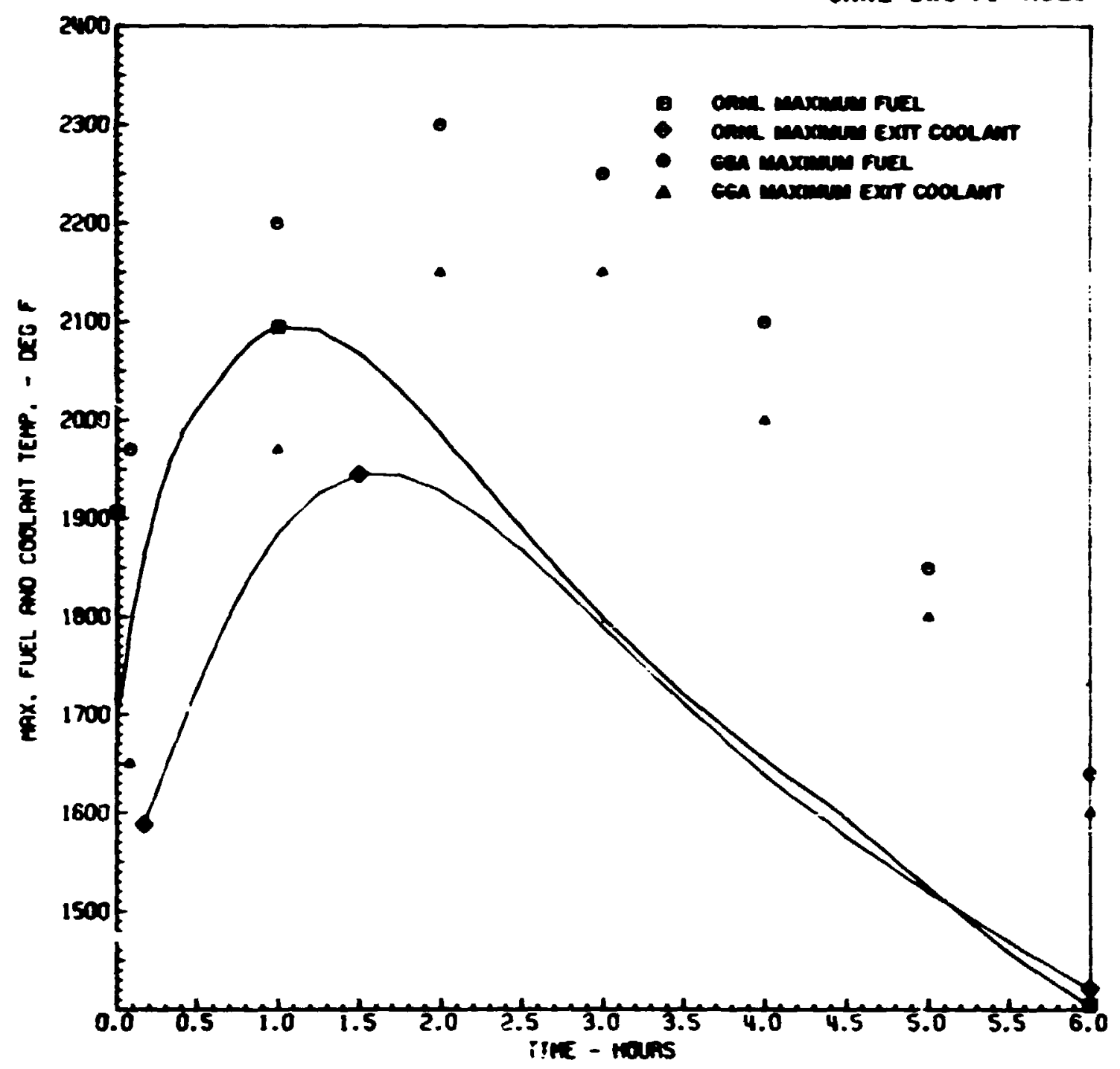

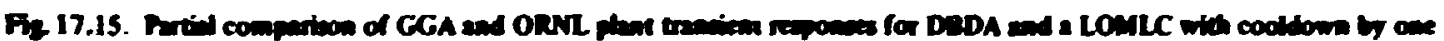

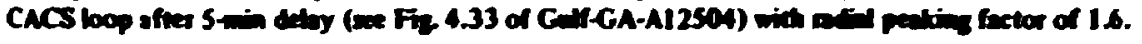

As $w$ ith case $C$. the values calculated at ORNL for the corlant and fue: iemperatures in case $D$ are lower than those presented by GCA. Again, the difference arises from the absence of :he bucyancy effect in the hot channel in the ORNL calculation: The effect is more pronounced for case $D$ than for case $C$ due to the absence of the short period of uperation on the main loop. which cookd down the entire core at the beginning of the accident.

\section{Furter code developinents}

In addition to the exclusion of the natural convection buoyancy effects in the ORNL calculations. the effect of the orifice settings at the reduced now rates have not been included. It is asumed that the orifices have been positioned to appropriately distribute flow during full-power operation. Under these full-flow conditions, the pressure losses over the orifice plus entrance and 
exit effects are proportional to the vetucity squared, while the pressure loss due to iniction in the channels is proportional to the veluxity to the 1.8 puwer. In the laminar range. the same type of relationship holds for the contraction and expansion losses, but the frictional lusses are now proportional to the velocity squared. At the same time. the relative losses due tu contraction and expansion and friction are changing as the flow deireases.

These two e'fects. which are iu sume degree interrelated. must be included to modity the distrioutio.i of total roulant tlow stipulated by GGA for the core. An addiconal subroutine will te inserted in the OKNL calculations to provide the proper amount of coolant flow to the :hannel with the higher power density.

It was noted in the ORNL alculation: hat the maximum fuel temperature shifted axially downward after siram of the reactor and subsequent reduced how of coolant. This is due to l::e lact that the peak axial power cecurs in the upper thurd of the core. During the transient. heat is comvectively transpurted from this axial pusition to the sooter lower portions of the cure. and thus. the maximum fuel temperature migrates downward. This effe: $:$ is also :vident in the curves presented by GGA and confirmed by discussion with George Malek.

The required modifications will be made in the ORNL compatations to reflect these requirements to aciu. rately represent the conditions at these low coslant flows.

\section{Developanent of plotting peckage in aid in anolysis of results from heat transfer codes}

A computer code has heen developed to create graphicai output to facilitate interpretation of the results from the HTCR mudels which are solved on the HEATING code. The graphical output includes the transient response of the maximum fuel temp rature and the cuolant exit temperature as well as oxial temperature profiles through the fuel ind he coulant channel. However. the plotting code is not fully operational.

\subsection{FAILURE OF FUEL PARTICLES UNDER HTGR OPERATING CONDITIONS}

\section{T. B. Lindemer F. J.lloman}

In establishing the temperature links for the operation of the fuel in the HTGR, basic studies were initiated relative to two failure mechanisms. The first was the mass transport, of "Amoeba," effer!! ihat results for the tirermal gradient across the fuel narticle during uperation. The seciond was directed wward an svaluation of the stresses that develop in the partikle cocting due io irradiation damage and char.zes in temperatur - levels.

\subsubsection{Failure of Paticles by Mas Trasport in a Temperature Gradient}

The work represented by this phase of the stud: was doumented in a topical reporl that developed he model for chemical iailure of custed partick fuels. . ie work was based on the model that in HTGR fuets. falure an cicur is the result of irradiation danage. high i-eernal pressure, or chemical rection. Failure is ageravate 1 by incre:ses in iemperature (or power density). which can uicur in nuclear ractor accidents. Coating failure constitutes:--muwal of a protective boundary and result; in increases in fission product release rates from coated particles. This reiease c..:is result in a gradual increase in the coolant circuit fission product inventury prowiding that this failuce rate is appreciable. This inventory is the maj.x source of radiuactive miterial that must be considered in the andysis of a hypothetical depressuriration acider:

Definition of laibite iemperatures with respect to operating temperature allows assessment of the neciessary rate of response of prolective syslims and the description of the consequences of couling acidents.

Codes exist fier the analyris of performance under normal conditions. but they tis not emphasive shcmical phenomena such as mass trusport involved in fucl failure. Therefore. this subrask will conce:atrate on such chemical phenomena.

\section{Cartide fuels}

Des:riptions of earbon of fuel transport under noniso-

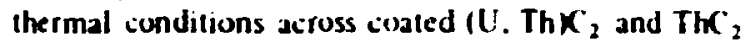
kernels by a soliri-state thermal diffusiun process appear to be adequate and an be obtained iron existing reports. $^{4}$ We will use this information (1) predict particle failure during the next several months as abnormal conditions of temperature and temperature gradient under accident inn Jitions become available to us from other tasks within this study.

\section{Oxide fuels}

Other less well understood mechanisms involving transport of carbon by its gaseous oxides appear to be

14. (. B. Sioll and O. M. Sisnsficld. Sratility of Irrediafiod Comedeparticle fiurls in a Temperafure thadient. Ciulfeis. AI2081 (Seplember 1972). 
assuriated with iailure of oxide fuels. The irradiation behavior of urania-bearing particles is ubserved is include the eventual iekase of fission gas from the particte when a temperature gradient exists ross the partick. An empirial correlation ton this release is avaibale from the results from the Dragon project. is This falure of the coating of the particte is assuriated with the transport of arbon from the hot to the cold sick of the partick and with the movement of the kemel up the temperature gradient. Mechanisms that may produce the transport of carbcn have been proposed in the literatur:. :ut prior to our recent work. no mathematical mod-1 has aren avalabla to predict the behavior observed in the studies fron: the Dragon prcject.

Recently we have developed a model that is based on the transport of arbon by the interdifiusion of $\mathrm{CO}$ and $\mathrm{CO}_{2}$ across the temperature gradient. This model assumes a uniform tolal pressure of all gases in the particle and local equilibrium in the $\mathrm{C}^{-} \mathrm{COCO}_{2}$ system: the latter condition establishes a gradient in the pariial pressure of $\mathrm{CO}$ and $\mathrm{CO}_{2}$ and the conditions necessany for transport of carbon. Three forms of the model have been developed and are given beluw.

SC-contining (Triso) particles. The analysis of the Dragun project data's led as io the conclusion that the SiC layer was cinmixally buffering the pressure of carbon monuxior in the particle to that for the $\mathrm{SiC}-\mathrm{CO}-\mathrm{C} \cdot \mathrm{SiO}$, eyuilibrium. Under these conditions, the mathematical form of the carbun-transport equation appears to be

$M=\frac{r\left(P_{\mathrm{CO}}+P^{\prime}\left(\mathrm{U}_{2}\right)\right.}{F_{f}(n R T / a \theta)} \frac{\epsilon^{\prime}}{q^{\prime}} \frac{d T}{d z} k P_{\mathrm{CO}}$

$$
x \ln \left|1+\frac{(n R T ! 20)_{f}}{P_{\mathrm{CO}}+P_{\mathrm{CO}_{2}}+P_{1}}\right|
$$

where

$a=$ ratio of the void : pace in the buffer layer kernal volume:

$\boldsymbol{F}=$ fissions per initial heavy metal atom (FIMȦ). $r_{r}$ :

$f=$ final

$\epsilon^{\prime} g^{\prime}=$ geometrial factor. $\sim 0.017$;

$i=$ initial:

$M=$ thickness of iarbon removed. $\mu \mathrm{m}$ :

15. 1, W. Giraham. "The Devekipment and Performance of ITTR Core Materials," pp. 494517 in Prexcredings of riosCowited Rracie" Informatom Mecting. Oak Rulge Vational

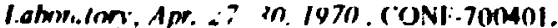

$n=$ moles of tission gas per mole of luel pe: = FIMA. $\approx 0.603$

$P_{\text {CO }}=$ average partial pressure of $\mathrm{CO}$

$P_{\mathrm{CO}_{2}}=$ averape pattial pressure of $\mathrm{CO}_{2}$.

$P_{1}=$ p.rtial presicure of the suating $q$ is er trained in the bufiet iaser

$R=82.06 \mathrm{~atm}^{-3} \mathrm{mcle}^{-1} \mathrm{f}^{-1} \mathrm{C}^{-i}$

$k=$ rate of arbsn transport va inte! tiffusion in the $\mathrm{COCO}$ svistem. $\left.\mu \mathrm{m} !^{-1}, \mathrm{I}^{-1} \mathrm{Cm}\right)^{-1}$ $\operatorname{stm}^{-1}$ i see Fig. 1-.16):

$T=$.rarage temperature. "K.

$t=$ time a! temperature. $x$ :

$d T d z=$ iemperatuie gradient. ' $C$ im:

$\theta=$ molar volime of the fuel. $\mathbf{s m}^{3}$ mota.

This model appeared to adequately describe the behaviur of the Dragon project fuel within their tempe:ature range of $14^{\prime} 5$ to $1900^{\circ} \mathrm{C}$ and may be useful for alculation ci tailure of Triso iuels under the conditions defined in this DRL nork. However. it should be cautioned that the present math:matical model has not been tested on Triso luels designed and operated under conditions prasalent iri the US. gascooled reaitors. Therefiore. the results obtained from such calcuiations should be considered tentative.

Biso (pyrocarbon coatings ondy) partickes in reactor. In the abrence of the $\mathrm{SiC}$ coating. no chemical sy ste.n is appaient for maintaining $P_{r} ;$ at a fixed value: it may therefore vary with bumar: be ause the consumption of oxygen by oxide-iorming fission produits does not exactly equal that released by 10: upon fissioning. $A$ model has been developed to accorsinuce e the variation of $P_{\mathrm{CO}}$ with burnup: this mesel is based c.n a linear release of $\mathrm{CO}$ with bumup and is

$$
\begin{aligned}
& M=\frac{n\left(d \eta^{\prime} d_{s}\right)\left(\epsilon^{\prime}\left(q^{\prime}\right) k\right.}{F_{f} \frac{R T}{d \theta}(m+n)}\left\{\dot{b}^{2} \ldots \frac{m b\left(\dot{m}+P_{R}\right)}{m+n}\right. \\
& +\frac{m^{2}\left(b+P^{2}\right.}{(m+n)^{2}} \mid \ln \left[1+\frac{(m+n) \frac{R T F_{f}}{d \theta}}{b+P_{l}}\right] \\
& \left.+\frac{m R T}{a \theta}\left|b \frac{m\left(b+P_{Z}\right)}{m+n}\right| F_{j}+1 / 2\left(\frac{m R T}{a \theta}\right)^{2} F_{f}^{-2}\right\}
\end{aligned}
$$

in which $b$ is initial pressure of $P_{(O)}(a t m)$ and $m$ is moles of carbon monoxide generated as a result of iurnup per mole of fuel oxide per ? FIMA. It is evident 


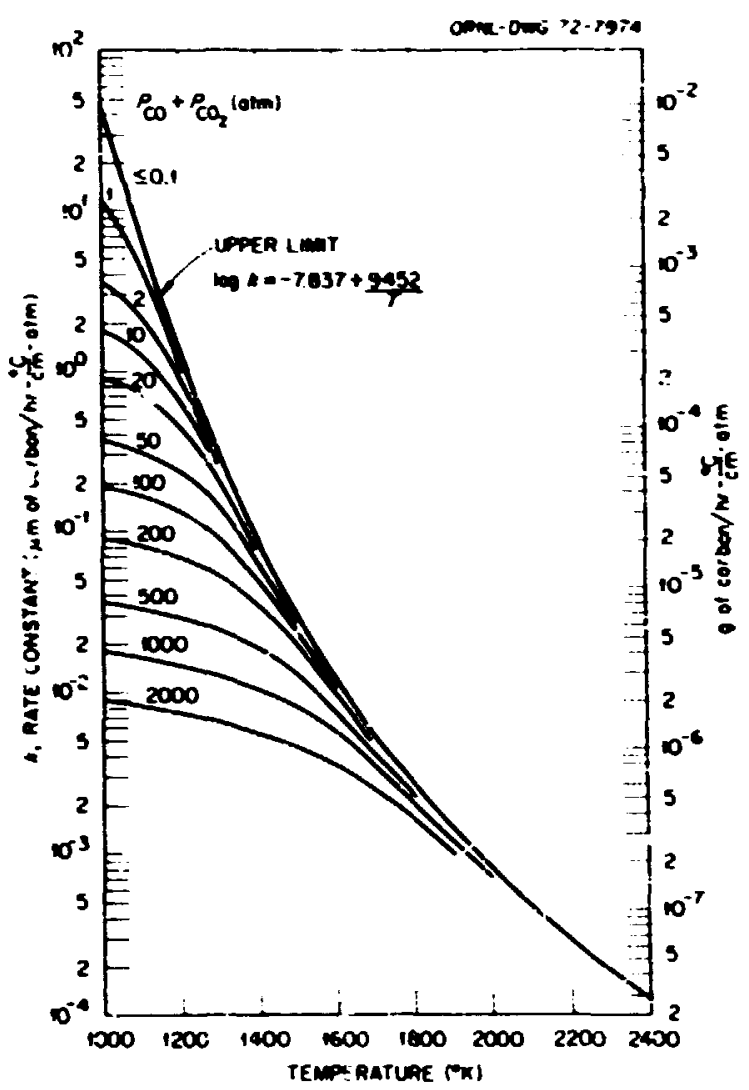

Fiz 17.16. Temperature and presaure dependence of the nte comatent $k$ for curbon transport vin interdifition in the $\mathrm{COCO}_{2}$ system.

that if $m=0$. E.q. (8) reduces to Eq. (7). Again. this equation has not been applicd io inlerpretation of aclual irradiation results because such results are jist becoming available under conditirns where the valuss of $m$. temperatures. and temperature gradients are sulficiently known. Therefore, iny predictions niade with the modsl must be considered tentative.

Out-of-reactor Bisc mudel. Here the pressures of $\mathrm{CO}$ and $v^{\circ}$ her gases in a coated varticie are invariant at a given temperature, and the model for carbon iransport becumes

$$
M=\frac{\epsilon^{\prime}}{g^{\prime}} k t \frac{d T}{d z} P_{\mathrm{COO}} \frac{P_{\mathrm{CO}}+P_{\mathrm{CO}_{2}}}{P_{\mathrm{CO}}+P_{\mathrm{CO}_{2}}+P_{\mathrm{B}}}
$$

Presint calculations indicate that this model predicts falure of as-coated Biso, coating, in out-of-reactor tests under conditions where a-tual experiments do not demonstrate failure. Since the unt-of-reactor model is based on well-known simpla theories and well-defined experimental data. there is no :leat reasin why the inodel alculations and experiniental results lisagiec. Either the lailuse mode is cirtrulled by a sluwer process, such as a themical reaiticn of $\mathrm{CO}, \mathrm{CO}_{2}$. and carbon, or the einerimental data were not taken with techniques serisiive enough io reveal tailure of the coatings.

In tivis repoting peried, cumput:s codes tor the iale':-:un al tixe rate of thinning $o^{\prime}$ the pyrovarbon coatiris in $\mathrm{COCO}_{2}$ interdittusion $\mathrm{i}_{1}$ the bulfer iayer of the uxide-fueled particles iave be.: under develupment. These resulis are compared wih observed t:havior in axide fuels and with rates $\mathrm{si}$ the decomposifion resction $2 \mathrm{CO} \rightarrow \mathrm{CC}_{2}+\mathrm{C}$ in $2 n$ : tten:pt to test the validity of the model. He are curren,ly alteluping to resolve this out-of-reatsr cis:repancy becuuse of its peitinence to the in-reaction Bis s model.

We are continuing to interpret ih: ver ninima available experitnental data for carbon transport iy the $\mathrm{CO}_{2} \mathrm{CO}_{2}$ mechanisin in ade particles. Sunic data are available from a KFA report ${ }^{16}$ for carbon transpirt and subseyuent hernel $\mathrm{n}_{1}$ 'vement in as-cuated $\mathrm{HO}_{2}+x$ part: cles. For such : system wur mathematical mot $1^{17}$ suggests

$$
M=\frac{\epsilon^{\prime}}{q^{\prime}} k t \frac{d T}{d z} P_{\mathrm{CO}} \frac{P_{\mathrm{CO}}+P_{\mathrm{CO}_{2}}}{P_{\mathrm{CO}}+P_{\mathrm{CO}_{2}}+P_{\mathrm{g}}}
$$

where

$$
\begin{aligned}
& M=\text { carbon tiansported }(\mu \mathrm{m}) \text {. } \\
& e^{\prime} / \varphi^{\prime}=\text { ratio of obcerved diffusir : cxefficient is) } \\
& k=\text { rate constan: for the C.CO- } \mathrm{rO}_{2} \text { iystem. } \\
& \text { log } k=-7.837+9452 \text {. } \mathrm{T} \text { (kei. 17). } \\
& t=\text { time (hr). } \\
& d T i d z=\text { icmperature gradient } 1^{\circ}(\mathrm{cm}) \text {. } \\
& P_{\left(\cdot 0 . P_{1} \cdot O_{2}\right.}=\text { pressure of } \mathrm{CO} \text { or } \mathrm{CO}_{2} \text { (atm). } \\
& P_{R}=\text { pressure or residual coating gases. usi- }
\end{aligned}
$$

In the KI:A experiments at $1700^{\circ} \mathrm{C}$ the as-coated value of $\mathrm{O} / \mathrm{U}$ was 2.005: upun subseçuent heating. ihe

16. A Nalismalis, R, Rotterdam, and B. T. Thecke, Toch. Rept. KFA-ItKW-IB 2/72, pn. 13 I6 (January 1972).

17. I. B. Lindemer and H. J. de Nordwall, All Analvesis of Chemical Failues of Crama Furl Particles in the MighTrmingalure Gas-(inded Rracfor, In he publistud is ilr. ORIV-TM remit. 
(1/U would be reduced 102.000 and the hyperstuchionetric oxysen would reai with carbon 10 form $\mathrm{CO}$. The value of $f_{c o}$ can be alculated fiom the ideai gas law; the ratio of free volume in the buftier layer to the superficial volume of the kernel calculatei from the phutomicrograp'is in the repurt. asuming a 50 \% Jense buffer lajer. was 0.82 . The value of $P_{C O}$ was therefore $40.0 \mathrm{a} ı \mathrm{~m}$. In the KFA experiments, they observed metallographically that $M=70 \mu \mathrm{m}$ at $1700^{\circ} \mathrm{C}$ in $480 \mathrm{hr}$ a: $d T / d=200^{\circ} \mathrm{C} / \mathrm{cm}$. We can prediet what $M$ should be from the above equation with $\epsilon^{\prime} / q^{\prime}=0.017$ obtained from ur analysis of the Dragon Project empirical correlation.' ${ }^{5}$ We calculate $M=58 \mu \mathrm{m}$, which is in good agreement with the observe.t behavior.

The KFA w'ork with kernels having an $\mathrm{O} / \mathrm{U}$ of $\mathbf{2 0 0 0}$ in the as-coated condition was performed over the temperature range of $14 \mathrm{Mi}$ io $1800^{\circ} \mathrm{C}$ for times up to $720 \mathrm{hr}$ at $d T / d z=200^{\circ} \mathrm{c} / \mathrm{cm}$ The value of $P_{C O}$ is not known. but values of 1 to $00 \mathrm{~atm}$ are indicated fiom the measurements $c::^{-1}$ Bildstein and Strig. ${ }^{18}$ At $1400^{\circ} \mathrm{C}$. Eq. (10) would give 8 to $160 \mu \mathrm{m}$ of carbon transported. dependinz on whether the low or high value of $P_{C O}$ is used; while at "ocon 0.6 to $6.2 \mu \mathrm{m}$ s. predicted. It is drubilui whether $<19 \mu \mathrm{m}$ of iransported carbon would be ubservable mitallugraphically because the carbon itansporied to the cold side would probably just densify the buffer layer. In viuw oi the uncertainty in the valise of $\boldsymbol{P}_{\mathrm{CO}}$. it would appear that the iack of observable transport is not inconsisteit with the predictions of the above equation.

We are curi intly applying the mathematical model to three different situations: to Triso and Bist) particles during irradiation and to as-coated particles out of reactor. To date. the Triso model used for the Dragon Project datals and the as-ioated model analyzed above appear (1) agiee with experimental work. The Biso in-reactur particle modei does not agree at present and wark is cont:auing on this cal zulation as information becomes available.

\subsubsection{Coateó-Particle-Performance Modeling}

The objective of this work is to provide evaluations of fuel degradation (stress analysis) for the U.S. AF.C Direc:nrate of Licensing. During the present reporting period, the three coated-particle-performance codes available to us have been cobtained and ma.j operational on tur computers. Tiese rides

1H. II. Bibstein and $\Lambda$. Stright. Deccrmination nf riases in Low finriciord Couled Oxidn Particles. Dragon Projece Report 728 (1,ugust 1971). Referin.e used with permission of Drapon Project.
STRETCH. ${ }^{19-21}$ TRISO. $^{22.23}$ and STRESS-2.24-26 each have unique apabilities and characteristics. STRETCH is capable only of analysis of Biso particles TRISO of Triso particies. and STRESS-: of any combination of cuatings up 10 a total of six.

Of the three :odes. SThESS-2 is potentially the most useful. In addition to its fexibility in being abie to model both Biso and Triso particks, it is substanially more sophisticated than the other two codes. It considers such events as gap formations between layers and subsequent clusing of the gaps, failures of the inner layers. and the subsequent changes in stresses anc displarement of the outer layers. Since the various cuatings are deposited at different temperatures. stresses can arise betore imadiation begins from thermal sources. STPESS? has an option which permits indusion of the fabrication stages in the performance history of the coated particle.

All the codes require relatively small amounts of computer time (about 30 sec for a single case of an IBM $360 / 91$ computer) and require mudest core storage (less thar. $200 \mathrm{~K}$ bytes).

All three codes have certain limitations, and the limitations are similar. In cach case the properties of the kernel and cuating are dose dependent but n'it temperature dependent. I his implies that the coated particle will cperate at one iemperature during irradiation and precludes accurate evaluation of the consequences of limperature changes.

Of the three coles, only STRETCH calculates the operating temperature of the kerne: and coatings from

19. J. W. Prados and J. L. Sco!l, Marhermurical Kadel for Predicting Coared Panicle Btrivior. ORNL.TM-1405 (March 1966).

20. :. W. Prados and :. G. Godfrey. STRETCH. A Computor Proksam for Arrdicting Corred-Parricle Irradiation Bchowo: Aendificarion IV. ORNL-TM-212? (April 1968).

21. J. W. Prados and J. L. Scott, "Mathematical Model for Predicting Coated Particle Behavior," Nucl. Appl. 2, 402 $\cdots 14$ (Octubet 1966).

22. J. L. Kaxe, “A Mathematical Model fur Cakculating S..e'xses in a Pyrocarbont and Silicon Carbide-Cozted Fuel Partick," J. Nucl. Marer. 29, 249 (1969).

23. J. L. Kaae. "A Mathematical Mowisl fr. Calcuiating Siresses in a Four-Layer Carbon-Silicon Carbitc-Coated Iuel Pritick." J. Vucl. Mcler. 32, ?2:2 (1969).

24. H. Waltiter and P. G. Novirik, Soress Ame!ysis in Comed Parricie fiuds. Parl I: Th.my and Fxamples. Pari II: Compurer etostamme Siress I, D. P. Report gO4 (Alugust 1968) (Part II. Isly (969).

25. K. Ro:agart7, Theorerical Investientions of Coated Parficle fuel Peiformane by Siresr Analysis. D. P. Report 648 (May 989).

24. II. Walther, A Madel for Stress Analygs in Coald Find Porticles, D. P. Report 683 (Oetober 1969). 
the ctoss section and reutron fluxes input. Thus, it appears that STRETCH would be the easies: to modify for cyctiv: irradiation historics, but the problem of introducing temperature-dependent properties would still remain. STRETCH and TRISO do not have failure mudels included, and fialure of the coatings must be implied irom the stresses calculated. As indicated. STRESS - calculates coating failures direcily and, in addition. alculates the consequences of the failure on the remaining unfaiked layers during subsequent irradiation.

\section{Comprivon of STRESS-2 and TRESO}

In perforning the comparison of these two codes. we have selected a Triso particte described in a recent paper by Gulden et al. ${ }^{27}$ The particle design charateristics and performance predictions 1 'etermined by GCA using TRISO) presented by Gulder are shown in Fig. 17.17. Unioi tunativ. the materials properties assumed

27. T. D. Gulden el al. "The Mechanial Design of Teisa Coated Partike Fuels for the Large HTGR." Vuct. Technsi.. 1611), 100) - (October 197?).

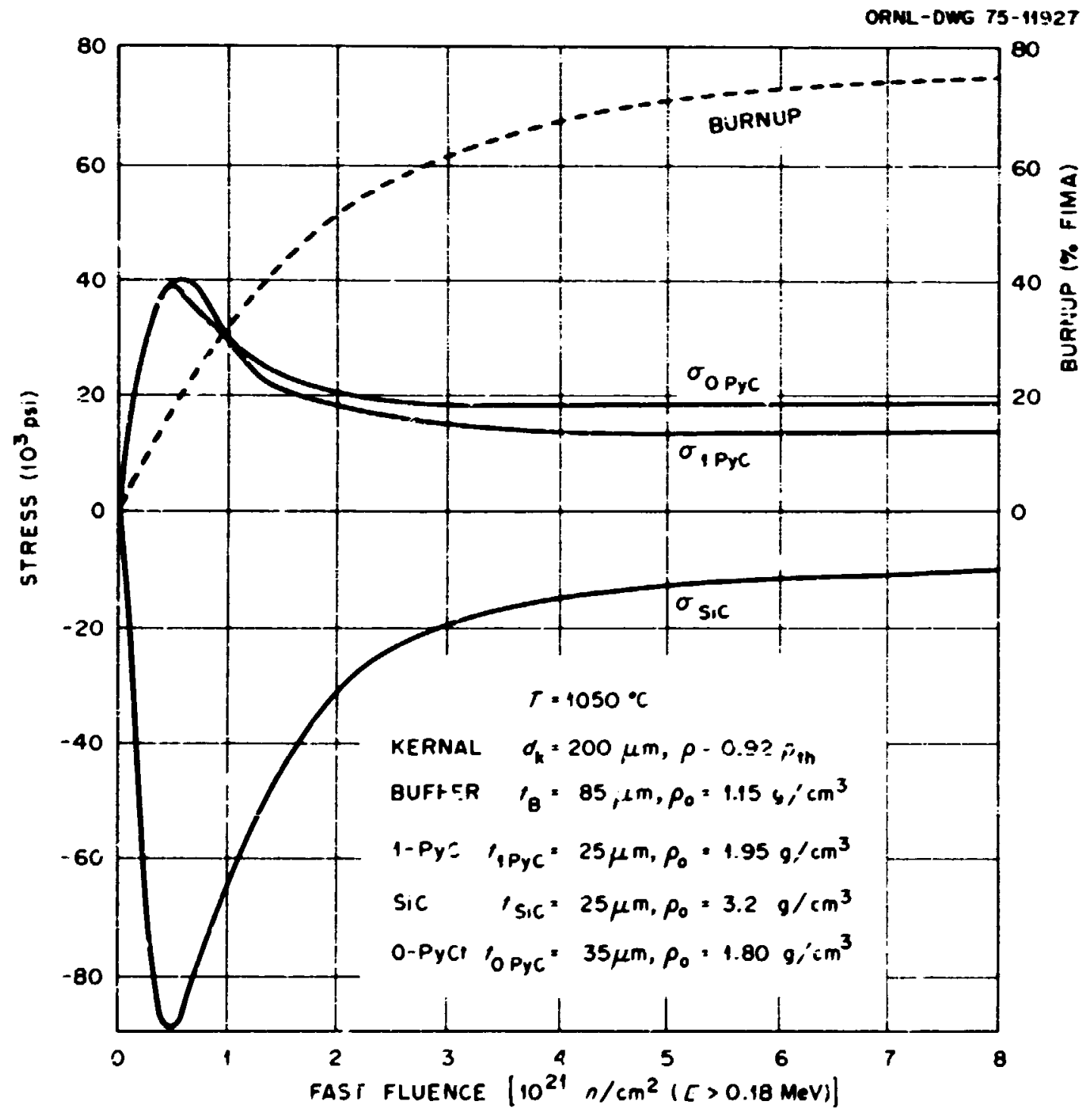

Fig 17.17. Coating streaces in Trieo fucide particle. 
for the kernel and coatings were nut described in the parer. o property values extraited from the literziure were used. The two most important properties in the predictions of pa:formance under irradiation are the creep constant and the irradiation-intuced deformation charateristics of the $\mathrm{PCC}$ inyers. We used a creep constant of $1.0 \times 10^{-27}(\mathrm{psi})^{-1}$ (neutrons $\left./ \mathrm{cm}^{2}\right)^{-1}$ and irradiation deformation characteristios described by the bruken curve in Fig. 17.18. The data of Kaxe e: al. 2* were applied to both $\mathrm{Py}_{\mathbf{y}} \mathrm{C}$ layers even though there was a slight differeike in density between the inner and outer PyC layers. Using these data in both rodes. the predicted performances shown in fig. 17.19 were obtaned. The very high densification rates drived from the data shown in Fig. 17.18 (broken curve) resulted in failure predicted for the inner PyC layer by STRESS 2; TRISO does not indicate falure.

To continue the comparison, the failure stiess used in the input to STRESS-2 was in rerun to obtain a valid comparisun. As ca, be seen from

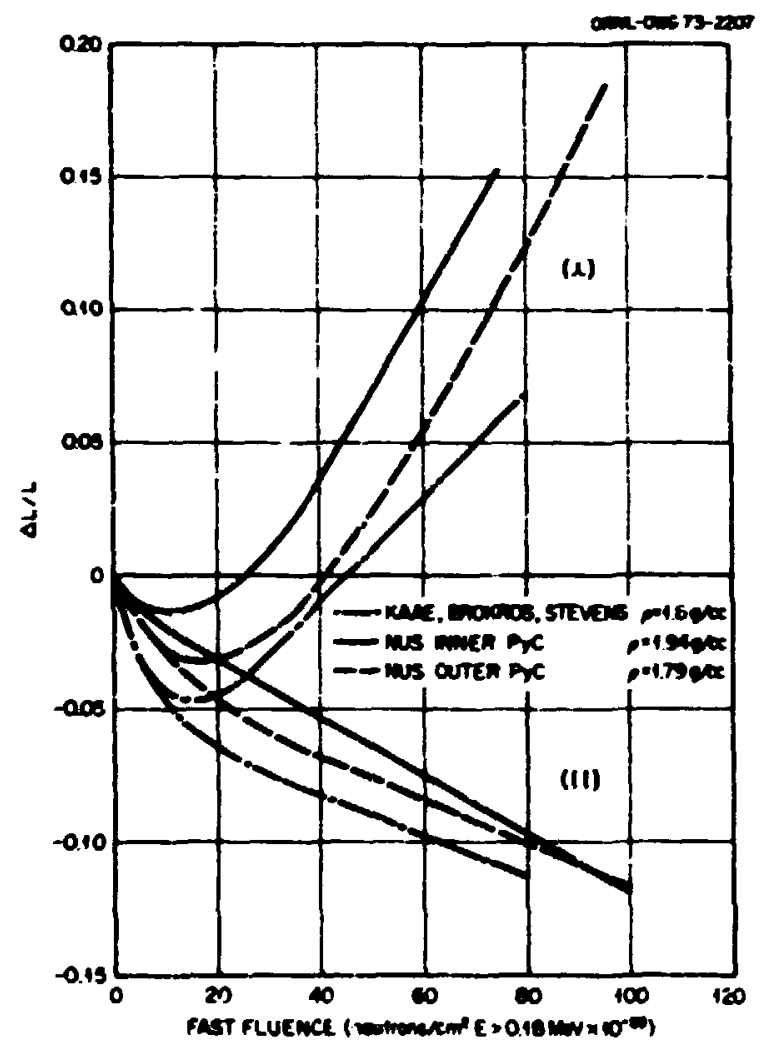

Fi. 17.18. Ismditiontinluced dimencional chanja of PrC.
Fig 17.19, the two codes compare very well. The gas pressures predicted by TRISO are slightly higher than those predicted by STRESS-2, but this can be partially explained in the differences in bumup used. STRESS-2 toes not calculati burnup, ind a bumup-vs-nuence relationship must be included in th: input. We used the curve shown in Fig 17.17. TRISO compiles the bumup relationship, and for tive rase studied, this burnup was slightly higher than that us-oi in the input for STRESS-2. The bumup curve comparison is shown in Fig. 17.20 .

A comparison of Fig. 17.17 and Fig 17.19 shows that the predicted stresses fo: the inser PyC and SiC layers are somewhat differint. We found this to be due to the irradiation-induced deformation data used. By using the data 29 from the solid curve it. Fig 17.18 for the inner PyC and the dashed curve in Fig 17.18 for the outer PyC, we were able to dupliste the performance piedictions presented b; Gulden et al. ${ }^{27}$ with both codes. These results are thown in Fig. 17.21.

From this comparison, we have concluded that TRISO and STRESS-2 are mathematicaly equivalent, although TR!SO; somswhat simpler. For example. TRIS: assumes ti.e SiC layer does not creep and is dimensionally stable under irradiation. Thus. it is not necessan; (or possible) to introwuce creep or irradiztion-irduced deformation da:. for this layer. The same is true for the buffer layer, although for different reasons. TRiSO asaumes that the buffer layer is weak and cannot impart loads to the other lavers excef: through the inechanism n! fuel swelling. With STRESS 2 it is possible to study the effect of faijure of one ior more layers on the stresses devsloped in the remariang untailed layers; this is rot possible with TR!Si?

\section{Comparison of STRESS 2 and STRETCH}

For this comparison we selected the Biso fissile particle presently planned for the OF-I capsule (irradiation test currently being fabricated for the Oak Ridge Resratch Reactor). This parlicle. a 4.2:1 (Th:UYO, kernel that is $350 \mu$ in diameter, is coated with a $100-\mu$ buffer and $\log _{-\mu}$ LTI layer. Tr. kernel, buffer, and LTI densities ware assumed to be 95.50 , and $86.4 \%$ of

28. J. L. Kase, J.C. Bocros. and D. W. Stevens, "Dimensional Changes and Creep of Pcorly Crystalline lsotropic Carbons and Carbrin-Sificon Alloys During irradiation." Corhon 10.57 I . 85 (1972).

29. Privatl communication, J. C. Scarbornugh. NUS retp. with I. J. Homan. ORNL. Feb. 6. 1973. 


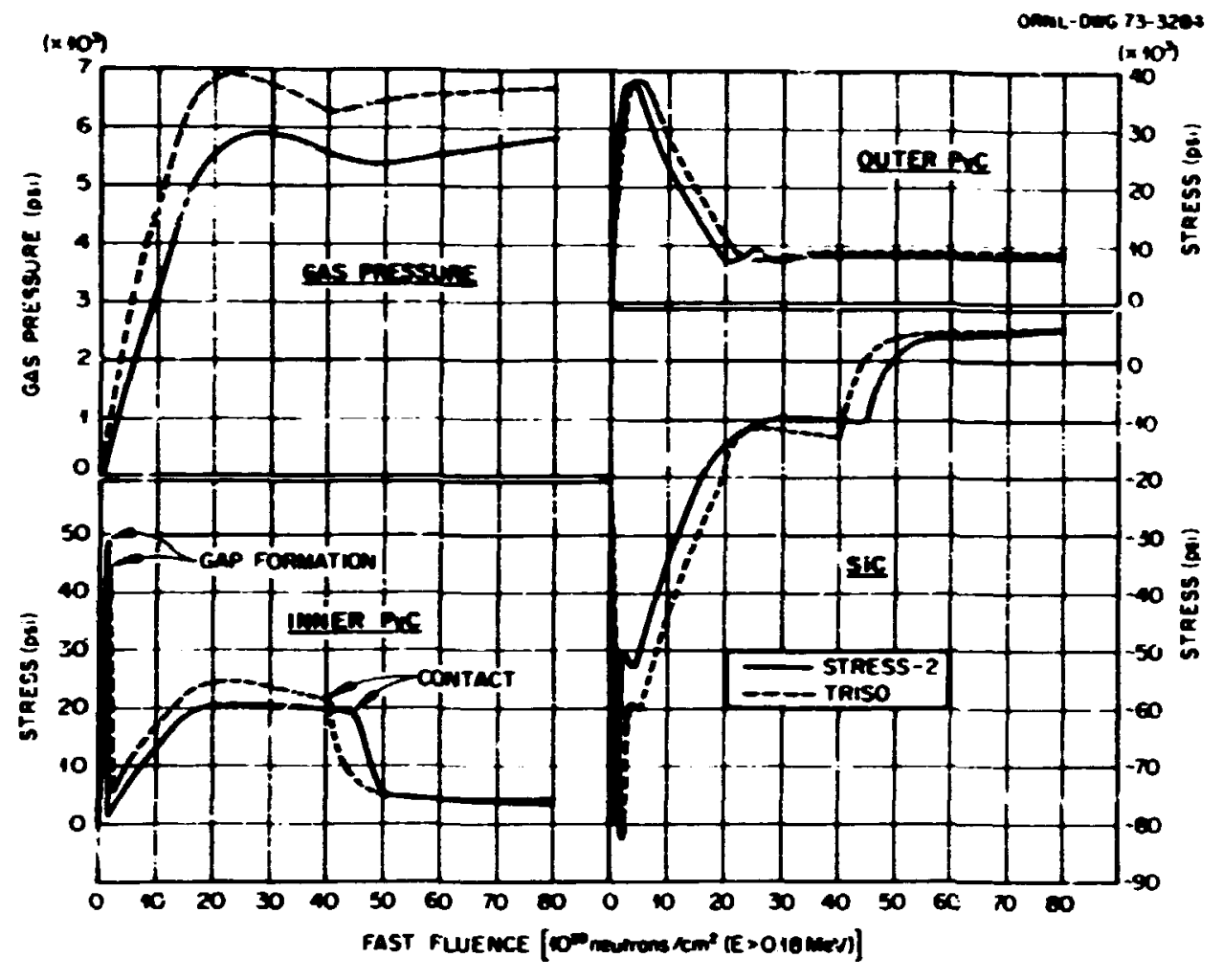

Fiz 17.19. Comparisen of STRRFSS-2 and TRISO performance codes.

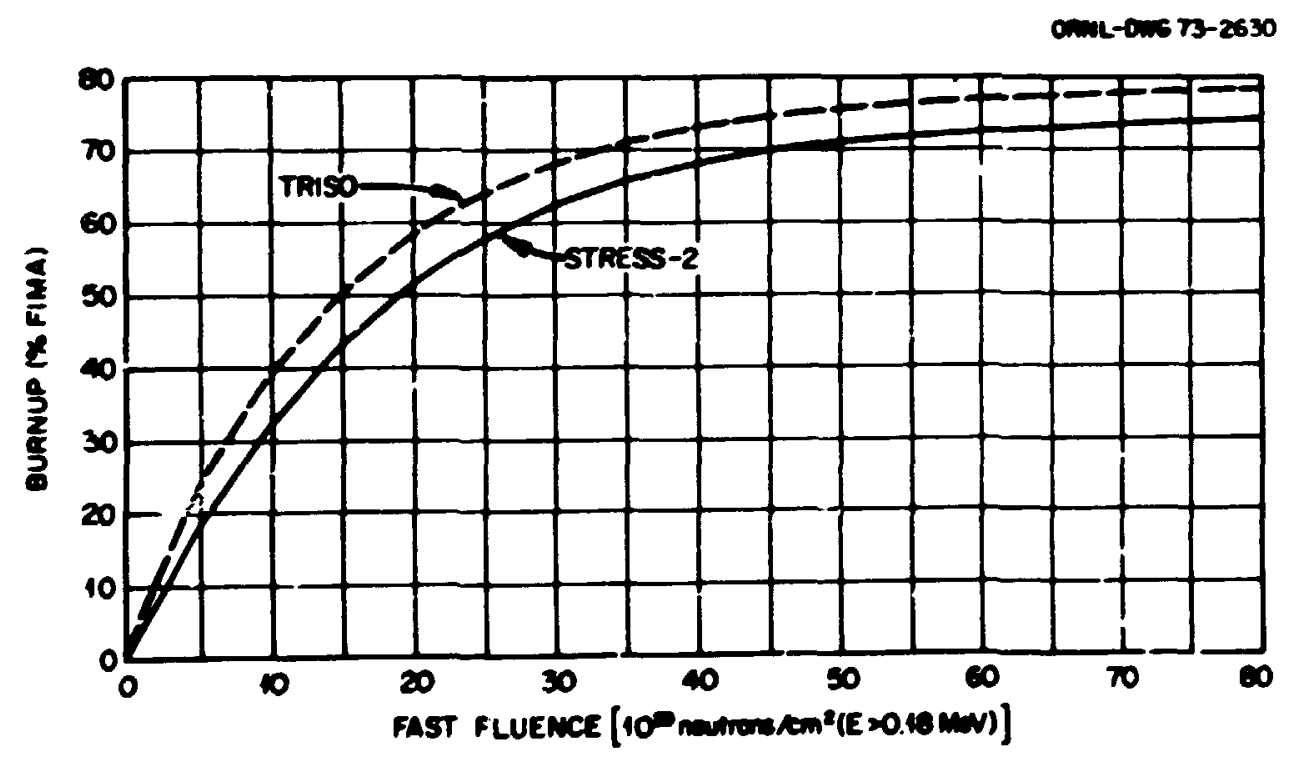

Fiz 17.20. Rumup curves used for TRUSO-STRESS-2 comparison. 


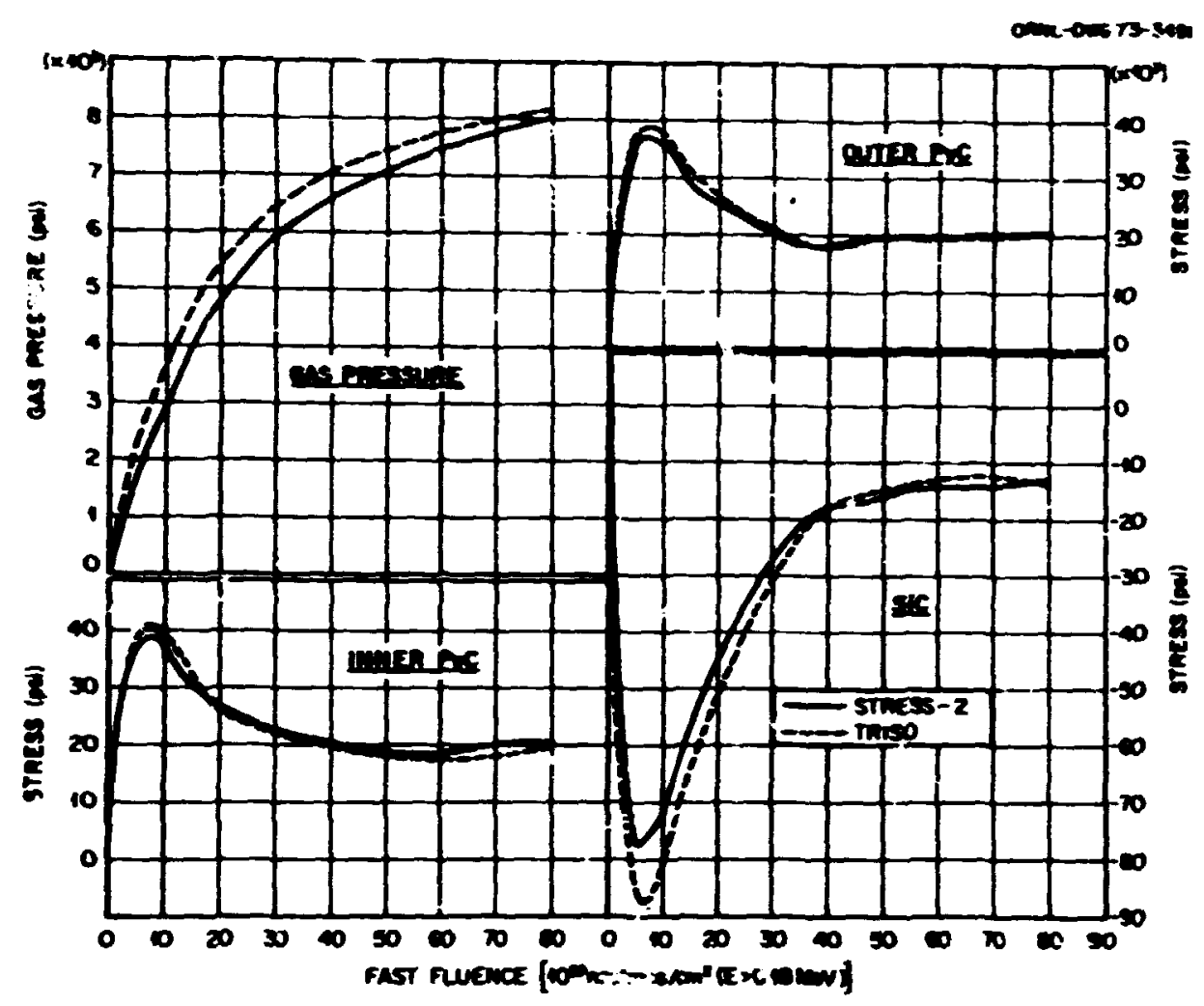

Fy 17.21. TRuSO-STRESS-2 comprivon for GGA paricke.

theoretical density respectively. The deposition teinperatures of the buffer and the LTI were 1470 and is i $5^{\circ} \mathrm{C}$. respectively, and the irradiation empresuri was assumed to be $1300^{\circ} \mathrm{C}$. Because STRESS-2 reouired the relationship between burnup and fluence as inpul. such a curve was computed with STRETCH and used in STRES:-2. This curve is shown in Fig. 17.22.

Calculations of iission gas pressure and LTI tangential stressts as functions of fast fluence are shown in Fig17.23 for both codes. Notice there is littie difference in the two curve: at the left of the figure below a fluence of about $60 \times 10^{20}$ neutrons $/ \mathrm{cm}^{2}$. At that point, the pressure calculated by STRESS-2 hegins io fatten cumpared with the pressuri calculated by STRETCH. The reason for this can be demonstrated by axamining the curves at the right of the figure, which show the tangential stresses calculated in the PyC. STRETCH consider: the buffer layer to be very weak and incapable of supporting loads either in tension or compression. Therefore, no loads are iransmitted from the buffer to the PyC during any phase of the

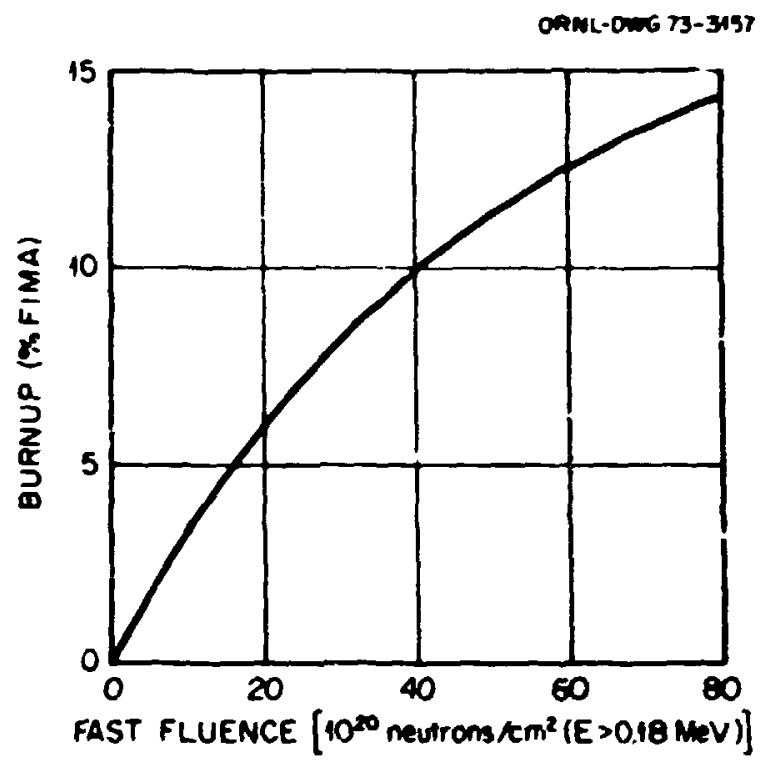

Py 17.22 Bumpor feence for STRFSS-2 w TRISO commarion. 


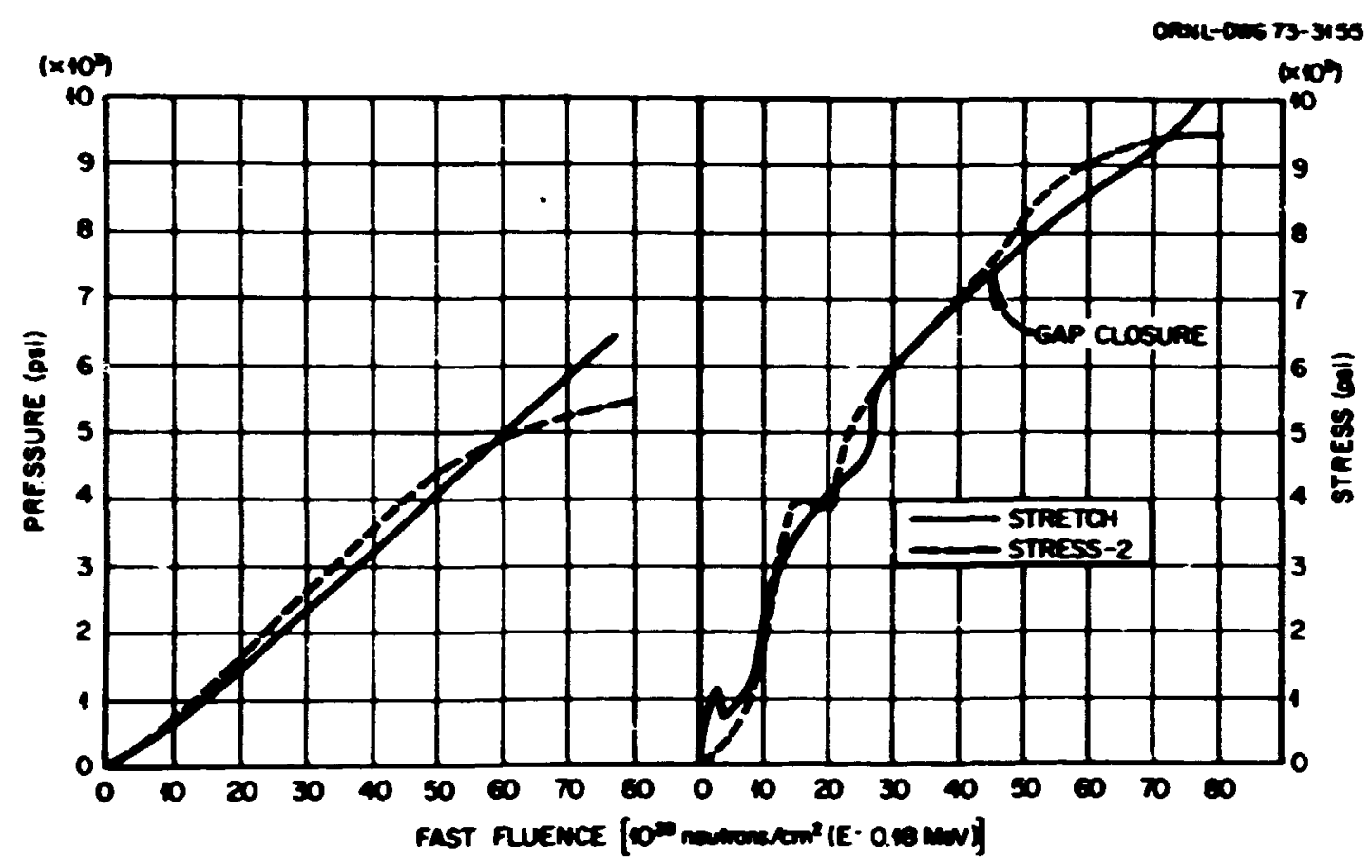

Fif 17.23. Comparion of STRETCH ard STRESS-2 codes.

irradiation history. On the other hand. the buffer properties in STRESS-2 are described in detail in the input.

In the case being studied. the input densitication characteristics of the two layers are as shown in Fig. 17.24. The buifer layer densifies very rapidly at first. but by $40 \times 10^{20}$ iast fluence the densification rate has decreased to zero. The PyC densifies more slowly at first, but continues to det sily throughout the entire irradiation history. At about $45 \times 10^{20}$ fast fluence the gap berween the buffer and $P y C$ closes (the zap furmed very early in life because of the difference in coating temperatures), and the stresses in the PyC layer increases slightly due to the continued densification and shrinkage down upon the buffer. The presence of the buffer prevents the PyC from shrinking as much as it would if there were no restraint, and this provides more space for the fission gas: this explains the observation noted earlier from :he left portion of Fig. 17.23.

\section{Conclusion}

The differences noted in predicted performance of

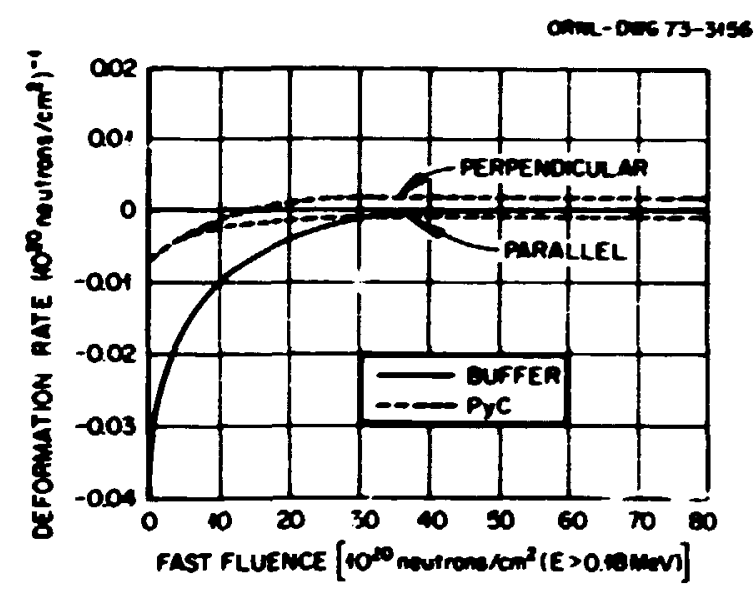

Fie 17.24. Dencification nates of bufier and ryc byes

the two codes are minor, and we have concluded that STRESS- 2 and STRETCH are mathematically equivalent. 


\subsection{SENSITVITY OF HTGR FUEL PERFORMANCE TO MATERLLL TROTERTIES AND PARTICLE DESIGN}

\author{
F. J. Human
}

\subsection{1 bntrodection}

The three coated particle performance models and their assariated computer programs as currently used at ORAil and GGA were shown to give equivalent results ior identical cases. The STRESS-? code was selected as the must potentially i:seful because of its thexibility and mathematival suph:itication. We then investigated the sensitivity of STRESS:- performance predictions to materials properties and particle design for a Tnse iusi.

The materials properive: for the kemel and eah coating required as input to STRESS-2 are listed below. Fach property an be represented as a funition of fli ence. anc properties must be supplied for planes b.th paralke and perpendicular to the plane of coating de pusition. The properties are:

1. clastik modulus

2. Poissunis ratio.

3. irradiation creep coefficitent.

4. thermal teep cueftivient.

5. Irradiation-induced densitication rate.

6. thermal expansion cuefficient.

7. temperature-independent expansion Itime-depend ent effects).

Thermal creen (item 4 ) is assumed 10 be at zero at the irradiation temperatures of interest for HTCR fuel. Temperature-dependent expansion (item 7 ) is not well understoud and is usualy set to zero in the input. These two properties will not be included in the sensitivity analysis.

Particke design characteristios required as input in STRESS? al. listed as fiolluws:

1. bumup-tluence relationship.

2. kernel diameter.

3. coating thicknesses.

4. iractional density of kernel and each coating.

5. temperature al which coat'ngs are deposited.

b. mukcular weight of fuel kemel.

7. number of fissile plus fertile atonis pes fuel molecule.

8. theoretical density of fuel kernel.

". irradiation temperalure.

10. fission gas release fraction.

\subsubsection{Sensitivity of Predicted Performence to Materiols Properties}

The sensitivity of predicted performance to materials properties and design parameters was determired by establishing a base case. varying the properties and parameters one at a time. and recurding the deviation of predicted performance from the base case. Properties and design parameters for the base case are shown in Table 17.1. This is basially the same particle described earlier by Gulden et al. ${ }^{27}$ i: should he recalls:d that properties in planes buth paraliel anc nerpendicular to the cuating deposioion rlane are rsquired. For thi: study it was assumer if that all coatinits vere isc:ropic at ine Amorning of the irradiation. so that numerical values would be equal in beth flanes. It has been established that the coatings become morc anisotropic with increased irradiation; this is due. in part. to the irradiation-induced deformation. This aspect of performance ian be modeled with STRESS-2 by usinz luence-dependent properties. However. for this study it was assumed that the properties remained constant throughout the irradiation. Irradiation-induced dimensiunal thanges for the butifer and PyC are not given in Table 17.1. The behavios assumed for both the inner and outer PyC cuatings is shown in Fig 17.25. To iompute stresses in the coating. STRESS-2 requires the rate of dimensiunal change at any puint in time. which is computed from the raw daia. such as shown in Fiz 17.25. The dimensional change rates for both buffer and $P C$ coatings used in this study were shown in Fig. 17.24.

Kernel and coating property dala have been increased and decreased by fact,rs of 2 and 10 from the base case values (excepi for Possun's ratio. which has been varied by inly a factor of 2). Kisulis for the kernel. buffer. PyC. and SK coalings are given in Tables 17.2 through 17.5 respectively. Basically. there categories of informalion are contained in these tables: the peak stresses in the PyC and SR coatings. the relatn c deviation of these siresses from base iase vajues. and t.re fluence at whih the peak stresses incurred. The sensitivily of a given property ian be lound quickly by looking a! the portion of the tables where the relative deviations are labulated. Mo sensitivity for a given property would be indivated by a value of unity under "relative deviation irom base case." Greater sensitivity is indicated" greater deviation irom unity.

From Tables 17.2 through 17.5. it is dear that predicted performance is insensitive to properties input fir the kernel and but er and tiat the irradiation. induced creep constants are the most important 


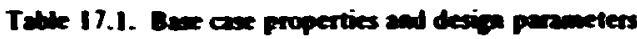

\begin{tabular}{|c|c|c|c|c|c|}
\hline & Kernel & Buifet & Inner Pyc & SiC & Outer Pre \\
\hline \multicolumn{6}{|c|}{ Propertics } \\
\hline 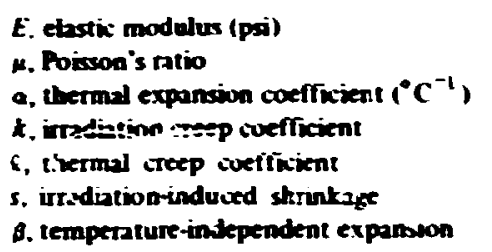 & $\begin{array}{l}2.8 \times 10^{7} \\
0.30 ? \\
8.2 \times 10^{-6} \\
0 \\
0 \\
0 \\
0\end{array}$ & $\begin{array}{l}1 \times 10^{5} \\
0.300 \\
5 \times 10^{-6} \\
1 \times 10^{-29} \\
0 \\
\text { See text } \\
0\end{array}$ & $\begin{array}{l}4 \times 10^{6} \\
0.25 \\
5.4 \times 10^{-6} \\
1 \times 10^{-27} \\
0 \\
\text { See 1ext } \\
0\end{array}$ & $\begin{array}{l}6 \times 10^{7} \\
0.18 \\
5.5 \times 10^{-0} \\
0 \\
0 \\
0 \\
0\end{array}$ & $\begin{array}{l}4 \times 10^{6} \\
0.25 \\
5.4 \times 10^{-6} \\
1 \times 10^{-27} \\
0 \\
\text { See rexi } \\
0\end{array}$ \\
\hline \multicolumn{6}{|c|}{ Dexien parameters } \\
\hline 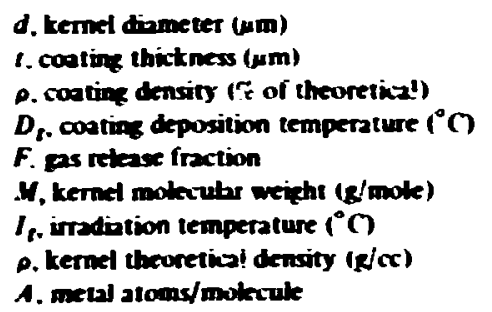 & $\begin{array}{l}200 \\
9= \\
1.0 \\
259 \\
1050 \\
11.68 \\
1.0\end{array}$ & $\begin{array}{l}85 \\
52.3 \\
1250\end{array}$ & $\begin{array}{l}25 \\
86.6 \\
1250\end{array}$ & $\begin{array}{l}25 \\
99 \\
1650\end{array}$ & $\begin{array}{l}35 \\
82 \\
1250\end{array}$ \\
\hline
\end{tabular}

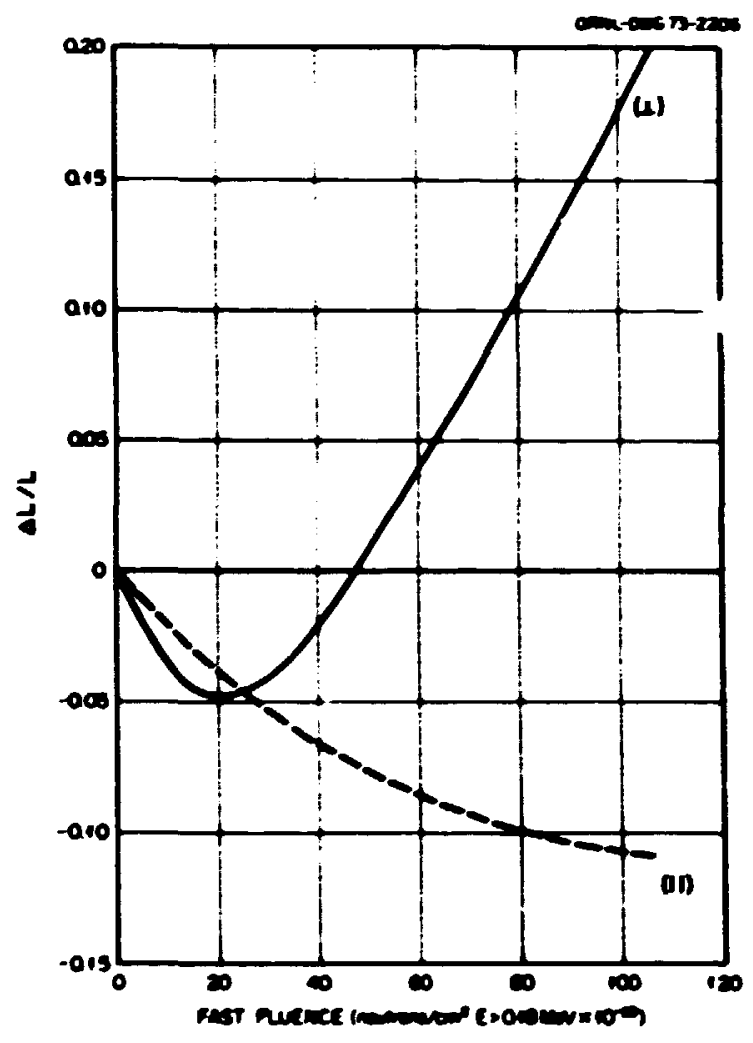

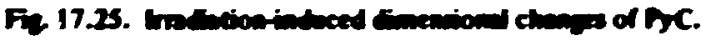




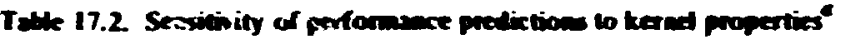

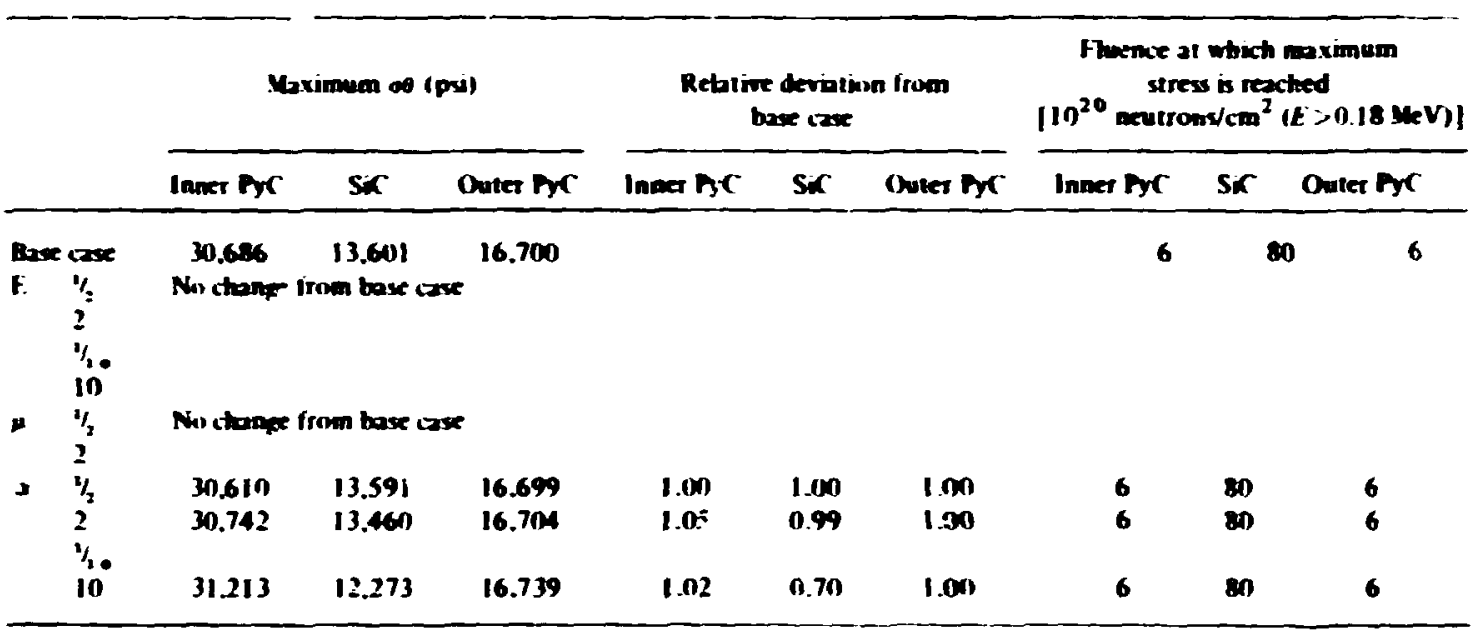

CDexignalium of porameter shown in Table 17.1.

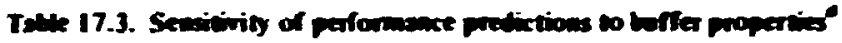

\begin{tabular}{|c|c|c|c|c|c|c|c|c|c|}
\hline & \multicolumn{3}{|c|}{ 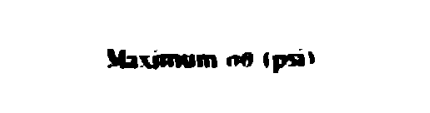 } & \multicolumn{3}{|c|}{$\begin{array}{l}\text { Retivive devioliun from } \\
\text { bove cose }\end{array}$} & \multicolumn{3}{|c|}{ 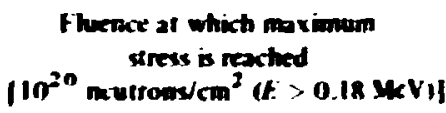 } \\
\hline & Innex Pre & Sir & Oulet PyC & Inder PyC & sir & Ooter Pro & Inanet PyC & Sir & Oneer AC \\
\hline Base case & 30606 & 13.601 & $16.7 \mathrm{mo}$ & & & & 6 & 80 & 6 \\
\hline & 30.6n1 & 13,611 & $16.7 \mathrm{mD}$ & 1.00 & 1.00 & 1.00 & 6 & $n$ & 6 \\
\hline & 30696 & 13.580 & $16.70 \mid$ & 1.00 & $1 . \mathrm{mp}$ & ISC & 6 & $m$ & 6 \\
\hline & 30.675 & 13.620 & 16.699 & 1.00 & I. In & 1.00 & 6 & 80 & 6 \\
\hline & 30.732 & 13.444 & 16.703 & I.MO & 0.99 & 1.00 & 6 & $8 n$ & 6 \\
\hline \multirow[t]{2}{*}{$\mu$} & 30.687 & 13.59 & $16.7 \mathrm{mo}$ & $1.0 n$ & 1.00 & 1.00 & 6 & $8 n$ & 6 \\
\hline & 29.432 & 20.164 & 16.714 & 0.06 & 1.48 & $\operatorname{lm}$ & 6 & 80 & 6 \\
\hline \multirow[t]{4}{*}{ a } & 3).616 & 13.601 & $16.7 \mathrm{~m}$ & $1 . \mathrm{m}$ & 1.90 & 1.00 & 6 & 80 & 6 \\
\hline & 3). 646 & 13.601 & 16.700 & 1.00 & $\ln (\mathrm{n})$ & 1.00 & 6 & $m$ & 6 \\
\hline & 3n.686 & $\mid 3.601$ & 16.700 & $\therefore$ ini & $\operatorname{lm}$ & 1.00 & 6 & 80 & $\alpha$ \\
\hline & 31.725 & 12.728 & 16.700 & I. $\boldsymbol{x}_{\mathrm{W}}$ & $n .94$ & 1.00 & 6 & 80 & 6 \\
\hline \multirow[t]{4}{*}{$k$} & 30.636 & 13.603 & $16.7 \mathrm{mn}$ & $\ln$ & $\operatorname{lm}$ & 1.00 & 6 & 80 & 6 \\
\hline & 30.686 & 13.603 & $16.7 \mathrm{~mm}$ & $1.0 n$ & 1.00 & 1.00 & 6 & 80 & 6 \\
\hline & $3 n .686$ & 13.601 & $16.7 \mathrm{~m}$ & 1.00 & I.m & 1.00 & 6 & 80 & 6 \\
\hline & $30.6 \times 6$ & 13.601 & $16.7 \mathrm{~mm}$ & 1.00 & $\mathrm{Im}$ & 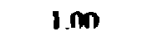 & 6 & 30 & 6 \\
\hline
\end{tabular}

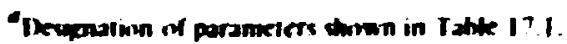




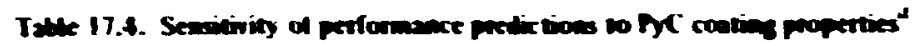

\begin{tabular}{|c|c|c|c|c|c|c|c|c|c|}
\hline & \multicolumn{3}{|c|}{ Mevimum on (pw) } & \multicolumn{3}{|c|}{$\begin{array}{c}\text { Rebive deristinns from } \\
\text { bue cose }\end{array}$} & \multicolumn{3}{|c|}{ 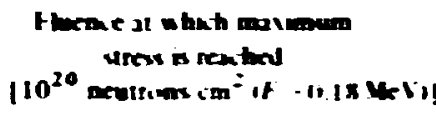 } \\
\hline & Inonet Ar. & sis & mare $\mathrm{nc}$ & Inner Pye & Sx & Omier Pr & Iner Pro & Sid & Inter Py \\
\hline Buer axe & 30.686 & 13.601 & $16.7 \mathrm{mb}$ & & & & 6 & $m$ & 6 \\
\hline \multirow[t]{4}{*}{ E $\because$} & $26.61 x$ & 12.8111 & 15.257 & 0.87 & 0.94 & 0.91 & 19 & $8 n$ & 10 \\
\hline & 33.711 & $1+.179$ & 17.674 & 1.10 & I. O4 & 1.06 & + & $\mathbf{n}$ & + \\
\hline & $(1.931)$ & 7.169 & $111.1 \times 9$ & 0.45 & 0.52 & 0.61 & 20 & $m$ & 25 \\
\hline & 36.622 & 14.694 & $18 \leq 47$ & 1.19 & 1.08 & 1.11 & 2 & en & 2 \\
\hline \multirow[t]{2}{*}{$\mu$} & 27.697 & 13.398 & $1651 ?$ & 11.97 & 1199 & 0.49 & 8 & 8 & 6 \\
\hline & 33.045 & $1+.025$ & $17.10 \geq 1$ & 1.188 & 1.03 & 102 & 4 & ai & + \\
\hline \multirow{2}{*}{$\begin{array}{l}i^{\circ} \\
\vdots \\
\text { lin }\end{array}$} & 29.975 & $1+.11 \geq 9$ & 16.594 & $10.9 x$ & 1.03 & 10.99 & 6 & $m$ & 6 \\
\hline & 29.692 & $1+\$ 14$ & 16594 & 10.97 & 1.06 & $n .99$ & $\mathbf{8}$ & $\mathbf{n}$ & 6 \\
\hline \multirow[t]{2}{*}{$\boldsymbol{k}$} & 16.825 & 210,33 & $\times .9 .3$ & 10.55 & 1.51 & 0.53 & + & 8 & + \\
\hline & 3.6311 & $25 . \mathrm{ken}$ & 1.910 & 0.12 & I.99i & 0.11 & 1 & 80 & : \\
\hline
\end{tabular}

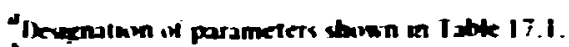

"Inne Ar layet broken duruse fabruation.

'Innet and inter Pyr byers broken dorma tibrisation

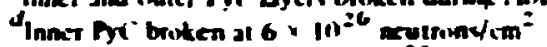

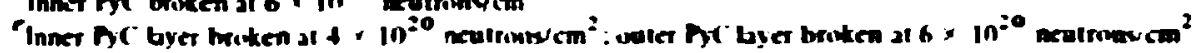

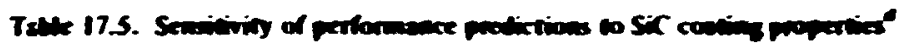

\begin{tabular}{|c|c|c|c|c|c|c|c|c|c|}
\hline & \multicolumn{3}{|c|}{ Varimang } & \multicolumn{3}{|c|}{ 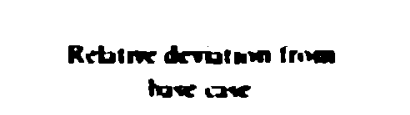 } & \multicolumn{3}{|c|}{ 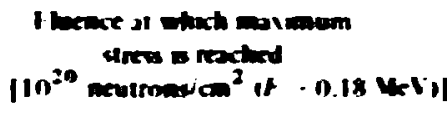 } \\
\hline & Inoxt ner & Sot & Oviet Me & $\operatorname{lnax} n$ & SA & Inet ne & Inex Por & sur & Onter Pro \\
\hline Buce ine & M.ans & I3. & $16.70 \mathrm{~m}$ & & & & 6 & $m$ & a \\
\hline 1. ': & 29.994 & 13.474 & $16+? 1$ & 0.99 & 11.99 & 109 & 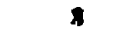 & $m$ & 6 \\
\hline 2 & 31.036 & $13.7 m$ & 16.812 & $\mathbf{I . 0 1}$ & I.nI & InI & 6 & $\mathbf{m}$ & 6 \\
\hline$\because$ & 26.550 & 11.653 & 15.056 & $n .87$ & $n .26$ & n9n & In & $\boldsymbol{m}$ & In \\
\hline in & 31.299 & 13856 & 16885 & I.nZ & 1.112 & i.nI & 6 & $m$ & a \\
\hline$':$ & M.515 & 13.575 & 16.670 & $1.0 \mathrm{n}$ & $\mathrm{Im}$ & I.n) & s & $m$ & 6 \\
\hline 2 & 30.825 & 13.653 & 16.738 & $\ln$ & I. no & $I .0 \mathrm{n}$ & s & $m$ & 6 \\
\hline$":$ & $31 \mathrm{smn}$ & 12.943 & $16 \times 13$ & 1.03 & n.95 & 1.01 & 6 & $m$ & 6 \\
\hline 2 & 29.525 & 15.943 & 16.471 & nom & 1.11 & 199 & $\pi$ & $m$ & 6 \\
\hline in" & 32.153 & $12,+22$ & 16.904 & $1.1: 5$ & 10.91 & InI & 6 & $m$ & 6 \\
\hline in: : & 11.859 & 2.311 & 18.159 & 119 & & " I M & $\therefore$ & m & sn \\
\hline in: $:$ & 111.219 & 2.4W & 13.73 & 113 & " IX & $n \times 2$ & +5 & $m$ & 45 \\
\hline $10^{-2 x}$ & .5 .404 & 12.284 & $1=544$ & 11.83 & n.m & 0.87 & h & $m$ & 6 \\
\hline $\ln ^{27}$ & jol.nas & $1+.393$ & $|6,+5|$ & $0.9 \mathrm{n}$ & $: 1 \mathrm{~m}$ & 11.99 & 6 & 75 & h \\
\hline
\end{tabular}

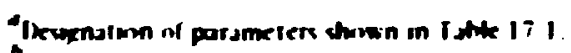

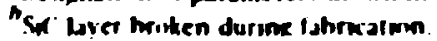


materiab properties lor the PC and Sit cuating

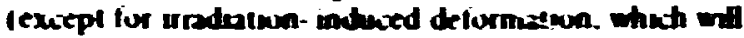

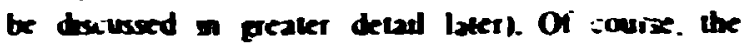
afurmatka - the tables onty tells pan of the ston. The complete cuoting stress and pas presure hisorics are plutied in Fo 17.36 for different inadiation creep cunstants in the PyC cooting. The baxe cox setuating as desiganied by a (I) next to the curve. It ian be seen from fie 17.26 that the mavanen stress in tbe SC crating vicurs at the end of the irradiation. while the maximum suress in the PyC coatings occurs quite eady.

It is relativety easy to vanj the materials properties stuma in Tables 17.2 through 17.5 around the base case values becsuse the property is described by a pair of numbers for eaci copting then fuence-related changes th the property are not considered. For irrodiationiadteced deformation. The tast is not quite so exy. Length chave vines. or deformation rate values a a

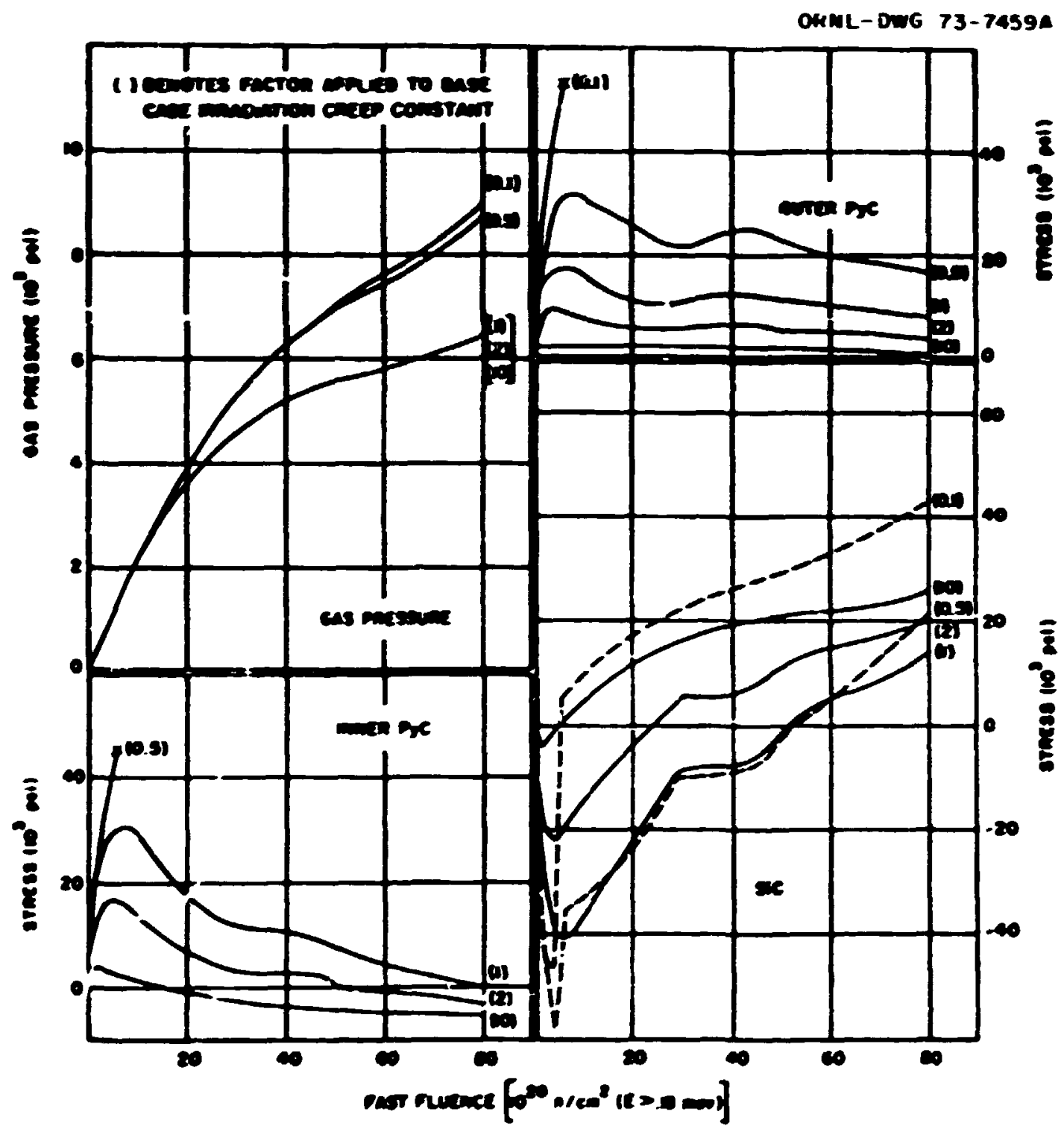

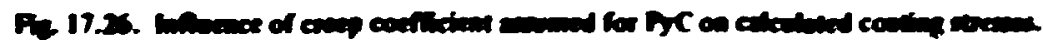


tunition of tluence. are iequired for the entire span of irradiation history of the partike. The sensitivity of the predicted periormance to this material property has been studied by using three disuinit sets of data to desiribe irradiation-induced deformation. One set of bata is shown in Fig. 1?.-5. Ind the othe: two are shown in Fig 17.18. The sensitivity of predicied perfiumance to thange; in this property is shuwn in Fiz 17.27. The variability amung the three sxis of irradiation-indued dimensional hinge data is quite small when cumpared with the variability censidered tor the wher materials properties. And. as shown in Fig. 17.27. this small amount of variability produces frerly signifieant changes in predicted periormanic.

\subsection{Divarion of Mhterints Property Sensitivity}

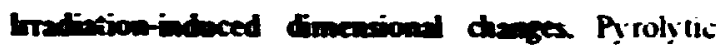

carbon chaiges dimenswns under arradation. With inatenal having preirradiation densilles of liss than 2.0 sici generally becoming mure kense arid injterials with preirradiation jensities greatei than $2 \cup$ gici beioning less iknse. ${ }^{30}$ The manner in whin inc density chanzes are listributed in direitions paralkel and perpendkular (i) the deposition plane (as shown in Fig- 17.25) us important to the performance of the cuatung under irradation. A greater rate of shrink a furrespunding to a less dense coaing) causes the outer Py (ckating io shink more rapidly upoxa the SiC coatung. generaled high compressive stresses in the $\mathrm{SK}$ and high tensile stresses in the outer PyC. The inner PyC will shnnk away from the $\mathrm{SC}$ coating and form a gap. The difierence in the rates of dimensional -2 ange in the parallel and perpendicular ditections is itseli a source

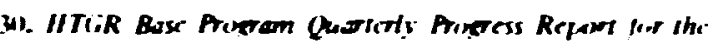

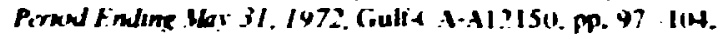

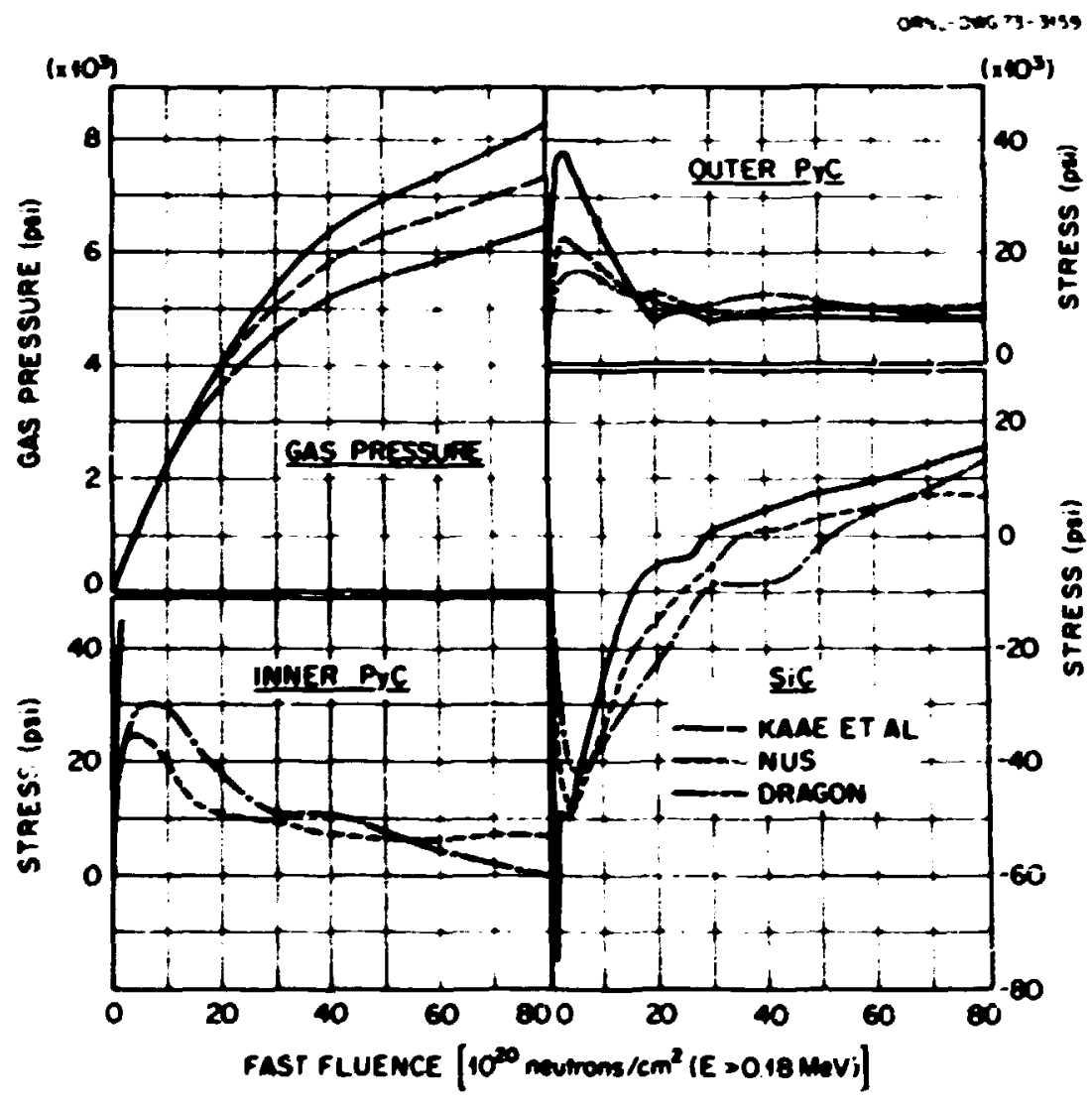

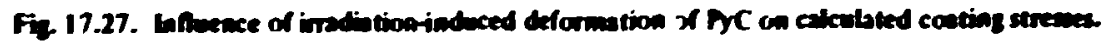


of st:ess-producing falure in the untestraned inner coacungs if the defurmation rates are sutably h:gh.

Irradiation-induced creep. Irradiation-induced ireep serves to relieve the stresses cuused by irradiationinduced deiumation. thermal sumries. and fission gas pressure. Lov ByC ereep rates lead to failure of the cootings. as shown in Fig 17.26. due to inability to relieve the i-resses. High P.C ereep rates result in substantially lower stresses in the PyC coatings due to rapid siress relaxation bu: in-reased stresses in the $\mathrm{SiC}$ ciating. which must now support the fiessure loads. due to the decreased strengths of the PyC coatings. The Sif coatings are generally thought to be dimensionally stable ard have a very low isep rale. Higher ireep rates in the SiC results in lower stresses in all layers. as shuwn in Table 17.5 .

Dermal expansion. Variation in thermal expansion coefficient values for the various coating about the base case values dues not significantly change the predicted coating stresses (Tables 17.2 through 17.5). Thermal stresses are relieved lainy quinis by ireep dering irradiation of the particte. Howeve'. during the fabrication phase of the histury. where th: cuatings are applied at dif erent temperatures an's the particle eventually brought down to rowm temperature prior to irradiation, some severe thermal stresses can develop which cannot be relieved by ireep. As shuwn in Tabic 17.4. increasing the P.C thermal expansion coefficient significantly from the base case value resulted in broken coatings during fabrication.

Ebatic modulus and Poison's natio. It is somewhat surprising that shanges in these pioperities do not influence the cuating stresses mure extensively than shown in Tabies 17.2 through 17.5. This question is resolved simewhat by Prados "observation' 9 that the stress equations for a hollow sphore reduce the classkial Lame equation (stresses Jependeni only on intemal prescure and geometry l for an isotropic materia! when creep is nor cunsidered. When ireep is considered. the dependence on elastic mudulus and Poissun's ralio is present but wisk. 20

\subsubsection{Sensitivity of Predicted Performaxe to Design Parmetes}

The base case design parameters for Triso -articles have been varied in similar fashion to the properties to determine sensitivity. The results are summarized in Table 17.6. which is similar (1) Tables 17.2 through 17.5. except that maximuin gas presaure is considered. Several observatiuns can be made from the able.

1. The relationship between the kemel and the buffer volumes appears (1) be the must significant design cunsideration. The partlike fisted cumpletely when the diameter of the kernel was duubled: when the dameter of the kernel wa halved. the gas pressure was redicced to a ven low level. Lojer stresses we'e nut gennificaritl influenced by the liw gas pressuit. Indiating ihat irraliation-induced oeformation mast acicint fur mus' of the coating stresses in this stuation. Rewicing the thickness of the : inter by a factur of I resulted in very high gas pressures an:: failure of the SCC layer.

2. Changes in the inje: frational densities io. the kemel and buffer influenced the SiC stresses. However. no influence resulted fror.l changing the inpul frational densives of the other layers. This indicates that infut densities for these layers are inuperative. and deas'ty changes must be reflected in the property librany. in partikular the irradiation-induced deformation chara: teristiks.

$\therefore$ Changes in the thikness of the P.C and SiC layers had sume impact on cumputer stresses. with ithe tmpait being greatest for the $\mathrm{SC}$ layer.

4. Thare is no signiticant influence of coating deposition iemperatures un predicted performance.

S. Kerrol motecular weight and particle irradiation temperature changes produced small performance variations. Gas release fractions strongly inlluenced fission gas pressures and siresces in the Sir coating. The shape of the burnap curve is not especially important.

\section{4 .5 Condusion}

The sensitivity analysis presented here for a Triso particle has indicated that. with the exception of the Pyr irradiation creep and deformation charareristics. the influence of materials properties on predicted performance is relatively small. In addition. of the design considerations, the relationship of kemel volum.e to buffer volume was must important. The influence of coating thickness changes wos greatest for the SiC layer.

\subsection{ANALYSES OF TRITIUM DISTRIBUTION AND RELEASE IN HTGR}

\section{E. L. Compere C.W. Vestur}

A mathematical model of the generation and distributiril of tritium in high-temperature gas-iculed reactors was previouly described by Freid. ${ }^{31}$ Th:s model was incorporated in a computer code. TRiT6O. which

31. S. II. Fred. "Tritium in UTr,R." in OR,V . Vuclegr

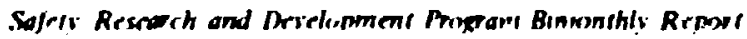

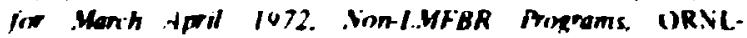
TM-3831. pr. 72 73: OR.VI Nucleo Sofely Rescer.h and Drvelopment Propem Bimonthly Repor, for Mav Jine 1472, Vim-I.MFBR Phereams. ORNL.TM-3906 po. 76 -?9. 


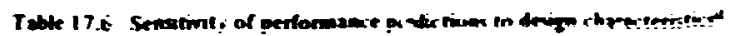

\begin{tabular}{|c|c|c|c|c|c|c|c|c|c|c|}
\hline & \multicolumn{3}{|c|}{ Usimem so ' } & \multicolumn{3}{|c|}{$\begin{array}{l}\text { Relatior devistopr Ifom } \\
\text { bux ids }\end{array}$} & \multicolumn{3}{|c|}{ 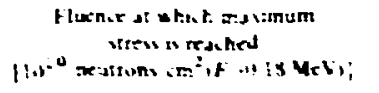 } & \multirow{2}{*}{ 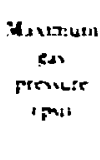 } \\
\hline & $\mathrm{Inm} \cdot \mathrm{nC}$ & $\mathbf{s x}$ & Ous: $n \mathbf{c}^{*}$ & Inner Pio & $5 x$ & Outer Pre & 'nerr Pi & $\sin$ & Wester Pro & \\
\hline $\begin{array}{l}\text { Jave iste } \\
\text { Lerne! }\end{array}$ & Sundo & 13.611 & 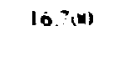 & & & & 0 & su & - & $6+5$ \\
\hline :d & - & & & & & & & & & 32.214 \\
\hline$:=4$ & $256: 0$ & 8.04 & 15.344 & 116 & & (i) 45 & $\mathbf{s}$ & si & 6 & $13 i$ \\
\hline$\therefore+5$ & $30 \therefore: 9$ & 16.5:? & $10.0 \%$ & 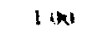 & $: 21$ & $(1(n)$ & - & 50 & 0 & 2.131 \\
\hline$\Delta \quad \leq$ & 30.33 & 11.003 & 16.645 & $\ln (N)$ & ist & $1 \mathrm{col}$ & 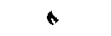 & kal & 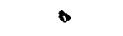 & 5.956 \\
\hline \multicolumn{11}{|l|}{ Butter } \\
\hline$\therefore$ & 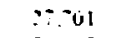 & $4: 32$ & $1: \leq \leq 1$ & 140 & & 1,15 & $\omega$ & sil & $\therefore$ & i. 145 \\
\hline$z^{\tau}$ & $3: .00^{\circ}$ & Bromen & $+50 y$ & $10=$ & & $2+3$ & 6 & 55 & $s$ & si.sst \\
\hline $2+5=$ & $45 \varphi^{\circ}$ & is.413 & $16.71 \%$ & $!(n)$ & $1: 5$ & $(\min$ & $n$ & su & 6 & 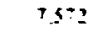 \\
\hline s $s=$ & $30.2 \leq 5$ & 10.104 & $16.0+2$ & $1: x$ & 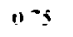 & $\vdots(\mathbf{w})$ & b & n11 & 6 & 5.6210 \\
\hline$D_{t}+\operatorname{lin} x \mathrm{C}$ & 30.67 & 1355 & $106 \times 4$ & $! 141$ & $I(n)$ & $1 \mathrm{~cm}$ & $\bullet$ & 311 & 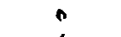 & 0.41 \\
\hline$D_{\text {Inter PaC }} \operatorname{low}^{2} \mathrm{C}$ & 30.035 & $13 . .54$ & 10.700 & $l(n)$ & $1(m)$ & $1(n)$ & 6 & 31 & s & $0 .+05$ \\
\hline$\therefore$ & 2511345 & $53 x$ & $1 ? .15$ & 13: & & $i: 16$ & 4 & sil & $:$ & 6.(1): \\
\hline$\because ?$ & :3 w1: & is.50: & in $A+2$ & 132 & 113 & $1(n)$ & $\mathbf{s}$ & $\therefore 1$ & 0 & 6.9w1 \\
\hline$\therefore 5$ & 30.686 & $\therefore \therefore 001$ & 10.700 & ! 14! & I & $(n)$ & $\epsilon$ & si) & $\bullet$ & $5+52$ \\
\hline $5:$ & 30.686 & $\{3.046\}$ & 10. $7 \mathrm{ml}$ & ||$M \mid$ & 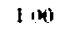 & I (m) & 0 & $w$ & 6 & 0.452 \\
\hline$n_{1}+1 \ln x+c$ & 30.000 & $13.75 k$ & !o $4 k$ & $\mid(k)$ & inl & $i(m)$ & $b$ & $\therefore$ & 6 & $1+40$ \\
\hline$\underset{5 x}{D} \quad 10 x=$ & H.0.4 & $13.45:$ & 10.643 & $\therefore(n)$ & 1194 & 1100 & 0 & 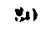 & $c$ & $0 .+17$ \\
\hline$\therefore !$ & 31004 & 6.758 & $171: 0$ & 101 & $(15)$ & $i \cdot j$ & 6 & sn & 6 & $0.46:$ \\
\hline ": & 30 !ny & $2 \div 521$ & $10.24 j$ & 93 & $2::$ & $n+?$ & $\therefore$ & (1) & 0 & 0.613 \\
\hline$\dot{5} 5$ & 30.696 & $13.60 \mathrm{i}$ & $: 0.00$ & $\therefore M$ & 14 & $10(x)$ & 6 & $M 1$ & $n$ & $6 .+52$ \\
\hline$D_{t}+100 \mathrm{C}$ & 30.684 & $13.60)$ & 16.?0) & $l(n)$ & I (m) & $1(n)$ & 6 & sin & $n$ & $6 .+52$ \\
\hline $\begin{array}{c}D_{1} \quad 100^{\prime} \mathrm{C} \\
\text { Oute: } \mathrm{P}_{3} \mathrm{C}\end{array}$ & 30.698 & (3.00: & 16.700 & 100 & I & $I(w)$ & 6 & wi & 6 & 0.451 \\
\hline It & 30.503 & 2.481 & $1+3: 1$ & 049 & $0 ! 3$ & 010 & 4 & 80 & h & $0+663$ \\
\hline$" B$ & $30=33$ & 18.715 & $15.5 \mathrm{do}$ & in & 139 & 111 & 6 & 3 & $n$ & 6.445 \\
\hline $0 \cdot 57$ & 30.656 & In: & 16.70. & 100 & $I 00$ & In & 6 & м) & $\cdot$ & 6.45 \\
\hline - Sir & 30.686 & 13011 & 16.790 & 100 & 110 & $\operatorname{lin}$ & $\therefore$ & $s_{11}$ & & A.t52 \\
\hline$D_{i} \cdot 10 \mathrm{j} \times \mathrm{C}$ & yo. nos & $1 ; 000$ & 10.649 & $(m)$ & $5 m$ & $10 \times 3$ & 0 & Wi: & $A$ & $6.65:$ \\
\hline $\mathrm{M}^{\mathrm{D}} \quad \leq 000 \mathrm{C}$ & $30.68:$ & $1 ;(n) \geq$ & $10.70 \mathrm{i}$ & $i(x)$ & 110 & 100 & $\cdot$ & sio & $\wedge$ & $6+5=$ \\
\hline $26^{\circ}$ & 30.716 & 12.110 & 10.047 & $\operatorname{lin}$ & 089 & $1(x)$ & $*$ & 310 & n & 6.109 \\
\hline $7 \$ 9$ & $30 \times 55$ & 15.157 & 16.714 & {$[1 ; 0$} & $i 11$ & $j(m)$ & $\wedge$ & so & A & 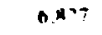 \\
\hline It & & & & & & & & & & \\
\hline $1150^{\circ} \mathrm{C}$ & 30.638 & 15628 & 16.7137 & $i m$ & 115 & 1,10 & $A$ & 80 & $n$ & $0.43:$ \\
\hline $950^{\circ} \mathrm{C}$ & 310.735 & 11ssi & 16.6 .93 & 100 & 985 & $\ln (m)$ & 6 & 80 & 6 & 5.961 \\
\hline 1.05 & 31.056 & $\geq 96$ & 16.060 & $|10|$ & & $\operatorname{lin}$ & 6 & in & $b$ & $3: 126$ \\
\hline F. 2.0 & 29.938 & 45.661 & 16.733 & 0.98 & $3 i n$ & 160 & $t$ & 80 & $b$ & 14.1025 \\
\hline Linces blimup & 11220 & 13.370 & 16.640 & $: 1,2$ & 1198 & $\operatorname{lon}$ & 6 & 80 & $n$ & A.ti: \\
\hline A. 2 & 29.822 & 96.627 & 16.813 & 097 & 710 & 101 & 6 & 80 & 6 & 23.201 \\
\hline
\end{tabular}

'Desqgat'on nf prupety or parameter showin in Table 171

Prallite ai $25 \times 10^{20}$ neutrons'sm?

coup formed

calcuiated the amounts of tritium in arious regions resulting from the various sources. Th s code was used as a starting point in the anjiysis of tritium distribution and relesse in IITGRs for the Birectorate of Licensing. Rerists fiom this analysis were documented in a upical sport ${ }^{32}$ which also described the cocie and dieussed possible exlension and refinement of tite calcuational model. An abstrait of the report is given below.

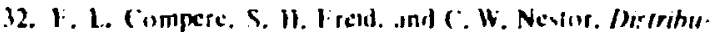

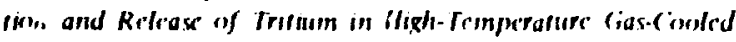

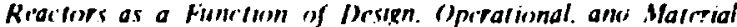
Paromerers, ORNI-TM.4.3113 (Junt 1974).
Abstraci

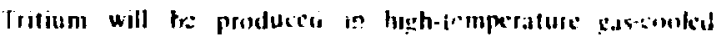

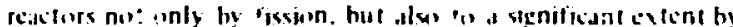
reveluons of neutrons with boron in surnable pouson and

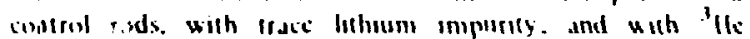

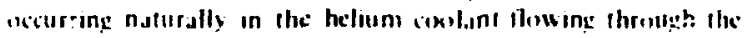

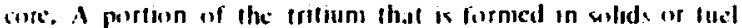
bay to releaded to the cooldant. Thes tritium mingle; whth the

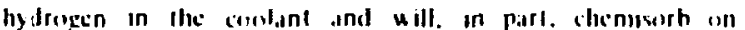

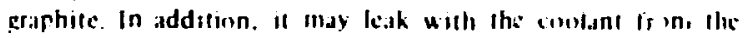

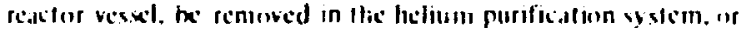

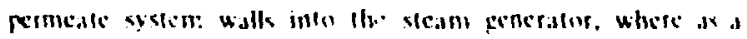

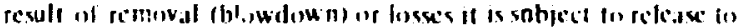
ibe environnient. 


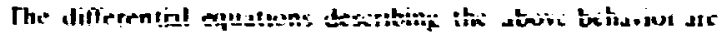
diveloned. Acsumptin $n$ of steady condtrions, including hydropen concerieration. for a period makes a pussible fo express the cistribu'ion as well as the production in the form of coupled $x: s$ vi linear first-under urdiniry difierential equarions. A generalized andytical solution of these is presented.

Inc abuve tritium generstiun and distribution mudel has bren incurpurated in a computes caxle. TRITGO. An illusstative calcution using parameters taken from the PSAR desctiption of the Fort St, Vain Reattir has been made. This indjeates that nos! of the tritium emerging from the primary coolant will kave teen generated by the ${ }^{3}$ hetn.p)T reation. A siznificant irscivon enters the steam generatur. The tritium in the steam anerater blowduwn, af ter proper dilution. may be cunsidered for reke:se to the envirunment. The cifects of varying a number uf system purme“ets are cunsidered. 


\title{
Part IV. Gas-Cooled Fast Reactor Program
}

\section{GCFR Irradiation Experiments}

\author{
A. W. Longest J. A. Cunlin
}

A series of fuel-rod irradiation tests have been conducted at ORNL in support of fuel develupment for th: Gas-Cooled Fast Br:eder Reactur (GCFR). The GCFR is being developed at General Atomic Company (GAC) with support from the U.S. Atomic Energy Commission (USAEC) and a zumber of electric utility iompanies. The fuels-irradiation progran for the GC:-R consists of buth thermal-and fast-flux testing in capsule ar.i loup experiments. Thermal-flux tests are treing perfurmed at OPNi in a series of capsule tests in the Oak Ridge Research Reaclur (ORK) p(r)lside facility. These tests, supported by the ISAEC, represent the combined efforts of CAC. ORNL, and Argonne Vitional Laboratory (ANL).

Two fiel-rod concepts for the GCFR have been investigated in the ORNL thermal-flux tests: a sealed fuel rod and a rented-and-pressure-equalices fuel rind. Earlier tests of 20 fuel rods of the sealed type (URR capsules P.I through P-X) indicated this concept to be a feasible bakup design: however. cladding temperatures and dimensions must be carcfully specified and con. trolled to insure that cladding ovality and subsequent failure by localized iladding collapse do not ociur under the high coulunt pressure $(1250 \mathrm{psig})$ in the GCFR.

The current irradiation lest. capsule GB-10, and the precieding onc. capsule (B-). were designed to permit an intial evaluation of the overal! performance of the vented-and-pressure-equalized fuel rnd which is the reference fuel-rod design for the G(i:R. Varicus aspects of the GCFR presst:aequalieation system' are alsu being studied in these tests. Posiirraciation examination of the GB-9 fuel rind, which was irradiated at 14.8 $\mathrm{kW}$ it peak pouer to a fuel burnup of spproximately 54,000 MWd metric ton of heary metal. continued at ANL and GAC into calendar ear 1973. The GB-4) experiment provided subs:antial infermation ${ }^{2-4}$ on the

I. R. J. Campana, "Pressure Fqualization System for GasCuoled Fast Breeder Reactor Fuel Elements." Vucl. Trcines. 12. 185 : Ontuber 1971).

2. A. W. L.inges! et al.. "Irradiation of GCl:R-ORR Capsule Gi-9." (iCR-TL Prongams Annu. Prog. ReD. Sept. 3i). 1971 ORNL-4760. pp. 14963.

3. A. W. Lonzest et al., "Irradiation of CiClR-ORR Capsule

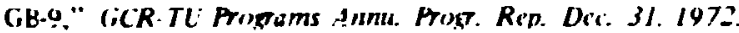
ORNL-4911. pp. 21315.

4. A. W. Longest et al., "Fission-Gis: Relcas- Measurements frum Fast Biceder (L,PuM, Fuel." Trans. A mer. Nucl. Soc 13. $604(1970)$.

5. A. W. Lungest, R. B. Fitts. and J. A. Conlin, "Fissiun Cras Release behavior in a Vented (U),Pu) $\mathrm{O}_{2}$ GClR Fuel Pin," Trans. Amer. Vuct. Sroc. 15, 197 (1972).

6. R. B. Fitts and F. L. Long. Jr., "Postirradiation Fxaminatinn of (;Cl:R-ORR Capsulc (;B-9." liCR Proprams Annu. Progr. Rep. Drc. 31. 1972. ORNL-4911.pp. 215 20.

7. S. Lunger et al.. "Vislatile lission Produ:t Migration and Platcout in GCleR Rod Irradiations." Trons. Amer. .Vuct. Soc. 15. $850(1972)$

8 R. J. Campana et al., "The f.ffect of Irradiation Results on the (;ClR Pressure Equalization Syster: (Veatting) design." Frans. Amer. Vucl. Sirc. 16, 109 (1973).

9. J. R. Lindgren et al.. Irradiation Testing in the Develop. mert of cias. Cooled last Brerter Reactor Furl filements. (iA-A1 2657 (1973). 
BLANK PAGE 
fission-provluct-reisase behavior to be expected from the GCFR vented fuil rod, and the results have been used in riany aspects of the GCFR pressureequalization system design. The GB-10 fuel rod. similar tw (GB- $\rightarrow$ but designed with even grater ipability for irreasuring fission product rele operated in three suciessive peak power steps: 12.13 .5 . and $14.8 \mathrm{~kW}$ it. Capsule GB-10 is unique in ihat it is providing. for the ilist tire direct measurements of the relsede an transport of lission products from tive mixcd-uxide fuel pelkets of an epe. ting iast breeder riscitor tuel rod.

\subsection{DESCRIPTION OF GCFR-ORR CAPSULE GB-10}

Thermal-flux irradiation ispsule GB-i0. which contains a IU.Pu O $\mathrm{O}_{2}$-iueled stainless-steel-zlad vented rod with a charival trap. has uperated suciessiully in the ORR poolside facility to a fuel butnup of $\mathbf{3 5 . 0 0 0}$ MWd metric ton of heavy metal: it is scheduled for a 2\%-year irradiation (o) a burnup of approximatel: 75.1000 MWd metric lon. The funl rod was operaled initialiy at a peak power level of $12 \mathrm{~kW}$ it $\left(565^{\circ} \mathrm{C}\right.$ peak :ladding OD (eniperature) to $a$ burnup of approximateiy 27.000 MWd metric ton and is currently operating at an intermediate power level of $1.3 .5 \mathrm{~kW} / \mathrm{ft}$ (6.30\% $\mathrm{C}$ peak cladding OD temperature). Following the completion of the $13.5-\mathrm{kW} / \mathrm{ft}$ operation. the power will be increased to ! $4.8 \mathrm{~kW} / \mathrm{fl} 16 \times 5^{\circ} \mathrm{C}$ peak sladding OD temperat ure ) for the remander of the irradiation. Other op rating conditions include $a 300^{\circ} \mathrm{C}$ cod irap temperature and cladding internal and external pressures of 1200 and 975 psig respectively. The test conditions are typical of those expecied fior a GCFR fuel rod except fi $r$ the absence of siginificant fast-meutron exposure.

The GE.10 fuel rind :s a shortened prototype of the GCFR rod with a ?-in.long region of 1 U.PuXO $\mathrm{O}_{2}$ solid peilet fuel. a 2-iri-lung upper hlanket region of depleted IOz. and a I-in.ling charciual trap. Sweep linc corneciings (o) the rod (Fig. IX.1) permil fission priduct release measuremerits under as many as ten different sweep thow morles. including passage is the sweep through the entire rod. winch simulates \& leak in the cladding of a GCFR fue: pin.

Mcasurement of fission produit release to date has ionsisted in contunuous monitoring of the iffuent sweep line activity and of analyarg. hy ganuna-ray spectronciry. sweep-gas samples taken on a p:riodic basis. In calendar year 1974. we plan to add to the efflisent sweep system an m-line (ielli) detefor systerl. a sampling systen lor taking large gas sample.

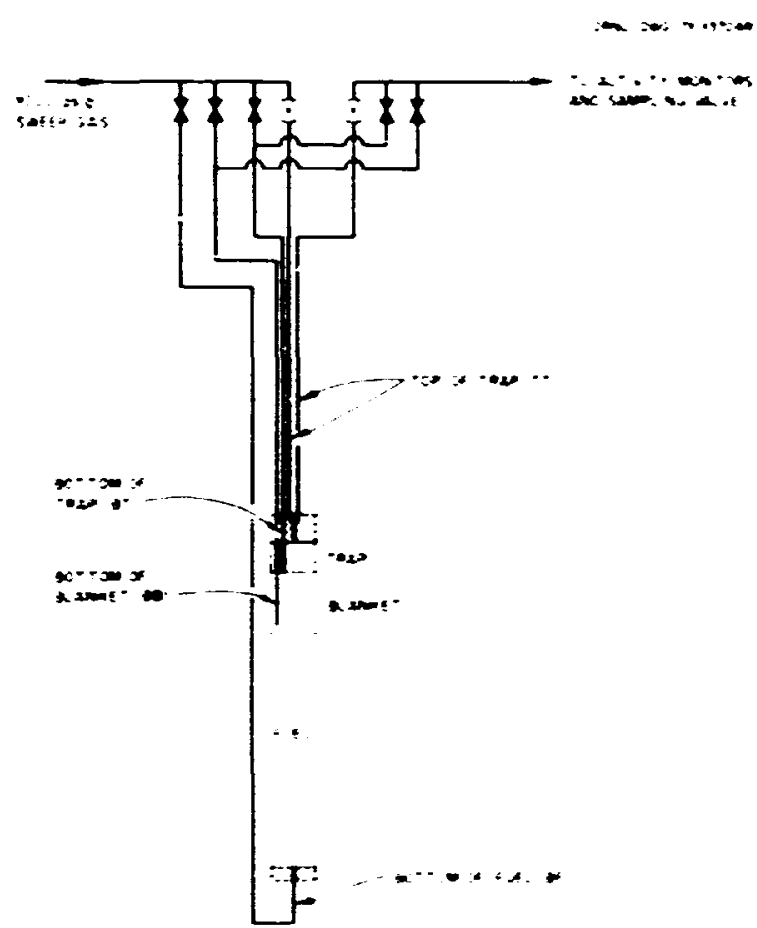

Fi. 18.1. Sweep tives for GCFR ORR capade G8.10.

for the determination of stable noble-gas relesce rates. and a system for semicontinuous monituring of tr.'ium release.

Capsule GB-10 was designed to proviste the more detailed fission product release and transport information needed for both the GCFR and the liquid-meta. corled last breeder reactor (LUFBR) development programs. A major objective of ispsule GB-10. in addition to providing information on the gaseun : 5 eron product release behavior. is to ublain additional needed informalion on the release. transpurt. and trapping of the volatile fission products.

The GB-10 capsule and fucl-rod design. planned operating cor.ditiuns. and experimental ressils ubtained early in the irradiation have been reparted in detail previously. 9 -1 I However, for the sake of completeness. sune of this information will be repealed in the following sections.

If. A. W. Lungest and J. A. Contin. "Design and Operation of CCFR-ORR CaDsule GB-10." (iCR Prowoms Annu. Pros. Rep. Dec. 3!. 1472. ORNL-4911. Pp. 22033.

11. J. R. Linderen e: al.. Planned Therma! Irratialion of

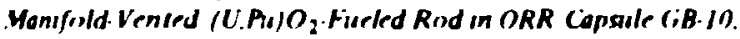
(iA-AI 2123 11973). 


\subsection{RESULTS FROM :RRADHATION TESTING OF CAPSULE GB-10}

\subsubsection{Sready-State Fission-Gas Rederse Rates vs Burmap}

Siteady-state fisslon-gas release rates have been measured as a funition: of time at power levels of II and $13 . j \mathrm{k}$ it it under all the planned sweep tlow mudes. I: pial irational release data $(R / B)$ are shown in Figs. IX.: and IX.3 fur sweep Iluw mudes TT.TT and BF-BB rsp-lively. The varuus GB-10 sweep t?.'W modes ate Wogen.tited by two ketters indicating the entrance point followed by two mure ktters indikatung the sxi: ruint fiom the ial rod. Reierning to Fig. 18.1. BF = but om of tuel. $\mathrm{TI}=$ lop of tharcoal trap. BT $=$ beitum it charcual trap. and BB = buttum oi upper blanket.

Relatively high initial fissiun-gas retease rates decreased by a factor of 10 during the first approximately 2500 MWid metrik lon barnup and then started an in-ressing trend that contunued iv approximately 6000
MWd metric iun. The release rates continued to increase. but at a very sluw rate. during the remainder of the 12kWift uperation. When the fuel-rud puwer was increased from 12 to $13.5 \mathrm{~kW}$.ft at a burnup of approximately 27.000 MWdimetric ton. the release rates imireased sharpiy. peaked. and then started a decreasing trend

During the fuel-rod power increase from 12 to 13.5 kW it. the sweep llow was directed through the fuel rod under mode BF-IT. Two gas samples were taken undzr sleady-stale cunditions pnor to the power iocrease. one was taken soun after the power increase. and two were Iaken the following day. The results of these samples. Iogether with the response of the ionization shamb.r on the high-pressure section of the effluent sweep line. desiribed the mixed-oxide-fuel release behavior during the power increase period iairly well. These release data and perunent operating conditions dunng and following the power irctease are plotced in Fig 18.4. The spikes in line ativity upon changing the flon; mode from

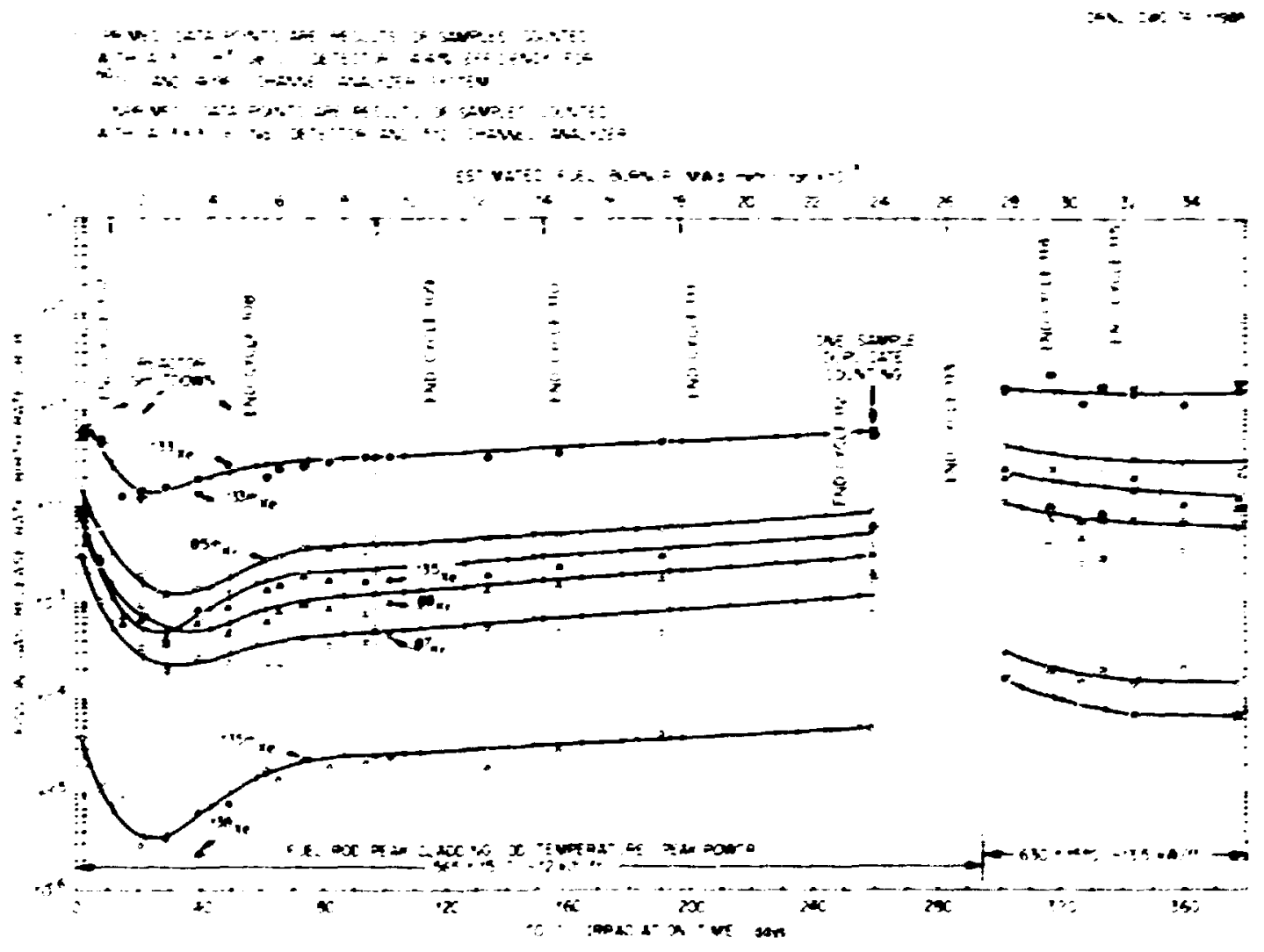

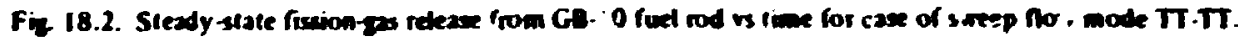




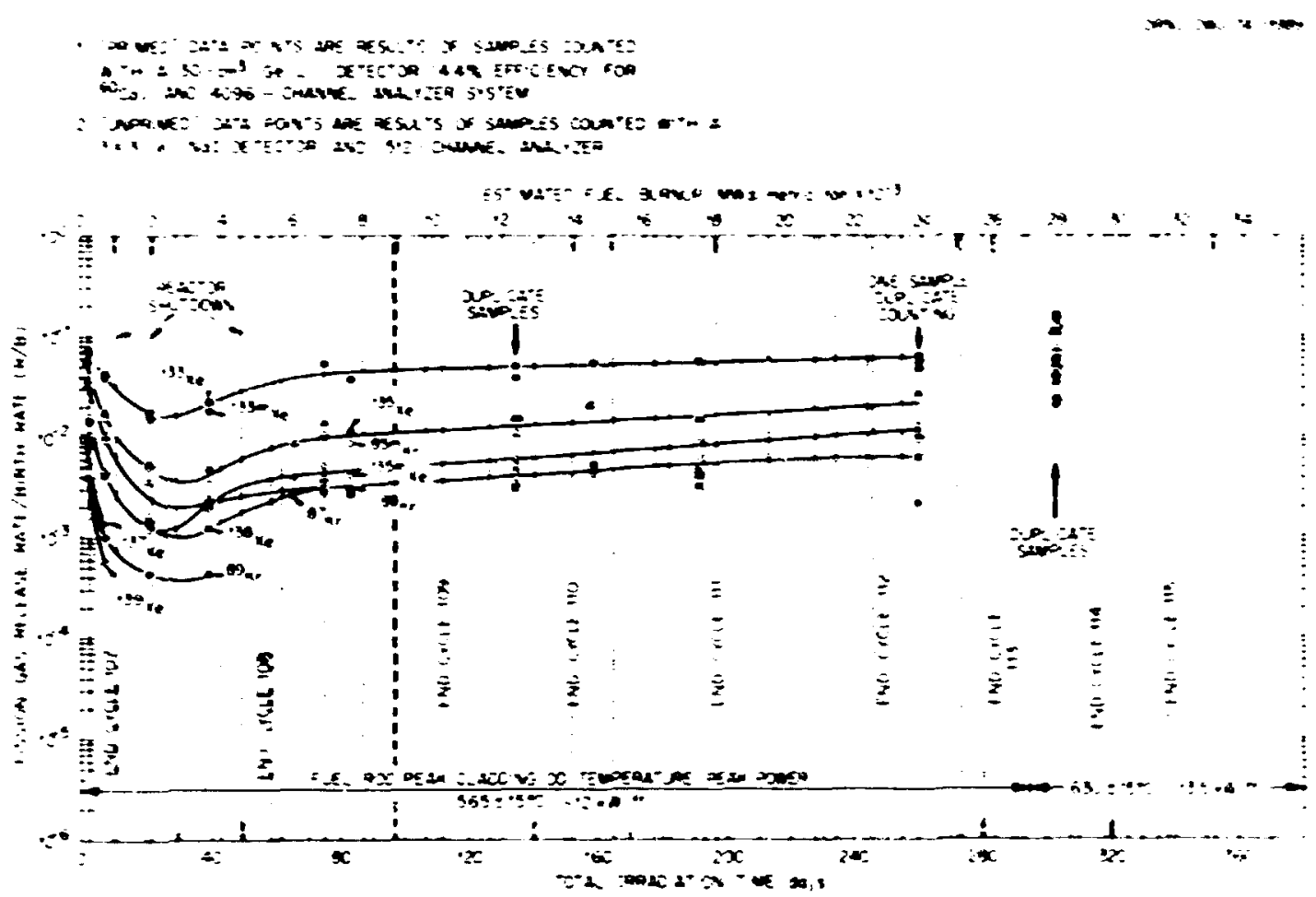

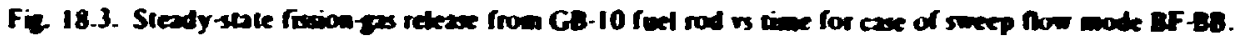

TT.TT to BF.TT ociurs:d as the inventory of fission ganes that acumulated in the rod under the TT-TT flow niode r.as swept from the rod and passed by the iunization chamber on the effluent sweep line.

The fission-gas release behavior cbserved during the operation of GB-10 to date has been consistent with that observed during the uperation of sapsule GB.9 in that there is a strong continuous release during the operation that is quite sensulive to puwer level and lemperature changes.

\subsubsection{Fi iun-Cas Releace Beturior Durise Startup and Shutdown}

There has been no evidence of significant bursts of xitivity release from the initially solid pellet fuel in GB-10 duning startup or shutdowil periods. When no bursts were observed irom :he hollow-pellet fuel in GB-9. Il was throught tha perhaps activity pulses from the fuel might disperse and not be detected because of the limitatiois of the sweep line arraniement. In GB-10. however. it has been possible to sweep the fuel region directly whik monitoring the effluent iweep line ativity for activity bursts.

\subsubsection{Fued-Rod Flow Rexistance os Burmup}

Pressure drup measurements are rustinely cblaned under siveral GB-10 sweep llow mertes by neeans of two 0 to 1500-psig pressure transducers lociated in the sweep system on the inlet side of the fue! rod. Because of their locations. the two elements sh-uld indicate the sume pressure when the TT inlet liac is being used: thus. 3 cheik of their agreement is ubtained under this fluw condition. When one of the alternate iniet flow lines is used. a pressure drop $\left(1^{\circ}\right)$ measurement that includes the fuel region resistance to flow is obtaned. However. the $\mathbf{I P}$ measurement a'ways indudes the piessure drop in the $\sim 70$ it of 0.027 -in. IU inlet line used fur ali but the TT inlet line. Pressure drop calculations indikate that $\sim 70 \mathrm{ft}$ of 0.027-in.-ID inlet sweep line aciounts for about 4 io 5 pst of the istal mezsured $1 P$ fiot the conditions of IUUA psig pressure and $1000 \mathrm{~cm}^{3}$ STPimin flou rate. In addition. operation under the various how .odes has shown that the upper blankel and charcual irap seclions of the rnd offer negligble ressiance to flow conpared with the io fi st 0.027-in.-ID inlet line. Thus, measuretienifs that are much greater than 5 psi indicate fuel region resistance 

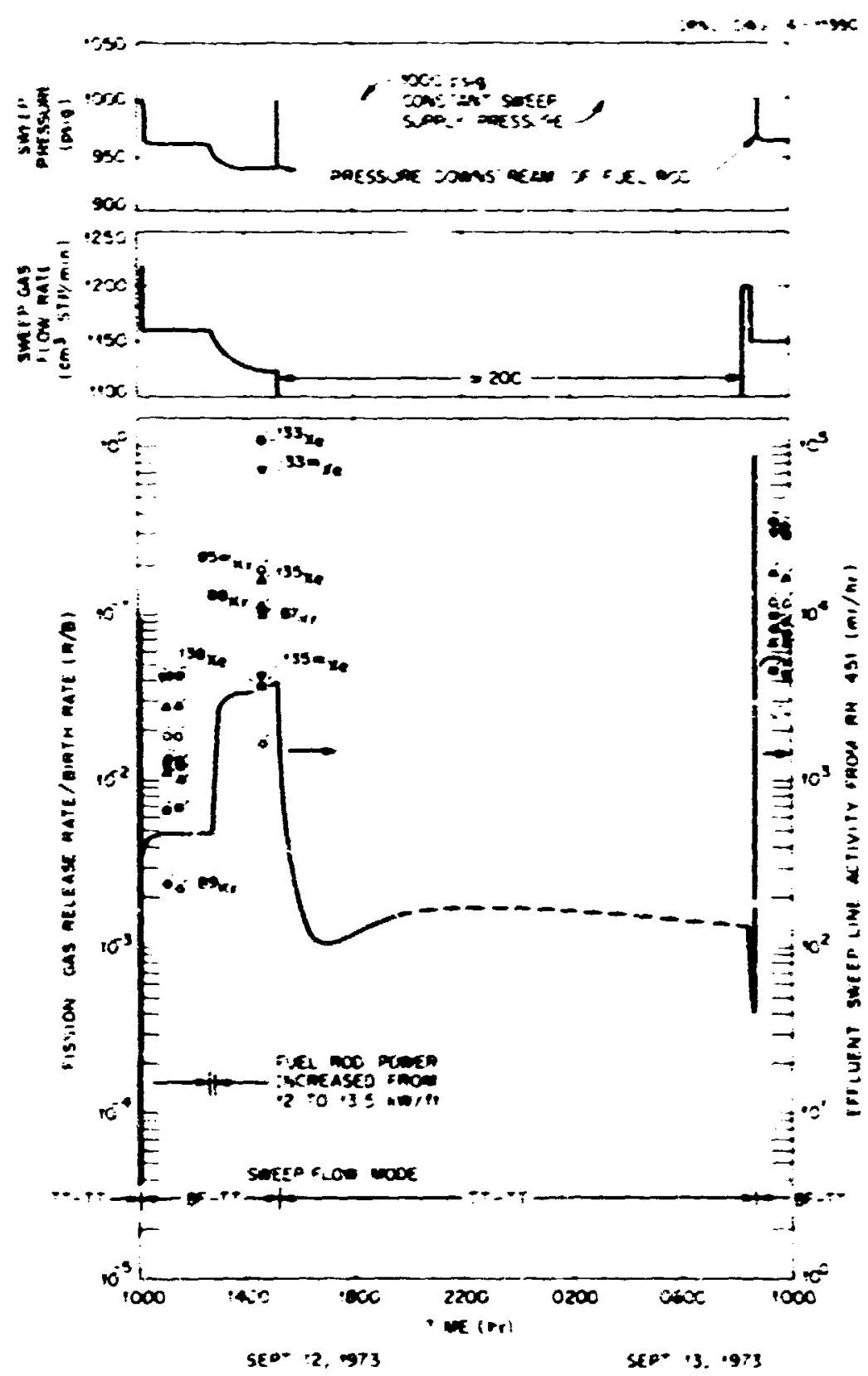

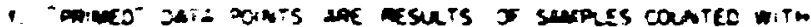

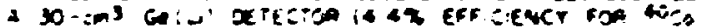

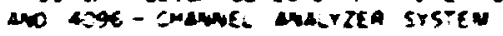

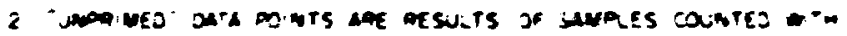

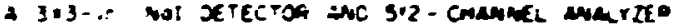

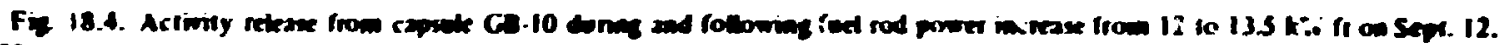
1973. 


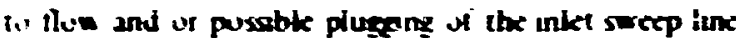
to the by ttium is ine rud

The pressure Arip modiminns to. date. although imits $:$. mi better than $: 5$ ps with the present

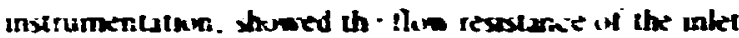
lune atd fuxl iviumn en the "ivid cundition:" to be -05

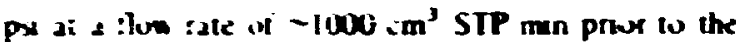

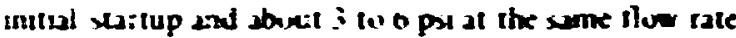
$1 i+$ punt where the tuei bumap wo - IX.100 Mis axtri ten and wire the correspunding haduztun under the Th.4 iendiunn" was -10 pis Pressure diferentul nokitions ander the hut indithn and

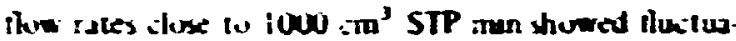
thms between :I and 70 psi durng the unitud statup. 2 dertease to -10 psa the first weet of irradiation - In pa to a fuel burnup $-1 x_{.}$i00 Mivi metrik ton. and a Later unirease to -10 pa by the end of the $12.5 \mathrm{k}$ if uperation. When the peak fueltod puwer was unieased

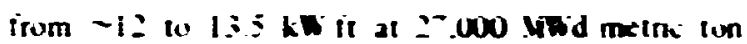
burmup. the pressure thiferentual in-rezsed irum to to 60 pa. as showri by the pressures plovted in Fig. Ixt Bs the acxi dy. the differentui had Irupped bach to to psi. Subsequeni data ubtaned at $1: 5 \mathrm{k} / \mathrm{h}$ it uperation shured + decrease lu - 50 psi at $>29.300$ MTid metin ton iuel burnup fullumed bi an imirease to 200 psi at :5,000 Vwd metri ton (Jari. 15.197 t).

\subsection{4 lodie-Depsition Meswerwents a 12 kw ff}

Capsule GB-10 was tull retraited on Apr 17. 1973. at an exlimatent fuet burnup st is. 100 Mid metric ton to measure shu!duwn xenun rekease ates luliuwing uperation at $12 \mathrm{~kW}$ it. A sernes ,f sweep gas umples were taken under arefully isntrulled flow conditions in an allempt is determine the equilibrium depusition of ${ }^{13} 1$ and ${ }^{133} /$ in the vasuess regunis of the fuel rod and in the eflluent swep line during the preceding petind of nomal steaty-siate peration wader flow mode TT.TT. Three sets of sumples were tai $\mathrm{cn}$. arnd in eanh ase the sampling order was BF.IT. BF.BT. BF-BB. TT-BE. TT-BT. and TT.TT. All sampics were taken wih the thariual trap and uppei blankel regions of the rod =lecirkilly heated to a charioal temperatire of $235 \%$ C. except ling the TT-TT samples. which were Iaken with the beaters oif. Samples were taken apro: rimately 5 -nin following the fliw mode changes. of 5 min faliowing cilfilf ot the healers in the ase of the TT.TT umples. Ali the samples were counter using the Sial deteclior system desinbed previously (see Fig. 18.2 for detecitor system desinpitioni.

The " ${ }^{33} X_{e}$ and 133 Xe release data ubianed are plotted in Fig. 185 and 18 , 6 respectively. Also shown

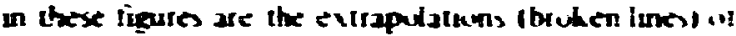
the venun rekexe ale bath to the time of thutden $n$

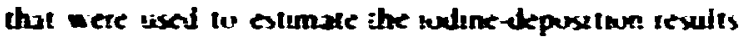

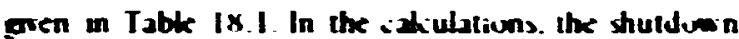

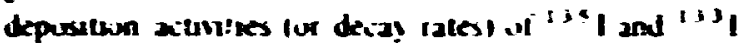
un eah the path wete asumed to be cyual to the -extrapulated sivuthwn retease rates" of theil cmen bugheers. Thes ssumptinn is ubjeit to sume yoestivn. sence the ventus rekase data departed irum the expaited sira tht tine betanior on the xemilus pluts and. usicad. Stumer an zutal buhiup. We do not have a

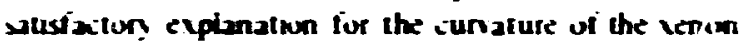
:etease dala on figs. IX.S and IX.6. In reahang udune-

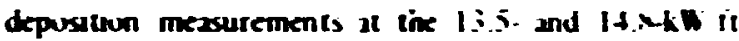
puner kvets. we hupe to be able to fullow the shutdumn cenun release for a longer penud of lume then we were abte to at the $12+k$ it level. Perhaps the bier results oil help explan the I:-ini it results.

\subsection{Longlined Activit) Deposition in Efithent Streep System}

A salution survey of the $68-10$ effluent lines in the reaitur piout was made on 0.1. 8.1473 . durng + reator shutduwn periud ifuel bumup of -20.500 Mkd metre tonl. The surves shuwed 300 to $700 \mathrm{mR}$ he :t:

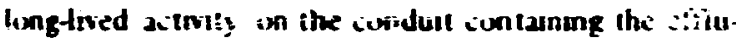
eni lines and $\sim 12 \mathrm{R} \mathrm{hr}$ at + junition box near the pink dam I ahout mokey between apsale and alve box) where welded cuppling exist wi the inges A sutscifuen: survey dunng a reailus shutdown pernud in lanuan

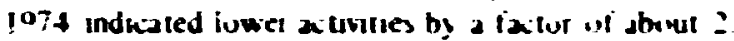
We plas I" contuatue sirveyung these lines and. II necessary. curtal sanpling a required to prevent insich higher buidup of dimls on the lines.

The $\mathrm{u}$ adution "if apsuie CB-10 was internpted on Q.t. 1\%. i973. when a siow leak derelopeci in a downstream iub-preasure secition of the sweep-gas

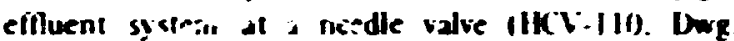
1-10040-06-124) ured to :cgulate the sweep thow rar: This valve was rephised dunng a rexiut shutdown on Nis. 6. 9. 1973. In iep.'aing the needk valve. we had to upen the valve box and remove the + in. of lead shelding fitm the vioing of the efiluent sweep line :alves While the !ad shielding was removed. we instailed several rees and valves in the high-pressure secilon oi the effluent sweep line II) !abillate later hoskup sf the koup with the on-line (iefili) gamma-tay deiectits In doing this work. we removed a 5-in -tong segmeit of the old line. The line segnient was cul on one end and hav a fitting on the other end 


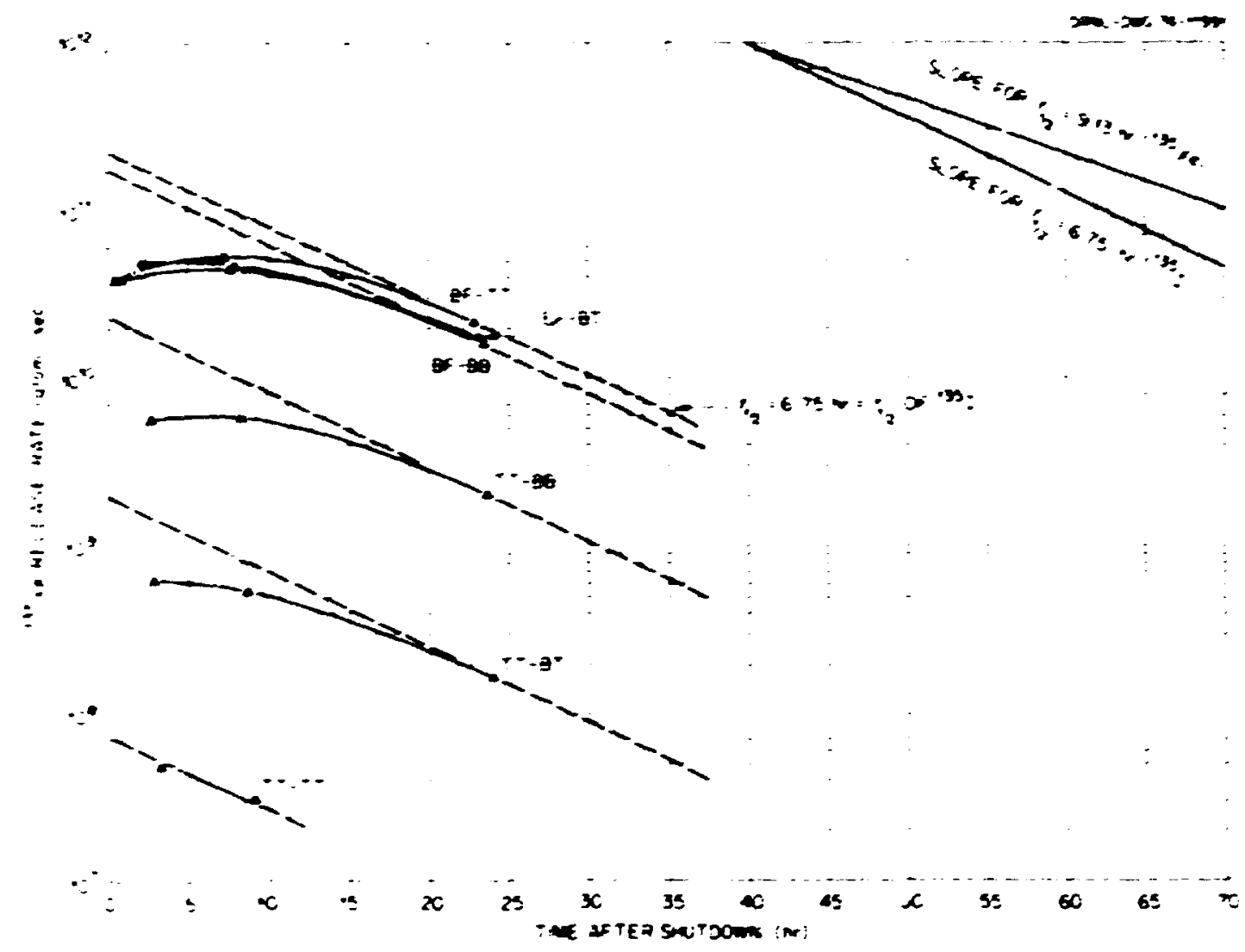

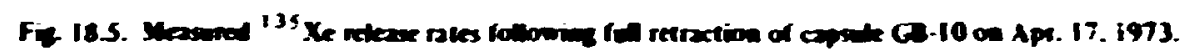

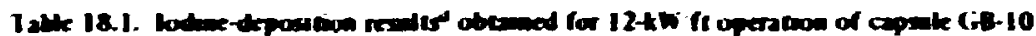

\begin{tabular}{|c|c|c|c|c|c|}
\hline \multirow{3}{*}{ 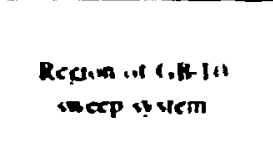 } & \multirow{3}{*}{$\begin{array}{l}\text { Sweep" } \\
\text { Thuse } \\
\text { rounde }\end{array}$} & \multicolumn{4}{|c|}{ 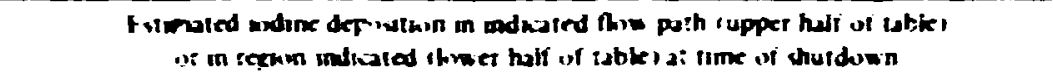 } \\
\hline & & & $\sqrt{3 \div 1}$ & & $\sqrt[3]{1}$ \\
\hline & & (Bises & I ration on tutat insentorts" & Curies & I saik:n of tutal inventors ${ }^{6}$ \\
\hline & 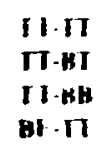 & 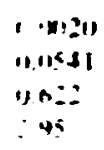 & $\begin{array}{l}+5 \cdot 10^{-6} \\
1: \cdot 10^{-4} \\
1+11^{-3} \\
1 \therefore 10^{-2}\end{array}$ & $\begin{array}{l}\text { Mi2: } \\
0.114 \\
1.24 \\
13.11\end{array}$ & $\begin{array}{l}2+10^{-4} \\
2.2 \times 10^{-4} \\
2+110^{-3} \\
25 \times 11^{-2}\end{array}$ \\
\hline IT-IT lines & & alnen & $+.5 \times 11^{\cdot 0}$ & 11.11 .24 & $2+\times 10^{-5}$ \\
\hline 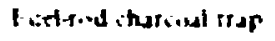 & & $0.015+!$ & $12 \cdot 10^{-4}$ & $11.11+$ & $2: 11^{-4}$ \\
\hline Cpper huniker & & $11.5 n x$ & $13 \cdot 11^{3}$ & 1.13 & $21 \cdot 11^{-3}$ \\
\hline I wel reghn mildies & & $5: \vdots$ & $12+11^{-2}:$ & if $x$ & $22 \cdot 11^{-2}$ \\
\hline
\end{tabular}

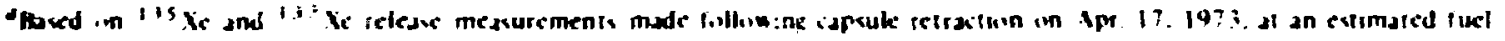

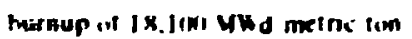

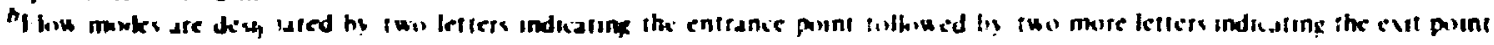

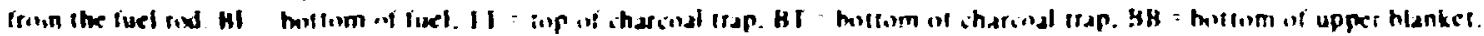

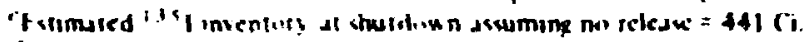

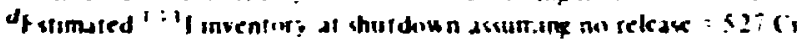




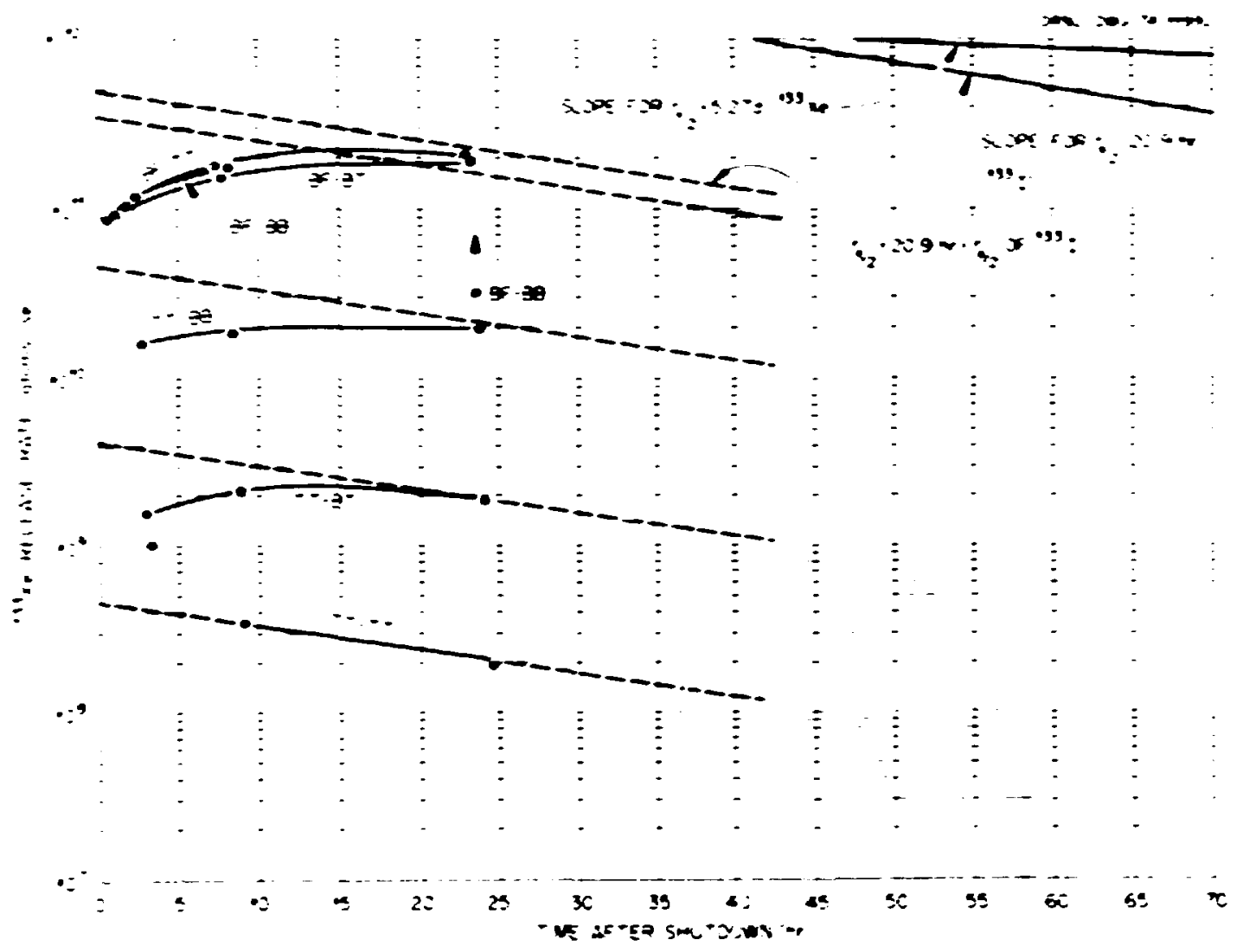

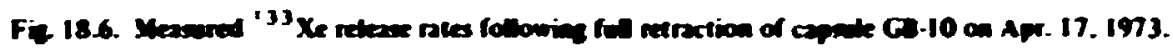

With the lead shielding removed from the effluent sweep line valving. the aitivity level was approximately $500 \mathrm{mR}$ hr near the valves and lines. This long-lived artivity was due to fission product deposition on the effluent sweep system surfizes. The needle valve (HVC.110) read $\sim 7 \mathrm{mR}$ hr atice remova. The 5 in.long

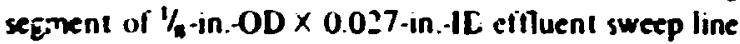
after :emoval read $\sim 300 \mathrm{mR}$ hr: the ativity was much hightr on the erd with the fitting than on the cut end. Both the needle valve and the segment of sweep line were cuunted using the Val deteitor systerr. (see Fig. 18.2). The capsule was shut down on Oil. 14. 197.3. The activity on the needle valve was cuunted on Suv. 7 . 1973. and that on the line segnent was cuunted viv. 8. 1973. The following activities were found to the present.

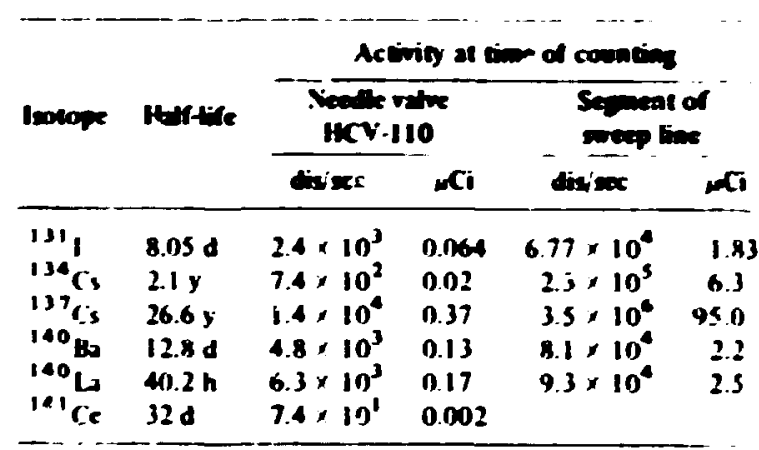

When the on-line Ge(Li) detector loop is plared is. operation. we may be the to obtain further informa liun un line depusition. Initially. at least. we plan to use 


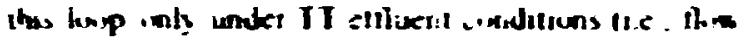
raves TT-IT. BT-TT. B\&IT. in BH-TTI axd it

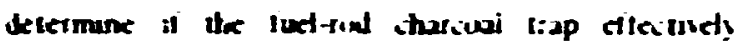
remmes "'I leve the pas strem. The idnmuindes

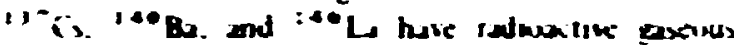

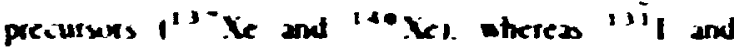

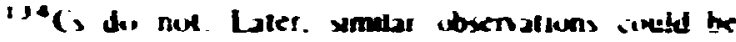
mode usuge the BT eifluert lune and perhaps the BB eilluent lane

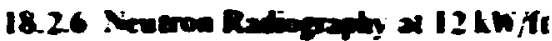

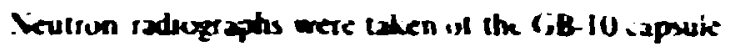
neat the end of the 1:-ill it uperating penod. Thex: radugraphs. taker. on tug Y. 1473. if ati simaled fuel bumup kevel of -20.100 . Whid metni lins. wetc compared with preuradution neuison idungraphs. The radiogaphs shored that the approumately 4 -in. 4 inig mixedeside ivel cotumn had xilled sbust is: in

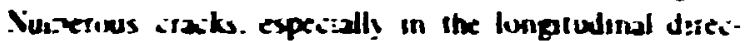
ivn. civuld be secol in the luel pelkets. but thete nas no' cide are that a sentral hute had develuped dunng

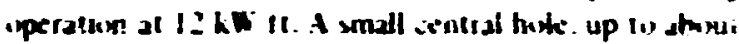

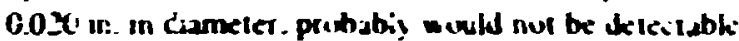

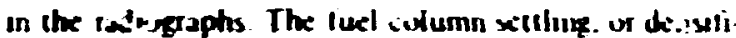

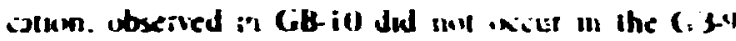

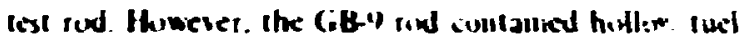
pelkets having an tatial denstl of "l, and the s al was

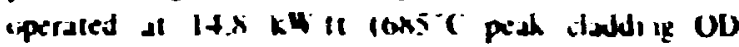
lemperdiusel throughuul its ifradiation. The misid

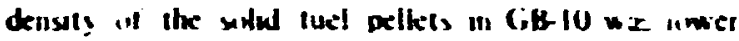

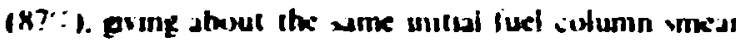

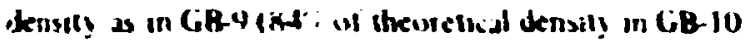

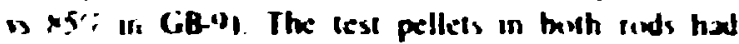
0.00n-1n. dished ends A central hate late - moxud: la be detecled by ixutron radugraph! is experied to lutm in

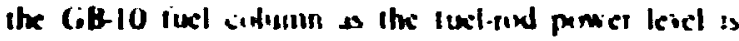
in.reased

The asidhricaled cere!ral twite in the limet two inrictied-lo: hailpeliets fbeling the ILPUN: chlumn| tod txicume slighly lumel shaped. with the

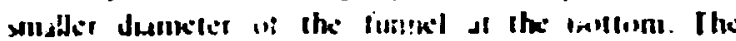

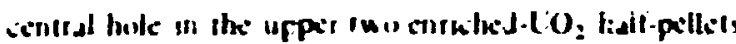

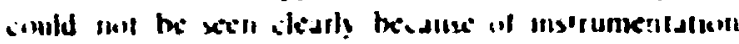
keds. The relliandir of the imel rials and capsule parts

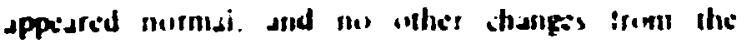
preirradistu in radiegraphs were detcilid

\section{IX.2.7 Ihecay Heationg in ine Charcual Trap}

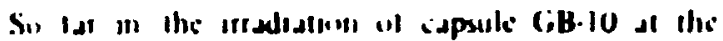

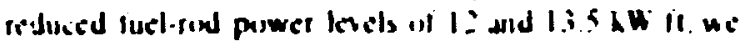

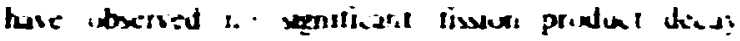

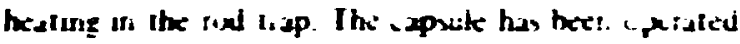

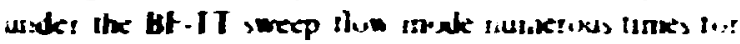

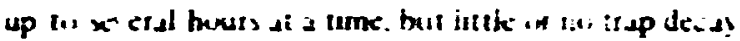

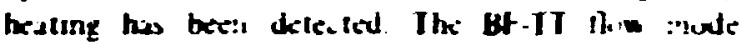

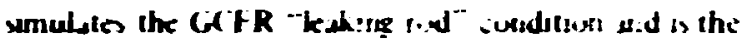

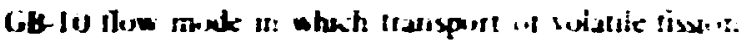

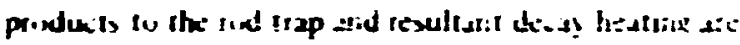

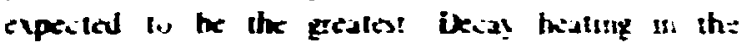
trappeng sy stem of the (AFR winht be of cialcer: it a

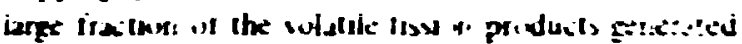

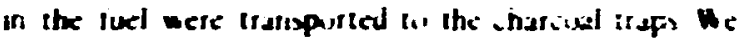

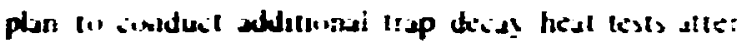

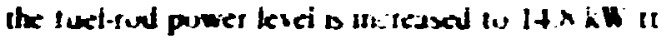

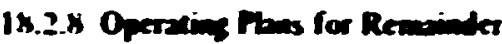 of I3.5-twitt Oparation}

Itk syutstion of experimetilal dats will -intinki st the present puwcr kesel of $135 \mathrm{i} / \mathrm{ll}$ it as woll as at the tiscal pusce ienel of It.x kW it In edditson. we expect int sapobulity tot study ing the tissin-pindunt-retesse

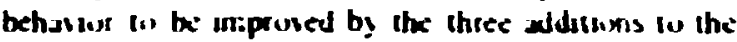

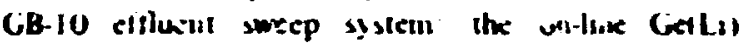
eumma-ts detecior \$siem. \& umplusg system lin Iding late ess smple! -1 hiet lat the determinition

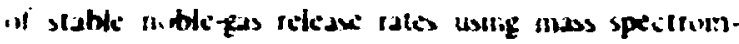

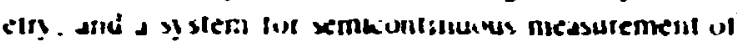

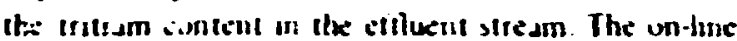

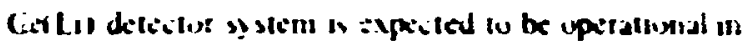

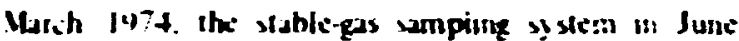

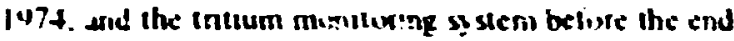
.31 alkendat leat 197t

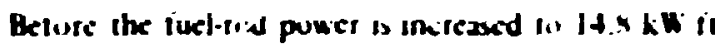

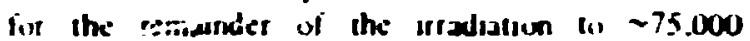
MHd mitric cun. we plan to innduit several speilai iests. Sunx of these will be easket is perfitm at the prexent lower-ativily releaxe kich than at thuse

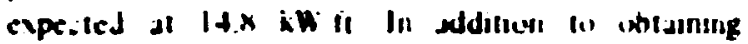
vidine-depantion mesurements and neut; il radiug-

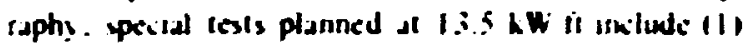
sledy. … uperation at linet sweep pressures 1200 and 200 pagl lo determule selease behasut as a

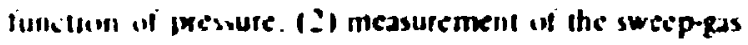

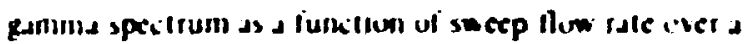
whe thin rate rallge iwale range of tistel tures from

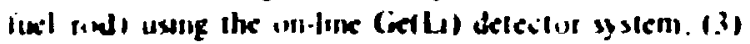

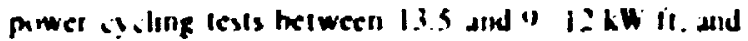
iti pressure ycling lesis leither at 1.35 or $1+x \mathrm{~kW}$ it) We apect lin complet: these tests and be ready lin It X.k Wi fineraluen by shusl Sepiember 1117 


\title{
19. CiCFR Steam-Cicnerator Modeling
}

\author{
U. H. Burhe J.P. Sunder:
}

Ihis shapter sovers the contunuation of a Isk that wa imitisted in Juls 1. 147? The purpuse a! this tast was $t_{1}$. develop + hybrid sumputer tivedel uf the steam generatur for a gas-ionted lasi breeder resitur ICCFR and lo uxe this nidel fo smulate vanus system transients as well as steady-state uperations. Is a first : wective. the resulis ublaned from rumung certan! presibed transents using this imodel weuld be com pared with thuse obtuned by the Cenersl Nixmi Company IGAC) irum therr computer mudel of the werall nuilear steam supply sistem. This wiveld hups inily validate the steam-enerali. portion? of their

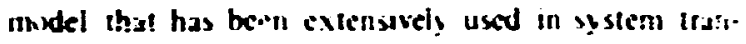
inent inaly xes.

\subsection{COMPUTER DESCRIPTION}

The ORNL hybrd cumputer being used un this lish cunsists "If a wind-state inaleg cumputer unterfieied l:, a dogial cumpuler. The anding cumputer is a siali-ofltheart computer with a $\pm 100-V$ reference. The anderg cumpuier consude aiso confans the cimponents lifr interiding with the digial simpiter. which ias a 36.bit wird length. \$2.000 words of iast menury, and s incle time if himul 1.45 user. It nicepls either assembly languace of FORTRAN IV programs. (um. municaturn with the analug computer is dicomplished through FORTRAX callable subriulines.

\subsection{DESCRJTION OF SYSTEM TO BE MODELED}

The purtion of the uverall system modeled in thas task iniludes the ieedwater now control value. The steam generatur leconomizer. evapuratur. and superheaterl. the helum circuiator lurbine control valve. and the puping interconikiling thex units Sillic input dedals (1) the cuatret valves ate reyulfed irom : ither patts of the sy stem in orcter lier them tw uperate in an atatoliatic moxde anc smic these sigiels arc got alalable in this indel, the contiol valois. as shoublated. Were inanually operated.

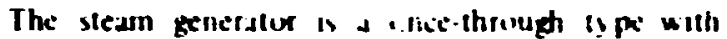
helically wound tubes. Iteat is iranstierred from heliun

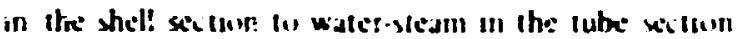

\subsection{MATHEMATKCAL MODEL OF STEAM GENERATOR}

The computer maxtel of the slean genteralor was develuped from a sel in couplid. nimlinear. parlial diffe:ential equations derived from the bus af corter.

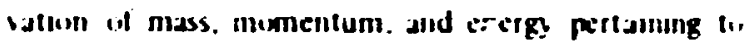
the priming and secoundan. Iluds. The cyualums. writle: in ine space dimerisull $x$ (the direction of

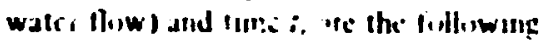

Cinse-vathell of inass (water):

$$
\frac{\partial \rho}{\partial t}+\frac{\partial}{c i}(\rho v)=0
$$

( inservatun in momentum (w:let)

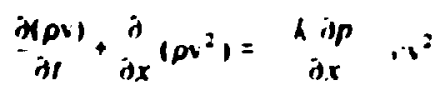

(inservatiun of energ (wati)

$$
\frac{\partial(\partial h)}{\partial t}+\frac{\partial(\rho h)}{\partial x}=k_{1} / 10 \quad T
$$




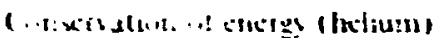

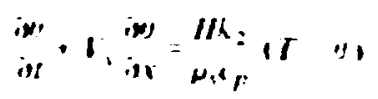

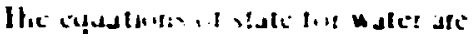

$$
\begin{aligned}
& \text { I } T_{1 p h} \\
& \text { p-Mf.h }
\end{aligned}
$$

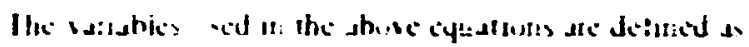
lillines,

$$
\begin{aligned}
& I=\text { usiet letrpestutic } \\
& \mu=\text { uster dersily. It } \|^{*} \text {. } \\
& \therefore=u+l i t \text { tiently. tp, } \\
& p=m \text { uict pressits:. pst. }
\end{aligned}
$$

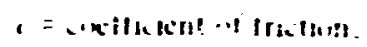

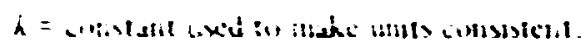

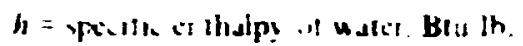

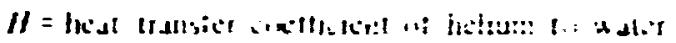

$$
\begin{aligned}
& \text { Bla } x_{i}: t: \text { : } 1 \text {, }
\end{aligned}
$$

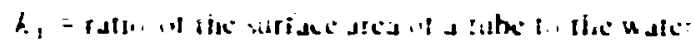

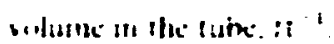

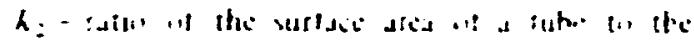

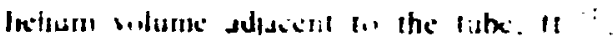

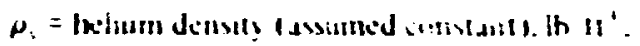

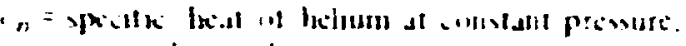

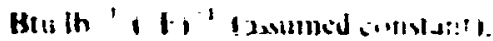

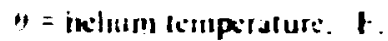

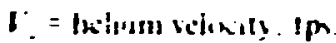

\section{9.+ COMPUTER HODEL DEVELOPMENT}

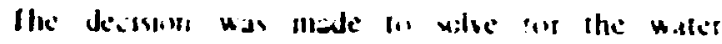

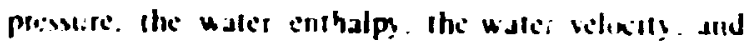

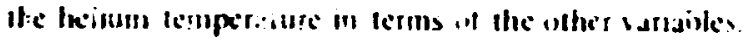

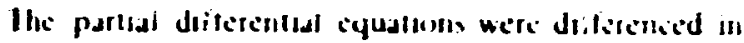

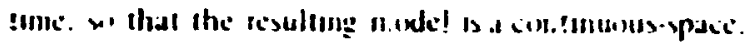

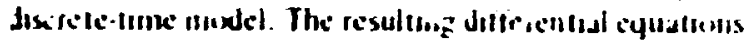
-ro

$$
\begin{aligned}
& \frac{d p}{d x}=\frac{\rho d}{h} \frac{d}{d x} \quad \frac{a}{h} \quad \frac{\rho}{h} \div \frac{d h}{\nu} .
\end{aligned}
$$

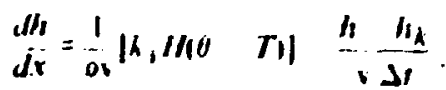

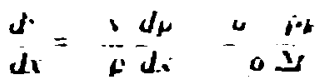

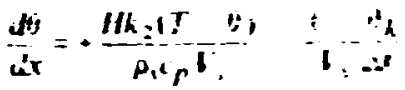

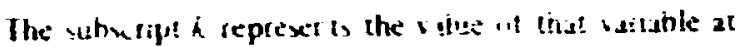

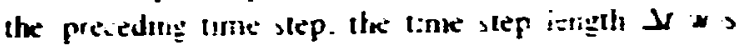
arbitrunly $x$ ta 1 is:

When impicmenung thexe equatiuns or: the inb brid

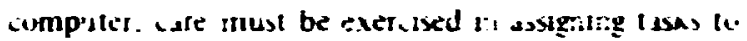
the digalit did soatug purtiens is that each nichire

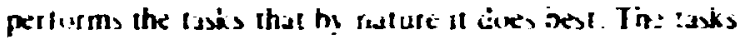

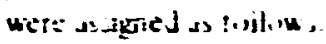

inolig c...npulet

1. Intepale difterentual equatings.

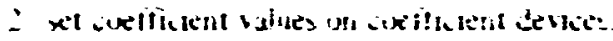

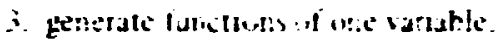

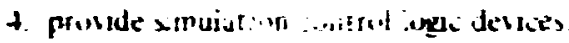

\section{Digilal compulcr}

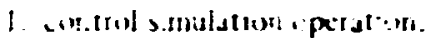

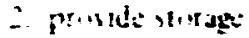

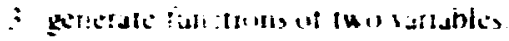

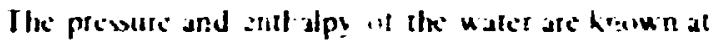

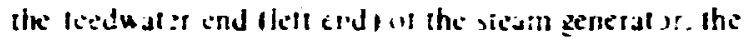

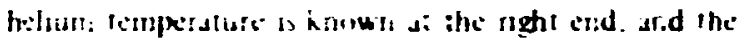

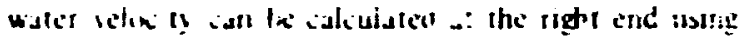

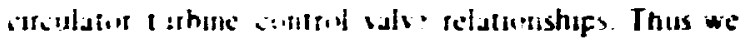

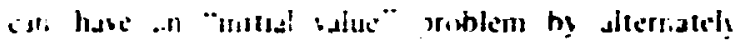
melegalung the uster prossure at:d emhalp! equatuats

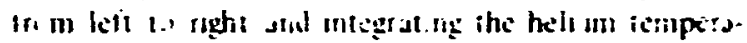

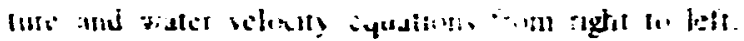

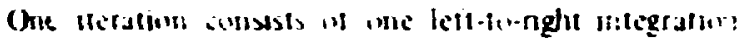

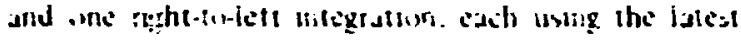
unturndihw intaned hy integratsig wh the uppusile dirctiont)

\subsection{STATUS OF TASK}

The program ha been written and "dehugged." dit: like lilli-power st ady-stale idse has bech run.

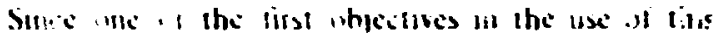

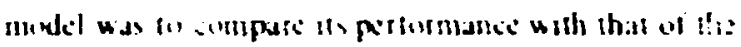

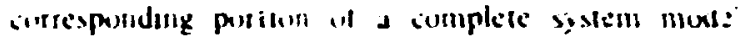

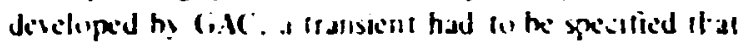

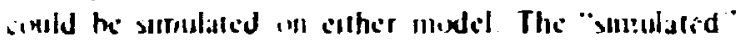

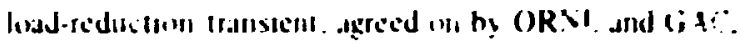
is inte that is used for model performance anpatison:s

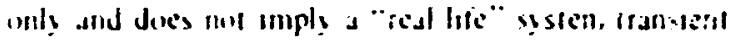
Ilec transicht was anplomenled in the following? mantrict 


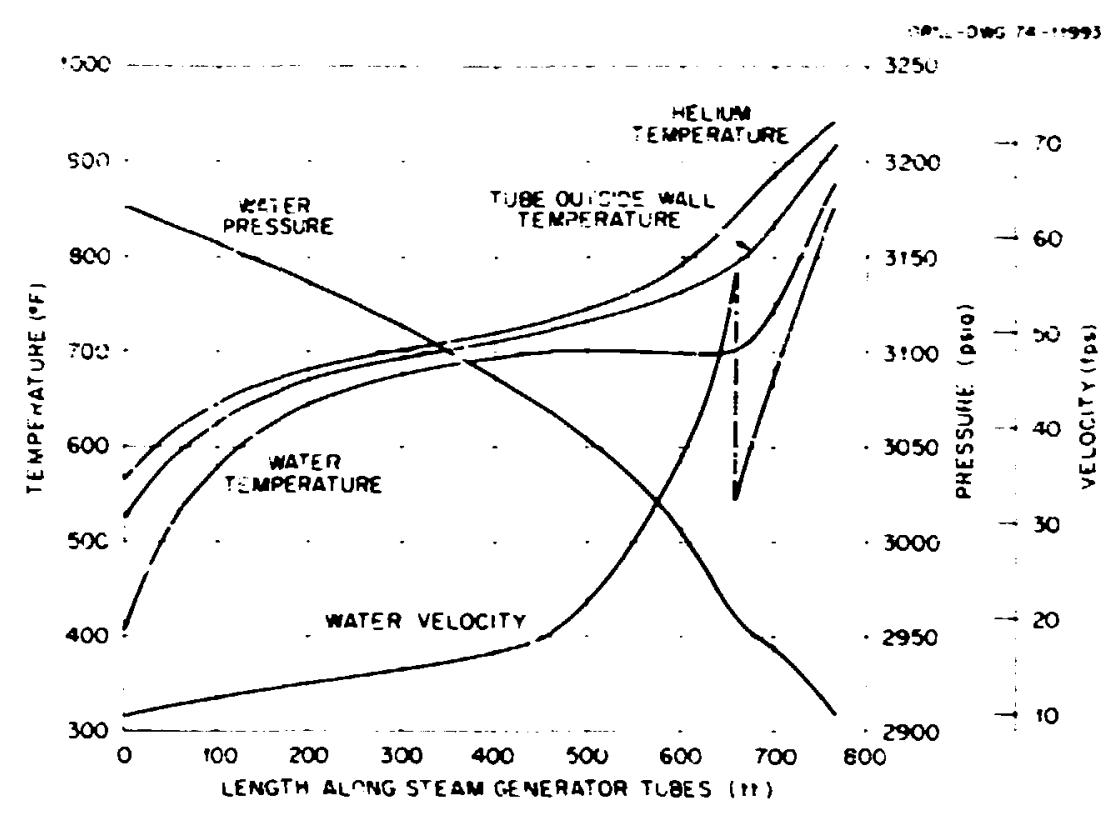

Fig. 19.1. Steady-state profics of temperature and ot her parameters at full desig load.

The system is initially operating at :ull design load in a steady statc. At transient time zero. the following ations are initiated:

1. The feedwater tlow control vilve opening arsa is decreased :rom its initial full load vai.s.: :o lU; of that value on a 2-mir tamp.

2. The circulator turbine control valve area is changed as in item I except that the ramp duration is $21 / 2$ nin.

3. The water conditions at the feedwater pump discharge remain constant at design full-load conditions.

4. The heit $m$ coxlant mass flow rate is ramped from the design full-luid value to $10 \%$; of that valua in $2 \%$ min.

It mus: be pointed out that this is not truly a load-reduction transient. Since this simulation model simulates only a portion of the complice steam system and since no au'omatic controllers are simulated, a irue load reduction cann $x$ t be simulated with it.

\subsection{RESULTS AND DISCUSSION}

The spatial plot: " : iive interesting variables for the steady-stale fill-tuad run are shiwn in Fig. 19.1. ":.,c time plots of the variables for th: sinulated loac reduction run are shown in Figs. 19.2 10 19.4.

The steady-sinte results were essentially the same as ihus: froin the GAC model. The shapes of the curves

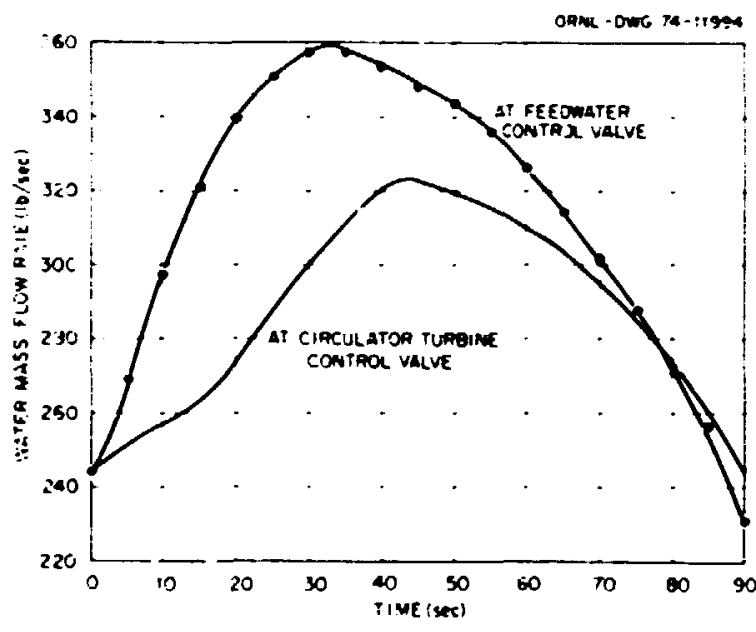

Fiz. is. .. Effects of simulated load reduction tnnsient on mass how rate of water in system.

for the simulated load-reduction transierit were very similar to thuse obtained by GAC. However. thers was some time displacement in the peaks, elc.. which was attributed to the fact that the ORNL mode! had no provision for the lieat capacity of the tube wall metal. This uversight will be corrected. Except for the above. mentioned oversight, it appears that the Iwo modils give essentially the same results for the same transients. 


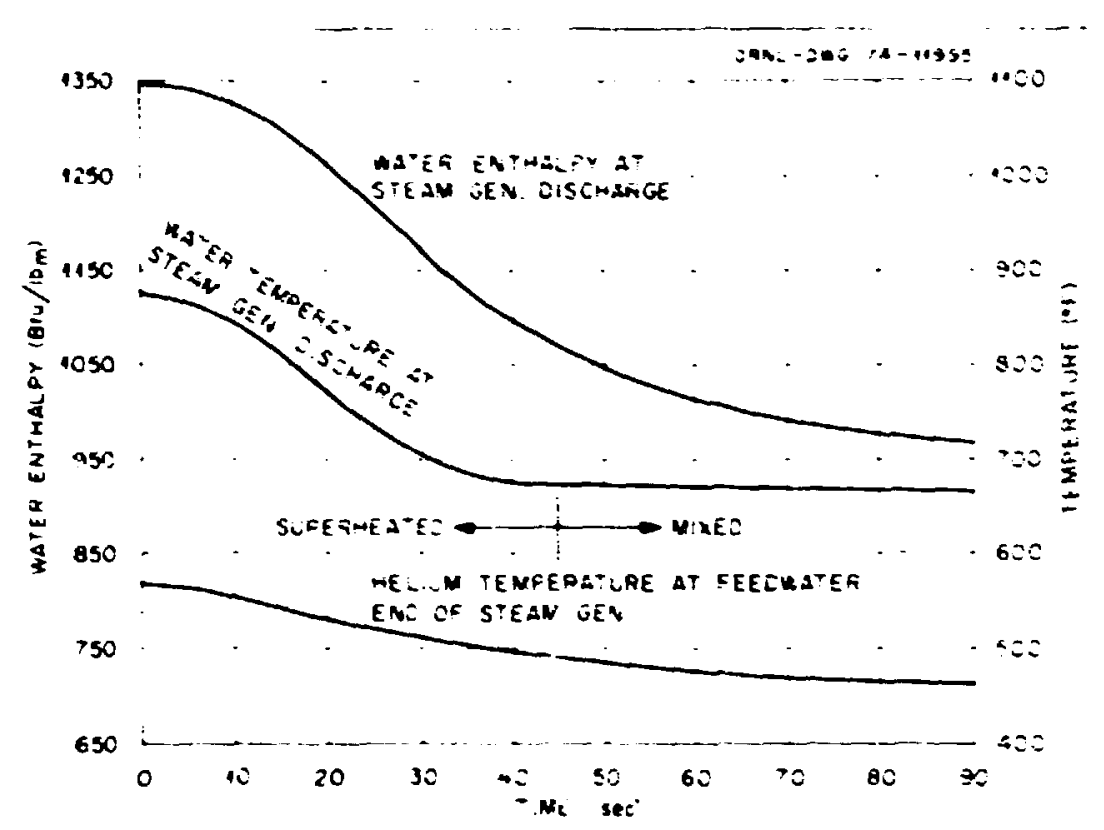

Fi. 19.3. Effects of simuthed load redoction transieat on water temperature and enthaipy in system.

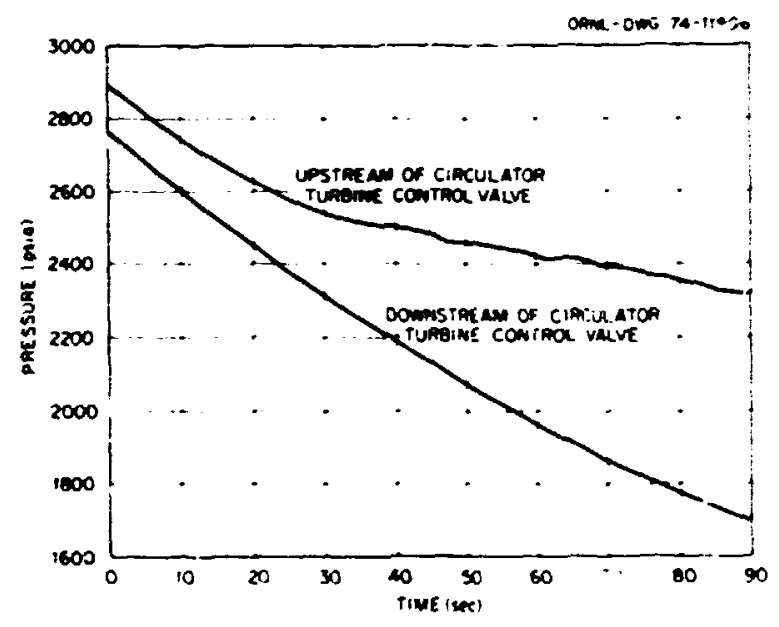

Fi2. 19.4. Effects of simulated load reduction transient on system pressure at circulator turtine conirot valve. 


\title{
20. GCFR Core Flow Test Facility
}

\author{
R. E. MacPhersun \\ A. G. Grindell
}

The Core Flow Test Facility (CFTF) for the gascooled fast reactor (GCFR) development program is being planned as an out-oí-reactor facility to supply helium at appropriate flow. :Enperature, and pressure contitions to a multipin test bundle that simulates a portion of a GCFR core. The bundle will consist of electric cartridge heaters that simulate the configuration of individual GCFR fuel and blanket pins. The facility will be used for experimentai studies of the structural and thermal responses of GCFR fuel-pin assemblies :o thermal and gas dynamic conditions associated witl steady-state and transient operation for comparison with predictions made with analytical nodels.
During the first two quarters of FY.1974. two planning meetings were held with General Atomi: Company personnel to initiate the definition of the test facility requirements. An increase in operating expense funding in the third quarter permitled us 10 start organizing a coni, ual design effurt. Studies werc initiated of the electrical power supply and control and helium cooiant flow control.

Before the end of FY-1974. we plan to produce a conceptual design of the fucility and to initiate preparation of the conceptual design desitription it accordanice with the planning chronology firr FY-1976 construction budget projects. 


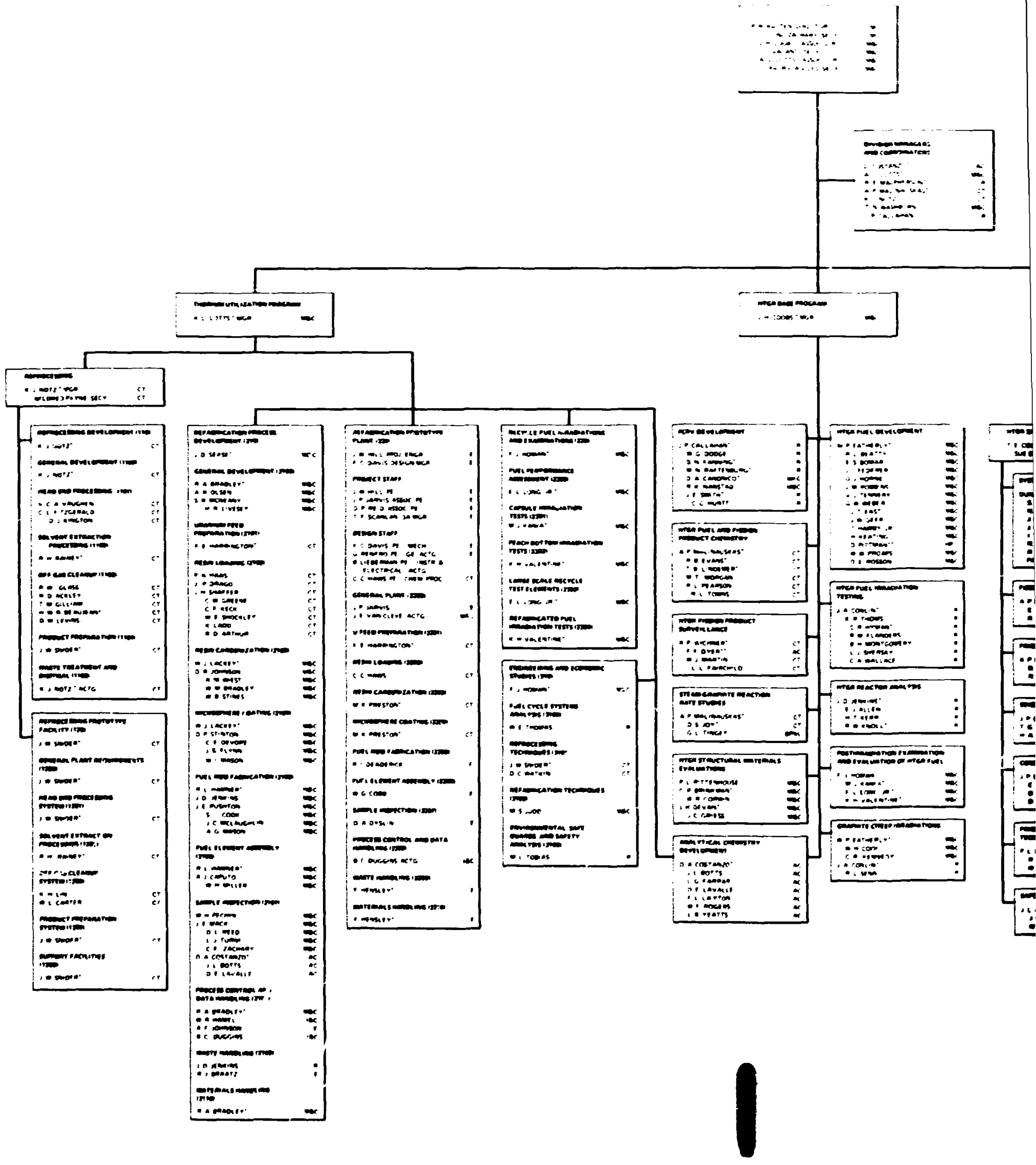




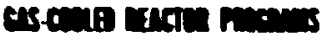

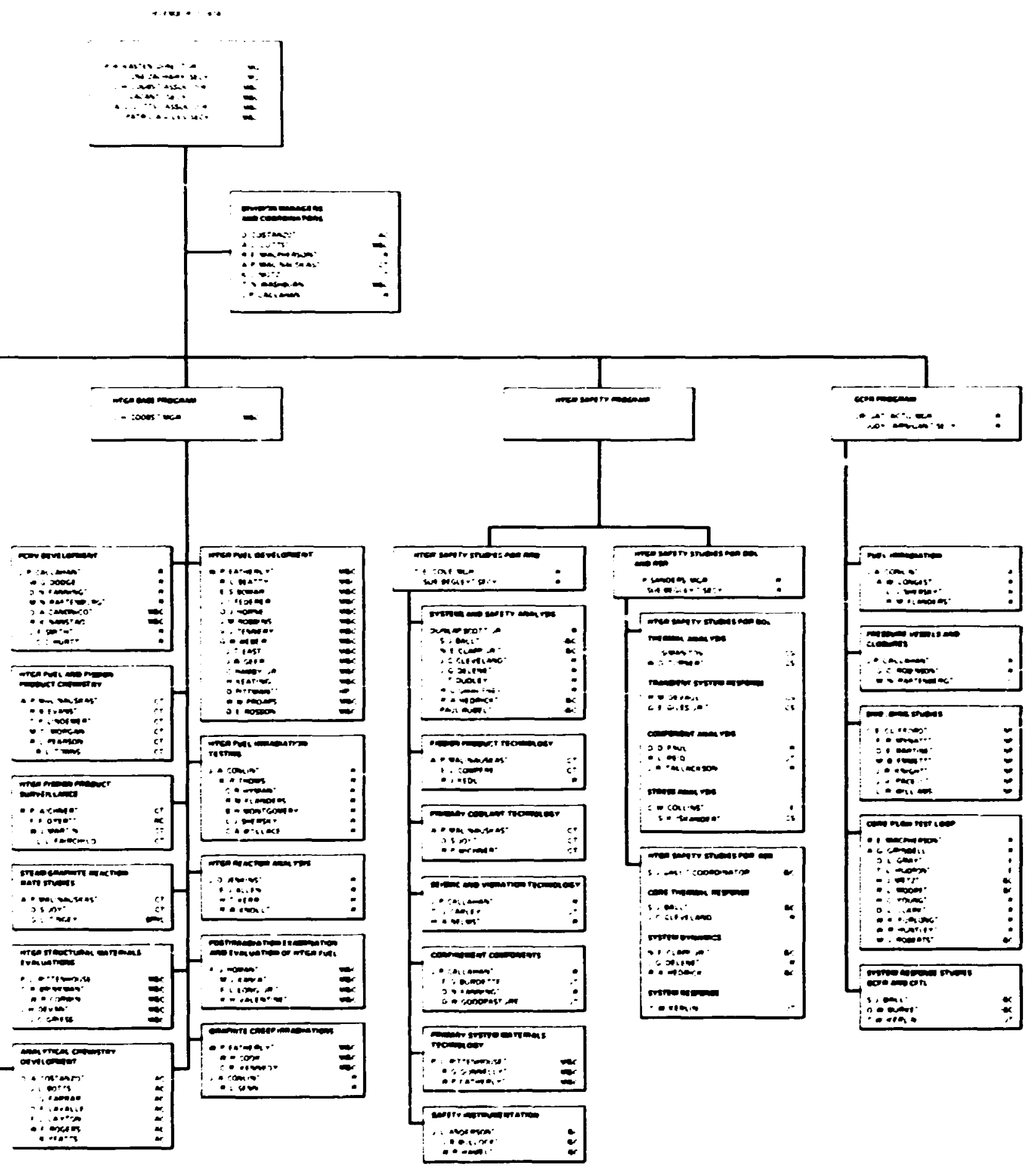

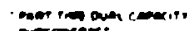

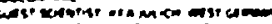

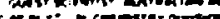

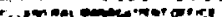

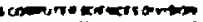

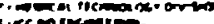

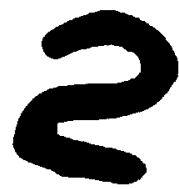

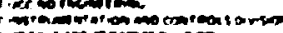

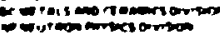

